Faculdade de Arquitetura e Urbanismo Universidade de São Paulo

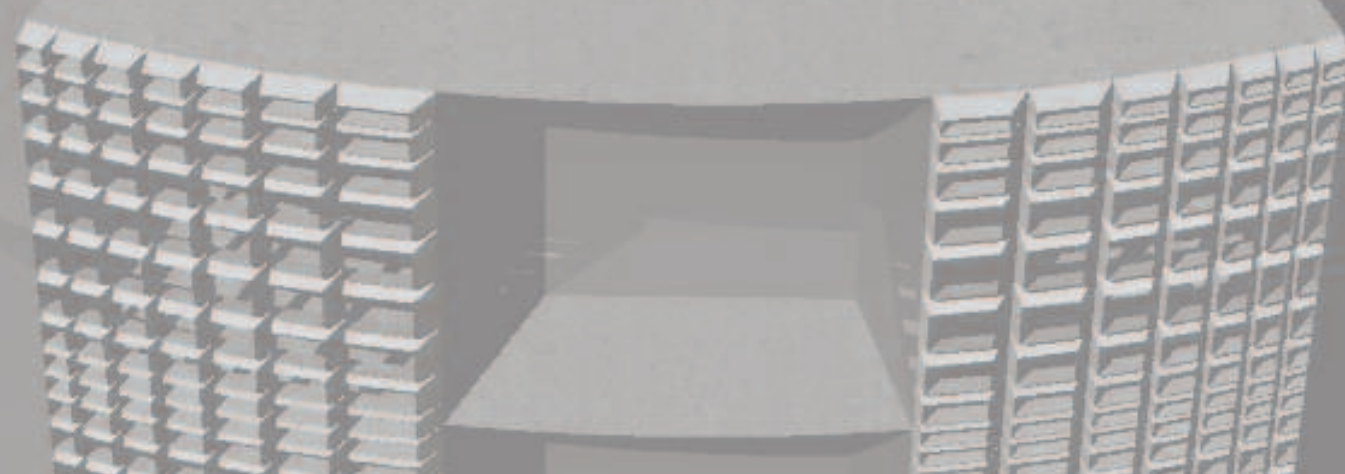

Avaliação de Desempenho Ambiental e Arquitetura Paramétrica Generativa para o Projeto do Edifício Alto

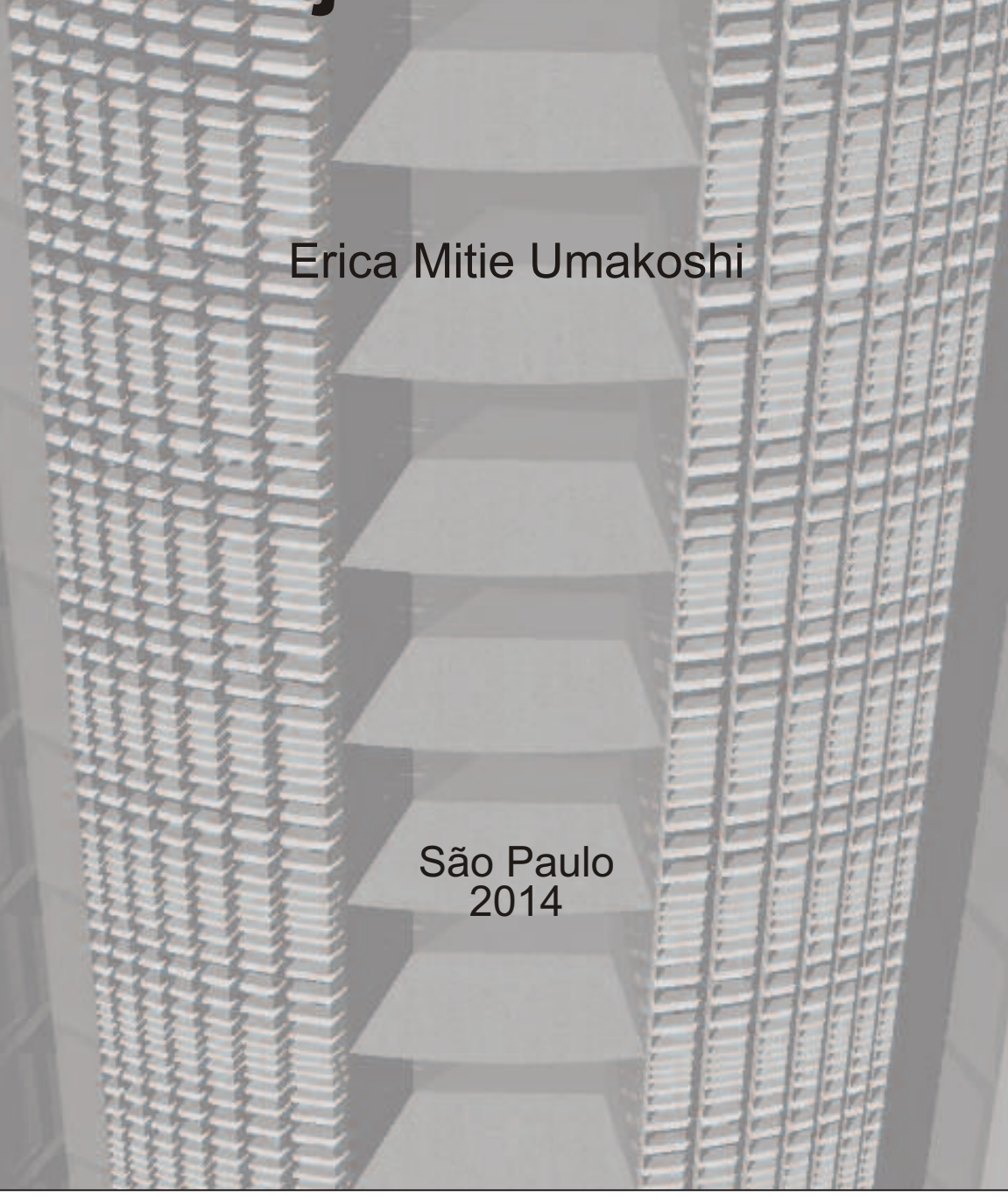



Erica Mitie Umakoshi

\section{Avaliação de Desempenho Ambiental e Arquitetura Paramétrica Generativa para o Projeto do Edifício Alto}

Tese apresentada a Faculdade de Arquitetura e Urbanismo da Universidade de São Paulo para obtenção do título de Doutor em Arquitetura e Urbanismo

Área de Concentração: Tecnologia da Arquitetura Orientadora: Prof. Dra. Joana Carla Soares

Gonçalves

São Paulo

2014 
AUTORIZO A REPRODUÇÃO E DIVULGAÇÃO TOTAL OU PARCIAL DESTE TRABALHO, POR QUALQUER MEIO CONVENCIONAL OU ELETRÔNICO, PARA FINS DE ESTUDO E PESQUISA, DESDE QUE CITADA A FONTE.

E-MAIL DA AUTORA: eumakoshi@gmail.com

Umakoshi, Erica Mitie

U48a Avaliação de desempenho ambiental e arquitetura paramétrica generativa para o projeto do edifício alto / Erica Mitie Umakoshi. -- São Paulo, 2014.

238 p. : il.

Tese (Doutorado - Área de Concentração: Tecnologia da Arquitetura) - FAUUSP.

Orientadora: Joana Carla Soares Gonçalves

1.Edifícios altos (Aspectos ambientais) 2.Projeto de arquitetura 3.Arquitetura paramétrica 4.Arquitetura generativa I.Título

CDU 721.011.27 
DEDICATÓRIA

Ao meu Amor Andre e à minha familia. 


\section{AGRADECIMENTOS}

Primeiramente, gostaria de agradecer à minha orientadora, amiga e professora, Doutora Joana Carla Soares Gonçalves, pelos questionamentos e pelo constante incentivo durante a pesquisa, orientação esta de fundamental importância para o direcionamento e a conclusão de mais uma etapa da pesquisa no tema do edifício alto. E principalmente pela necessidade da busca contínua pelo conhecimento e dedicação ao ensino da arquitetura.

Aos professores doutores Norberto Moura e Doris Kowaltowski, que, durante o Exame de Qualificação, expuseram suas críticas e comentários, dotados de grande importância para a conclusão da pesquisa.

E a todos os professores e pesquisadores do LABAUT - Laboratório de Eficiência Energética e Conforto Ambiental - que participaram, de alguma forma, desta pesquisa: Prof. Dra. Márcia Alluci, Anésia B. Frota, Roberta Consentino Kronka Mulfarth Denise Duarte, Leonardo Monteiro e Carolina Gusson.

Aos professores do Architectural Association Visiting School: Robert Smith Stuart, do escritório Kokkugia, Anne Save de Beaurecueil e Franklin Lee, do anglobrasileiro SUBdV, Sandro Tubertini, do escritório de engenharia ambiental inglês BDSP, Affonso Orciuoli, Arthur Mamou-Mani, Yooujin Kim, Ernesto Bueno e Thiago Mundim, pelo conhecimento transmitido e pela participação no projeto final apresentado durante o workshop. Às arquitetas Carolina Gusson, Heloisa Kempter e Renata Marangoni, pela participação no desenvolvimento do trabalho final apresentado no workshop.

Ao professor Arthur Lara pelos conhecimentos e pelas discussões acerca do projeto paramétrico e sobre a arquitetura generativa.

À professora Doutora Gabriela Celani pela receptividade e abertura para discutir e informar a pesquisa.

Ao engenheiro Klaus Bode, do escritório de engenharia e consultoria BDSP Partnership, em Londres, pela disponibilização de imagens e informações técnicas sobre os edifícios.

À amiga e pesquisadora Doutoranda Paula Shinzato por dividir e apoiar 
nos momentos mais difíceis da pesquisa e na alegria das conquistas.

À pesquisadora Doutora Mônica Marcondes, pela amizade, discussão sobre os edifícios altos, paciência e ensinamentos do programa computacional TAS.

À pesquisadora Doutoranda Bruna Luz, pelo carinho e disponibilidade de responder aos questionamentos em relação ao programa computacional Ecotect e as dúvidas de iluminação.

Ao meu marido, Andre Kuniochi, que tanto me apoiou e incentivou durante o desenvolvimento da pesquisa, participando e dividindo as dúvidas e as incertezas do processo de amadurecimento da pesquisa. Um revisor exemplar que sempre está disponível para ajudar. Um companheiro e amigo para todas as horas.

À minha família, pelo apoio incondicional, contínuo incentivo e compreensão.

A CAPES, Coordenação de Aperfeiçoamento de Pessoal de Nível Superior, pelo apoio financeiro dado à pesquisa.

A todos, os meus mais sinceros agradecimentos.

Erica Mitie Umakoshi 


\section{RESUMO}

UMAKOSHI, E. Avaliação de Desempenho Ambiental e Arquitetura Paramétrica Generativa para o Projeto do Edifício Alto. 238p. Tese (Doutorado). Faculdade de Arquitetura e Urbanismo, Universidade de São Paulo, São Paulo, 2014.

\section{Resumo:}

A pesquisa parte-se da hipótese de que critérios quantitativos e qualitativos de desempenho ambiental são definidores da expressão formal da arquitetura paramétrica do edifício alto. Pretende-se comprová-la com a criação e a aplicação de um método de projeto arquitetônico que relacione avaliação paramétrica de desempenho ambiental e a geração da forma. Essa hipótese surgiu da utilização sem critérios claros e precisos de desempenho ambiental na geração das formas dos edifícios altos, e vem de encontro ao conceito contemporâneo de conforto, da adaptação, das respostas específicas. O objetivo geral do trabalho é propor uma metodologia de projeto arquitetônico que relacione avaliação paramétrica de desempenho ambiental com critérios qualitativos e quantitativos e a geração da forma. Ou seja, compreender como os critérios de desempenho ambiental podem informar a geração da forma utilizando para isso, ferramentas paramétricas como no caso do Rhinoceros e o seu plug-in Grasshopper. A pesquisa apresenta os edifícios ícones de desempenho ambiental, discutindo os parâmetros de projeto, o desempenho real e as novas questões do conforto adaptativo. Além disso, são apresentados os critérios de desempenho utilizados para informar a metodologia de projeto paramétrico de geração da forma. Discute-se o papel da ventilação natural e das áreas envidraçadas no projeto do edifício alto. A questão do projeto paramétrico e generativo é introduzida, apresentando-se os principais conceitos, as tecnologias, os processos e as ferramentas. Por fim, o método resulta em um conjunto de diretrizes de projeto e critérios de desempenho, desenvolvidos para a formulação dessa proposta de avaliação, podendo ser visualizado, no final, em um modelo teórico do edifício alto para a cidade de São Paulo. Os produtos da tese foram: (I) critérios qualitativos e quantitativos de desempenho ambiental do edifício alto, (II) metodologia de projeto paramétrico informada por critérios ambientais, (III) solução projetual para edifícios de escritórios que utilizem ventilação e iluminação natural como estratégia principal para atingir o conforto dos usuários e reduzir o consumo de energia.

Palavras chave: Edifício Alto, Desempenho Ambiental, Projeto, Arquitetura Paramétrica, Arquitetura Generativa. 


\section{ABSTRACT}

UMAKOSHI, E. Environmental Performance Assessment and Parametric and Generative Architecture of the Tall Building Design. 238p. Thesis (Doctoral). Faculdade de Arquitetura e Urbanismo, Universidade de São Paulo, São Paulo, 2014.

\section{Abstract:}

The research starts from the hypothesis that quantitative and qualitative criteria for the environmental performance are defining the formal expression of parametric architecture of tall building. We intend to prove it with the creation and implementation of a method for architectural design that relates parametric evaluation of environmental performance and the generation of form. This hypothesis arose from the use without clear and precise criteria of the environmental performance in form generating of tall buildings, and comes against the contemporary concept of comfort, the adaptation of specific responses. The general objective of this work is to propose an architectural design methodology that relates parametric evaluation of environmental performance with qualitative and quantitative criteria and the generation of form. Understand how environmental performance criteria can inform the generation of form using, parametric tools as the Rhinoceros and its plug-in Grasshopper. The research presents icons of environmental performance buildings, discussing the design parameters, real performance and new issues of adaptive comfort. Moreover, the performance criteria used to inform the methodology of parametric design generation are presented. It discusses the role of natural ventilation and glazed areas in the design of tall building. The issue of parametric and generative design is introduced, presenting key concepts, technologies, processes and tools. Finally, the method results in a set of design guidelines and performance criteria developed to the formulation of this evaluation proposal, and could be viewed at the end, in a theoretical model of the tall building to the city of São Paulo. The products of the thesis were: (I) qualitative and quantitative criteria for environmental performance of tall building (II) parametric design methodology informed by environmental criteria, (III) design solution for office buildings using natural ventilation and daylight as the main strategy to achieve the user comfort and reduce energy consumption.

Keywords: Tall Building, Environmental Performance, Architectural Design, Parametric Architecture, Generative Design. 
LISTA DE FIGURAS

Figura 01 - Edifício do HSBC. Fonte: <www.fosterandpartners.com> acessado em novembro

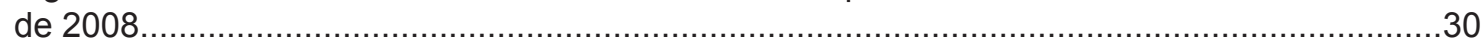

Figura 02 - Interior do edifício do HSBC. Fonte: <www.fosterandpartners.com> acessado em

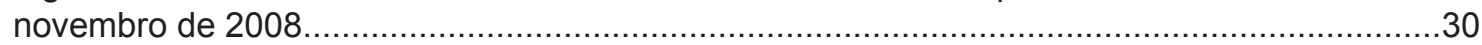

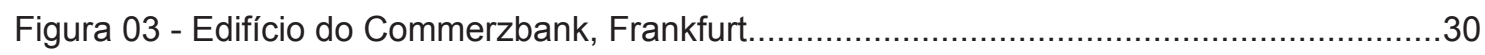

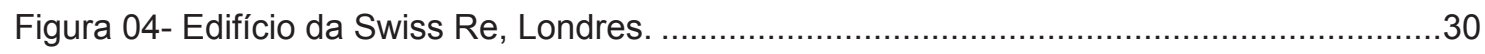

Figura 05 - Fig. 5: Edifício Heron Tower, Londres. Fonte: www.herontower.com, acessado em

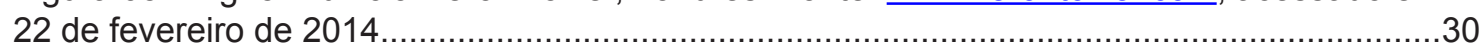

Figura 06 - 122 Leadenhall, Londres. Fonte: POWEL, 2006 ............................................ 30

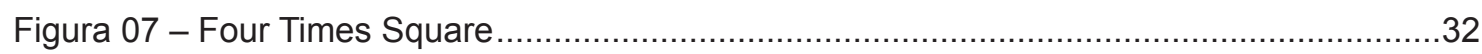

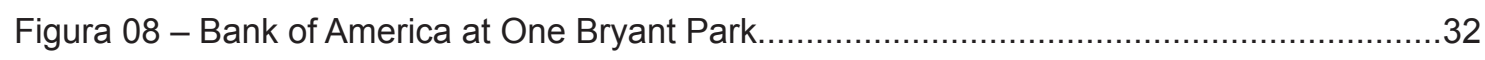

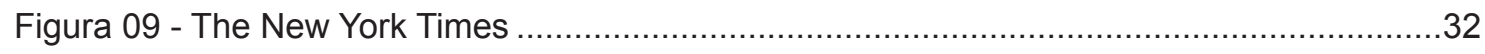

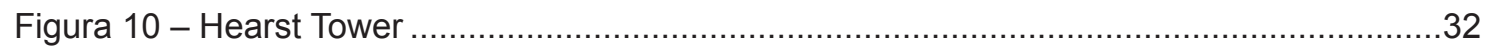

Figura 11 - BBK Bank (em construção), Bilbao, Espanha. Zaha Haddid. Fonte: www.evolo.us

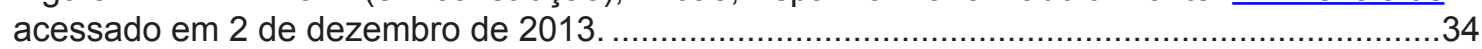

Figura 12 - Detalhe da fachada do BBK Bank (em construção), Bilbao, Espanha. Zaha Haddid.

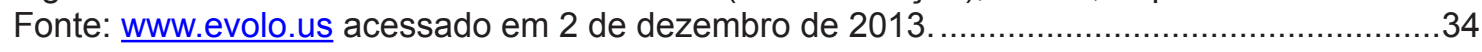

Figura 13 - SOHO Hailun Plaza, Shanghai, China. UNStudio. Fonte: www.evolo.us acessado em 20 de setembro 2013.

Figura 14 - Detalhe do painel da fachada do edifício SOHO Hailun Plaza, Shanghai, China.

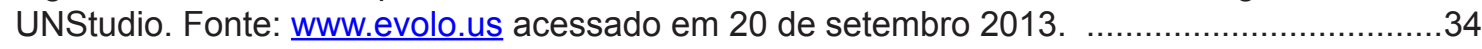

Fig. 15 - Estratégias para reduzir o consumo de energia nos edifícios....................................44

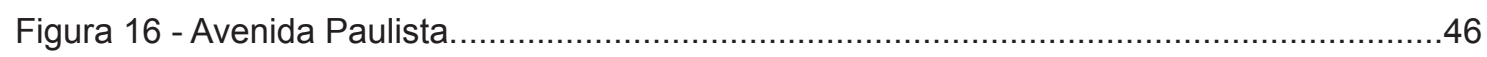

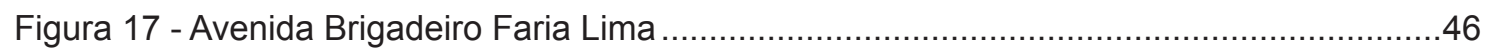

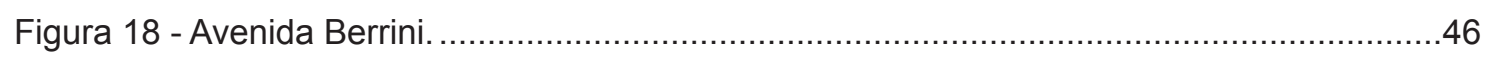

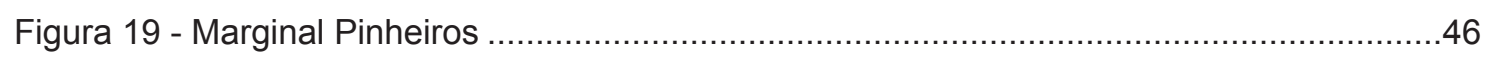

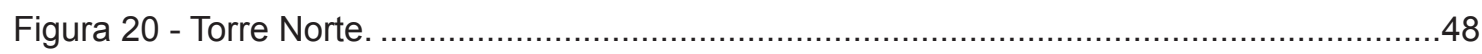

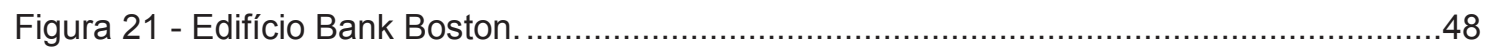

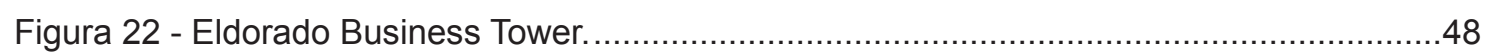

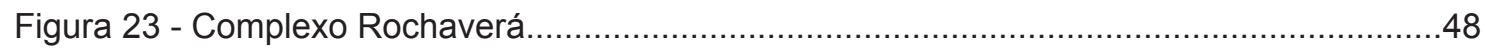

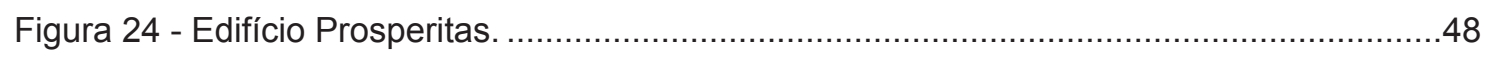

Figura 26 - Planta do edifício Commerzbank. Fonte: Fonte: <www.fosterandpartners.com>

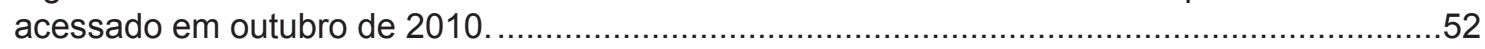

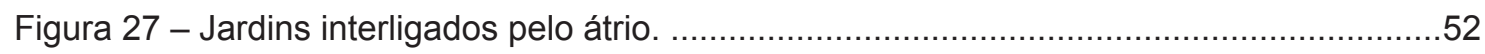

Figura 28 - Corte do edifício com os jardins interligados pelo átrio. Fonte: <www.

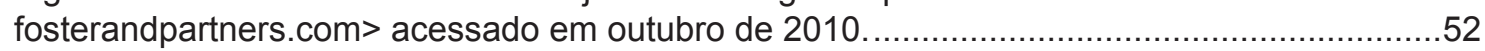

Figura 29: Esquema do zoneamento horizontal do pavimento tipo, com a indicação da 
setorização das três zonas de climatização e diferentes estratégias de ventilação. Fonte: Joana

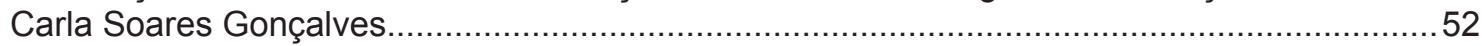

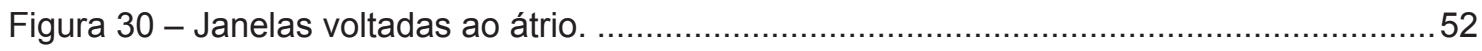

Figura 32 - Corte esquemático que demonstra a ventilação do escritório e o meio ambiente externo. Fonte: <www.fosterandpartners.com> acessado em outubro de 2010 ......................54

Figura 31 - Janelas da fachada.

Figura 33 - Corte esquemático da janela, identificando os seus componentes. Fonte: <www.

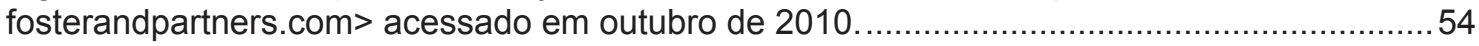

Figura 34 - Escritórios celulares voltados para a fachada. ....................................................... 54

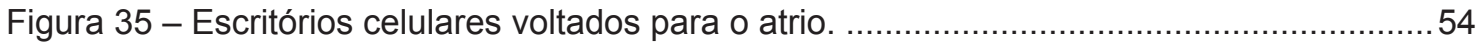

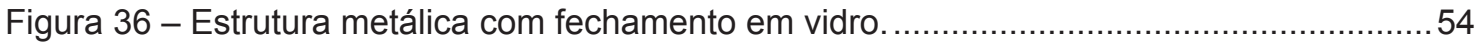

Figura 37 - Implantação. Fonte: <www.fosterandpartners.com> acessado em outubro de 2010.

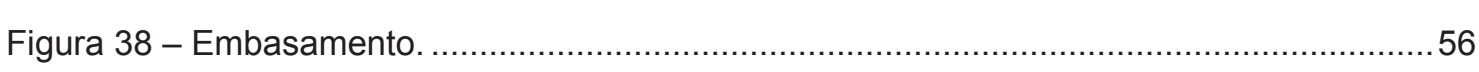

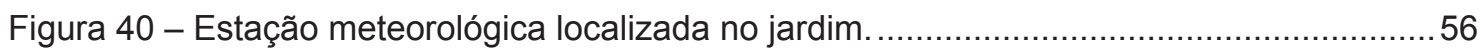

Figura 42: Planta do pavimento tipo, com a área de planta livre voltada para a fachada exterior, sendo essa resultante da junção entre a zona externa e a intermediária. Vale observar que a zona interna, voltada para o átrio e os jardins, continua separada. Fonte: GONÇALVES, UMAKOSHI, 2011.

Figura 41: Vista interna da área de escritórios resultante da junção dos escritórios celulares junto à fachada externa, em resposta ao acrescimo da ocupacao em 2008. Fonte: Keunjoo Lee, 2011.

Figura 39: Zona de conforto para o clima de Frankfurt am Main, na Alemanha (latitude $50 \mathrm{oN}$ ), criada a partir do calculo da temperatura operativa interna desejavel ("temperatura de conforto", OTn). Fonte: ASHRAE (2009).

Figura 43: Médias mensais do consumo de energia da sede do Commerzbank no período de 1999 a 2008, comparadas ao consumo em 2007 e 2008. Fonte: Peter Muschelknautz, Sede do Commerzbank .

Figura 44: Consumo mensal de energia eletrica em $\mathrm{kWh} / \mathrm{m} 2$ (desde1999), comparado a metas nacionais (alemãs) para o desempenho energético de edifícios de escritório (EnEV 2007).

Fonte: Peter Muschelknautz, Sede do Commerzbank

Figura 45: Médias mensais do consumo de energia térmica para o sistema de aquecimento e arrefecimento do edifício, durante o período de 1999 a 2008, comparadas as metas nacionais para o desempenho energético de edifícios de escritório (EnEV 2007).Fonte: Peter Muschelknautz, Sede do Commerzbank.

Figura 46 - Médias mensais do consumo de energia térmica exclusivamente para o aquecimento do edifício, durante o período de 1999 a 2008, comparadas ao consumo de 2007 e 2008. Fonte: Peter Muschelknautz, Sede do Commerzbank.

Figura 47 - Médias mensais do consumo de energia térmica exclusivamente para o arrefecimento do edifício, durante o período de 1999 a 2008, comparadas ao consumo de 2007 e 2008. Fonte: Peter Muschelknautz, Sede do Commerzbank

Figura 51 - Implantação. Fonte: < http://www.fosterandpartners.com> acessado em novembro de 2013. 
Figura 52 - Planta. Fonte: < http://www.fosterandpartners.com> acessado em novembro de 2013.

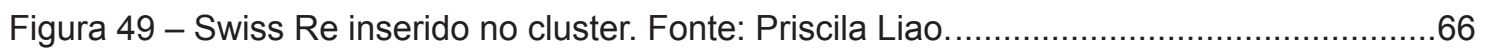

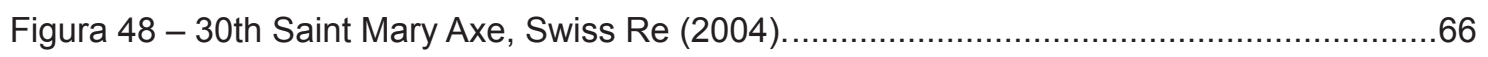

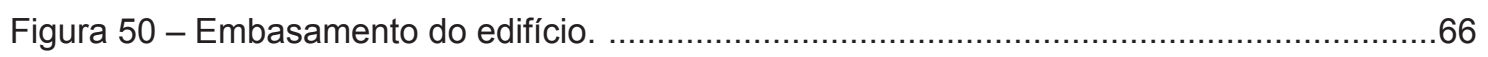

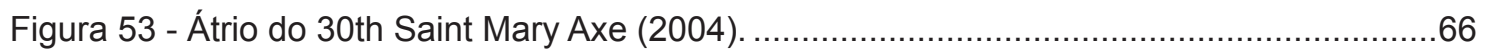

Figura 54 - Aberturas para ventilação dos átrios. Fonte: < http://www.fosterandpartners.com>

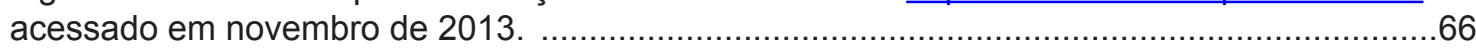

Figura 55 - 110 Bishopsgate Tower. Fonte: www.kpf.com acessado em setembro, 2012 _.......69

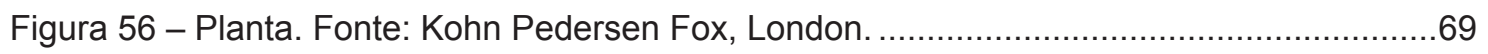

Figura 57 - Forma em U, com átrio central. Fonte: Kohn Pedersen Fox, London......................69

Figura 58 - Vilas de três pavimentos. Fonte: Kohn Pedersen Fox, London. .............................69

Figura 59 - 122 Leadenhall. Fonte: www.skyscrapercity.com, acessado em janeiro, 2014.......71

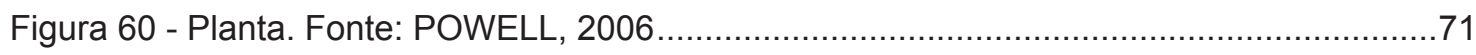

Figura 61 - Implantação. Fonte: POWELL, 2006 .............................................................

Figura 62 - Vilas verticais de sete pavimentos. Fonte: www.skyscrapercity.com, acessado em

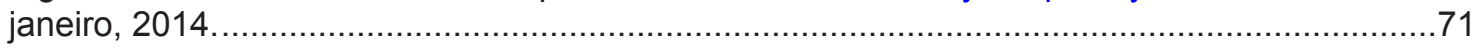

Fig. 63 - Selo LEED e pontuação. Fonte: adaptado de www.usgbc.org .................................79

Figura 64 - As 14 categorias da certificação AQUA. Fonte: AQUA (2010) .................................80

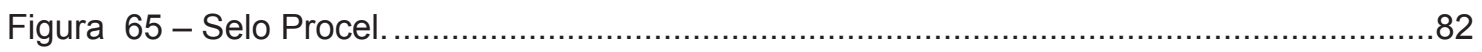

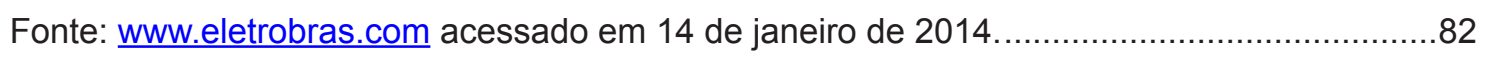

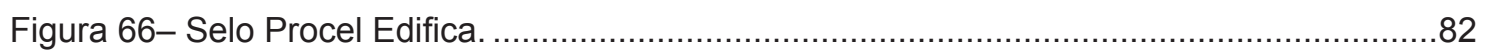

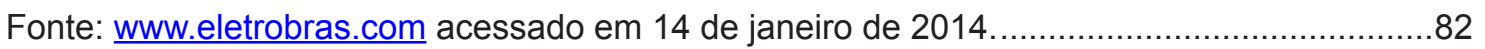

Figura 67 -: Modelo Adaptativo adotado de conforto térmico baseado no conceito de

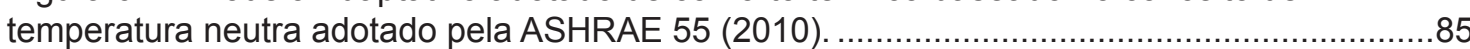

Figura 69 - Conforto adaptativo: elementos de controle dos usuários. Fonte COTTA, 2012 ...87

Figura 70 - Espaços internos do edifício sede do instituto Energy Resource Institute (TERI), em Bangalore, na Índia, projetado para ser naturalmente ventilado por todo o ano. Para atingir o conforto térmico os seus ocupantes fazem uso de ventiladores. Foto: Nikhil Deotarase ...........87

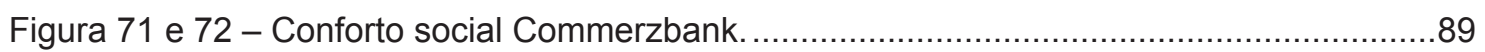

Figura 73 - O Edifício Martinelli (1929). Fonte: http://www.skyscrapercity.com/ acessado em 23 de janeiro de 2014.

Figura 74 - Temperatura média mensal na cidade de São Paulo. Fonte: Ecotect Weather Tool (Meteonorm 6.1).

Figura 75 - Diagnóstico climático para a cidade de São Paulo pelo método de Givoni. Fonte: Climaticus (Alucci, 2011)

Figura 76 - Média da radiação horizontal direta e difusa na cidade de São Paulo. Os dados de radiacao foram extraidos do banco de dados do programa Meteonorm 6.1 (Meteotest, 2009). 
Figura 77 - Rosa dos ventos para a cidade de São Paulo. Fonte: Ecotect Weather Tool (Meteonorm 6.1).

Figura 78 - Gráfico com a variação das temperaturas segundo os modelos de De Dear, Humphreys e Ashrae 55

Figura 79 - Oportunidades de adaptação para atingir o conforto e o seu efeito na temperatura.

Fonte: Baker, 2009 apud Conceição, 2010.

Figura 80 - Comparação entre as temperaturas de conforto e depois das medidas adaptativas.

Figura 81 - Valores mínimos para a velocidade do ar correspondendo a $80 \%$ e $90 \%$ de aceitação dos usuários. Fonte: Lamberts et al, 2010

Figura 82: Tipologias de janelas contempladas nas simulações de ventilação. Fonte: CIBSE, 1999.

Figura 83- O Edifício CBI Esplanada é extremamente marcante na paisagem do Vale do Anhangabaú.

Figura 85 - Dimensões do edifício, dos ambientes no $15^{\circ}$ pavimento e do átrio central.......... 110

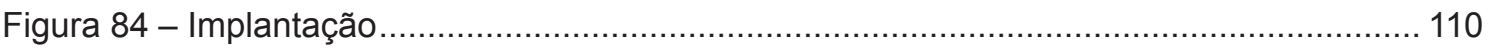

Figura 86 - Dois ambientes analisados no $15^{\circ}$ pavimento ....................................................... 112

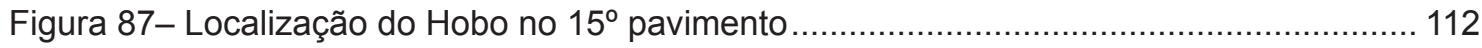

Figura 88 - Localização do Hobo no $15^{\circ}$ pavimento perto da janela ...................................... 112

Figura 92- Localização do Hobo no $26^{\circ}$ pavimento............................................................ 112

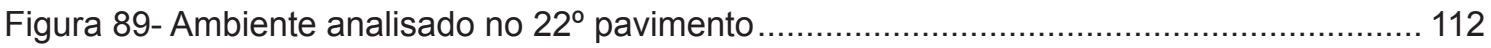

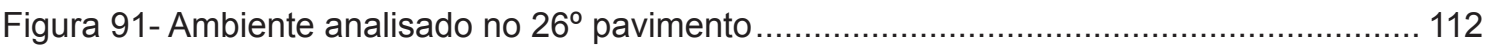

Figura 90 - Localização do Hobo no $22^{\circ}$ pavimento ............................................................... 112

Figura 93- Dados de temperatura extraídos do site do IAG..................................................... 113

Figura 94 - Dados de radiação direta extraídos do site do IAG. .......................................... 113

Figura 95- Dados de radiação difusa extraídos do site do IAG................................................ 113

Figura 96- Dados de velocidade do vento extraídos do site do IAG. ...................................... 113

Figura 97- Dados de umidade extraídos do site do IAG........................................................ 113

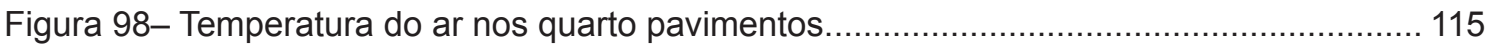

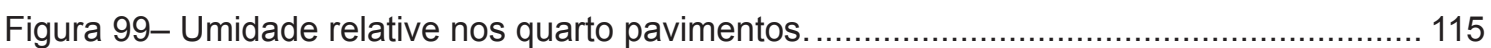

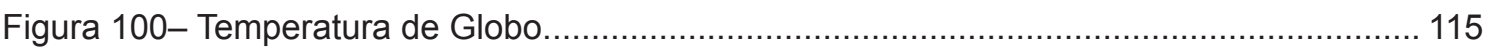

Figura 102- Tarja preta colocada no vidro para obter a temperatura superficial do vidro ........ 116

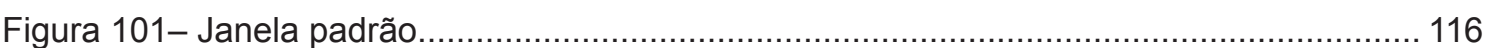

Figura 103, 104, 105 - Imagem do termovisor da área do escritório, do vidro da janela e do

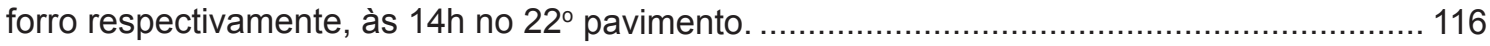

Figura 107- Localização dos pontos onde foram realizadas as medições de iluminação natural no $22^{\circ}$ pavimento

Figura 108 - Localização do luxímetro num dos postos de trabalho no $22^{\circ}$ pavimento (Ponto 1) 
Figura 109- profundidade do $22^{\circ}$ pavimento onde foram tomadas as medidas de iluminação natural.

Figura 110 - medição de iluminação no $22^{\circ}$ pavimento em 4 pontos. 118

Figura 111- Níveis de iluminação natural medidos pelos hobos do dia 3 até o dia 9 de maio.

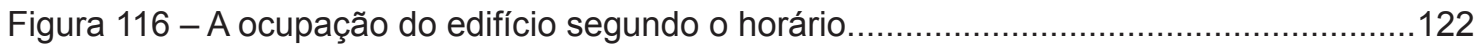

Figura 117- A utilização dos equipamentos segundo o horário..............................................122

Figura 118 - O impacto da área envidraçada na carga térmica de resfriamento

Figura 119- O impacto do sombreamento na redução da carga térmica $\left(\mathrm{kWh} / \mathrm{m}^{2}\right.$.ano) de resfriamento num WWR de 50

Figura 120 - O impacto do sombreamento na redução da carga térmica ( $\mathrm{kWh} / \mathrm{m} 2$.ano) de resfriamento num WWR de 90.

Figura 121 - O impacto do sombreamento da radiação direta e difusa na redução da carga térmica $(\mathrm{kWh} / \mathrm{m} 2$.ano) de resfriamento num WWR de 50, 70 e 90.

Figura 122 - O impacto do sombreamento e da massa exposta e ventilação noturna na redução da carga térmica ( $\mathrm{kWh} / \mathrm{m} 2$.ano) de resfriamento num WWR de 50.

Figura $123-\mathrm{O}$ impacto do aumento na temperatura de setpoint do ar condicionado de $24^{\circ} \mathrm{C}$ para $25^{\circ} \mathrm{C}, 260 \mathrm{C}$ e $28^{\circ} \mathrm{C}$ na redução da carga térmica $\left(\mathrm{kWh} / \mathrm{m}^{2}\right.$.ano) de resfriamento num WWR de 90.

Figura 124 - Simulação térmica de uma semana típica de verão com janelas abrindo 30\%. Fonte: Bentley Tas.

Figura 125- Simulação térmica de uma semana típica de inverno com janelas abrindo 10\%.

Fonte: Bentley Tas.

Figura 126 - Sistema Linear de projeto corrente no mercado. Fonte: Thuesen et al, 2010 ...137

Fig.127: Esquema de projeto dentro do conceito de modelagem BIM. Fonte: Gao et al, 2010.

Fig.128. - Gráfico com os valores agregados a cada fase do projeto. Fonte: Eastman et al, 2008.

Fig. 129- Projeto iSaw desenvolvido a partir de algoritmos. Fonte: http://www.kokkugia.com/

Fig. 130 - Knowledge Center no Masdar City. Fonte: <masdarcity.ae/en/64/built-environment/ masdar-institute-campus > acessado em janeiro 2014 ........................................................... 145

Fig. 131- Edifício Sun Rise Zaha Haddid.

Fonte: http://www.evolo.us/architecture/sunrise-tower-in-kuala-lumpur-zaha-hadid/ acessado

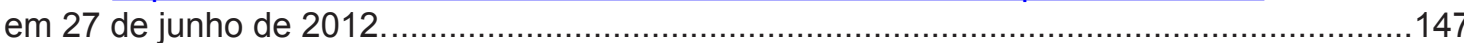

Fig. 132- edifício Swiss Re.

Figura 133: Simulacao da iluminacao natural na camara do Senado, com resultados do Fator de Luz Natural (Daylight Factor), revelando uma boa distribuicao homogenea da luz, medidos no plano de trabalho. Fonte: BDSP Partnership

Figura 134- Grashopper.... 


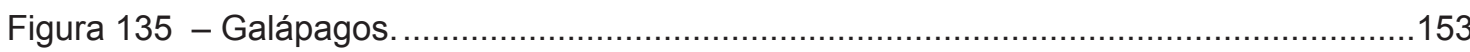

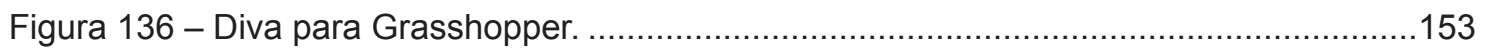

Figura 139 - Modelo gerado no software Revit e a simulação de insolação no software Ecotect. . 153

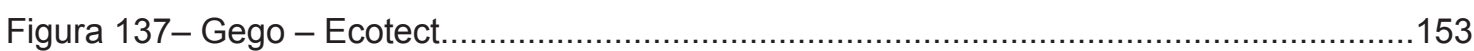

Figura 138: Estudos de insolação realizados no Ecotect utilizando apenas as volumetrias do

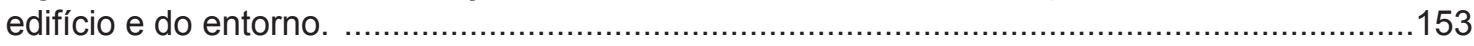

Figura 140- Localização da cidade de Chennai, em Tamil Nadu, Índia. (Fonte: Google.com) 161

Figura 141- Temperatura média mensal de bulbo seco. (Fonte: Meteornorm, v6.1) ...............161

Figura 142- Processo de elaboração da forama. (Fonte: Bhatla, 2011)..................................161

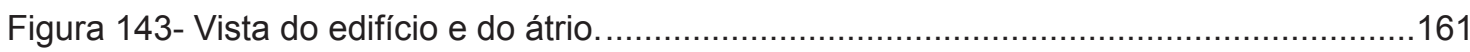

Figura 144- Hierarquia das áreas comuns e privativas nas vilas.........................................161

Figura 147 - Corte com as temperaturas de um dia típico de verão somente utilizando a

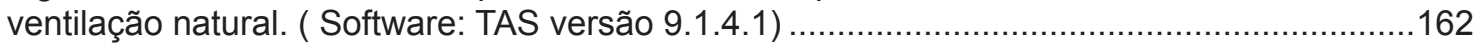

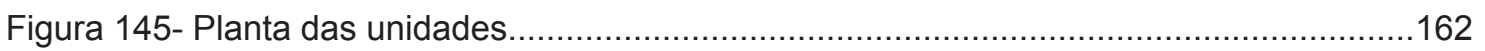

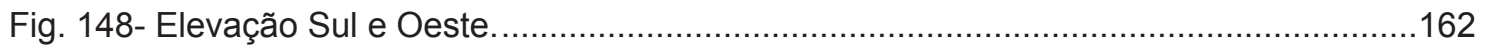

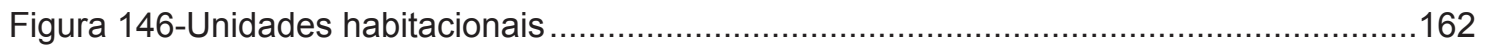

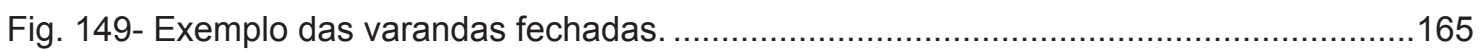

Fig. 150- Localização da cidade de Seoul, Coréia do Sul. Latitude: 37,6 Longitude: 127 (Fonte: google.com).

Fig. 151- Temperatura, radiação e conforto na cidade de Seoul. (Fonte: Meteornorm, v6.1)..165

Figura 153 - Estudo de geração da forma: rotação, inclinação e corte...................................165

Fig. 152- Estratégias para a redução no consumo de energia. (Fonte: PAEK, 2011) ..............165

Figura 154 - Edifício após modelagem de corte e inclinação.................................................166

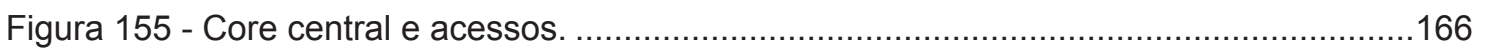

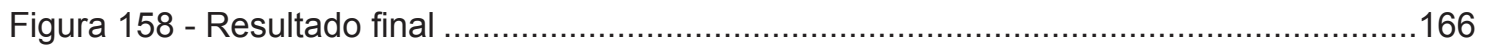

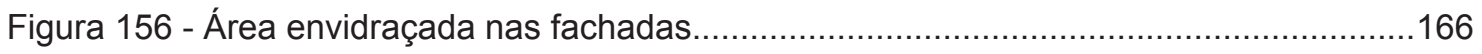

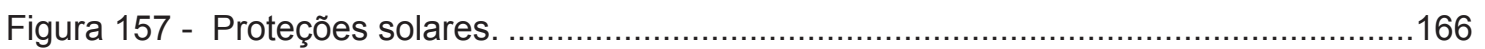

Figura 159 - Nova organização dos espaços internos de um edifício de escritório. ................170

Figura 160 - Temperatura e radiação na cidade de Santiago, Chile. (Fonte: Meteornorm, v6.1)

Figura 161 - Simulação de iluminação natural com diferentes profundidades. (Fonte:

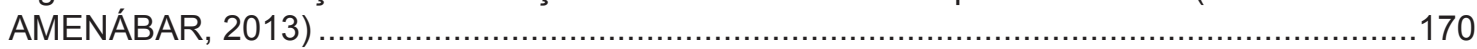

Figura 162 - Simulação de iluminação natural com usos. (Fonte: AMENÁBAR, 2013) ............170

Figura 164- Planta dividida em blocos separadas por atividades. (Fonte: AMENÁBAR, 2013)

Figura 163 - Doze diferentes usos divididos em quatro áreas distintas. (Fonte: AMENÁBAR, 2013) 
Figura 165- Fissuras e aberturas laterais na fachada oeste. (Fonte: AMENÁBAR, 2013) ......172

Figura 166- Imagem do Grasshopper usado na distribuição dos elementos da fachada. (Fonte: AMENÁBAR, 2013).

Figura 167- Fachada norte com os elementos distribuídos na fachada. (Fonte: AMENÁBAR, 2013)

Figura168- Vista sudoeste do edifício. (Fonte: AMENÁBAR, 2013).....................................173

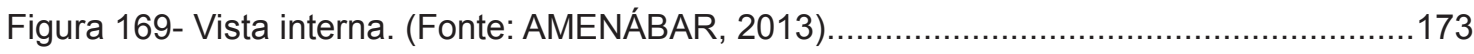

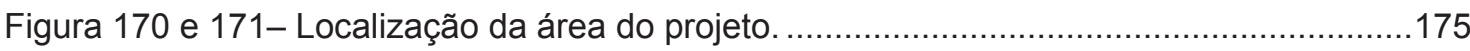

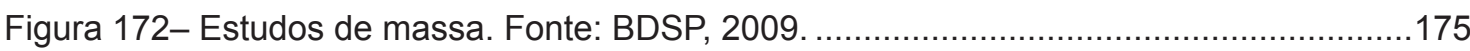

Figura 173 - Estudos para planta e localização do core de elevadores. Fonte: BDSP, 2009. 175

Figura 174 - Estudos analíticosde estratégias para o conforto, fase 1. Fonte: BDSP, 2009....175

Figura 178 e 179- Estudos analíticos de iluminação e ventilação natural, fase 3. Fonte: BDSP, $2009 .$.

Figura 175- Estudos analíticos de iluminação, fase 2. Fonte: BDSP, 2009..........................176

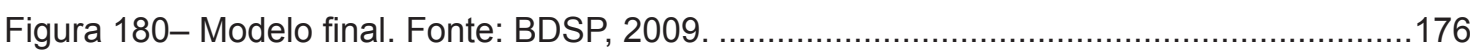

Figura 176 - Estudos analíticos de porcentagem do tempo em que se pode usar ventilação natural dependendo da profundidade da planta, fase 3. Fonte: BDSP, 2009. .......................176

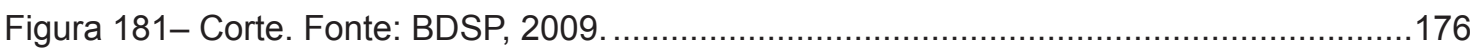

Figura 177 - Estudos analíticos de consumo de energia dependendo da estratégia utilizada,

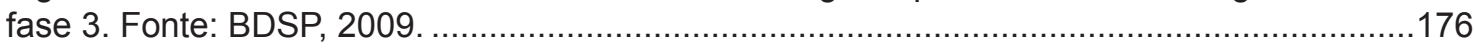

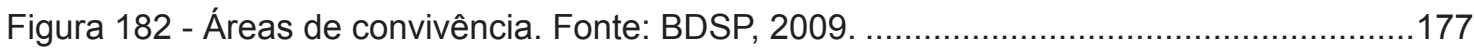

Figuras 183 e 184 - Desenho da forma triangular inicial sobre tecido elástico........................180

Figuras 185 e 186 - Padrão geométrico gerado a partir da forma triangular. . ........................180

Figuras 187 e 188 - A esquerda, forma gerada com estrutura externa e a direita, tripé com

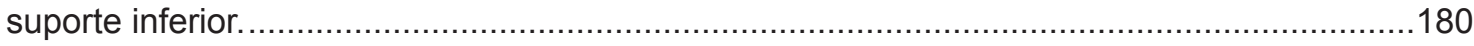

Figura 189 - Teste no modelo físico para as aberturas. .................................................. 180

Figura 190 - Modelo digital cortado à laser sobre um tecido elástico. .................................183

Figura 193 - Vista externa da composição dos componentes da fachada. Modelo eletrônico gerado pela combinação dos programas Rhino e Grasshopper. ...........................................183

Figura 195 - Corte na CNC da maquete do edifício projetado. ...............................................183

Figura 191 - Aberturas no tecido devido ao tensionamento do mesmo. ..................................183

Figura 194 - Modelo eletrônico do edifício alto, com a indicação do angulo de inclinação dos planos verticais, objetivando o autos sombreamento parcial da forma....................................183

Figura 196 - Modelo físico do novo edifício alto, resultado do um processo paramétrico de

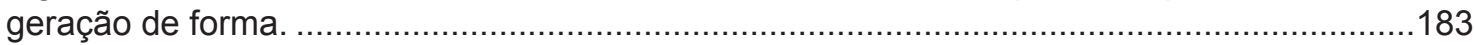

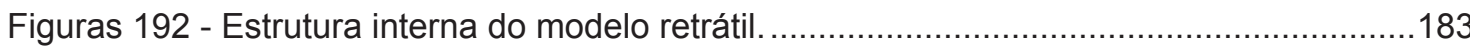

Figura 198 - Simulação do desempenho da iluminação natural no pavimento tipo às 9 horas no verão. 


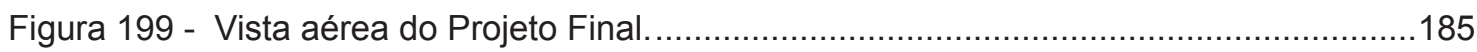

Figura 200- Processo de projeto.

Figura 201 - Imagem que representa as funções e as opções de vedação para a fachada:

opaca, translúcida e transparente. (AMENÁBAR, 2013).

Figura 202 - Imagem que representa os passos para definir qual elemento excluir da fachada utilizando funções como "maior que" e "menor que" para os valores. ....................................196

Figura 204 - Forma Elíptica, jardins, recorte na fachada e o core de elevadores..................198

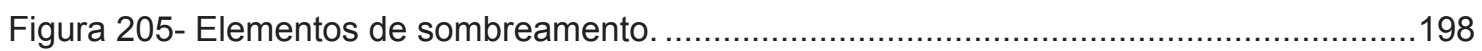

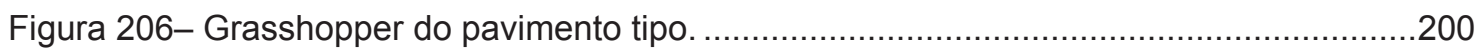

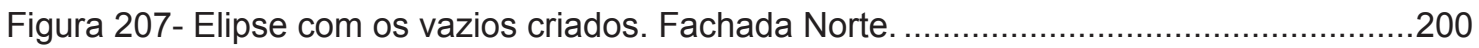

Figura 209 - Modelo sendo analisado no Ecotect através do link Geco do Grasshopper........201

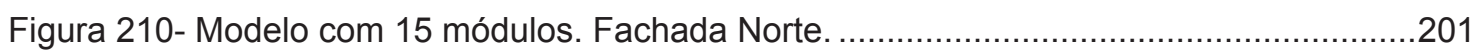

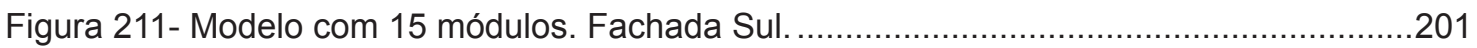

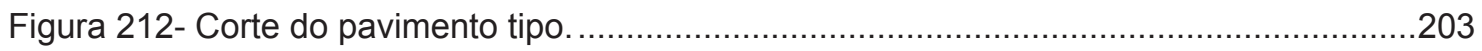

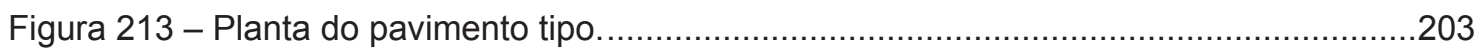

Figura 214 - Modelo da treliça triangular com dois tipos de abertura. ....................................203

Figura 216 - Componentes desenvolvidos: Norte, Sul, Leste e Oeste. .................................204

Figura 217- Modelo simplificado no Ecotect, fachada Sul 9h, verão. .....................................204

Figura 215- Penetração de sol através do painel de treliça triangular. ....................................204

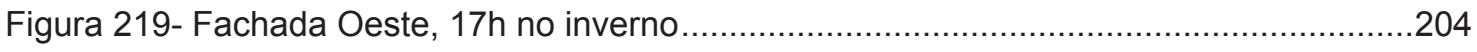

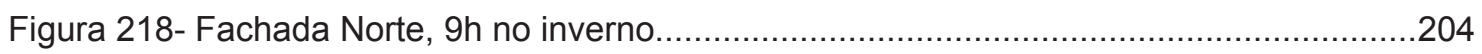

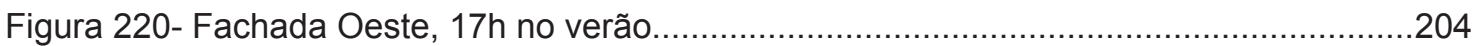

Figura 221 e 222- Componentes nas fachadas Leste e Norte, e nas fachadas Norte e Oeste.

Figura 223 e 224- Componentes nas fachadas Sul e Leste, e nas fachadas Oeste e Sul. .....205

Figura 225 e 226 - Penetração de sol na fachada Sul as 9h e 17h respectivamente..............205

Figura 228 - Nova distribuição do componente quadrado na fachada Norte. .........................206

Figura 229- Elemento de sombreamento vertical na fachada Sul, Leste e Oeste. .................206

Figura 230 - Grasshopper do componente quadrado na fachada Norte...............................207

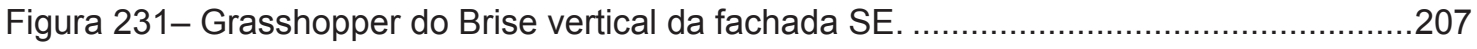

Figura 233 - Desempenho luminoso em DF do segundo pavimento. ....................................209

Figura 234- Gráfico de distribuição luminosa no pavimento................................................209

Figura 235 - Desempenho luminoso em lux do segundo pavimento, às 9h no verão com o céu

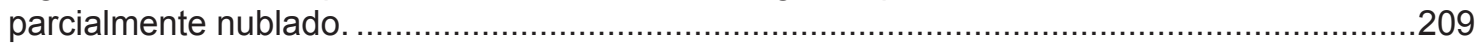

Figura 232- Desempenho luminoso em lux do segundo pavimento. ....................................209

Figura 236 - Desempenho luminoso em lux do segundo pavimento, no verão com o céu parcialmente nublado em quatro horários distintos. 
Figura 238- Desempenho luminoso em lux do segundo pavimento, no inverno com o céu parcialmente nublado em quatro horários distintos.

Figura 237- Desempenho luminoso em lux do segundo pavimento, às 9h no inverno com o céu parcialmente nublado.

Figura 239- Penetração de sol pelas fachadas no verão às 9h, 13h, 15h e 17h. ...................210

Figura 240- Penetração de sol pelas fachadas no inverno às 9h, 13h, 15h e 17h. ................ 211

Figura 241- Penetração de sol pelas fachadas nos equinócios às 9h, 13h, 15h e 17h. ….... 211

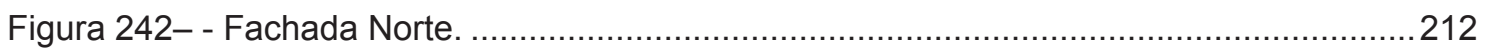

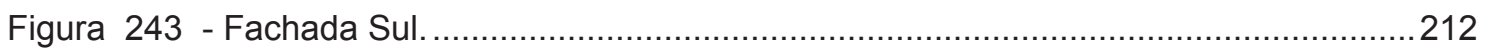

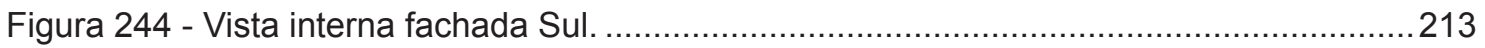

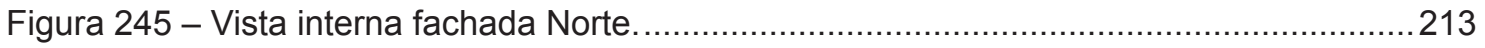


SUMARIO

$\begin{array}{ll}\text { DEDICATÓRIA } & 1\end{array}$

AGRADECIMENTOS 3

$\begin{array}{lr}\text { RESUMO } & 5\end{array}$

$\begin{array}{ll}\text { ABSTRACT } & 7\end{array}$

$\begin{array}{ll}\text { Introdução } & 27\end{array}$

Capítulo 1: O Desempenho Ambiental e a Eficiência Energética dos Edifícios Altos 43

Introdução 43

1.1 Desempenho Energético e Benchmarks 45

1.2 São Paulo 46

1.3 Precedentes de uma arquitetura ambiental 51

1.3.1Commerzbank (1998, Frankfurt, Alemanha) 51

1.3.2 30th Saint Mary Axe (2004, Londres, Inglaterra) 64

1.3.3 110 Bishopsgate (Heron Tower), (2011, Londres, Inglaterra) 67

1.3.4 122 Leadenhall Street (em construção, Londres) 70

1.4 Considerações finais $\quad 72$

$\begin{array}{ll}\text { Capítulo } 2 \text { - Critérios de desempenho } & 77\end{array}$

$\begin{array}{ll}\text { Introdução } & 77\end{array}$

2.1 Certificações - Panorama brasileiro 78

2.2 Conforto adaptativo 83

2.3 Critérios Qualitativos(CQL) e Quantitativos (CQT) de Desempenho 90

$\begin{array}{ll}\text { 2.3.1 Critérios Qualitativos (CQL) } & 91\end{array}$

$\begin{array}{ll}\text { 2.3.2 Critérios Quantitativos (CQT) } & 93\end{array}$

2.4 Considerações Finais $\quad 94$ 
Capítulo 3 - O Papel da Ventilação no Projeto do Edifício Alto de Melhor Desempenho para a Cidade de São Paulo

Introdução

3.1 Contexto Climático 100

3.2 Considerações sobre áreas envidraçadas: Iluminação e Ventilação 105

3.3 O Edifício CBI-Esplanada 108

3.3.1 Localização

3.3.3 Desempenho da Iluminação Natural no $22^{\circ}$ pavimento

3.3.4 Considerações sobre a ocupação

3.4 Estudos Analíticos: simulação de desempenho térmico 120

$\begin{array}{ll}\text { 3.4.1 Orientação e WWR } & 124\end{array}$

$\begin{array}{ll}\text { 3.4.2 Sombreamento } & 125\end{array}$

3.4.3 Massa Térmica, Ventilação e Temperatura de conforto 127

$\begin{array}{lr}3.5 \text { Considerações Finais } & 130\end{array}$

Capítulo 4 - Estudos de Forma: Novos Processos de Projeto - a Metodologia Bim, a Arquitetura Paramétrica e Algorítmica

Introdução:

4.1 BIM e a Arquitetura:

4.2 Em busca da forma: Arquitetura Paramétrica e Algorítmica 140

4.3 Arquitetura baseada em desempenho ambiental e energético: 144

$\begin{array}{ll}\text { 4.4 Processos analíticos de avaliação de desempenho } & 148\end{array}$

4.5 Ferramentas: 152

$\begin{array}{ll}\text { 4.6 Considerações Finais } & 155\end{array}$

Capítulo 5 - Abordagem Conceitual e Estratégia Metodológica para o Projeto do Edifício Alto de Melhor Desempenho Ambiental - Combinando Estudos Analíticos e Processos 
Generativos de Forma 159

Introdução

5.1 Exercícios de Projeto do Programa de Mestrado Sustainable Environmental Design, da Architectural Association School of Architecture (SED - AA)

5.1.1 Tall Communities: Passive urban housing for the Tropics - Suraksha Bhatla (BHATLA, 2011)

5.1.2 Environmental Performance of adaptive building design: urban housing in Seoul Korea - Jeewon Paek (PAEK, 2011)

5.1.3 Rethinking office building typology in continental mediterran climate (Tomás Swett Amenábar, 2013) 168

5.2 Projeto Viol 173

5.2.1 A proposta para o concurso de projeto

5.2.2 Elaboração da forma: estudos analíticos pró-projeto

5.3 Projeto Paramétrico e Prototipagem Rápida: um Exercício de Projeto para a Fachada de um Edifício Alto, AA Visiting School, São Paulo, 2011

5.3.2 Desenvolvimento do componente

5.3.3 O Edifício: modelagem e prototipagem digital 184

5.4 Considerações Finais

Capítulo 6 - Aplicação Metodológica de Intervenção Projetual e Avaliação de Desempenho de um Estudo de Caso na Cidade de São Paulo (Projeto)

Introdução

6.1 Método de projeto

6.1.1 Procedimentos analíticos

6.1.2 geração de forma - com ênfase no projeto do edifício alto 
6.2.3 Desenvolvimento do componente 202

6.2.4 Simulação de lluminação 208

$\begin{array}{ll}\text { 6.2.5 Projeto final } & 211\end{array}$

6.3 Considerações finais 213

$\begin{array}{ll}\text { Capítulo 7: Considerações Finais } & 217\end{array}$

$\begin{array}{ll}\text { 7.1 Conclusões } & 217\end{array}$

$\begin{array}{ll}\text { 7.1.1 Síntese dos capítulos } & 217\end{array}$

7.1.2 Validação da Hipótese 230

$\begin{array}{ll}\text { 7.1.3 Produtos da Pesquisa } & 230\end{array}$

$\begin{array}{ll}\text { 7.2 Considerações finais } & 231\end{array}$

$\begin{array}{ll}\text { 7.3 Desdobramentos Futuros } & 232\end{array}$

REFERÊNCIAS BIBLIOGRÁFICAS $\quad 237$ 
Introdução 
Avaliação de Desempenho Ambiental e Arquitetura Paramétrica Generativa para o Projeto do Edifício Alto 


\section{Introdução}

A presente pesquisa dá continuidade ao trabalho iniciado na dissertação de mestrado da autora, intitulado "Uma Visão Crítica do Edifício Alto sob a ótica da Sustentabilidade"1, cujo objetivo principal foi a elaboração de uma visão crítica sobre os edifícios altos apresentados, nas últimas duas décadas, como sustentáveis. Destacaram-se características do projeto arquitetônico em relação ao desempenho ambiental, bem como conceitos e definições de projeto e sustentabilidade, recursos tecnológicos, conforto ambiental e critérios de desempenho ambiental do edifício, como, por exemplo, efeitos de sombra e vento no entorno. Foram retratadas, ainda, questões energéticas e considerações globais sobre o tema da arquitetura e da sustentabilidade.

Do ponto de vista da arquitetura e da engenharia, o edifício alto pode ser definido como aquele que necessita de um alto nível tecnológico para funcionar apropriadamente, ou seja, características como forma, circulação vertical e sistemas funcionam diferentemente quando comparados a edifícios de menor altura (GONÇALVES, UMAKOSHI, 2011).

Com o desenvolvimento tecnológico do século 20, os edifícios alcançaram a altura de 20 pavimentos. À partir dessa altura, a circulação vertical precisa ser diferenciada e, por esse motivo, durante muito tempo, tanto na Europa como nos EUA, o limite de 20 pavimentos foi tido como definição de edifício alto.

A última definição do CTBUH (www.ctbuh.org) estabelece que não é o número de pavimentos e nem a altura que importam para se definir um edifício alto e, sim, se o projeto, o uso e a operação são diferenciados devido à altura.

Já sob a perspectiva urbana, um edifício é considerado alto quando comparado ao seu entorno construído, ou seja, um edifício de 20 pavimentos na cidade de Nova lorque ou em Chicago não seria considerado alto, tendo em vista que o gabarito nessas cidades são respectivamente de 40 e 60 pavimentos.

Dessa forma, o conceito de edifício alto sustentável adotado neste trabalho engloba os seguintes aspectos: ser parte de um planejamento urbano desenvolvido para reorganizar e intensificar a densidade urbana; estar localizado nas proximidades de

1 Pesquisa realizada com auxílio financeiro do Conselho Nacional de Desenvolvimento Científico e Tecnológico (CNPq). 
Avaliação de Desempenho Ambiental e Arquitetura Paramétrica Generativa para o Projeto do Edifício Alto

núcleos de transporte público; evitar o comprometimento da qualidade ambiental dos espaços públicos da cidade, incluindo calçadas, ruas, praças e áreas verdes, assim como a insolação de edifícios vizinhos, por efeito de sombreamentos; apresentar níveis satisfatórios de iluminação natural nos ambientes internos em $80 \%$ do tempo de ocupação; objetivar um consumo de energia durante a vida útil do edifício que seja direcionado à emissão zero de CO2 (GONÇALVES, 2003).

Grandes cidades norte-americanas, como Nova lorque e Chicago, começaram a desenvolver os seus modelos de edifícios altos no final do século 19. Os primeiros edifícios foram balizados pelas tecnologias da época, que restringiam tanto a altura, dadas as limitações de estrutura e acessibilidade, como a profundidade, uma vez que a iluminação natural era escassa (WILLIS, 1995). Contudo, foi à partir da Segunda Guerra Mundial que passaram a ser construídas e difundidas, pelo mundo, as torres seladas de vidro, edifícios altos conhecidos como estilo internacional. As novas tecnologias, como o ar-condicionado, os elevadores de alta velocidade, o aço e a pele de vidro permitiram o incremento da altura e da profundidade das plantas, isolando o edifício do ambiente externo (FRAMPTON, 1997). Esse modelo, em diversas cidades do mundo, passou, então, a ser exportado e copiado por se tratar de um ícone da arquitetura contemporânea, que simbolizava a pujança econômica da época.

No entanto, a crise energética dos anos 1970 chamou a atenção do mundo para a tipologia do edifício alto selado, que era um grande consumidor de energia, surgindo como solução, nos anos 1980, os edifícios chamados inteligentes, cuja eficiência dos sistemas prediais e a redução do consumo energético concentrou a atenção dos projetistas e engenheiros (ANDRADE, 2000). Vale ressaltar, entretanto, que a eficiência dos sistemas prediais, ainda que tenha reduzido o consumo energético, não chegou a otimizar as estratégias passivas de ventilação e iluminação natural. Em decorrência disso, a arquitetura, mesmo com o aprimoramento das tecnologias, continuou, na grande maioria dos casos, sendo a mesma, revelando-se comum o projeto e a construção de edifícios de plantas profundas, de pé-direito baixo, de fachadas de vidro e climatizados artificialmente em, praticamente, $100 \%$ do tempo de operação.

Verifica-se, ademais, que as mudanças na arquitetura começaram a ganhar importância 
na agenda internacional dos projetos com a apresentação do Relatório Brundtland (1987) e da Agenda 21 (1992), que trataram das questões de sustentabilidade como a grande preocupação do século 21 , destacando as múltiplas relações do tripé econômicosocial-ambiental. É nesse momento, a partir da década de 1990, que os escritórios de arquitetura, principalmente os europeus, passam a, de fato, dar maior importância às questões ligadas ao impacto e ao desempenho ambiental dos edifícios altos, surgindo, assim, uma nova geração de edifícios altos com preocupações ambientais.

Cabe lembrar que o destacado desempenho ambiental, nessa última geração de edifícios altos, sustentáveis, verdes ou ambientalmente corretos, alia questões de energia ao meio ambiente, fator esse determinante na redução do consumo energético e também do impacto ambiental. Somam-se a isso questões de conforto ambiental desejadas e exigidas pelos usuários desses edifícios, que incluem conforto térmico, acústico, luminoso e ergonômico. Destaca-se como um ícone da mudança no universo da arquitetura de grandes edifícios o projeto do Hong Kong and Shanghai Bank Headquarters (1986), em Hong Kong (fig. 01 e 02), primeiro edifício alto com considerações ambientais e que utiliza o átrio central como estratégia para iluminação e ventilação natural, tendo sido desenvolvido pelo escritório de arquitetura Norman Foster and Partners. Vale notar, porém, que foi com o projeto do edifício Commerzbank (1998), em Frankfurt (fig. 03), que a equipe Norman Foster and Partners conseguiu otimizar estratégias passivas de iluminação e ventilação natural, as quais, utilizadas na maior parte do período de ocupação do edifício, possibilitaram atingir um alto desempenho ambiental baseado em estratégias passivas sem precedentes (DAVIS, 1997).

Observa-se, ainda, que as mudanças na arquitetura do edifício alto em prol do desempenho ambiental estão ocorrendo em maior número e com melhor qualidade na Europa. Essa nova geração de edifícios altos com preocupações ambientais, que começou a ser desenvolvida no final dos anos 1990, consolida-se, atualmente, com a construção de novos edifícios, como são os casos da Swiss Re (fig. 04), da Heron Tower (fig. 05) e da 122 Leadenhall (fig. 06), todos em Londres.

Londres, Nova lorque e São Paulo são cidades que se destacam por serem grandes centros financeiros e por concentrarem as discussões acerca de edifícios altos. Da 
Avaliação de Desempenho Ambiental e Arquitetura Paramétrica Generativa para o Projeto do Edifício Alto

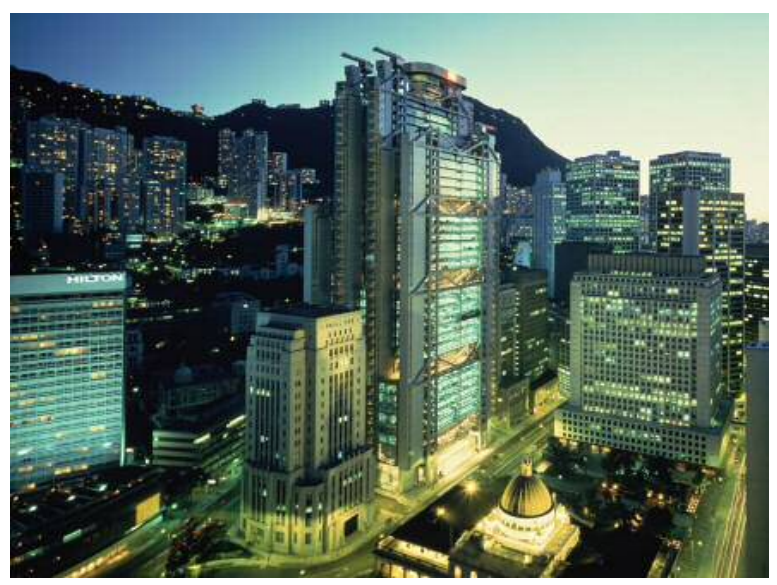

Figura 01 - Edifício do HSBC. Fonte: <www. fosterandpartners.com> acessado em novembro de 2008

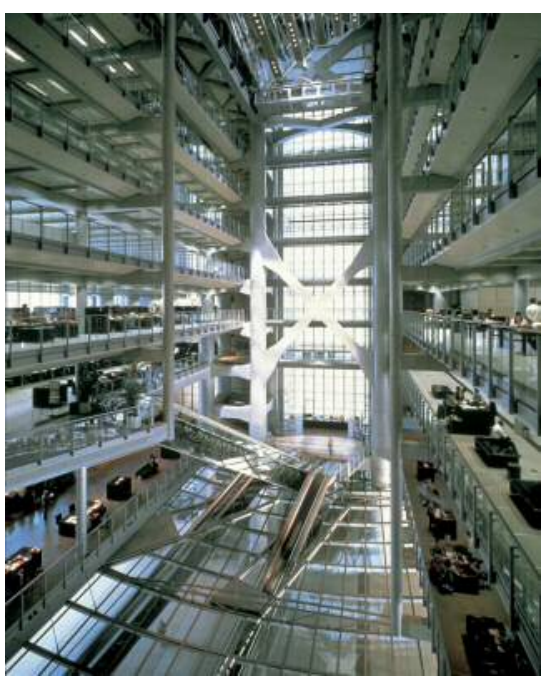

Figura 02 - Interior do edifício do HSBC. Fonte: <www.

fosterandpartners.com> acessado em novembro de 2008

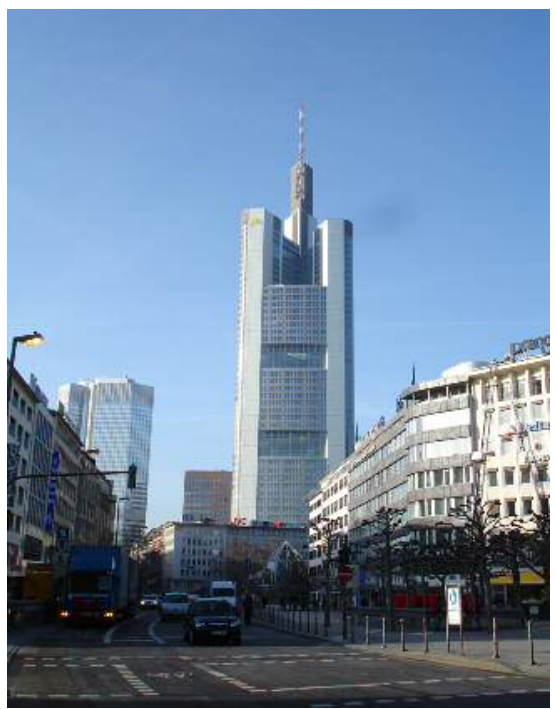

Figura 03 - Edifício do Commerzbank, Frankfurt

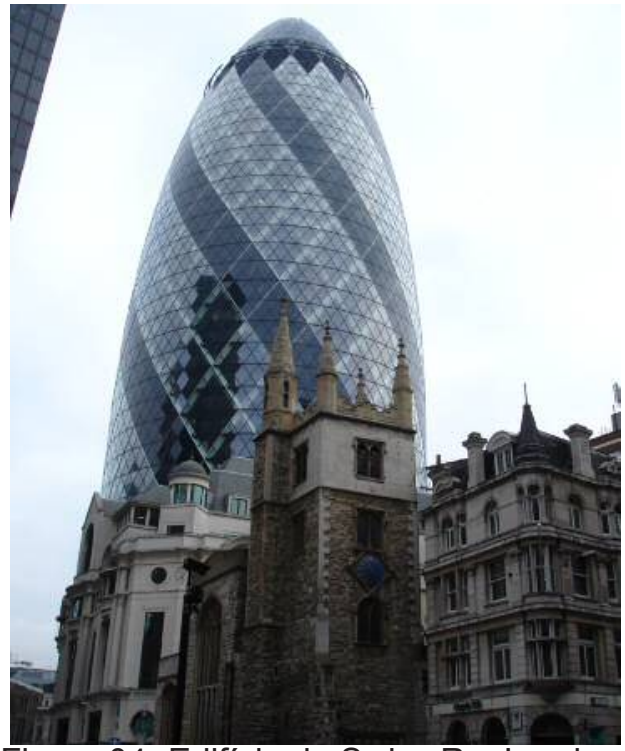

Figura 04- Edifício da Swiss Re, Londres.

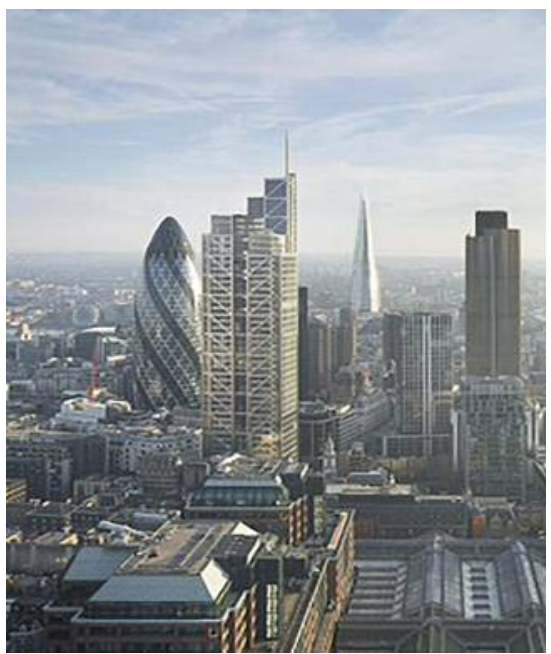

Figura 05 - Fig. 5: Edifício Heron Tower, Londres. Fonte: www. herontower.com, acessado em 22 de fevereiro de 2014.

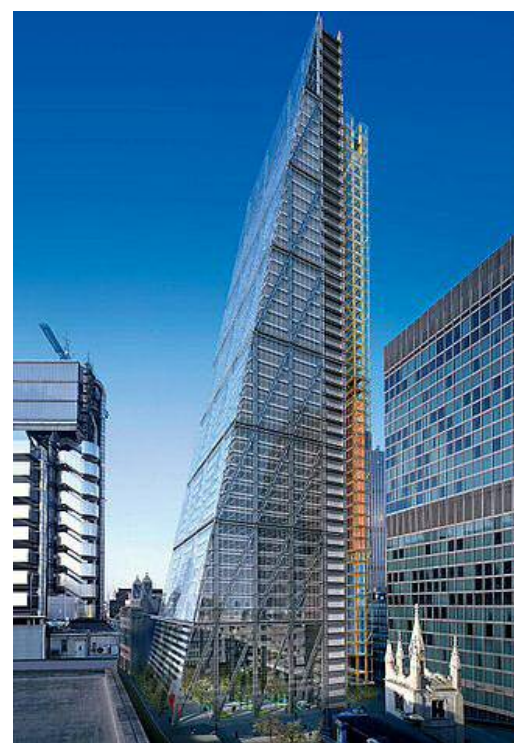

Figura 06 - 122 Leadenhall, Londres. Fonte: POWEL, 2006. 
análise desses contextos urbanos e de outros na Ásia, Europa e América, nota-se a existência de diferentes posicionamentos em relação à implantação de edifícios altos (GONÇALVES, 2003). Londres, a capital cultural e financeira do Reino Unido, tem mostrado ao mundo um legado arquitetônico que hoje se destaca pela construção de edifícios altos e pelo planejamento urbano. Juntamente a outros órgãos reguladores, a força do poder público, bem como a participação da sociedade no processo de aprovação desses edifícios, resultam numa arquitetura de alta qualidade, pautada na redução do impacto ambiental, no conforto dos usuários e da vizinhança e, ainda, na garantia de que os corredores visuais primordiais da cidade não serão afetados (TAVENOR, 2004). No entanto, ainda que haja o incentivo ao adensamento do bairro The City e a sua consolidação como o Eastern Cluster, advindo do apoio do então prefeito, Kevin Livingstone, e da aprovação do plano de desenvolvimento The London Plan (2002), Londres continuará a ser uma cidade primordialmente de altura média (CABE, 2003).

Por outro lado, nos Estados Unidos, Nova Iorque destaca-se das outras cidades por tratar o edifício alto como um instrumento do urbanismo moderno e por promovê-lo mundialmente. Nova lorque, diferentemente de Londres, teve o seu crescimento urbano pautado por uma forma orgânica guiada, praticamente, pelas leis do mercado imobiliário, que, através dos investimentos privados, foi se consolidando em determinados setores da cidade. Enquanto a Europa possui um Estado altamente responsável pelo planejamento urbano, Nova lorque vive, até hoje, o liberalismo, no qual o setor privado investe e decide onde e como construir (UMAKOSHI, 2008).

Exemplos dessa nova geração de edifícios altos que buscam a qualidade ambiental e o desempenho energético eficiente são o Four Times Square e o Bank of America at One Bryant Park, ambos do escritório de arquitetura Fox \& Fowle, o The New York Times, do arquiteto Renzo Piano e do escritório Cook + Fox Architects, e a Hearst Tower, do escritório Norman Foster and Partners. Apesar do apelo sustentável e da redução do impacto ambiental, as torres são inteiramente de vidro, de planta quadrada e core central, ou seja, não foram identificadas mudanças significativas no modo de projetar a arquitetura. O único que apresenta uma diferenciação é o edifício The New York Times, que apresenta um brise tubular nas fachadas. Perceba-se que esse apelo sustentável, 
Avaliação de Desempenho Ambiental e Arquitetura Paramétrica Generativa para o Projeto do Edifício Alto

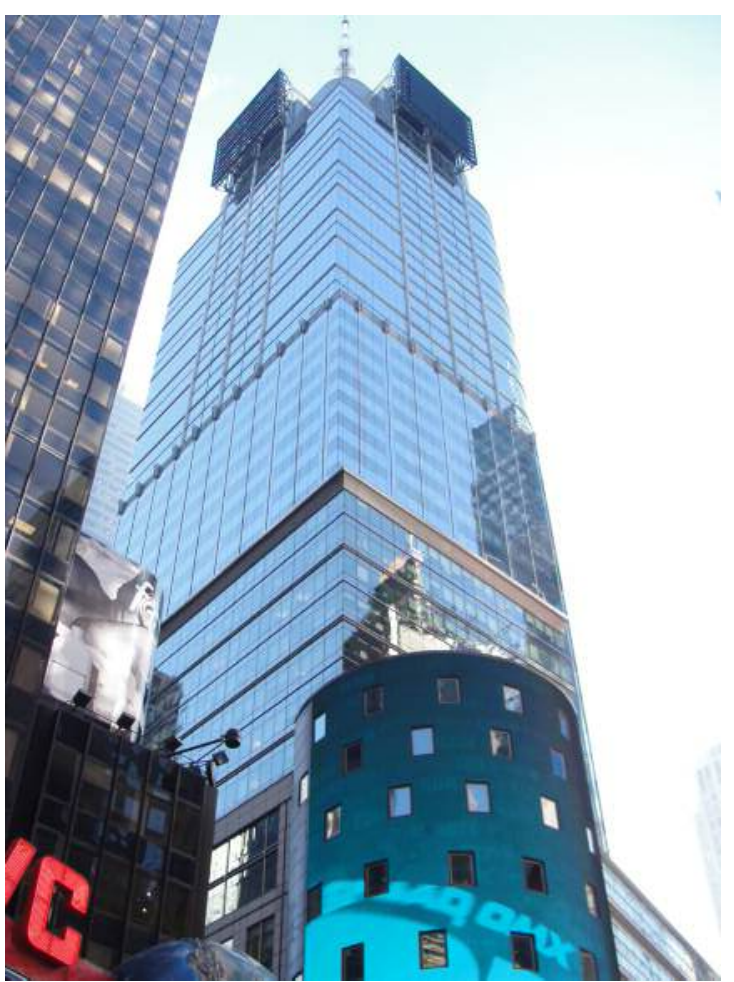

Figura 07 - Four Times Square

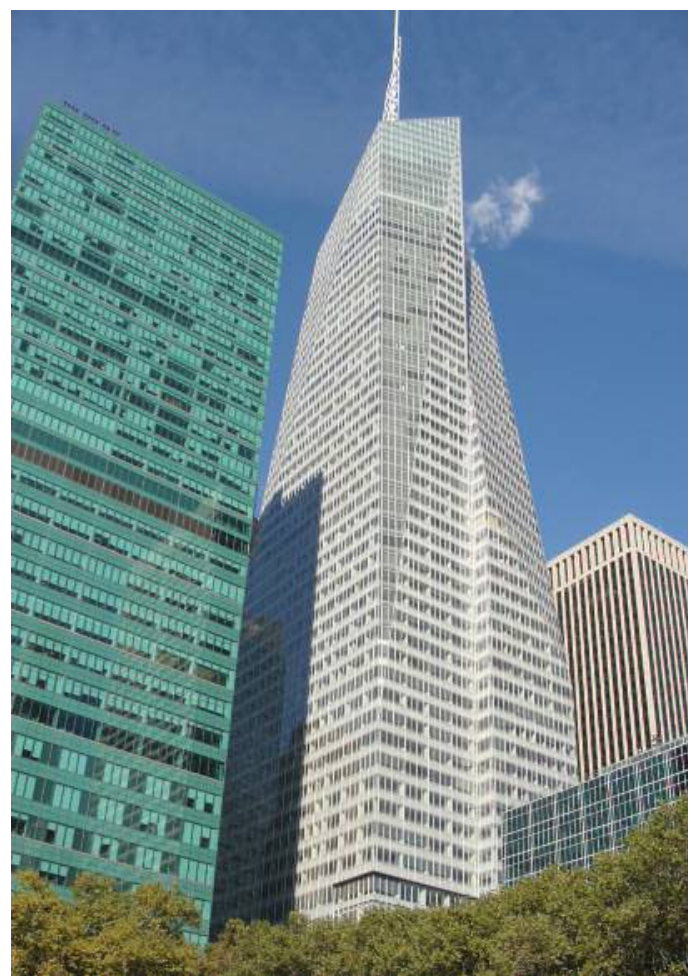

Figura 08 - Bank of America at One Bryant Park

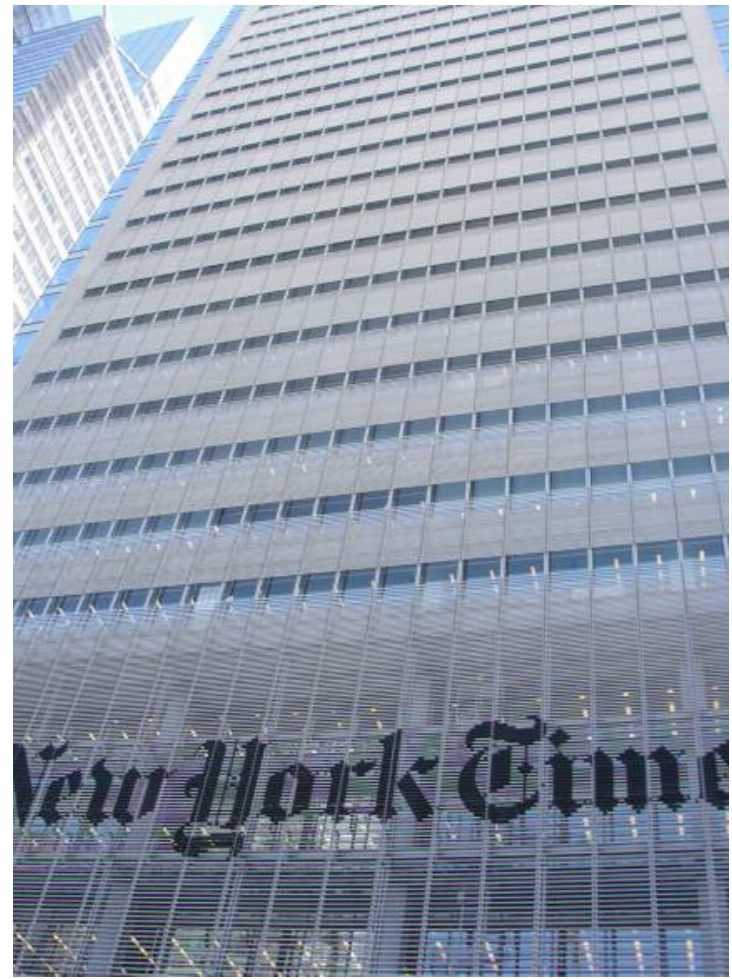

Figura 09 - The New York Times

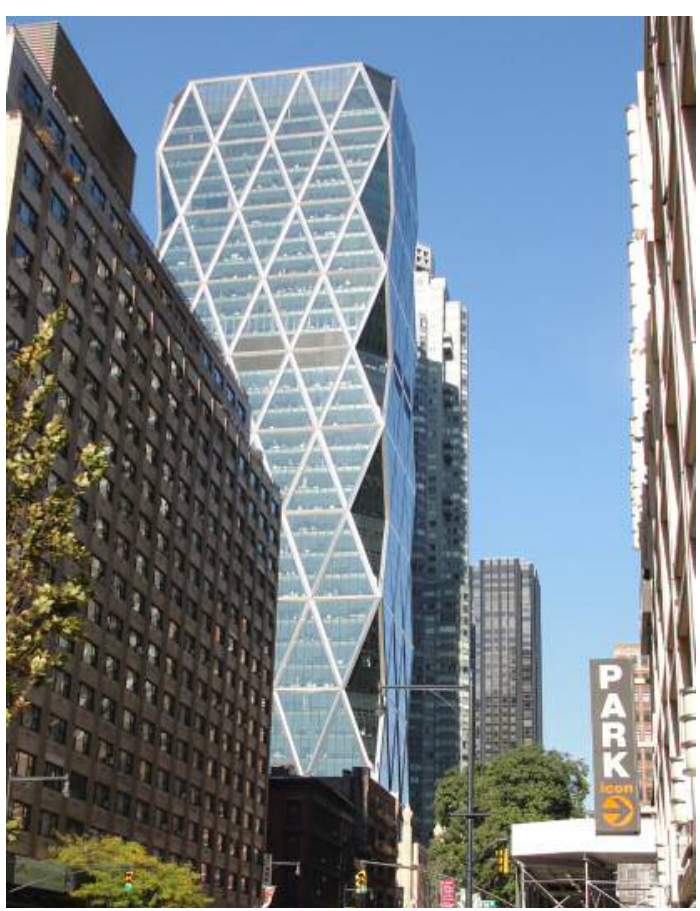

Figura 10 - Hearst Tower 
na verdade, só está relacionado à tecnologia dos sistemas e à escolha dos materiais empregados.

As discussões acerca do aquecimento global, da sustentabilidade e da eficiência energética das edificações mostraram que as cidades americanas, como um todo, revelam-se atrasadas em relação às cidades européias, tanto em termos de legislação como em termos de exemplos construídos.

São Paulo, por sua vez, iniciou a sua verticalização já nas primeiras décadas do século 20, por intermédio de edifícios residenciais e de escritórios. Os edifícios de escritórios tiveram ciclos de construções em diferentes partes da cidade (NOBRE,2000). A arquitetura de edifícios de escritórios de Rino Levi, nas décadas de 1930 e 1940, são exemplos de destaque no que se refere ao conforto ambiental e eficiência energética.

Nos anos 1990, a busca pela imagem internacional da arquitetura de torres de escritórios resultou na chegada dos edifícios importados, nos quais o projeto de arquitetura e dos sistemas prediais são definidos por padrões internacionais: fachadas de vidro e condicionamento do ar por $100 \%$ do período de ocupação (GONÇALVES, 2003).

Com relação às questões de sustentabilidade, é importante destacar, inicialmente, que recente é a preocupação com o desempenho ambiental na cidade de São Paulo. As mencionadas questões estão ligadas, em sua maioria, à busca pela certificação ambiental. As exigências do mercado internacional têm promovido algumas mudanças no processo de projeto de sistemas prediais e de fachadas. Embora não representem mudanças significativas na arquitetura do edifício alto, já começam a aparecer os edifícios aclamados como ambientalmente conscientes (UMAKOSHI, 2008).

Essa arquitetura de edifícios altos, com destaque para a arquitetura ambiental, vem sendo avaliada por sistemas de pontuação com formato checklist para a obtenção de certificações ambientais, com constatado valor de mercado. No entanto, esses sistemas de avaliação não representam uma metodologia ou procedimento de projeto para um melhor desempenho ambiental, mas, como o próprio nome já diz, é um sistema de avaliação.

Com isso, nesse contexto de pressões globais e locais por edifícios comerciais de 
Avaliação de Desempenho Ambiental e Arquitetura Paramétrica Generativa para o Projeto do Edifício Alto
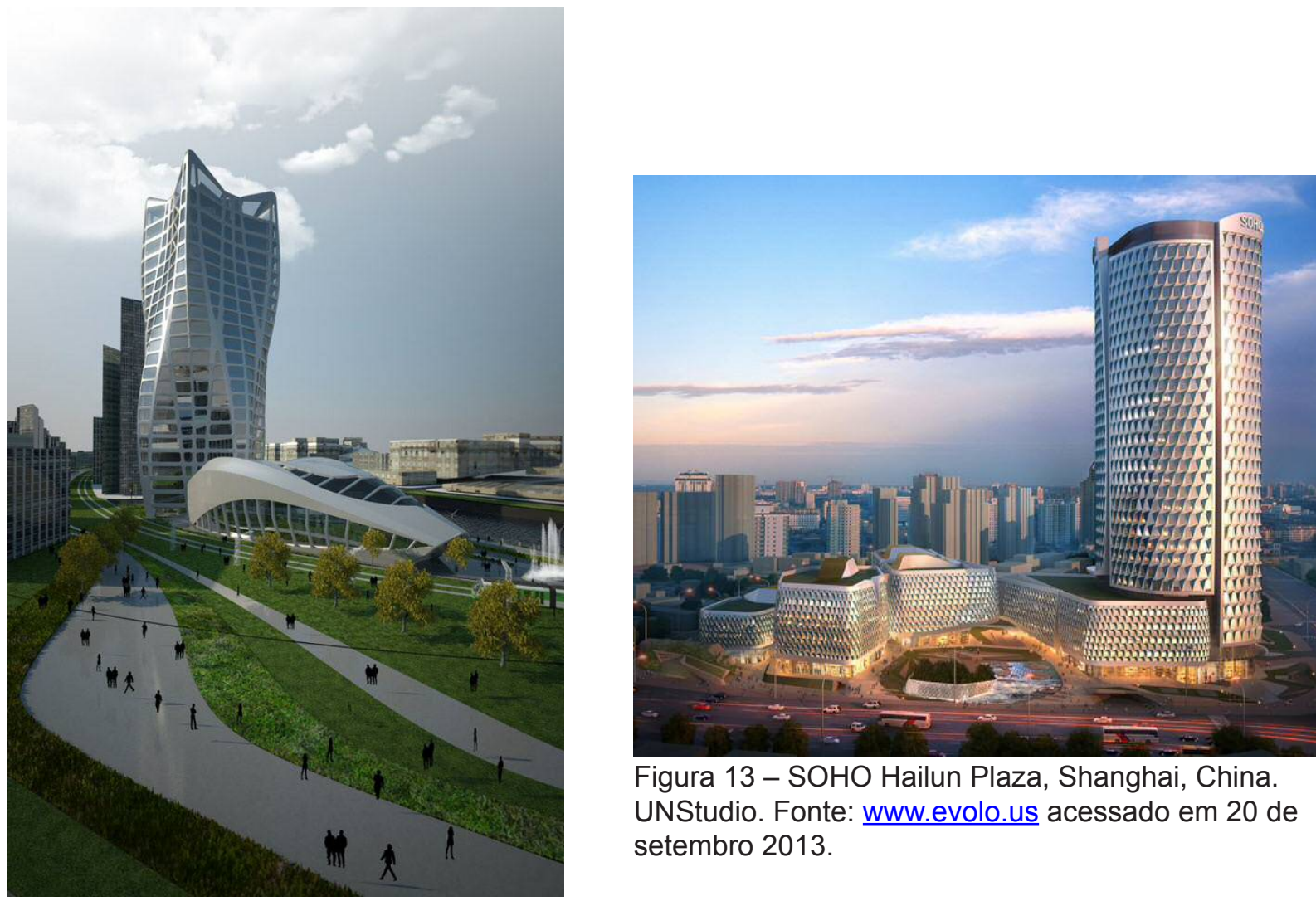

Figura 13 - SOHO Hailun Plaza, Shanghai, China. UNStudio. Fonte: www.evolo.us acessado em 20 de setembro 2013.

Figura 11 - BBK Bank (em construção), Bilbao, Espanha. Zaha Haddid. Fonte: www. evolo.us acessado em 2 de dezembro de 2013.
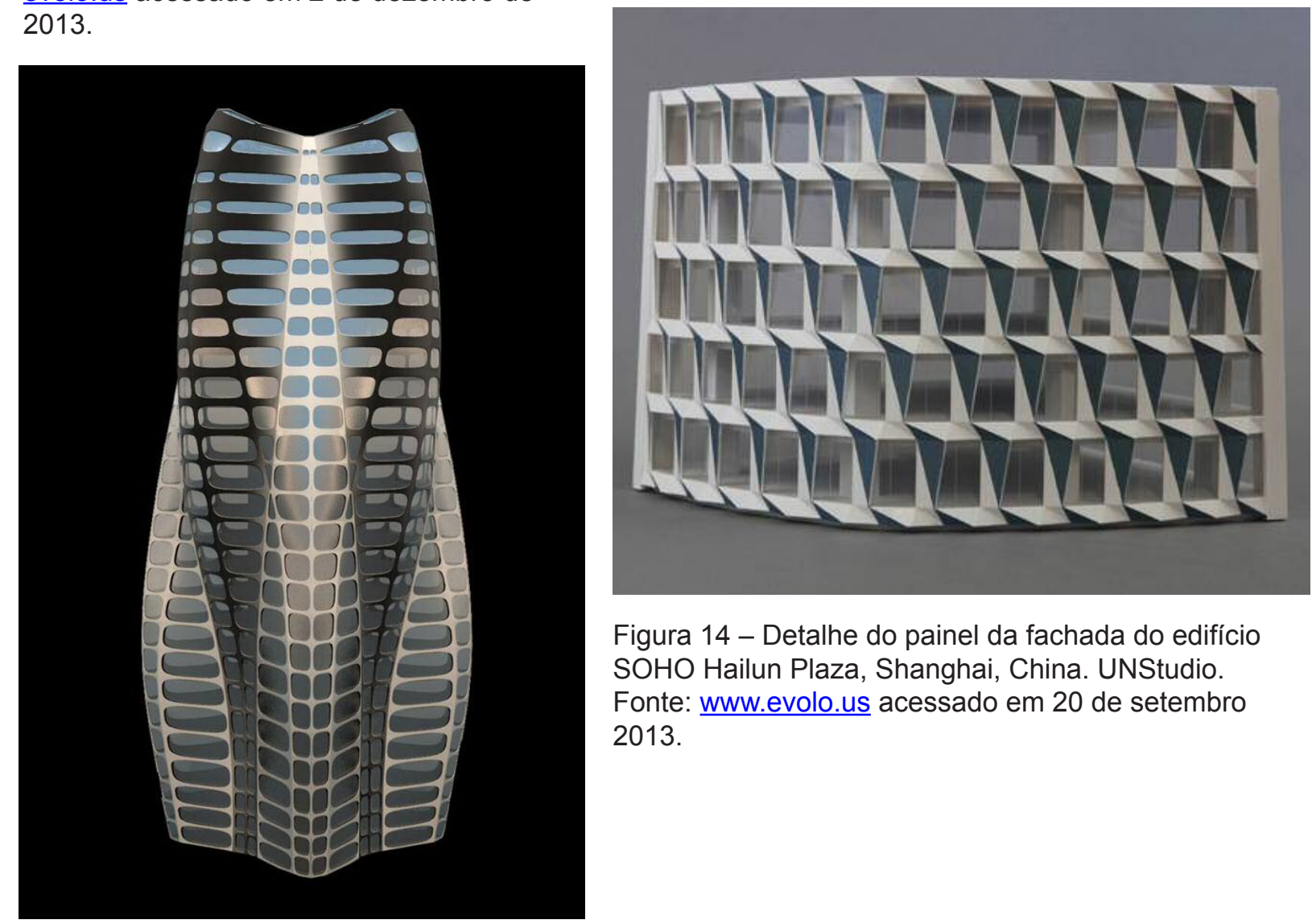

Figura 14 - Detalhe do painel da fachada do edifício SOHO Hailun Plaza, Shanghai, China. UNStudio. Fonte: www.evolo.us acessado em 20 de setembro 2013.

Figura 12 - Detalhe da fachada do BBK Bank (em construção), Bilbao, Espanha. Zaha Haddid. Fonte: www.evolo.us acessado em 2 de dezembro de 2013. 
melhor qualidade ambiental e eficiência energética, faz-se necessária uma metodologia de avaliação local que vá além dos índices que indiquem se o edifício foi aprovado ou não, ou que dê qualquer premiação relativa a esses números. Além dos critérios quantitativos, é imprescindível que essa avaliação contemple também critérios qualitativos que consigam fazer a distinção entre uma boa arquitetura com qualidade ambiental de uma arquitetura que satisfaça apenas ao mercado.

Além das questões relacionadas à Sustentabilidade, a partir do final da década de 1990 e mais intensamente nos anos 2000 , técnicas digitais começaram a ser empregadas como estratégias geradoras da forma e, com isso, os arquitetos passaram a ter em mãos uma grande diversidade de composições formais. As novas ferramentas digitais vêm proporcionando uma renovação nas formas dos edifícios altos, introduzindo um novo repertório de curvas e deformações (NATIVIDADE, 2010). As formas produzidas são caracterizadas pelo alto nível de complexidade, presente tanto na expressão formal quanto nos processos de concepção exclusivamente digitais (Mitchel, 2005). O processo de projeto passa, então, a ter conceitos, lógicas, metodologias e conteúdos exclusivamente digitais, interações entre processos e produtos que geram formas.

A difusão das tecnologias digitais incorporou ao repertório arquitetônico conceitos como não repetitivo, evolucionário, arquitetura topológica, diferenciação, arquitetura Blob, dentre outros (OXMAN, 2008). Além disso, permitiu aos arquitetos projetarem de forma mais livre, podendo discutir a geometria e a matemática das formas ao invés de utilizar formas pré-definidas dos softwares CAD (PETERS, PETERS, 2013)

Além da óbvia capacidade de cálculo, a imprevisibilidade entre dados de input e output, que se dá em nível altamente abstrato, e o projeto baseado em técnicas e operações totalmente digitais desafiam os nichos tradicionais de projeto, tais como a tomada de decisão, a criatividade, a intuição, a intenção e o controle. A partir desses princípios básicos, Terdizis (2006) argumenta que os computadores complementam o raciocínio humano porque oferece perspectivas distintas dele.

De modo geral, além da proficiência em computação, a utilização dessas estratégias ordena certas competências digitais, tais como noções de composição, gráficos vetoriais, manipulação de imagem, modelagem de superfície, modelagem de sólidos, edição de 
Avaliação de Desempenho Ambiental e Arquitetura Paramétrica Generativa para o Projeto do Edifício Alto

vídeo, renderização, animação, operações de banco de dados e interface com a web, além de conhecimento de geometria e afins. No entanto, a lista cada vez maior e mais exigente em habilidades múltiplas não deve significar o desenvolvimento da destreza computacional em detrimento de posicionamento crítico.

Dessa forma, pode-se dizer que esse processo depende muito do domínio e da habilidade do projetista sobre as ferramentas geradoras de forma. Aish (2005) afirma que o processo constitui-se do controle das regras geradores versus o resultado formal. Por isso, grandes escritórios de arquitetura possuem núcleos especializados em arquitetura digital, como é o caso do Specialist Modelling Group (SMG) no escritório de arquitetura Foster + Partners, do Digital Technology Group no Herzog \& de Meuron, do SMART Solution no escritório BURO Happold, e do Gehry Technologies no escritório do arquiteto Frank Gehry, dentre outros.

Com relação às questões ambientais, Friesen (2009) afirma que a simulação computacional articula a forma com a informação e pode ser incorporada na geração de uma forma ambientalmente responsável. O mecanismo que codifica essa relação navega entre dois mundos, o virtual e o meio ambiente natural, e representa um grande passo em relação à interpretação de informações.

Os avanços nos sistemas computacionais para o projeto arquitetônico têm possibilitado um sofisticado nível de precisão e controle, não somente na fabricação, mas também na simulação e na mediação de forças ambientais e estruturais. Os resultados podem ser vistos através de muitos exemplos de componentes de coberturas e fechamentos verticais que se modificam em função de algum parâmetro estipulado, como, por exemplo, a radiação solar (Beaurecueil; Lee, 2009).

Novas conexões entre o projeto paramétrico, as simulações energéticas e a otimização dos algoritmos permitem uma customização de partes do edifício ou até do edifício como um todo, em busca de um melhor desempenho energético (Glassman, 2011). Essa abordagem integrada já foi utilizada por muitos projetistas para esculpir torres em determinados contextos e desafiar a engenharia do edifício alto e o potencial morfológico dessa tipologia.

No entanto, sem a definição clara dos parâmetros de projeto, com a escolha de critérios 
corretos, a geração de forma pode se tornar um simples exercício de software, sem atingir a forma desejada para se resolver as questões inicias do projeto. Por isso, ressalta-se a necessidade de se desenvolver uma metodologia de projeto que alie os critérios de desempenho às ferramentas de geração da arquitetura paramétrica.

\section{Hipótese}

Parte-se da hipótese de que critérios quantitativos e qualitativos de desempenho ambiental são definidores da expressão formal da arquitetura paramétrica do edifício alto. Pretende-se comprová-la com a criação e a aplicação de um método de projeto arquitetônico que relacione avaliação paramétrica de desempenho ambiental e a geração da forma. Essa hipótese surgiu da utilização arbitrária, ou seja, sem critérios claros e precisos de desempenho ambiental na geração das formas dos edifícios altos, e vem de encontro ao conceito contemporâneo de conforto, da adaptação, das respostas específicas.

\section{Objetivos}

O objetivo geral do trabalho é propor uma metodologia de projeto arquitetônico que relacione avaliação paramétrica de desempenho ambiental com critérios qualitativos e quantitativos e a geração da forma. Ou seja, compreender como os critérios de desempenho ambiental podem informar a geração da forma, utilizando, para isso, ferramentas paramétricas, como o Rhinoceros e o seu plug-in Grasshopper. Pretendese que esse método resulte em um conjunto de diretrizes de projeto e critérios de desempenho, desenvolvidos para a formulação dessa proposta de avaliação e visualizado em um modelo teórico do edifício alto para a cidade de São Paulo.

\section{Método}

O método utilizado consiste em:

- Rever, organizar e selecionar os critérios qualitativos (UMAKOSHI, 2008);

- Extrair e ampliar, através de uma avaliação crítica, os índices propostos por Gonçalves (2003) e Gonçalves e Umakoshi (2010);

- Definir critérios qualitativos e quantitativos de desempenho ambiental para o edifício alto; 
Avaliação de Desempenho Ambiental e Arquitetura Paramétrica Generativa para o Projeto do Edifício Alto

- Elaborar uma metodologia de projeto utilizando os critérios qualitativos e quantitativos para a geração paramétrica da forma;

- Aplicar essa metodologia em um modelo teórico de edifício alto para a cidade de São Paulo, formulado a partir de diretrizes projetuais que visem a um melhor desempenho ambiental;

- Analisar os resultados obtidos.

\section{Produtos}

Os produtos da tese são os seguintes: (I) critérios qualitativos e quantitativos de desempenho ambiental do edifício alto, (II) metodologia de projeto paramétrico informada por critérios ambientais, (III) solução projetual para edifícios de escritórios que utilizem ventilação e iluminação natural como estratégia principal para atingir o conforto dos usuários e reduzir o consumo de energia.

\section{Estrutura do trabalho}

A tese está organizada em oito capítulos.

No primeiro capítulo, é apresentado o estado da arte na discussão acerca do desempenho ambiental do edifício alto. Primeiramente, discute-se a questão energética no uso e operação dos edifícios altos, depois, apresenta-se uma visão sobre São Paulo e a verticalidade e, em seguida, são apresentados alguns dos edifícios ícones no tocante ao desempenho ambiental.

No segundo capítulo, são apresentados os critérios de desempenho que serão utilizados para informar a metodologia de projeto paramétrico de geração da forma. Inicia-se com a apresentação do panorama das certificações de desempenho no Brasil e, em seguida, para um melhor entendimento das novas questões do conforto ambiental, discute-se o conforto adaptativo. Por fim, apresenta-se os critérios qualitativos e quantitativos que serão utilizados no método.

O terceiro capítulo discute o papel da ventilação natural no projeto do edifício alto, sendo apresentado o resultado de uma medição de variáveis ambientais, como a temperatura do ar, a temperatura de globo, a humidade relativa e os níveis de iluminação natural, de um edifício que utiliza a ventilação natural como o principal meio de arrefecimento. Além 
disso, são apresentados os resultados de simulações de desempenho térmico de um edifício base realizadas no software Bentley TAS, para a verificação do desempenho térmico utilizando a ventilação natural como estratégia para a redução do consumo de energia e o alcance do conforto térmico. E, também são discutidas questões acerca das áreas envidraçadas em relação ao seu papel na ventilação e na iluminação natural. No capítulo quatro, é introduzida a questão do projeto paramétrico, sendo apresentados os principais conceitos, as tecnologias BIM (Building Information Modeling), a discussão da arquitetura baseada no desempenho, os processos analíticos de avaliação do desempenho e as ferramentas para tanto.

No capítulo cinco, são apresentados exercícios de projeto que envolvem tanto critérios de desempenho como metodologias paramétricas de geração da forma. Buscou-se compreender como essas novas ferramentas de projeto estão sendo utilizadas, e como e quais critérios foram empregados na geração da forma.

No capítulo 6, apresenta-se a metodologia de projeto paramétrico baseada em critérios ambientais e a sua aplicação em um exercício de projeto para a cidade de São Paulo. No capítulo 7 estão as conclusões e, no capítulo 8, as referências bibliográficas. 

Capítulo 1: 
Capítulo 1 - O Desempenho Ambiental e a Eficiência Energética dos Edifícios Altos

Avaliação de Desempenho Ambiental e Arquitetura Paramétrica Generativa para o Projeto do Edifício Alto

42 


\section{Capítulo 1: O Desempenho Ambiental e a Eficiência Energética dos Edifícios Altos} Introdução

O impacto da altura e o alto consumo energético nos edifícios altos geram críticas e discussões, baseadas na ideia de que os edifícios altos consomem significativamente mais energia do que qualquer outro tipo de edificação. No entanto, cabe ressaltar que a questão energética dos edifícios altos é bem mais complexa. Um edifício alto convencional pode consumir mais energia do que um edifício de escritórios mais baixo, porém, a questão vai além da altura, pois itens relacionados ao projeto do edifício, como profundidade da planta, geometria, fachada, bem como os sistemas prediais, estão diretamente ligados ao consumo de energia.

Sabe-se que quanto mais alto o edifício, melhor é o seu desempenho quanto à iluminação natural e à ventilação, tendo em vista que as plantas são mais estreitas. Com isso, pode-se dizer que, quanto mais alto o prédio, maior o potencial de desempenho ambiental, sendo importante, contudo, frisar que esse desempenho está ligado diretamente às condições climáticas, ao projeto e à ocupação.

Outro fator a influenciar muito o consumo energético é o tipo de ocupação, tendo em vista que edifícios comerciais, residenciais ou hotéis possuem uma frequência de entrada e saída do edifício bem distinta. Com relação ao deslocamento, pode-se dizer que dois são os tipos, um referente à entrada e à saída, e outro relativo ao deslocamento entre os pavimentos, no caso de empresas que ocupem vários andares no edifício. Em se tratando de edifício alto de uso comercial, o consumo de energia relacionado ao transporte vertical não é muito diferente do de um edifício de médio porte.

Usualmente, a crítica referente ao consumo excessivo de energia tem como referência os edifícios altos comerciais convencionais de planta quadrada e profunda, de fachada de vidro selada, com core de elevadores central. Nesses casos, inevitavelmente o edifício irá consumir grande quantidade de energia, no entanto, cabe ressaltar que o problema está relacionado ao projeto do edifício e não diretamente à altura, pois não segue as regras básicas do desempenho ambiental.

Segundo Gonçalves e Bode (2011b), o projeto do edifício alto com foco no melhor desempenho ambiental, diferentemente do modelo convencional, é caracterizado por uma abordagem mais abrangente, envolvendo tanto aspectos da arquitetura como da engenharia de sistemas. Neste 
contexto, a abordagem de edifícios de baixo consumo energético pode ser resumida em três grandes etapas: a primeira relaciona-se à redução da demanda de energia através de um projeto arquitetônico de inserção climática e uma revisão nos critérios de conforto; a segunda etapa envolve o uso de sistemas tecnológicos eficientes e de baixo impacto ambiental, enquanto a etapa três está direcionada ao menor impacto ambiental relacionado ao consumo de energia no uso e operação do edifício, envolvendo o uso de energias renováveis (solar, geotérmica e eólica, dentre outras) (fig. 15).

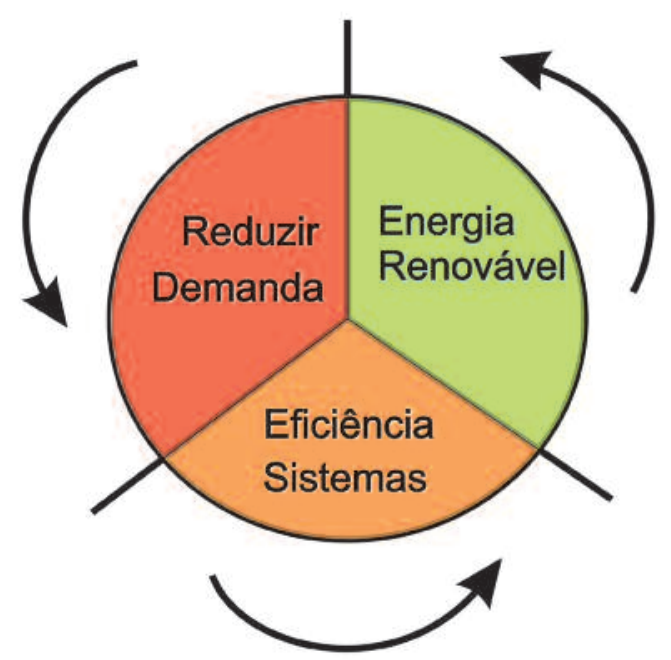

Fig. 15 - Estratégias para reduzir o consumo de energia nos edifícios.
De uma perspectiva ambiental e energética, o projeto arquitetônico do edifício alto ambiental de escritórios necessita de uma revisão completa do modelo convencional, revisão esta que abrange as plantas profundas - que se tornam mais estreitas para permitir melhor iluminação natural, o aumento da comunicação visual, a fachada de vidro - que é redesenhada de acordo com as condições locais de exposição à radiação, e as possibilidades e o uso eficiente da ventilação natural.

Em relação à utilização de estratégias passivas (estratégias de projeto que contribuem para melhorar as condições ambientais em edifícios sem consumir energia), a importância da iluminação natural está associada ao seu impacto direto no bem-estar, na produtividade e na qualidade global do espaço interno do edifício (BAKER and STEEMERS, 2002). Por outro lado, trata-se a ventilação natural de uma questão mais polêmica, apesar de uma série de edifícios altos construídos ao longo do século 20 , localizados em diversas condições climáticas (São Paulo, Londres e Frankfurt), demonstrarem que a ventilação natural é possível e vantajosa (GONCALVES, UMAKOSHI 2010).

Um estudo realizado pelo National Renewable Energy Laboratory, do governo dos Estados Unidos, em 5.375 edifícios comerciais, mostrou que, em novos edifícios, o uso de iluminação artificial mais eficiente e natural e de sombreamento pode resultar em uma economia de energia de, aproximadamente, $65 \%$ (TORCELINE et al, 2006). No Reino Unido, especificamente, diretrizes 
de consumo de energia indicam que, com a introdução da ventilação natural em edifícios de escritórios nos períodos mais favoráveis do ano, pode-se obter uma economia de energia entre 55 e $60 \%$ (CIBSE, 2004).

\subsection{Desempenho Energético e Benchmarks}

Os chamados níveis de referência ou Benchmarks de energia têm sido usados como parâmetros desde a crise do petróleo de 1970, estabelecendo metas para os novos edifícios baseados nos melhores exemplos da época. Na Europa, um grupo significativo e representativo de países constituem-se em líderes no campo de conservação de energia, implementando rápidos desenvolvimentos. São eles Reino Unido, Alemanha, Suíça, Áustria, Holanda e países Escandinavos, cada qual tentando atingir a redução determinada para a emissão de carbono.

O desempenho energético de um edifício depende das decisões tomadas durante a fase de construção, dentro de um processo de projeto afinado, e de uma série de variáveis relacionadas com a ocupação. Em outras palavras, a operação real de um edifício é muito mais complexa do que um cenário de simulação. Por esta razão, apesar de todos os rigorosos processos de predição de consumo energético, baseados em simulações computacionais durante o processo de projeto, essas previsões geralmente destoam significativamente do desempenho real do edifício.

A única forma real de avaliação da eficiência energética de um edifício é através da medição da quantidade de energia consumida por ele depois de um certo período de ocupação. Recomenda-se um período mínimo de dois anos antes da realização de avaliações energéticas e de comparações com outros edifícios e com benchmarks (GONÇALVES; UMAKOSHI, 2010). Isso porque o gerente do edifício precisa de um tempo razoável para ajustar a operação do edifício de um modo mais adequado e eficiente, ajustando as necessidades dos usuários, as suas expectativas, conforto e conservação de energia. Entretanto, sistemas de avaliação e benchmarks são baseados em projeto e pouco é o incentivo existente para se avaliar o pós ocupação.

Dentro de um certo contexto, os chamados benchmarks são influenciados pelo clima, pela cultura e pelos fatores técnicos e operacionais, que são, essencialmente, parâmetros de projeto dentro de um determinado contexto. Por isso, a utilização e a comparação entre benchmarks de 
diferentes contextos pode causar uma interpretação equivocada.

No Reino Unido, as diretrizes de consumo energético indicam que, para um edifício de escritório mecanicamente ventilado, o consumo é de 300-330 kWh/m2/ano, para um edifício dentro das boas práticas, 173-186 kWh/m2/ano, e, para edifícios naturalmente ventilados, 127-145 kWh/m2/ ano (CISBE, 2004). No entanto, é imprescindível conhecermos a área da qual estamos tratando, ou seja, qual foi a área considerada para o cálculo, pois, no Reino Unido, se utiliza área bruta e, na Alemanha, área útil.

Assim, é importante frisar que devemos tratar com cautela a complexidade da redução do consumo de energia, principalmente no que se refere às certificações, pois muitos edifícios alcançam a pontuação máxima na certificação mesmo com elevado consumo de energia.

\subsection{São Paulo}

Maior cidade da América do Sul, São Paulo é também conhecida como a área urbana mais desenvolvida e a mais próspera economia da mesma. É considerada o laboratório de projeto de edifícios altos na América Latina (GONÇALVES, 2003). A sua verticalização iniciou-se já nas primeiras décadas do século 20, por intermédio de edifícios residenciais e de escritórios.

A tipologia de escritórios, em especial, se desenvolveu ao longo do tempo, em diferentes partes da cidade (NOBRE,2000). Estudos mostram que se formaram centros de verticalização em diferentes bairros da cidade a cada 30 anos, na área central (1920-1950), na Avenida Paulista (1950-1980), na Avenida Brigadeiro Faria Lima (1970-1980), na parte oeste do bairro de Pinheiros e na Avenida Luís Carlos Berrini (1980-1990) e, atualmente, na avenida Nações Unidas (GONÇALVES, UMAKOSHI, 2010).

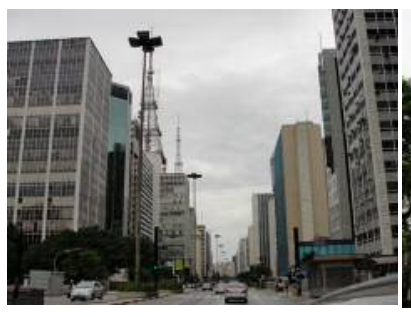

Figura 16 - Avenida Paulista.

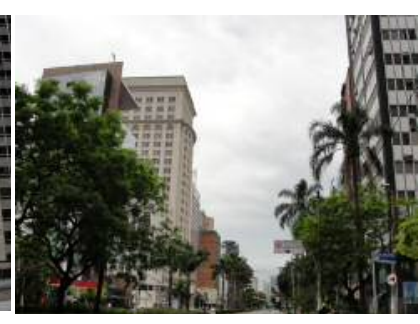

Figura 17 - Avenida Brigadeiro Faria Lima

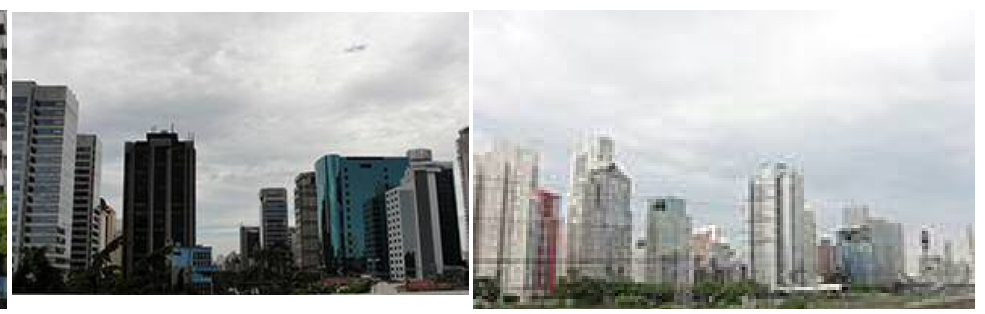

Figura 18 - Avenida Berrini. Figura 19 - Marginal Pinheiros

Enquanto a Europa demonstra uma grande preocupação com relação às estratégias urbanas e aos critérios ambientais para a inserção dos edifícios altos, São Paulo sofre com a falta de planejamento urbanos, criando ilhas de verticalização, isoladas do centro da cidade pela falta de 
infraestrutura urbana, principalmente pela deficiência do transporte público. De fato, as pressões do mercado especulativo no processo de transformações urbanas que começaram no final dos anos 1980 não foi acompanhado do desenvolvimento da infraestrutura urbana, que chegou tardiamente. Com isso, acumularam-se impactos negativos tanto sociais quanto econômicos e ambientais, aumentando-se os problemas de mobilidade na cidade, a poluição e o desconforto dos pedestres.

A cidade de São Paulo nunca participou da corrida internacional pelo título de edifício mais alto do mundo, sendo, a maior parte dos seus edifícios construídos nos últimos dez anos na Avenida Nações Unidas, considerados baixos quando comparados aos edifícios nos Estados Unidos, Europa, Ásia e, recentemente, no Oriente Médio. O edifício mais alto da atualidade, a Torre Norte (1999) (fig. 20) possui 167 metros de altura, 38 pavimentos, sendo de 10 a 20 pavimentos mais baixo do que os edifícios tipo nos Estados Unidos.

Com relação aos aspectos ambientais, pode-se dizer que a arquitetura de edifícios de escritórios de Rino Levi, nas décadas de 1930 e 1940, são exemplos de destaque no que se refere ao conforto ambiental e à eficiência energética. Construídos no auge do modernismo brasileiro, carregam importantes lições de inserção urbana, de tecnologia estrutural e de sistemas e de conforto ambiental de valor atemporal (BRUAND, 2005).

Já nos anos 1990, a abertura do mercado brasileiro e a consequente busca pela imagem internacional da arquitetura de torres de escritórios resultou na chegada dos edifícios importados, nos quais o projeto de arquitetura e os sistemas prediais são definidos por padrões internacionais (GONÇALVES, 2003). Nesse grupo estão o Birmann 21, a nova sede do Bank Boston (fig. 21) na marginal do rio Pinheiros (Avenida das Nações Unidas) e outros na Avenida Nova Faria Lima. O padrão que passou a ser adotado tem como referência a arquitetura norte americana de plantas profundas, fachadas de vidro e climatização total. Assim, o consumo energético dessa tipologia passou a ser uma grande questão.

Com a introdução de questões ligadas à sustentabilidade, as quais, no cenário internacional, particularmente nos Estados Unidos, estão relacionadas à redução do consumo de energia atreladas à melhoria do desempenho dos sistemas, discussões semelhantes passaram a surgir e a ser aplicadas em São Paulo. Um dos primeiros edifícios dessa nova geração é o Eldorado Business Tower (fig. 22), do escritório Aflalo \& Gasperini, que, apesar de ser aclamado verde, 
Capítulo 1 - O Desempenho Ambiental e a Eficiência Energética dos Edifícios Altos

Avaliação de Desempenho Ambiental e Arquitetura Paramétrica Generativa para o Projeto do Edifício Alto

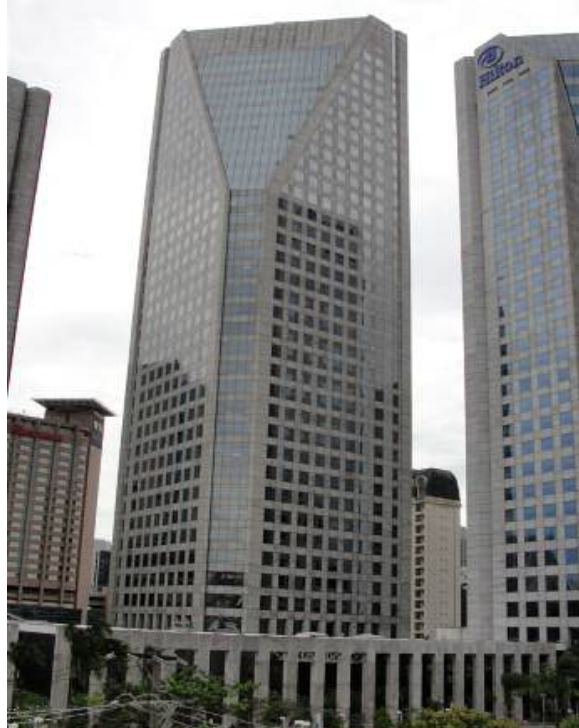

Figura 20 - Torre Norte.

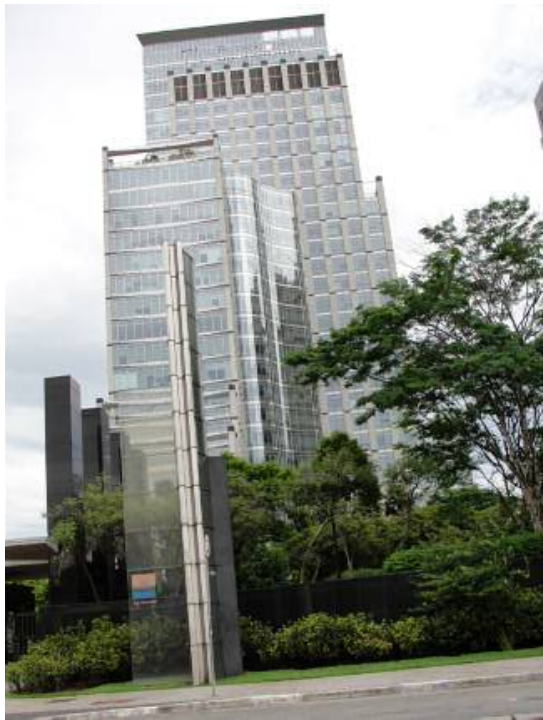

Figura 21 - Edifício Bank Boston.

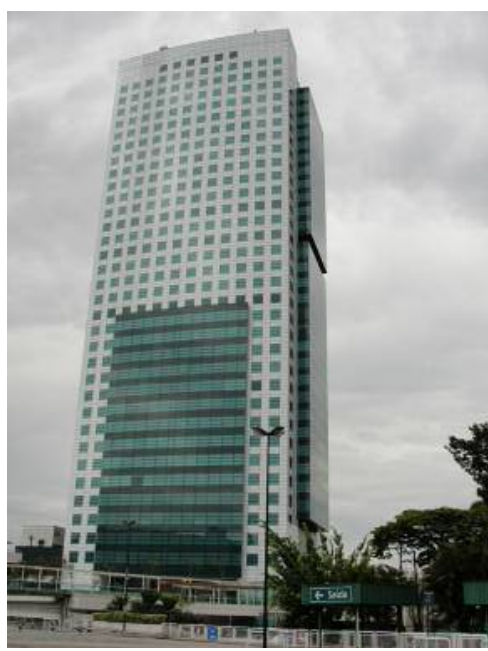

Figura 22 - Eldorado Business Tower.

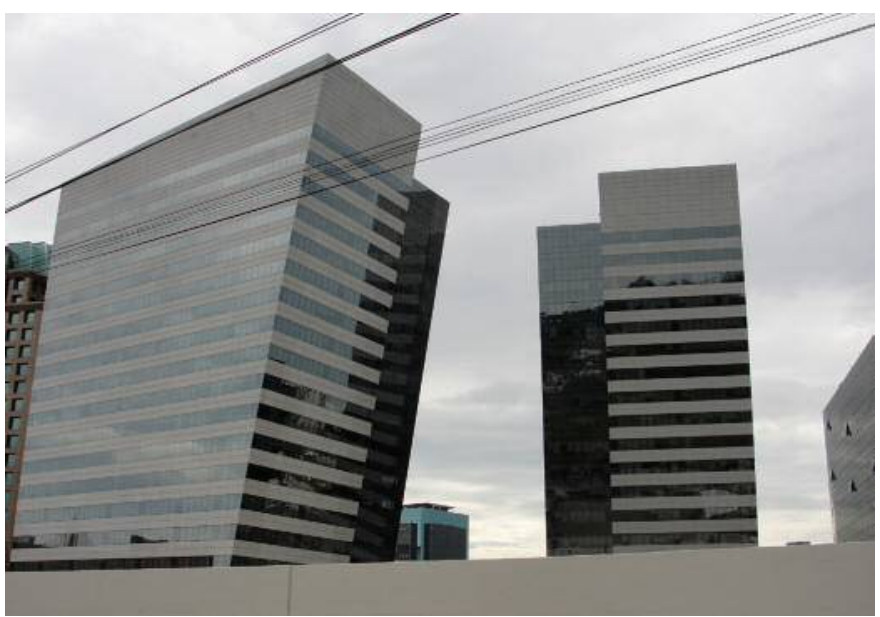

Figura 23 - Complexo Rochaverá.

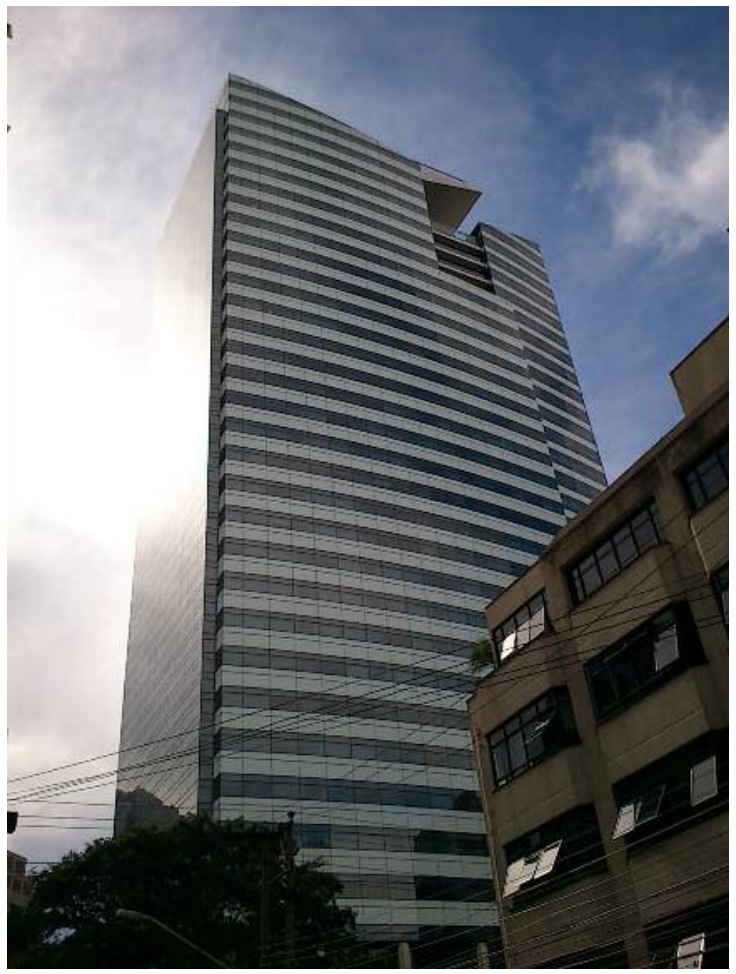

Figura 24 - Edifício Prosperitas. 
ainda não explora as questões de estratégias passivas e de localização que incentive o uso de transporte público, dentre outras características. As estratégias estão muito mais ligadas à eficiência dos sistemas prediais do que às questões de desempenho da arquitetura (UMAKOSHI, 2008).

Atualmente, as exigências do mercado internacional têm promovido algumas mudanças no processo de projeto, principalmente nas grandes capitais como São Paulo e Rio de Janeiro. A busca pela certificação americana LEED - The Leadership in Energy and Environmental Design, criado pelo United States Green Building Council (USGBC), por exemplo, vem fazendo com que renomados escritórios de arquitetura realizem mudanças no processo de projeto de sistemas prediais e fachadas. Embora não se tratem de mudanças significativas na arquitetura propriamente dita do edifício alto, já começam a aparecer os edifícios aclamados como mais ambientalmente conscientes (UMAKOSHI, 2008).

Em São Paulo, três projetos se destacam na busca da certificação americana LEED, sendo eles: o complexo Rochaverá (fig. 23) e o edifício Eldorado Business Tower (fig. 22), na Marginal do Rio Pinheiros, e o Prosperitas (fig. 24), na Av. Luis Carlos Berrini, todos esses do escritório de arquitetura Aflalo \& Gasperini.

Essa arquitetura de edifícios altos, com destaque para a arquitetura ambiental, vem sendo avaliada por sistemas de pontuação com formato checklist para a obtenção de certificações ambientais. Os sistemas têm caráter voluntário e atuam como instrumentos de valorização no mercado (SILVA, 2003). Vale destacar que esses sistemas de avaliação não representam uma metodologia ou procedimento de projeto para um melhor desempenho ambiental, mas, como o próprio nome já diz, é um sistema de avaliação. A exigência de desempenho ambiental (térmico, acústico, luminoso e ergonômico, dos quais os itens térmico e luminoso estão ligados ao consumo de energia) aparece em todos os sistemas com diferentes pesos no conjunto.

Pela natureza do assunto, que é o desempenho ambiental do edifício em operação, os critérios de avaliação devem ser locais, o que deveria inviabilizar a comercialização desses selos. No entanto, o sistema americano, o LEED, é exportado para diferentes contextos ambientais e climáticos e está se tornando, cada vez mais, uma ferramenta de mercado. O LEED, em particular, vem sendo criticado, nos últimos anos, nos Estados Unidos e no Canadá pelo fato de edifícios certificados não corresponderem a um menor consumo de energia quando comparados ao cenário local (GIFFORD, 2008). 
No Brasil, além do LEED, existem outros instrumentos de avaliação sendo utilizados, como o Referencial Técnico de Certificação AQUA, que foi adequado para a realidade brasileira em parceria com a Fundação Vanzolini, e o novo Programa Brasileiro de Etiquetagem - PBE do PROCEL EDIFICA. O tema das certificações será retomado e aprofundado no capítulo 2.

Ao analisar o clima da cidade de São Paulo, observa-se que apesar de possuir um clima ameno e considerado confortável durante $70 \%$ do $a^{1}{ }^{1}$, as estratégias passivas de ventilação são, muitas vezes, comprometidas pelo alto nível de ruído e de poluição do ar, o que leva à utilização de tecnologias complexas para vencer esse problema ou à adoção, simplesmente, da solução mais fácil: fachada selada e ar-condicionado, que quase sempre vêm acompanhadas de uma série de problemas decorrentes dessa opção, como por exemplo a baixa qualidade do ar. Além do ruído e da poluição, outro fator importante que pode comprometer o conforto interno de ambientes de escritório é a alta carga térmica gerada pela ocupação do edifício. No entanto, segundo Marcondes (2010), é possível garantir conforto térmico em edifícios de escritórios em São Paulo por, no mínimo, $80 \%$ do ano, utilizando soluções de fachadas que possibilitem a ventilação natural.

Com isso, pode-se dizer que o clima da cidade de São Paulo favorece a adoção de estratégias passivas, tanto de iluminação quanto de ventilação, contanto que o usuário possa ter o controle da velocidade do ar, da iluminação, podendo adaptar o seu meio ambiente à sua percepção de conforto.

Assim, apesar do clima da cidade de São Paulo ser favorável à adoção de estratégias passivas de iluminação e ventilação, sabe-se que as questões de desempenho que passaram a influenciar no projeto dessa tipologia de escritórios ficaram restritas a atender a uma certificação internacional que ainda não está totalmente adequada à nossa realidade, tanto climática quanto energética. Ou seja, as questões de sustentabilidade que foram incorporadas pelo mercado estão muito mais ligadas ao atendimento da certificação, no caso brasileiro, o LEED, do que realmente melhorar o seu desempenho ambiental. Como reflexo desse pensamento, surgiram edifícios como o complexo Rochaverá e o edifício Prosperitas, que pouco mudaram a sua arquitetura para atender ao padrão da certificação LEED. Tendo em vista que os exemplos nacionais dessa tipologia baseada no desempenho não refletiram os verdadeiros princípios da arquitetura ambiental, os estudos de caso a serem analisados nesta pesquisa não contemplarão exemplos nacionais, ficando restritos a exemplos internacionais de comprovado desempenho.

1 Dados obtidos a partir do software Climaticus 4.2, desenvolvido por ALUCCI e FERREIRA, LABAUT-FAUUSP(2011). 


\subsection{Precedentes de uma arquitetura ambiental}

\subsubsection{Commerzbank (1998, Frankfurt, Alemanha)}

\begin{tabular}{|l|l|}
\hline Projeto & Commerzbank HQ \\
\hline Localização & Frankfurt AM Main, Alemanha, Latitude 50 \\
\hline Cliente/Investidor & Commerzbank \\
\hline Arquitetura & Norman Foster and Partners, London \\
\hline Engenharias & $\begin{array}{l}\text { Ove Arup and Partners, Roger Preston and Partners, Pedderson } \\
\text { and Ahrens, Schaad and Hoezel and Stangier Partner }\end{array}$ \\
\hline Uso do Empreendimento & Escritórios, residências e comércio \\
\hline Altura & 258 metros \\
\hline Número de Pavimentos & 56 \\
\hline Área do Pavimento Tipo & $896,33 \mathrm{~m}^{2}$ \\
\hline Área Total & $100.000 \mathrm{~m}^{2}$ \\
\hline Status/ Fase & Construído em 1998 \\
\hline Estacionamento & 300 vagas para automóveis e 200 para bicicleta \\
\hline
\end{tabular}

Fonte: GONCALVES, 2003.

A nova sede do Commerzbank em Frankfurt (fig. 25) foi objeto de concurso internacional em 1992, que selecionou como vencedor o projeto liderado pelo escritório de arquitetura Norman Foster and Partners. O objetivo do concurso foi criar um espaço de trabalho com boa comunicação interna entre os usuários, que gerasse um incremento na produtividade, somado às questões ambientais e ao menor consumo energético. Para isso, foram utilizados sistemas prediais que balanceavam estratégias passivas de iluminação e ventilação, e modos ativos de iluminação de climatização, permitindo que o edifício pudesse funcionar de acordo com o clima externo. Esses sistemas podem ser controlados pelos usuários do edifício, o que, desde o seu primeiro ano de ocupação, tem gerado uma constatada satisfação dos usuários.

O edifício de 56 pavimentos e 258 metros de altura tem uma planta baixa de forma triangular, com três áreas retangulares nas laterais do triângulo interligadas pelas colunas de circulação vertical nos vértices da planta e um átrio central (fig. 26). A forma e orientação do edifício eliminaram a orientação oeste, muito vulnerável aos ganhos excessivos de calor no verão.

Em altura, o edifício é dividido em grupos de 12 pavimentos chamados de "vilas", em que o vazio criado pelos terraços laterais e o átrio central permite a formação de fluxos de ar resultantes da 
Capítulo 1 - O Desempenho Ambiental e a Eficiência Energética dos Edifícios Altos

Avaliação de Desempenho Ambiental e Arquitetura Paramétrica Generativa para o Projeto do Edifício Alto

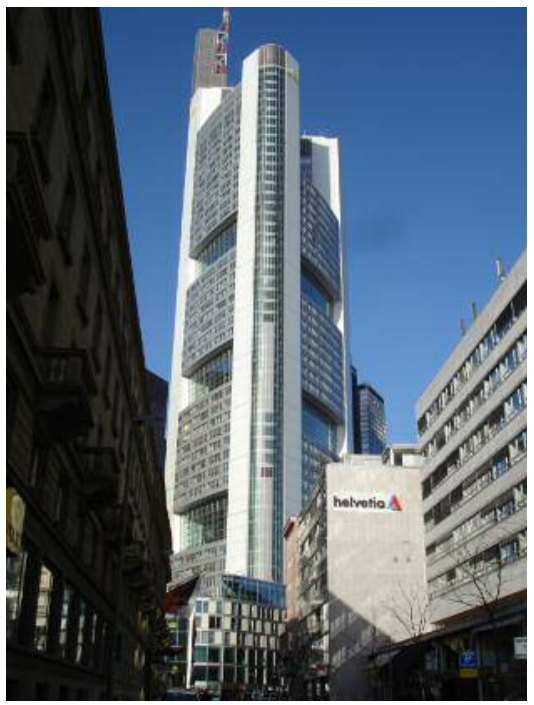

Figura 25 - Edifício Commerzbank.

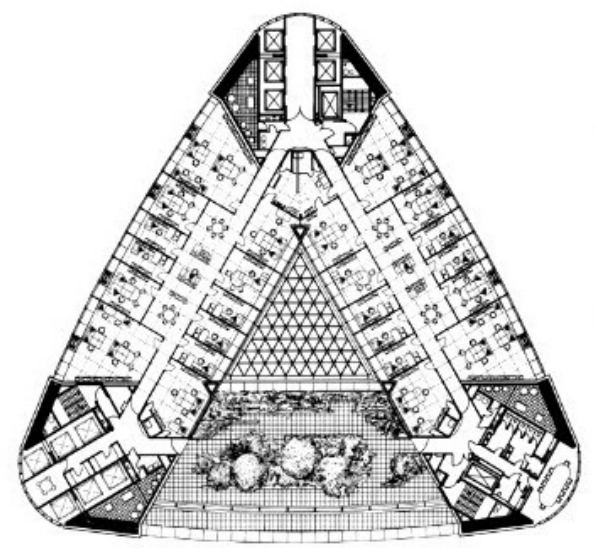

Figura 26 - Planta do edifício Commerzbank. Fonte: Fonte: <www. fosterandpartners.com> acessado em outubro de 2010.

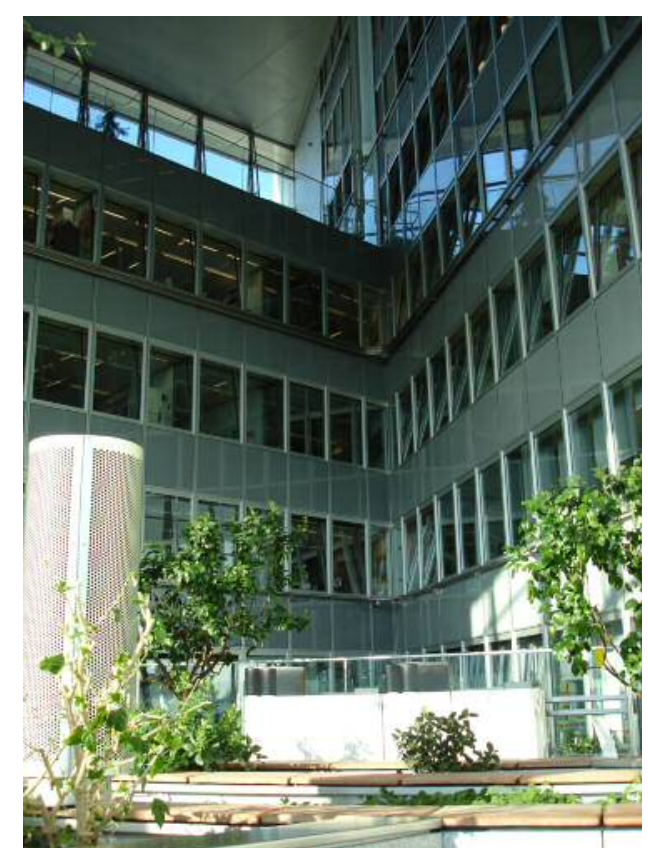

Figura 27 - Jardins interligados pelo átrio.

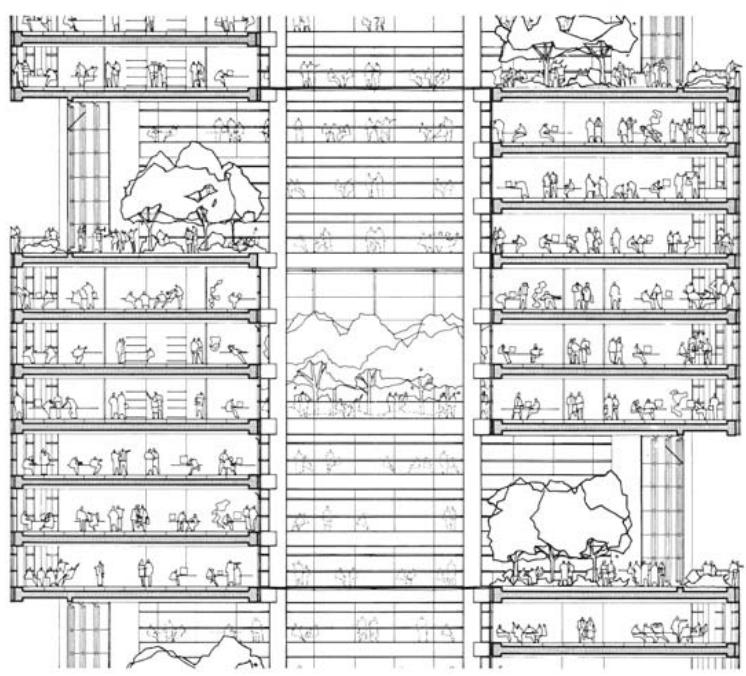

Figura 28 - Corte do edifício com os jardins interligados pelo átrio. Fonte: <www.

fosterandpartners.com> acessado em outubro de 2010.

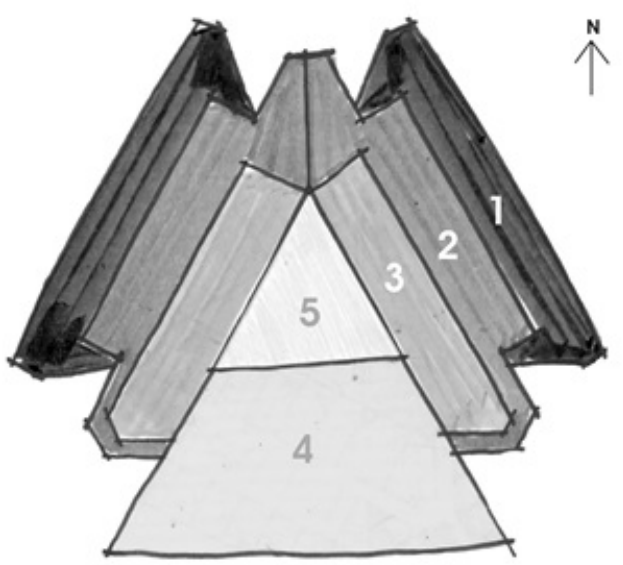

Figura 29: Esquema do zoneamento horizontal do pavimento tipo, com a indicação da setorização das três zonas de climatização e diferentes estratégias de ventilação. Fonte: Joana Carla Soares Gonçalves

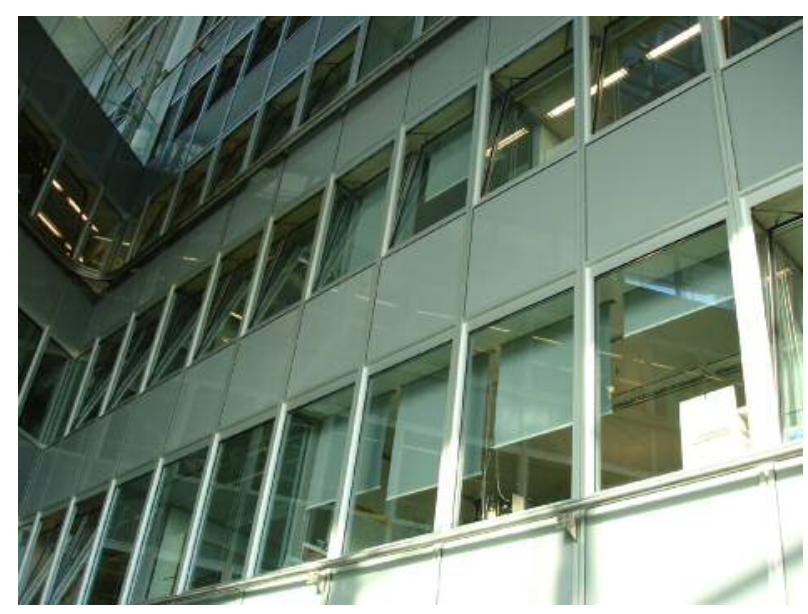

Figura 30 - Janelas voltadas ao átrio. 
combinação do efeito chaminé com a ação dos ventos. Cada vila possui três jardins de pé-direito quádruplo, um em cada lateral, conectados pelo átrio central (fig. 27e 28). A divisão do grande átrio central em quatro blocos foi uma medida necessária para o controle das pressões de vento criadoras do efeito chaminé.

O arranjo dos espaços internos, com o átrio e os jardins, permite o acesso da luz natural e da ventilação natural no interior do edifício, além de criar uma zona de mediação climática entre os espaços internos e o clima externo ${ }^{2}$. Os jardins permitem, ainda, um convívio social dos ocupantes do edifício, sendo utilizados pelos usuários tanto para descanso como para trabalho e reuniões. Esse arranjo estrutural permitiu a construção de um edifício significativamente mais alto do que aqueles que possuem restrição de altura devido à profundidade da planta regulamentada pela norma de desempenho alemã. Esta determina que não deve existir nenhum posto de trabalho localizado a mais de 6 metros da fachada, para preservar o acesso a luz natural e as vistas ao exterior.

A principal estratégia de projeto para a redução do consumo de energia foi o uso da ventilação natural. A planta triangular é divida em uma zona de escritórios periféricos, voltados para o exterior, uma zona interna de circulação e espaços de reunião e, por último, uma zona de escritórios voltados para o átrio central (fig. 29). Cada uma dessas zonas tem um sistema separado de climatização e ventilação. Sempre que as condições climáticas externas permitirem (temperaturas internas acima de $17^{\circ} \mathrm{C}$ e abaixo de $26^{\circ} \mathrm{C}$, e ventos abaixo de $15 \mathrm{~m} / \mathrm{s}$ ), os escritórios periféricos terão suas janelas abertas para a ventilação natural, controlada pelos usuários.

Das três zonas de escritórios do pavimento tipo, aquela voltada para o átrio central (fig. 30) apresenta condições mais favoráveis para a abertura das janelas e o aproveitamento da ventilação natural, por estar protegida contra ventos de alta velocidade, que acabam impedindo a ventilação natural. Já no caso dos escritórios voltados para o exterior, a abertura das janelas é viabilizada com a inclusão de painéis externos de vidro (fig. 31), que servem como proteção à incidência direta dos ventos na abertura. Além dessa proteção, persianas no interior do vidro duplo das janelas oferecem controle do acesso da luz direta e do ofuscamento sobre o plano de trabalho.

As zonas periféricas são ventiladas naturalmente em média por $80 \%$ do período de ocupação, enquanto as zonas internas podem ser ventiladas naturalmente por todo o

2 Vale destacar que pela qualidade ambiental gerada em todos os espaços internos devido a presença dos jardins e dos átrios, as autoridades locais permitiram que o projeto rompesse com o limite de altura pré-estabelecido para o terreno (GONCALVES, 2003)

Umakoshi, Erica Mitie 
Capítulo 1 - O Desempenho Ambiental e a Eficiência Energética dos Edifícios Altos

Avaliação de Desempenho Ambiental e Arquitetura Paramétrica Generativa para o Projeto do Edifício Alto

54
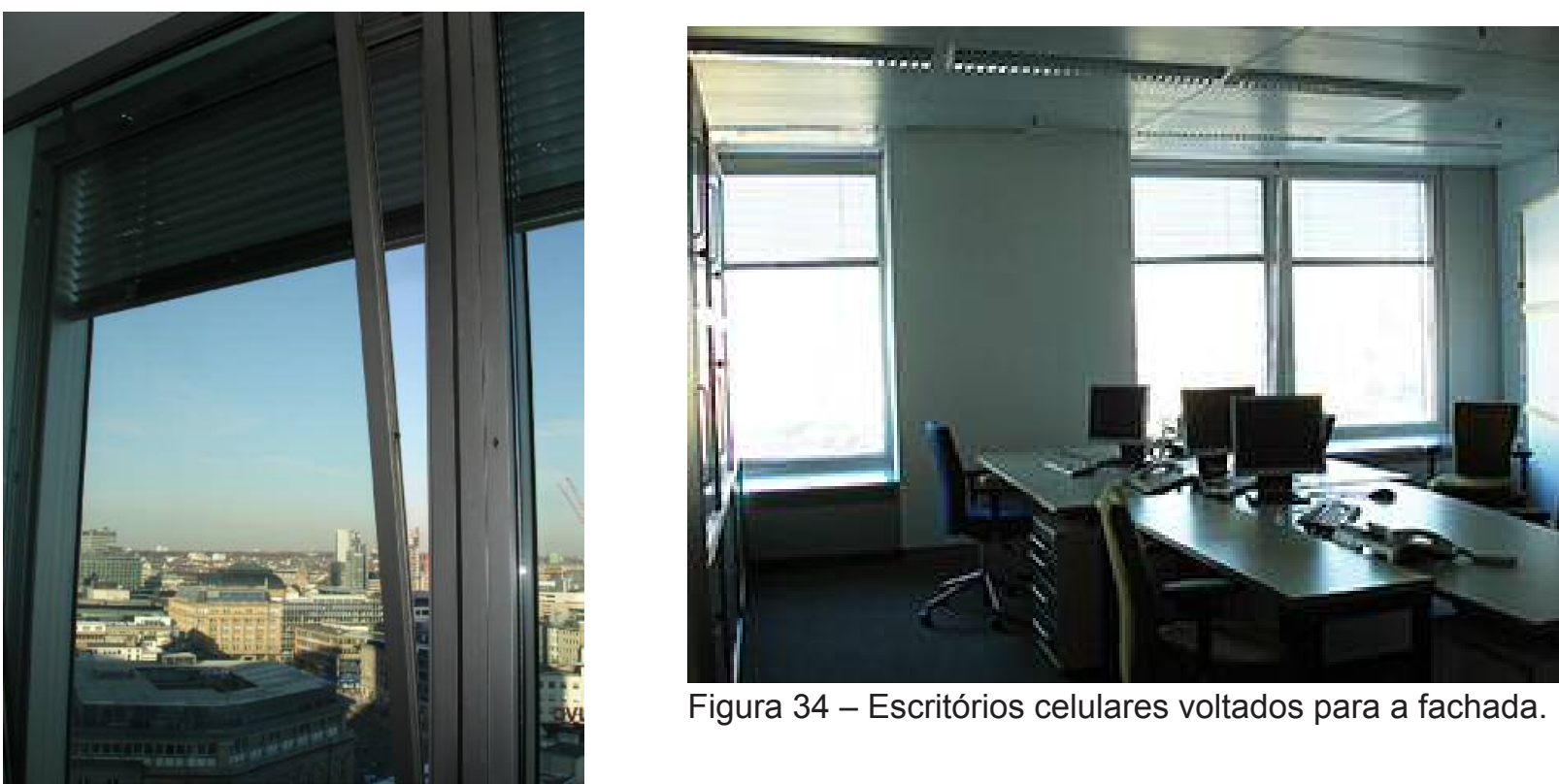

Figura 34 - Escritórios celulares voltados para a fachada.

Figura 31 - Janelas da fachada.

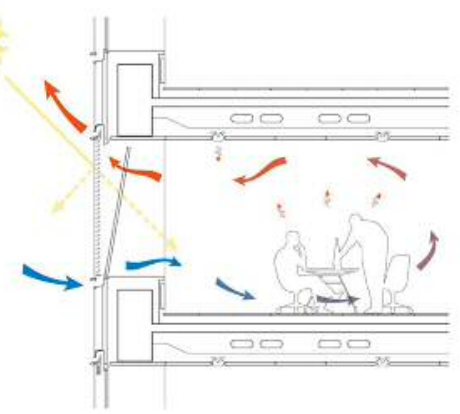

Figura 32 - Corte esquemático que demonstra a ventilação do escritório e o meio ambiente externo. Fonte: <www. fosterandpartners.com> acessado em outubro de 2010.

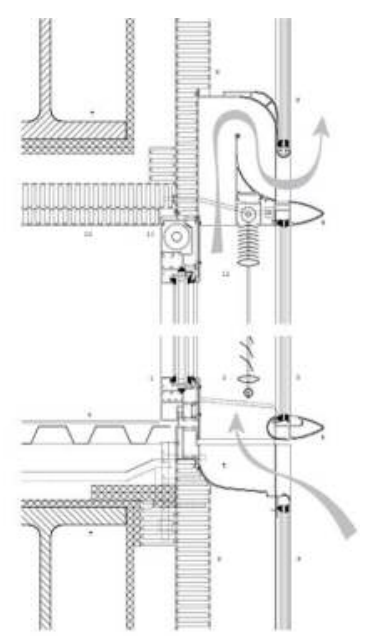

Figura 33 - Corte esquemático da janela, identificando os seus componentes. Fonte: $<$ www.fosterandpartners.com> acessado em outubro de 2010.

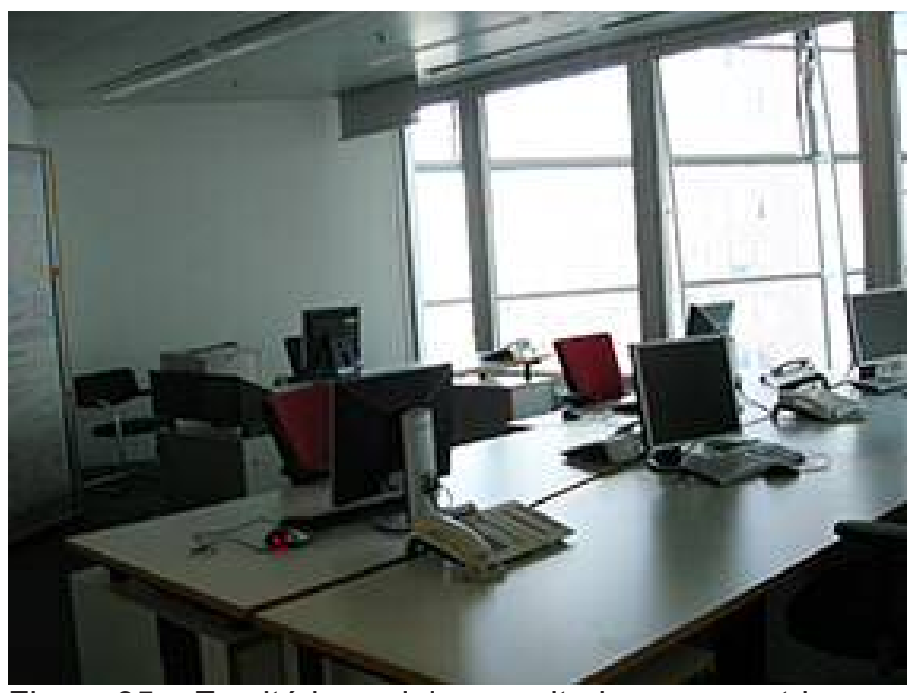

Figura 35 - Escritórios celulares voltados para o atrio.

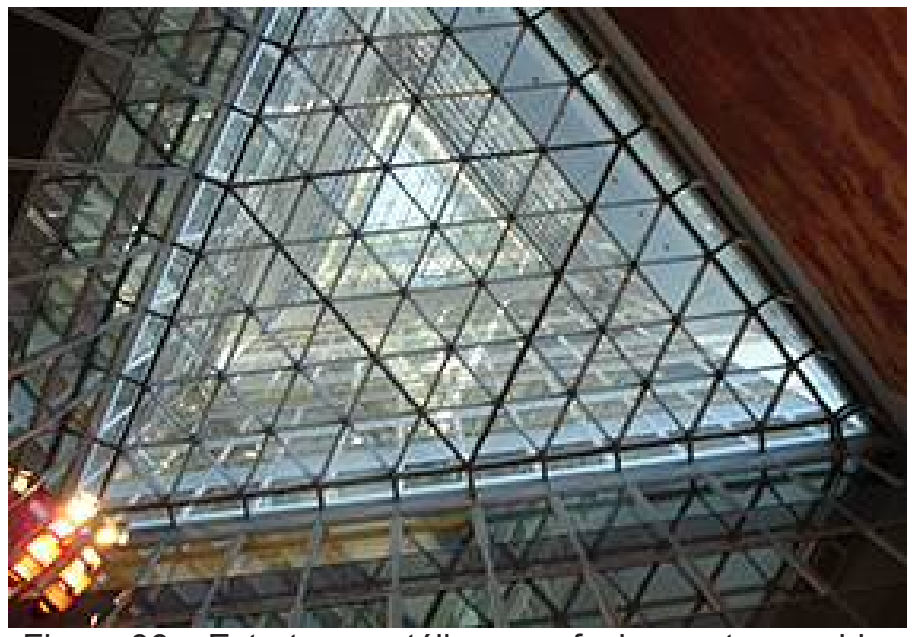

Figura 36 - Estrutura metálica com fechamento em vidro. 
período. Caso as condições externas não favoreçam a ventilação natural, as aberturas são automaticamente travadas, sem a possibilidade de intervenção do usuário. As áreas de trabalho são subdivididas em salas com divisórias de vidro, garantindo que o usuário, ou um pequeno grupo deles, possa intervir nas suas condições de conforto térmico regulando a abertura das janelas e o uso de persianas, sem causar o desconforto de demais usuários, como é comum em ambientes de trabalho de planta livre (fig. 34 e 35). O sistema de resfriamento de ar é feito por forros gelados e ventilação mecânica, e o aquecimento por meio de aquecedores convencionais.

Quanto à iluminação natural, a estrutura metálica com fechamento em vidro que separa as "vilas" dá continuidade a passagem da luz natural (fig. 36). Além da ventilação e da iluminação natural, os terraços e o vazio central dos átrios teve o objetivo possibilitar a ampla comunicação entre os espaços internos e as vistas ao exterior, conferindo uma expressão arquitetônica distinta ao edifício alto.

Urbanisticamente, o Commerzbank tem uma posição de destaque no distrito financeiro da cidade, marcando o ponto de altura máxima do conjunto de torres. Devido à sua localização, usufrui de uma boa conexão com as linhas de metrô, ônibus e trams. O embasamento da torre de escritórios possui 6 pavimentos com unidades residenciais, lojas e um auditório (fig. 37 e 38). O recuo do edifício do alinhamento da calçada e a presença do embasamento minimizam os riscos de desconforto do pedestre devido a turbulências de ventos. Por outro lado, o edifício demonstrou ter um efeito positivo de incremento da ventilação urbana no verão, quando há pouca ocorrência de ventos (GONÇALVES, 2003).

Dados consumo energético, da sede do Commerzbank em Frankfurt, em uso e operação registrados ao longo de uma década fazem dele uma das mais importantes referencias de desempenho ambiental da tipologia do edifício alto. Isso se deve ao fato da possibilidade de ventilação natural em todos os ambientes de trabalho, da comunicação visual entre espaços internos em diferentes pavimentos, das vistas ao exterior a partir das áreas internas nos pavimentos, do controle do usuário sobre a penetração da luz natural nos ambientes de trabalho e da criação de áreas de interação social e transição climática.

Ambientalmente, o clima temperado de Frankfurt, caracterizado por verões amenos, 


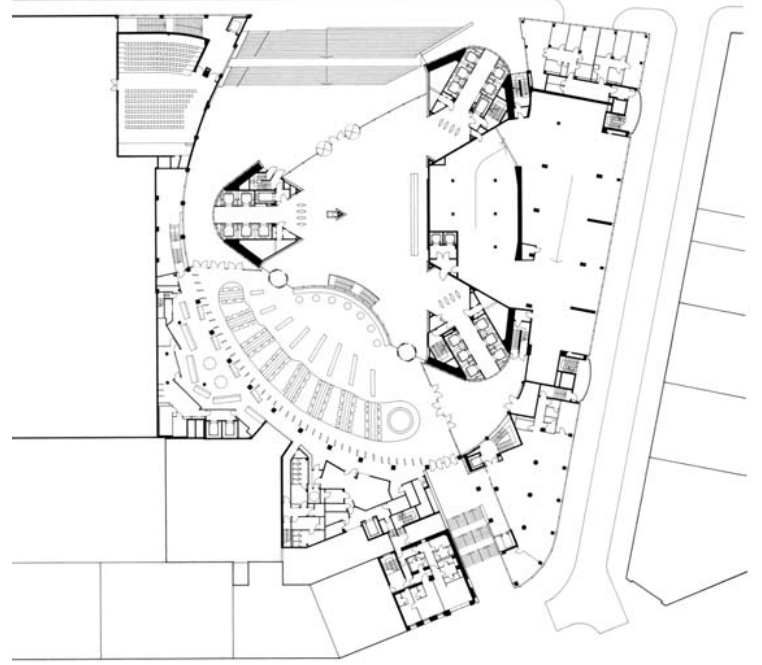

Figura 37 - Implantação. Fonte: <www. fosterandpartners.com $>$ acessado em outubro de 2010.

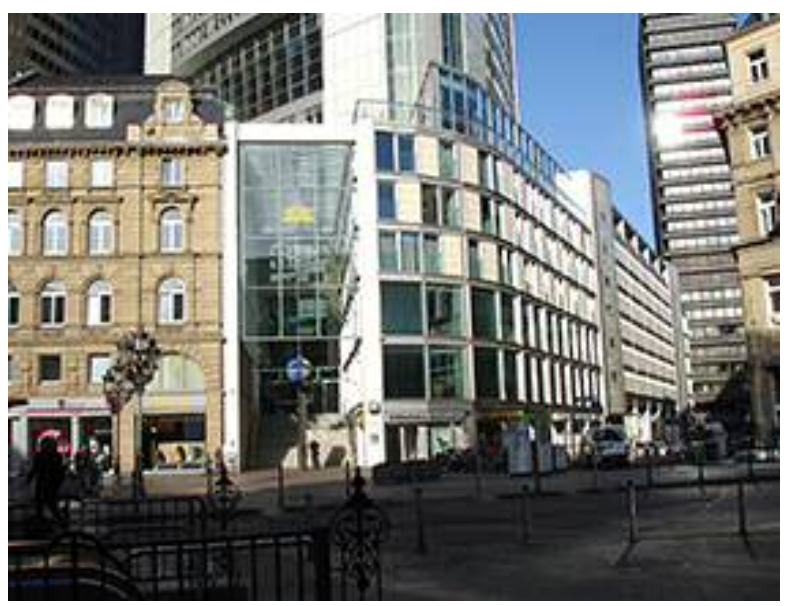

Figura 38 - Embasamento.

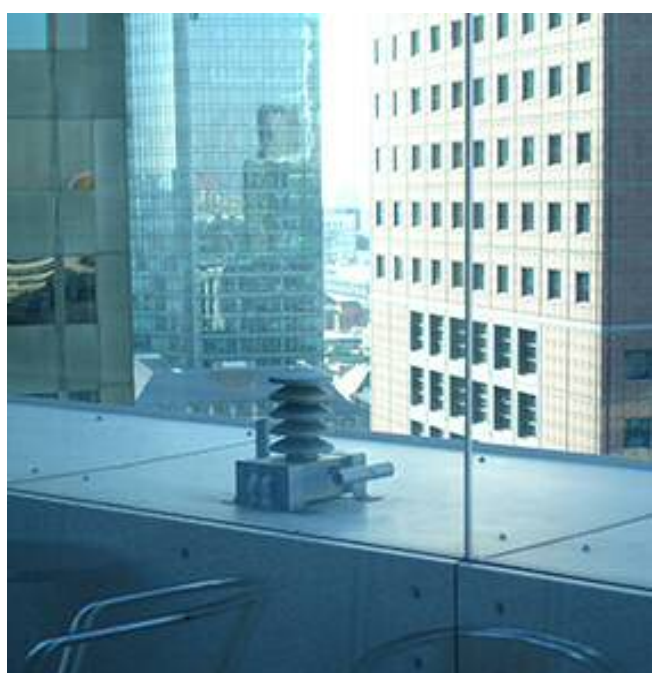

Figura 40 - Estação meteorológica localizada no jardim.

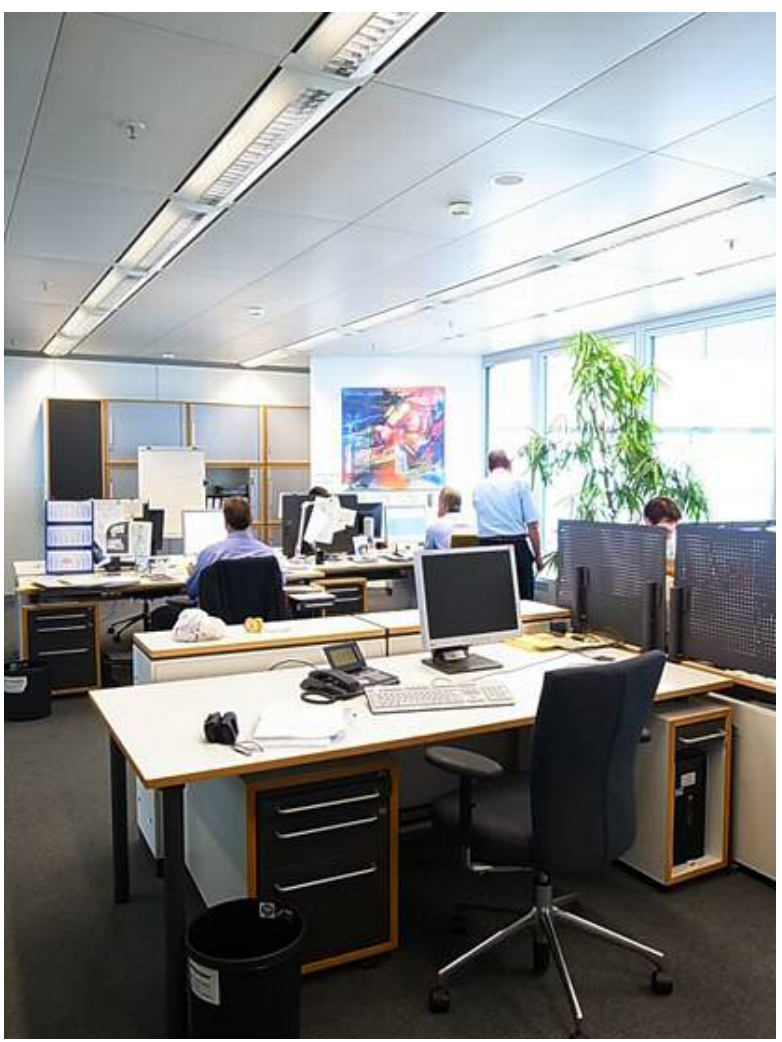

Figura 41: Vista interna da área de escritórios resultante da junção dos escritórios celulares junto à fachada externa, em resposta ao acrescimo da ocupacao em 2008. Fonte: Keunjoo Lee, 2011.

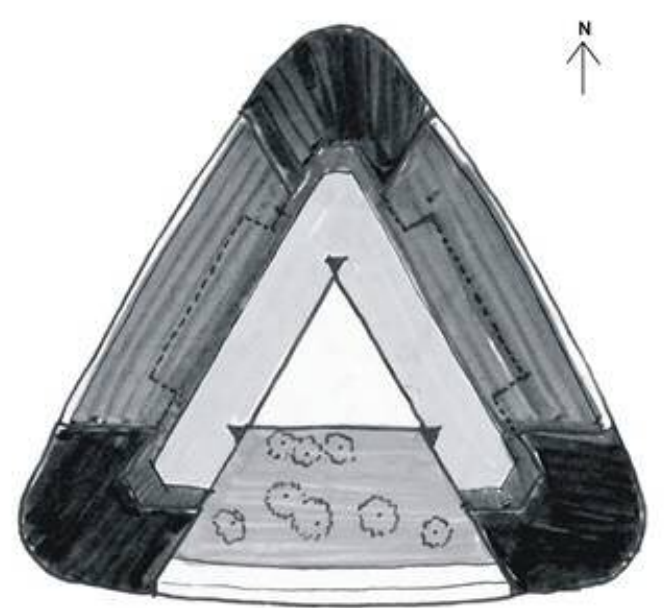

Figura 42: Planta do pavimento tipo, com a área de planta livre voltada para a fachada exterior, sendo essa resultante da junção entre a zona externa e a intermediária. Vale observar que a zona interna, voltada para o átrio e os jardins, continua separada. Fonte: GONÇALVES, UMAKOSHI, 2011. 
apresenta condições favoráveis para o uso da ventilação natural por grande parte do período de ocupação. As médias mensais da temperatura do ar variam de $1^{\circ} \mathrm{C}$ em janeiro a $18,7^{\circ} \mathrm{C}$ em agosto. Assim, o aquecimento do espaço interno nos meses de inverno é o objetivo principal da climatização artificial.

Segundo o diagnóstico climático, o condicionamento de ar no verão pode ser dispensado. No entanto, vale ressaltar que as temperaturas máximas nos dias mais quentes do verão podem ultrapassar os $30^{\circ} \mathrm{C}$. Por isso, o sombreamento se faz necessário para bloquear os ganhos excessivos de calor pela insolação direta, enquanto a ventilação remove a carga térmica gerada pela ocupação.

É importante mencionar que, no caso do Commerzbank, os ganhos na qualidade

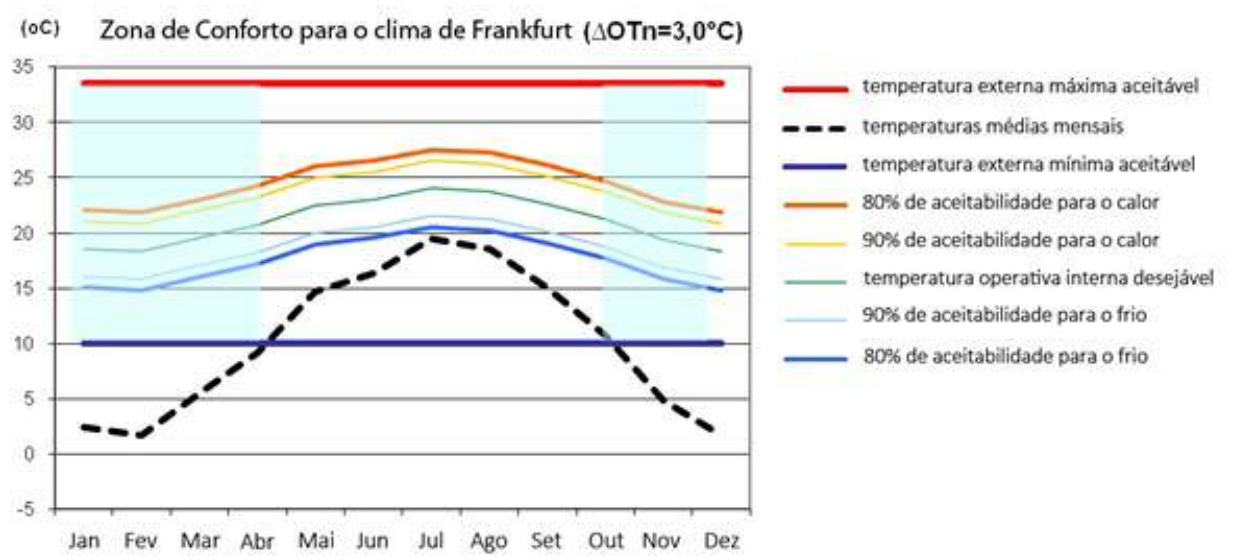

Figura 39: Zona de conforto para o clima de Frankfurt am Main, na Alemanha (latitude $50 \mathrm{oN}$ ), criada a partir do calculo da temperatura operativa interna desejavel ("temperatura de conforto", OTn). Fonte: ASHRAE (2009).

ambiental e arquitetônica tem consequências sobre o conceito convencional de eficiência do espaço. Devido principalmente à área ocupada pelos terraços e o átrio central, apenas 35 por cento da área total construída da torre é computada como área efetiva de estações de trabalho. No entanto, mesmo não fazendo parte da área útil computável, os terraços são efetivamente parte do ambiente de trabalho, com condições microclimáticas intermediárias entre o ambiente interno e externo.

Visando o controle das condições ambientais internas, estações meteorológicas foram instaladas nos nove terraços das três primeiras vilas e foram programadas para 0 monitoramento das condições microclimáticas nesses espaços de transição, com especial atenção para a velocidade dos ventos (fig. 40). Simultaneamente, uma décima 
estação na cobertura registra continuamente as variáveis do clima externo.

Enquanto os dados registrados pela estação da cobertura alimentam o sistema de controle das janelas voltadas para o exterior, os dados enviados pelas estações dos terraços informam o controle de janelas voltadas aos átrios. Com base nessas informações, a central de controle dos sistemas prediais (Building Management System) opta pela ventilação natural ou mecânica em cada zona do pavimento, caracterizando o chamado modo misto de climatização.

Além da setorização dos sistemas no pavimento, a compartimentação vertical permite que uma vila inteira esteja aberta para a ventilação natural, enquanto aquela imediatamente superior ou inferior esteja operando com a ventilação mecânica, dependendo das condições de vento. Apesar da automatização, o controle das aberturas permite uma interação entre os ocupantes e a condição microclimática na qual ele está, pois é dele a opção de acionar a abertura das janelas, mediante condições externas favoráveis à ventilação natural, assim como decidem sobre a abertura e o fechamento das persianas de bloqueio da radiação solar direta.

Com relação aos sistemas prediais de climatização, a busca pela máxima eficiência energética levou à separação das funções, ou seja, a ventilação mecânica foi separada do aquecimento e do resfriamento ativo. Assim, nos períodos mais quentes do ano, um sistema de forros gelados atua na remoção da carga térmica dos ambientes de escritórios, podendo ser combinado à ventilação natural ou mecânica, dependendo das temperaturas externas e da velocidade dos ventos. No caso de ventos fortes, mesmo com temperaturas aceitáveis, as janelas se fecham automaticamente, requisitando a ventilação mecânica.

Como apresentado em Goncalves e Umakoshi (2010), as avaliações do desempenho ambiental realizadas durante a fase de projeto confirmaram a hipótese de que as zonas internas de escritórios voltadas para os átrios apresentam a menor demanda anual por aquecimento e arrefecimento e as melhores condições para a ventilação natural, como consequência das condições microclimáticas resultantes no interior das vilas protegidas pelo fechamento dos terraços.

Maiores restrições à ventilação natural são identificadas nos pavimentos da última vila 
(aberta ao ambiente externo), devido a frequência de ventos de alta velocidade. Da mesma forma, voltando-se para as fachadas externas, por conta do efeito dos painéis de proteção, janelas só precisam ser fechadas quando expostas a ventos acima de $9 \mathrm{~m} / \mathrm{s}$. Como resultado, o edifício como um todo usufrui da ventilação natural por aproximadamente 80 por cento do ano, com uma variação de mais ou menos 5 por cento, mostrando um desempenho melhor do que os $60 \%$ previstos no projeto ${ }^{3}$.

A combinação do átrio central com os terraços laterais cria uma zona mediação climática, um ambiente de transição entre o clima externo e o interior do edifício. No verão, a temperatura máxima registrada nos terraços pelo sistema de automação predial não ultrapassa os $27^{\circ} \mathrm{C}$ e no inverno, um sistema de aquecimento sob o piso, alimentado pela rede urbana de distribuição de calor (district heating), faz com que a temperatura mínima não seja menor que $5^{\circ} \mathrm{C}$.

Em 2002, quatro anos após a conclusão do edifício, as nove estações meteorológicas dos terraços deixaram de operar, permanecendo apenas a da cobertura. O objetivo dessa medida foi a simplificação dos controles de automação predial, no que se refere a abertura das janelas. A satisfação dos usuários dos escritórios voltados para os átrios, com a ventilação natural e as consequentes oscilações de temperatura, inclusive no verão, influenciaram a decisão de aumentar o controle do usuário sobre a operação das janelas das zonas internas e externas de escritórios.

No cenário original de projeto, as janelas eram fechadas no momento em que as temperaturas internas chegavam ao limite de $26^{\circ} \mathrm{C}$, sendo então, a ventilação mecânica acionada juntamente ao sistema de resfriamento ativo. Com a mudança no modo de operação, passa a ser critério dos usuários o momento de fechamento das janelas em função de temperaturas mais elevadas. Contudo, o sistema de automação predial continua assumindo o controle sobre o fechamento das janelas quando ventos, acima dos $9 \mathrm{~m} / \mathrm{s}$, são registrados pela estação da cobertura, ou no caso da temperatura interna cair abaixo dos $17^{\circ} \mathrm{C}$.

Com um maior controle dos usuários sobre as suas próprias condições de conforto térmico, é possível que temperaturas internas acima dos $26^{\circ} \mathrm{C}$ sejam aceitas, ou seja, a simplificação do sistema de automação e o maior controle dos usuários sobre as

3 Informação retirada de http://www.fosterandpartners.com/projects/ commerzbank-headquarters/acessado em 20 janeiro de 2012.

Umakoshi, Erica Mitie 
condições térmicas dos ambientes internos aumentou a independência dos sistemas de climatização ambiental, reduzindo ainda mais a demanda energética do edifício.

Em 2008 da população do edifício passou de 2.400 para 2.820 ocupantes. A fim de acomodar a nova população, os escritórios celulares das zonas externas junto as fachadas foram abertos e somados a zona intermediária de circulação, transformandose em planta livre e permitindo que toda a área pudesse ser beneficiada pela ventilação natural (fig.41). Já os escritórios celulares voltados para os átrios foram mantidos como no projeto original, com ambientes de trabalho mais privados e pleno aproveitamento da ventilação natural (fig. 42).

\section{Desempenho energético 4}

Para a análise dos dados de consumo de energia da sede do Commerzbank é necessário que seja identificado o tipo de energia e de sistemas prediais em questão. $O$ edifício conta com o fornecimento de energia elétrica diretamente da rede da infraestrutura urbana para iluminação artificial, equipamentos, elevadores, bombas e equipamentos da ventilação mecânica; e de energia térmica (calor), também provida pela rede distrital urbana, que alimenta o sistema de aquecimento do ar com radiadores a base de água quente, e os chillers de absorção do equipamento de condicionamento de ar.

No caso do arrefecimento, forros gelados são acionados para a remoção da carga térmica interna, enquanto trocadores de calor conectados à ventilação mecânica fazem o resfriamento do ar externo, aproveitando as temperaturas relativamente mais baixas do fluxo de ar extraído do ambiente interno. A fim de maximizar a eficiência energética do sistema, a ventilação mecânica é descentralizada, tendo trocadores de calor e uma unidade de distribuição de ar (air handling unit) a cada vila de 12 pavimentos. Os forros gelados funcionam a base de água fria fornecida pelos chillers de absorção de calor, alimentados pela rede distrital urbana. Desse modo, o consumo de energia elétrica no processo de resfriamento do ar é restrito ao sistema distribuição da agua gelada e ao funcionamento dos equipamentos da ventilação mecânica.

Consumo de energia elétrica

Olhando inicialmente para a energia elétrica, dados medidos pelo sistema de automação

4 Os dados sobre o consumo de energia do Commerzbank foram fornecidos pelo engenheiro Peter Muschelknautz, encarregado pelos sistemas prediais do edifício, na visita técnica de 2009 (GONÇALVES, UMAKOSHI 2010). 
predial do edifício, indicam que o consumo teve uma variação relativamente pequena ao longo da primeira década de ocupação, sendo de pouco mais de $10 \%$, variando de $105 \mathrm{kWhr} / \mathrm{m}^{2}$ a $120 \mathrm{kWhr} / \mathrm{m}^{2}$ (fig. 43)5. Isso se deve ao fato do consumo de energia elétrica ter uma pequena parcela dedicada ao sistema de climatização, sendo a maior parte destinada à iluminação artificial e aos equipamentos. Assim, a variação mencionada pode ser atribuída ao acréscimo de aproximadamente 1/3 da população do edifício, nos últimos anos, influenciando no uso de equipamentos, elevadores e iluminação artificial. A figura 44 mostra que o consumo anual de energia elétrica está abaixo das metas nacionais de desempenho para edifícios de escritório, não apenas quando comparado a aqueles com condicionamento de $\operatorname{ar}\left(155 \mathrm{kWhr} / \mathrm{m}^{2}\right)$, mas também em relação aos edifícios com ventilação mecânica e aquecimento ativo, mas sem o sistema de arrefecimento (125kWhr/m²), (EnEV 2007).

Consumo de energia térmica

Assim como o consumo de energia elétrica, o consumo de energia térmica variou ao longo da década. Nesse caso, a diferença nos níveis de consumo pode estar associada às variações climáticas entre os anos e, consequentemente, ao impacto na demanda por aquecimento e arrefecimento dos ambientes internos.

Dados medidos entre 1999 e 2008 mostram que o consumo de energia térmica variou de $105 \mathrm{kWhr} / \mathrm{m}^{2}$ a $127 \mathrm{kWhr} / \mathrm{m}^{2}$ (fig. 45). Assim como para a energia elétrica, os valores do consumo anual de energia térmica estão abaixo de todas as metas nacionais de desempenho energético para edifícios de escritório, incluindo aqueles climatizados artificialmente $\left(190 \mathrm{kWhr} / \mathrm{m}^{2}\right)$, bem como os edifícios com ventilação mecânica e aquecimento $\left(160 \mathrm{kWhr} / \mathrm{m}^{2}\right)$ e, ainda, os edifícios ventilados naturalmente $\left(135 \mathrm{kWhr} / \mathrm{m}^{2}\right)$ (EnEV 2007).

No entanto, considerando separadamente os valores de consumo de energia voltados ao aquecimento dos de arrefecimento, encontra-se uma diferença significativa em cada um dos dois modos de climatização, ao longo do período de dez anos. Os dados revelam que no ano de 2003 o consumo para o aquecimento foi o menor e para o

5 O cálculo do consumo de energia por metro quadrado utilizou como base a área útil do edifício totalizando $85,500 \mathrm{~m}^{2}$, do qual fazem parte os espaços de escritório, as salas de reunião, a circulação, as salas de conferência e todos os demais espaços internos utilizados para as atividades do edifício.

Umakoshi, Erica Mitie 


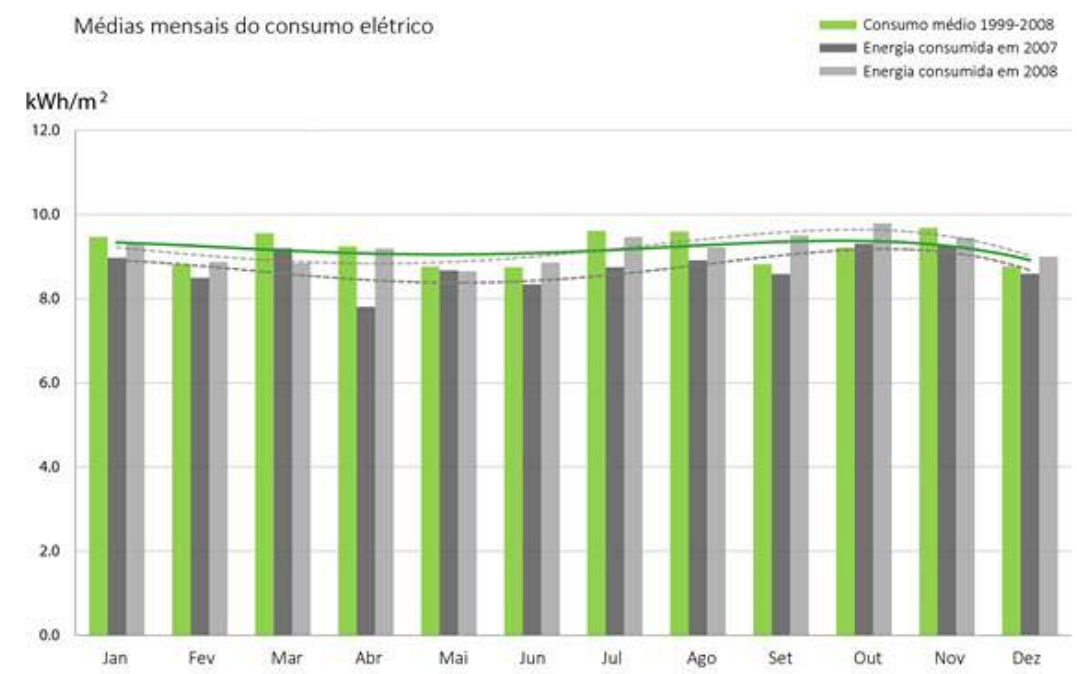

Figura 43: Médias mensais do consumo de energia da sede do Commerzbank no período de 1999 a 2008, comparadas ao consumo em 2007 e 2008. Fonte: Peter Muschelknautz, Sede do Commerzbank

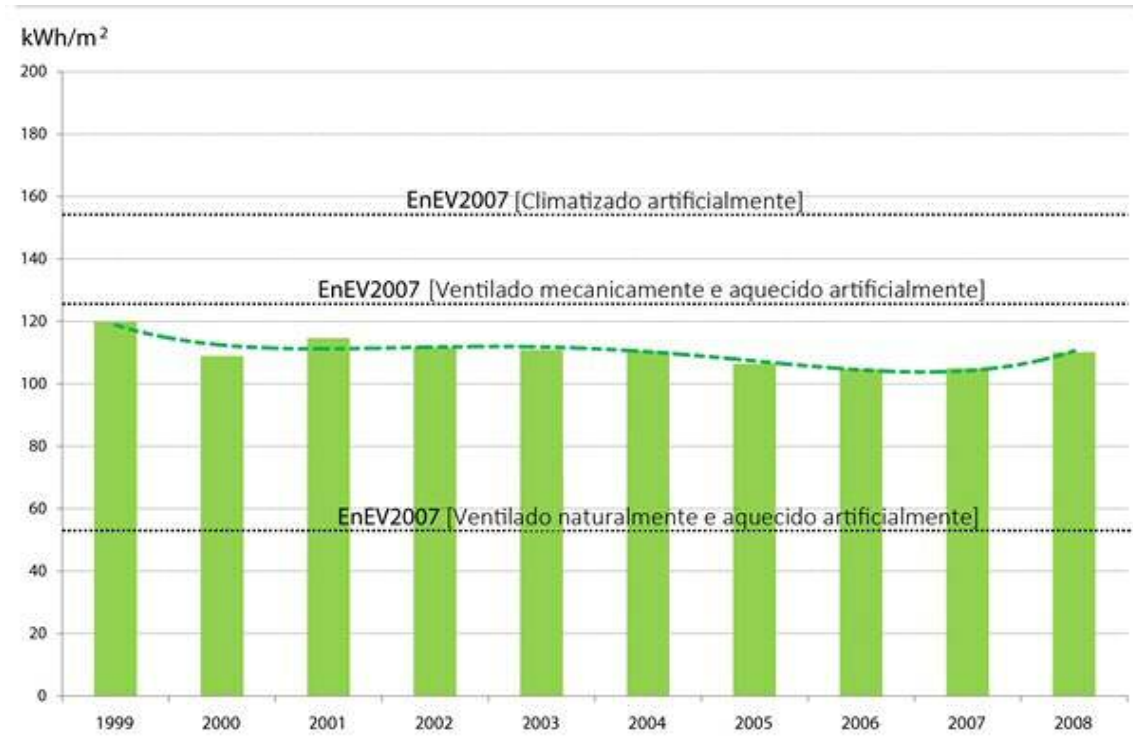

Figura 44: Consumo mensal de energia eletrica em kWh/m2(desde1999), comparado a metas nacionais (alemãs) para o desempenho energético de edifícios de escritório (EnEV 2007). Fonte: Peter Muschelknautz, Sede do Commerzbank

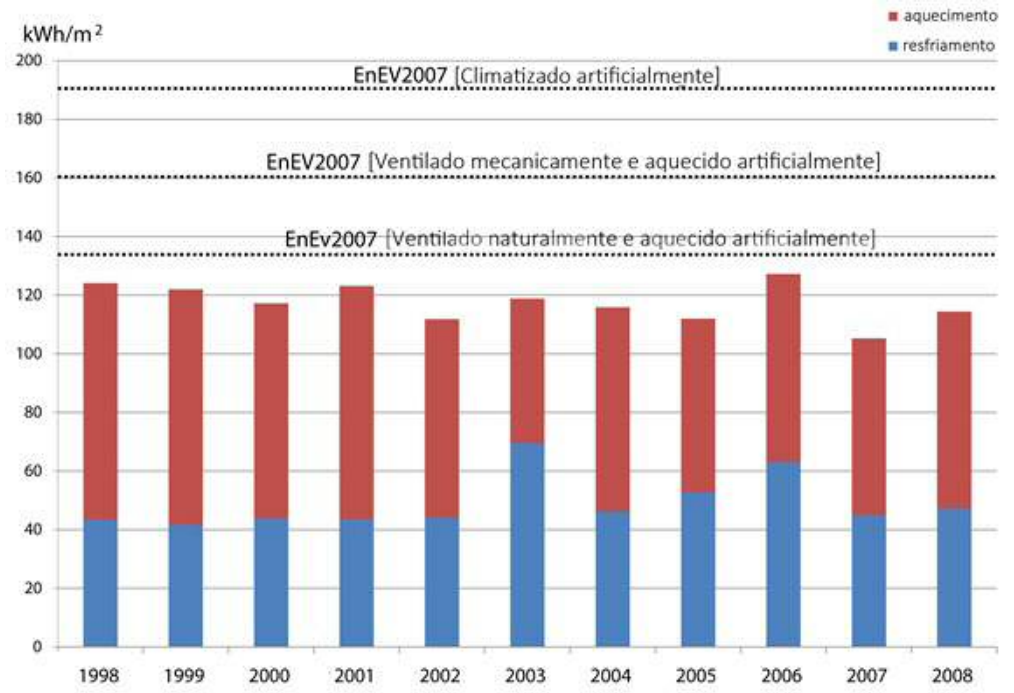

Figura 45: Médias mensais do consumo de energia térmica para o sistema de aquecimento e arrefecimento do edifício, durante o período de 1999 a 2008 , comparadas as metas nacionais para o desempenho energético de edifícios de escritório (EnEV 2007).Fonte: Peter Muschelknautz, Sede do Commerzbank 
arrefecimento, o maior, enquanto os anos de 1998 e 2001 tem um perfil exatamente oposto, confirmando a hipótese do impacto do clima na demanda por energia para a climatização. Os valores, para o aquecimento dos espaços, oscilaram entre $49 \mathrm{kWhr} / \mathrm{m}^{2}$ e $81 \mathrm{kWhr} / \mathrm{m}^{2}$ (fig. 46), sendo esses semelhantes ao caso do arrefecimento, que ficou entre $42 \mathrm{kWhr} / \mathrm{m}^{2}$ e70kWhr/m² (fig. 47). Em ambos, a diferença entre o consumo mínimo e o máximo fica ao redor de 60 por cento.

A comparação entre os dados de consumo de energia do Commerzbank e as metas alemãs de desempenho demonstra o desempenho superior do estudo de caso, validando

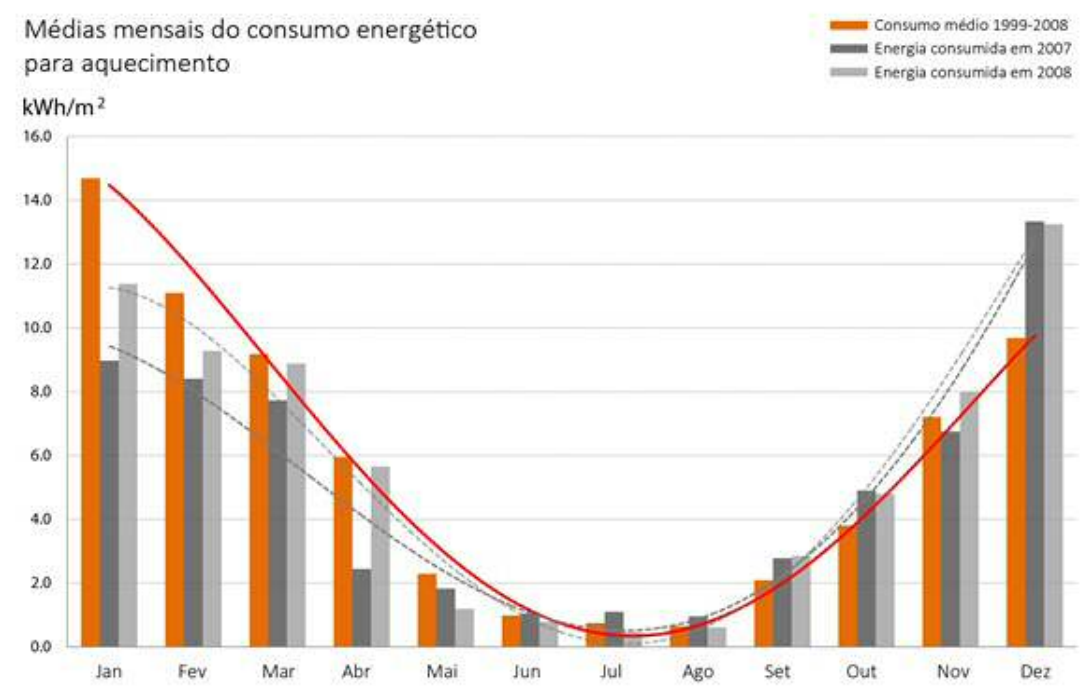

Figura 46 - Médias mensais do consumo de energia térmica exclusivamente para o aquecimento do edifício, durante o período de 1999 a 2008, comparadas ao consumo de 2007 e 2008. Fonte: Peter Muschelknautz, Sede do Commerzbank

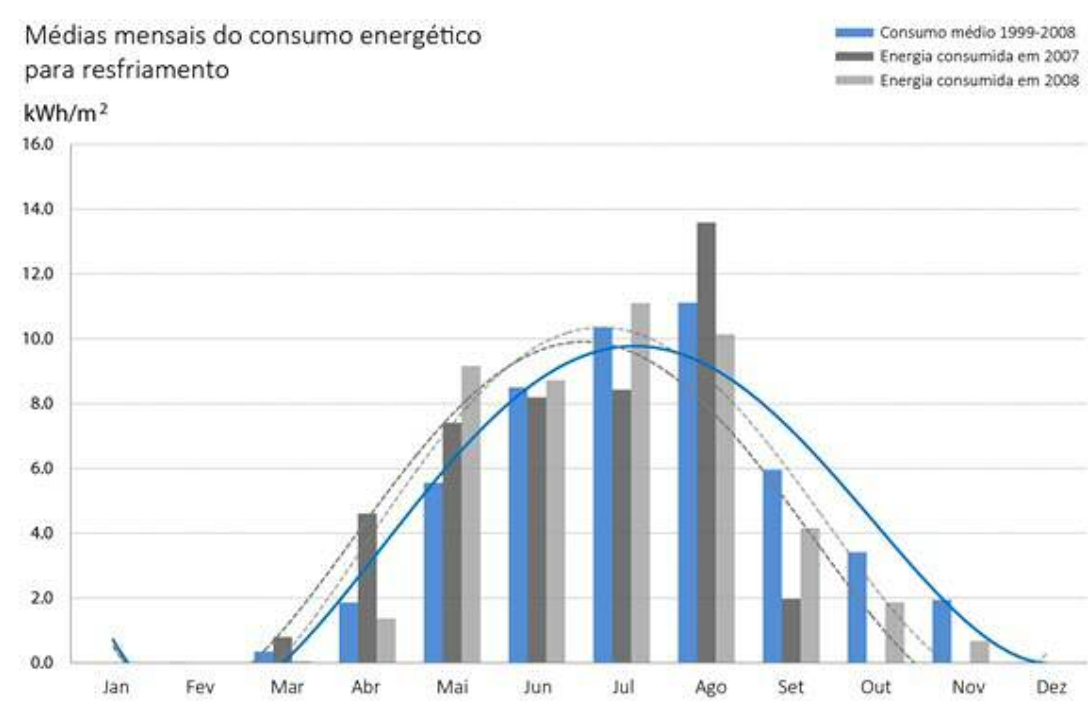

Figura 47 - Médias mensais do consumo de energia térmica exclusivamente para o arrefecimento do edifício, durante o período de 1999 a 2008, comparadas ao consumo de 2007 e 2008. Fonte: Peter Muschelknautz, Sede do Commerzbank 
seu papel de ícone internacional do edifício alto de melhor desempenho ambiental com referência ao uso da ventilação e iluminação natural em edifícios comerciais de grande porte e altura.

Entretanto, o valor do desempenho ambiental do Commerzbank vai além dos números da questão energética. Com seu projeto arquitetônico original, sistemas prediais integrados ao conceito do edifício de menor impacto ambiental, usuários preparados para um ambiente de trabalho diferenciado (menos dependente dos sistemas de climatização artificial), o edifício do Commerzbank reestabelece a cultura do edifício de escritório com ventilação natural, aceitando as oscilações de temperatura do ar e as condições de conforto térmico inerentes a ela.

\subsubsection{0th Saint Mary Axe (2004, Londres, Inglaterra)}

\begin{tabular}{|l|l|}
\hline Projeto & Swiss Re Headquarters (30 St Mary Axe) \\
\hline Localização & Londres, Inglaterra, Latitude $52^{\circ}$ Norte \\
\hline Cliente/lnvestidor & Swiss Reinsurance Company \\
\hline Arquitetura & Foster and Partners \\
\hline Engenharias & $\begin{array}{l}\text { Gardiner and Theobald, Hilson Moran Partnership Ltd., BDSP } \\
\text { Partnership, Ove Arup and Partners- London, RWG Associates, } \\
\text { Sandy Brown Associates }\end{array}$ \\
\hline Uso do Empreendimento & Escritórios e comércio na base \\
\hline Altura & 180 metros \\
\hline Número de Pavimentos & 41 pavimentos \\
\hline Área do Pavimento Tipo & $1.171 \mathrm{~m}^{2}$ à $1.549 \mathrm{~m}^{2}$ \\
\hline Área Total & $76.400 \mathrm{~m}^{2}$ \\
\hline Status/ Fase & Construído em 2004 \\
\hline Estacionamento & Não disponível \\
\hline
\end{tabular}

Fonte: GONÇALVES, 2003.

Construído em 2004 em Londres, o edifício alto 30 Saint Mary Axe (antiga sede da empresa Swiss $\mathrm{Re}$ ) é outro caso conhecido internacionalmente, um exemplo de síntese entre forma e espaços de transição, projetado para a ventilação natural. Possui 41 pavimentos e 180 metros de altura (fig. 48), e está localizado no distrito financeiro de Londres, The City, uma região que concentra a vocação para a construção de edifícios altos de escritórios na cidade. Por sua localização central, o empreendimento é bem servido de transportes públicos como ônibus e metrô. Faz parte de um cluster de edifícios altos com alturas variando entre 84 a 183 metros (fig. 49).

A sua forma inusitada, com planta circular com diâmetros variados, é o que o diferencia Umakoshi, Erica Mitie

FAU-USP, fev. 2014 
dos edifícios vizinhos e faz dele um marco na paisagem da cidade. Devido a sua forma de dupla curvatura, os efeitos de ventos são minimizados no nível do pedestre (fig. 50). Urbanisticamente, a forma curva também permite maior visão do céu a partir do

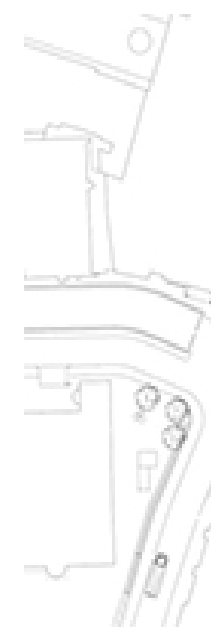

Figura 51 - Implantação. Fonte: < http://www. fosterandpartners.com> acessado em novembro de 2013.

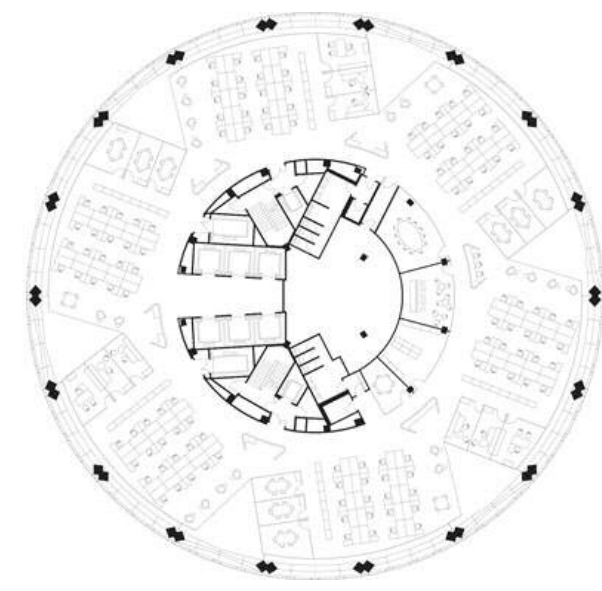

Figura 52 - Planta. Fonte: < http://www. fosterandpartners.com $>$ acessado em novembro de 2013.

nível térreo e dos edifícios vizinhos, possibilitando um maior acesso da luz natural e da insolação. ${ }^{6}$

A concepção do edifício 30th Saint Mary Axe foi baseada no ambiente de trabalho idealizado por Buckminster Fuller nos anos 1970, os quais possuíam envoltórias de módulos triangulares e com jardins internos. Seis átrios verticais de seis pavimentos de altura, projetados em espiral e posicionados no perímetro da planta, cortam a planta circular no formato de uma estrela, criando nichos de acesso da luz natural até as partes mais internas dos pavimentos e possibilitando comunicação visual entre os pavimentos (fig. 53). A fachada dupla ventilada foi projetada para possibilitar a ventilação natural do edifício alto, comunicando os átrios com o meio exterior.

Estudos analíticos demonstraram uma economia de $20 \%$ no consumo energético do sistema de condicionamento de ar em decorrência da forma circular compacta e, consequentemente, da menor área de exposição a radiação solar, quando comparada à forma retangular convencional (BDSP,1998).

O edifício foi projetado para ser naturalmente ventilado sempre que a temperatura

6 É importante destacar que, apesar de construído, as informações apresentadas a seguir sobre o desempenho ambiental do edifício fazem referência a dados de projeto, e não do edifício em operação, fornecidos pelo escritório de engenharia e consultoria BDSP Partnership (BDSP,1998). 


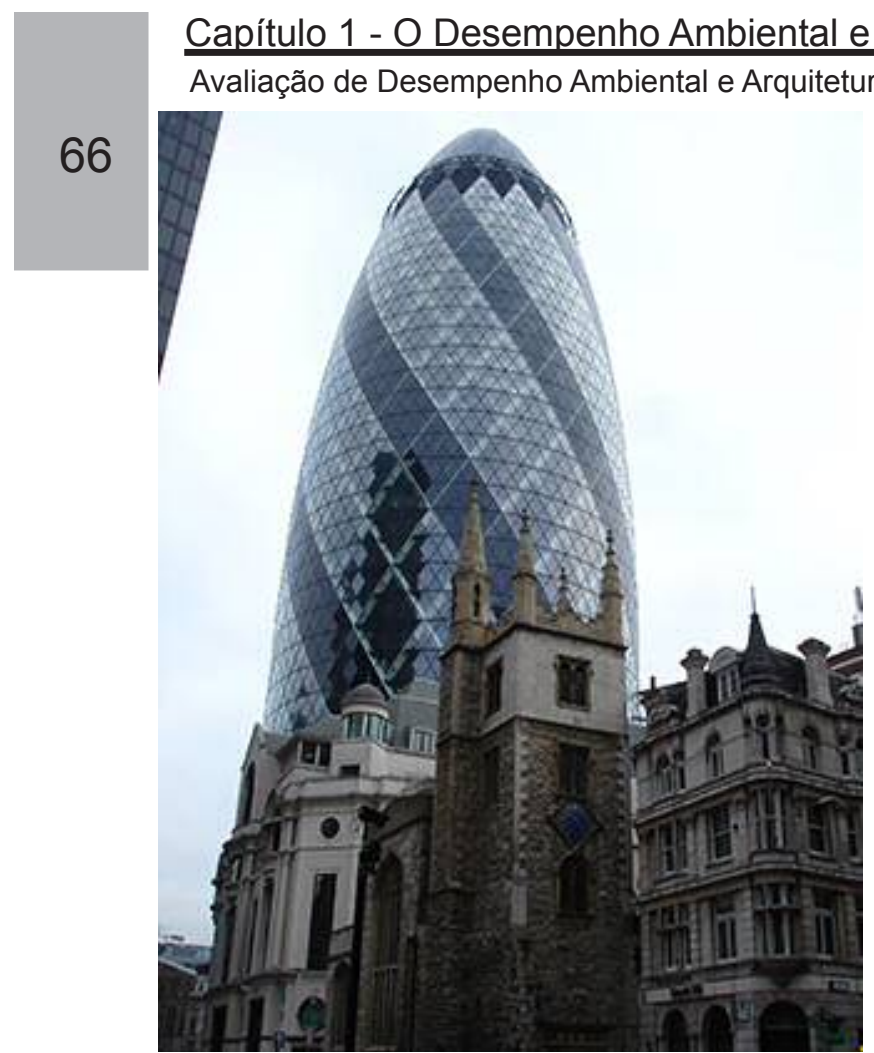

Figura 48 - 30th Saint Mary Axe, Swiss Re (2004).

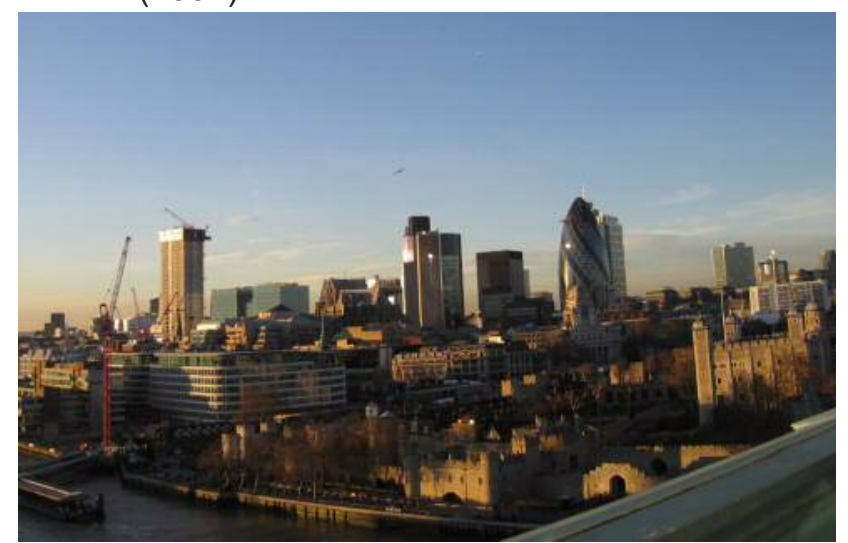

Figura 49 - Swiss Re inserido no cluster. Fonte: Priscila Liao.

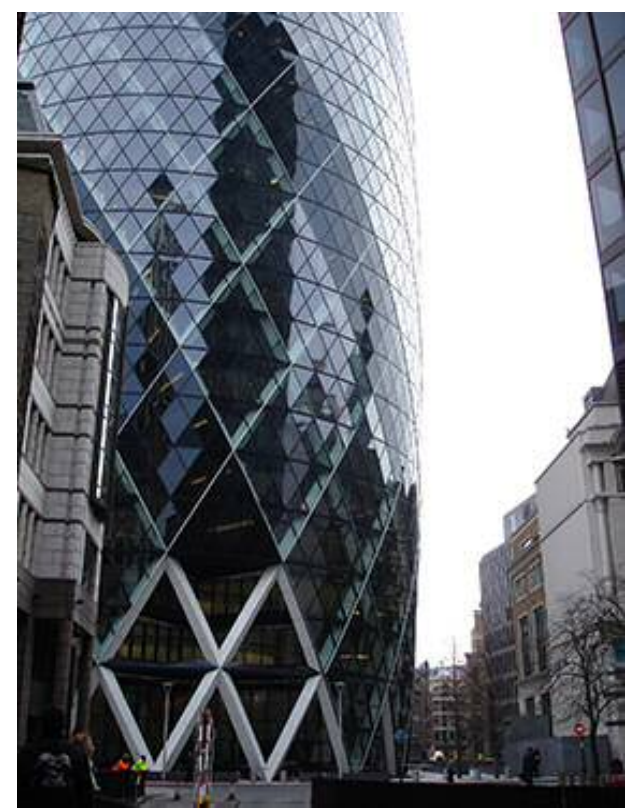

Figura 50 - Embasamento do edifício.

Umakoshi, Erica Mitie

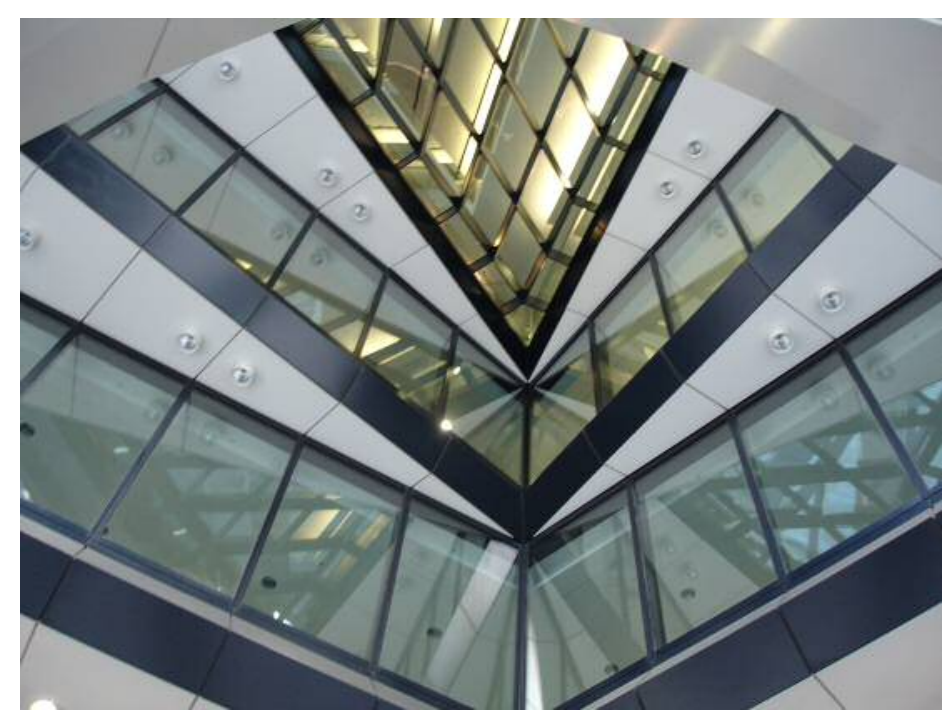

Figura 53 - Átrio do 30th Saint Mary Axe (2004).

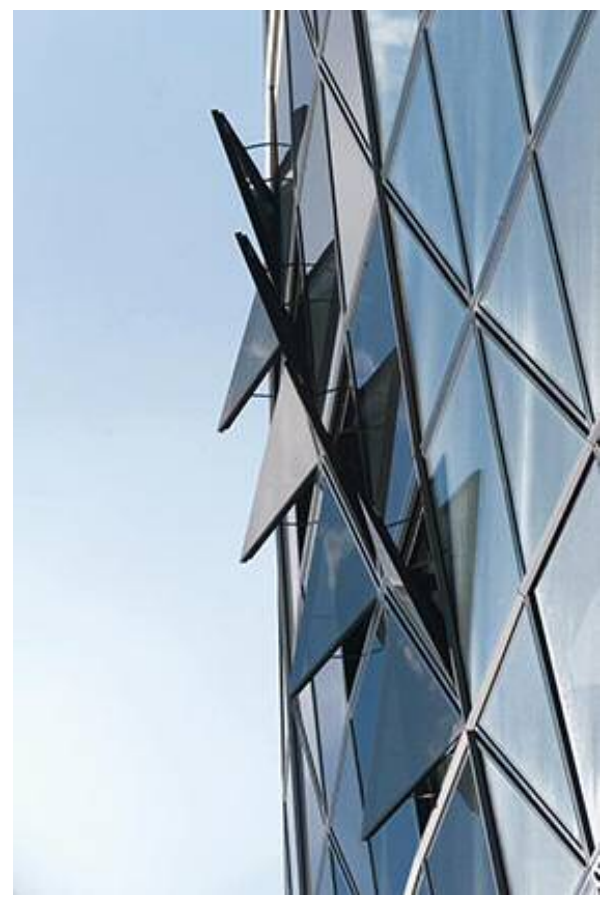

Figura 54 - Aberturas para ventilação dos átrios. Fonte: < http://www.fosterandpartners.com> acessado em novembro de 2013. 
externa for superior à $5^{\circ} \mathrm{C}$ e inferior à $26^{\circ} \mathrm{C}$, a umidade relativa for inferior a $60 \%$ e o vento inferior a $10 \mathrm{~m} / \mathrm{s}$. A ventilação natural foi projetada para acontecer pelos átrios, que são abertos para o exterior através de uma fachada dupla com uma cavidade ventilada e persianas para a proteção contra a radiação direta (fig. 54). Os ambientes de escritório se comunicam diretamente com o espaço dos átrios, porém são fechados para o exterior. Levando em consideração o conforto térmico dos usuários, a ventilação natural pode ser utilizada em $40,8 \%$ a $75,6 \%$ do período de ocupação. Essa variação acontece segundo a temperatura de set point e organização do espaço interno, ou seja, caso a temperatura seja de $240 \mathrm{C}$, com planta livre, a ventilação pode ocorrer em $40,8 \%$ do período de ocupação, e, caso a temperatura de set point seja de $260 \mathrm{C}$, com planta celular, a ventilação pode ocorrer em $75,6 \%$ do tempo.

Diretrizes para um menor consumo de energia em edifícios de escritório no Reino Unido apontam para o potencial de 55 a 60 por cento de economia de energia (o equivalente a faixa de $127-145 \mathrm{kWh} / \mathrm{m} 2$ por ano), como decorrência da introdução da ventilação natural (CIBSE, 2004).

No entanto, vale comentar que diferente do caso do Commerzbank, as informações disponíveis sobre a ex-sede da empresa Swiss Re no centro de Londres, são dados exclusivamente de projeto e não do uso e ocupação do edifício, fato que leva a incertezas sobre o desempenho real do edifício de forma tão inusitada.

1.3.3 110 Bishopsgate (Heron Tower), (2011, Londres, Inglaterra)

\begin{tabular}{|l|l|}
\hline Projeto & 110 Bishopsgate \\
\hline Localização & Londres, Inglaterra, Latitude $52^{\circ}$ Norte \\
\hline Cliente/Investidor & Heron Properties International, London \\
\hline Arquitetura & Kohn Pedersen Fox International \\
\hline Engenharias & Ove Arup and Partners International \\
\hline Uso do Empreendimento & Escritórios, com comércio e lazer na base \\
\hline Altura & 183 metros \\
\hline Número de Pavimentos & 42 pavimentos \\
\hline Área do Pavimento Tipo & 3.350 m² $^{2}$ por vila (3 pavimentos) \\
\hline Área Total & 63.105 m $^{2}$ \\
\hline Status/ Fase & Construído 2011 \\
\hline Estacionamento & 10 vagas para automóveis e 51 para bicicletas \\
\hline
\end{tabular}

Fonte: GONCALVES, 2003.

O edifício 110 Bishopsgate, também conhecido como Heron Tower (fig. 55), construído 
em 2011, possui 42 pavimentos e 183 metros de altura e vem reforçar o cluster de edifícios altos no distrito financeiro de Londres. Por possuir localização central, o empreendimento é bem servido em relação ao transporte público, tanto de ônibus, como de metrô, por essa razão, são disponibilizas apenas 10 vagas de estacionamento para automóveis e 51 vagas para bicicletas. Estudos em túnel de vento constataram que não haverá mudanças significativas nos regimes de ventos, porém, foi verificado um acréscimo na velocidade dos ventos no nível do pedestre, a ser resolvido com a colocação de vegetação de copas altas no local (KPF, 2001).

O projeto do edifício seguiu quatro diretrizes principais: atender às demandas de mercado, produzir uma arquitetura de referência, utilizar conceitos de desempenho ambiental ligados a aspectos arquitetônicos e tecnologias, e reforçar a paisagem urbana do distrito financeiro de Londres ${ }^{7}$. Ao final, avaliado pelo sistema BREEAM ${ }^{8}$ de certificação, obtendo a classificação "excelente"".

A forma em "U" da planta foi escolhida para a criação de um átrio central, que foi orientado a norte, a fim de permitir o acesso e a boa distribuição da luz natural difusa no interior dos ambientes (no hemisfério Norte) (fig.57). O edifício é dividido em 11 "vilas" de escritórios, de 3 pavimentos cada (fig. 58), onde a comunicação visual acontece através do átrio. Devido ao formato da planta, nenhuma área com potencial para abrigar postos de trabalho fica a mais de 9 metros do perímetro do pavimento.

O núcleo de circulação vertical, banheiros e distribuição dos sistemas está localizado na fachada sul, liberando a planta para uma ocupação mais livre, sem obstrução, e

7 Esse foi um dos primeiros projetos que passou por um intenso processo de estudos de impactos ambientais, e outras questões da sustentabilidade para a sua aprovação pelas autoridades locais $(\mathrm{KPF}, 2001)$.

8 BREEAM (Building Research Establishment Environmental Assessment Method) é o sistema de avaliação de desemepenho ambiental desenvolvido no Reino Unido para avaliar edifícios de escritórios quanto às questões de mudanças climáticas, uso de recursos naturais, impacto ambiental, juntamente com a alta qualidade, segurança e salubridade dos ambientes internos. A pontuação são divididas por categorias: energia, transporte, poluição, material, água, ecologia, uso da terra, saúde, bem estar, e gestão. A classificação final vai desde Pass até Excelent. (BRE, 1998)

9 As informações apresentadas a seguir são referentes a dados de projeto extraídos essencialmente do processo de submissão para aprovação legal para a construção do edifício (KPF, 2001). 


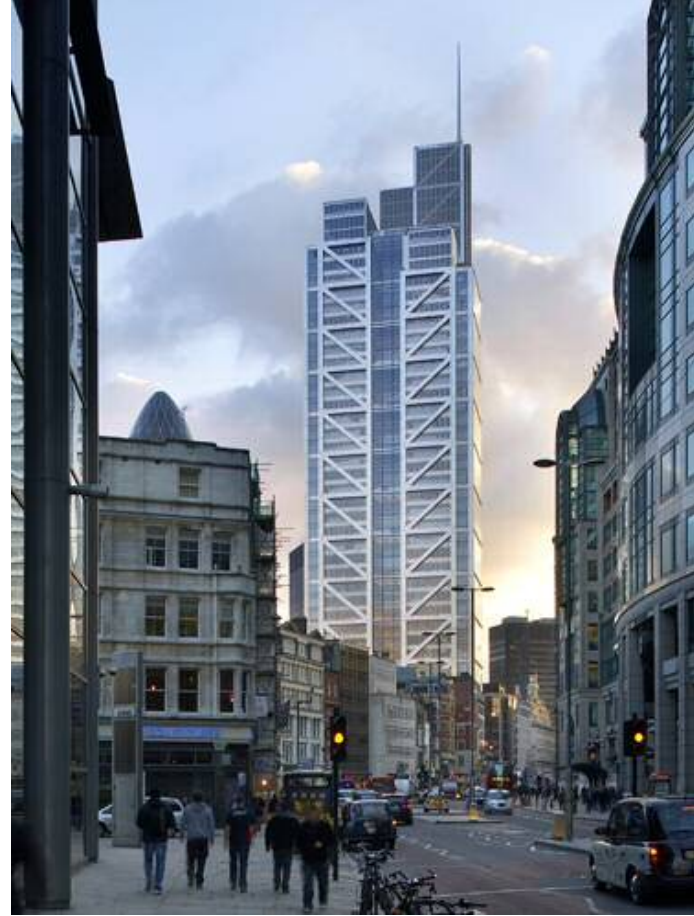

Figura 55 - 110 Bishopsgate Tower. Fonte: www.kpf.com acessado em setembro, 2012.

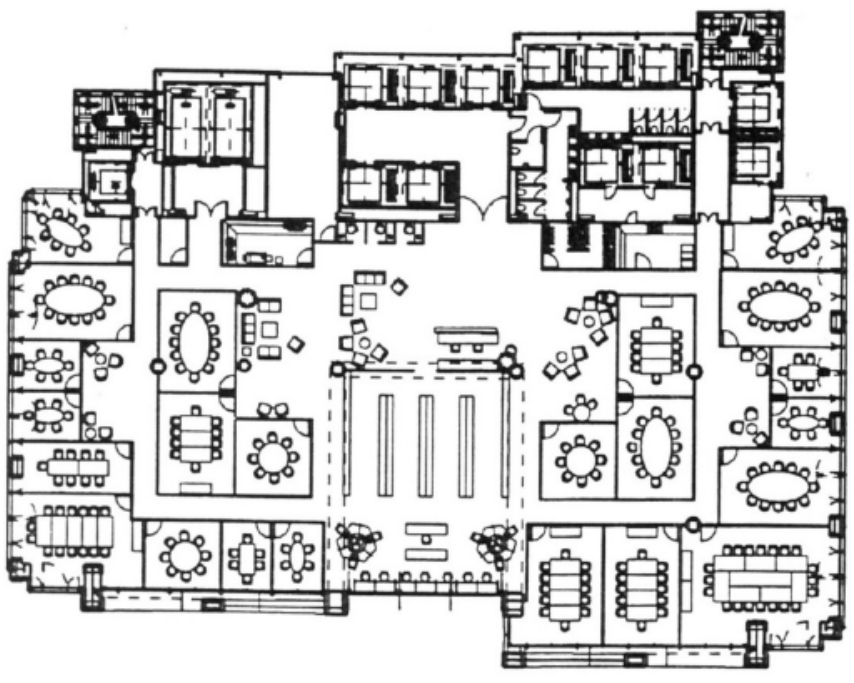

Figura 56 - Planta. Fonte: Kohn Pedersen Fox, London.

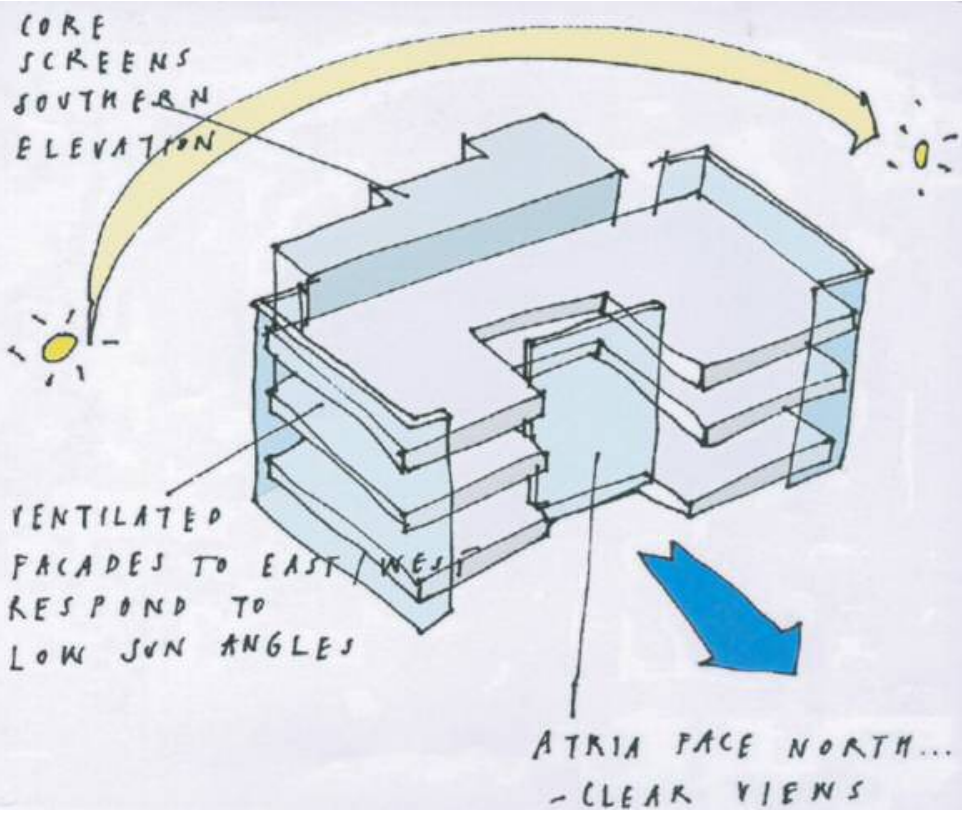

Figura 57 - Forma em U, com átrio central. Fonte: Kohn Pedersen Fox, London.

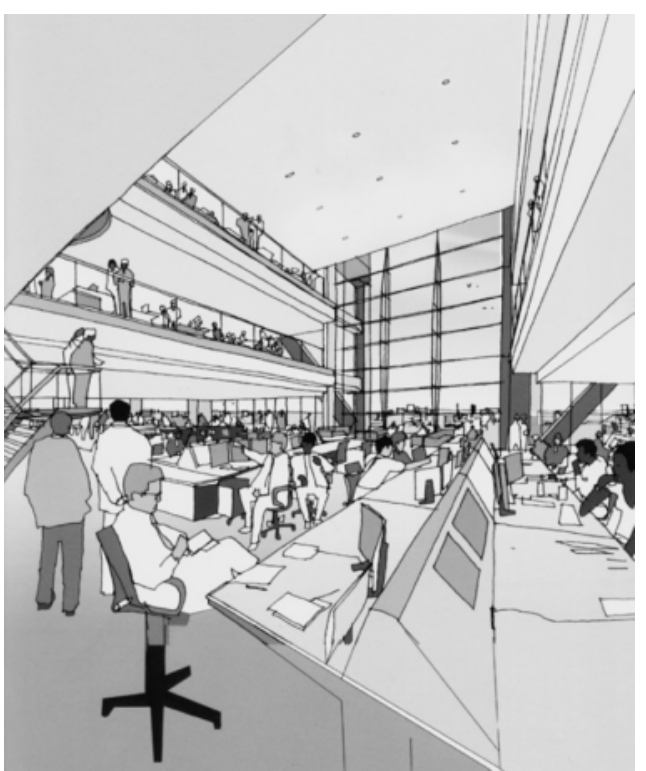

Figura 58 - Vilas de três pavimentos. Fonte: Kohn Pedersen Fox, London.

protegendo os ambientes internos do impacto da radiação solar direta. Além disso, a fachada sul é revestida por painéis fotovoltaicos.

As fachadas laterais se diferenciam do pano de vidro da fachada norte. Voltadas para o leste e oeste, são constituídas por uma fachada dupla com cavidade ventilada e proteção solar interna, que possibilita a ventilação natural nos períodos mais favoráveis do ano. A fachada dupla também 
funciona em conjunto com o sistema de climatização, fazendo o retorno do ar interno nos períodos de condicionamento artificial ${ }^{10}$. As previsões, na fase de projeto, de redução no consumo de energia eram de $25 \%$ a $30 \%$ quando comparadas a um edifício de boa arquitetura totalmente condicionado artificialmente. (KPF, 2001)

1.3.4 122 Leadenhall Street (em construção, Londres)

\begin{tabular}{|l|l|}
\hline Projeto & 122 Leadenhall Street \\
\hline Localização & Londres, UK, latitude $52^{\circ}$ Norte \\
\hline Cliente/lnvestidor & Britsh Land Company \\
\hline Arquitetura & Rogers Stirk Harbour + Partners \\
\hline Engenharias & Ove ARUP and Partners \\
\hline Uso do Empreendimento & Escritório \\
\hline Altura & 224 metros \\
\hline Número de Pavimentos & 50 pavimentos \\
\hline Área do Pavimento Tipo & $1.983 \mathrm{~m}^{2}$ no $5^{\circ}$ pavimento até $583 \mathrm{~m}^{2}$ no $45^{\circ}$ pavimento \\
\hline Área Total & $98.000 \mathrm{~m}^{2}$ \\
\hline Status/ Fase & Em construção \\
\hline Estacionamento & 22 vagas para automóveis e 339 para bicicletas \\
\hline
\end{tabular}

Fonte: Material disponível em www.cityoflondon.gov.uk. Acessado em agosto 2008.

O edifício alto de escritórios 122 Leadenhall (fig. 59), com 52 pavimentos e 224 metros de altura, está sendo construído em frente a outro edifício emblemático da década de 60 (projetado pelo mesmo escritório de arquitetura Richard Rogers and Partners), a sede da empresa de seguros Loyds ${ }^{11}$. A torre se destaca na paisagem por sua forma triangular, que é resultante da diminuição de $75 \mathrm{~cm}$ em profundidade a cada pavimento (fig. 60). Além de resultar em uma forte expressão formal, essa redução gradual dos pavimentos implica em ganhos de iluminação natural para os espaços internos. ${ }^{12}$

10 Existe ainda, o fornecimento de água gelada, que pode ser usada pelo inquilino em estratégias de climatização de menor consumo energético, como os forros gelados.

11 O projeto começou a ser desenvolvido em 2002, foi submetido ao Corporation of London em setembro de 2004, e aprovado em abril de 2005. Para a sua aprovação o projeto foi analisado por diversos órgãos entre eles o CABE (Committee for Architecture of the Built Environment) e o English Heritage, ambos apoiaram e incentivaram a construção do edifício, que vem reforçar o grupo (cluster), de edifícios altos no bairro. (GONÇALVES, 2010).

12 As informações a seguir foram extraídas de entrevistas com os arquitetos (A.

Young, 2009) e o material submetido a Coorporation of London para aprovação legal (www.cityoflondon.gov. 


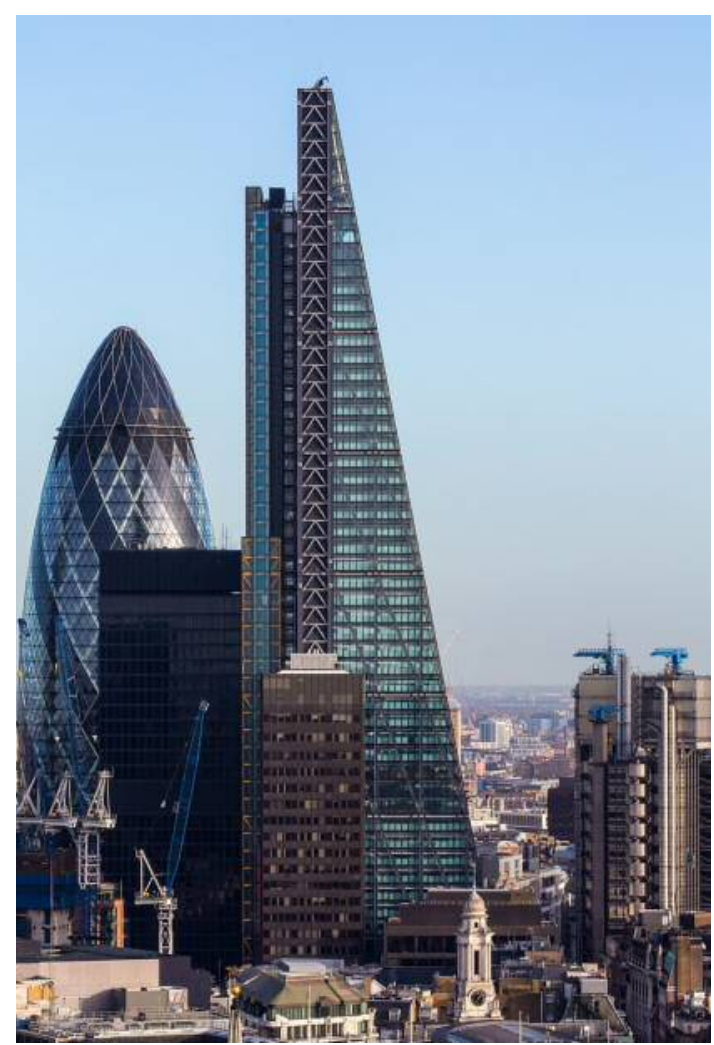

Figura 59 - 122 Leadenhall. Fonte: $w w w$. skyscrapercity.com, acessado em janeiro, 2014.
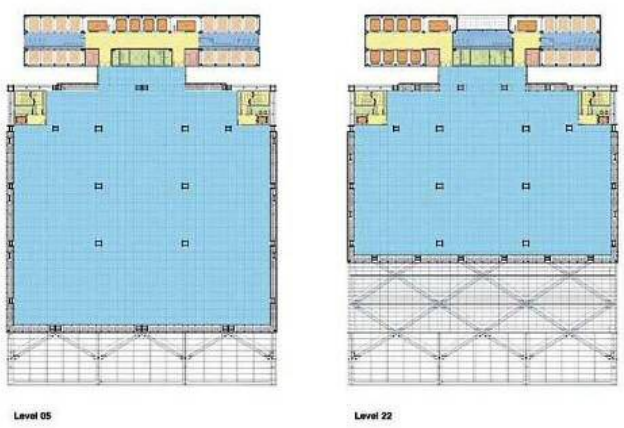

Figura 60 - Planta. Fonte: POWELL, 2006

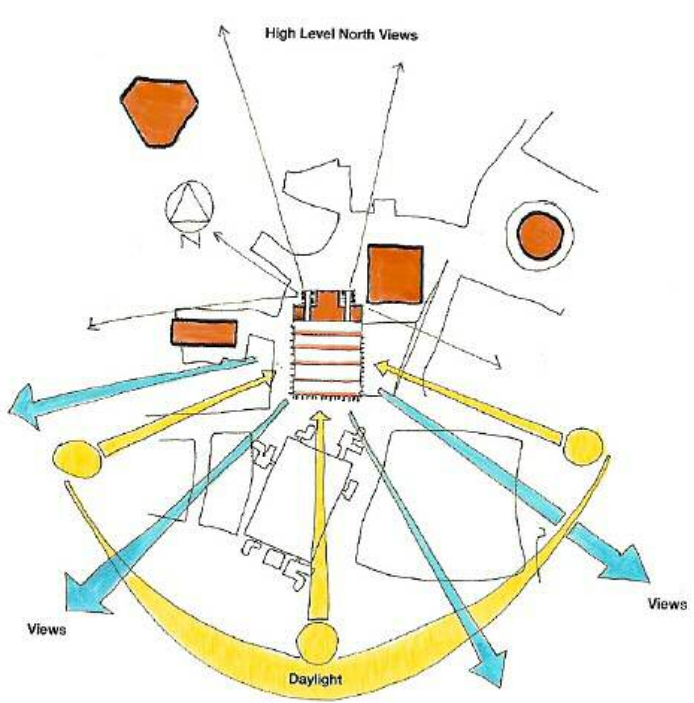

Figura 61 - Implantação. Fonte: POWELL, 2006.

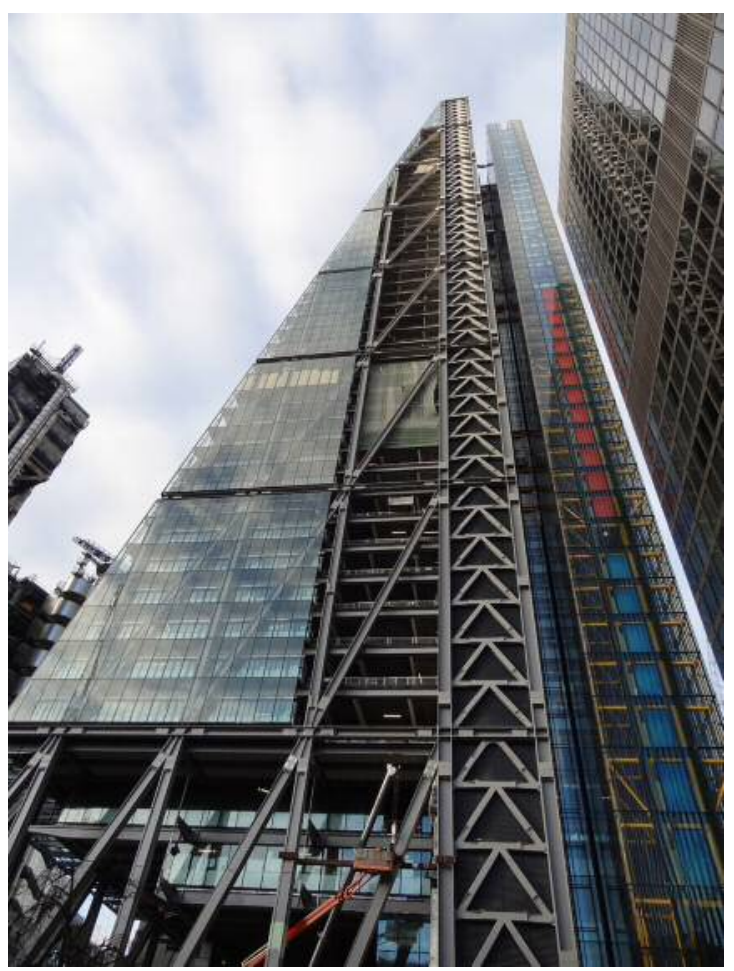

Figura 62 - Vilas verticais de sete pavimentos. Fonte: www.skyscrapercity.com, acessado em janeiro, 2014.

Os ambientes de escritório (áreas servidas) e os espaços de elevadores, banheiros e escadas (áreas que servem) foram estrategicamente separados em dois blocos verticais conectados por uma circulação horizontal. A orientação do edifício, com os escritórios voltados para o sul e os serviços para o norte, foi resultado dos critérios de inserção urbana do edifício no terreno, sua visibilidade no grupo de edifícios altos existentes e seu impacto na vista de edifícios históricos do entorno, em especial da Catedral de Saint Paul (fig. 61). 
A modulação estrutural divide o edifício em "vilas" verticais de sete pavimentos (fig. 62) e também setoriza verticalmente a fachada dupla ventilada. A significativa exposição à radiação solar, decorrente da orientação e da inclinação da fachada, levou à adoção de um detalhado projeto de proteções solares internas à fachada dupla, que também foi incorporado nas fachadas leste e oeste. A fachada norte, do bloco de circulação vertical e serviços, possui um tratamento diferenciado devido à sua função e orientação. A fachada dupla das orientações sul, leste e oeste são compostas por um vidro duplo interno e um vidro simples externo, com aberturas a cada sete pavimentos para tomada e extração de ar. No entanto, não existe a possibilidade de ventilação natural dos ambientes de escritório. Um sistema de persianas no interior do vidro duplo é controlado conforme às necessidades de proteção e de abertura de cada orientação.

No caso do 122 Leadenhall, não foram declarados estudos de estimativa de consumo de energia.

Urbanisticamente, o embasamento do edifício alto é constituído por sete pavimentos de lojas, espaços para exposições, e uma praça de acesso público. Devido à proximidade da rede de transportes públicos, o empreendimento oferece apenas 22 vagas de estacionamento. Quando construído, será o quinto edifício mais alto de Londres, ficando atrás do London Bridge Tower, Bishopsgate Tower, Minerva Tower e outra torre em Canary Warf.

\subsection{Considerações finais}

Visando desmistificar as questões de consumo energético do edifício alto, é preciso que os dados de consumo sejam disponibilizados e analisados separadamente antes de se formar uma opinião sobre altura versus maior consumo de energia. Sem esses dados, é difícil ter certeza do real impacto da altura no consumo energético.

É interessante notar que, o sucesso do desempenho ambiental do Commerzbank está baseado em princípios fundamentais do desempenho ambiental para a ventilação e iluminação natural, combinados a soluções arquitetônicas relativamente simples e bem resolvidas. Nesse caso, as simulações computacionais de avaliação ambiental serviram essencialmente para a formulação de uma estimativa desse desempenho na fase de 
projeto e não para determinar aspectos fundamentais do projeto arquitetônico, com acontece em outros casos em que a forma e o tratamento arquitetônico é resultado direto de simulações computacionais.

Por sua qualidade ambiental e desempenho energético, que se reverte em qualidade arquitetônica, a sede do Commerzbank em Frankfurt am Main permanece sendo um dos edifícios altos de escritórios da Alemanha de maior destaque no cenário internacional. Curiosamente, apesar de seu baixo consumo de energia ( $20 \%$ a menos de energia do que foi previsto $)^{13}$, o edifício não passou por nenhum processo de certificação ambiental, como a grande maioria dos edifícios aclamados como de melhor desempenho ambiental. Mesmo sem a associação de nenhuma certificação de "edifício verde", o sucesso do desempenho ambiental do Commerzbank mostrou uma repercussão notória. A exemplo disso, outros edifícios de escritórios em Frankfurt foram influenciados pela cultura da ventilação natural estabelecida pelo Commerzbank, incluindo seus vizinhos mais próximos que passaram por processos de substituição completa de fachadas, criando a possibilidade de abertura das esquadrias para a ventilação natural.

A última geração de edifícios altos de escritório em Londres revela uma arquitetura que trabalha as possibilidades da forma na busca de uma solução diferenciada, disputando por maior destaque na paisagem. Nesse contexto de explorações arquitetônicas, a forma está intrinsecamente ligada ao desenho dos pavimentos, cuja geometria e dimensionamentos são justificados, pelo menos parcialmente, por razões de natureza ambiental, principalmente com respeito ao acesso da luz natural e às oportunidades de comunicação visual entre espaços internos (e também entre interior e exterior).

No caso dos edifícios em Londres, apesar dos custos, do valor agregado e do real benefício dessas soluções diferenciadas de caráter ambiental, ainda não estarem totalmente esclarecidas, esses edifícios superam a "fórmula econômica" do modelo convencional da arquitetura comercial de escritórios ao redor do mundo, da planta retangular de grande dimensões (a chamada "planta profunda"), do core central e da fachada "cortina" hermeticamente selada.

Quanto ao projeto das fachadas, vale destacar que, em comparação ao projeto do Commerzbank, os novos edifícios de Londres trazem soluções mais complexas,

13 Informação retirada de http://www.fosterandpartners.com/projects/ commerzbank-headquarters/ acessado em 20 janeiro de 2012.

Umakoshi, Erica Mitie 
associadas à tipologia da fachada dupla, que certamente tem um papel fundamental na imagem do edifício alto comercial de "alto desempenho ambiental". No entanto, o desempenho energético do edifício em operação ainda não foi constatado, sendo apenas verificado em teoria e estudos analíticos de projeto, que são bastante simplificados e não refletem a realidade da ocupação de um edifício desse porte.

Entretanto, enquanto o sucesso do empreendimento for medido em valor econômico por metro quadrado, dificilmente um edifício como o Commerzbank será reproduzido fora do contexto europeu. Isso se deve, especialmente, à extensa área destinada ao uso comum ao redor dos átrios, os "jardins verticais", que refletem em área ganha em qualidade ambiental, o que aumenta o conforto e a interação dos usuários, alcançando níveis maiores de produtividade.

Apesar do caráter inovador e do valor icônico associado a este grupo de edifícios, os exemplos europeus aqui discutidos devem ser tomados como um grupo de edifícios que representa uma primeira iniciativa de desafio ao modelo comercial convencional, informando tecnicamente e inspirando arquitetonicamente novos projetos sobre questões de qualidade ambiental e eficiência energética associadas a soluções arquitetônicas, e não só sobre sistemas prediais. No entanto, esses exemplos não podem ser tomados como soluções universais, dadas as diferenciações socioeconômicas, culturais e ambientais de cada contexto para os quais novos edifícios altos vem sendo projetados e construídos. 


\section{Capítulo 2:}




\section{Capítulo 2 - Critérios de desempenho}

\section{Introdução}

Atualmente, quando o mercado se refere a edifícios de melhor desempenho ou sustentáveis, logo aparecem as certificações de desempenho ambiental, ou os selos verdes. Esses sistemas de avaliação são baseados em critérios quantitativos que são divididos em diferentes categorias, com pontuações atreladas a eles. E, dependendo da sua pontuação, podem receber selos que identificam o seu desempenho. Com isso, fica mais fácil para o mercado imobiliário identificar e comparar determinados empreendimentos.

No entanto, vale ressaltar que é preciso ter cautela ao se deparar com esses selos, pois, nem sempre, representam o real desempenho e a qualidade do edifício. Gonçalves (2003) mostrou na análise comparativa de dois estudos de caso, a Torre Norte e o Commerzbank, que é preciso ter cautela ao compará-los, pois ambos apresentaram o mesmo desempenho a partir de critérios quantitativos, mas com qualidades ambientais distintas. Provando, assim, que é preciso entender e identificar quais critérios são importantes numa avaliação.

No que diz respeito à questão dos indicadores de desempenho, em uma perspectiva global, pode-se dizer que a emissão de carbono é um dos parâmetros mais importantes para se medir o impacto ambiental dos edifícios. No entanto, um edifício classificado como de baixa emissão de carbono pode não ser, necessariamente, energeticamente eficiente, no caso de estar associado ao consumo de fontes de energia renováveis ou menos poluentes ${ }^{1}$. Dessa forma, para se obter um real e abrangente entendimento do desempenho energético do edifício, ambos indicadores devem ser considerados: consumo de energia e emissão de $\mathrm{CO}_{2}$.

É importante destacar, ainda, que a eficiência energética e a qualidade ambiental são dois assuntos diferentes, tendo em vista que a qualidade ambiental não pode ser medida simplesmente por meios de indicadores de consumo de energia. Um forte argumento sobre o futuro dos edifícios altos está ligado ao conceito e à qualidade do ambiente de trabalho. Isso se deve ao fato de que, durante os primeiros 25 anos de vida de um edifício de escritórios, em geral, $85 \%$ dos custos são relacionados ao gasto

1 Como no caso do estoque edificado das cidades brasileiras, cuja matriz energética ainda é predominantemente de origem hídrica (74\%) (BEN, 2011).

Umakoshi, Erica Mitie 
Avaliação de Desempenho Ambiental e Arquitetura Paramétrica Generativa para o Projeto do Edifício Alto

com pessoal (WBCSD, 2007). No entanto, apesar desse ser um conceito amplamente aceito, com exceção dos edifícios emblemáticos, a questão da qualidade no ambiente interno ainda não mudou os parâmetros de projetos convencionais, que primam pela cultura de ambientes controlados artificialmente por $100 \%$ do período de ocupação e a maximização da metragem quadrada de área útil.

Consequentemente, como colocado por Gonçalves e Umakoshi (2010), indicadores comerciais convencionais, tais como eficiência do espaço em área útil e $\mathrm{kWh} / \mathrm{m}^{2}$, são tipicamente usados para avaliação de um empreendimento "economicamente bem sucedido", sem considerar a qualidade e o real valor ambiental do edifício. Visando contribuir para mudança do mercado, é necessária uma revisão crítica sobre a qualidade ambiental, bem como sobre o que agrega "valor" ao projeto de edifícios altos de escritórios. A definição clássica de área útil, que atribui o mesmo valor de locação para todas as áreas, simplifica demais e representa um importante obstáculo ao desenvolvimento e à propagação da qualidade ambiental em empreendimentos comerciais.

\subsection{Certificações - Panorama brasileiro}

Atualmente, o Brasil, assim como outros países, vêm utilizando, adaptando e desenvolvendo selos de desempenho ambiental e energético que classificam as edificações, dando maior visibilidade de marketing a elas. Os sistemas de certificação de maior uso no Brasil são os nacionais PBE Edifica (Plano Nacional de Eficiência Energética), o AQUA (Alta Qualidade Ambiental) e o Selo Casa Azul da Caixa; e os internacionais LEED (Leadership in Energy and Environmental Design) e BREEEAM (Building Research Establishment Environmental Assessment Method).

Os sistemas de certificação de edifícios baseiam-se em critérios distribuídos em um conjunto de categorias, aos quais são atrelados valores mínimos e máximos a serem somados numa pontuação final, que determina a classificação alcançada dentro de uma escala da certificação. De acordo com cada certificação, tanto o processo, como seus critérios, categorias e pontuação apresentam variações.

Em 1998, foi lançada a versão piloto nos Estados Unidos (EUA) do sistema de certificação ambiental, o LEED 1.0 - Leadership in Energy and Environmental Design pelo Conselho 
Americano de Edifícios Verdes (USGBC-sigla em inglês). Este sistema de certificação americano representa, além de uma avaliação de desempenho, uma estratégia de marketing para os empreendimentos certificados, tanto nos Estados Unidos quanto no Brasil, conforme constatou TOY (2010). Este selo coloca o Brasil, hoje, no sexto lugar no ranking de número de processos de certificação LEED, após os EUA, Canada, Índia, Emirados Árabes e China.

A certificação ambiental LEED é um sistema voluntário e aplicável a qualquer tipo de construção, em diferentes fases do empreendimento. Trata-se de um modelo que vem sendo utilizado em diversos países. No Brasil, até maio de 2012, existiam 51 edifícios certificados pelo sistema LEED e outros 616 registros acumulados, sendo mais da metade edifícios comerciais situados na cidade de São Paulo (GBC_BRASIL, 2012).

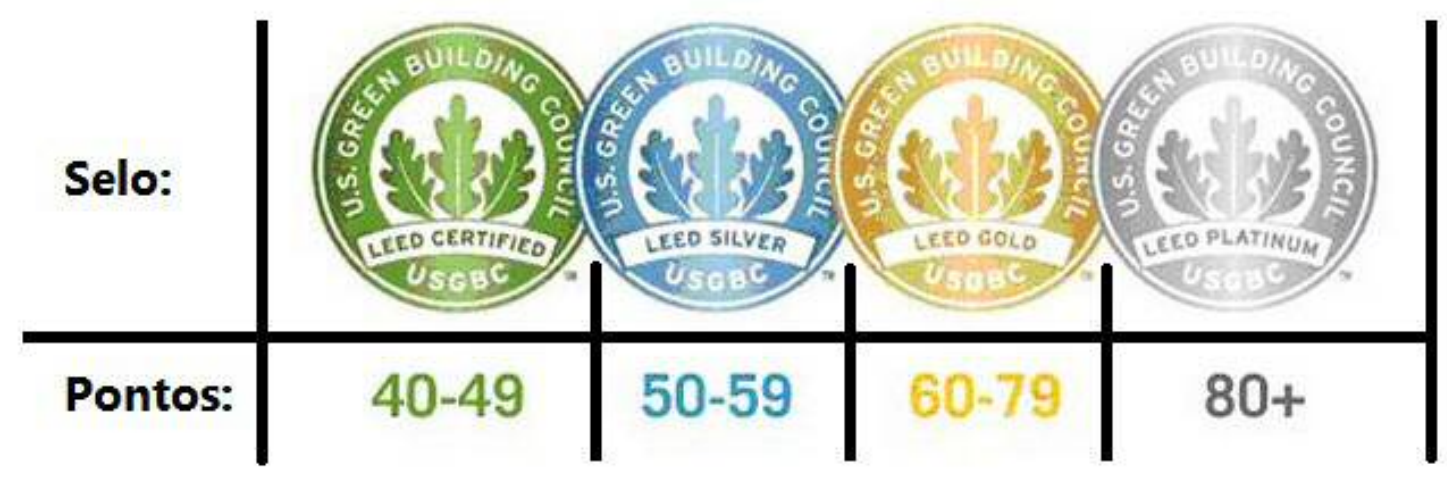

Fig. 63 - Selo LEED e pontuação. Fonte: adaptado de www.usgbc.org

No Brasil, a organização não governamental Green Building Council Brasil, GBCB, foi criada em 2007 para promover a prática dos chamados "edifícios verdes" e, consequentemente, incentivar o desenvolvimento da indústria da construção de menor impacto no país. Segundo GBC BRASIL (2012), a versão do LEED adaptada para o Brasil, conhecido como LEED $®$ BRASIL, está sendo, atualmente, formulada pelo Comitê de Adaptação do GBC Brasil. Ela inclui algumas modificações, tais como: alteração do sistema métrico, medidas de desempenho (como a norma de desempenho, a NBR15575-1:2003), redução de pontos creditados para o uso de energia não poluente, que, no caso brasileiro, é predominantemente energia proveniente de hidroelétricas.

Outra certificação nacional originária de um sistema internacional é o selo AQUA, adaptado em 2007 pela Fundação Carlos Alberto Vanzolini (FCAV), vinculada à Escola 
Avaliação de Desempenho Ambiental e Arquitetura Paramétrica Generativa para o Projeto do Edifício Alto

Politécnica da Universidade de São Paulo, a partir da certificação HQE, desenvolvida pelo Comitê Científico da Tecnologia da Construção (CSTB) da França. O selo AQUA baseiase na avaliação do desempenho de um edifício, desde o processo de concepção até a conclusão da obra, caracterizando-se como um sistema de gestão do empreendimento. Até junho de 2013, existiam 80 edifícios com esta certificação no Brasil, com outros em processo de auditoria para a obtenção do selo.

A certificação AQUA é definida como um processo de gestão de projeto, que tem o objetivo de obter a qualidade ambiental de um empreendimento novo ou reabilitado, sendo que, para tanto, baseia-se em duas referências de desempenho (AQUA, 2013): o Referencial do Sistema de Gestão do Empreendimento (SGE), que avalia o sistema de gestão ambiental implementado pelo empreendedor, e o Referencial da Qualidade Ambiental do Edifício ( $Q A E)$, que avalia o desempenho técnico e arquitetônico da edificação.

Visando a obtenção da certificação, é necessário o atendimento a todas as 14 categorias e a verificação por meio de auditorias presenciais ao longo de três etapas do programa: concepção (projeto), realização (construção) e uso dos empreendimentos (obra concluída).

Por exigir desempenho mínimo em todos os critérios, permite maior flexibilidade às soluções de projeto, que podem ser adotadas de acordo com o contexto, considerando fatores como o clima, vegetação, cultura e aspectos particulares do ambiente construído e das comunidades locais. Os níveis de desempenho variam de: excelente para as

\begin{tabular}{|c|c|}
\hline $\begin{array}{c}\text { GERENCIAR OS IMPACTOS SOBRE O } \\
\text { AMBIENTE EXTERIOR }\end{array}$ & $\begin{array}{l}\text { CRIAR UM ESPAÇO INTERIOR SADIO E } \\
\text { CONFORTÁVEL }\end{array}$ \\
\hline SITIOE CONSTRUÇÄO & CONFORTO \\
\hline RELAÇÃO DO EOHFICIO COM O SEU ENTORNO & CONFORTO HIOROTÉRMICO \\
\hline $\begin{array}{l}\text { ESCOCHA INTEGRADA DE PRODUTOS, SISTEMAS E PROCESSOS } \\
\text { CONSTRUTINOS }\end{array}$ & CONFORTO ACÚSTICO \\
\hline $\begin{array}{l}\text { CANTEIRO OE OBRAS COM BAIXO IMPACTO } \\
\text { AMBENTAL }\end{array}$ & $\begin{array}{l}10 \text { CONFORTO VISUAL } \\
11 \text { CONFORTO OLFATIVO }\end{array}$ \\
\hline GESTĀO & SAÚDE \\
\hline GESTÃO DAENERGIA & 12 QUAUDADE SANITÁRIA DOS AMBIENTES \\
\hline GESTÃO DAAGGUA & 13 QUALIDADE SANIT́́RIA DO AR \\
\hline 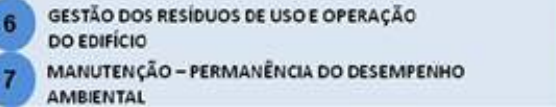 & 14 QUALIDADE SANIT́RIA DA ÁGUA \\
\hline
\end{tabular}

Figura 64 - As 14 categorias da certificação AQUA. Fonte: AQUA (2010). 
melhores práticas (3 pontos excelente no mínimo); superior para as boas práticas (4 pontos superior); e bom para as práticas correntes e legislação (7 pontos no máximo), totalizando 14 itens.

Por sua vez, o selo PROCEL EDIFICA, que foi instituído em 2003, possui como foco a eficiência energética das edificações. A partir de 2009, uma parceria do Inmetro com o Procel Edifica viabilizou a implantação dos Regulamentos para o Nível de Eficiência Energética de Edificações, com os quais seriam outorgadas etiquetas que mostrassem o desempenho das edificações em relação à eficiência energética.

Asua base técnica foi desenvolvida por meio de um Convênio entre a Eletrobrás/PROCEL Edifica e a Universidade Federal de Santa Catarina (UFSC), através do Laboratório de Eficiência Energética em Edificações (LabEEE), juntamente com a participação da ST Secretaria Técnica de Edificações.

Em 2009, foi publicado o Regulamento Técnico da Qualidade para o Nível de Eficiência Energética de Edifícios Comerciais, de Serviços e Públicos (BRASIL, 2009) e, em 2010 , o Regulamento para edificações Residenciais (BRASIL, 2010b). Atualmente, a aplicação destes regulamentos é de caráter voluntário, entretanto, de acordo o PNEf - Plano Nacional de Eficiência Energética (BRASIL, 2011a), a etiquetagem será obrigatória para prédios públicos em, no máximo, 10 anos; para edificações comerciais e de serviços, em 15 anos, e, para edificações residenciais, em 20 anos. Pela primeira vez, o Plano Nacional de Energia - PNE 2030 impõe uma meta de eficiência energética para 2030: redução de $10 \%$ da demanda projetada.

Atualmente, existem avaliações distintas que separam as edificações comerciais, de serviços e públicas (BRASIL, 2010a) das edificações residenciais (BRASIL, 2012a).

O nível de eficiência energética avaliado através dos métodos é ilustrado em uma etiqueta semelhante às demais emitidas pelo Inmetro para equipamentos e eletrodomésticos. A classificação é apresentada na forma de níveis cuja categorização varia de A (mais eficiente) a $E$ (menos eficiente). No caso das edificações, existem dois tipos de etiquetas: uma para o projeto e outra para a edificação construída. Atualmente, já foram emitidas 43 etiquetas para edificações comerciais, de serviços e públicas e 687 etiquetas para edificações residenciais. 
Avaliação de Desempenho Ambiental e Arquitetura Paramétrica Generativa para o Projeto do Edifício Alto

A avaliação do nível de eficiência energética é feita através dos métodos descritos nos Regulamentos Técnicos da Qualidade (RTQs): método prescritivo e de simulação. O método prescritivo é mais simplificado e pode ser utilizado para a maioria das edificações. Utiliza-se o método de simulação para geometrias mais complexas. Apesar de ser mais complexo e requerer capacitação, a simulação computacional é mais precisa, podendo alcançar níveis de desempenhos mais altos.

Determinado o nível de eficiência energética através de um dos métodos de avaliação, avalia-se o atendimento aos pré-requisitos e às possibilidades de bonificações. Os prérequisitos são necessários para determinados níveis de eficiência energética. Já as bonificações são somadas ao nível de eficiência com o objetivo de valorizar iniciativas que representem economia de energia e/ou a utilização de recursos renováveis.

A etiqueta geral contempla os três sistemas avaliados: envoltória, iluminação artificial e condicionamento de ar, além do detalhamento do atendimento aos pré-requisitos e das bonificações. É possível, ainda, obter etiquetas parciais através da combinação de dois sistemas.

Provavelmente, o grande paradoxo da maioria dos sistemas de certificação é a ênfase no sistemas prediais e a carga de tecnologia na operação de edifícios, que, de certa forma, promove um distanciamento dos usuários do controle das suas condições ambientais, não possibilitando uma adaptação climática. A busca pela obtenção de um

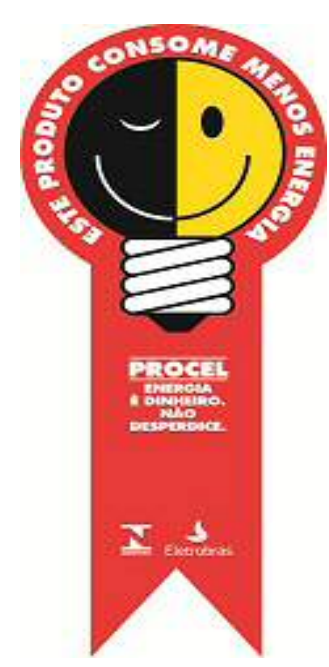

Figura 65 - Selo Procel.

Fonte: www.eletrobras. com acessado em 14 de janeiro de 2014.

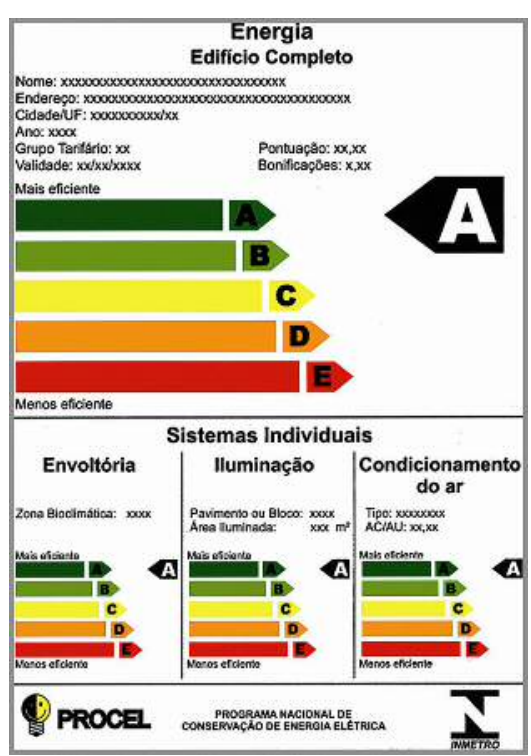

Figura 66- Selo Procel Edifica.

Fonte: www.eletrobras.com acessado em 14 de janeiro de 2014. 
maior número possível de pontos dentro de uma avaliação check list, em muitos casos, está desassociada de uma abordagem mais ampla sobre o desempenho ambiental e energético do edifício.

No Brasil, as empresas multinacionais são as pioneiras na exigência de uma certificação em seus edifícios, conforme constatado pela GBCB (2012). Entende-se que as empresas utilizam o selo "verde" como uma estratégia de marketing e consideram, pela confiabilidade de sua aplicação no mercado americano, que ao cumprirem com os critérios da certificação estão contribuindo para a construção e ocupação de edifícios com um menor consumo de energia, quando comparado aos convencionais.

No entanto, a indisponibilidade de dados de consumo de energia estimados em simulação e submetidos aos sistemas de certificação, bem como aqueles medidos durante o uso e ocupação de edifícios, constitui um impedimento para o entendimento da real contribuição dessas certificações em diferentes contextos.

\subsection{Conforto adaptativo}

O termo conforto pode ser definido de várias maneiras diferentes, tais como uma sensação de bem estar, acolhimento, etc. Psicologicamente, o conforto pode ser a relação entre as pessoas e o seu entorno imediato. Já quando se fala em sociologia, o conforto é o envolvimento das pessoas e dos edifícios com a sociedade, é o chamado conforto social. Para os geógrafos, o conforto é a relação sentida pelas pessoas entre os espaços internos e os externos. E, para os engenheiros, o conforto é o estado para o qual as pessoas são levadas quando uma inovação tecnológica consegue oferecer condições ideais aos espaços internos. O conforto também pode ser associado à saúde humana, definido não apenas pela ausência de alguma doença, mas em termos gerais de um bem estar físico, mental e social (World Health Organisation, 1946 apud Chapells and Shover, 2004). Os significados de conforto tem mudado significativamente nos últimos cem anos, e isso tem afetado muito as condições ambientais internas das edificações e a demanda por energia. (Capells, Shove, 2004)

As pessoas passam muito tempo dentro dos edifícios, sejam eles moradias ou trabalho, e, por isso, pode-se dizer que a relação entre pessoas, edifícios e clima é complexa e interdependente, e possui grande impacto sobre o consumo de energia. Há tempos 
Avaliação de Desempenho Ambiental e Arquitetura Paramétrica Generativa para o Projeto do Edifício Alto

existe um grande interesse em se avaliar a interação entre o homem, o conforto, as tecnologias e o meio ambiente. Sendo que a questão mais importante na relação de qualidade ambiental de um edifício é o conforto térmico (Cena e Clark, 1981), o qual é definido, pela Sociedade Americana de Aquecimento, Refrigeração e Ar-Condicionado Engineers (ASHRAE, 2009), como o estado de espírito que expressa satisfação com o ambiente térmico.

Sabe-se que o conforto térmico contribui para o conforto humano devido ao equilíbrio termo-fisiológico do corpo humano. Ele representa a interação de variáveis ambientais (temperatura do ar, temperatura radiante média, umidade e velocidade do ar) com variáveis pessoais do ocupante (taxa metabólica e vestuário). Além disso, a fisiologia humana e os aspectos climáticos e culturais também tem influência sobre o conforto térmico. Com isso, as condições de conforto irão variar de pessoa para pessoa, de acordo com a hora do dia e a estação do ano, além das experiências e preferências ambientais das mesmas.

Deve-se considerar que o conforto térmico é um tema, por natureza, multidisciplinar. Versa acerca de aspectos de projeto, engenharia, biometeorologia, fisiologia humana e psicologia. Ressalte-se que o corpo humano tem sua própria temperatura, regulando as respostas às condições do local (sudorese e vasodilatação em ambientes quentes, e constrição e tiritar em ambientes frios). A resposta de um ocupante para o meio ambiente será fortemente dependente de sua condição física, de sua aclimatação e de sua capacidade de adaptação.

Apesar do modelo de conforto sofisticado e detalhado desenvolvido por Fanger, e após décadas de sua aplicação, os especialistas e mesmo instituições como ASHRAE reconheceram que a percepção de conforto térmico não só é determinado por uma resposta fisiológica do corpo humano, mas também influenciada pelo fundo cultural e pelas condições psicológicas associadas com as oportunidades de adaptação às condições ambientais locais, ou seja, é preciso levar em conta as variações culturais e climáticas nas interpretações individuais do conforto.

Avaliar o nível de conforto térmico é fundamental para o estabelecimento de padrões de desempenho ambiental e energético de edifícios, mas não requer apenas uma 


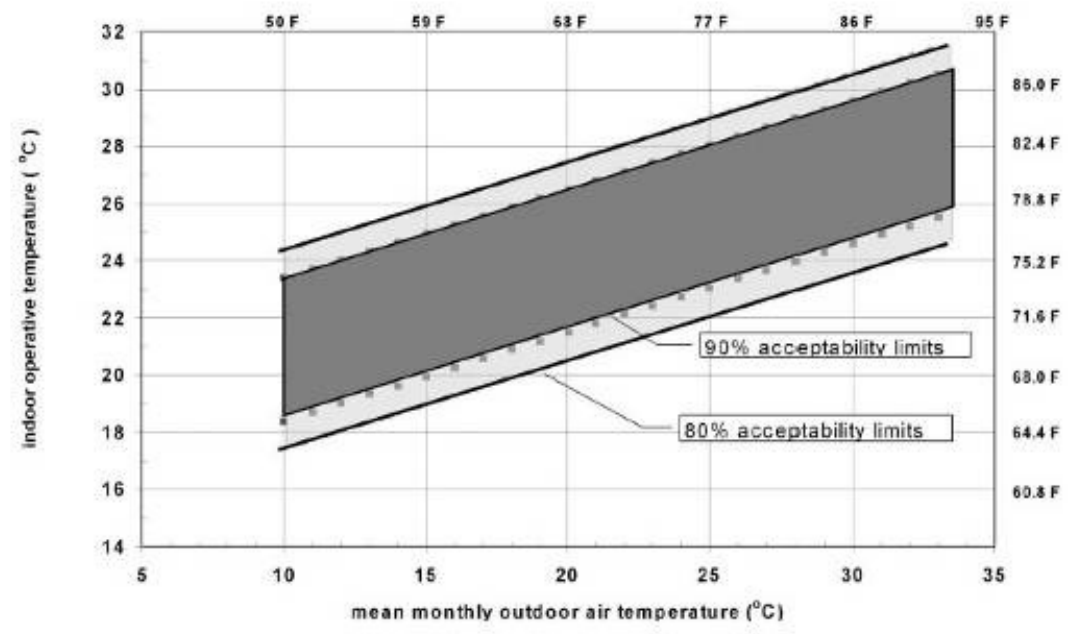

Figura 67 -: Modelo Adaptativo adotado de conforto térmico baseado no conceito de temperatura neutra adotado pela ASHRAE 55 (2010).

compreensão do que o corpo humano pode suportar, mas até que ponto as pessoas estão dispostas a fazer mudanças comportamentais na forma de experimentarem o conforto em seu ambiente. Isso afeta a maneira como o usuário interage com seu ambiente, desde a escolha para baixar persianas e limitar a penetração de sol em determinados momentos do dia, ou para colocar um agasalho quando a temperatura externa cai, ou, ainda, para se deslocar no ambiente, na busca por melhores condições de conforto. Em suma, edifícios de menor impacto ambiental exigem um envolvimento mais proativo entre ocupante, edifício e ambiente, o que reflete no grau de técnicas com soluções passivas e, se realmente necessárias, as ativas possíveis de ser empregadas. Ocupantes que vivem permanentemente em edifícios com ar-condicionado desenvolvem grandes expectativas com relação ao controle de temperatura e homogeneidade. Por outro lado, os ocupantes que vivem em edifícios não climatizados, ventilados naturalmente, são geralmente mais capazes de controlar seu ambiente e se habituam à variabilidade climática e diversidade térmica. Assim, suas preferências térmicas estendem-se a uma ampla gama de temperaturas e velocidades do ar. Além disso, pessoas que utilizam o transporte público para chegar ao trabalho tem uma adaptação ao meio ambiente muito maior do que as pessoas que vão trabalhar de carro com o ar-condicionado ligado, as quais exigem uma maior homogeneidade térmica (YANNAS, 2008). 
Avaliação de Desempenho Ambiental e Arquitetura Paramétrica Generativa para o Projeto do Edifício Alto

Yannas (2008) afirma que já foi confirmado através de pesquisas e justificado psicologicamente que as pessoas residentes e mesmo as visitantes de cidades de clima quente podem responder muito bem à variação diária de temperatura através dos mecanismos de adaptativos naturais do corpo humano. E afirma que é inaceitável que um ambiente climatizado mantenha uma temperatura interna tão baixa que chegue a apresentar $200 \mathrm{C}$ de diferença com a temperatura do ar externo.

Dentro desse contexto, tem-se o conceito de conforto adaptativo, que se aplica tanto a edifícios passivos, como aos que utilizam sistemas ativos de arrefecimento ou aquecimento. O pressuposto fundamental da zona de conforto do modelo adaptativo é que os ocupantes do edifício tenham o potencial de se ajustar e encontrar as suas condições de conforto através de mudanças individuais em roupas, atividade, postura, localização, dentre outras. Além disso, os ajustes de condições térmicas podem também ser conseguidos através da utilização de controles, tais como a abertura de janelas, os ajustes de diferentes tipos de persianas, de abertura de portas e até mesmo meios alternativos de aquecimento localizado ou estratégias de arrefecimento. Ao proporcionar a possibilidade dos ocupantes dos edifícios de interferir no clima interno de acordo com sua própria preferência de conforto, maiores níveis de satisfação podem ser alcançados ao lado de economias significativas de energia.

De Dear et al. (1997) propôs um dos primeiros modelos de conforto adaptativo e, com base em dados coletados em um amplo estudo de campo, Humphreys e Nicol (1998) propuseram outro modelo de conforto adaptativo. O pressuposto fundamental dessa abordagem é expressada pelo princípio que codifica o comportamento dos ocupantes do edifício e que tem duas formas básicas: (a) ajuste para a temperatura ideal de conforto por mudanças nas roupas, atividade, postura, etc., para que os ocupantes se sintam confortáveis em condições prevalecentes (fig. 68); (b) ajuste das condições internas pelo uso de controles, tais como janelas, persianas, ventiladores e, em determinadas condições, de aquecimento ou de refrigeração mecânica (fig. 69). Os ocupantes também podem migrar ao redor do ambiente para encontrar melhores condições microclimáticas. Tais comportamentos adaptativos provaram que a temperatura de conforto está intimamente relacionada à temperatura média do ar exterior.

Quando os padrões de conforto do modelo adaptativo são utilizados, o uso de ventilação 


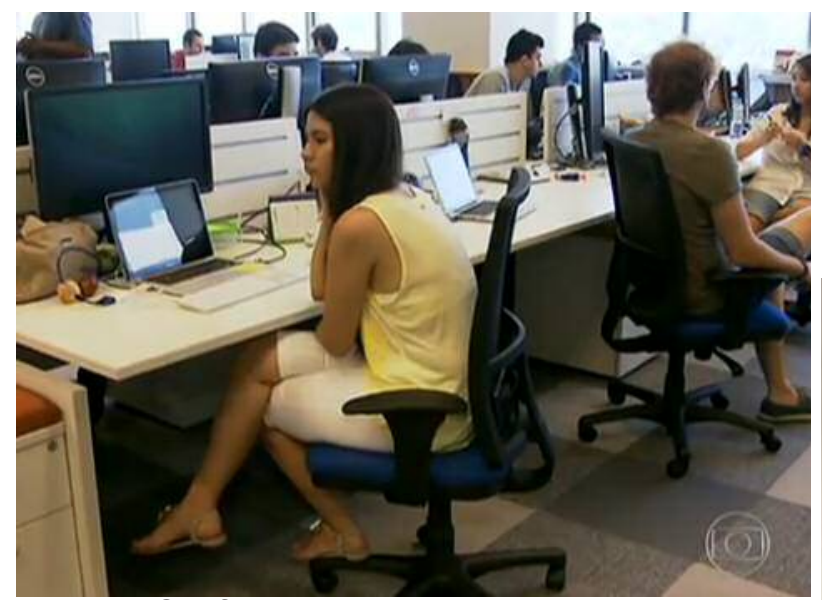

Figura 68 - Conforto adaptativo: mudança de vestuário no verão de São Paulo em 2014. Fonte: Globo.com.br, acessado em 11 de fevereiro de 2014
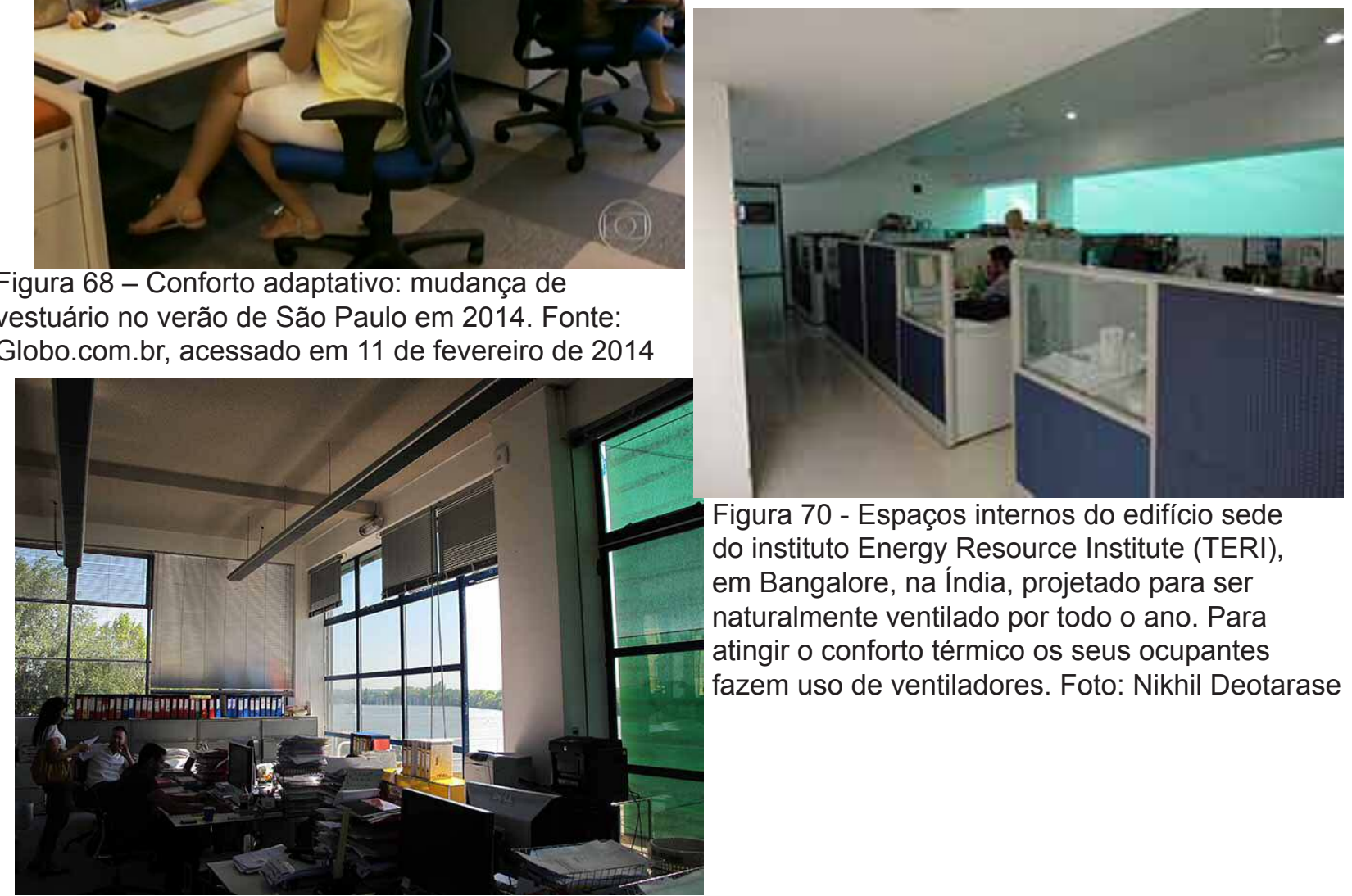

Figura 70 - Espaços internos do edifício sede do instituto Energy Resource Institute (TERI), em Bangalore, na Índia, projetado para ser naturalmente ventilado por todo o ano. Para atingir o conforto térmico os seus ocupantes fazem uso de ventiladores. Foto: Nikhil Deotarase

Figura 69 - Conforto adaptativo: elementos de controle dos usuários. Fonte COTTA, 2012.

natural e do modo misto (estratégia que alterna a ventilação natural e o condicionamento de ar) em edifícios torna-se muito mais fácil, porque deixam de existir as bandas estreitas de temperatura e a necessidade de homogeneidade para se atingir o conforto térmico. Isso será possível, desde que os ocupantes tenham a possibilidade de controle de dispositivos para se adaptarem às condições microclimáticas ambientais (fig. 70). Assim, o consumo de energia para aquecimento e arrefecimento será reduzido.

Enquanto, com base na teoria de Fanger, o conceito de conforto térmico foi promovido por décadas como sendo um "produto" a ser comprado, o conforto térmico promovido pelos modelos adaptativos é um objetivo a ser alcançado pelo usuário, a um custo financeiro e ambiental mais baixo e resultados finais com maiores graus de satisfação dos usuários. Leaman e Bordass (2000) sugerem que as pessoas são mais tolerantes às condições internas à medida em que tenham maior oportunidade de controle 
Avaliação de Desempenho Ambiental e Arquitetura Paramétrica Generativa para o Projeto do Edifício Alto

disponíveis, por exemplo, persianas, janelas que podem ser abertas, etc. Heerwagen e Diamond (1992) concluíram que a manutenção de conforto é uma atividade reflexiva e que as pessoas preferem mudar as condições pessoalmente a deixar que o edifício decida o que deve ser feito.

Humphreys (1995) argumenta que as pessoas não são destinatárias inertes do ambiente, mas que interagem com ele para otimizar as suas próprias condições. Nesta perspectiva, o desafio para os engenheiros e arquitetos é projetar um ambiente no qual as pessoas consigam tornar-se confortável, ou, ainda, proporcionar a oportunidade para os usuários de diminuir o seu desconforto (LEAMAN, BORDASS, 1995).

Olhando-se de uma perspectiva mais holística, a influência de fatores urbanos, como o modo de transporte e a distância entre espaços de habitação e de trabalho, e a experiência das condições ambientais ao longo desse percurso também afetam a percepção de conforto ambiental no interior do edifício. Isto acrescenta outro nível de complexidade ao assunto, com fatores tais que, muitas vezes, não são levados em conta no projeto das edificações e nos desafios para o alcance de condições de conforto (YANNAS, 2008).

O conceito de conforto adaptativo responde às questões de flutuações climáticas e de aclimatação das pessoas, mas, por outro lado, aspectos determinantes de projeto, incluindo a localização dos edifícios, o tratamento do entorno imediato e os meios de acesso, têm grande impacto na qualidade de vida no ambiente urbano. Considerações nesse sentido são fundamentais a fim de se concretizar plenamente o conforto ambiental. Ao alterar as expectativas convencionais com relação às condições ambientais internas, uma grande quantidade de energia consumida na operação de edifícios em diferentes zonas climáticas do mundo pode ser economizada, sem comprometer a qualidade ambiental dos edifícios e, na verdade, melhorando-a em inúmeros casos. A exemplo disso, estudos analíticos de desempenho térmico realizados para ambientes de trabalho no clima da cidade do Rio de Janeiro mostraram uma redução de $22 \%$ da demanda energética de resfriamento anual do ambiente, alterando os parâmetros de conforto de $24^{\circ} \mathrm{C}$ e $50 \%$ de umidade relativa para $26^{\circ} \mathrm{C}$ e $65 \%$ de umidade relativa (Marcondes et al, 2010). Para se conseguir essas mudanças, a alteração de comportamento e padrões de conforto precisa ser acompanhada por uma mudança na concepção convencional de 
edifícios (principalmente em arquitetura comercial dedicada à produção de edifícios de escritórios), a fim de responder melhor ao clima local.

Tem-se aqui a noção de conforto térmico não como uma necessidade fisiológica pura, mas como uma experiência ambiental. A consideração do caso do Commerzbank, por exemplo, sendo esse um caso real de aplicação da noção de "conforto social" (Cole, 2008), inclui conceitos como a relação entre os habitantes, locais de trabalho e territórios e como essa relação proporciona a experiência de conforto no nível de um grupo de indivíduos.
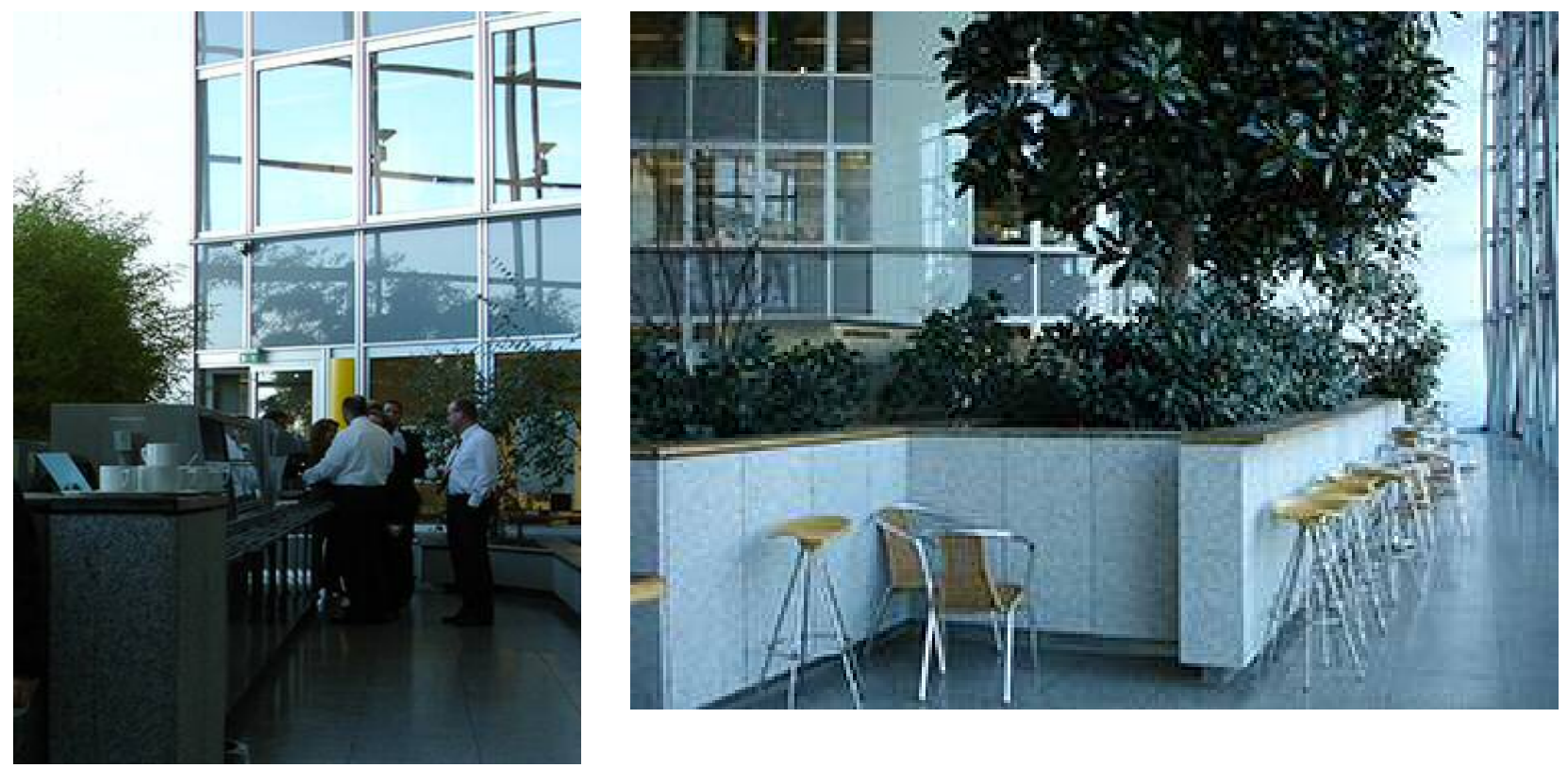

Figura 71 e 72 - Conforto social Commerzbank.

Atualmente, os especialistas estão discutindo a substituição da visão homogênea ou uniforme das condições ambientais em geral por uma diversidade e possibilidade de adaptação dos usuários. Para isso, é absolutamente fundamental prestar atenção nos padrões de ocupação de um determinado projeto, incluindo as variações de densidade de ocupação e da demanda pelo uso de equipamentos a longo do período de ocupação.

De fato, estar fora da zona de conforto pode ser uma ótima oportunidade para uma mudança, para uma situação criativa, para algo que leve o usuário a experimentar e interagir, de fato, com o ambiente em que está. Muda-se, portanto, necessariamente, o modo de pensar o projeto e os ambientes de edifícios e cidades. Não se deve, por meio 
Avaliação de Desempenho Ambiental e Arquitetura Paramétrica Generativa para o Projeto do Edifício Alto

do projeto, impor condições que certamente não trarão conforto ou satisfação à maioria dos usuários, mas, sim, projetar de modo a fornecer variabilidade e meios necessários para que os usuários nos diferentes ambientes possam se adaptar, buscando conforto e satisfação enquanto indivíduos e coletividade.

\subsection{Critérios Qualitativos(CQL) e Quantitativos (CQT) de Desempenho}

A complexidade de se avaliar o desempenho ambiental do edifício alto, juntamente com a falta de dados dos edifícios em operação, faz com que, atualmente, desconheçase o real desempenho dessa tipologia. Com isso, faz-se necessário a definição de parâmetros apropriados e relevantes que possam caracterizar e diferenciar os edifícios altos denominados ambientais, incluindo os avanços e as suas limitações.

Os parâmetros de altura, eficiência e flexibilidade do espaço, além do consumo de energia, são os mais conhecidos e discutidos no cenário global, no entanto, se mostram muito limitados para avaliar o desempenho real do edifício alto ambiental, não conseguindo avaliá-lo de uma forma contemporânea que contemple as novas questões ligadas ao desempenho, à expressão arquitetônica e aos valores econômicos. Esses parâmetros não conseguem avaliar questões relacionadas à qualidade ambiental e ao bem estar dos usuários, além da densidade real de ocupação, emissões de CO2 e questões de impacto urbano.

Os critérios estão divididos em duas partes, os qualitativos e os quantitativos. Os primeiros estão ligados a uma avaliação de observação do espaço urbano e interno, informações de conceitos e processo de projeto, além de respostas às questões climáticas. Já os quantitativos referem-se a dados de desempenho do edifício, que podem ser medidos e calculados. No entanto, vale ressaltar que nem todos estão ligados somente ao desempenho do edifício alto, podendo ser aplicados em outras tipologias de edificação. Primeiramente, serão apresentados os critérios qualitativos desenvolvidos na dissertação de Umakoshi (2008), onde se procurou levantar os critérios que não podem ser medidos e nem quantificados mas que possuem uma influência relevante no desempenho do edifício. Os critérios estão divididos em 7 categorias: (1) impacto visual e paisagem, (2) 
conforto do pedestre e impacto ambiental no entorno, (3) expressão arquitetônica, (4) luz natural, (5) ventilação natural, (6) eficiência energética e (7) comunicação dos espaços internos e organização do layout. Os itens 1 e 2 referem-se ao desempenho ambiental de edifícios altos propriamente dito, no entanto, os demais podem ser aplicados a qualquer tipologia de edificação. Em resumo, temos três áreas de interesse: impacto no entorno, qualidade ambiental interna e eficiência energética.

Na sequência, serão apresentados os critérios quantitativos, que foram desenvolvidos na tese de doutorado de Gonçalves (2003) e revisados no livro The Environmental Performance of Tall Building (GONÇALVES e UMAKOSHI, 2010). Vale ressaltar que os critérios extraídos da tese e do livro já foram revistos e incluíram o modelo adaptativo, estando mais enxutos e menos deterministas. Os critérios estão divididos em três categorias: (1) eficiência do espaço, (2) eficiência ambiental interna do edifício e (3) eficiência energética e o impacto ambiental do edifício.

\subsubsection{Critérios Qualitativos (CQL)}

\section{CQL1- Impacto Visual e Paisagem}

- Inserção do edifício em um conjunto já existente (cluster).

- Inserção numa política de planejamento de edifícios altos. Importante porque gera infraestrutura e tem impacto no térreo.

- Criação de um ícone geográfico.

- Não interferência em centros históricos ou monumentos isolados.

\section{CQL2- Conforto do Pedestre e Impacto Ambiental no Entorno}

- Tratamento de possíveis turbulências com proteções, precaução na implantação. Na maioria dos casos, é mais favorável do que desfavorável, particularmente no nosso clima quente e úmido.

- Projeção de sombras indesejáveis no entorno. Importante quando se fala em parques e edifícios residenciais. É mais problemático do que as turbulências.

- Impacto das fachadas no entorno imediato, pois reflete de modo não controlado e não previsto a radiação direta. 


\section{CQL3- Expressão Arquitetônica}

- Síntese entre tecnologia, forma, orientação e outros aspectos arquitetônicos para o desempenho ambiental do edifício.

\section{CQL4- Luz Natural}

- Planta estreita. Se beneficia da vista do exterior, além da luz natural.

- Fachada com proteções solares e com controle de ofuscamento.

- Objetivos: alcançar níveis mínimos para o uso de escritório e distribuição homogênea dos níveis de iluminação. Além disso, oferecer oportunidade ao usuário do controle da sazonalidade dos níveis de iluminação natural. Foco no usuário, oportunidade de adaptação. Na iluminação e na ventilação, não é homogeneidade que se busca. É importante que o projeto ofereça oportunidade de adaptação, com um projeto menos determinista.

\section{CQL5- Ventilação Natural}

- Oportunidade de adaptação do usuário com a utilização e operação das aberturas para a ventilação natural.

- Evitar a radiação direta.

- Temperatura de conforto com base no conforto adaptativo.

\section{CQL6- Eficiência Energética}

- Redução do consumo de energia comparado aos padrões locais, por intermédio de estratégias arquitetônicas.

- Estratégias para diminuição de demanda energética nas horas de pico através de novas tecnologias.

- Redução do impacto de demanda na rede.

- Inclusão de estratégias passivas de iluminação e ventilação.

- Estratégias de tratamento de fachada para redução do consumo de energia.

CQL7- Comunicação dos Espaços Internos e organização do layout. 
-Promoção de convivência e das interações sociais no interior do edifício pela comunicação visual no interior do pavimento, na área do uso comum e no dimensionamento de plantas.

\subsubsection{Critérios Quantitativos (CQT)}

\section{CQT1- Eficiência do Espaço:}

- área útil total/área total construída (\%)

- área útil total do uso principal (escritórios ou residências)/ área útil total (\%)

- área útil total do uso principal (escritórios ou residências)/usuário(\%) Considerando horários variados com diferentes frequências do uso do espaço. $\left(10 \mathrm{~m}^{2} /\right.$ pessoa e $12 \mathrm{~m}^{2} /$ pessoa - influência direta na geração de calor interno. Quanto menor a área por ocupante, maior o peso da ocupação nos ganhos internos de calor).

\section{CQT2- Eficiência Ambiental Interna do Edifício:}

- área de uso comum/ área útil total(\%) - átrios, jardins e espaços de convivência.

- horas de ventilação natural/ horas de conforto no ambiente externo( $\leq 1 \leq)$.

- área classe $1 /$ total do uso principal(escritórios ou residências). Área classe 1 é a área do edifício que é servida por condições satisfatórias de luz natural. Esse critério identifica a porcentagem de zona passiva de iluminação e climatização.

- Zonas de conforto estabelecidas para casos de ambientes com condicionamento artificial.

\section{CQT3- Eficiência Energética e o Impacto Ambiental do Edifício:}

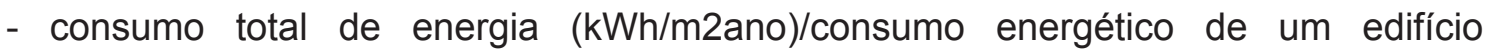
convencional(kWh/m2ano) (\%).

- consumo total de energia/ área útil total $(\mathrm{kWh} / \mathrm{m} 2 \mathrm{ano})$.

- consumo total de energia/usuário (kWh/pessoa ano).

- emissão de $\mathrm{CO}_{2}$ em relação ao total de energia consumida pelo edifício (toneladas/ $\mathrm{m}^{2}$ ano) 


\subsection{Considerações Finais}

Devido à complexidade técnica e científica envolvida no desenvolvimento de edifícios energeticamente eficientes, a avaliação analítica, com o apoio de ferramentas de simulação computacional baseadas em critérios quantitativos e qualitativos específicos, desempenha um papel determinante na precisão, na velocidade e na melhor comunicação visual das questões ambientais dentro do processo de projeto. Objetiva, ainda, conhecer melhor e em mais detalhes o desempenho dos edifícios na fase de projeto, a fim de melhorar a qualidade ambiental interna e otimizar o uso de sistemas de condicionamento ambiental.

No entanto, apesar da importância de estudos preditivos do desempenho ambiental de edifícios na fase de projeto, uma das principais barreiras à melhoria do projeto em geral consiste na lacuna entre dados teóricos e aqueles baseados no cenário real de ocupação.

Isso ocorre porque o desempenho energético de um edifício em operação é bastante afetado por fatores que estão além do projeto, incluindo rotinas de gerenciamento, comportamento dos usuários e mudanças climáticas (COLE, BROWN, McKAY, 2010). Além disso, o sucesso do desempenho energético dos edifícios não pode ser garantido pelo projeto e suas simulações computacionais, mas sim pela continuidade entre projeto e ocupação.

O desempenho real do edifício Commerzbank é um dos bons exemplos a revelar a interação entre os sistemas prediais e o comportamento adaptativo dos usuários, ou seja, o poder de interação entre os usuários e os sistemas do edifício confere um maior poder de controle das condições microclimáticas do seu entorno imediato, concedendo, assim, uma condição de conforto aos mesmos.

Como pontuado por Gonçalves e Bode (2011a), aprender com a experiência real de edifícios ocupados é parte fundamental do processo de projeto de edifícios de melhor desempenho ambiental. Contudo, dados sobre o desempenho de edifícios ocupados são uma importante, porém rara, fonte de informação. São poucos os edifícios altos de escritórios ao redor do mundo - cuja imagem esteja relacionada a um bom desempenho 
ambiental - que divulgam dados de consumo energético e de satisfação dos usuários.

Na versão do LEED de 2009, que dá base à versão LEED V4 lançada em 2013, a avaliação do pós ocupação é considerada de forma não obrigatória, somando pontos extras caso seja feita. Como estas avaliações implicam em custos e esforços adicionais, normalmente ela não é implementada. Na medida em que as certificações ganham credibilidade e popularidade de uso, entende-se que esta etapa deveria ser incluída no processo, visando comprovar o real desempenho ambiental do edifício.

Além disso, no projeto dos edifícios contemporâneos, particularmente aqueles que se declaram ambientalmente corretos, é essencial que seja ampliada a definição de "valor", incluindo parâmetros, como áreas bem servidas de luz natural, espaços semiabertos que possibilitem interação social, comunicação visual interna, bem como critérios de flexibilidade e adaptabilidade espacial com intervenção mínima no projeto e na construção.

Com isso, pode-se dizer que o processo de projeto pode ser favorecido na busca por um selo de desempenho ambiental, independentemente da certificação em questão, por requerer certa integração entre diferentes agentes do projeto e, efetivamente, avaliações de desempenho ambiental na fase de projeto. Porém, sem a comprovação do real melhor desempenho ambiental e energético dos edifícios em uso e operação, a certificação não passará de um simples instrumento de mercado, desprovida de valor real. 

Capítulo 3: 


\section{Capítulo 3 - O Papel da Ventilação no Projeto do Edifício Alto de Melhor Desempenho para a Cidade de São Paulo}

\section{Introdução}

Ao se visar a redução do consumo de energia nos edifícios, as soluções técnicas são, geralmente, as mais utilizadas, tais como o isolamento térmico e os sistemas de resfriamento e aquecimento, ou seja, busca-se a eficiência nos equipamentos ao invés de técnicas que realmente façam com que esse consumo reduza de maneira significativa. Estratégias como proteção solar, ventilação natural e mudanças no comportamento dos usuários podem trazer resultados mais rápidos e duradouros (LAMBERTS et al, 2010).

São Paulo possui em sua malha urbana edifícios que utilizam tanto estratégias passivas de iluminação e ventilação, como aqueles totalmente selados.

Os edifícios construídos na primeira metade do século 20 caracterizam-se por uma volumetria que possibilita a penetração da luz natural em praticamente toda a área do pavimento, devido à presença de átrios e de reentrâncias na planta do edifício. Como exemplo, o Edifício Martinelli de 1929, do arquiteto Giuseppe Martinelli. Além da iluminação, essas características arquitetônicas permitem, ainda, a ventilação natural dos ambientes por meio da abertura dos caixilhos nas fachadas e da movimentação das bandeiras colocadas acima das portas internas.

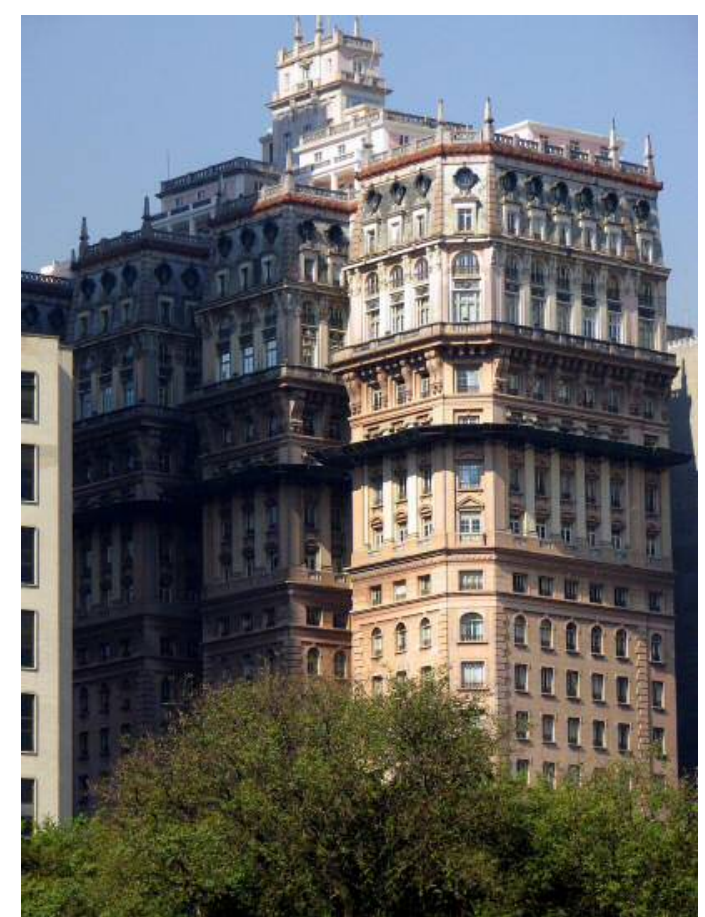

Figura 73 - O Edifício Martinelli (1929). Fonte: http://www.skyscrapercity.com/ acessado em 23 de janeiro de 2014.
A partir de 1940, começam a surgir os primeiros edifícios de escritório de Arquitetura Moderna no centro de São Paulo e, com eles, a elevação no percentual de vidro na fachada. A circulação desses edifícios tornase central à planta e, na maioria dos casos, o átrio central é eliminado, como exemplo, pode-se citar o Edifício CBI-Esplanada.

Com o intuito de verificar o papel da ventilação natural no condicionamento de ambientes de escritório, foram realizadas medições de temperatura do ar, da temperatura de globo e da umidade relativa, bem como de níveis de iluminação natural no edifício CBI-Esplanada 
no período de 2 a 17 de maio de 2012. Através da coleta desses dados, objetivou-se compreender o desempenho térmico dos pavimentos a partir da utilização da ventilação natural dos ambientes em diferentes alturas com diferentes ocupações e, principalmente, analisar o papel do usuário como controlador dessas aberturas. E, para complementar esses estudos, foram realizadas simulações de desempenho térmico utilizando o software Bentley TAS em um edifício de planta quadrada e com 30 pavimentos de altura. Sabe-se que estratégias de projeto para a utilização de ventilação natural requerem tipos diferentes de informações de conforto térmico em comparação com os produzidos para edifícios que utilizam ar condicionado (OSELAND, HUMPHREYS, 1993). Assim, como visto no capítulo anterior, as questões de conforto adaptativo, além de novas estratégias que busquem atender às necessidades individuais dos usuários, precisam ser medidas e calculadas para serem colocadas em prática num exercício de projeto que será apresentado no capítulo 6 .

\subsection{Contexto Climático}

São Paulo, cujas coordenadas geográficas são 233' de latitude sul e $46^{\circ} 4^{\prime}$ de longitude oeste, possui clima tropical de altitude. Como se pode ver na figura 74 , a temperatura pode ficar acima de $33^{\circ} \mathrm{C}$ no verão e abaixo de $8^{\circ} \mathrm{C}$ no inverno, mas, durante a maior parte do ano, as temperaturas permanecem entre $15^{\circ} \mathrm{C}$ e $25^{\circ} \mathrm{C}$.

Da análise do diagnóstico climático para a cidade de São Paulo a partir do método do Givoni (Alucci, 2011), pode-se dizer que 17\% das horas do ano estão dentro da zona de conforto, sendo que o restante, $83 \%$ das horas, estão em desconforto, dos quais apenas $17,4 \%$ são realtivos à baixa temperatura. A principal estratégia destacada para se atingir o conforto é a ventilação, correspondendo a $63,5 \%$ das horas e apenas $3,1 \%$ necessitando de refrigeração. Com isso, pode-se concluir que as temperaturas de verão não são consideradas grandes desafios para o projeto se conseguirmos bloquear os ganhos solares com elementos de sombreamento e criarmos estratégias para a ventilação natural.

O clima da cidade de São Paulo apresenta uma peculiaridade que exige atenção extra, visando minimizar os ganhos de calor provenientes da radiação solar. A Figura 76 mostra 


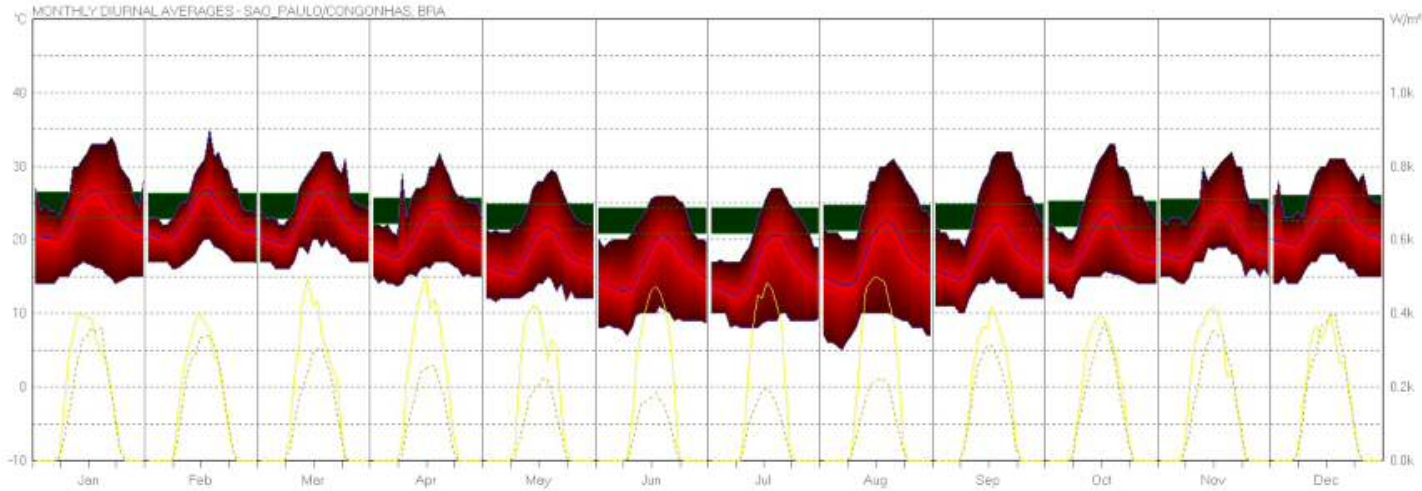

Figura 74 - Temperatura média mensal na cidade de São Paulo. Fonte: Ecotect Weather Tool (Meteonorm 6.1).

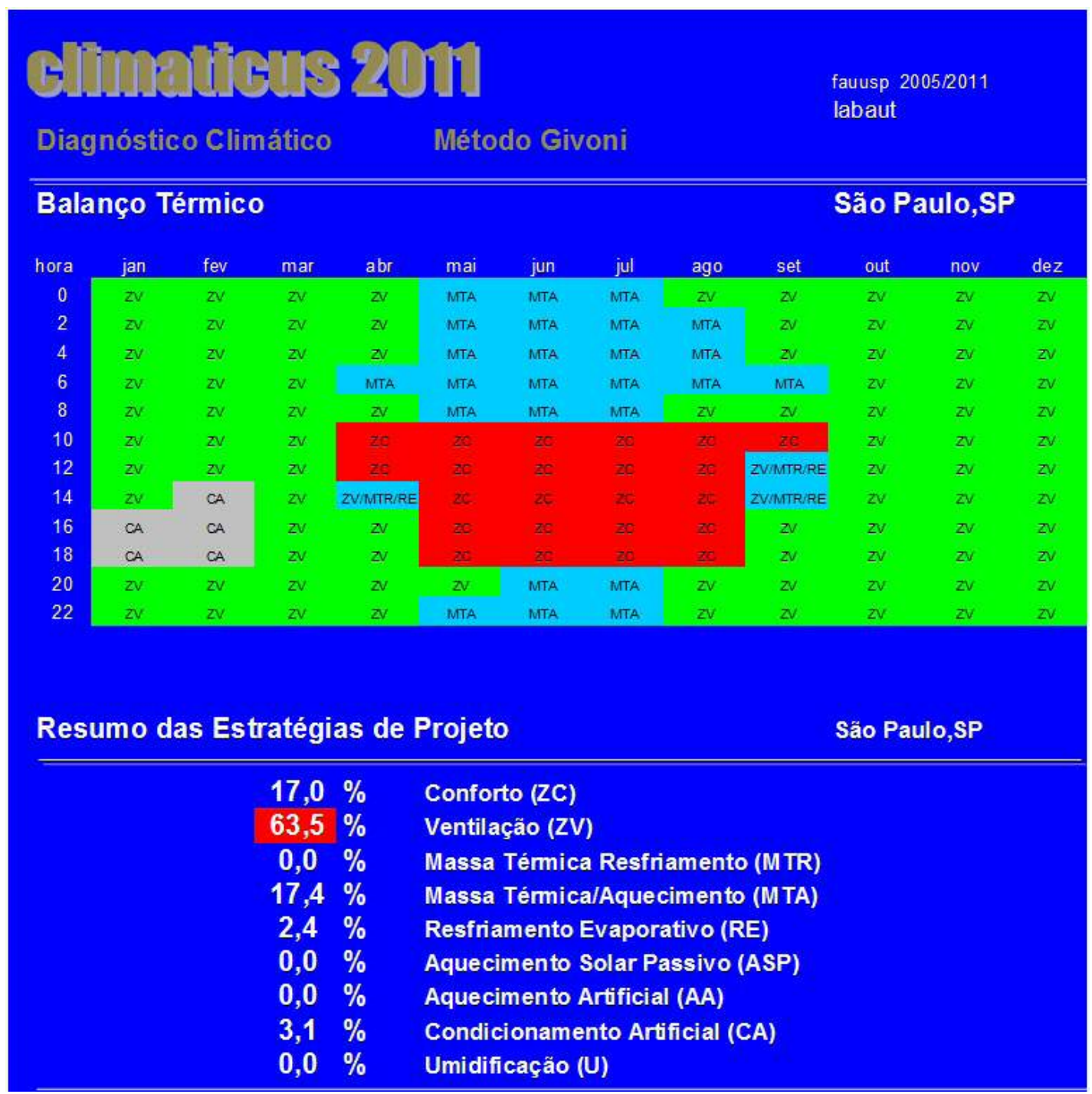

Figura 75 - Diagnóstico climático para a cidade de São Paulo pelo método de Givoni.

Fonte: Climaticus (Alucci, 2011)

que, ao longo do ano, as quantidades de radiação solar direta e difusa incidentes em um plano horizontal são bastante semelhantes. Isto ocorre devido à alta frequência de céu encoberto, com o expressivo percentual de $60 \%$ das ocorrências anuais, $19 \%$ de 


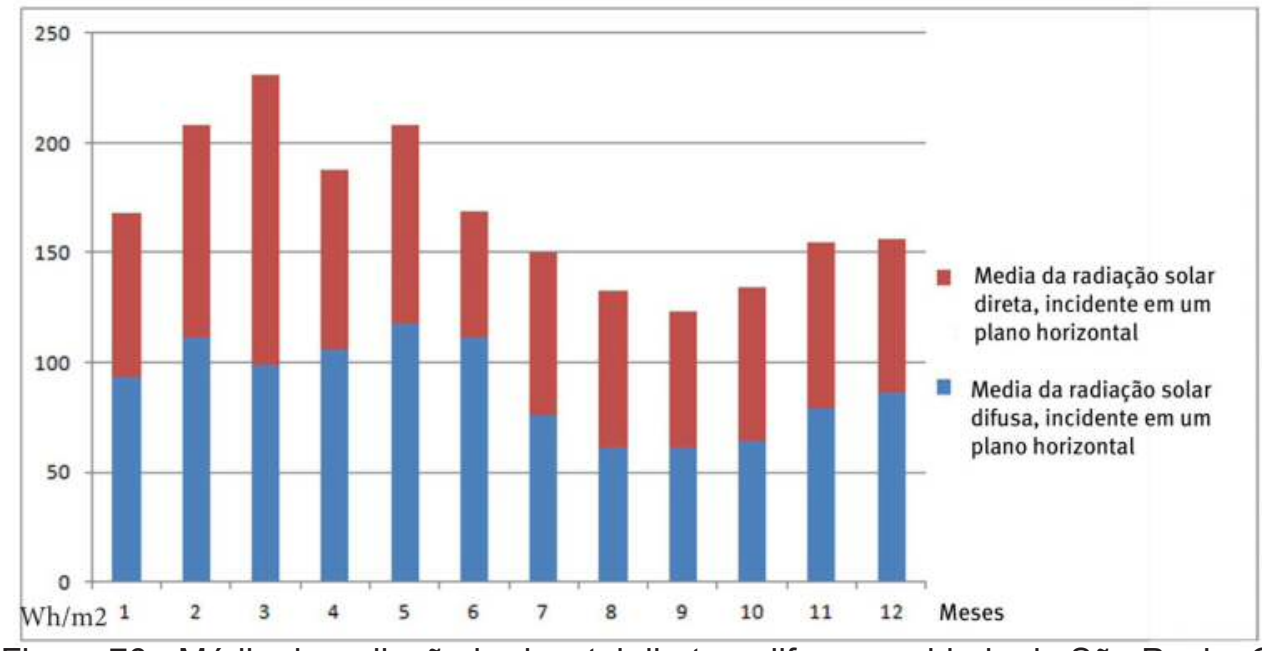

Figura 76 - Média da radiação horizontal direta e difusa na cidade de São Paulo. Os dados de radiacao foram extraidos do banco de dados do programa Meteonorm 6.1 (Meteotest, 2009)

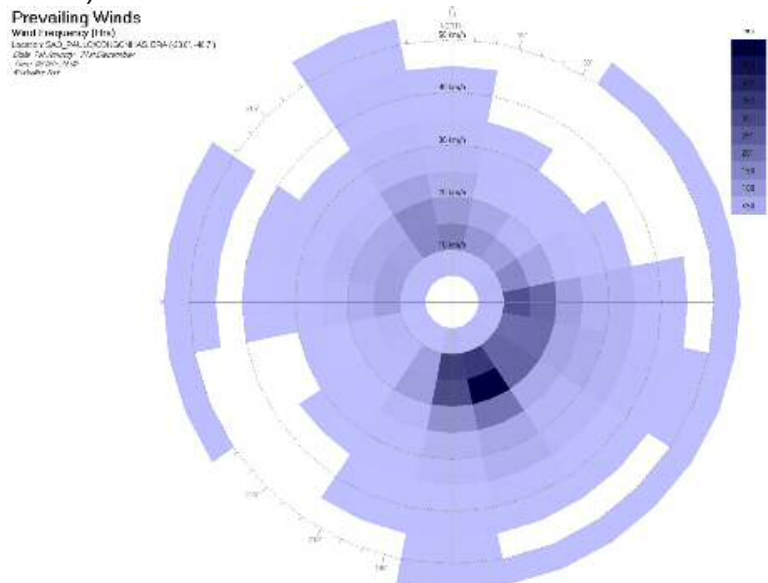

Figura 77 - Rosa dos ventos para a cidade de São Paulo. Fonte: Ecotect Weather Tool (Meteonorm 6.1).

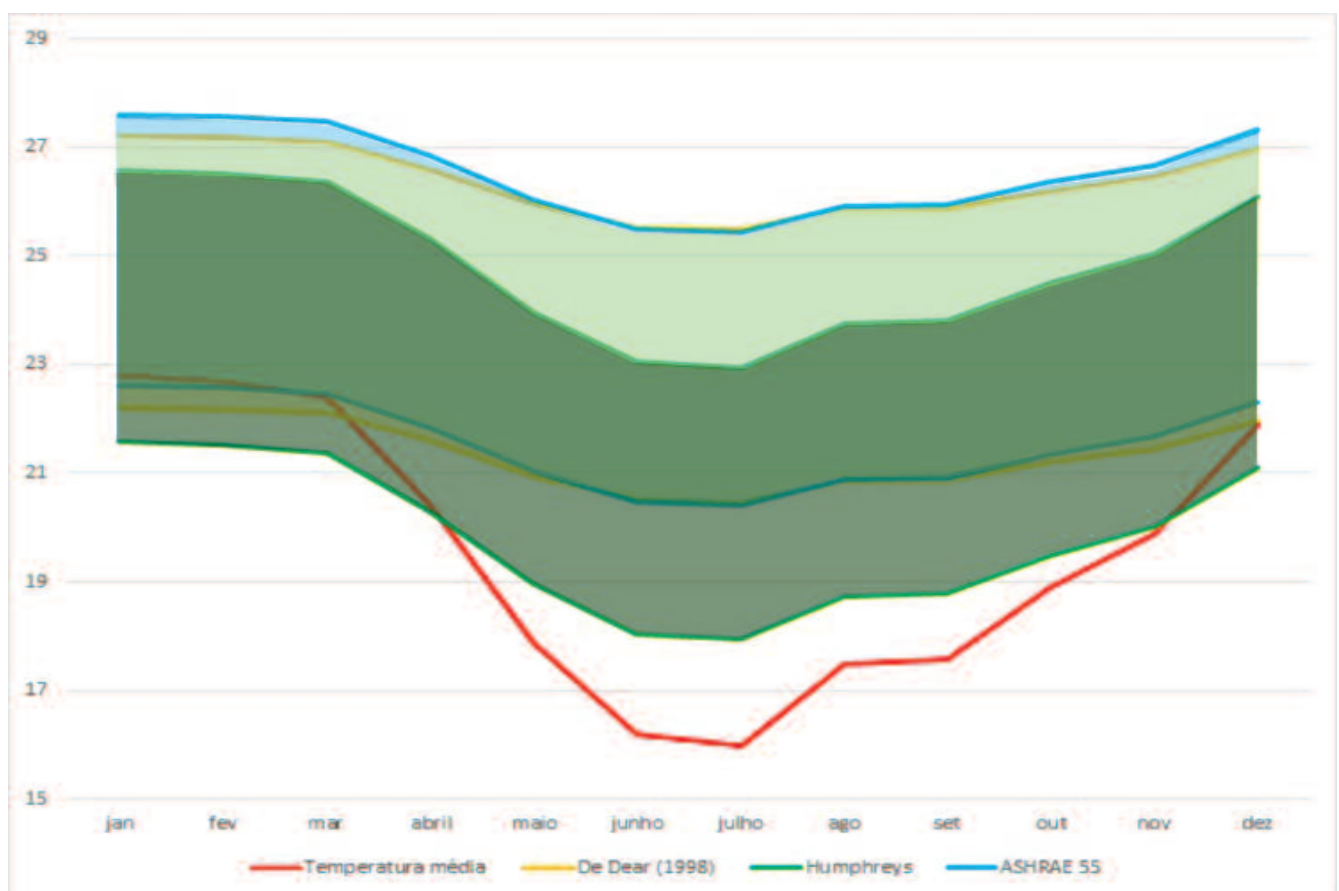

Figura 78 - Gráfico com a variação das temperaturas segundo os modelos de De Dear, Humphreys e Ashrae 55. 
parcialmente nublado e apenas $21 \%$ de céu claro. Da análise da figura abaixo, podese dizer que a radiação difusa é tão importante quanto a direta, sendo que, em alguns meses, como abril, maio e junho, é superior à direta. Uma das estratégias mais eficientes no bloqueio da radiação difusa é a redução das áreas envidraçadas, minimizando a visão do céu, ou através de elementos externos de proteção solar.

Com relação à umidade relativa, pode-se afirmar que a média anual é de $80 \%$, sendo a ventilação natural, por isso, tão importante para que se atinja o conforto, já que a movimentação do ar ajuda na retirada do exesso de umidade. A direção principal dos ventos é sudeste, como pode ser visto na figura 77. A velocidade do vento varia de $2 \mathrm{~m} / \mathrm{s}$ à $4 \mathrm{~m} / \mathrm{s}$ por praticamente o ano todo.

Segundo o zoneamento bioclimático brasileiro (NBR 15220-3), São Paulo está classificada como zona 3 e possui como estrtégias para atingir o conforto: aberturas médias, proteção solar das aberturas, ventilação cruzada, inércia térmica e permissão para a entrada de sol no inverno.

Já em relação ao conforto adaptativo, foi feita uma comparação entre três abordagens distintas: De Dear $98\left(\mathrm{Toc}=18.9+0.255^{*} \mathrm{Tm}\right)$, Humphreys $\left(\mathrm{Tn}=11.9+0.534^{*} \mathrm{Tm}\right) \mathrm{e}$ Ashrae $55\left(\mathrm{Tn}=17.8+0.32^{*} \mathrm{Tm}\right)$ (fig. 78). Após analisar o gráfico, pode-se dizer que o modelo que mais se aproxima do clima de São Paulo é o modelo de Humphreys, que possui temperaturas no inverno mais baixas do que os outros dois modelos e no verão não tão altas.

Como visto no capítulo 2, sabe-se que o conforto não é resultado apenas das temperaturas internas e externas, existindo outros fatores ambientais aptos a influenciarem, como os níveis de iluminação, a movimentação do ar e a capacidade de adaptação, dentre outros. Com relação à capacidade de adaptação, ela pode ocorrer de duas formas distintas: mudando-se o ambiente para atingir o conforto, abrindo as janelas, abaixando as persianas, mudando-o de local; mudando-se as condições do usuário, alterando as vestimentas, modificando a atividade ou tendo acesso a bebidas geladas ou quentes. Essas duas formas de se atingir o conforto podem alterar as temperaturas em até 6 graus (fig. 79).

Com isso, é possível observar a variação na temperatura de conforto a partir da adoção 
Capítulo 3 - O Papel da Ventilação no Projeto do Edifício Alto de Melhor Desempenho para a Cidade de São Paulo Avaliação de Desempenho Ambiental e Arquitetura Paramétrica Generativa para o Projeto do Edifício Alto

dessas medidas para a adaptação (fig. 80). Dessa forma, nota-se que os valores das temperaturas se tornaram muito mais flexíveis e com uma amplitude muito maior, possivelmente resultando em poucas horas de desconforto durante $\mathrm{o}$ ano.

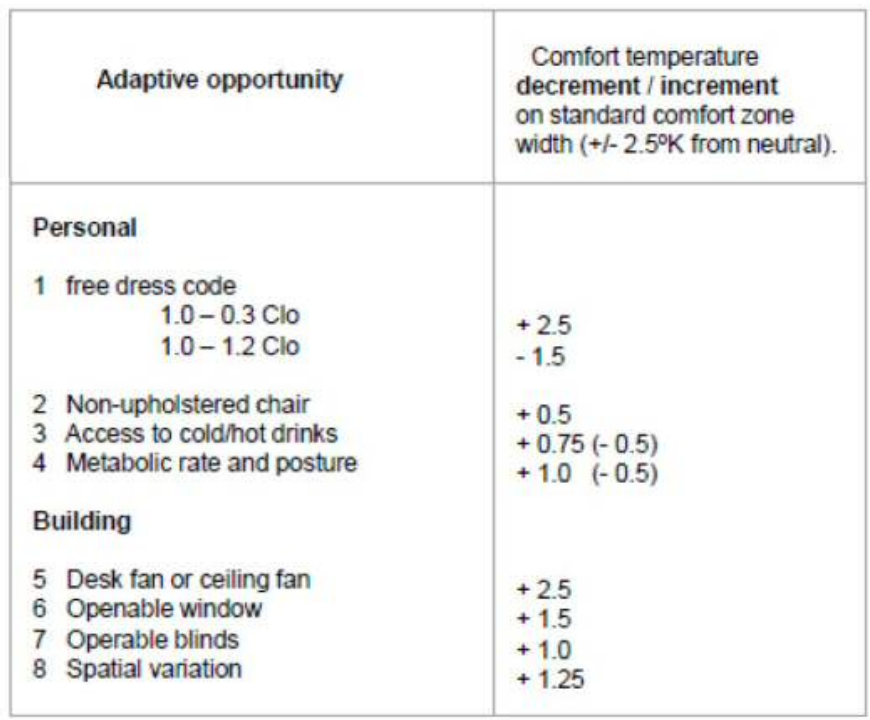

Figura 79 - Oportunidades de adaptação para atingir o conforto e o seu efeito na temperatura. Fonte: Baker, 2009 apud Conceição, 2010.

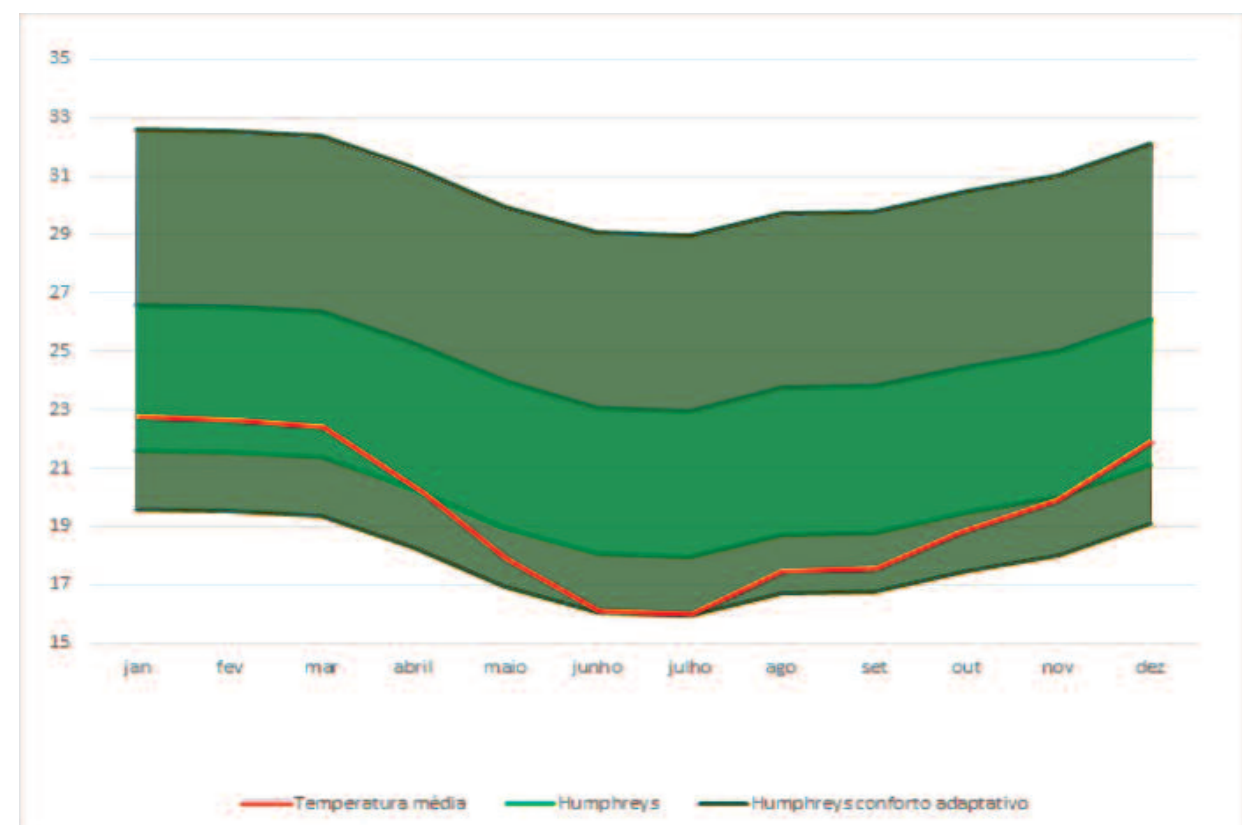

Figura 80 - Comparação entre as temperaturas de conforto e depois das medidas adaptativas. 


\subsection{Considerações sobre áreas envidraçadas: Iluminação e Ventilação}

As janelas são a parte transparente da envoltória do edifício, sendo por meio dela que o usuário tem contato com o meio externo através de vistas, da iluminação e da ventilação. Assim, são elas o elemento mais visual da fachada (BAKER, STEEMERS, 2002), podendo ocupar até $100 \%$ da área exposta. Justamente pela sua grande dimensão nos edifícios altos de escritórios, elas também são responsáveis pelo conforto ou não dos usuários e pelo consumo energético ligado à lluminação e ao condicionamento ambiental.

Como regra geral, muitos autores afirmam que o alcance da iluminação natural dentro de um ambiente é, aproximadamente, de duas vezes o pé-direito do ambiente. No entanto, Baker e Steemers (2002) afirmam que o alcance da iluminação natural é de duas vezes a distância do piso à parte superior da janela. Com isso, pode-se dizer que, quanto mais alta a janela, maior será o alcance da iluminação natural devido ao aumento do fator de céu. Cabe ressaltar que outros fatores, como elementos de proteção solar, ângulos de obstrução e tipo de vidro, irão influenciar diretamente no desempenho da iluminação no ambiente.

Ainda segundo Baker e Steemer(2002), a qualidade da iluminação natural não está relacionada à quantidade e, sim, à distribuição da mesma no plano de trabalho $(900 \mathrm{~mm}$ acima do piso) e ao controle do ofuscamento. Yannas (2008) menciona, ainda, a importância da proteção solar em todas as orientações em climas quentes para se bloquear o ganho solar, ou seja, é mais importante conhecer o nível de exposição das área envidraçadas do que a orientação do edifício propriamente dita.

Outro fator muito importante que deve ser levado em consideração é a sensação térmica dos usuários quando o sol bate diretamente sobre ele. Baker e Steemer (2002) afirmam que a sensação térmica desses usuários podem ser de 3 a $70 \mathrm{C}$ superior à temperatura do ar. Com isso, a principal consequência da falta de controle da radiação direta é o fechamento de persianas e o acionamento da iluminação artificial durante todo o período de ocupação. Sendo assim, Cotta (2012) afirma que é necessário proteger as aberturas, principalmente, na parte da manhã, quando os usuários chegam para trabalhar. Assim, 
será possível garantir que as persianas não impeçam a iluminação e nem a ventilação natural. No caso do uso de escritórios, é importante que haja uma iluminação de 300 lux no plano de trabalho para que o usuário não precise de uma complementação artificial. No entanto, de acordo com Baker (2009), o mínimo de iluminação aceitável utilizando o computador é de 150 lux.

Além da iluminação natural, outros fatores ligados diretamente às aberturas são as vistas para o exterior e a ventilação. As vistas para o exterior são importantes num edifício de escritórios. Wells (1996) entrevistou 2500 trabalhadores em diferentes edifícios de escritórios, sendo que $89 \%$ dos entrevistados disseram que a vista para o exterior é importante. Outro pesquisador, Osterhaus (2001), depois de avaliar 9 edifícios nos Estados Unidos e na Alemanha, chegou à conclusão de que a vista para o exterior é tão importante para os usuários que o ofuscamento nas fachadas leste e oeste pode ser ignorado, contanto que haja uma boa vista ao exterior.

A ventilação, por sua vez, é muito importante quando se fala da qualidade do ar no interior dos edifícios. No caso de São Paulo, duas estratégias merecem destaque: a ventilação noturna combinando temperaturas externas mais baixas e massa térmica dentro do edifício; a ventilação durante o uso do edifício que aumenta a velocidade do ar internamente, retirando o calor acumulado e aumentando o conforto dos usuários. Como regra geral, sabe-se que uma velocidade de ar de $2 \mathrm{~m} / \mathrm{s}$ pode produzir um efeito de resfriamento equivalente a $3^{\circ} \mathrm{C}$ na temperatura do ar (CIBSE, 1999), no entanto, Holger Koch-Nielsen (2002) afirma que velocidades de ar acima de $1 \mathrm{~m} / \mathrm{s}$ sobre a área de trabalho pode causar problemas com papéis.

Com relação à orientação da fachada e ao aproveitamento dos ventos predominantes, Ghiablakou (2010) afirma que as orientações, tanto perpendiculares $\left(90^{\circ}\right)$ como obliquas $\left(45^{\circ}\right)$, são favoráveis à ventilação natural. Quanto à profundidade da planta, Baker (2009) afirma que, se a ventilação for feita apenas por uma fachada, a profundidade máxima deve ser três vezes o pé-direito do ambiente e seis vezes se a ventilação for cruzada.

Lamberts et al (2010) afirma que, para regiões com o clima como o da cidade de São Paulo, a ventilação natural, combinada com elementos de proteção solar, é a estratégia (passiva) mais eficiente para se atingir o conforto térmico. Além disso, ressalta que os ambientes naturalmente ventilados devem proporcionar aos usuários possibilidades 
de adaptação e condições internas aceitáveis. Ou seja, o usuário irá experimentar um ambiente com temperaturas que irão variar de acordo com o horário e com as estações do ano, podendo atingir o seu conforto através de manipulação das aberturas e através de ventiladores idividuais ou de teto.

Os ventiladores são necessários, pois temperaturas operativas superiores à $260 \mathrm{C}$ exigem uma maior movimentação de ar (ARAÚJO, 1996; ANDREASI et al, 2010; GONÇALVES, 2001).

Com relação à tipologia de janela a ser adotada, Cotta (2012) afirma que a janela

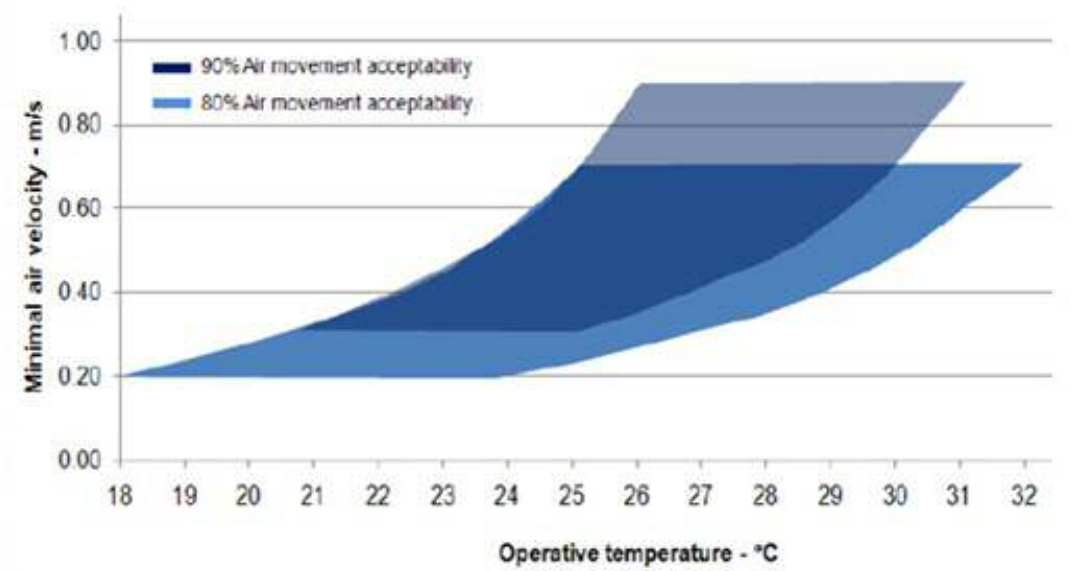

Figura 81 - Valores mínimos para a velocidade do ar correspondendo a 80\% e 90\% de aceitação dos usuários. Fonte: Lamberts et al, 2010.

pivotante é a que oferece o melhor controle dos ventos, proporcionando ao ocupante a oportunidade de direcionar o fluxo de ar e regular a área efetiva de abertura de acordo com as suas necessidades. As janelas maxim-ar invertidas, como as encontradas no edifício Commerzbank em Frankfurt, possuem um bom potencial para serem utilizadas em maiores panos de vidro (permitindo melhores vistas), evitando correntes de ar causadoras de desconforto por frio, e demandam baixa necessidade de operação do ocupante. Esse tipo de janela é mais recomendado em áreas próximas ao teto, já que não oferecem tantos artifícios para controle do vento.
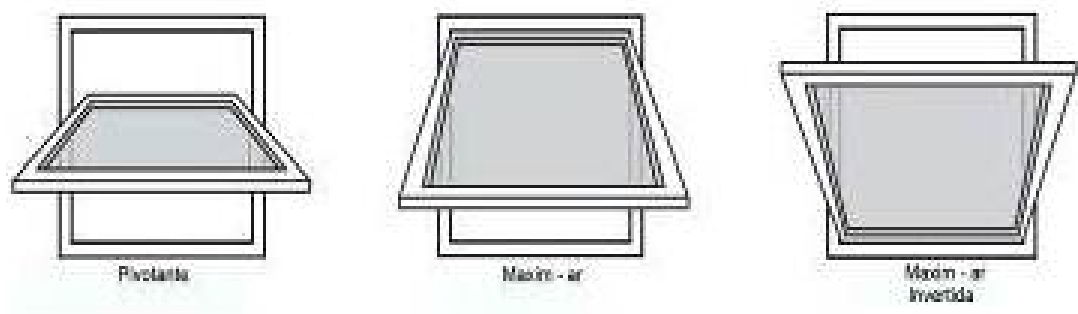

Figura 82: Tipologias de janelas contempladas nas simulações de ventilação. Fonte: CIBSE, 1999.

Umakoshi, Erica Mitie 


\subsection{O Edifício CBI-Esplanada}

Na época de sua construção, o edifício CBI Esplanda foi, para a cidade de São Paulo, um grande marco arquitetônico na paisagem urbana em razão de seu projeto inovador, bem como um marco tecnológico por utilizar novos materiais, equipamentos e técnicas construtivas (XAVIER et al, 1983).

Este edifício foi o primeiro do pós-guerra com estrutura racional, panos de vidro e de planta livre, uma novidade para a época, tendo em vista que os edifícios comerciais eram compartimentados em pequenas salas ao longo de corredores escuros.

Foi o primeiro arranha-céu construído no Vale do Anhangabaú e rompeu com as relações espaciais previstas entre o parque, a avenida e os prédios de Ramos de Azevedo. $O$ Edifício foi tombado pelo Compresp (Conselho Municipal de Preservação do Patrimônio Cultural e Ambiental da Cidade de São Paulo) em 1992.

A planta característica da arquitetura racionalista é composta por dois conjuntos de núcleos simétricos, banheiro articulados com as escadas, elevadores e hall. Isto

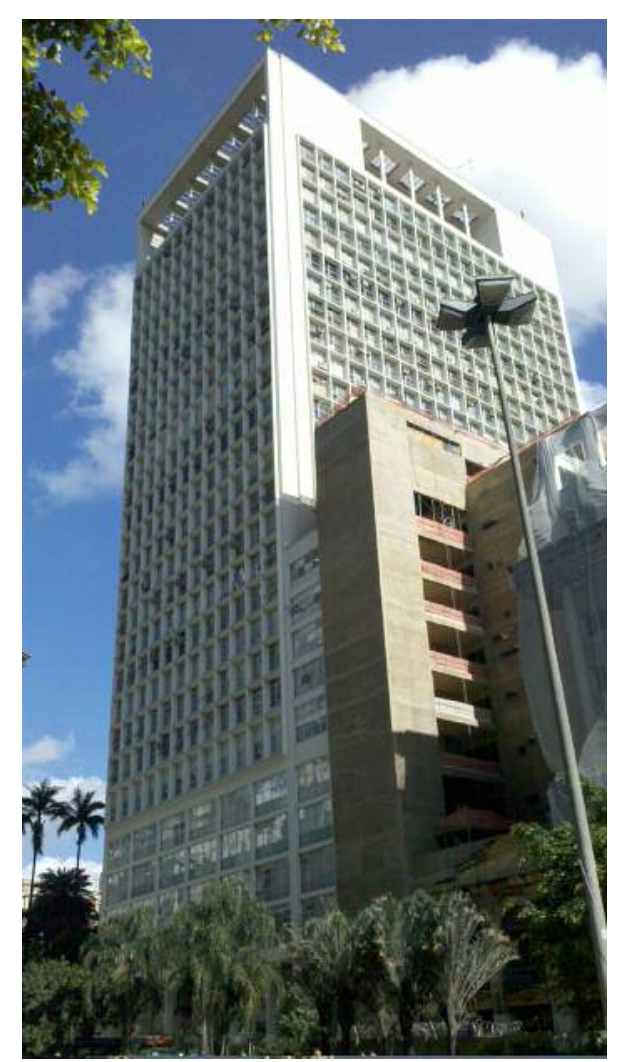

Figura 83- O Edifício CBI Esplanada é extremamente marcante na paisagem do Vale do Anhangabaú.

Umakoshi, Erica Mitie permite que a planta possa ser dividida em até quatro grandes escritórios, servidos dois a dois pela circulação. A organização da planta demonstra a racionalidade da arquitetura, com a estrutura de concreto e colunas periféricas independentes da fachada de vidro, no entanto, alinhados no eixo paralelo. O átrio central envidraçado cria um grau de transparência e comunicação visual entre lados opostos da planta (FUJIOKA, 1996).

As fachadas orientadas para o norte $(\mathrm{N})$, Sul $(\mathrm{S})$, leste $(L)$ e oeste $(O)$ oferecem vistas panorâmicas da região circundante. Apesar da qualidade do espaço criado pelas vistas, as fachadas de vidro sem proteção sofrem o risco de ofuscamento e superaquecimento devido à falta de controle da radiação solar

Os materiais utilizados para a construção do edifício foram, basicamente, o concreto aparente 
armado - o edifício era a maior estrutura em volume de concreto armado no mundo na época da sua construção - e caixilho de ferro com vedação em vidro comum. As únicas superfícies revestidas eram as lajes de piso, que receberam uma camada de contrapiso de $5 \mathrm{~cm}$. As demais superfícies foram pintadas na cor branca. Com o passar dos anos, os condôminos executaram reformas internas, fazendo com que a maioria dos pavimentos não dispusessem de planta livre, sendo que alguns materiais internos foram modificados.

Em visita realizada em maio de 2012, verificou-se que todos os pisos se encontram revestidos, desde forrações até pisos elevados. Em alguns andares, também houve revestimento de forro, o que fez com que o pé direito, bem como o vão luz, fossem diminuídos. Em alguns escritórios, foram construídas paredes divisórias de diferentes tipos de materiais, que vão desde o laminado fenólico melamínico até blocos de concreto revestidos. Desta forma, os espaços internos perderam os benefícios térmicos da inércia fornecida no projeto original pelos pisos e tetos expostos.

Com relação à climatização dos ambientes, o edifício foi projetado para utilizar a ventilação natural como estratégia para a retirada do calor acumulado nos ambientes. No entanto, verificou-se, na visita, que foram instalados equipamentos de ar-condicionado tanto de janela como splits. No $15^{\circ}$ pavimento, notou-se a predominância de ar-condicionado de janela, já no $22^{\circ}$ e no $26^{\circ}$ pavimentos, os equipamentos utilizados eram os splits.

Tabela 3 : Dados Gerais do edifício

\begin{tabular}{|l|l|}
\hline Edifício: & CBI Esplanada \\
\hline Ano de término da construção: & 1948 \\
\hline Arquiteto: & Lucjan Korngold \\
\hline Local: & São Paulo \\
\hline Número de Pavimentos: & 30 andares, 2 subsolos e cobertura \\
\hline Altura do Edifício: & 110 metros \\
\hline Pé direito dos pavimentos: & 2,91 metros \\
\hline Uso: & escritórios \\
\hline Materiais: peitoril de concreto aparente pintado & $\mathrm{h}=0,50 \mathrm{~m}$ \\
de branco & e $=0,15 \mathrm{~m}$ \\
& $\lambda=1,91 \mathrm{~W} / \mathrm{m}^{\circ} \mathrm{C}$ \\
& $\alpha=0,25$ \\
\hline Materiais: vidro + caixilho + persiana vertical de & $\mathrm{h}=2,41 \mathrm{~m}$ \\
lâminas finas (cor média) & e $=0,004 \mathrm{~m}$ \\
& Str $=0,50$ \\
\hline Materiais: laje concreto piso e teto & e $=0,20 \mathrm{~m}$ \\
& $\mathrm{~d}=2.200 \mathrm{Kg} / \mathrm{m}^{3}$ \\
\hline
\end{tabular}

Umakoshi, Erica Mitie 


\subsubsection{Localização}

O edifício está localizado no centro da cidade de São Paulo (latitude 2330'S), esquina da Praça Ramos de Azevedo e Rua Formosa (Vale do Anhangabaú). A fachada Leste (L) é completamente desobstruída, possibilitando a vista do Vale do Anhangabaú, enquanto a fachada Norte $(\mathrm{N})$ é totalmente obstruída até o $7^{\circ}$ andar e, acima, é completamente desobstruída. Já a fachada Oeste (O) tem o entorno imediato desobstruído, porém, após o afastamento de aproximadamente 06 metros, tem-se o Edifício Votorantim, antigo Hotel Esplanada, hoje sede da Votorantim, com 40 metros de altura, e a fachada Sul (S) é completamente desobstruída, possibilitando a vista da Praça Ramos de Azevedo.

A figura 84 apresenta a localização do edifício.

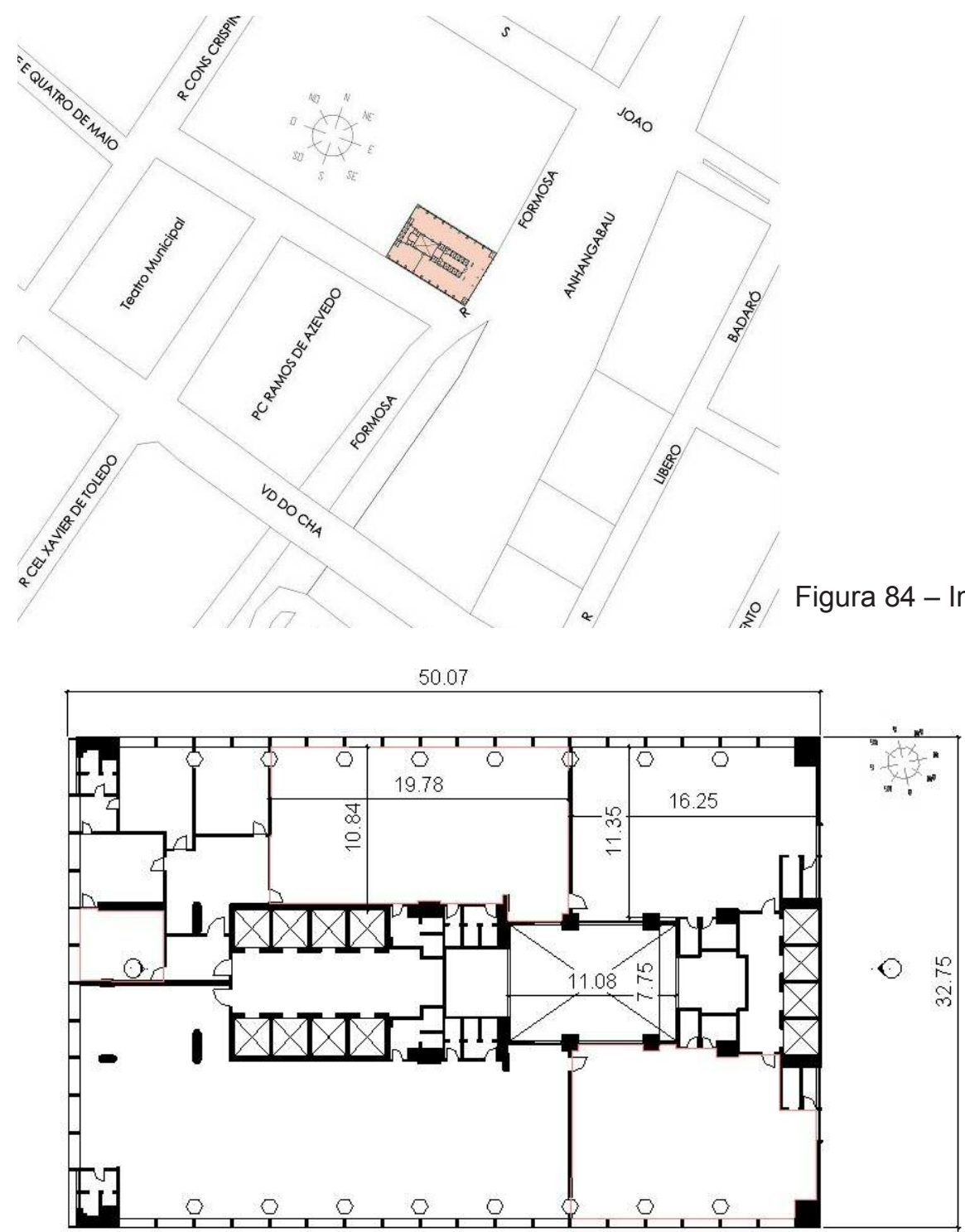

Figura 85 - Dimensões do edifício, dos ambientes no $15^{\circ}$ pavimento e do átrio central. 


\subsubsection{Desempenho Térmico}

Buscando identificar o papel da ventilação natural no condicionamento dos ambientes de escritório em diferentes alturas, com diferentes ocupações, além de analisar o papel do usuário como controlador dessas aberturas, foi realizada uma medição das variáveis climáticas em três pavimentos distintos no edifício CBI-Esplanda, $15^{\circ}, 22^{\circ}, 26^{\circ}$ pavimentos, que são ocupados pela empresa de engenharia e arquitetura HagaPlan. Cada pavimento possui padrões distintos de ocupação, mas, em todos, os usuários têm a possibilidade de controlar a abertura da janela.

Para identificar as condições de conforto térmico, foram medidas a temperatura do ar, a temperatura de globo, a umidade relativa e o nível de iluminação com o equipamento hobo durante o período de 2 a 17 de maio de 2012, em quatro pontos, sendo dois no $15^{\circ}$ pavimento, um no $22^{\circ}$ e um no $26^{\circ}$. Em paralelo a isso, foram realizadas medições de níveis de iluminação no primeiro dia (2 de maio de 2012 ), no $22^{\circ}$ pavimento, em quatro pontos.

Além disso, nesse mesmo dia, foram realizadas medições de temperatura superficiais do vidro1 e da laje para a verificação de seus comportamentos quando comparados com a temperatura do ar. Para isso, foi utilizado o equipamento termovisor.

Assim, para essas medições, foram utilizados 04 hobos, 04 luxímetros e um equipamento termovisor, fornecidos pelo Laboratório de Conforto Ambiental e Eficiência Energética da Universidade de São Paulo - LABAUT.

3.3.2.1 Dados Ambientais -Dados climático do IAG-USP para o período de medição

Os dados acerca das condições climáticas da cidade de São Paulo para o período de medição foram fornecidos pelo instituto de Astronomia, Geofísica e Ciências Atmosféricas da Universidade de São Paulo. Tais dados de temperatura do ar, umidade, radiação global e velocidade de vento foram tomadas no Aeroporto de Congonhas, a aproximadamente 10 quilômetros do local da medição. A leitura de temperatura revela dias amenos, típicos do clima da cidade de São Paulo, com temperaturas variando entre $15^{\circ} \mathrm{C}$ e $25^{\circ} \mathrm{C}$. Os níveis de umidade estavam razoáveis, com níveis favoráveis de vento,

1 Para medir a temperatura do vidro foi colado na superfície interna um material opaco (fita isolante), numa área sombreada. Dessa forma, o material entrou em equilíbrio térmico do vidro e pôde-se obter a temperatura do vidro.

Umakoshi, Erica Mitie 
Capítulo 3 - O Papel da Ventilação no Projeto do Edifício Alto de Melhor Desempenho para a Cidade de São Paulo Avaliação de Desempenho Ambiental e Arquitetura Paramétrica Generativa para o Projeto do Edifício Alto

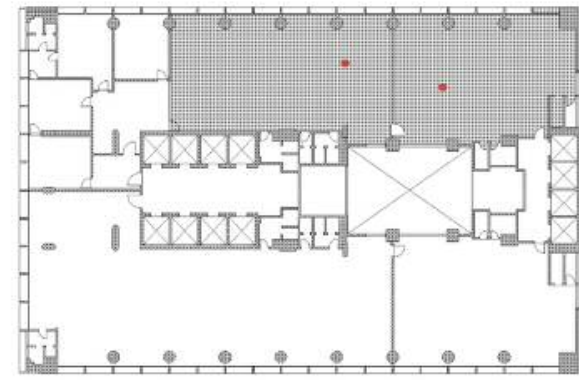

- Localizaçăo do Hobo

Figura 86 - Dois ambientes analisados no $15^{\circ}$ pavimento

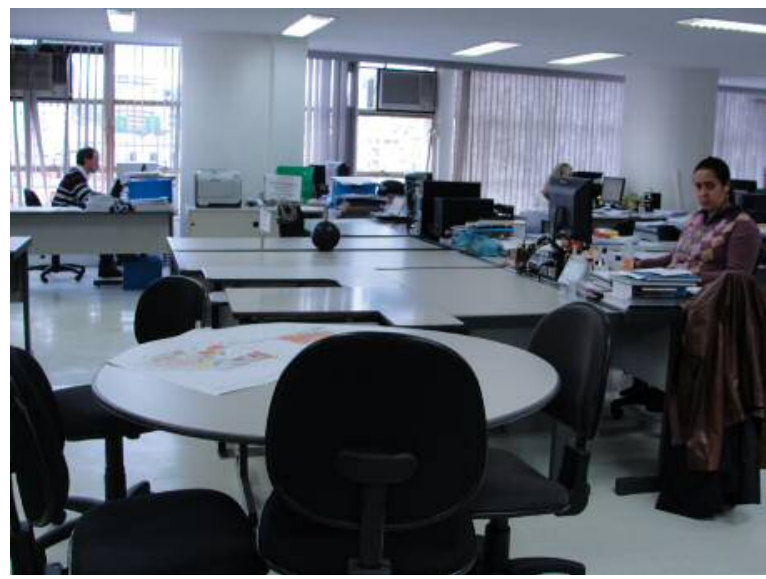

Figura 87- Localização do Hobo no $15^{\circ}$ pavimento

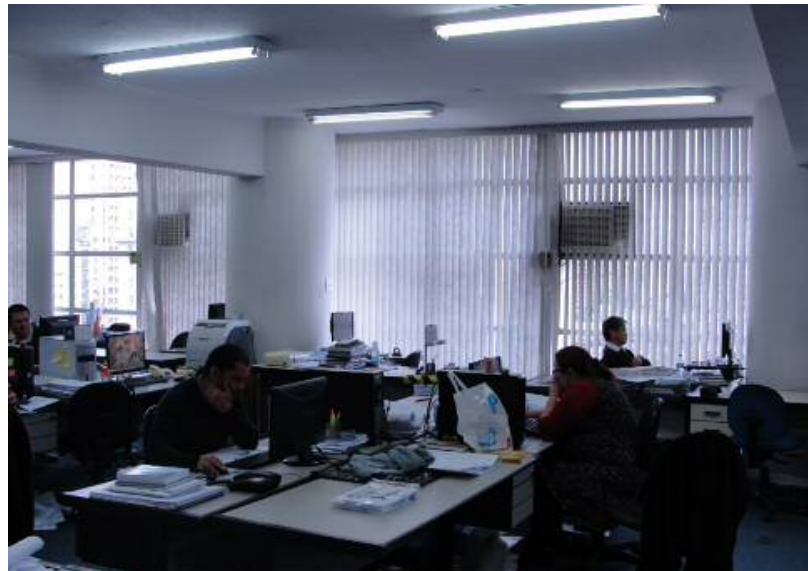

Figura 88 - Localização do Hobo no $15^{\circ}$ pavimento perto da janela

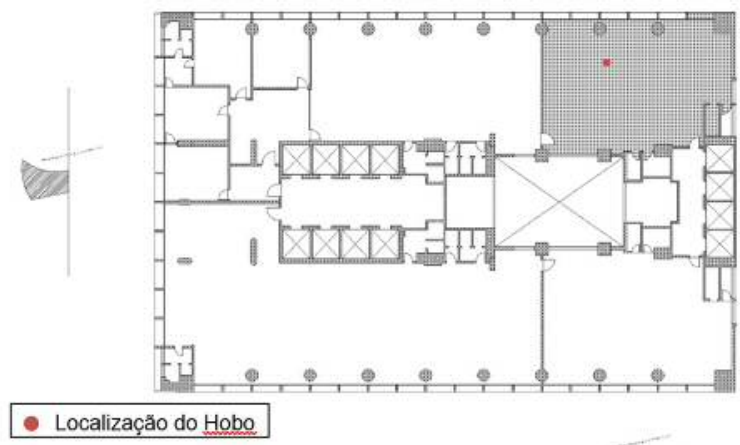

QPegers

Figura 89- Ambiente analisado no $22^{\circ}$ pavimento

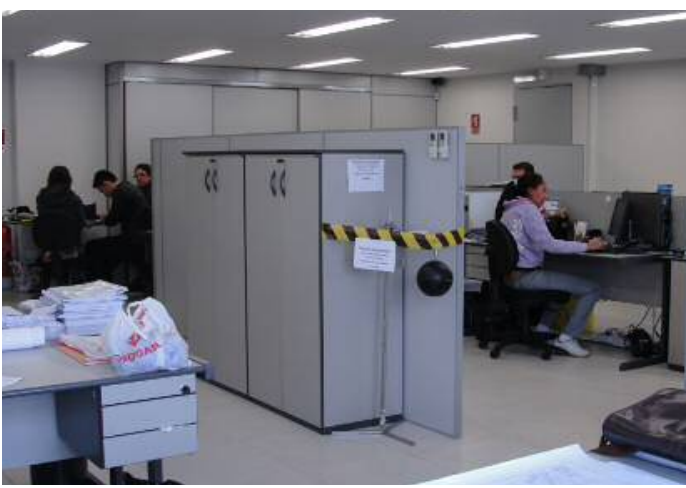

Figura 90 - Localização do Hobo no $22^{\circ}$ pavimento

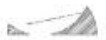

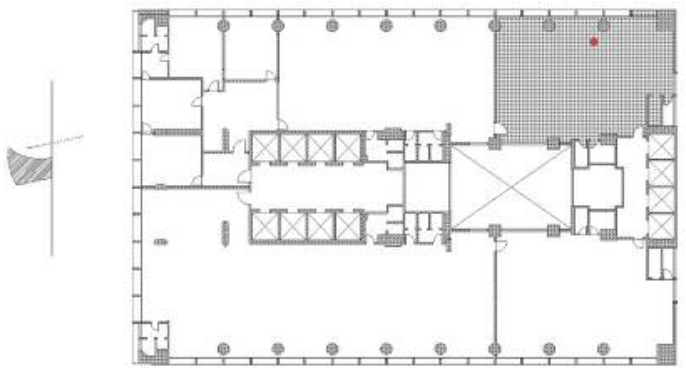

- Localizaçăo do Hobo

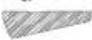

Figura 91- Ambiente analisado no $26^{\circ}$ pavimento

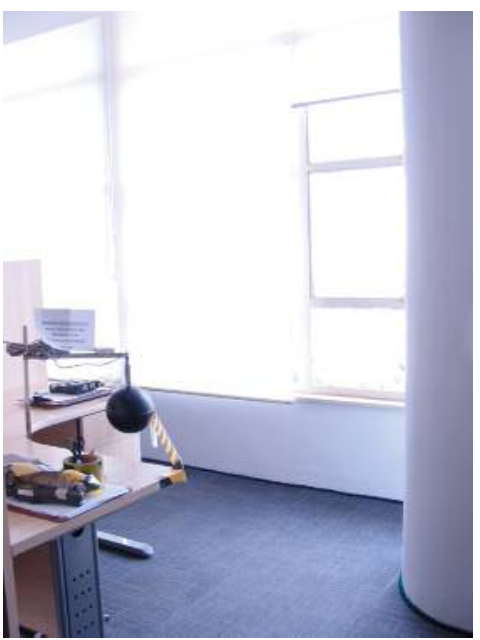
Hobo no $26^{\circ}$ pavimento 

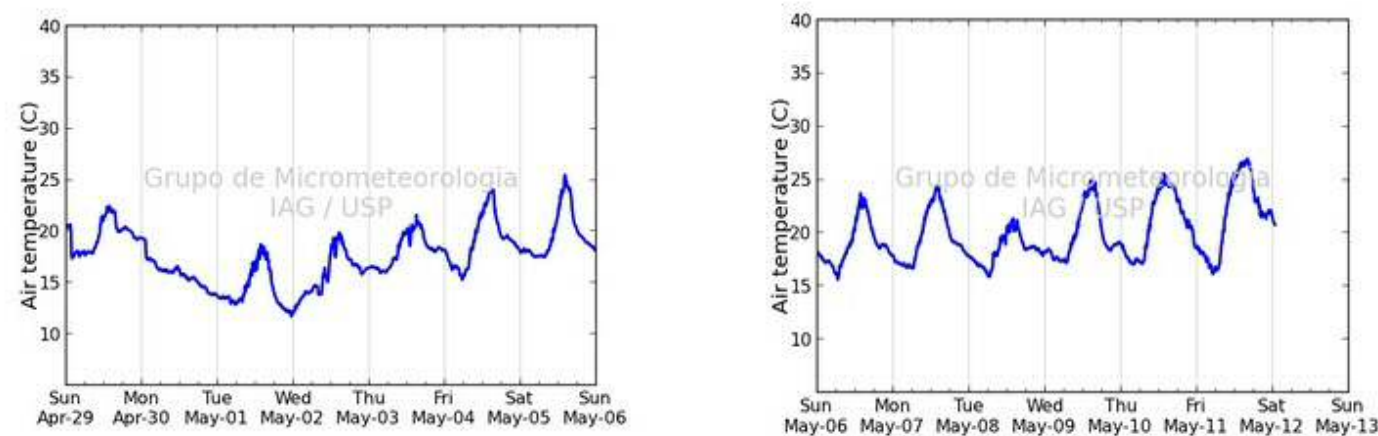

Figura 93- Dados de temperatura extraídos do site do IAG.
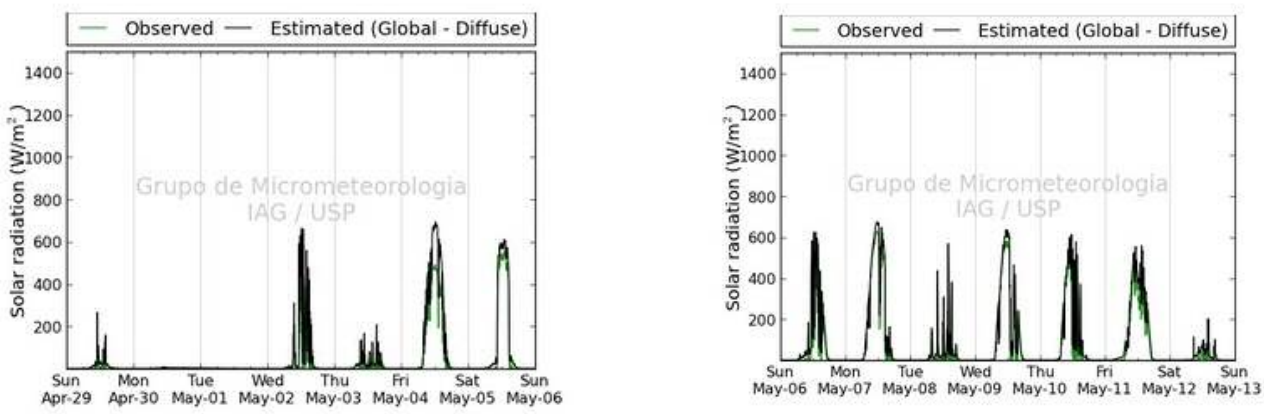

Figura 94 - Dados de radiação direta extraídos do site do IAG.
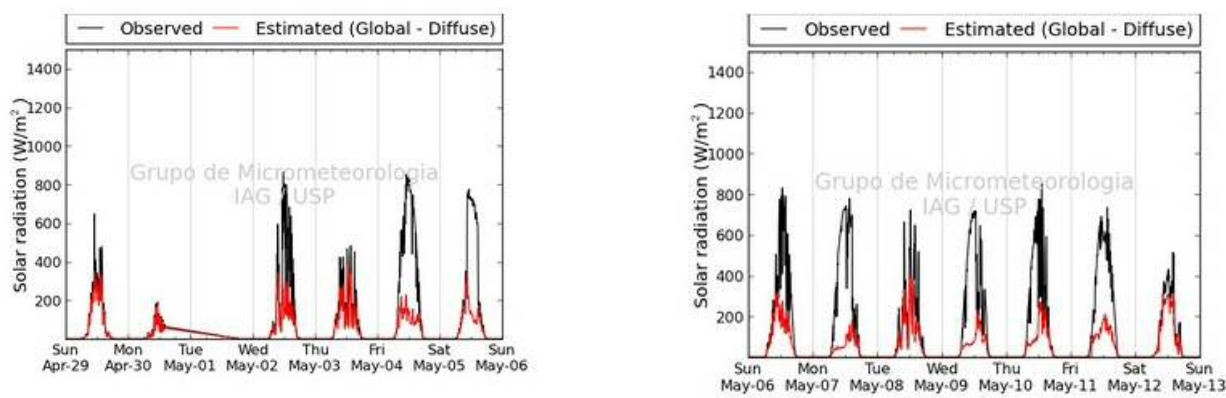

Figura 95- Dados de radiação difusa extraídos do site do IAG.
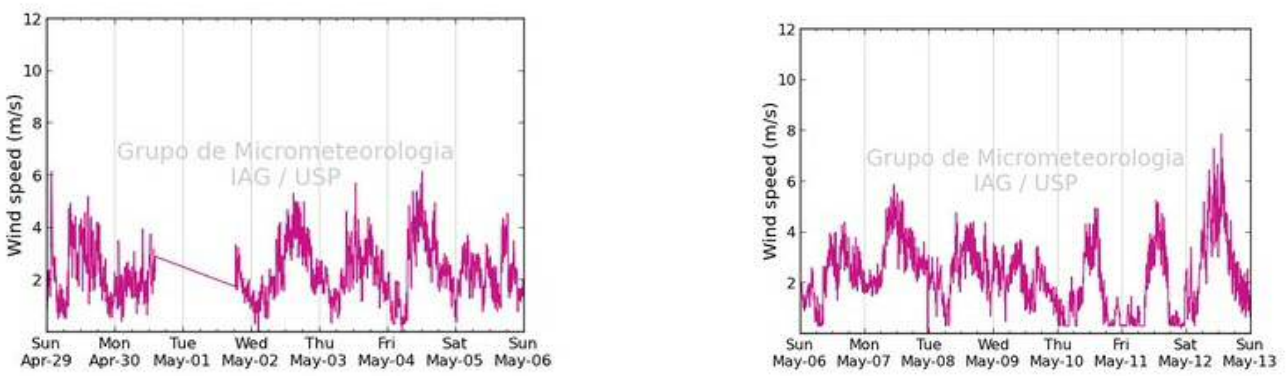

Figura 96- Dados de velocidade do vento extraídos do site do IAG.
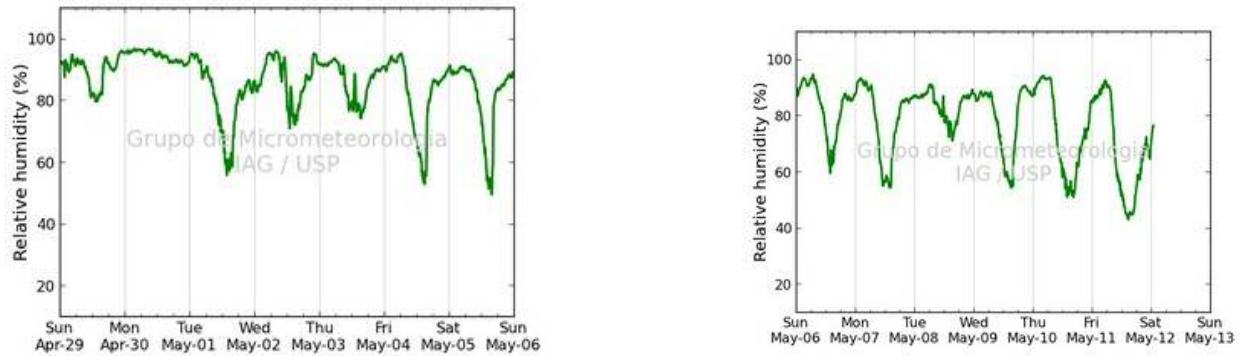

Figura 97- Dados de umidade extraídos do site do IAG. 
variando entre $1,5 \mathrm{~m} / \mathrm{s}$ e $4,0 \mathrm{~m} / \mathrm{s}$. A radiação solar provou ser o parâmetro climático mais crítico, alcançando $800 \mathrm{w} / \mathrm{m} 2$ e chamando a atenção para a necessidade de proteções solares.

\subsubsection{Dados extraídos do hobo}

É interessante notar que, mesmo com os ganhos internos das atividades de escritório, as temperaturas internas não foram superiores do que as temperaturas externas, enquanto a umidade relativa permaneceu em níveis confortáveis, provando ser bom o desempenho do edifício, que conta com boa inércia. Foi observado que os ocupantes do $22^{\circ}$ pavimento, com as suas estações de trabalho próximas às janelas, preferem deixa-las abertas durante todo o período de ocupação. Da análise dos dados, observouse uma significativa queda na temperatura durante o final de semana, o que indica que alguma janela foi deixada aberta durante o período.

Além disso, como consequência da ventilação natural, os valores da temperatura de globo são muito parecidas com a temperatura do ar. Isso pode ser comprovado à partir da análise do gráfico de temperatura, o qual demonstra que, em todos os pavimentos em que a janela permaneceu aberta fornecendo ventilação natural suficiente, foi mantida a temperatura interna em condição de conforto, mesmo sem proteção solar adequada.

\subsubsection{Dados do Termovisor no $22^{\circ}$ pavimento}

As medições com o equipamento Termovisor indicaram que quando não estiveram sob o efeito do sol, as temperaturas da superfície da janela mostraram-se abaixo dos valores da temperatura do ar, não afetando, consequentemente, o conforto térmico. A temperatura da superfície do forro indica que, embora a estrutura de concreto da laje não esteja exposta aos espaços internos, um certo grau de sua inércia térmica foi mantido. Em outras palavras, o forro adiciona uma razoavelmente fina camada de isolamento. Tabela 2- Comparação dados obtidos com a medição através do hobo e do termovisor

\begin{tabular}{|l|l|l|l|}
\hline Horário & Temp. ar hobo & $\begin{array}{l}\text { Temp. vidro } \\
\text { Termovisor }\end{array}$ & $\begin{array}{l}\text { Temp. forro } \\
\text { Termovisor }\end{array}$ \\
\hline $13 \mathrm{~h}$ & $19.3^{\circ} \mathrm{C}$ & $18.2^{\circ} \mathrm{C}$ & $17.3^{\circ} \mathrm{C}$ \\
\hline $14 \mathrm{~h}$ & $19.8^{\circ} \mathrm{C}$ & $18.1^{\circ} \mathrm{C}$ & $17.2^{\circ} \mathrm{C}$ \\
\hline $15 \mathrm{~h}$ & $20.4^{\circ} \mathrm{C}$ & $18.5^{\circ} \mathrm{C}$ & $17.9^{\circ} \mathrm{C}$ \\
\hline $16 \mathrm{~h}$ & $19.8^{\circ} \mathrm{C}$ & $17.9^{\circ} \mathrm{C}$ & $17.8^{\circ} \mathrm{C}$ \\
\hline
\end{tabular}



Avaliação de Desempenho Ambiental e Arquitetura Paramétrica Generativa para o Projeto do Edifício Alto

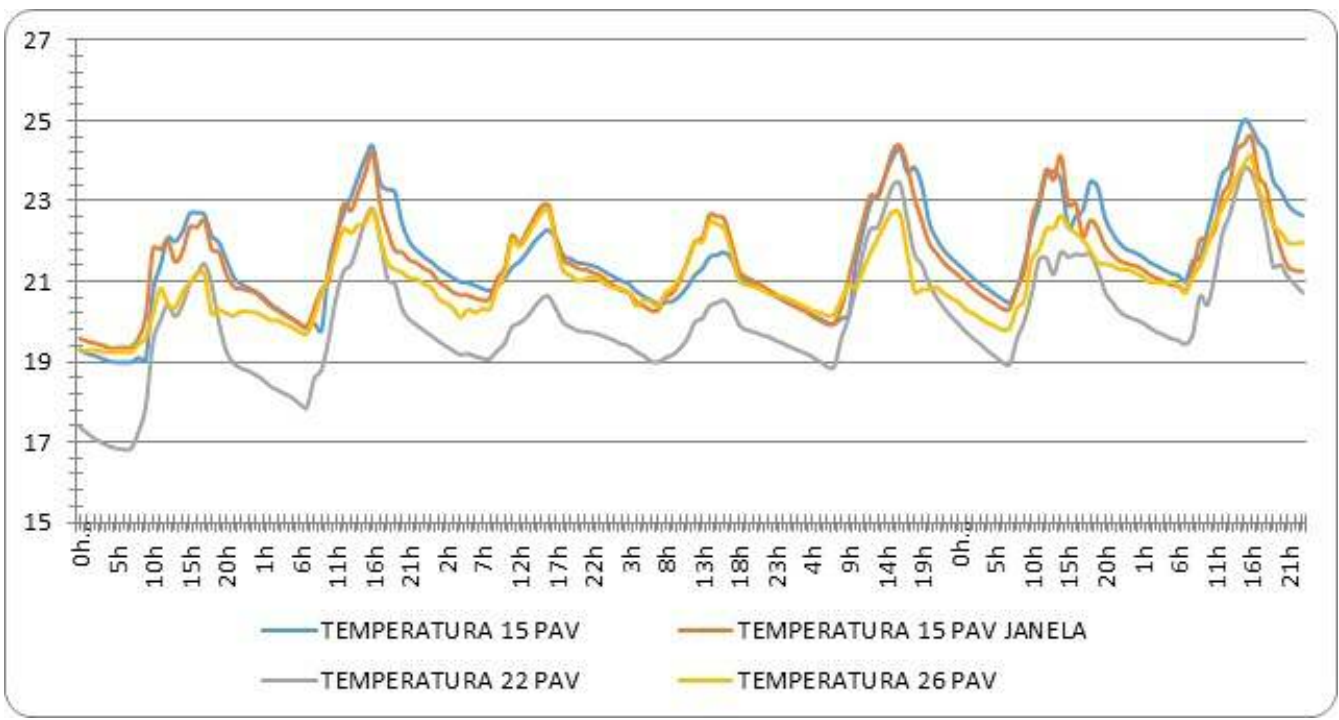

Figura 98- Temperatura do ar nos quarto pavimentos.

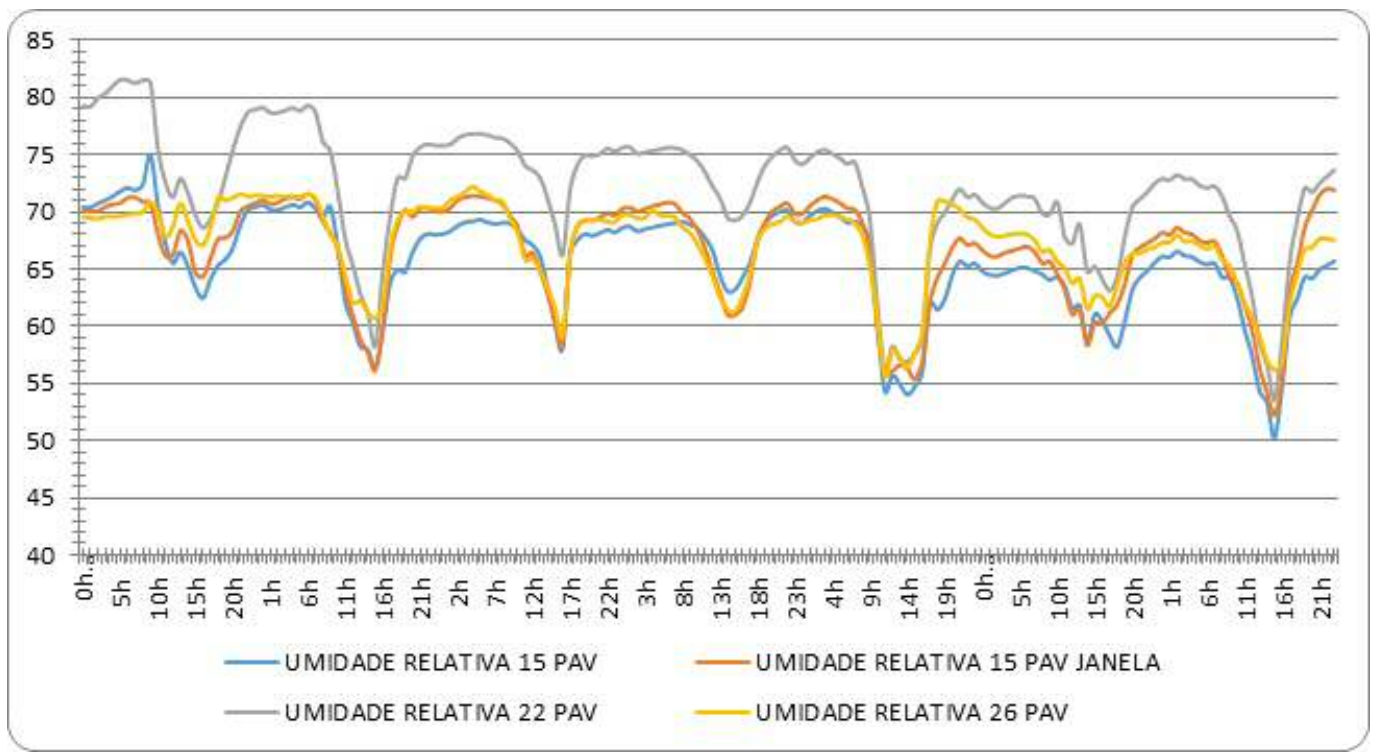

Figura 99- Umidade relative nos quarto pavimentos.

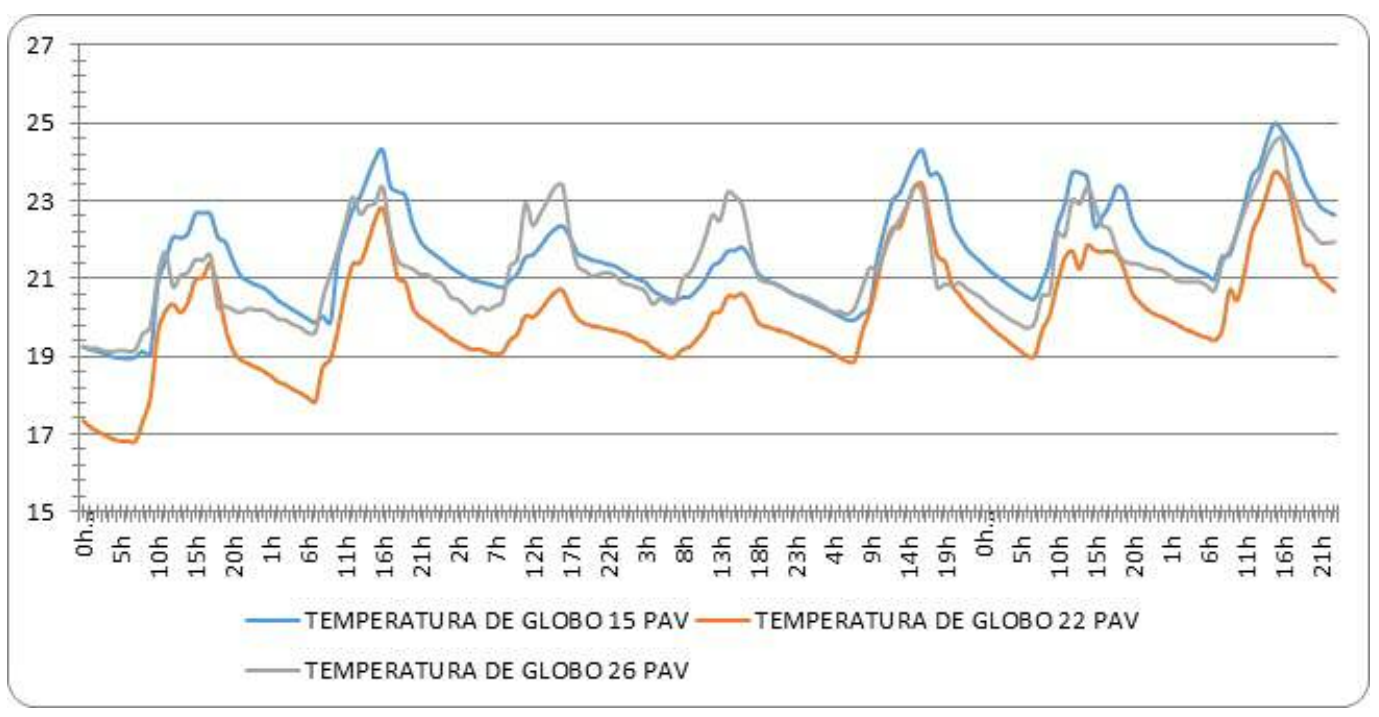

Figura 100- Temperatura de Globo. 
Capítulo 3 - O Papel da Ventilação no Projeto do Edifício Alto de Melhor Desempenho para a Cidade de São Paulo Avaliação de Desempenho Ambiental e Arquitetura Paramétrica Generativa para o Projeto do Edifício Alto
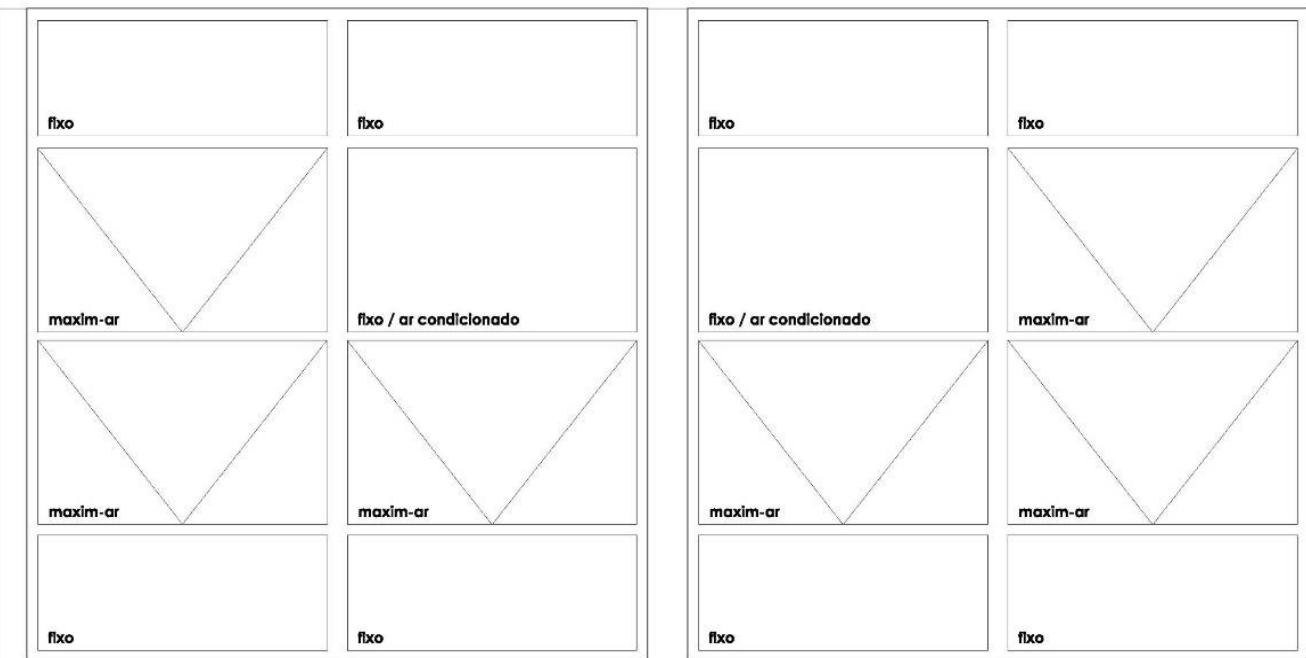

Figura 101- Janela padrão
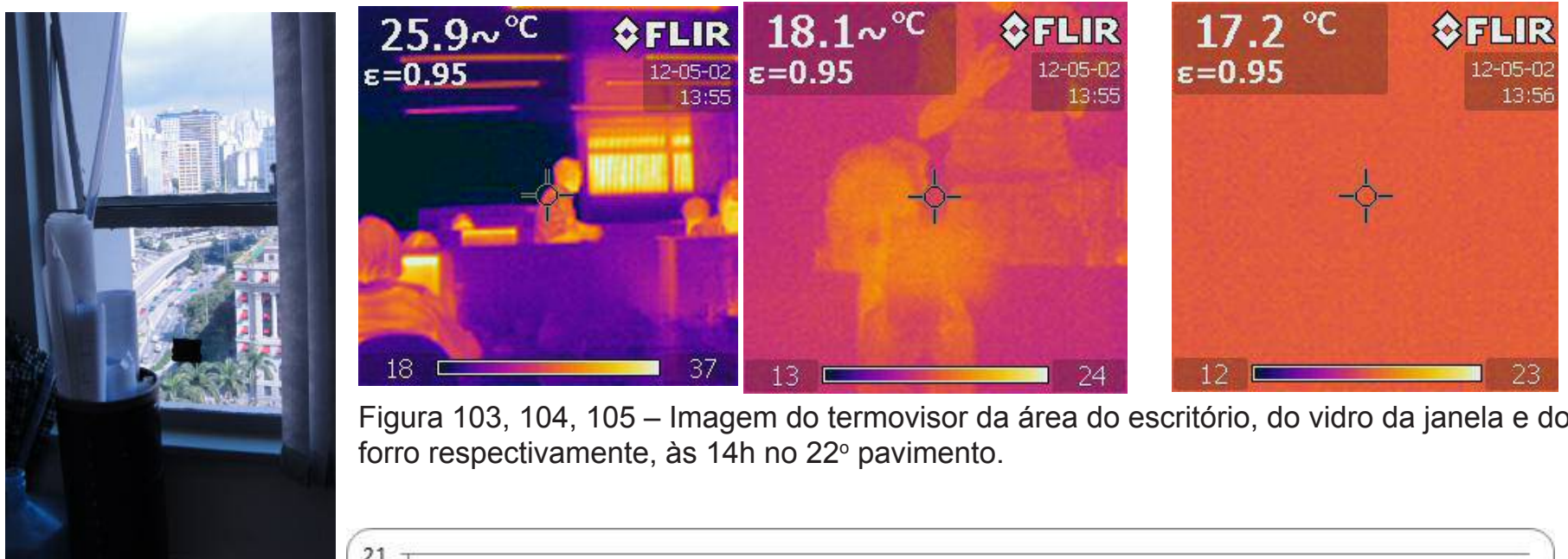

Figura 103, 104, 105 - Imagem do termovisor da área do escritório, do vidro da janela e do forro respectivamente, às $14 \mathrm{~h}$ no $22^{\circ}$ pavimento.

Figura 102- Tarja preta colocada no vidro para obter a temperatura superficial do vidro

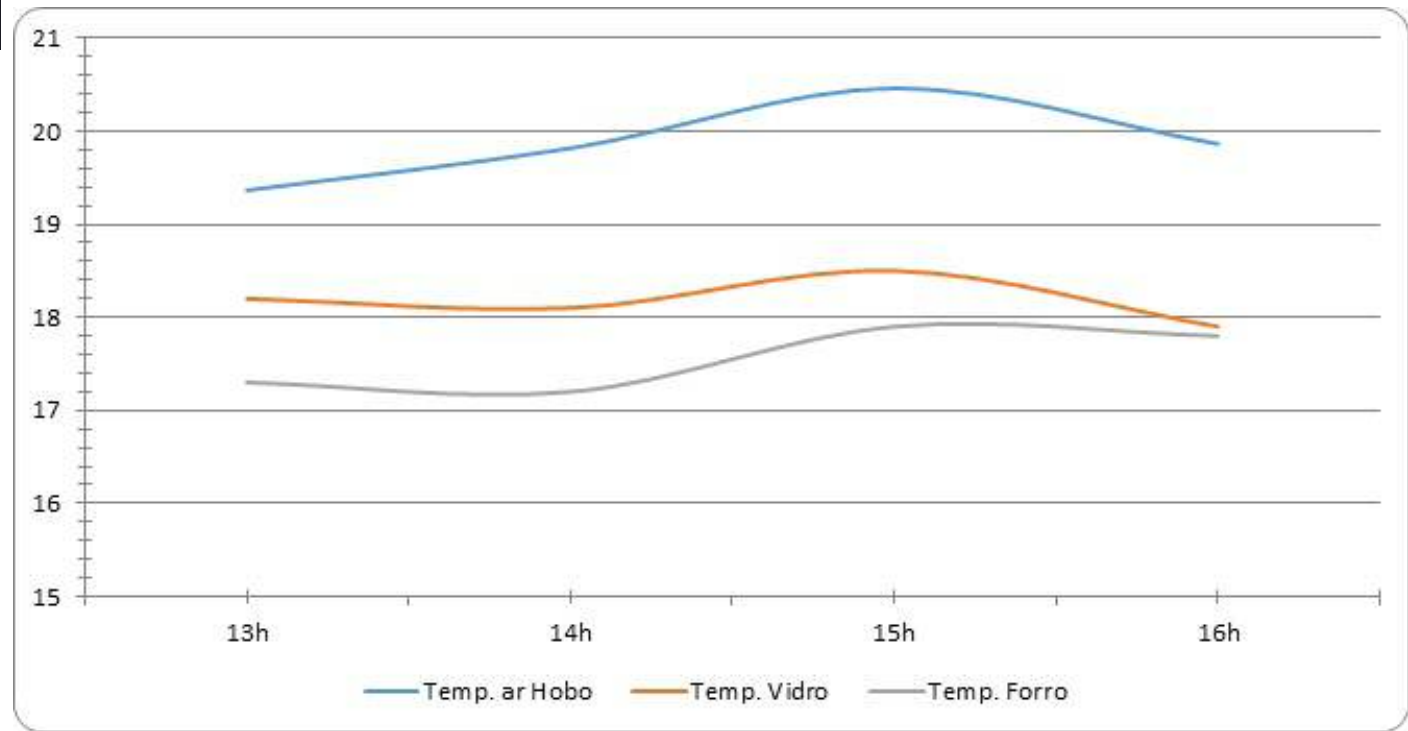

Figura 106- Comparação entre a temperatura do ar, a temperatura superficial do vidro e do forro. 


\subsubsection{Desempenho da lluminação Natural no $22^{\circ}$ pavimento}

A medição de iluminação natural foi, no dia 02 de maio de 2012, realizada durante a visita ao edifício no $22^{\circ}$ pavimento, devido à concessão dos usuários. Tendo em vista a restrição na utilização da iluminação artificial durante o período de medição, o local e os horários ficaram restritos à aceitação dos usuários. Para a medição de iluminação natural foram utilizados quatro luxímetros, posicionados segundo mostra a figura 23. As medidas foram realizadas das $12 \mathrm{~h}$ às $14 \mathrm{~h}$.

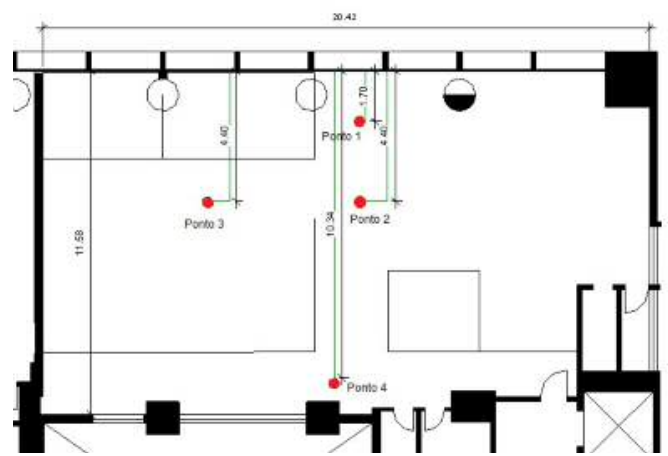

Figura 107- Localização dos pontos onde foram realizadas as medições de iluminação natural no $22^{\circ}$ pavimento.

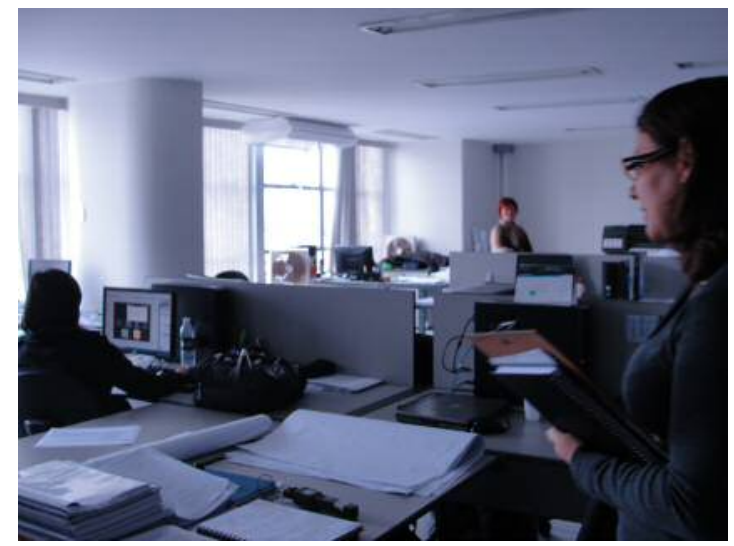

Figura 108 - Localização do luxímetro num dos postos de trabalho no $22^{\circ}$ pavimento (Ponto 1 )

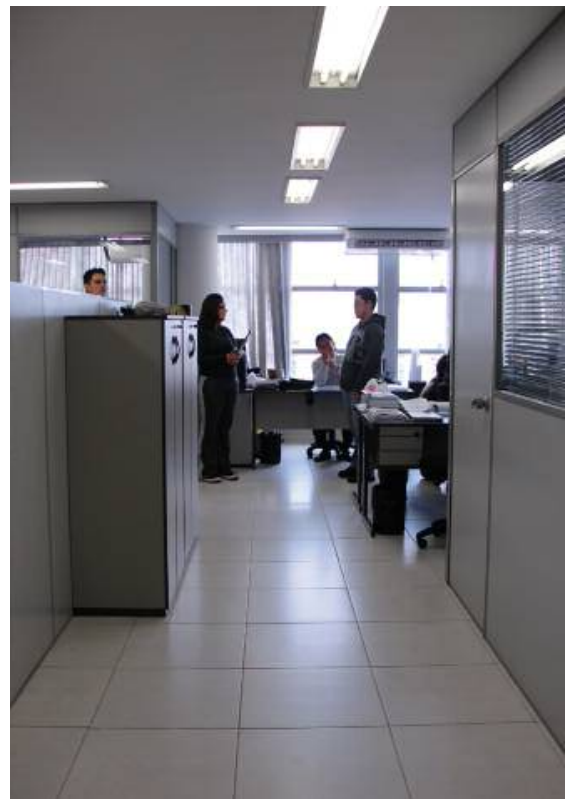

Figura $109-$ profundidade do $22^{\circ}$ pavimento onde foram tomadas as medidas de iluminação natural

No ponto 1 , próximo à fachada ( $80 \%$ de área envidraçada), altos níveis de iluminância foram medidos. Entretanto, devido à presença de persianas internas, a quantidade de iluminação natural reduz drasticamente quando se distancia da fachada, alcançando níveis insuficientes para o uso de escritórios. É preciso ressaltar que as divisórias não passam da altura de 1,2 m, permitindo o acesso da iluminação natural e da ventilação natural no pavimento. 
Capítulo 3 - O Papel da Ventilação no Projeto do Edifício Alto de Melhor Desempenho para a Cidade de São Paulo Avaliação de Desempenho Ambiental e Arquitetura Paramétrica Generativa para o Projeto do Edifício Alto

Tabela 3- Medição de iluminação natural no $22^{\circ}$ pavimento em 4 pontos distintos

\begin{tabular}{|l|l|l|l|l|}
\hline Horário & Ponto 1 & Ponto 2 & Ponto 3 & Ponto 4 \\
\hline $12 \mathrm{~h}$ & 1400 lux & 170 lux & - & - \\
\hline $13 \mathrm{~h}$ & 891 lux & 218 lux & 112 lux & 43 lux \\
\hline $14 \mathrm{~h}$ & 791 lux & 160 lux & 91 lux & 42 lux \\
\hline $15 \mathrm{~h}$ & 780 lux & 138 lux & 94 lux & 33 lux \\
\hline $16 \mathrm{~h}$ & $670 \operatorname{lux}$ & 76 lux & 48 lux & 16 lux \\
\hline
\end{tabular}

Tabela 4- Medição de iluminação natural no $22^{\circ}$ pavimento em 4 dias distintos pelo Hobo

\begin{tabular}{|l|l|l|l|l|}
\hline Horário & $\begin{array}{l}\text { Dia } 5 \text { maio } \\
\text { sábado }\end{array}$ & $\begin{array}{l}\text { Dia 6 maio } \\
\text { domingo }\end{array}$ & $\begin{array}{l}\text { Dia 12 maio } \\
\text { sábado }\end{array}$ & $\begin{array}{l}\text { Dia 13 maio } \\
\text { domingo }\end{array}$ \\
\hline $12 \mathrm{~h}$ & 216 lux & 193 lux & 248 lux & 59 lux \\
\hline $13 \mathrm{~h}$ & 201 lux & 232 lux & 232 lux & 35 lux \\
\hline $14 \mathrm{~h}$ & 232 lux & 209 lux & 240 lux & 35 lux \\
\hline $15 \mathrm{~h}$ & 225 lux & 272 lux & 75 lux & 20 lux \\
\hline $16 \mathrm{~h}$ & 106 lux & 225 lux & 20 lux & 27 lux \\
\hline
\end{tabular}

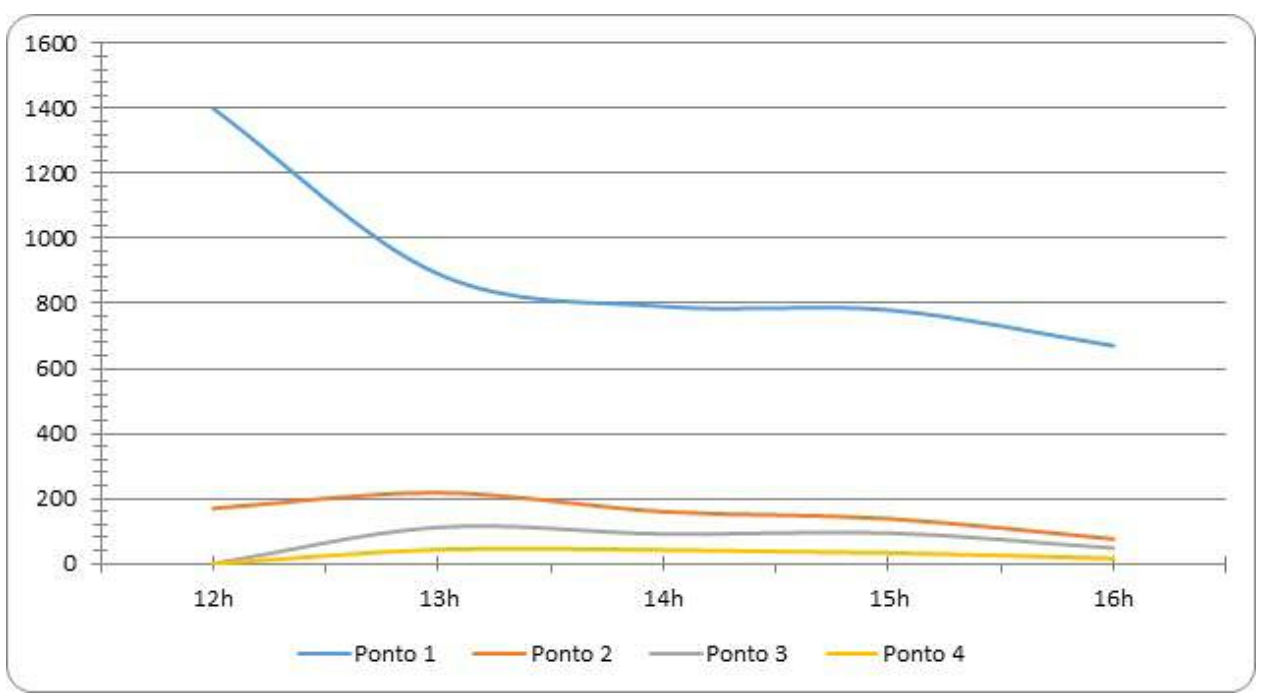

Figura 110 - medição de iluminação no $22^{\circ}$ pavimento em 4 pontos.

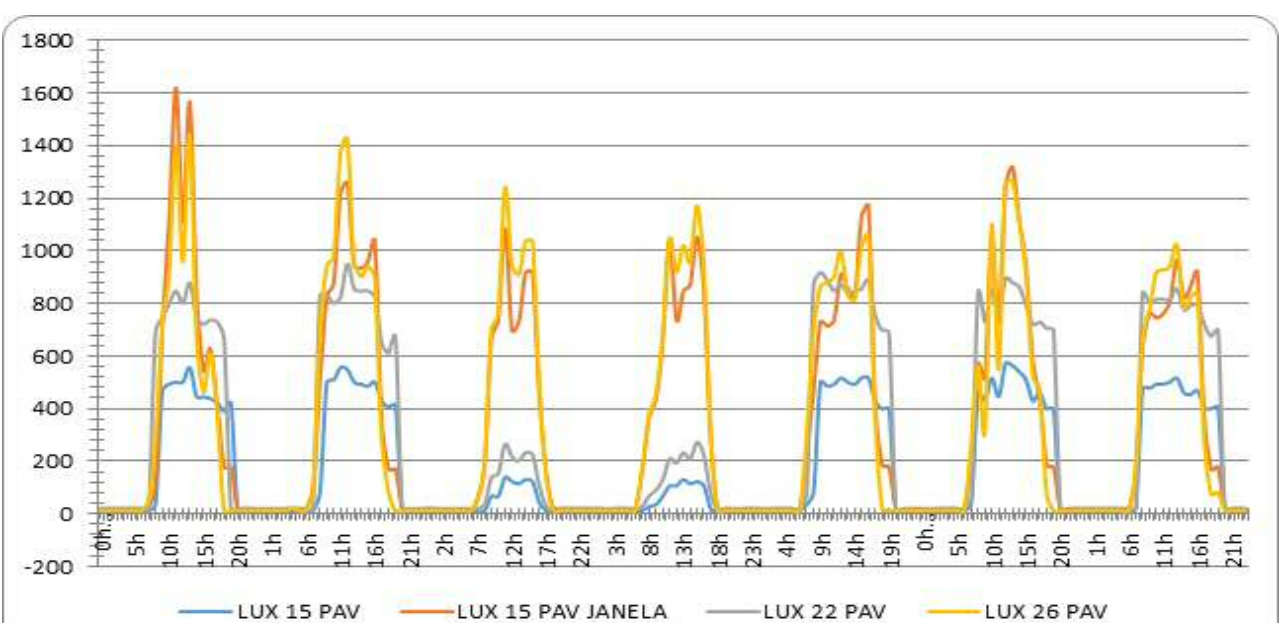

Figura 111- Níveis de iluminação natural medidos pelos hobos do dia 3 até o dia 9 de maio. Umakoshi, Erica Mitie

FAU-USP, fev. 2014 
As medidas iniciais de iluminação natural, de níveis de iluminância tomados simultaneamente com as variáveis térmicas, mostraram que as áreas perto das janelas podem chegar a mais de 1000 lux (ver figuras 2, 3 e 4 para a localização dos pontos), isto é, podem ser uma fonte de ofuscamento se não forem devidamente controlados. Distanciando-se alguns metros da janela, os dados mostram níveis satisfatórios de iluminação, perto de 400 lux, desde as persianas internas não estejam fechadas.

\subsubsection{Considerações sobre a ocupação}

A análise dos dados mostraram que o pavimento com maior ocupação, o $15^{\circ}(171 \mathrm{~m} 2 \mathrm{e}$ $209 \mathrm{~m} 2$ ), obteve as maiores temperaturas internas registradas, enquanto o $22^{\circ}$ pavimento (172 m2), com menor ocupação, apresentou as menores temperaturas, confirmando a relação entre a ocupação e as condições térmicas.

Observações realizadas durante o período de medição mostraram que a abertura e o fechamento das janelas são controlados diretamente pelo usuário mais próximo a elas. Este fato limita a abertura da janela somente a uma pessoa, por isso, se o usuário em questão não quiser abrir a janela, esta permanecerá fechada por todo o período de ocupação, o que pode comprometer as condições de conforto de todo o ambiente, principalmente no período mais quente do verão. Infelizmente, as janelas voltadas ao átrio central, que poderiam contribuir para uma ventilação cruzada, são mantidas fechadas. A abertura dessas janelas, que se localizam na face oposta às janelas da fachada, poderiam melhorar as condições de conforto térmico, reduzindo a necessidade de utilização do sistema de condicionamento de ar.

Por outro lado, a falta de proteção contra radiação direta também foi identificada como um dos impedimentos à ventilação natural. Durante as horas de insolação direta na fachada, na falta de proteção solar, os usuários utilizam as persianas internas para se proteger, o que acaba dificultando a passagem de ar. Como consequência, dois problemas ocorrem: a necessidade de iluminação natural e de ar condicionado para que os usuários consigam atingir a situação de conforto desejada. O problema de insolação direta nas estações de trabalho cria situações de superaquecimento e de ofuscamento, que poderiam ser resolvidas com o afastamento dessas estações de trabalho da janela e a colocação de elementos de sombreamento na parte externa da fachada. 
Uma questão problemática observada, relacionada com a eficiência energética no edifício durante a visita, foi o fato da iluminação artificial da área de trabalho ser acionada por um único interruptor. Um novo sistema de iluminação artificial é preciso, e essa troca poderia reduzir significativamente o consumo relacionado à iluminação artificial.

\subsection{Estudos Analíticos: simulação de desempenho térmico}

Buscando entender melhor o desempenho de um edifício alto, foram realizadas simulações de desempenho térmico na ferramenta computacional Bentley TAS Simulator V8i v 9.2.1 (Thermal Analysis Simulation). Essa ferramenta realiza simulações térmicas dinâmicas das 8760 horas do ano levando em consideração estratégias passivas, como a ventilação natural, e ativas, como o aquecimento e a refrigeração.

Para entender melhor o desempenho de cada componente e de cada fachada, foi modelado um edifício com características similares ao padrão encontrado na cidade de São Paulo, ou seja, de planta quadrada, com 30 pavimentos, com forro e piso elevado, materiais e ocupação típicos da tipologia, no qual foi analisado um pavimento inferior (5) e um superior (28).

Os estudos analíticos incluem análises paramétricas sobre os impactos dos seguintes fatores no desempenho do edifício:

1 - ORIENTAÇÃO,

2 - WWR

3 - SOMBREAMENTO,

4 - MASSA TÉRMICA,

5 - TEMPERATURAS DE CONFORTO

6 - VENTILAÇÃO NATURAL

O objetivo dos estudos é, primeiramente, entender a relação entre esses diferentes parâmetros e o desempenho térmico e energético do edifício alto, visando encontrar a melhor combinação a fim de se alcançar um desempenho ambiental satisfatório para essa tipologia. 
O modelo utilizado para os estudos se caracteriza por:

- pavimento tipo $30 \mathrm{~m} \times 30 \mathrm{~m}$

- escritório celular $6 \mathrm{~m} \times 6 \mathrm{~m}$

- pé-direito $2,70 \mathrm{~m}$, piso a piso $3,55 \mathrm{~m}$

- parede: $\mathrm{U}=2,7 \mathrm{~W} / \mathrm{m} 2 \mathrm{oC}$

- vidro: $\mathrm{U}=5,7 \mathrm{~W} / \mathrm{m} 2 \mathrm{oC}$

- forro (vão $0,14 \mathrm{~m}$ e fibra mineral-U=0,85W/m2oC) e piso elevado com carpete (vão de $0,20 m+0,05 m$ piso)

- temperatura de setpoint: $240 \mathrm{C}$

- ocupação (sensível): 19.9 Kwh/m2ano

- ocupação (latente): 17.3 Kwh/m2ano

- iluminação: $27 \mathrm{Kwh} / \mathrm{m} 2 \mathrm{ano}$

- equipamento: $28.6 \mathrm{Kwh} / \mathrm{m} 2 \mathrm{ano}$

- horário de ocupação: 9h - 20h
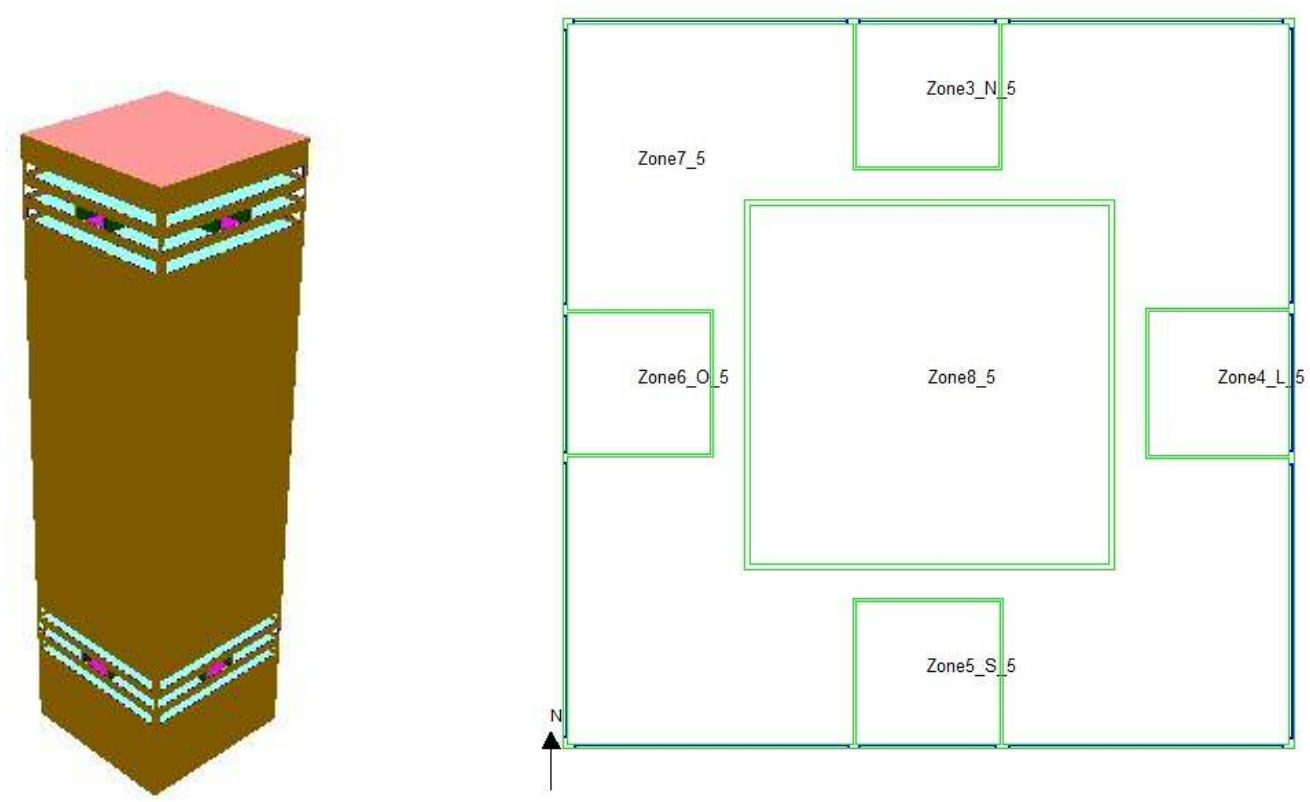

Figura 112 e 113 - Modelo 3D do edifício e a planta do pavimento a ser avaliado. 
Capítulo 3 - O Papel da Ventilação no Projeto do Edifício Alto de Melhor Desempenho para a Cidade de São Paulo Avaliação de Desempenho Ambiental e Arquitetura Paramétrica Generativa para o Projeto do Edifício Alto

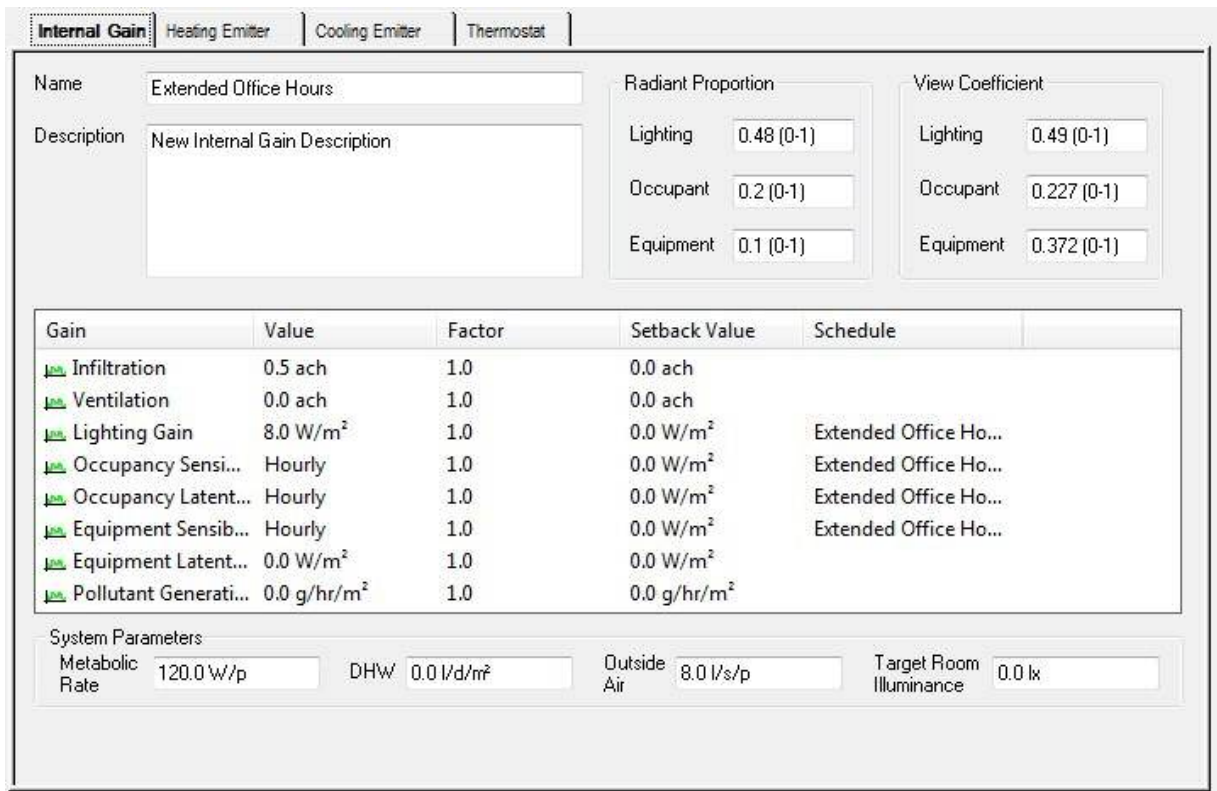

Figura 114 - Características das cargas internas do edifício.

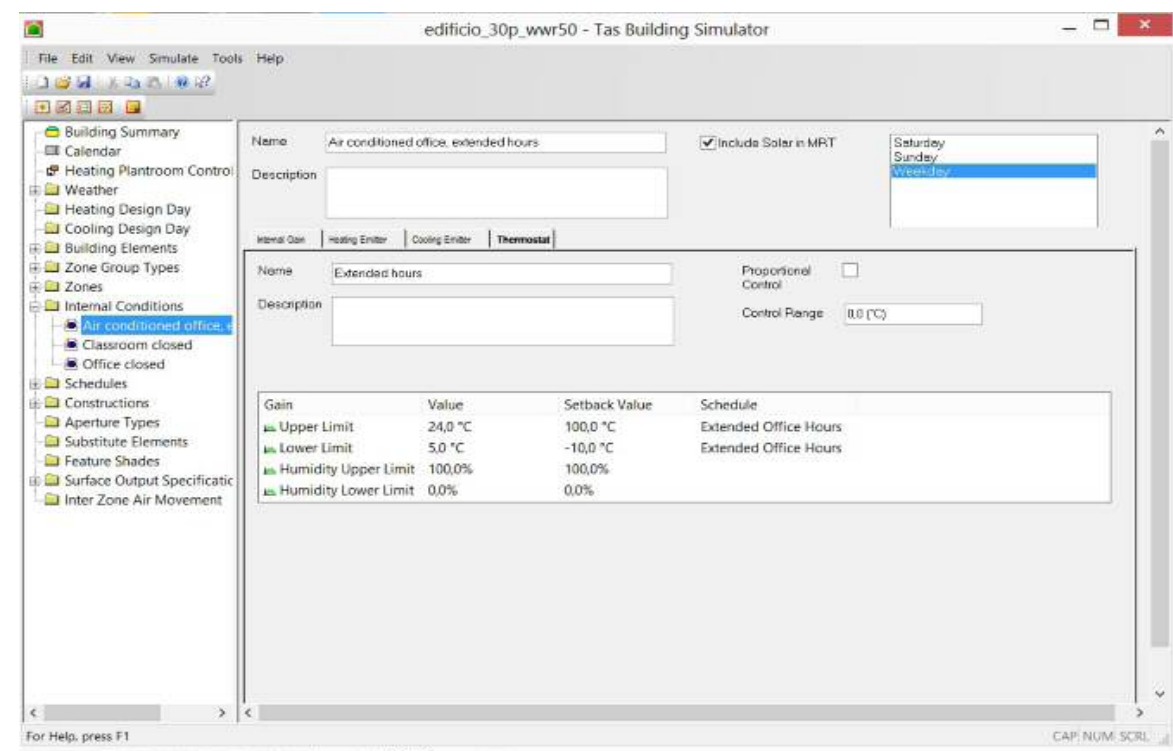

Figura 115 - Características do Ar condicionado.

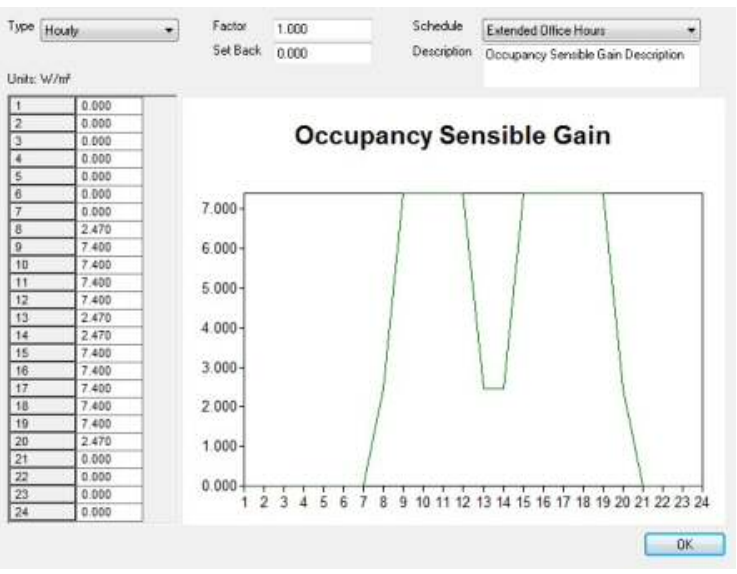

Figura 116 - A ocupação do edifício segundo o horário.

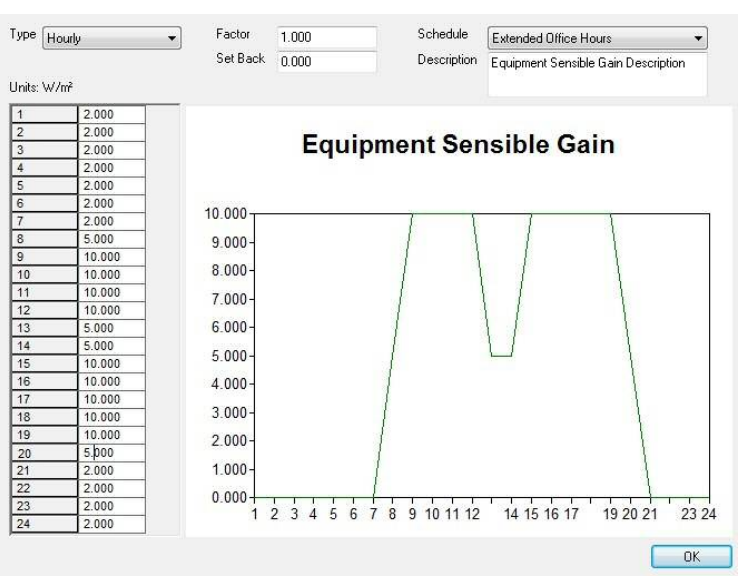

Figura 117- A utilização dos equipamentos segundo o horário. 
Tabela 05 - Cenários de simulação do caso base

\begin{tabular}{|c|c|c|c|c|c|}
\hline WWR & VIDRO & ORIENTAÇÃO & SOMBREAMENTO & MASSA & $\begin{array}{l}\text { TEMPERATURA } \\
\text { DE CONFORTO } \\
\text { E VENTILAÇÃO } \\
\text { NATURAL }\end{array}$ \\
\hline \multirow[t]{13}{*}{$50 \%$} & \multirow[t]{12}{*}{ Simples } & \multirow[t]{12}{*}{ N/S/L/O } & NA & Forro & $24^{\circ} \mathrm{C}$ (setpoint) \\
\hline & & & \multirow[t]{5}{*}{$1 \mathrm{~m}$} & Forro & $24^{\circ} \mathrm{C}$ (setpoint) \\
\hline & & & & \begin{tabular}{|l|} 
Forro \\
\end{tabular} & $26^{\circ} \mathrm{C}$ (setpoint) \\
\hline & & & & \multirow[t]{3}{*}{ Laje exposta } & Ventilação noturna \\
\hline & & & & & $\begin{array}{l}\text { Ventilação noturna + } \\
\text { ventilação mecânica }\end{array}$ \\
\hline & & & & & $\begin{array}{l}\text { Ventilação noturna } \\
+ \text { ventilação natural } \\
26^{\circ} \mathrm{C}\end{array}$ \\
\hline & & & $2 m$ & Forro & \multirow[t]{7}{*}{$24^{\circ} \mathrm{C}$ (setpoint) } \\
\hline & & & Shading $50 \%$ & Forro & \\
\hline & & & Shading $70 \%$ & Forro & \\
\hline & & & \multirow[t]{3}{*}{ Shading $90 \%$} & Leve/exposta & \\
\hline & & & & Média & \\
\hline & & & & pesada & \\
\hline & Duplo & N/S/L/O & NA & Forro & \\
\hline \multirow[t]{6}{*}{$70 \%$} & \multirow[t]{6}{*}{ Simples } & \multirow[t]{6}{*}{ N/S/L/O } & NA & \multirow[t]{6}{*}{ Forro } & \multirow[t]{6}{*}{$24^{\circ} \mathrm{C}$ (setpoint) } \\
\hline & & & $1 \mathrm{~m}$ & & \\
\hline & & & $2 m$ & & \\
\hline & & & Shading 50\% & & \\
\hline & & & Shading $70 \%$ & & \\
\hline & & & Shading $90 \%$ & & \\
\hline \multirow[t]{8}{*}{$90 \%$} & \multirow[t]{7}{*}{ Simples } & \multirow[t]{7}{*}{$\mathrm{N} / \mathrm{S} / \mathrm{L} / \mathrm{O}$} & NA & Forro & $24^{\circ} \mathrm{C}$ (setpoint) \\
\hline & & & $1 \mathrm{~m}$ & Forro & $24^{\circ} \mathrm{C}$ (setpoint) \\
\hline & & & $1 \mathrm{~m}$ & Forro & $26^{\circ} \mathrm{C}$ (setpoint) \\
\hline & & & $2 m$ & Forro & $24^{\circ} \mathrm{C}$ (setpoint) \\
\hline & & & Shading $50 \%$ & Forro & $24^{\circ} \mathrm{C}$ (setpoint) \\
\hline & & & Shading $70 \%$ & & \\
\hline & & & Shading $90 \%$ & & \\
\hline & Duplo & N/S/L/O & & Forro & $24^{\circ} \mathrm{C}$ (setpoint) \\
\hline
\end{tabular}




\subsubsection{Orientação e WWR}

Para entender melhor o desempenho individual de cada orientação, foram divididos os ambientes em células com apenas uma fachada exposta. Com isso, foram testadas quatro orientações: Norte, Sul, Leste e Oeste. Com relação à área envidraçada, o objetivo foi testar o desempenho real de três WWRs (Window Wall Ratio): 50\%, 70\% e $90 \%$.

Na figura 118, pode-se comparar o impacto da área envidraçada em cada orientação em relação à carga térmica de resfriamento anual (Kwh/m2ano). As fachadas Norte e Oeste são as que recebem maior insolação e, por isso, necessitam de maior carga térmica para resfriamento. No caso da fachada Norte, a redução no WWR de $90 \%$ para $70 \%$ implica numa redução de $15 \%$ da carga térmica anual de resfriamento. Quando comparamos o WWR de $90 \%$ para $50 \%$, essa diferença é ainda maior, chegando a $30 \%$ de redução. Em termos de desempenho, pode-se dizer que a fachada Norte, com um WWR de $50 \%$, possui um desempenho equivalente à fachada Sul, com um WWR de $90 \%$, à fachada leste, com um WWR de $70 \%$, e à fachada Oeste, com um WWR de $50 \%$. Com isso, mesmo sendo um primeiro estudo no qual só foi observada a porcentagem de área envidraçada, já se pode dizer que as fachadas não podem receber o mesmo tratamento.

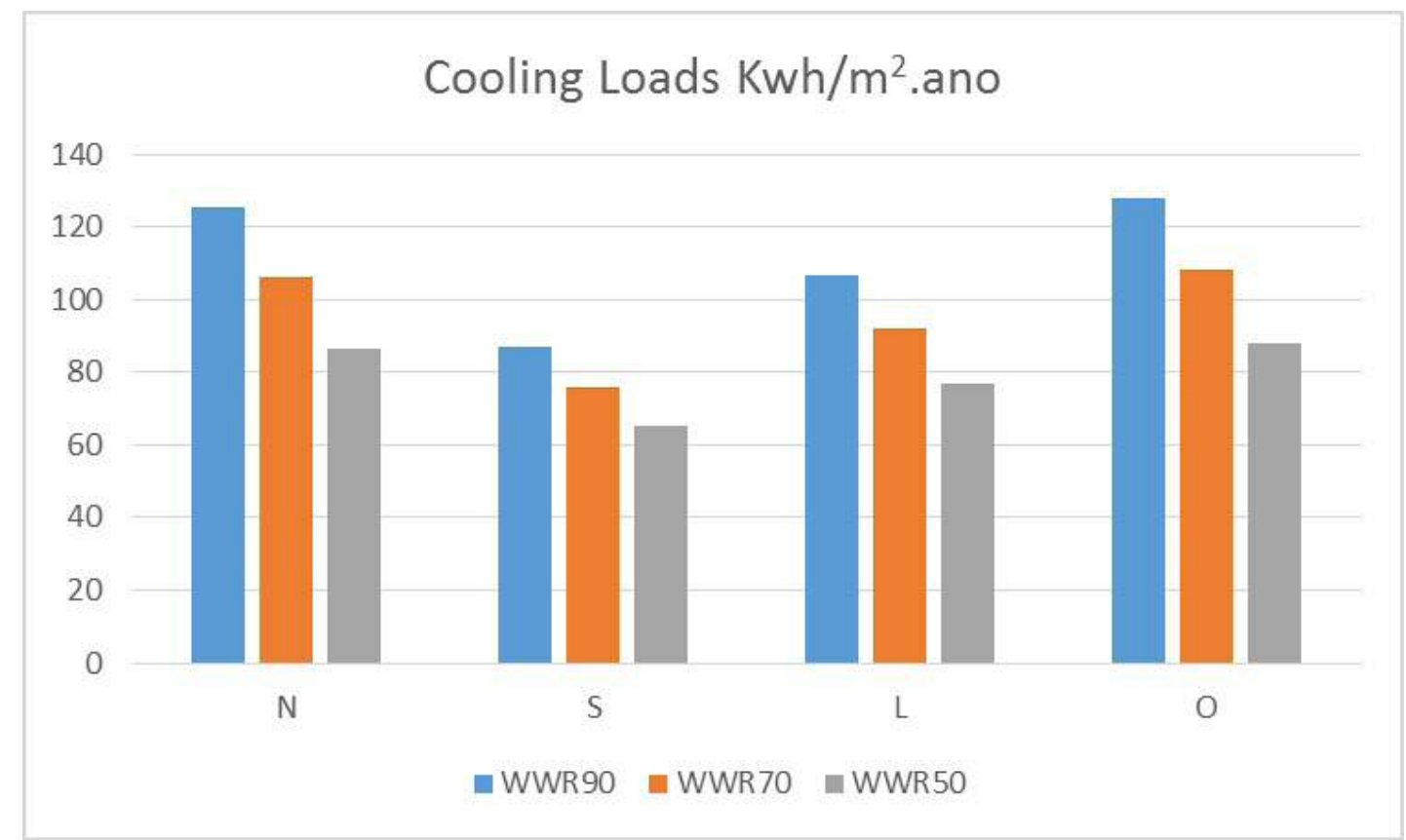

Figura 118 - O impacto da área envidraçada na carga térmica de resfriamento 


\subsubsection{Sombreamento}

Nos estudos de sombreamento, foram mantidas as quatro orientações e os três WWRs. Foram testados dois tamanhos de brise horizontal: de $1 \mathrm{~m}$ e de $2 \mathrm{~m}$, sendo que, com relação ao sombreamento, foram testados três tipos externos ao vidro, que barravam, respectivamente, $50 \%, 70 \%$ e $90 \%$ da radiação solar incidente. No entanto, vale ressaltar que, nesse exercício, não foram testados as possíveis formas do brise e do sombreamento.

$\mathrm{Na}$ figura 119, podemos observar a redução significativa da carga térmica tanto na fachada norte como na fachada oeste ao acrescentar um brise. A redução da carga térmica na fachada norte, ao se colocar um brise horizontal de $1 \mathrm{~m}$ de profundidade, foi de 33 , e de $47 \%$ com um brise de $2 \mathrm{~m}$. Já para a fachada Sul, essa redução fica em $24 \%$ e $35 \%$, para a fachada Leste $28 \%$ e $41 \%$, e, para a Oeste, $29 \%$ e $43 \%$.

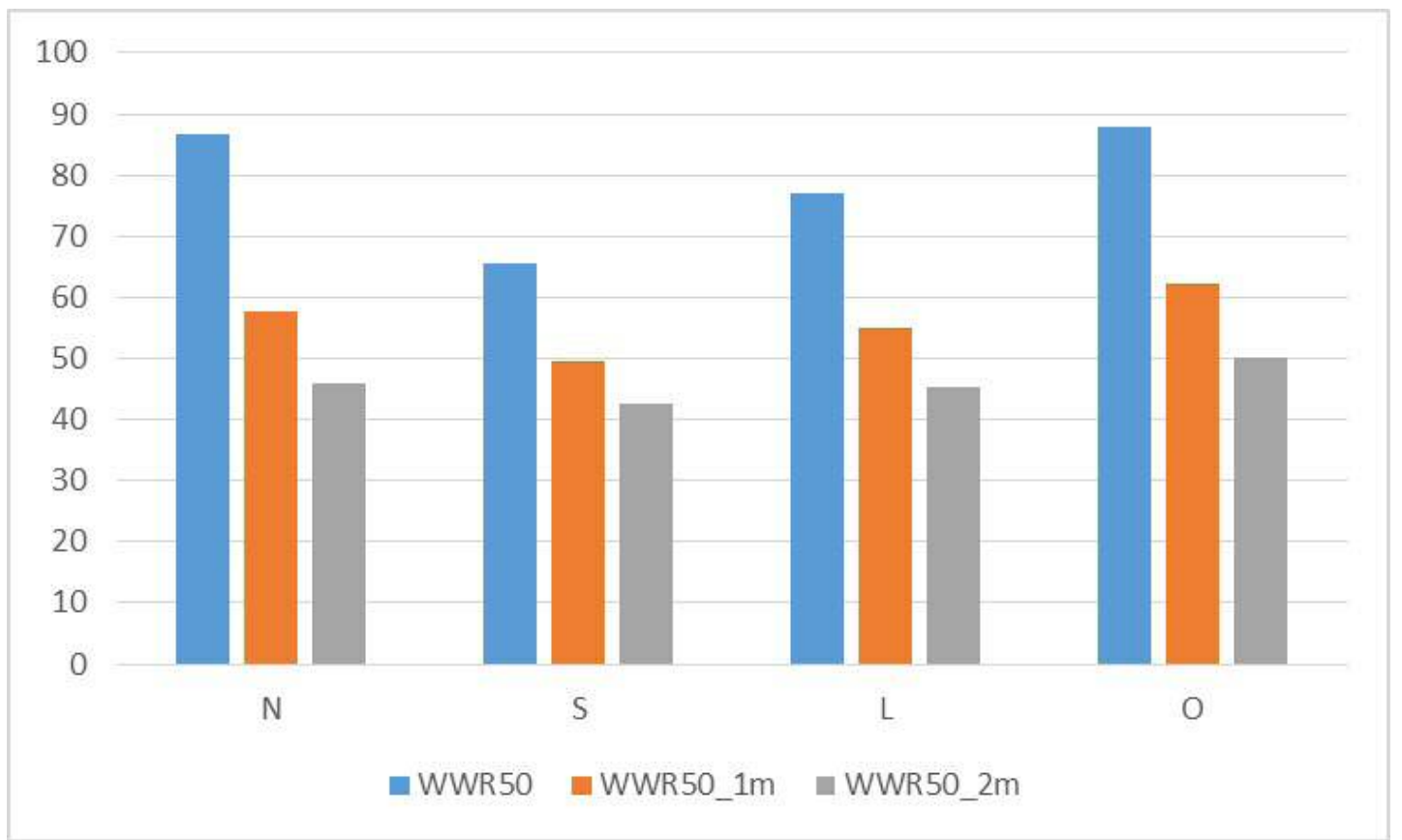

Figura 119- O impacto do sombreamento na redução da carga térmica $\left(\mathrm{kWh} / \mathrm{m}^{2}\right.$.ano) de resfriamento num WWR de 50

Devido a sua maior área exposta à radiação solar, essa redução observada num WWR de $50 \%$ é, percentualmente, menor em um WWR de 90\%, como podemos observar fa figura 120. A redução na carga térmica para resfriamento na fachada Norte foi de $29 \%$ ao se colocar o brise de $1 \mathrm{~m}$, e de $46 \%$ quanto ao brise de $2 \mathrm{~m}$. No caso da fachada Sul, a redução foi de $20 \%$ e $32 \%$, em relação à fachada Leste, de $25 \%$ e $39 \%$ e, para 


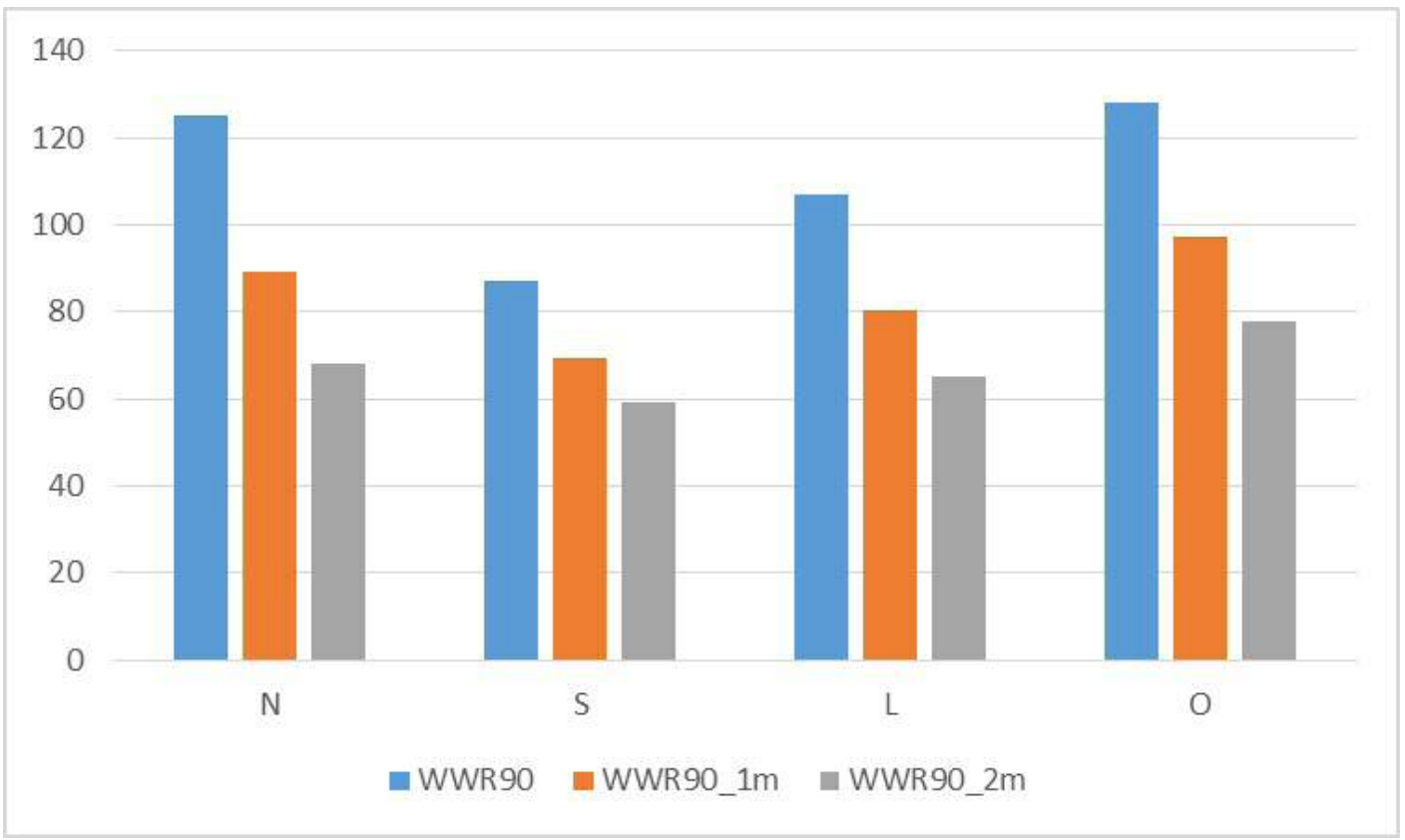

Figura 120 - O impacto do sombreamento na redução da carga térmica $(\mathrm{kWh} / \mathrm{m} 2$.ano) de resfriamento num WWR de 90.

a Oeste, $24 \%$ e $39 \%$. Com isso, fica clara a importância da proteção solar das áreas envidraçadas, já que a maior redução é na adoção do brise, sendo que o tamanho e o formato deverão ser discutidos separadamente.

No entanto, pode-se observar com as simulações que, apesar da grande exposição de uma fachada com WWR de $90 \%$, se bem sombreada, ela poderá alcançar um desempenho satisfatório num clima como o de São Paulo. Como pode ser observado na figura 121, a fachada Norte com um WWR de $70 \%$ e um brise de $1 \mathrm{~m}$ possui uma

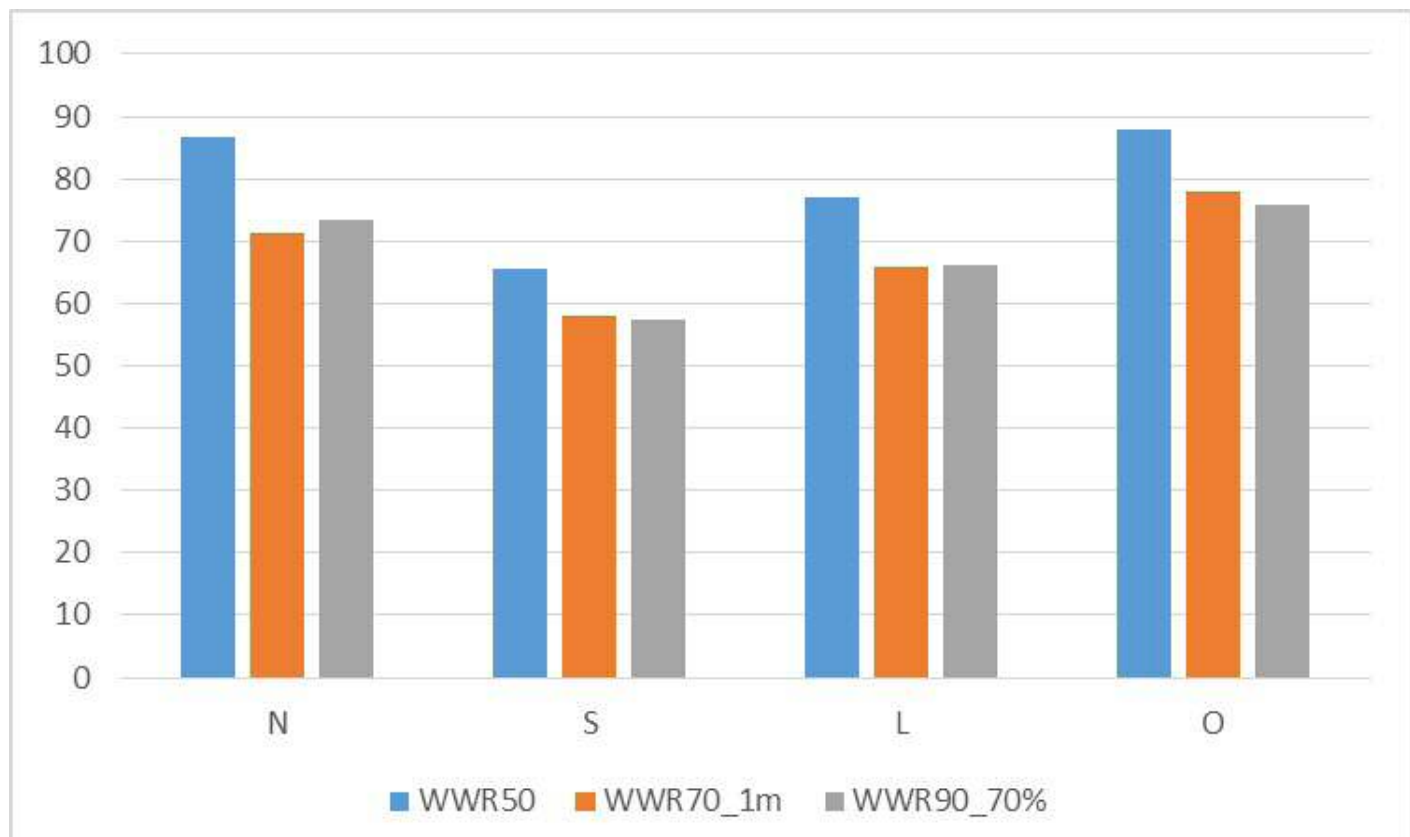

Figura 121 - O impacto do sombreamento da radiação direta e difusa na redução da carga térmica (kWh/m2.ano) de resfriamento num WWR de 50, 70 e 90. 
redução de $17 \%$ na carga térmica de resfriamento quando comparada a uma fachada de WWR de $50 \%$ sem sombreamento. E o que é ainda mais interessante observar é que uma fachada de WWR de $90 \%$ com $70 \%$ da insolação barrada possui uma redução de $15 \%$ na carga térmica quando comparada a uma fachada de WWR de $50 \%$ sem sombreamento. Dessa forma, é importante ressaltar que a utilização de grandes panos de vidro só são possíveis quando bem sombreados. Em fachadas como a Sul e a Oeste, a redução da carga térmica é maior ao se utilizar um WWR de $90 \%$ com $70 \%$ da insolação barrada do que ao seu usar um WWR de 70\% com um brise de $1 \mathrm{~m}$. Já na fachada Sul, o desempenho dos dois WWRs são bem equivalentes.

\subsubsection{Massa Térmica, Ventilação e Temperatura de conforto}

Para testar a massa térmica e a ventilação noturna, foram rodadas simulações com o modelo de WWR $50 \%$ e, com os resultados, gerou-se a figura 122 . Nele podemos observar que o fato de se deixar a laje exposta e permitir uma ventilação noturna das $21 \mathrm{~h}$ até as $7 \mathrm{~h}$, com uma abertura de 10\%, gera uma redução de $18 \%$ na carga térmica quando comparado ao mesmo modelo com sombreamento. Foi feita, ainda, uma outra simulação, abrindo-se $20 \%$ da janela no período noturno. No entanto, a diferença foi pequena, subindo para $21 \%$ a redução na carga térmica. Assim, uma pequena mudança na configuração do pavimento e a abertura da janela num período não ocupado do edifício pode contribuir com a redução no consumo energético anual para o resfriamento, pois retira-se o calor acumulado durante o dia através da ventilação.

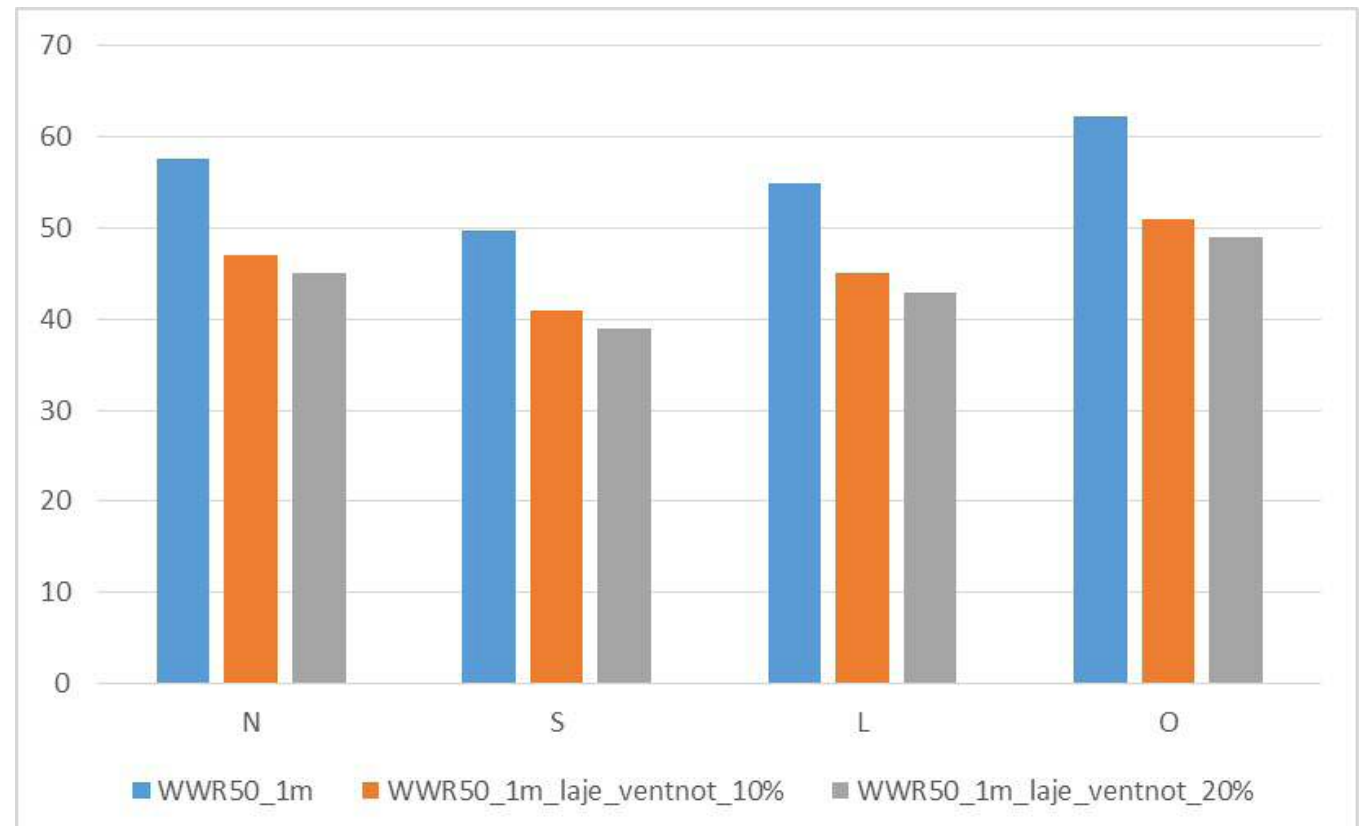

Figura 122 - O impacto do sombreamento e da massa exposta e ventilação noturna na redução da carga térmica $(\mathrm{kWh} / \mathrm{m} 2$.ano) de resfriamento num WWR de 50.

Umakoshi, Erica Mitie 
Quando falamos sobre conforto térmico e ar-condicionado, estamos focando, principalmente, na temperatura de setpoint do equipamento, pois é ela que vai determinar o tempo e a potência com a qual o mesmo irá trabalhar. Visando entender melhor a mudança no consumo de energia para o resfriamento, realizou-se uma simulação na qual foi alterada a temperatura de setpoint de $24^{\circ} \mathrm{C}$ para $250 \mathrm{C}, 26^{\circ} \mathrm{C}$ e $28^{\circ} \mathrm{C}$.

$\mathrm{Na}$ primeira alteração de temperatura, de $24^{\circ} \mathrm{C}$ para $25^{\circ} \mathrm{C}$, pode-se observar uma redução de $14 \%$ na carga térmica para resfriamento na fachada Norte, $16 \%$ na Sul, $15 \%$ na Leste e $13 \%$ na Oeste. Aumentando-se a temperatura para $26^{\circ} \mathrm{C}$, a redução chega a $27 \%$ na fachada Norte, $31 \%$ na Sul, $29 \%$ na Leste e $25 \%$ na Oeste. No entanto, essa redução é significativa quando a temperatura chega a $28 \mathrm{oC}$, reduzindo em $43 \%$ a carga na fachada Norte, $30 \%$ na Sul, $37 \%$ na Leste e $52 \%$ na Oeste. Mas, vale ressaltar que essa temperatura de $28^{\circ} \mathrm{C}$, mesmo sendo condizente com os limites apontados pelos modelos adaptativos de conforto térmico, necessita de uma aceitação cultural, tendo em vista que as pessoas já estão acostumadas ao resfriamento com uma temperatura muito inferior a essa. Nota-se, ainda, que, apesar de terem sido desenvolvidos para edificios ventilados naturalmente, o uso dos limites de conforto gerados pelos modelos adaptativos em edificios condicionados artificialmente está atrelado a economias relevantes de energia, além da constatação de que a dependência do condicionamento artificial pode ser questionada.

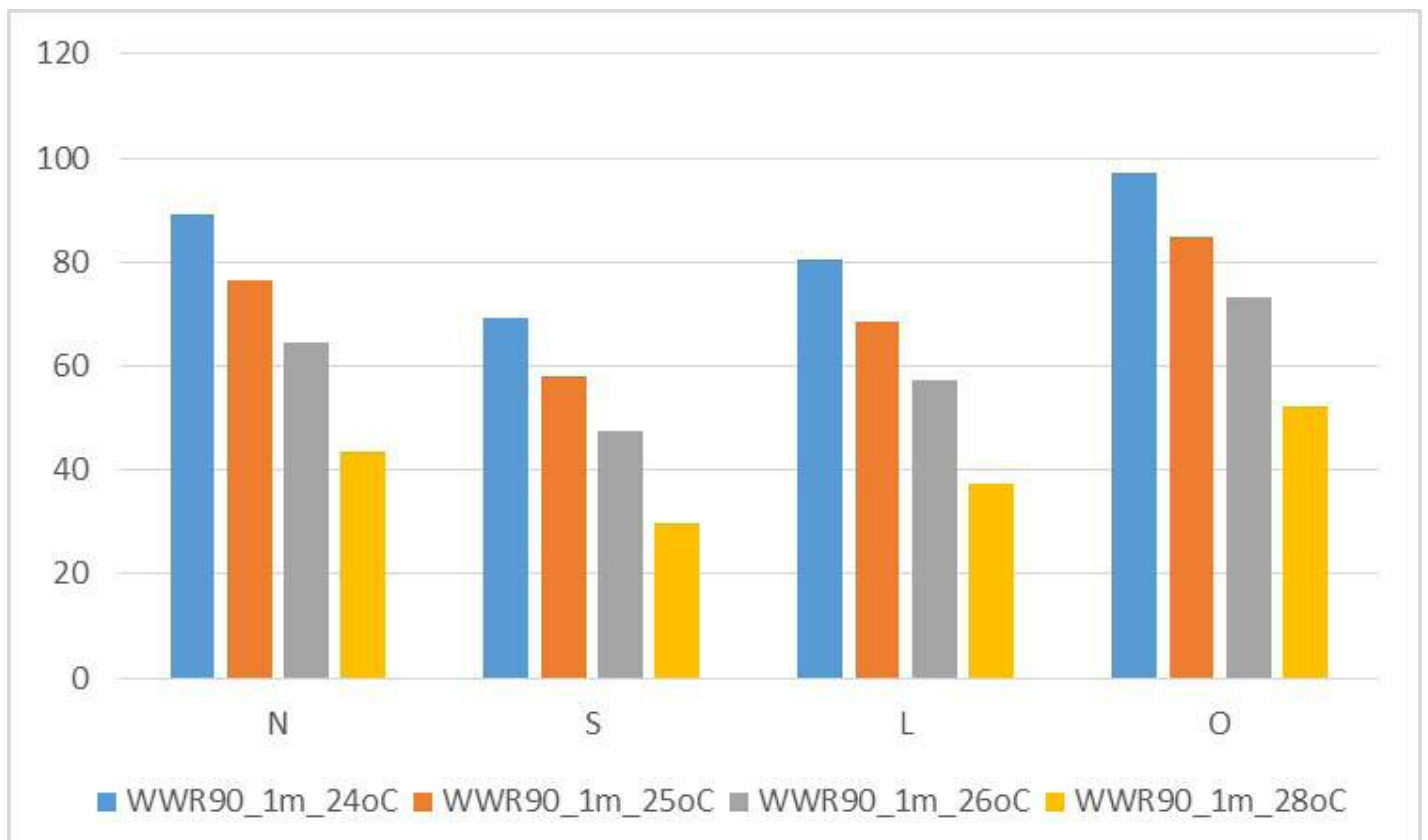

Figura 123- O impacto do aumento na temperatura de setpoint do ar condicionado de $24^{\circ} \mathrm{C}$ para $25^{\circ} \mathrm{C}, 260 \mathrm{C}$ e $28^{\circ} \mathrm{C}$ na redução da carga térmica $\left(\mathrm{kWh} / \mathrm{m}^{2}\right.$.ano) de resfriamento num WWR de 90. 
As simulações de ventilação natural foram realizadas para um WWR de $50 \%$, com um brise de $1 \mathrm{~m}$, com as janelas abrindo $30 \%$ e $10 \%$ no período noturno. Na figura 124, podemos observar uma semana do verão, onde as temperaturas, por algumas horas, ultrapassaram os limites do conforto, indicando a necessidade de se ligar 0 ar-condicionado. No entanto, caso o sombreamento seja feito de maneira adequada, principalmente na fachada oeste, essas temperaturas serão mais amenas e, provavelmente, ficarão dentro das linhas de conforto.

Já na figura 125, podemos observar uma semana típica de inverno, onde as temperaturas não variaram tanto como a externa, tendo sido a ventilação natural reduzida a $10 \%$ da abertura nas janelas, dada a geração de calor interno e a inércia térmica do edifício.

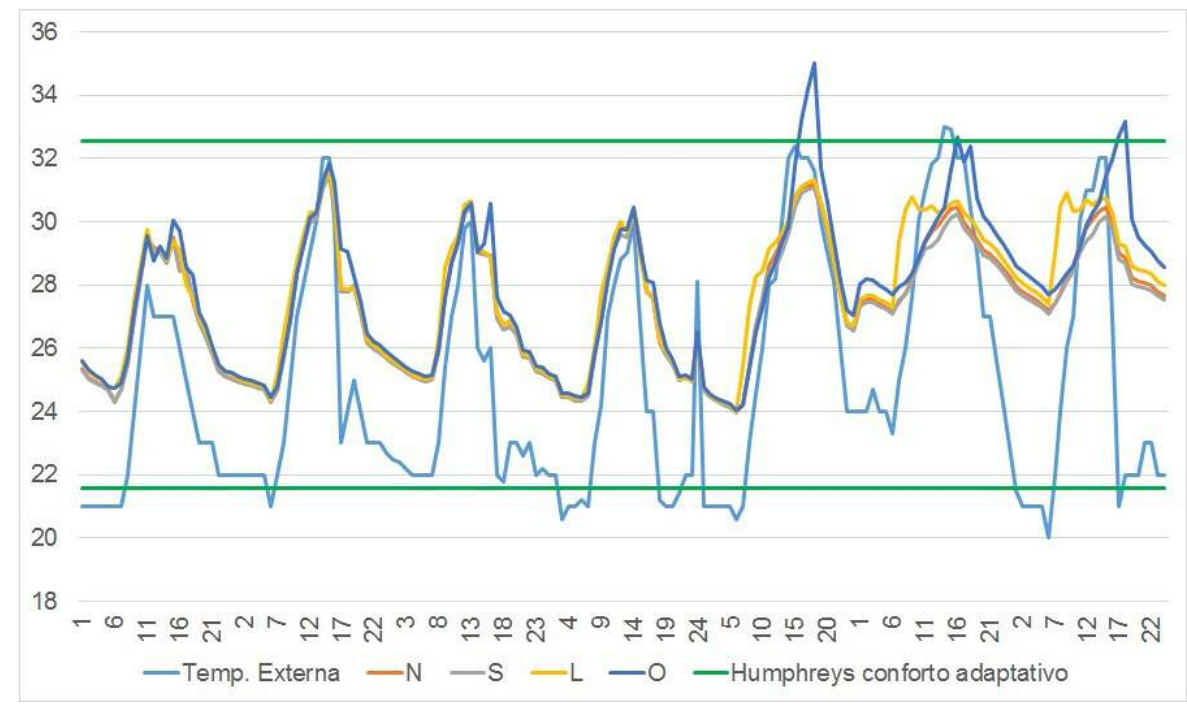

Figura 124 - Simulação térmica de uma semana típica de verão com janelas abrindo $30 \%$. Fonte: Bentley Tas

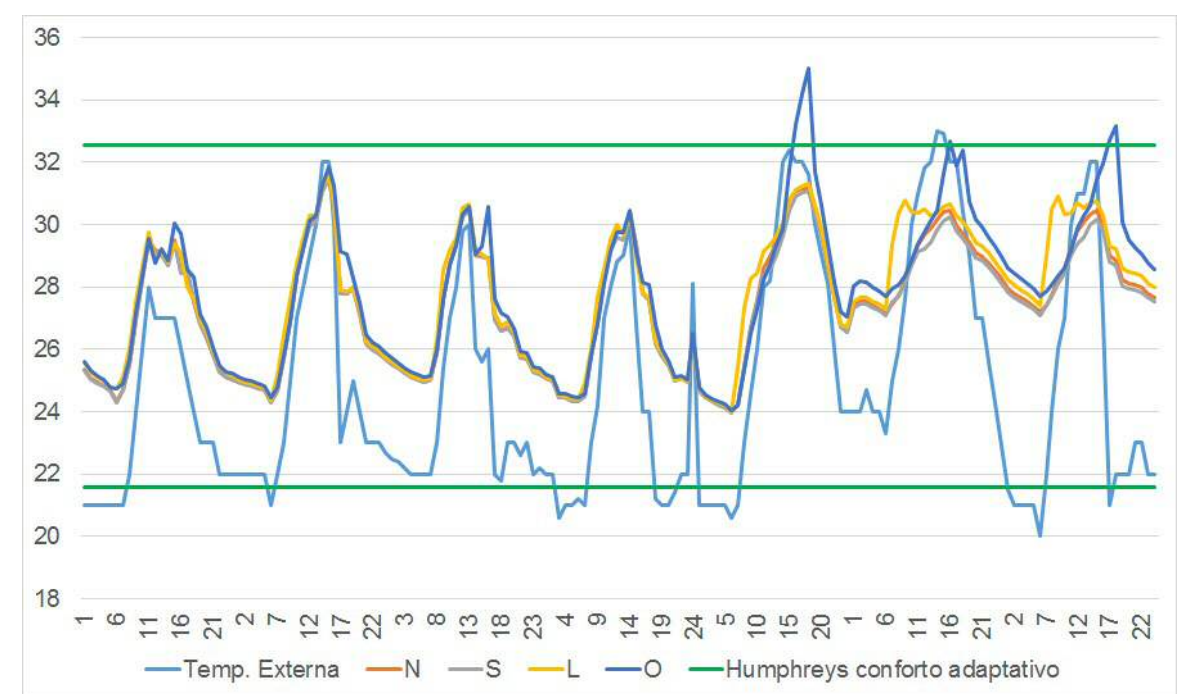

Figura 125- Simulação térmica de uma semana típica de inverno com janelas abrindo 10\%. Fonte: Bentley Tas

Umakoshi, Erica Mitie 


\subsection{Considerações Finais}

Ao contrário do que vem sendo construído na cidade de São Paulo nas últimas décadas, as medições no edifício CBI-Esplanada e as simulações de desempenho térmico demonstraram que edifícios de escritórios em São Paulo podem ser ocupados sem a necessidade dos sistemas de condicionamento do ar ao longo de todo o ano, desde que haja um controle efetivo da radiação solar em todas as orientações, disponibilidade de movimento de ar e a oportunização de adaptação aos usuários através do controle da abertura das janelas e de dispositivos como ventiladores de mesa ou teto. No inverno, as cargas térmicas de ocupação e o controle das aberturas permitem que os ambientes de trabalho não dependam de isolamento térmico ou de aquecimento para se alcançar o conforto.

Nos períodos mais quentes do ano, é importante ressaltar que os ganhos de calor provenientes de ocupação são um desafio maior ao alcance de condições de conforto térmico do que o clima propriamente dito, uma vez que, mesmo com a inércia térmica e as altas taxas de ventilação, ainda foram encontradas horas remanescentes de superaquecimento. No entanto, esta quantidade de horas de superaquecimento não justifica a adoção de ar-condicionado, já que a disponibilidade de oportunidades de adaptação ao ambiente térmico é suficiente para que se melhore o conforto dos usuários nas horas de mais calor.

As simulações de desempenho térmico, que consideraram janelas de vidro simples, também demonstraram que edifícios de escritórios em São Paulo não necessitam de vidro duplo para o conforto térmico de seus usuários, em nenhum momento do ano. $\mathrm{E}$, com relação aos testes com massa térmica exposta, foi verificado que o teto é a parte que mais contribui com a inércia térmica, já que o ar quente tende a subir dentro do ambiente.

Ressalte-se, ainda, que fatores específicos do contexto urbano, como a qualidade do ar e o ruído, podem ter um impacto significativo no projeto de janelas e na viabilidade da ventilação natural. Fatores culturais e de adaptação dos usuários são elementos chave para o funcionamento adequado das estratégias passivas de ventilação e de iluminação natural. Caso não seja permitida uma adaptação dos mesmos para que possam atingir 
níveis satisfatórios de conforto, seja através de ventiladores de mesa ou de luminárias individuais, nenhuma dessas estratégias poderá ser viabilizada, tendo em vista que, em edifícios como o Commerzbank, que utiliza bem as estratégias passivas, os usuários estão totalmente adaptados à operação dos sistemas e aceitam as variações climáticas da região. 

Capítulo 4: 
Capítulo 4 - Estudos de Forma: Novos Processos de Projeto - a Metodologia Bim, a Arquitetura Paramétrica e Algorítmica Avaliação de Desempenho Ambiental e Arquitetura Paramétrica Generativa para o Projeto do Edifício Alto 


\section{Capítulo 4 - Estudos de Forma: Novos Processos de Projeto - a Metodologia Bim, a Arquitetura Paramétrica e Algorítmica}

\section{Introdução:}

As novas ferramentas digitais vêm proporcionando uma renovação nas formas dos edifícios altos, introduzindo um novo repertório de curvas e deformações (Natividade, 2010). As formas produzidas são caracterizadas pelo alto nível de complexidade, presente tanto na expressão formal quanto nos processos de concepção exclusivamente digitais (Mitchel, 2005). O processo de projeto passa, então, a ter conceitos, lógicas, metodologias e conteúdos exclusivamente digitais, interações entre processos e produtos que geram formas.

Metodologias de projeto computacional, no começo dos anos 1990 , foram caracterizadas em parte pela apropriação de softwares de animações, originalmente desenvolvidos para a modelagem de formas e comportamentos humanos (Beaurecueil; Lee, 2009). Esses softwares permitiram a experimentação de noções como fluidez e dinâmica.

No âmbito dessa nova forma de projetar, verifica-se o aparecimento de novas metodologias de projeto, que utilizam ferramentas computacionais altamente tecnológicas capazes de gerar modelos em 3D totalmente parametrizados, orientados a objetos e capazes de armazenar informações detalhadas dos mesmos. Enquanto a experimentação de formas na arquitetura se concentra em softwares que permitem essa manipulação livremente, projetando com parâmetros, algoritmos e até códigos genéticos, a indústria da construção se concentrou em trabalhar de maneira mais linear, com o armazenamento e tratamento de dados e a otimização da construção, como no caso do BIM (OTTCHEN, 2009).

Com o passar do tempo, a arquitetura, a engenharia e a indústria da construção passaram a desenvolver seus próprios softwares de maneira independente e com propósitos diferenciados, distanciando-se. No entanto, atualmente, essas tecnologias voltam-se a se cruzar, trocando dados e desenhos de uma maneira muito mais dinâmica e sem a perda de informações no processo, através da interoperabilidade dos softwares. Assim, muitos projetistas continuam projetando de maneira intuitiva e, depois, migram para o BIM no momento da construção ou da produção. 


\subsection{BIM e a Arquitetura:}

O mercado da indústria da construção vive, hoje, um cenário de crescimento, que exige um maior volume de construção em menos tempo. Diante disso, os profissionais do setor, tanto engenheiros como arquitetos e consultores, vêm trabalhando em ritmo acelerado para atender às demandas. No entanto, dentro da cadeia do processo de projeto e construção, cada profissional utiliza um software diferente para a realização do seu trabalho, aumentando o tempo despendido, a geração de erros e, consequentemente, os custos finais do projeto e da obra.

Com isso, Lairesen (2002) afirma que não há como a indústria da construção dar um passo à frente utilizando apenas as ferramentas computacionais correntes no mercado. É necessária, segundo ele, a troca de termos tradicionais como o CAD (Computer Aided Design) por aquele que ele afirma ser definitivo, o BIM (Building Information Modeling). A metodologia BIM envolve todas as etapas relacionadas à vida do edifício, que vai desde o projeto até a construção, a fabricação, o uso e a manutenção. Ela apoia-se em duas tecnologias principais, a modelagem paramétrica e a interoperabilidade. No que se refere ao método de trabalho, utiliza conceitos como colaboração, coordenação e interoperabilidade.

Existem várias definições para o tema. Segundo Toledo $(2010)^{1}$, BIM é o modelo digital do edifício que representa não só as suas características geométricas, mas também o inter-relacionamento entre os seus componentes e os inúmeros parâmetros e atributos destes. Fornece, ademais, informações relevantes para a tomada de decisão pelos diferentes agentes envolvidos em todo o ciclo de vida da edificação. Sendo assim, Toledo (2010) afirma que o BIM é uma representação digital compartilhada, fundada em padrões abertos de interoperabilidade. Para a Graphisoft e a Bentley Systems, o BIM representa, respectivamente, o edifício virtual e o projeto integrado do edifício (LAISERIN, 2002).

Apesar de suas várias definições, é consenso que o BIM supre a necessidade de se reduzir a fragmentação entre os agentes da construção civil, melhorando a sua eficiência e reduzindo os custos de perda de informação ao longo do processo de projeto, da construção e da manutenção do edifício (ANDRADE; RUSCHEL, 2011).

1 Notas de aula da disciplina PCC5113 - Modelagem da Informação da Construção (BIM), 2010. 
A implantação da metodologia BIM implica, necessariamente, em mudanças no processo de projeto, de construção e de acompanhamento durante o ciclo de vida do edifício. Traz novos processos de projeto baseados na coordenação, na interoperabilidade e no compartilhamento de informações (ANDRADE, RUSCHEL, 2011). Pode-se dizer que o projeto de um edifício dentro do conceito BIM deixa de ser um sistema linear, que começa pelo arquiteto e termina na entrega do edifício construído, e passa a ser um modelo no qual todos os profissionais envolvidos no processo de projeto interagem durante todas as suas fases, principalmente na primeira delas, evitando erros e aumentando a velocidade de projeto.

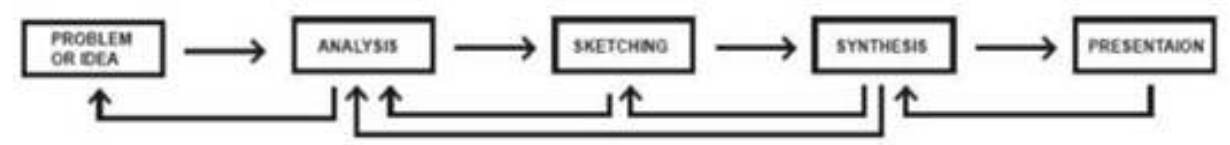

Figura 126 - Sistema Linear de projeto corrente no mercado. Fonte: Thuesen et al, 2010.

O processo de projeto, segundo Lawson (1997, apud THUESEN et al, 2010), pode ser divido em três fases: desenho, análises e modificações. Dentro da primeira fase, na qual o arquiteto está trabalhando com as ideias inicias, ele precisa de informações ligadas aos aspectos estéticos, funcionais e técnicos do edifício.

A interação entre o arquiteto, o engenheiro e os demais profissionais envolvidos nessa fase não é, atualmente, sincronizada, podendo haver perda de algumas informações ou sobreposições, gerando erros no modelo final e grande perda de tempo. Dentro da metodologia de trabalho que envolve o modelo BIM, a interação da equipe multidisciplinar se dá desde as primeiras fases do projeto, fator que agiliza o processo e o torna mais rico, podendo ser chamado de integrated process design.

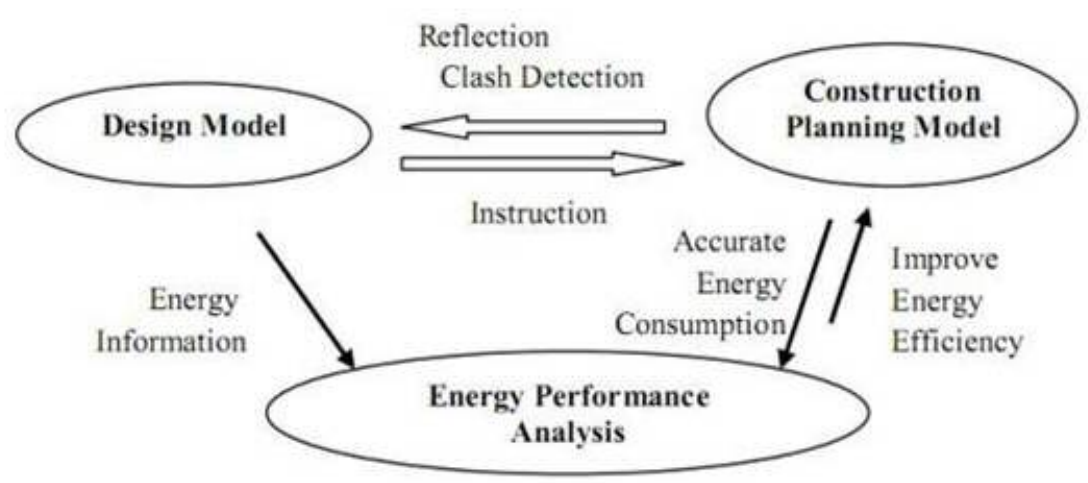

Fig.127: Esquema de projeto dentro do conceito de modelagem BIM. Fonte: Gao et al, 2010. 
É na primeira fase conceitual do projeto que são realizados estudos analíticos sobre o local de implantação do edifício, sobre volumetria, orientação, programa de necessidades, aspectos de sustentabilidade e eficiência energética. Nessa fase, a modelagem dentro de softwares BIM pode ser tão conceitual quanto croquis arquitetônicos e modelos físicos de estudos volumétricos. Ressalta-se que a modelagem 3D BIM permite, desde o princípio, estudos de conforto ambiental, de consumo energético, de desempenho estrutural e de conformidade com os códigos e legislações, além de estimativas de custos, o que não é possível dentro da metodologia de projeto corrente (EASTMAN et al, 2008). Essas avaliações podem ser sucessivas e num curto intervalo de tempo, melhorando a qualidade do projeto e resultando em soluções mais coerentes com os requisitos de desempenho estabelecidos no programa arquitetônico. É nessa fase que as tomadas de decisões irão influenciar mais nos custos, no desempenho e na qualidade da edificação.

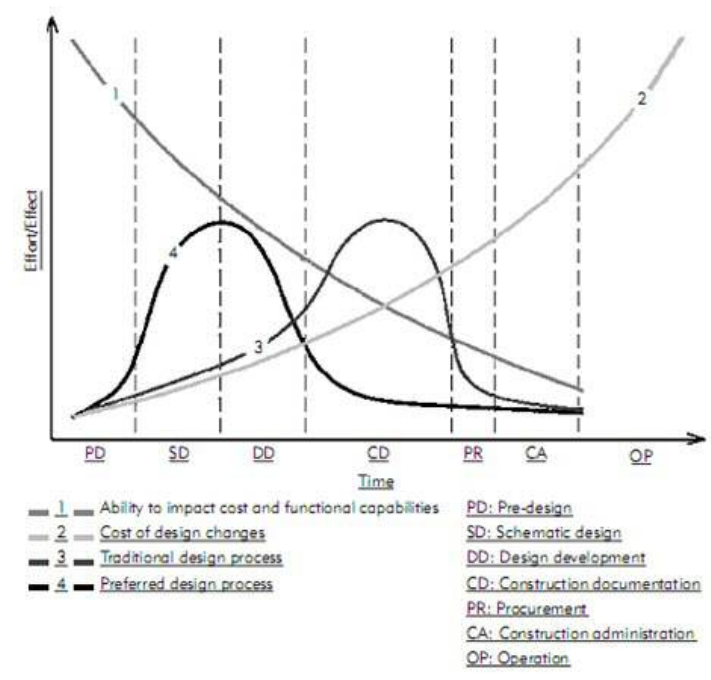

Fig.128. - Gráfico com os valores agregados a cada fase do projeto. Fonte: Eastman et al, 2008.

Um dos principais conceitos no qual o BIM se apoia é a troca de informação entre a equipe envolvida. Andrade e Ruschel (2011) afirmam que é preciso saber identificar como e quando trocar as informações, além de quais devem ser trocadas, pois, assim, será possível compartilhar e coordenar as informações do modelo virtual por diferentes agentes, em distintas atividades e estágios do processo de projeto.

A troca de dados e informações entre o arquiteto e toda a equipe envolvida é feita 
por arquivos de mesmo padrão, permitindo, assim, que diferentes softwares possam ler essas informações. Com isso, para que se tenha uma boa interoperabilidade, é importante a implementação de um padrão de protocolo de troca de dados entre os softwares durante a fase de projeto. O principal protocolo público utilizado é o Industry Foundation Classes (IFC), que é um modelo não proprietário de dados do edifício baseado em objetos (ANDRADE, RUSCHEL, 2011).

Ainda dentro do conceito BIM, nota-se que os modelos são interativos e operados pela geometria associativa, são parametrizados, agregam informações sobre o projeto de determinada maneira que os modelos tradicionais não são capazes de representar (NATIVIDADE, 2010). Esses modelos BIM deixam de ser documentos estáticos de duas dimensões para se constituírem em entidades tridimensionais com possibilidade de inclusão de dimensão temporal (4D) e de custos (5D), além de compatibilização automatizada por meio de clash detection (conflitos de projeto).

Ou seja, o projeto utiliza informações paramétricas orientadas ao objeto, que, ao sofrer modificações, desencadeia mudanças em todos os desenhos, os quais deixam de ser linhas para serem representações interativas do modelo (KRYGIEL; NIES, 2008). Por exemplo, ao se remover uma porta em planta, ela é automaticamente é retirada de todas as elevações e cortes, modificando a planilha de custo.

A fase de documentação, ou seja, da produção dos desenhos, vem ao final do processo, deixando de ser o objetivo principal do contrato. Entrega-se ao final do trabalho um modelo virtual completo, que possui informações tanto relacionadas ao desenho como à operação, contemplando todo o ciclo de vida da edificação (BENTLEY)2.

Para Succar (2009), o Integrated Projetct Delivery (IPD) representa o momento de fusão dos domínios tecnológicos, dos processos e das políticas voltadas à otimização dos resultados do projeto, que aumenta o valor agregado, reduz as perdas e melhora a eficiência nas fases de projeto, fabricação, construção e operação do edifício. É o modelo completo com todas as informações necessárias para a construção, operação e manutenção do edifício ao longo de sua vida útil.

Nota-se, assim, queautilização dametodologiaBIM tem, como benefícios, a documentação integrada, a visualização das etapas de projeto e de construção, a montagem de uma

2 Apresentação de slides de aula. (TOLEDO, 2010) 
Capítulo 4 - Estudos de Forma: Novos Processos de Projeto - a Metodologia Bim, a Arquitetura Paramétrica e Algorítmica Avaliação de Desempenho Ambiental e Arquitetura Paramétrica Generativa para o Projeto do Edifício Alto

base de dados de materiais, as avaliações relacionadas à sustentabilidade, o planejamento das fases da construção, o gerenciamento do pós-ocupação e do empreendimento em geral. No entanto, a implementação dessa metodologia requer uma mudança lenta e gradual no modo de projetar e na formação e capacitação técnica da equipe, que passa a ser multidisciplinar. Dessa forma, cabe ressaltar que não é o foco da pesquisa trabalhar a metodologia BIM como um todo, uma vez que se trata de um trabalho sobre metodologia de projeto arquitetônico que não conta com uma equipe multidisciplinar, ou seja, que trabalha apenas a parte do projeto de arquitetura.

\subsection{Em busca da forma: Arquitetura Paramétrica e Algorítmica}

À partir do final da década de 1990 e mais intensamente nos anos 2000, as técnicas digitais começaram a ser empregadas como estratégias geradoras da forma e, com isso, os arquitetos começaram a ter em mãos uma grande diversidade de composições formais (NATIVIDADE, 2010). Nesta pesquisa, serão discutidas três das principais tendências de metodologias da arquitetura geradas digitalmente, quais sejam: a paramétrica, a algorítmica e a baseada em desempenho.

No entanto, antes de se discutir as metodologias, faz-se necessária a introdução de alguns conceitos base dessa nova forma de projetar. Primeiramente, o termo computational desing, ainda sem tradução oficial para o português, segundo Celani (2014, no prelo3), refere-se à metodologia de projeto que utiliza procedimentos sistemáticos e a lógica matemática para a geração da forma sem necessariamente utilizar o computador. Além deste, os termos CAD (Computer-Aided Design) e o CAAD (Computer-Aided Architectural Design) precisam ser diferenciados, pois o primeiro faz referência o desenho assistido pelo computador e o segundo tem o objetivo de utilizar o computador de maneira exploratória na busca da excelência do projeto de arquitetura, e, não apenas, a eficiência no desenho (CELANI, 2014, no prelo).

Outros dois termos muitos discutidos referem-se aos dois processos digitais de destaque na arquitetura atualmente, o processo paramétrico e o algorítmico. Segundo Meredith (2008), o processo paramétrico é baseado em relações entre objetos, nas quais uma modificação pode se propagar por todo o sistema. Leach (2008) afirma que um projeto paramétrico relaciona dimensões e parâmetros à geometria dentro de um intervalo pré- 
definido. Com isso, ao se modificar um desses parâmetros, todo um sistema é alterado. No entanto, os softwares paramétricos não criam, necessariamente, um novo vocabulário de formas, mas garantem uma rapidez de mudança e controle das mesmas.

Já o processo algorítmico, segundo Leach (2008), é aquele que utiliza processos matemáticos para a resolução de problemas de projeto. É um processo de projeto onde o arquiteto não manipula a forma e, sim, um código, ou um script, através de uma sequências de operações lógicas (CELANI, 2014-no prelo).

Assim, pode-se dizer que o processo paramétrico está ligado à manipulação das formas e o processo algorítmico refere-se à utilização de um código. Certamente, processos paramétricos e algorítmicos respondem a problemas diferentes em projeto, no entanto, podem participar do mesmo processo, ou seja, a forma pode ser gerada através da utilização de algoritmo e modificada através de um processo paramétrico.

Na concepção de Yu et al (2013), o processo paramétrico de projeto é dinâmico baseado em regras, controlado por variação e parâmetros, no qual soluções múltiplas de projeto podem ser desenvolvidas em paralelo. O termo parâmetros está relacionado a fatores que determinam uma série de variações. Em arquitetura, parâmetros são, geralmente, definidos como controle do edifício ou fatores ambientais. No processo de projeto paramétrico, os projetistas não apenas aplicam o conhecimento de projeto, mas também definem regras e as suas relações lógicas utilizando parâmetros. (YU et al 2013)

Natividade (2010) afirma que o processo paramétrico é interativo porque, durante a manipulação das propriedades geométricas da forma, o software confere ao usuário um feedback visual instantâneo, isto é, trata-se de uma ação recíproca entre modificação do parâmetro e a alteração da forma. Já o processo algorítmico é iterativo, que é sinônimo de repetição, vem da Informática e designa o processo de resolução de uma equação ou de um problema mediante uma sequência finita de operações em que o resultado é o objeto.

Dentro desse processo de repetição algorítmica está o processo generativo, que é a produção da forma através de regras, relações e princípios generativos. Oxamn (2006) afirma que, nesse caso, o foco do projeto muda de patamar: ao invés se usar uma forma, tenta-se encontrar uma à partir de técnicas geradoras. Celani (2014-no prelo) 
afirma que um sistema generativo é um processo de projeto indireto, onde o objetivo não é a forma em si, mas um conjunto de soluções geradas sistematicamente com a aplicação de um método.

Com isso, essa nova metodologia de projeto exige que o arquiteto tenha bons conhecimentos, tanto das ferramentas quanto dos conceitos de geometria e matemática, para interpretar quais parâmetros são necessários para se conseguir a forma desejada. No entanto, vale ressaltar que a variedade de formas que podem ser geradas pela geometria tradicional é limitada, as novas técnicas computacionais de geração de forma revolucionaram a geometria (POTTMAN et al, 2007)

Robert Aish (2005) identificou três temas fundamentais que correspondem a aspectos operativos do processo algorítmico. Trata-se o primeiro da noção de controle (indireto) por meio de dependência geométrica, que consiste na descrição da geometria que nunca será construída ou vista, mas que controla indiretamente o que será construído. Esse tipo de controle torna possível explorar variações de projeto e novas soluções espaciais e, a partir daí, encontrar uma configuração que permita a construção. O segundo referese à decomposição do objeto intencionado em partes ou componentes que podem ser descritos nas regras ou nos códigos dos scripts. Por fim, trata-se o terceiro do pensamento algorítmico propriamente dito, isto é, do desejo de explorar sutilezas geométricas que vão além do que a coordenação mão-olho pode oferecer.

Os elementos linguísticos podem ser constantes ou variáveis e os procedimentos são divididos em classes e bibliotecas. As operações básicas são aritméticas, lógicas, combinatórias, relacionais e classificatórias, organizadas em regras gramaticais e sintáticas específicas. Estes elementos e operações são concebidos para abordar a natureza numérica dos computadores e, ao mesmo tempo, proporcionar os meios para compor padrões lógicos através de descrições métricas (Natividade, 2010). Os princípios, vale destacar, são usados para compor diversos tipos de algoritmos que servem a diferentes propósitos e intenções.

Os algoritmos, em geral, definem certas propriedades básicas do objeto que serão preservadas ao longo do processo, embora não seja possível predizer exatamente a forma final. O designer não parte de uma forma pré-estabelecida, mas de regras que 
regem a forma. Portanto, o grau de indeterminação é muito maior que no processo paramétrico.

Em função da capacidade de processamento do computador, os algoritmos podem gerar soluções inovadoras, merecendo destaque, ainda, a capacidade humana de imaginação, haja vista que o computador testa, em pouco tempo, todas as combinações possíveis para as regras estabelecidas nos scripts. Além da óbvia capacidade de cálculo, a imprevisibilidade entre dados de input e output, que se dá em nível altamente abstrato, desafiam os nichos tradicionais de projeto, tais como atomada de decisão, a criatividade, a intuição, a intenção e o controle. À partir desses princípios básicos, Terdizis (2006) argumenta que os computadores complementam o raciocínio humano porque oferece perspectivas distintas dele. O processo evolui por meio de repetições do procedimento até que o designer encontre uma solução que julgue satisfatória. Por esta razão, denomina-se processo evolutivo.

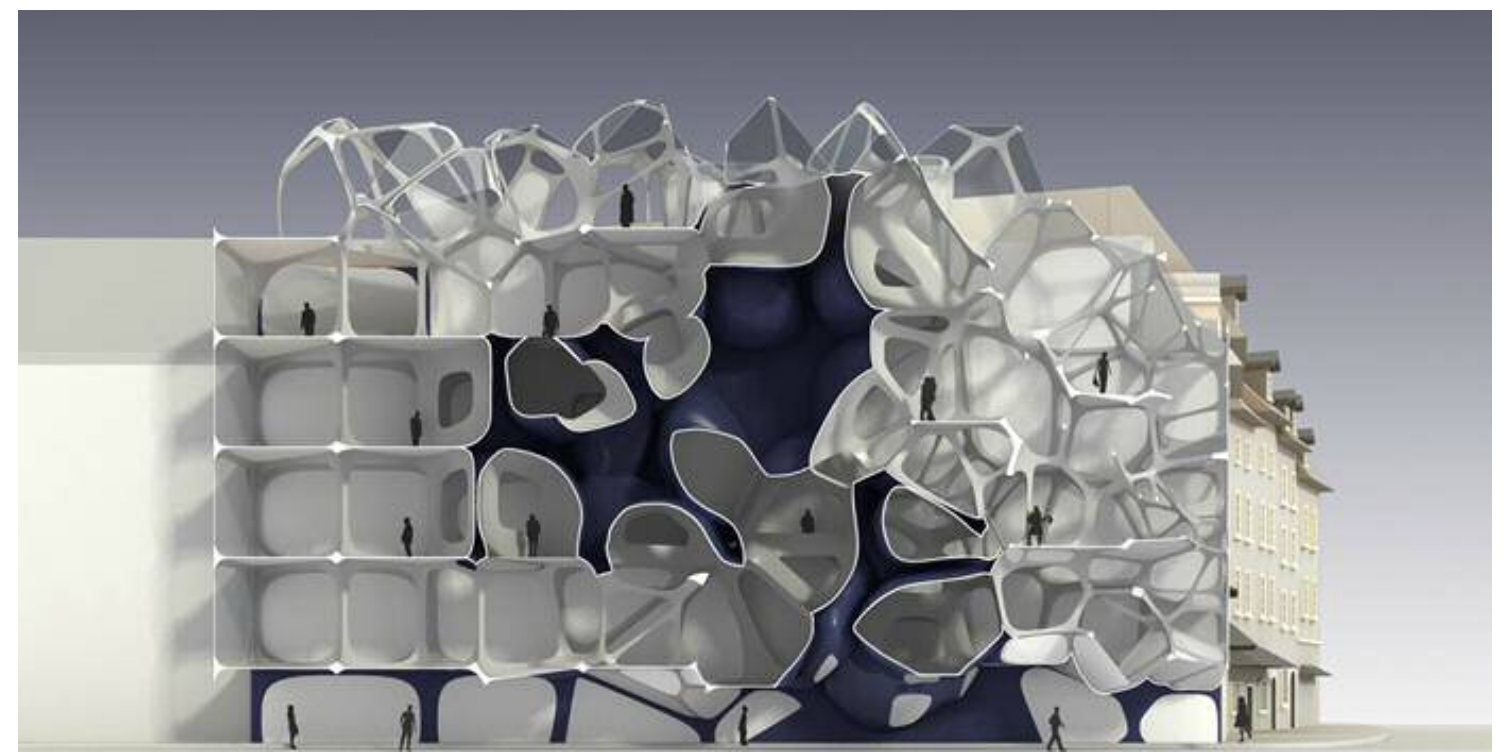

Fig. 129- Projeto iSaw desenvolvido a partir de algoritmos. Fonte: http://www.kokkugia.com/

Dessa forma, pode-se dizer que esse processo depende muito do domínio e da habilidade do projetista sobre as ferramentas geradoras de forma. Diante disso, Aish (2005) afirma que o processo constitui-se do controle das regras geradores versus o resultado formal.

De modo geral, além da proficiência em computação, a utilização dessas estratégias ordena certas competências digitais, tais como noções de composição, gráficos 
vetoriais, manipulação de imagem, modelagem de superfície, modelagem de sólidos, edição de vídeo, renderização, animação, operações de banco de dados e interface com a web, além de conhecimento de geometria e afins. No entanto, a lista cada vez maior e mais exigente em habilidades múltiplas não significa o desenvolvimento da destreza computacional em detrimento de posicionamento crítico.

Utilizando-se o potencial criativo humano e a capacidade de processamento computacional de maneira sinérgica e complementar, é possível produzir novos conceitos, ideias e formas. Nesse sentido, o algoritmo pode ser visto como uma ferramenta de projeto que pode levar, não somente à produção de formas originais, mas também de novos conceitos e ideias.

Kostas Terdizis (2006) aponta que a manipulação das formas complexas em software de modelagem não representa, por si só, a quebra de paradigmas, uma vez que a lógica de projeto permanece intocada. A verdadeira quebra de paradigma só poderá ocorrer com a utilização das ferramentas digitais de modo totalmente inovador a ponto de modificar a maneira de pensar a arquitetura. Para tanto, seria necessário extrapolar certos nichos de pensamento cristalizados não só pelo paradigma moderno como também pelas limitações da mente humana.

Transferir o ato de tomada de decisão do plano consciente da mente humana para um agente inconsciente como o computador pode gerar grandes mudanças na maneira de pensar a arquitetura, a qual se deu fundamentalmente através do domínio total do arquiteto sobre o objeto projetado. Em outras palavras, os computadores podem ser capazes de complementar o raciocínio humano, haja vista que podem sugerir perspectivas distintas do mesmo (Terdizis, 2006).

Michael Meredith (2008) alerta que não só as arquiteturas algorítmicas, mas também as arquiteturas geradas digitalmente como um todo jamais devem vir desacompanhadas de atitude crítica, a fim de não se tornar um determinismo tecnológico moderno com nova roupagem. Ou seja, o poder de decisão através de técnicas computacionais não é aleatório, é conferido pelo arquiteto e pelos usuários da arquitetura, ou seja, são eles que decidem o que deve ou não ser realmente construído.

\subsection{Arquitetura baseada em desempenho ambiental e energético:}

Segundo Friesen (2009), a simulação computacional articula o modo como a informação 
pode ser incorporada na geração de uma forma ambientalmente responsável. O mecanismo que codifica essa relação navega entre dois mundos, o virtual e o meio ambiente natural, e representa um grande passo em relação a interpretação de informações.

Os softwares e as técnicas para a pesquisa de desempenho ambiental tem sido desenvolvidos desde o final da década de 1970. (Yannas em Beaurecueil; Lee, 2009) Os avanços nos sistemas computacionais para o projeto arquitetônico tem possibilitado um sofisticado nível de precisão e controle, não somente na fabricação, mas também na simulação e na mediação de forças ambientais e estruturais. Os resultados podem ser vistos através de muitos exemplos de componentes de coberturas e fechamentos verticais que se modificam em função de algum parâmetro estipulado, como por exemplo, a radiação solar. (Beaurecueil; Lee, 2009)

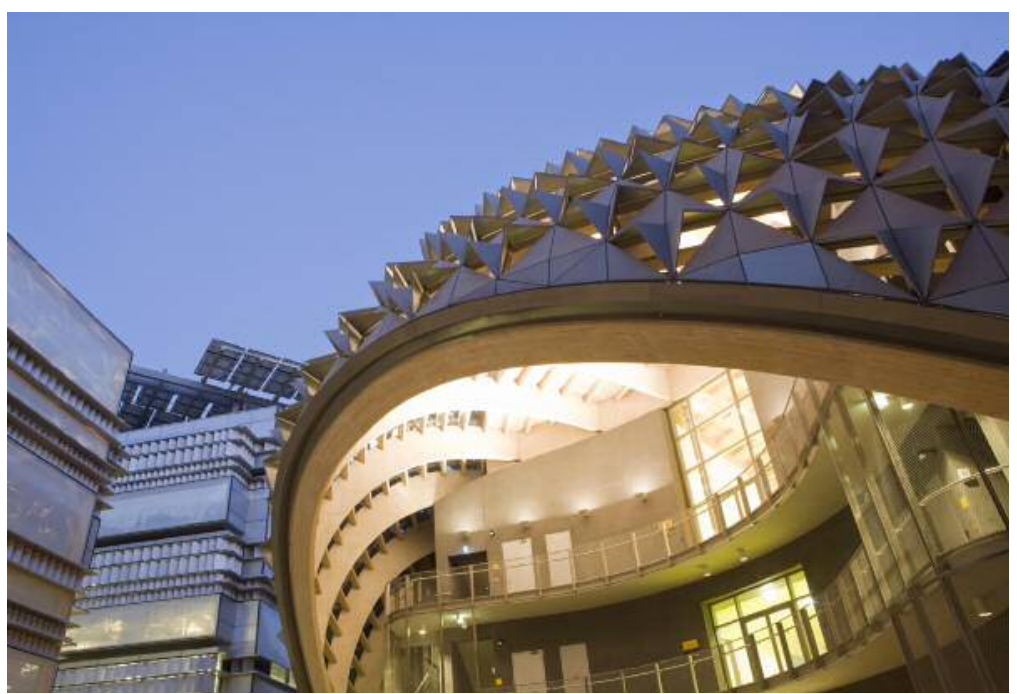

Fig. 130 - Knowledge Center no Masdar City. Fonte: <masdarcity.ae/en/64/ built-environment/masdar-institute-campus> acessado em janeiro 2014.

Os testes digitais abrangem não somente a modelagem 3D ou numérica, mas também as simulações de processos ambientais nos edifícios que nos permitem perguntar e responder perguntas do tipo "e se?" (Yannas em Beaurecueil; Lee, 2009). Simulações de desempenho ambiental (térmico, lumínico e de ventilação) geralmente têm a forma de estudos paramétricos ou sensitivos.

Novas conexões entre o projeto paramétrico, as simulações energéticas e a otimização dos algoritmos permitem uma customização de partes do edifício ou até do edifício 
como um todo, em busca de um melhor desempenho energético (Glassman, 2011) ${ }^{4}$.

As novas ferramentas digitais estão agregando, ao projeto paramétrico, as simulações energéticas e os algoritmos, gerando um grande potencial para a criação de novas expressões arquitetônicas, que são justificadas pelo seu desempenho. Essa abordagem integrada já foi utilizada por muitos projetistas para esculpir torres em determinados contextos e desafiar a engenharia do edifício alto e o potencial morfológico dessa tipologia. (Glassman, 2011)

Com isso, é preciso entender e saber operar essas ferramentas, que permitem a interoperabilidade entre os softwares, questionando de maneira correta para resolver os problemas de projeto relacionados ao desempenho ambiental. Vale ressaltar que, caso seja buscado apenas o melhor desempenho, sem levar em conta o usuário, o projeto estará sujeito ao fracasso, sendo o funcionalismo levado ao extremo ${ }^{5}$.

A análise de desempenho é um princípio de projeto que considera alguns parâmetros prioritários ao qual o edifício tem que responder. Nessa abordagem a prioridade é o desempenho do edifício e não na forma (Kolaveric; Malawaki, 2005). É importante ressaltar que, neste caso, o software não gera a forma propriamente, mas instrui o designer na mudança da geometria para o alcance do melhor desempenho dentro do aspecto analisado, para depois submetê-la novamente à análise.

Conceitualmente, as análises de desempenho têm cumprido papel pragmático nas arquiteturas digitais. As técnicas de simulação de desempenho têm sido empregadas para simular aspectos quantitativos e qualitativos do edifício e, assim, oferecer nova aproximação entre design arquitetônico e o ambiente do projeto (Kolaveric; Malawaki, 2005). As arquiteturas de vanguarda digital têm se utilizado de vários processos generativos digitais para abrir novos territórios de explorações conceituais, formal e tectônicos, articulando a morfologia arquitetônica centrada nas propriedades emergentes

\section{GLASSMAN, E. Performance Optimization VS Adaptation} as Applied to Tall Buildings. Trabalho da disciplina GSD 6433: The Environmental Performance of Tall Building, Harvard University, Center for the Environment, dezembro, 2011.

5 Informação verbal colhida na palestra técnica "Alargar horizontes com a aplicação de projetos sustentáveis", proferida pelo presidente eleito da ASHRAE Thomaz Watson, na Escola Politécnica, USP, em 29 de maio de 2012. 
e nas propriedades adaptativas da forma.

Determinar os diferentes aspectos performativos de um certo projeto, reconciliando, muitas vezes, objetivos conflitantes com o desempenho e gerando formas criativas e eficazes são alguns dos principais desafios do projeto baseado em desempenho (Kolaveric; Malwaki, 2005).

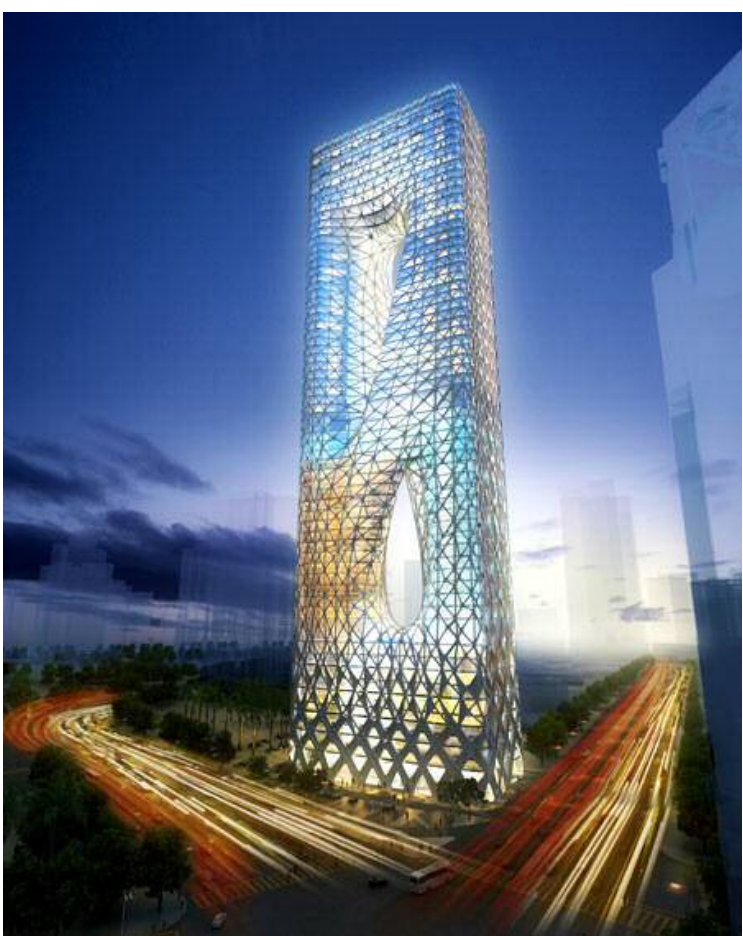

Fig. 131- Edifício Sun Rise Zaha Haddid.

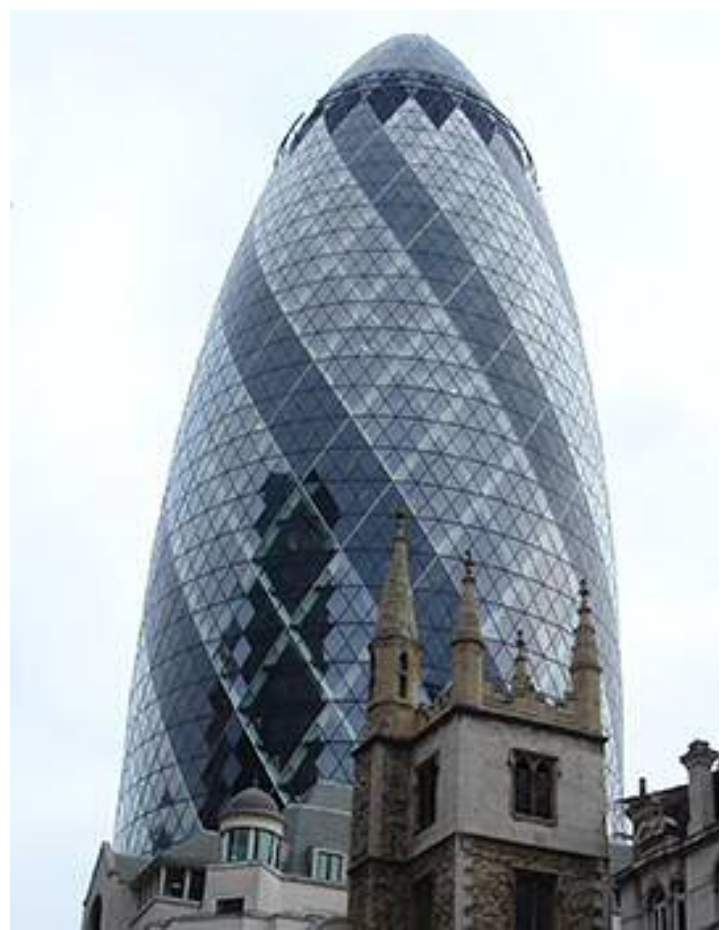

Fig. 132- edifício Swiss Re.

Fonte: http://www.evolo.us/architecture/sunrisetower-in-kuala-lumpur-zaha-hadid/ acessado em 27 de junho de 2012.

Estudos mais recentes têm tentado comprovar que a complexidade formal das arquiteturas geradas digitalmente pode surgir da manipulação de parâmetros utilitários, como é caso, por exemplo, dos dados de conforto ambiental do contexto de projeto. Essa nova abordagem vem adquirindo cada vez mais adeptos, haja vista que, nesse tipo de arquitetura, baseada em desempenho, o emprego do computador pode extrapolar a simples questão formal, trazendo uma complexidade de nova ordem.

Na opinião de Friesen (2009), nós já temos as ferramentas que nos permitem alcançar um alto nível de diferenciação e controle. Por exemplo, pode-se realizar uma simulação de insolação e retirar dela informações como os ângulos da trajetória solar e transformá- 
lo em um script ou um código e, com isso, gerar um conjunto de formas ambientalmente responsáveis. Essa variedade de soluções livra-nos do reducionismo, do convencional, da forma baseada na função, sendo proporcionando, assim, um processo de projeto mais dinâmico. Com isso, possibilita-se o desenvolvimento de uma metodologia em que a forma é direcionada, diretamente, pelas análises de desempenho ambiental, facilitando um engajamento com as forças ambientais. Isso permite ao arquiteto maior criatividade ao usar os resultados das simulações de desempenho ambiental como critério de projeto. Com essas novas tecnologias que mesclam a engenharia e a arquitetura, surge a grande oportunidade dos projetistas terem o controle de todos os aspectos do processo de projeto. Simulações de desempenho ambiental e o processo de projeto com algoritmos customizados levam o arquiteto a ter de volta o controle do processo de projeto e da fabricação.

\subsection{Processos analíticos de avaliação de desempenho}

A cobrança crescente pela quantificação do consumo de energia em edifícios ao redor do mundo fez das simulações computacionais de desempenho energético e ambiental uma parte essencial do processo de projeto. Os métodos de avaliação de desempenho, apoiados em técnicas de simulação computacional, vieram aprimorar o processo de projeto com a investigação criteriosa sobre o impacto dos vários aspectos arquitetônicos e do programa de atividades no desempenho ambiental dos edifícios. Desse modo, a eficiência de soluções projetuais derivadas da interpretação arquitetônica dos princípios da física pode ser comprovada, quantificada e aprimorada.

As ferramentas de simulação de desempenho ambiental podem ser utilizadas em três estágios complementares, mas diferentes: antes do projeto arquitetônico, contribuindo de uma forma generativa, durante o projeto para testar e afinar as ideias e no final do projeto, para avaliar o desempenho propriamente dito e retroalimentar o processo. Aetapa do pré-projeto é, de longe, a mais importante, pois ajuda os arquitetos a encontrarem o caminho certo para o melhor desempenho (Yannas em Beaurecueil; Lee, 2009).

Segundo Yannas (2009), simulações de desempenho ambiental não geram soluções de projeto, mas oferecem a possibilidade de teste e avaliam possíveis alternativas que 0 
usuário pode escolher e melhorar. No entanto, este processo requer conhecimento dos fenômenos físicos envolvidos para identificar quais parâmetros valem a pena serem testados. Os testes envolvem comparações entre os efeitos de variações dos valores de cada parâmetro de uma forma controlada.

O conjunto de dados climáticos estão disponíveis e organizados em um banco de dados que podemos conectar ao computador para termos um grande mapa de dados. O que há de diferente, atualmente, é que se pode utilizar esses dados para controlar um processo de projeto mais dinâmico, distanciando-se de uma metodologia convencional de projeto. Friesen $\left(2009^{6}\right)$ afirma que, para controlar esse processo dinâmico, é preciso desenvolver um algoritmo que, alimentado pelos dados, possa extrair a informação que leve à geração da forma. Se esse tipo de algoritmo já existisse, com a necessidade de, tão-somente, realizar o download do mesmo para plugá-lo ao seu modelo, não seria possível a criação de uma solução inteligente de projeto, utilizando uma metodologia pré-existente. Os arquitetos têm, então, mais controle sobre o processo de projeto, em todos os níveis, pois podem manipular as informações através do processo. Controle computacional significa alcançar uma precisão muito grande em termos de informação e dados, permitindo-se criar não apenas uma única solução, mas um conjunto de possíveis soluções.

A criação e a manipulação desses algoritmos não é instantânea. Segundo Friesen (2009), trabalhar com esse tipo de dados requer mais tempo para configuração. O importante é que se decida com quantas variáveis o projeto irá trabalhar, pois, se o projetista for aumentando a complexidade e inserindo mais variáveis, no final ele terminará com uma quantidade enorme de dados que não podem ser utilizados de uma maneira direta. Por isso, é importante limitar a quantidade de variáveis ao invés de tentar resolver todos os problemas de uma só vez.

Variáveis do desempenho térmico e luminoso de edifícios podem ser quantificadas e visualizadas por meio de simulações computacionais, incluindo temperatura, umidade, movimento do ar, insolação, sombreamento e níveis de iluminação (figura 1). Programas de avaliação do desempenho ambiental do projeto arquitetônico oferecem uma sofisticada e clara comunicação visual dos fenômenos da física aplicada ao ambiente

6 . (Friesen em Beaurecueil; Lee, 2009) 
Capítulo 4 - Estudos de Forma: Novos Processos de Projeto - a Metodologia Bim, a Arquitetura Paramétrica e Algorítmica Avaliação de Desempenho Ambiental e Arquitetura Paramétrica Generativa para o Projeto do Edifício Alto

construído, facilitando sua compreensão e aproveitamento no processo de projeto. Processo esse que se beneficia da rápida verificação do desempenho comparativo de soluções alternativas.
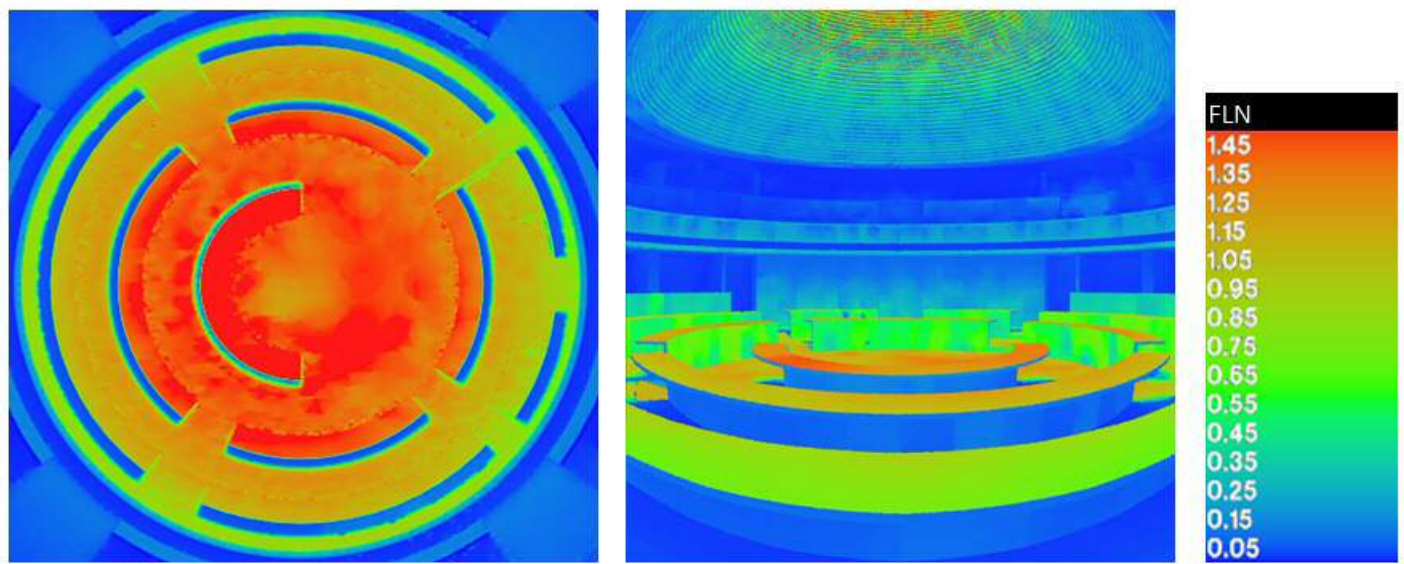

Figura 133: Simulacao da iluminacao natural na camara do Senado, com resultados do Fator de Luz Natural (Daylight Factor), revelando uma boa distribuicao homogenea da luz, medidos no plano de trabalho. Fonte: BDSP Partnership

No campo do desempenho térmico e energético, uma das maiores vantagens das técnicas computacionais, quando comparadas aos métodos analíticos mais simplificados, é a possibilidade da avaliação termodinâmica, que considera variações do clima externo, bem como do padrão de ocupação e, ainda, os efeitos da inércia térmica da construção ao longo do tempo. Com relação aos resultados, no caso de edifícios dependentes de sistemas de climatização artificial, as simulações de termodinâmica fornecem dados de carga térmica de resfriamento e/ou aquecimento, dependendo do clima em questão e dos requisitos de desempenho. Já para edifícios cujas condições ambientais sejam determinadas por estratégias passivas, a simulação de termodinâmica viabilizará a quantificação desse potencial, com a identificação do total de horas em que os espaços internos apresentam condições de conforto térmico, de acordo com parâmetros específicos e pré-estabelecidos.

Passando da etapa de quantificação do desempenho para uma abordagem mais qualitativa da arquitetura, as simulações computacionais contribuem para o entendimento das condições ambientais possíveis de serem alcançadas em decorrência de mudanças climáticas do dia ou do ano, assim como da utilização de estratégias de adaptação às condições ambientais e das variações no uso dos espaços. Dessa maneira, os benefícios 
das simulações computacionais para a avaliação do projeto arquitetônico vão além do cálculo de cargas térmicas ou temperaturas extremas.

Como colocado por Yannas (2012) em Adaptive Architecturing, fala-se, aqui, da caracterização e visualização de aspectos da qualidade ambiental interna tomada pela perspectiva do usuário e alcançada por meio de recursos do projeto (fixos e/ou flexíveis para a adaptação ambiental), em condições climáticas não apenas críticas, mas também típicas do ano e do clima interno dos edifícios. Nessa caracterização, reúnem-se informações sobre temperaturas, umidade, movimento do ar, insolação, sombreamento, luminosidade, vistas ao exterior, transições microclimáticas e quaisquer outros fatores importantes para a qualidade de um determinado ambiente.

Por outro lado, no entanto, pode-se argumentar que a qualidade ambiental faz parte da dimensão temporal da arquitetura, ou seja, é uma condição dinâmica percebida durante a experiência de uso e ocupação do espaço. Por isso, é impossível de ser completamente capturada por imagens de simulação.

Tanto sob o aspecto quantitativo das cargas térmicas ou das temperaturas, como da avaliação mais qualitativa do ambiente, é fundamental considerar que os métodos analíticos de simulação computacional não passam de simplificações da realidade (mesmo nos modelos matemáticos mais elaborados), enquanto o uso e a operação de edifícios, assim como a satisfação dos usuários, são questões mais complexas do que o que pode ser representado pelos procedimentos de simulação. Tal complexidade não se refere à reprodução dos fenômenos da física ou aos modelos de cálculo matemático, mas sim à imprevisibilidade e às variações do clima, além das inúmeras possibilidades que definem o comportamento e as preferências dos usuários.

Metodologicamente, sabe-se que o maior benefício dos procedimentos analíticos e das simulações computacionais para as análises de desempenho ambiental reside nas etapas iniciais de projeto, concomitantemente à definição do partido arquitetônico. Quando aplicados somente nas etapas finais do projeto, o seu papel se resume a uma ação corretiva e restrita, muitas vezes resultando em uma contribuição marginal para o desempenho ambiental dos edifícios. Ao contrário disso, quando incluídos nas etapas de concepção e consolidação do projeto, passam a fazer parte do processo de criação das soluções projetuais, dando, efetivamente, forma e qualidade à arquitetura. 


\subsection{Ferramentas:}

Natividade (2010) afirma que, para a obtenção dos modelos digitais, os arquitetos e outros agentes ligados ao projeto utilizam softwares desenvolvidos para outras áreas, sendo que, com isso, os projetos, em geral, são desenvolvidos em determinadas ferramentas, como o CAD. Depois, são analisados em softwares de desempenho e renderizados em softwares de animação, não havendo opções voltadas exclusivamente à arquitetura.

Nesse contexto, os softwares de maior crescimento na arquitetura têm sido aqueles que permitem a modelagem de superfícies topológicas no plano cartesiano, associada a recursos de parametrização e interpretação de linguagem de programação algorítmica. Uma ferramenta muito utilizada no projeto paramétrico é o Grasshopper, um plug-in que opera com o Rhino 3-D, software de modelagem criado por Robert McNeel and Associates. Grasshhoper é um editor gráfico algorítmico que cria modelos associativos através de uma interface visual que exige pouco ou nenhum conhecimento de programação em script. Os usuários criam uma árvore lógica que contém funções e parâmetros que geram a geometria, sendo que qualquer alteração nos parâmetros modifica diretamente a geometria resultante (McNeel, 2010).

Outro plug-in mais recente, que guarda interação com o Grasshopper, é o Galápagos, o qual trabalha com a geração de formas no modo evolutivo. Este componente utiliza algoritmos genéticos para encontrar as melhores soluções através de critérios previamente definidos pelo usuário. As diversas variáveis de uma geometria paramétrica são tratadas como genes, que são reproduzidos para encontrar a solução mais desejável para um determinado problema (Rutten, 2010).

A ferramenta DIVA para Grasshopper foi desenvolvida pelos pesquisadores do G(SD)2 dentro da Harvard Graduate School of Design. DIVA é um plug-in desenvolvido originalmente para o Rhino, que permite aos usuários conduzir uma série de avaliações de desempenho do seu modelo 3-D. Estas avaliações incluem mapas de radiação solar, visualizações no Radiance, avaliações de iluminação natural, acesso ao sol e análise de ofuscamento. Ele também gera um envelope solar para os designers, que podem gerar uma forma máxima de sua construção para garantir o acesso solar a uma parte específica do seu entorno (Glassman, 2011). 


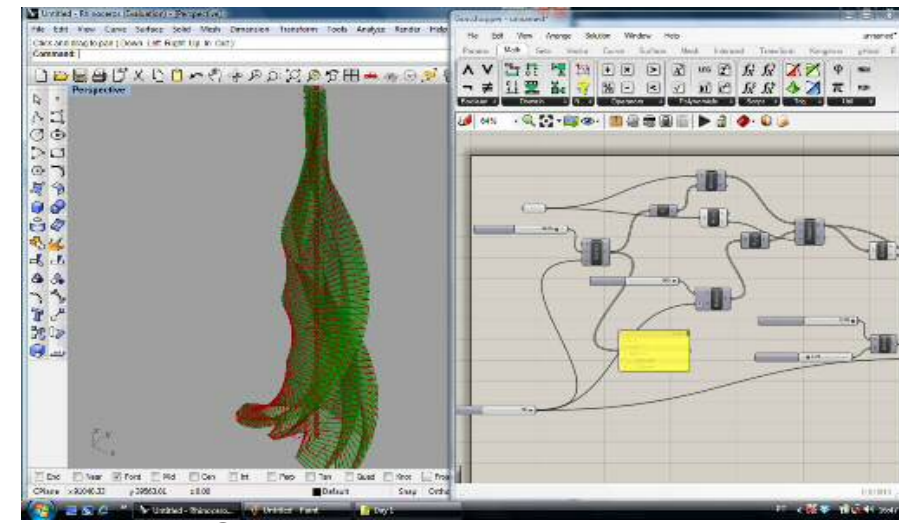

Figura 134- Grashopper

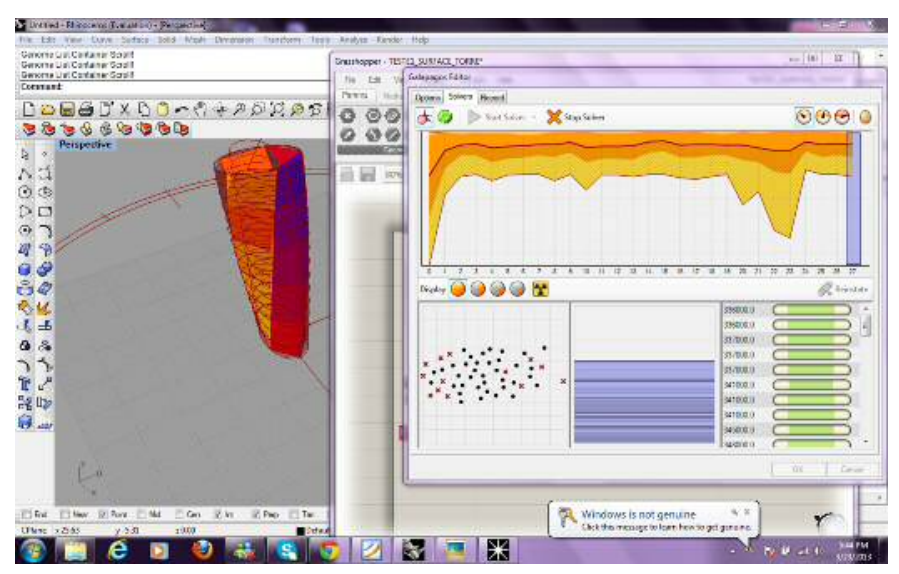

Figura 135 - Galápagos.

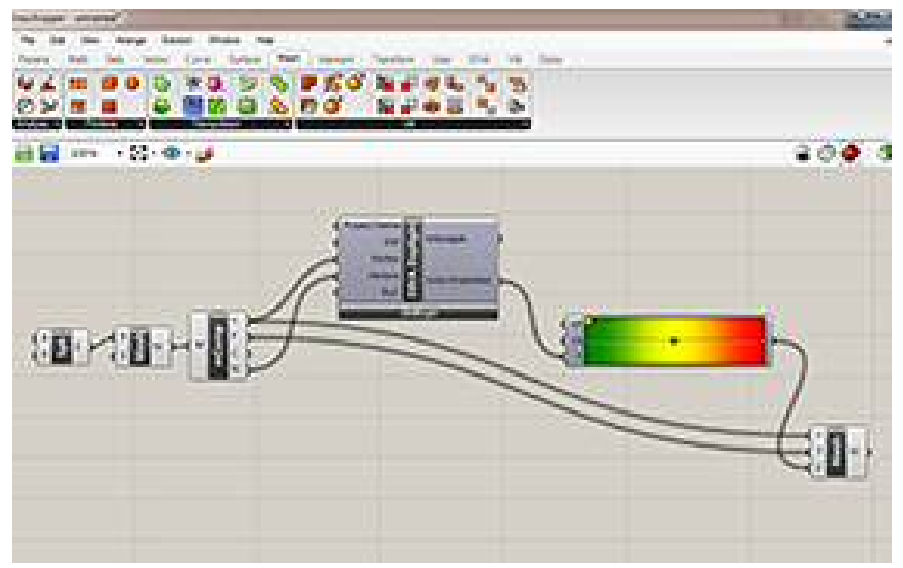

Figura 136 - Diva para Grasshopper.

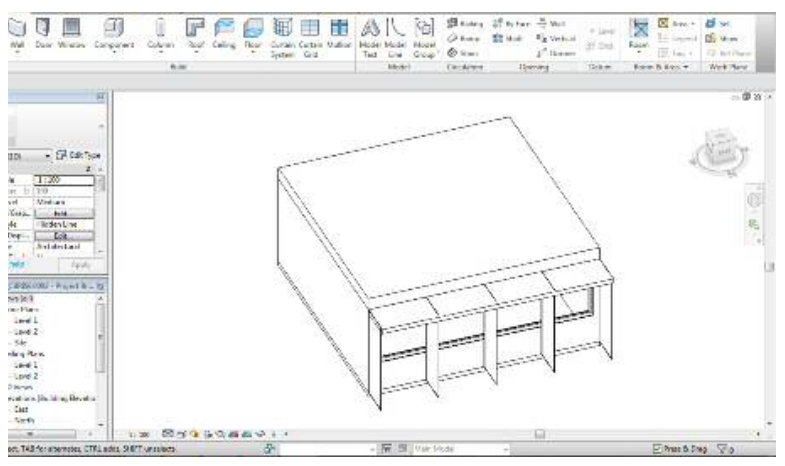

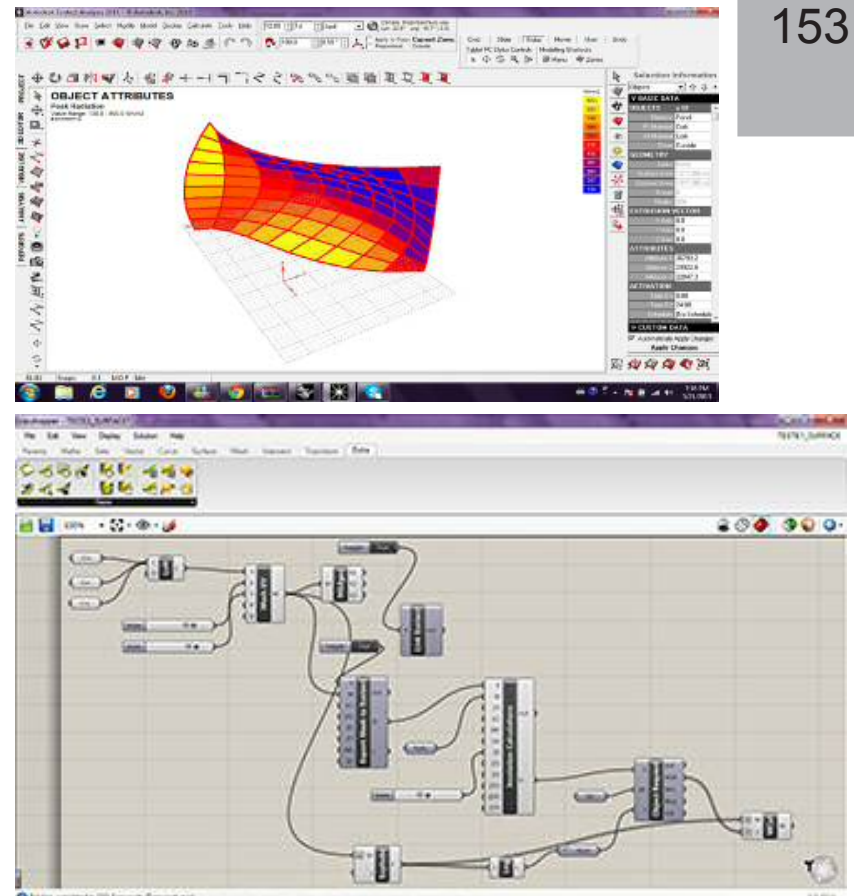

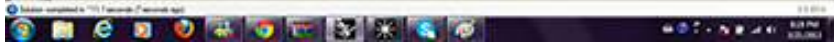

Figura 137- Gego - Ecotect

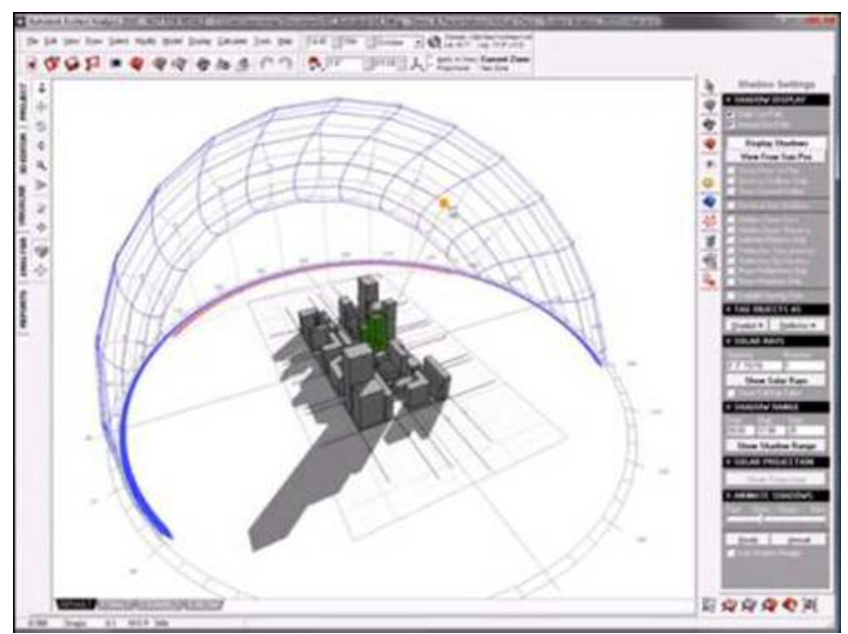

Figura 138: Estudos de insolação realizados no Ecotect utilizando apenas as volumetrias do edifício e do entorno.

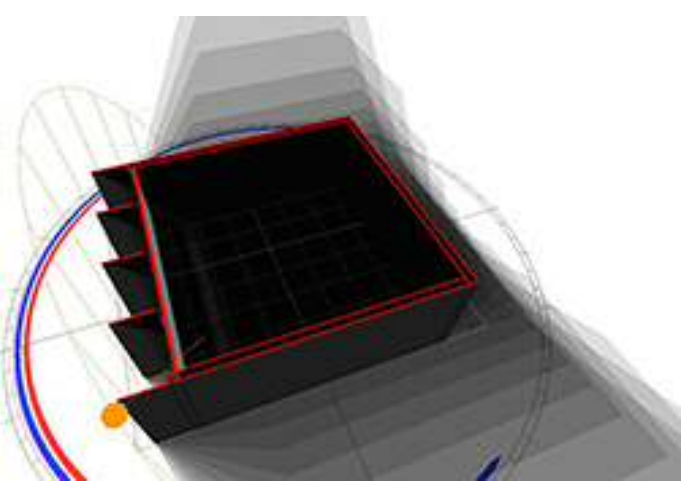

Figura 139 - Modelo gerado no software Revit e a simulação de insolação no software Ecotect.

Umakoshi, Erica Mitie 
Capítulo 4 - Estudos de Forma: Novos Processos de Projeto - a Metodologia Bim, a Arquitetura Paramétrica e Algorítmica Avaliação de Desempenho Ambiental e Arquitetura Paramétrica Generativa para o Projeto do Edifício Alto

Outra ferramenta inclusa no DIVA para o Grasshopper é o Viper, um componente que conecta a geometria do modelo Rhino ao Energy Plus. Este componente permite calcular o desempenho energético do modelo. Os usuários podem especificar o clima, o tipo de uso, as cargas internas e as propriedades térmicas dos materiais de superfície do seu modelo do Rhino (Sargent, 2011).

O potencial do DIVA para o Grasshopper é revelado na redução do tempo para a realização de avaliações de desempenho, podendo ser facilmente aplicado a toda série de estudos de projeto (Reinhart, Niemasz e Sargent, 2011). Usando o plug-in evolutivo Galápagos, o desempenho ambiental pode ser otimizado para as variáveis geométricas criadas no modelo paramétrico (Glassman, 2011).

Outras ferramentas úteis que ligam o Grasshhopper a softwares de simulação têm sido desenvolvidos. Uma das mais notáveis é o componente Geco, desenvolvido por Ursela Frick e Thomas Grabner do @[uto] e que liga o Grasshopper ao Ecotect. O componente exporta uma malha para o Ecotect para serem feitas análises de radiação solar e iluminação natural. O Ecotect, então, realiza a simulação e envia os resultados para o Grasshopper (Frik; Grabner, 2011). E, novamente, os resultados podem ser utilizados para a otimização do projeto com o Galápagos.

O Ecotect diferencia-se dos demais softwares por permitir uma análise rápida e extremamente visual de simulações ligadas à insolação e à iluminação do edifício. Desde os primeiros desenhos volumétricos, é possível entender quais serão os impactos do seu edifício nos vizinhos, e o inverso também, permitindo, assim, uma primeira análise que trará uma ideia para as aberturas e as alturas, dentre outros aspectos.

Cabe ressaltar que, para que um edifício seja mais sustentável em termos de menor consumo energético, aproveitando ao máximo as estratégias passivas de iluminação e ventilação, é necessário que esses estudos sejam realizados logo na concepção do projeto. É importante lembrar que medidas corretivas não resolvem os problemas instalados, apenas amenizam o efeito dos erros cometidos.

São várias as possibilidades de simulação utilizando apenas o Ecotect, tanto do exterior do edifício como do interior. $\mathrm{O}$ aprofundamento das análises a serem utilizadas vai depender do nível de conhecimento do arquiteto na operação e entendimento dos resultados, bem como, da necessidade de dados que o modelo exigirá. 


\subsection{Considerações Finais}

As novas ferramentas digitais fornecem novos modelos de representação, novas metodologias de avaliação e novas técnicas de exploração de formas. O desenvolvimento dessas novas ferramentas permite aos arquitetos a criação de projetos novos e de melhor desempenho ambiental, analisando-as simultaneamente durante o processo de uma forma interativa e eficiente.

No entanto, as mudanças que podemos ver nas ferramentas não é acompanhada pela forma como as escolas de arquitetura ministram as aulas de geometria. Assim, a geração de formas dentro de um conceito computacional só será explorada a fundo quando novos conceitos de geometria, como superfícies topológicas, curvas, vetores, malhas, fractais, dentre outros, forem introduzidos no ensino de arquitetura.

As ferramentas computacionais vêm redefinindo a prática da arquitetura e da construção. Os arquitetos vêm, com isso, ampliando a sua área de atuação desde o processo de projeto e fabricação até a construção. Vale ressaltar que, dentro da metodologia de projeto, existe uma abordagem diferente da academia e do mercado da construção, enquanto os modelos algoritmos e a arquitetura generativa vêm sendo desenvolvidos dentro das universidades e dos grupos de pesquisa como o Specialist Modelling Group no Foster and Partners, o Gery Technologies spun off do Gery Partners, o Advanced Geometry Unit no ARUP e o CODE na Zaha Hadid Architects. As ferramentas paramétricas BIM, por sua vez, vêm sendo utilizadas dentro do mercado da construção. Ou seja, as formas complexas são geradas dentro de ferramentas que utilizam modelos algorítmicos e, depois, são enviadas a programas computacionais que possibilitam que as mesmas possam ser construídas.

Com relação à otimização paramétrica e às variações algorítmicas, pode-se dizer que não são elas problemas fundamentais na arquitetura, sendo que o uso de modelos eletrônicos não garante o sucesso do projeto. Apesar de tratar-se a tecnologia de um importante componente da arquitetura, existem muitos outros parâmetros não quantificáveis, tais como as relações, pressões culturais, os usuários, dentre outros aspectos, que não podem ser tratados simplesmente como determinismo tecnológico. 
Capítulo 4 - Estudos de Forma: Novos Processos de Projeto - a Metodologia Bim, a Arquitetura Paramétrica e Algorítmica Avaliação de Desempenho Ambiental e Arquitetura Paramétrica Generativa para o Projeto do Edifício Alto

Os benefícios e possibilidades de design oferecidas pelas ferramentas digitais são muito grandes, mas os parâmetros que definem a arquitetura ainda são escolhidos pelos arquitetos. Da mesma forma, são eles que decidem quais arquiteturas valem a pena ser construídas. Dessa forma, Natividade (2010) afirma que acreditar que a tecnologia resolverá todos os nossos problemas é, vale frisar, ingenuidade.

O projeto paramétrico, bem como a prototipagem rápida, vem sendo discutida tanto no âmbito da universidade como na prática profissional. Como frisado anteriormente, Pupo e Celani (2011) afirmam ser preciso que haja uma atualização dos profissionais e dos estudantes de forma constante e gradual, sendo que, para isso, é imprescindível a realização de treinamentos e atualizações através de workshops.

Acredita-se que as estratégias algorítmicas e paramétricas para a geração de forma são ferramentas poderosas na solução de problemas cuja complexidade, nível de incerteza, ambiguidade ou número de soluções possíveis requer a relação sinérgica entre mente humana e o computador. No entanto, sem rigor e crítica, os projetos gerados digitalmente permanecerão apenas como exercícios de software. 
Capítulo 5: 
Capítulo 5 - Abordagem Conceitual e Estratégia Metodológica para o Projeto do Edifício Alto de Melhor Desempenho Ambiental Avaliação de Desempenho Ambiental e Arquitetura Paramétrica Generativa para o Projeto do Edifício Alto 


\section{Capítulo 5 - Abordagem Conceitual e Estratégia Metodológica para o Projeto do Edifício Alto de Melhor Desempenho Ambiental - Combinando Estudos Analíticos e Processos Generativos de Forma}

\section{Introdução}

Os exercícios de projeto analisados neste capítulo são exemplos da introdução de critérios objetivos e quantitativos de desempenho ambiental no processo de projeto paramétrico que busca a geração da forma, definindo a chamada arquitetura generativa.

Primeiramente, serão apresentados três projetos desenvolvidos no Programa de Pósgraduação Sustainable Environmental Design, da Architectural Association School of Architecture, no nível de Mestrado. Pode-se observar, nos três casos, a ênfase na elaboração da forma, que é informada por resultados de estudos analíticos, desenvolvidos especificamente para cada projeto, contemplando as particularidades do programa de atividades, do clima e do contexto urbano.

Na sequência, tem-se a proposta desenvolvida pela equipe formada pelos escritórios Foster and Partners e BDSP Partnership, de Londres, para o Projeto Viol (2009), que foi tema de um concurso de arquitetura para um edifício alto a ser construído na zona sul da cidade de São Paulo. Assim como os estudos do Programa de Pós-Graduação Sustainabe Environmental Design, esse projeto possui um processo de geração da forma arquitetônica diretamente informado por conceitos e critérios de desempenho ambiental, também caracterizando um tipo de processo generativo, mas sem o uso de ferramentas avançadas para a geração da forma.

Diferentemente dos exemplos vistos até então, o último exercício de projeto, que fez parte de um workshop promovido pela Architectural Association Visiting School, em São Paulo, 2011, enfatiza as possibilidades do processo generativo da forma arquitetônica. Esse exercício de projeto baseou-se em métodos e programas avançados de geração paramétrica de forma.

\subsection{Exercícios de Projeto do Programa de Mestrado Sustainable}

Environmental Design, da Architectural Association School of

Architecture (SED - AA) 
Capítulo 5 - Abordagem Conceitual e Estratégia Metodológica para o Projeto do Edifício Alto de Melhor Desempenho Ambiental Avaliação de Desempenho Ambiental e Arquitetura Paramétrica Generativa para o Projeto do Edifício Alto

5.1.1 Tall Communities: Passive urban housing for the Tropics - Suraksha Bhatla (BHATLA, 2011)

\section{- Objetivos, Programa e Partido arquitetônico}

A proposta desse trabalho foi alcançar o conforto térmico em um edifício alto residencial na cidade de clima quente e úmido de Chennai, na Índia, utilizando duas estratégias principais: proteção solar e ventilação natural. O programa de projeto incluiu 100 unidades habitacionais de 2 dormitórios.

\section{- Contexto Climático}

O clima da região é caracterizado como sendo quente e úmido, com duas estações definidas: verão quente e úmido, de abril a setembro, e inverno frio e seco, de outubro a março. O período mais quente é entre os meses de maio e junho, quando as temperaturas atingem de 38 a $42^{\circ} \mathrm{C}$, e o período mais frio é entre novembro e janeiro, quando as temperaturas ficam no entorno de 18 a $20^{\circ} \mathrm{C}$ (fig. 141). Assim, o ponto crítico desse clima é o calor, que perdura por praticamente seis meses do ano, sendo o inverno ameno.

\section{- Abordagem analítica}

O Desenvolvimento do projeto de arquitetura foi precedido por estudos analíticos, que utilizaram as ferramentas computacionais TAS e ECOTECT, com modelos geométricos simplificados, visando compreender o desempenho de algumas estratégias como o dimensionamento do sombreamento, o impacto das áreas envidraçadas e da orientação solar, a profundidade da planta, dentre outras.

A partir dos estudos analíticos de desempenho ambiental de espaços internos no contexto climático especifico de Chennai, foi estabelecido: orientação norte e sul para as maiores fachadas, elementos de proteção solar de 1 a $2 \mathrm{~m}$ de largura, varandas com 2,5 a $3 \mathrm{~m}$ de profundidade, isolamento térmico nas paredes e coberturas, porosidade no edifício para facilitar a ventilação (espaços abertos), corredores ventilados naturalmente, átrios com 6 metros de profundidade e de 4 a 5 pavimentos de altura. As unidades devem ter $2 \mathrm{H}$ de profundidade, com $25 \%$ de janela em relação ao piso.

Ao final do projeto, foram realizados estudos de avaliação que mostraram que estratégias de sombreamento, espaços de mediação climática e isolamento nas paredes externas 


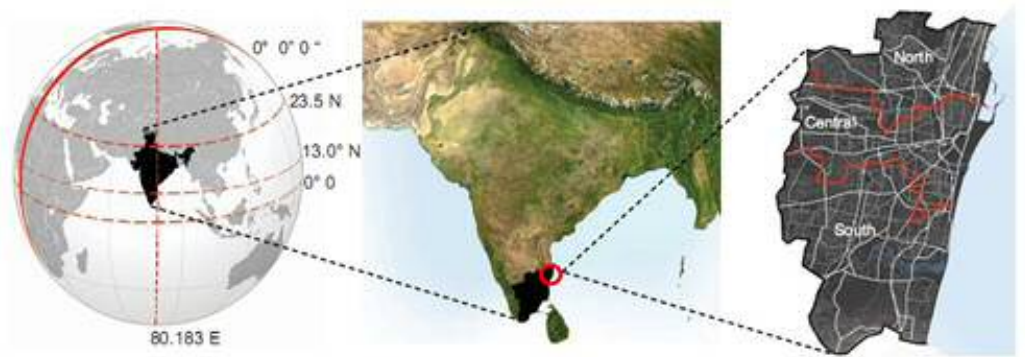

Figura 140- Localização da cidade de Chennai, em Tamil Nadu, Índia. (Fonte: Google.com)

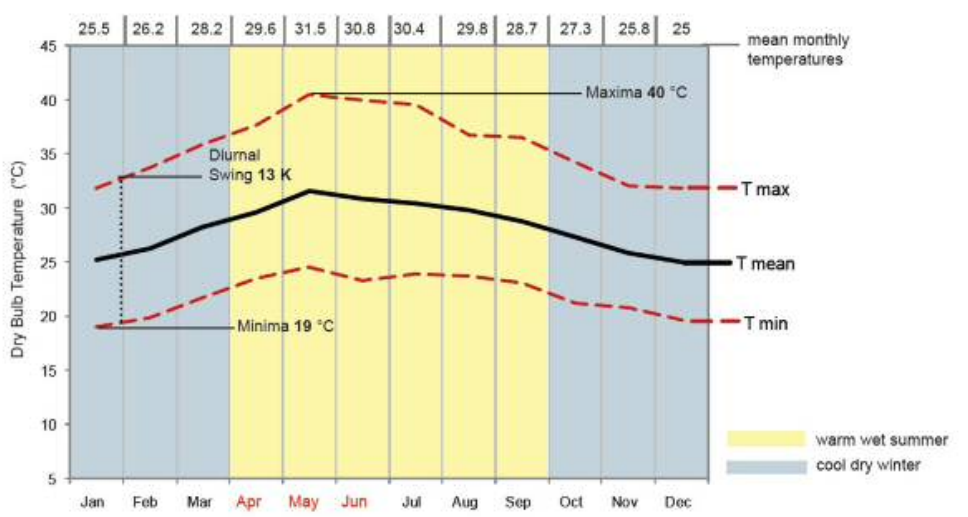

Figura 141- Temperatura média mensal de bulbo seco. (Fonte: Meteornorm, v6.1)
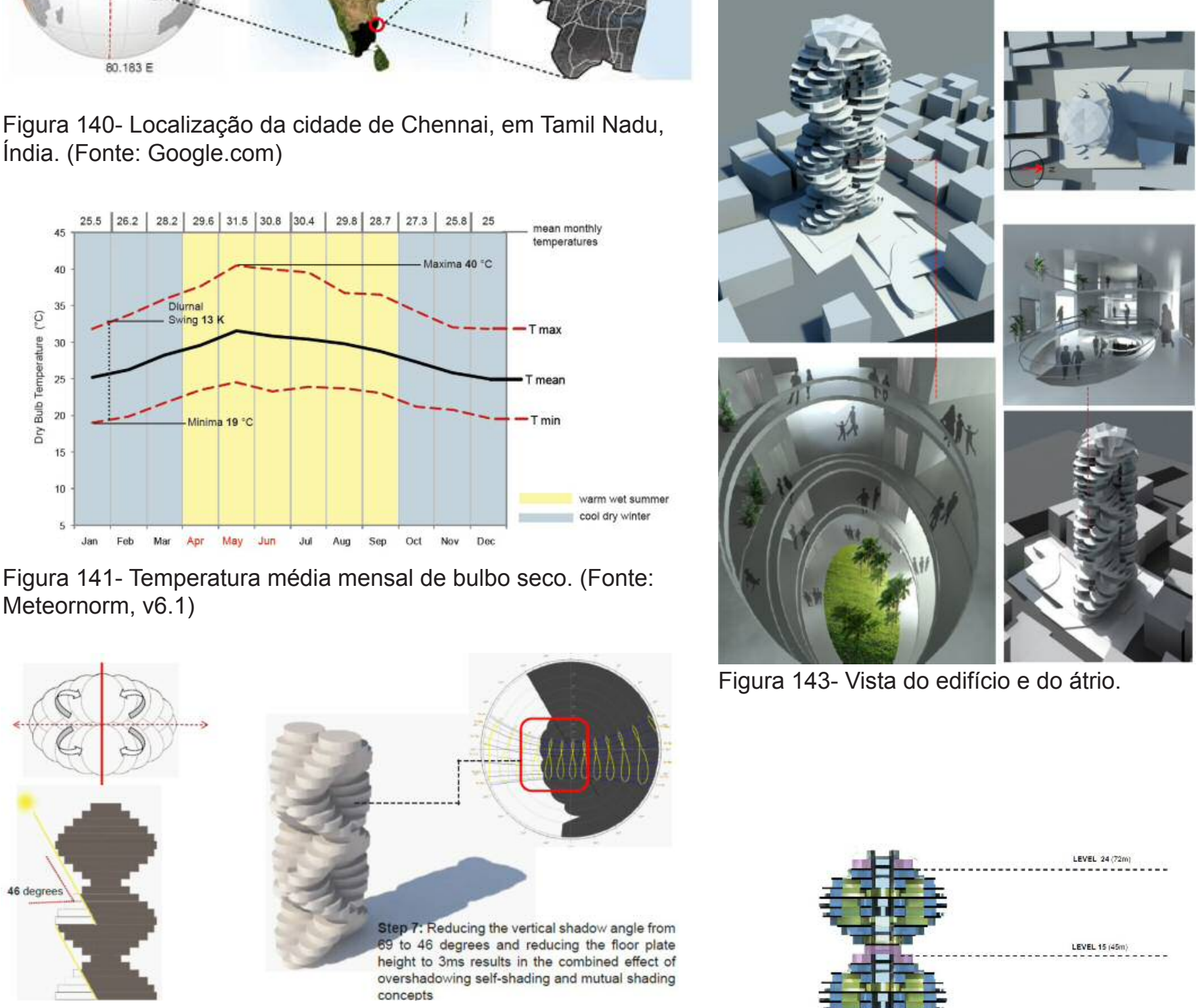

Figura 143- Vista do edifício e do átrio.

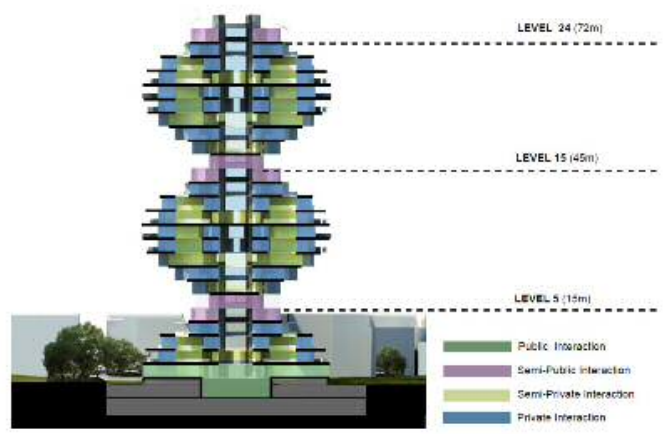

Figura 144- Hierarquia das áreas comuns e privativas nas vilas.

Figura 142- Processo de elaboração da forama. (Fonte: Bhatla, 2011) 
Capítulo 5 - Abordagem Conceitual e Estratégia Metodológica para o Projeto do Edifício Alto de Melhor Desempenho Ambiental Avaliação de Desempenho Ambiental e Arquitetura Paramétrica Generativa para o Projeto do Edifício Alto
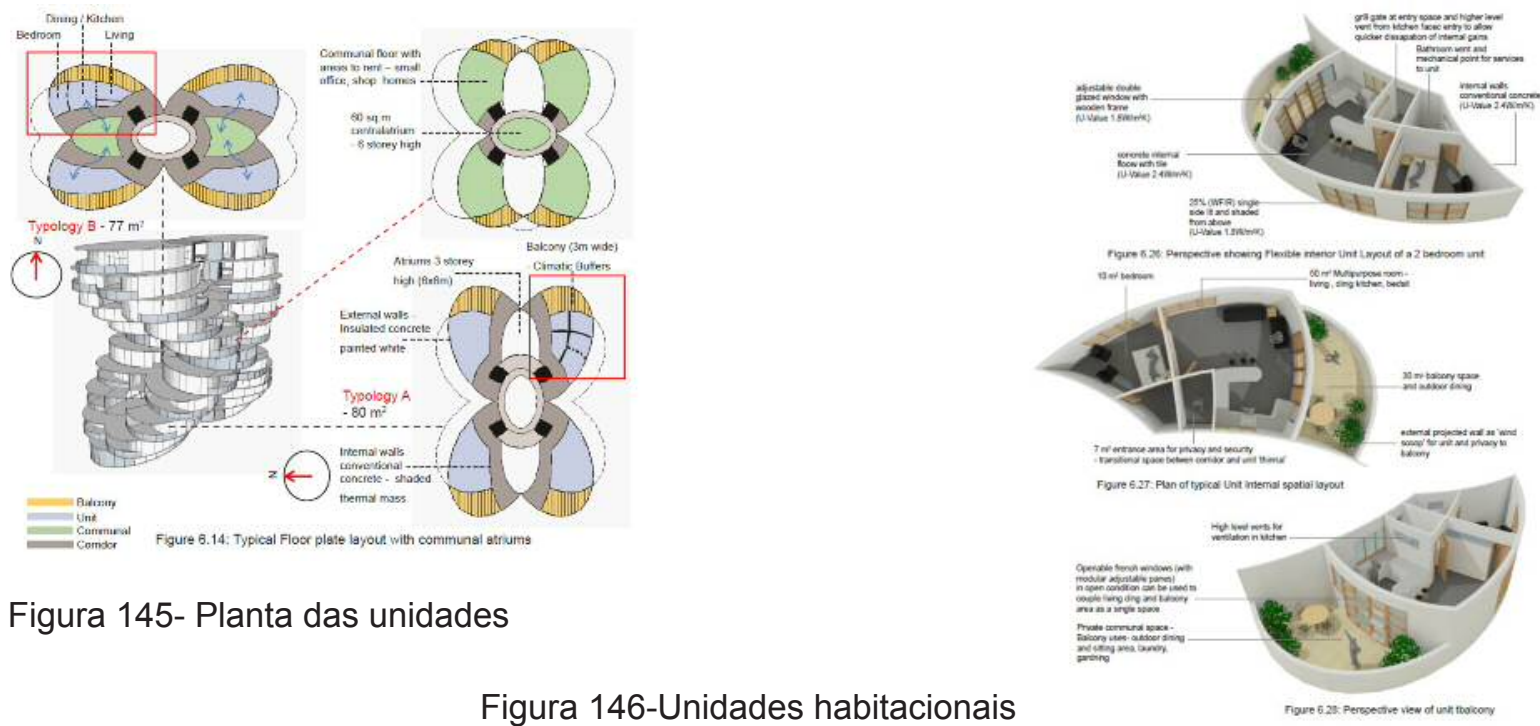

Figura 146-Unidades habitacionais

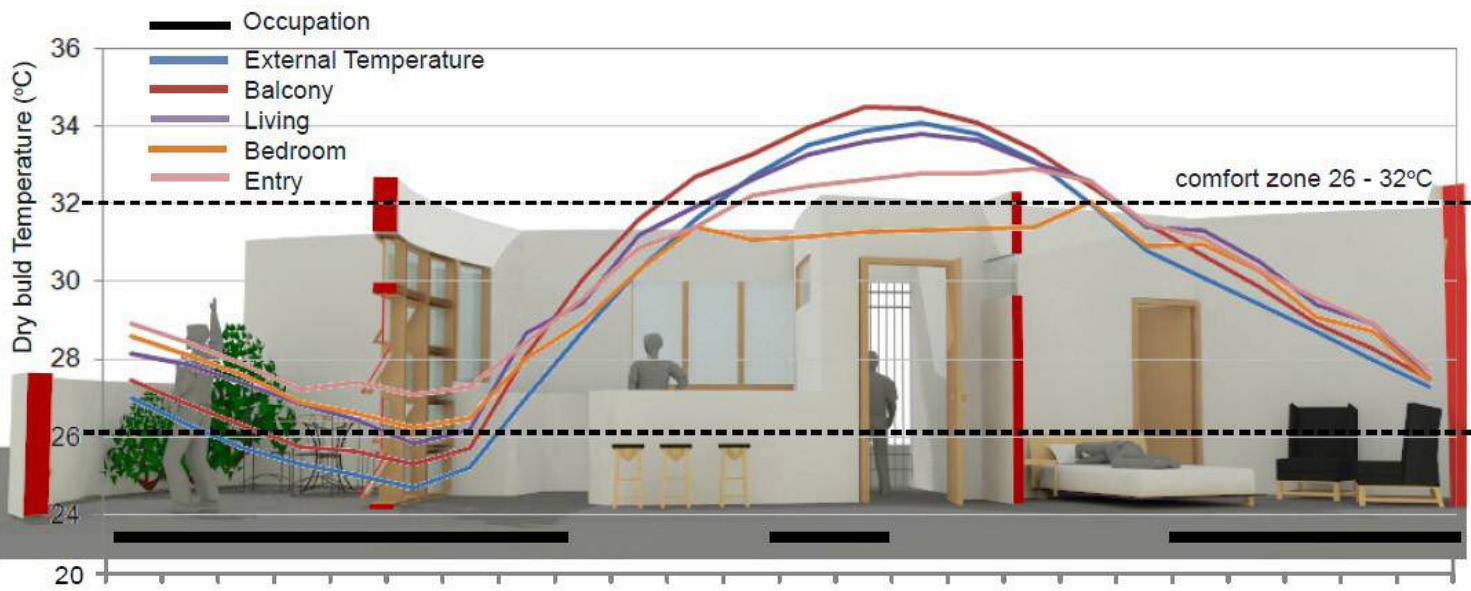

$103,103,103,103,103,103,103,103,103,103,103,103,103,103,103,103,103,103,103,103,103,103,103,103$
12
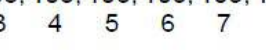
$9 \quad 10 \quad 11 \quad 1213$

Figura 147 - Corte com as temperaturas de um dia típico de verão somente utilizando a ventilação natural. ( Software: TAS versão 9.1.4.1)
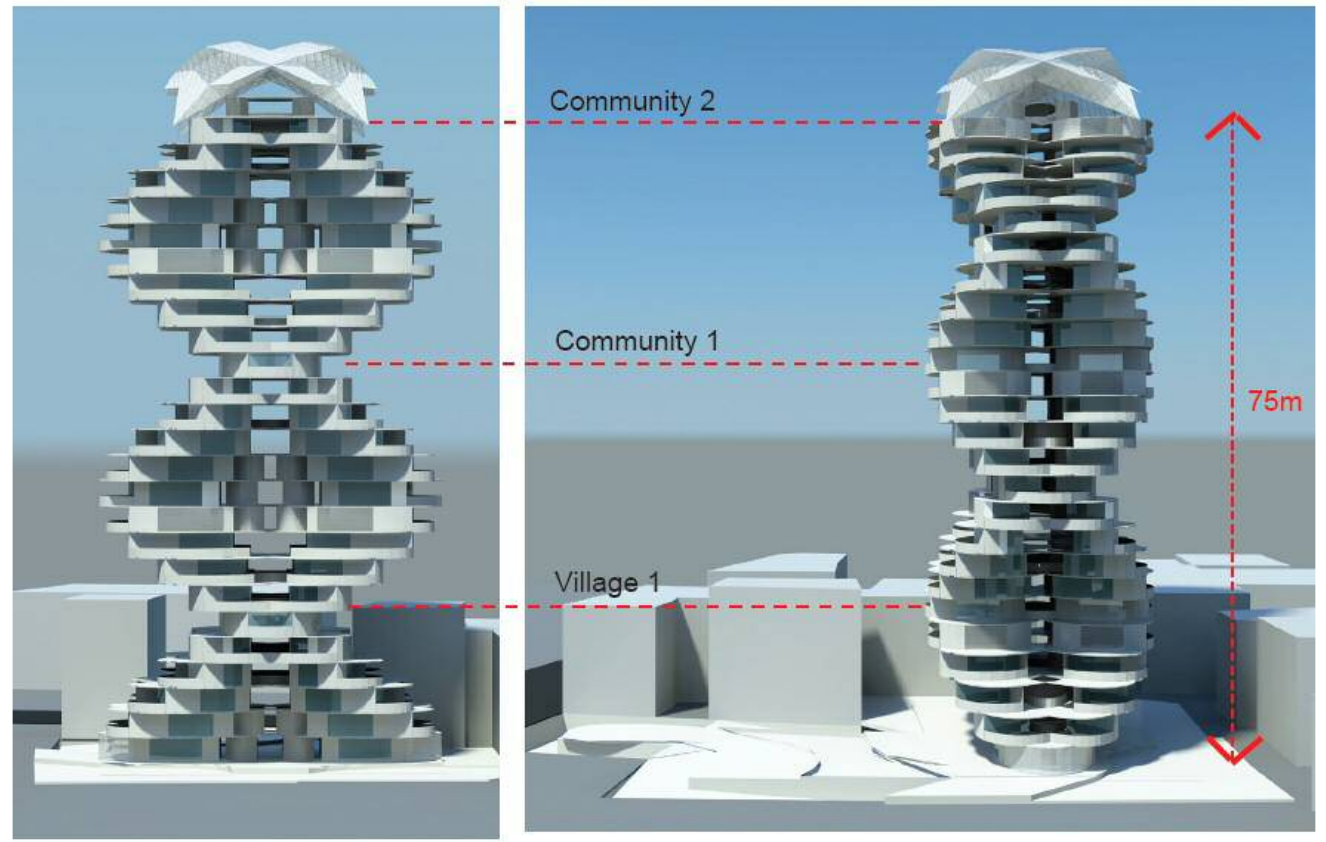

Fig. 148- Elevação Sul e Oeste. 
podem reduzir em $50 \%$ o consumo de energia. No entanto, o ponto mais importante da pesquisa foi confirmar que é possível atingir o conforto térmico nos apartamentos residenciais projetados para Chennai, em $60 \%$ do ano, por meio da ventilação natural (fig. 141).

\section{- Processo de elaboração da forma}

Estudos preliminares de impacto da radiação solar direta na forma arquitetônica demonstraram que a melhor opção de forma é a forma oval. Partindo da forma oval, a rotação de uma planta de base resultou no auto sombreamento desejado e na possibilidade de vazios para a formação de varandas, terraços e átrios (fig. 142).

A partir das diretrizes estabelecidas pelos estudos analíticos, o processo de elaboração da forma tomou como ponto central de desenvolvimento o auto-sombreamento que a sequência de pavimentos do edifício alto pode proporcionar. O problema do sombreamento foi então tratado em três etapas: pela orientação e trabalho da forma, uma parte significativa da radiação solar direta passa a ser bloqueada; em um segundo momento, a criação de terraços e demais espaços de transição afastam os espaços internos do impacto da radiação solar direta, onde essa ainda é significativa (fig. 143); por último, o zoneamento dos espaço internos e os uso de elementos de sombreamento nas fachadas (externos e internos) permitem o controle dos usuários sobre a radiação residual (fig. 144).

Cabe ressaltar que nesse projeto não foi utilizada nenhuma ferramenta de geração paramétrica da forma que caracteriza o processo de projeto da arquitetura generativa. No entanto, todo o desenvolvimento seguiu a lógica paramétrica de evolução da forma, baseada em critérios e parâmetros de desempenho.

5.1.2 Environmental Performance of adaptive building design: urban housing in Seoul Korea - Jeewon Paek (PAEK, 2011)

\section{- Objetivos, Programa e Partido arquitetônico}

Desde a sua primeira construção em 1962, edifícios residenciais logo se tornaram padrão de construção na Coréia, especialmente na capital Seoul. As construções em lâmina, adaptadas dos modelos da arquitetura racional dos anos 1930, se transformaram nos 
edifícios altos residenciais dos anos 90, que consumiam o dobro de energia do antigo modelo.

Devido ao rigor do clima no inverno, a varanda do edifício, tipo lâmina do modernismo, era aberta no verão, fechada com vidro no inverno e funcionava como área de transição climática ao longo do ano, minimizando a demanda por aquecimento no inverno (fig. 149). Os edifícios altos residenciais da atualidade suprimiram a varanda como espaço de transição e mediação climática, incorporando essa área extra como parte da sala de estar, medida essa que teve claras implicações no desempenho energético da unidade habitacional.

Frente a essa realidade, esse exercício de projeto foi motivado pelo desafio de projetar edifícios altos residenciais com qualidade ambiental e maior eficiência energética, em um contexto urbano de crescente adensamento pela verticalização do ambiente construído e um contexto climático de invernos frios e verões quente-úmidos.

\section{- Contexto Climático}

O clima de Seoul é temperado e se caracteriza por um verão quente e úmido, com temperatura média de $250 \mathrm{C}$ e um inverno frio variando de $-10 \mathrm{C}$ a $-30 \mathrm{C}$. Devido às baixas temperaturas no inverno, as varandas funcionam como áreas de transição, impedindo a perda de calor de dentro das unidades. No verão, essas varandas contribuem para a ventilação natural dos ambientes.

\section{- Abordagem analítica}

Foram realizados estudos analíticos acerca da porcentagem de vidro na fachada, que resultaram em diferentes arranjos de área envidraçada e em diferentes proteções solares, que podem servir tanto como barreira ao sol, como proteção contra a perda de calor durante as noites de inverno (isolamento térmico).

Os estudos mostraram que, utilizando o vidro duplo low-e, isolando as paredes externas, e utilizando proteções solares isolantes que servem como fechamento para as janelas durante a noite, é possível reduzir em $30 \%$ o consumo de energia para o aquecimento e em $55,2 \%$ a energia para a refrigeração das unidades habitacionais (assumindo a 


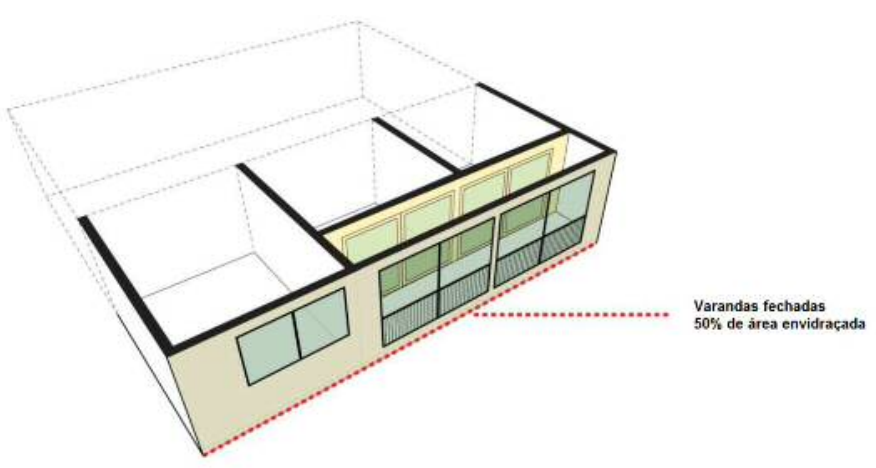

Fig. 149- Exemplo das varandas fechadas.
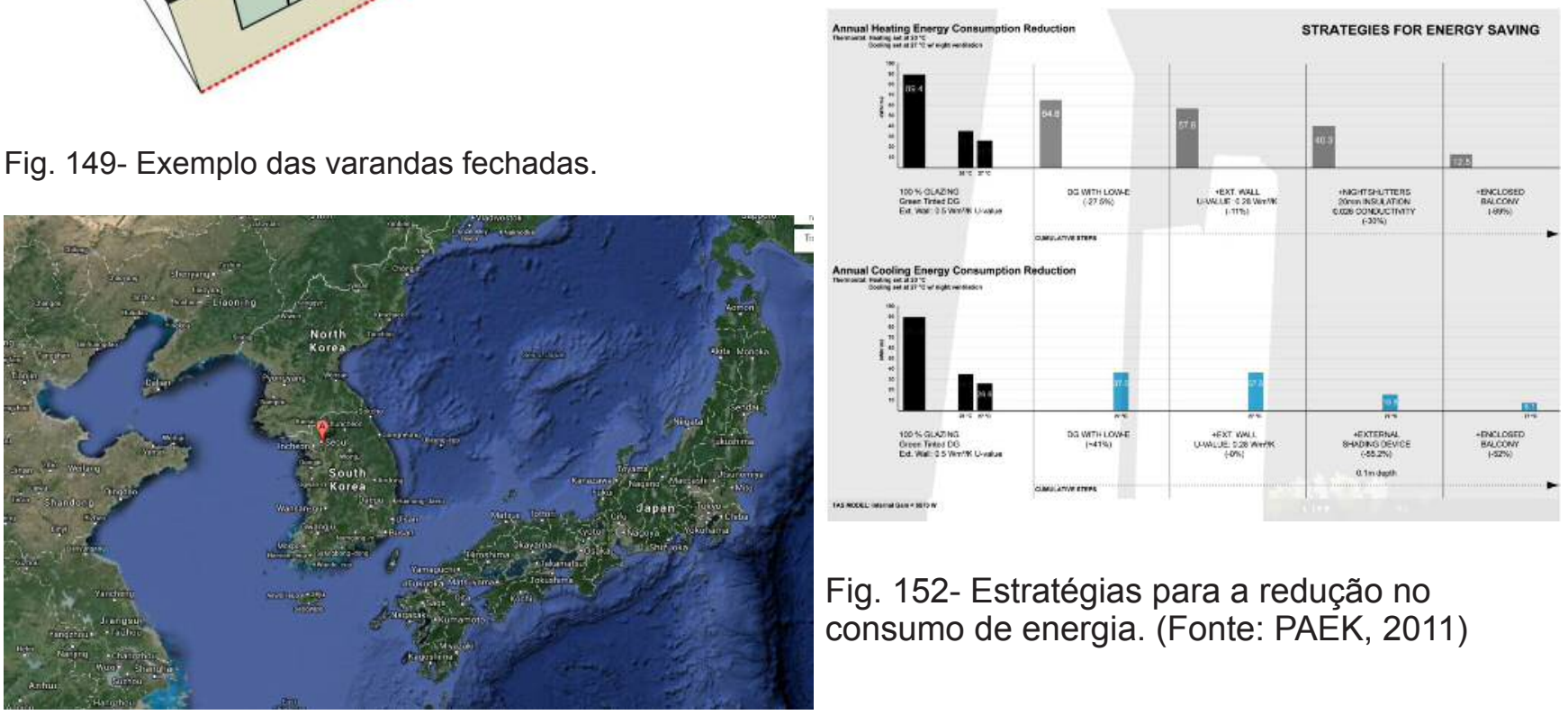

Fig. 152- Estratégias para a redução no consumo de energia. (Fonte: PAEK, 2011)

Fig. 150- Localização da cidade de Seoul, Coréia do Sul. Latitude: 37,6 Longitude: 127 (Fonte: google.com)

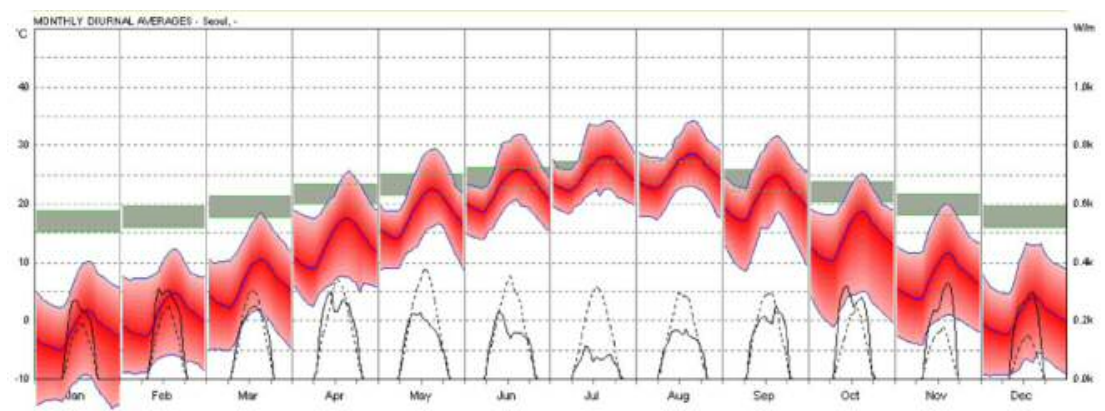

Fig. 151- Temperatura, radiação e conforto na cidade de Seoul. (Fonte: Meteornorm, v6.1)

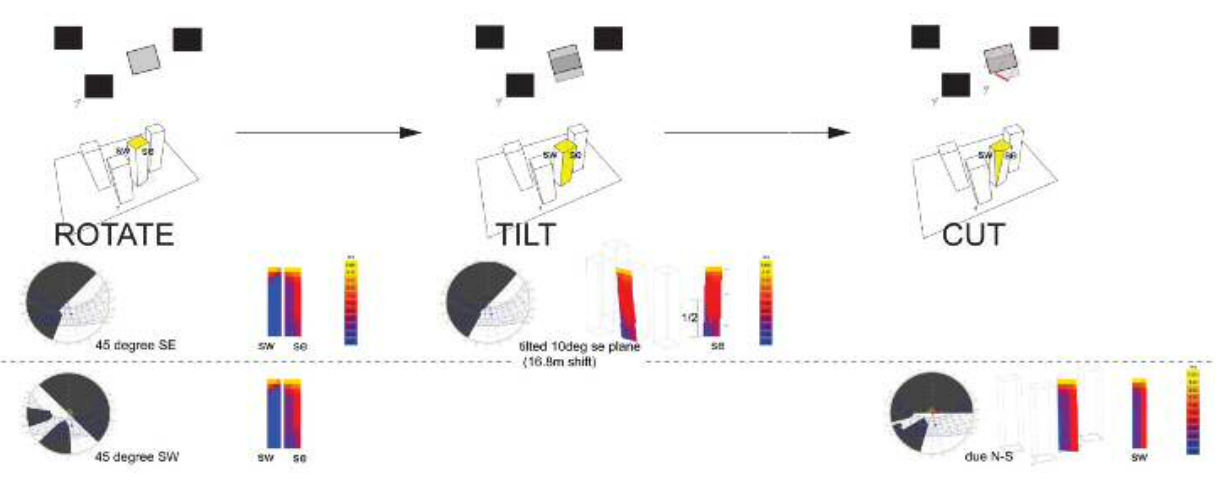

Figura 153 - Estudo de geração da forma: rotação, inclinação e corte. 
Capítulo 5 - Abordagem Conceitual e Estratégia Metodológica para o Projeto do Edifício Alto de Melhor Desempenho Ambiental Avaliação de Desempenho Ambiental e Arquitetura Paramétrica Generativa para o Projeto do Edifício Alto

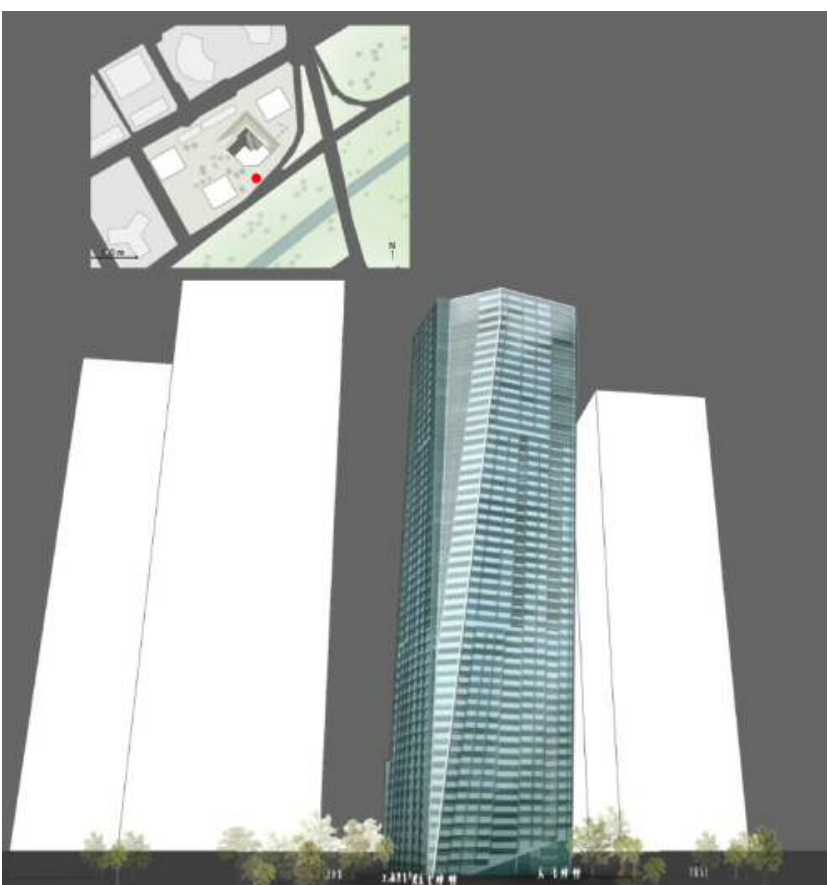

Figura 154 - Edifício após modelagem de corte e inclinação.

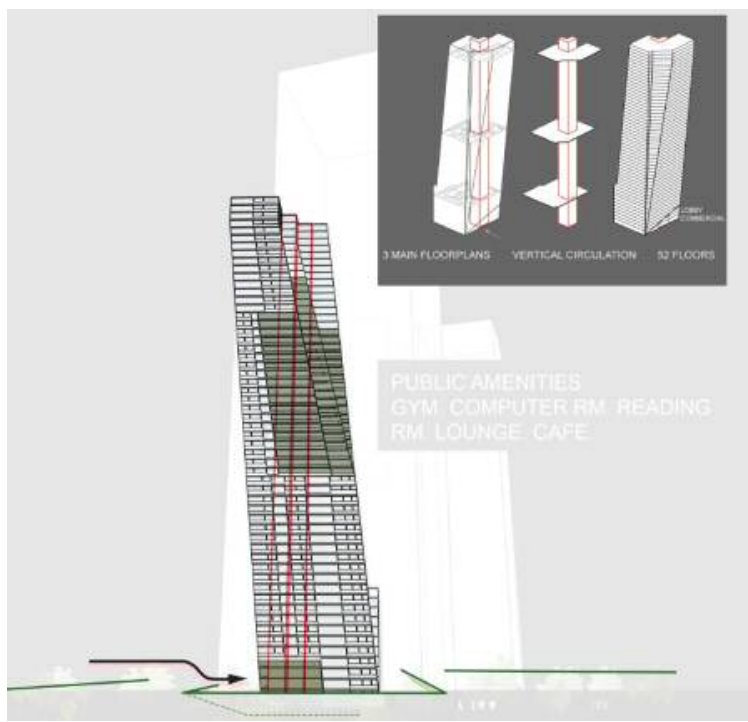

Figura 155 - Core central e acessos.
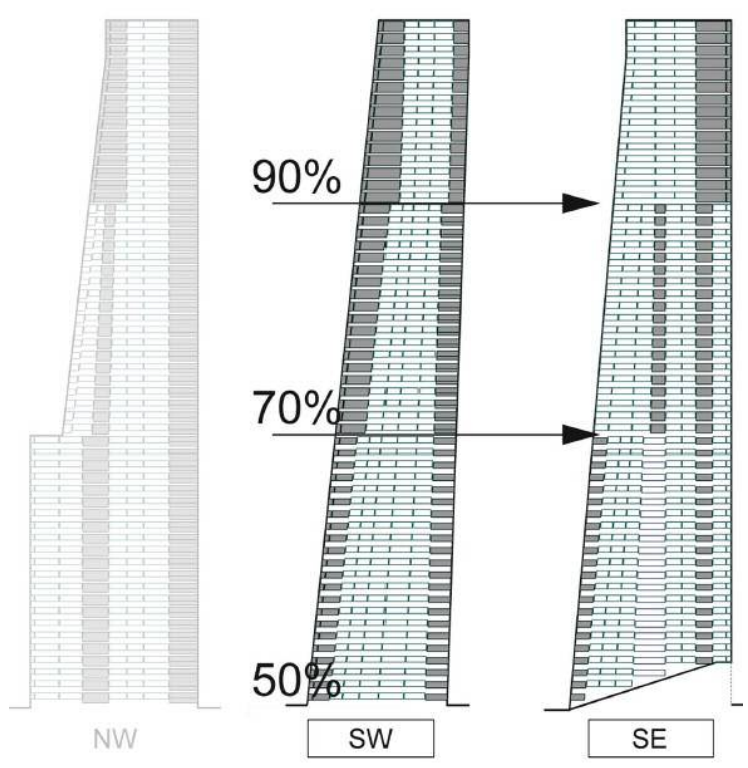

Figura 156 - Área envidraçada nas fachadas.

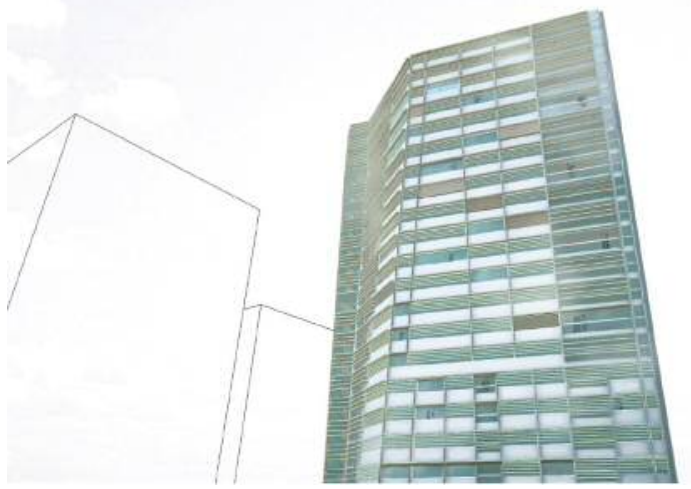

Figura 157 - Proteções solares.

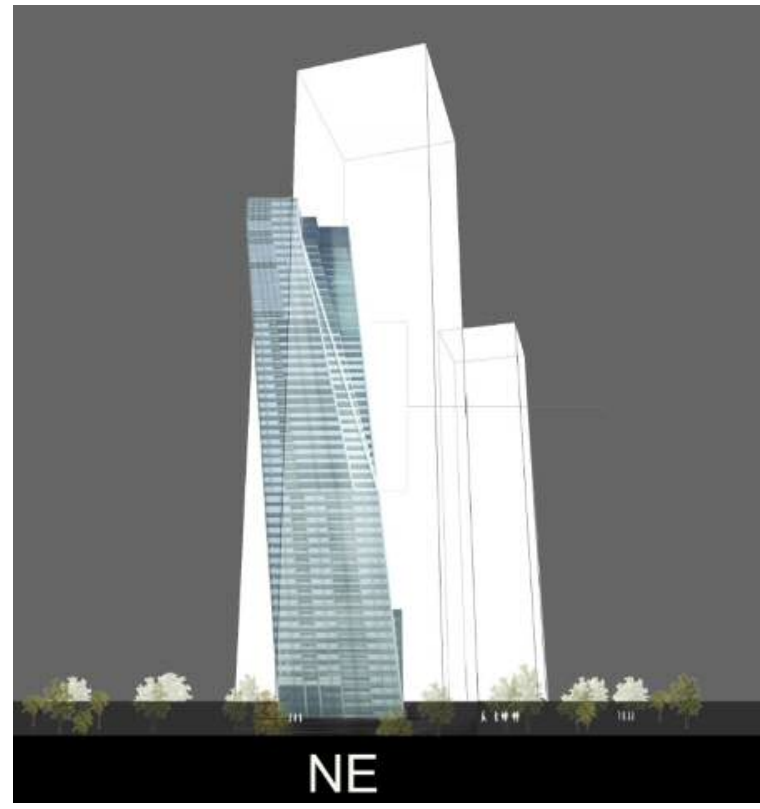

Figura 158 - Resultado final FAU-USP, fev. 2014 
adoção de sistemas de climatização devido à dificuldade em ventilar naturalmente edifícios altos), podendo-se chegar a um consumo inferior a $12,5 \mathrm{kWh} / \mathrm{m} 2$ por ano para aquecimento e $8,1 \mathrm{kWh} / \mathrm{m} 2$ por ano para refrigeração (ver figura 152).

\section{- Processo de elaboração da forma}

Visando reduzir o consumo e buscar uma solução para a verticalização e o adensamento de bairros residenciais, esse exercício de projeto propõe uma intervenção em um edifício alto num bairro já verticalizado de Seoul. Utilizando estratégias como rotação, inclinação e corte da forma de um edifício alto de planta originalmente quadrada, a intenção do projeto foi oferecer um maior acesso ao sol às unidades habitacionais e, com isso, melhorar o desempenho ambiental, principalmente nos dias frios do ano, quando a demanda pelos sistemas de climatização é maior.

A primeira estratégia foi rotacionar a forma original em 450 na direção SE, pois essa é a melhor orientação segundo estudos analíticos (fig. 153). Depois disso, observando as obstruções laterais pelos demais edifícios altos, buscou-se aumentar o acesso ao sol no inverno nas fachadas sudeste e sudoeste, inclinando as fachadas e recortando a planta, a fim de diminuir a obstrução dos edifícios vizinhos e aumentar a visão e o céu. Já nas fachadas voltadas a NE e NW, como o desempenho era pior do que as outras duas, pela baixa insolação, a estratégia utilizada foi adotar varandas envidraçadas, como nos precedentes residenciais locais, minimizando as perdas de calor pela envoltória (fig. 154 e 155).

Tendo finalizado o trabalho da forma, o passo seguinte foi avaliar o desempenho das fachadas de acordo com a área envidraçada, que variou não só em relação à orientação (como já estabelecido nos estudos analíticos), mas também em função da altura do pavimento, por conta do efeito de obstrução do entorno. Na fachada sudeste, os quartos permaneceram com $70 \%$ de área envidraçada, enquanto as salas ficaram com $90 \%$ de área envidraçada nos pavimentos superiores (onde a exposição à radiação é máxima), $70 \%$ nos pavimentos intermediários e $50 \%$ nos pavimentos inferiores (fig. 156). A redução da área envidraçada de cima para baixo foi calculada a fim de diminuir as perdas de calor pelo vidro, uma vez que os ganhos solares são menores devido à obstrução. Além disso, foi desenvolvida uma proteção solar externa composta por isolante térmico para 
evitar a perda de calor nas noites de inverno (fig. 157).

Nas fachadas noroeste e nordeste, foram mantidos as varandas fechadas como mediadoras climáticas, com $50 \%$ de área envidraçada na fachada interna. Na fachada sudoeste, foram projetados elementos de proteção solar.

Nesse projeto, a diferenciação das fachada ao longo da altura do edifício foi feita pela aplicação direta de critérios de desempenho térmico no projeto de cada pavimento do edifício alto. Esse mesmo processo poderia ter sido realizado com o auxílio de ferramentas de modelagem paramétrica da forma arquitetônica, que resultaria em uma solução final bem parecida, porém, com uma diferenciação gradual de área de vidro em cada pavimento, ao invés da delimitação precisa de três zonas verticais.

5.1.3 Rethinking office building typology in continental mediterran climate (Tomás Swett Amenábar, 2013)

\section{- Objetivos, Programa e Partido arquitetônico}

Esse exercício de projeto partiu do princípio de que o projeto de edifícios de escritórios da atualidade não contemplam os fatores climáticos, o contexto urbano e as novas tecnologias que redefinem constantemente o ambiente de trabalho, sendo o resultado uma tipologia que se repete, com alta demanda por energia mas com pouca ligação com as novas formas de se trabalhar (fig. 159), com o espaço destinado às atividades e com o contexto físico. Com isso, o objetivo da pesquisa foi criar um novo cenário de projeto para uma nova configuração espacial, tendo sido aplicado no contexto urbano hipotético de clima mediterrâneo na cidade de Santiago.

\section{- Contexto Climático}

Ao longo do ano, a média diária da temperatura do ar varia entre $8,40 \mathrm{C}$ e $210 \mathrm{C}$. As temperaturas mais altas ocorrem entre os meses de dezembro e fevereiro e as mais baixas, entre junho e agosto. $\mathrm{O}$ ano pode ser dividido em três períodos: um período quente que vai de novembro até março, com as temperaturas variando de $17,40 \mathrm{C}$ a 21oC; um período ameno em abril e outubro, com temperaturas em torno de 14,5oC; e um período frio de maio a setembro, com temperaturas variando entre $8,40 \mathrm{C}$ e $11,7 \mathrm{oC}$. 


\section{- Abordagem analítica}

Pontos verificados pelos estudos analíticos: a importância do controle da insolação em diferentes épocas do ano, o potencial da massa térmica e do isolamento térmico durante as horas de ocupação, a eficiência da ventilação natural para o conforto e o resfriamento do edifício no período noturno.

Para os estudos analíticos, tomou-se como base uma forma simples (shoe box), em que foram analisados três cenários: no primeiro, analisou-se a iluminação natural, a profundidade e a porcentagem de área envidraçada na fachada; no segundo, ganhos solares, orientação e porcentagem de área envidraçada na fachada; e, no terceiro, desempenho térmico e ganhos de calor interno, separando os espaços de uso coletivo e individual.

Por meio desses estudos foram, então, estabelecidas diferentes profundidades para a planta do ambiente de trabalho em função de dois parâmetros: a orientação e o WWR (window wall ratio). A fim de alcançar iluminação natural suficiente durante o período de ocupação (níveis de iluminação variando de 100 a 300 lux, das 9 às 20 horas), os valores de WWR de $50 \%, 66 \%$ e $75 \%$ foram atrelados a profundidades de $12 \mathrm{~m}, 15 \mathrm{~m}$ e $18 \mathrm{~m}$, respectivamente (fig. 161 e 162).

As conclusões e recomendações de projeto foram extraídas dos estudos analíticos, quais sejam:

- Atualmente, os ganhos internos são representados por apenas um valor para todas as áreas, o que pode sobrecarregar os sistemas sem a real necessidade. No entanto, há uma distribuição desigual de ganhos internos nos espaços de trabalho, que deve ser considerada na configuração do layout e no projeto das diferentes fachadas.

- Nesse clima, em particular, as condições internas têm uma influência maior no ambiente interno do que o clima externo.

- A insolação direta não é confortável sobre as estações de trabalho, mas pode ser aceita nas áreas comuns ou na circulação, melhorando a qualidade dos espaços sem afetar o conforto térmico.

- Ventilação noturna, massa térmica e controle solar são estratégias efetivas que reduzem 

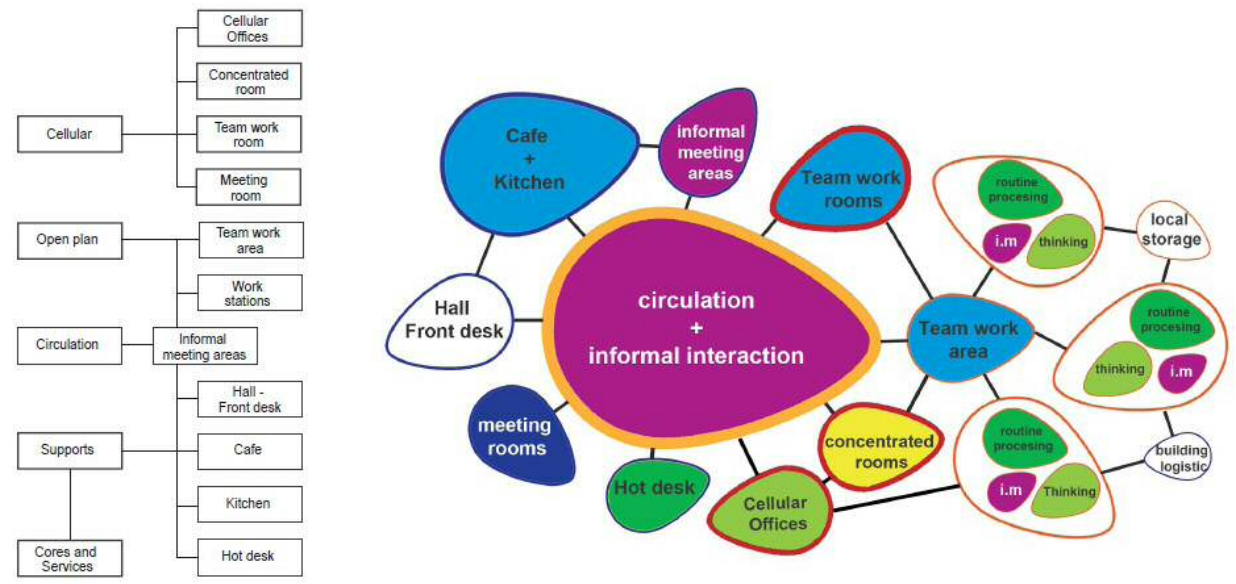

Figura 159 - Nova organização dos espaços internos de um edifício de escritório.

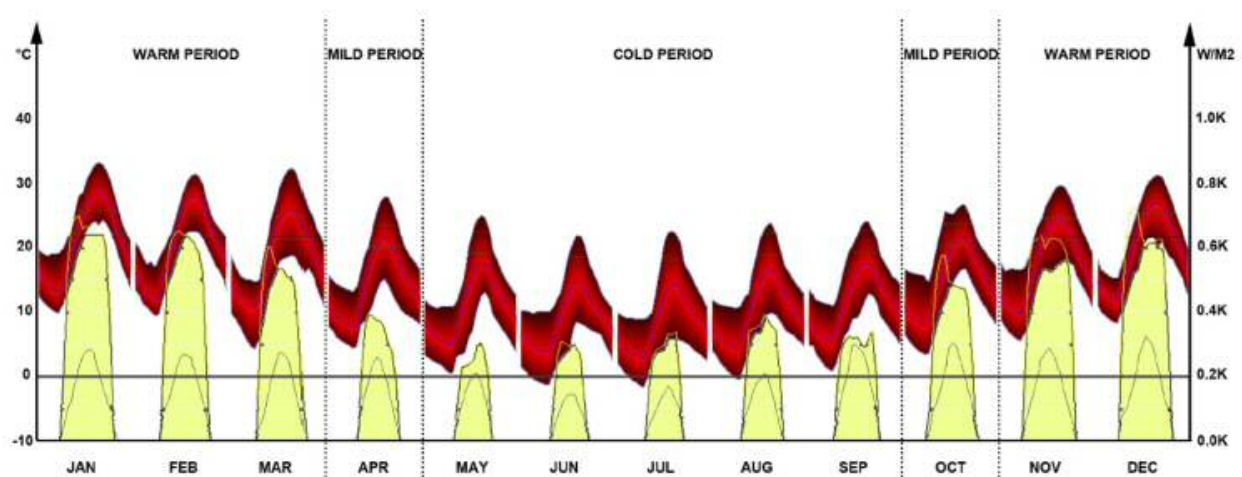

Figura 160 - Temperatura e radiação na cidade de Santiago, Chile. (Fonte: Meteornorm, v6.1)

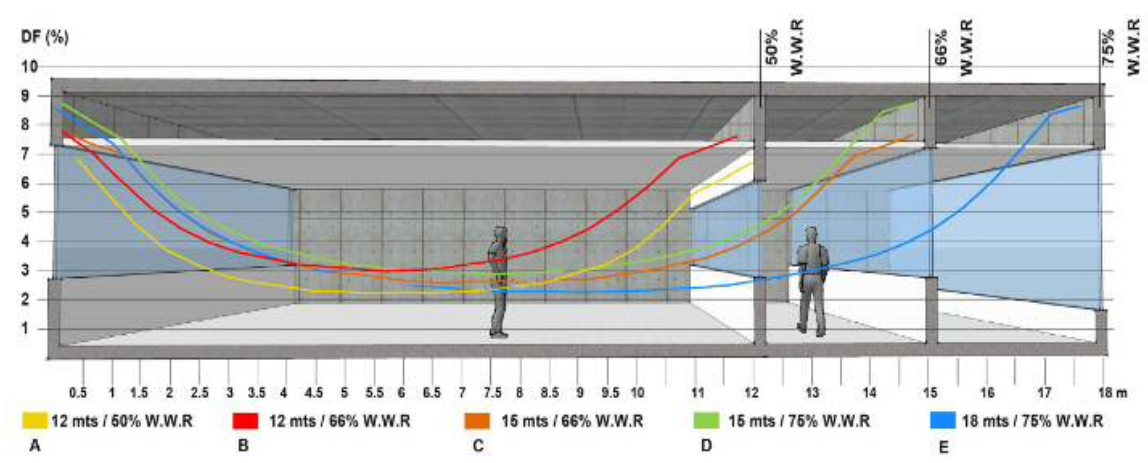

Figura 161 - Simulação de iluminação natural com diferentes profundidades. (Fonte: AMENÁBAR, 2013)

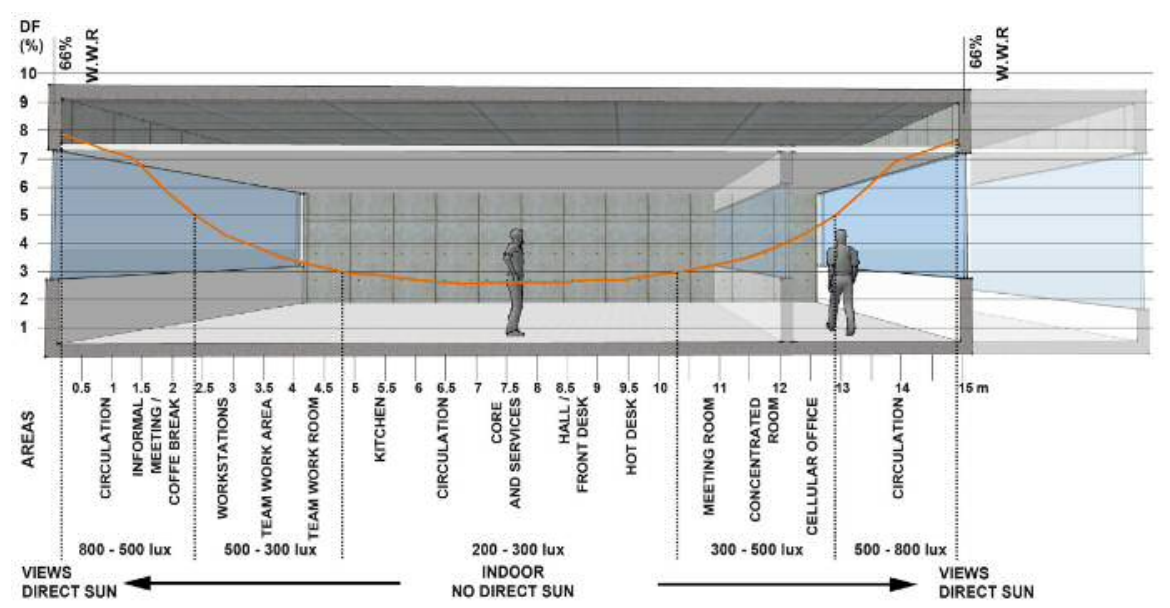

Figura 162 - Simulação de iluminação natural com usos. (Fonte: AMENÁBAR, 2013) 
a carga térmica de resfriamento nos edifícios localizados no clima Mediterrâneo.

- O impacto do contexto urbano varia ao longo da altura do edifício e das orientações, demandando estratégias diferentes por nível e por fachada.

\section{- Processo de elaboração da forma}

Nesse exercício de projeto, a forma arquitetônica foi definida, em grande parte, na etapa conceitual, com base em considerações acerca do programa de atividades, qualidade ambiental e eficiência energética. Nesse sentido, as principais estratégias arquitetônicas para a acomodação do programa de atividades e a inserção contextual do projeto foram: vilas verticais criadas para responder à flexibilidade do mercado e layout interno dividido em diversas zonas, conforme as condições internas e as necessidades dos usuários, criando "edifícios independentes" (fig. 163)

A planta foi dividida em blocos através de aberturas irregulares, que foram separadas por atividades diferentes (ver figura 164). As "fissuras" permitiram não somente a criação de zonas de transição entre os espaços, mas, também, o acesso da iluminação e da ventilação natural (ver figura 165). Após a definição da forma do edifício, a fachada foi projetada parametricamente para responder ao impacto físico do contexto em termos de radiação solar, das cargas térmicas anuais e da necessidade de acesso à iluminação natural.

Ou seja, o projeto arquitetônico é constituído por duas etapas distintas, mas complementares: a elaboração da forma, que segue um processo informativo, no qual os estudos analíticos de desempenho ambiental, específicos para esse programa, foram utilizados na definição de dimensões fundamentais do projeto, sendo esses a profundidade da planta e a altura do pé-direito dos vários espaços internos, com diferentes orientações. Com isso definido, foram realizados estudos paramétricos específicos para a composição das fachadas, de diferentes orientações.

Para o projeto da fachada utilizando a metodologia paramétrica de composição, foram selecionados três tipos de componentes: painel transparente, painel translúcido e painel opaco. Cada fachada foi analisada separadamente, dentro de um contexto urbano hipotético, com o objetivo de prover iluminação natural em níveis satisfatórios, sem causar ofuscamento e sem prejudicar o conforto térmico. Os componentes das fachadas foram especificados em estudos analíticos, de acordo com critérios de desempenho 
Capítulo 5 - Abordagem Conceitual e Estratégia Metodológica para o Projeto do Edifício Alto de Melhor Desempenho Ambiental Avaliação de Desempenho Ambiental e Arquitetura Paramétrica Generativa para o Projeto do Edifício Alto

172

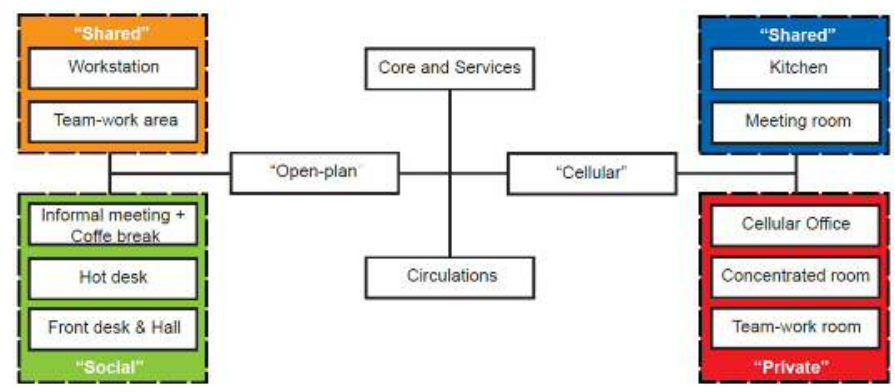

Figura 163 - Doze diferentes usos divididos em quatro áreas distintas. (Fonte: AMENÁBAR, 2013)

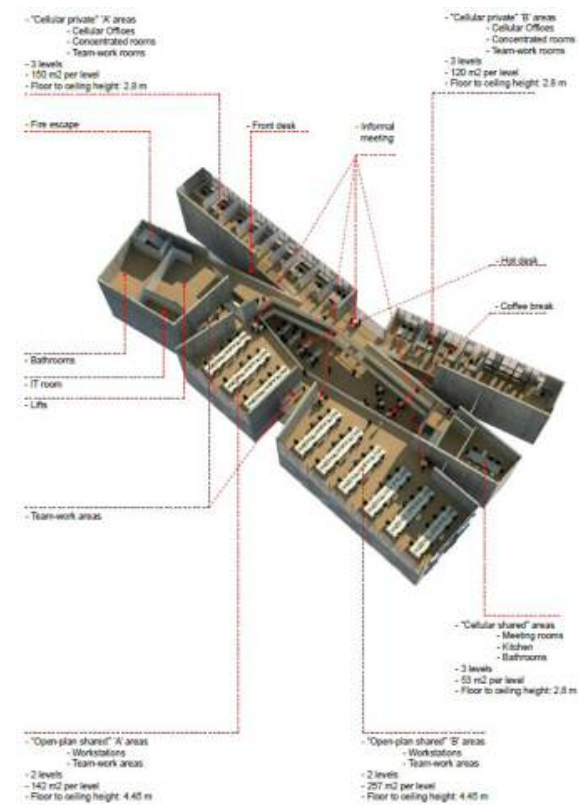

Figura 164- Planta dividida em blocos separadas por atividades. (Fonte:

AMENÁBAR, 2013)

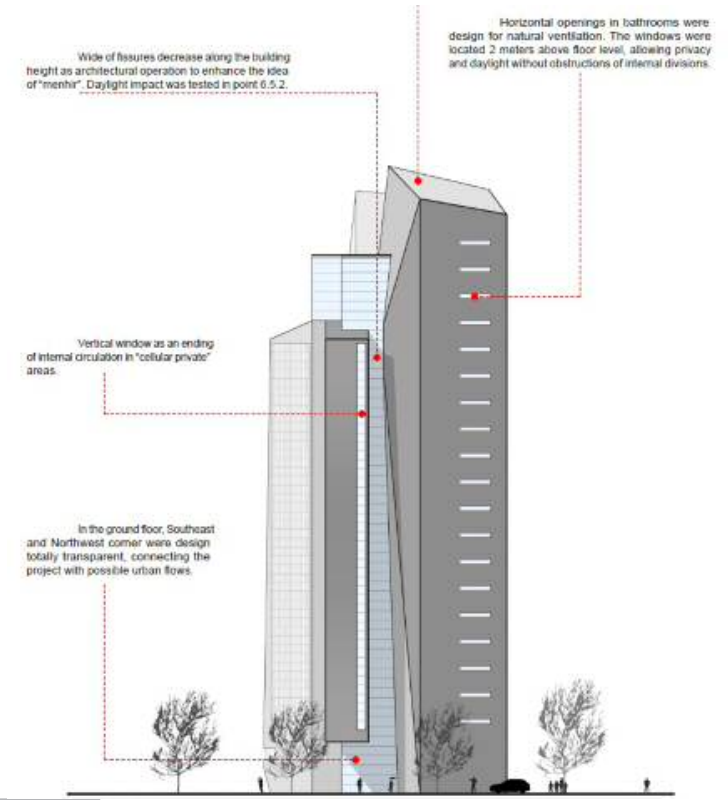

Figura 165- Fissuras e aberturas laterais na fachada oeste. (Fonte: AMENÁBAR, 2013)

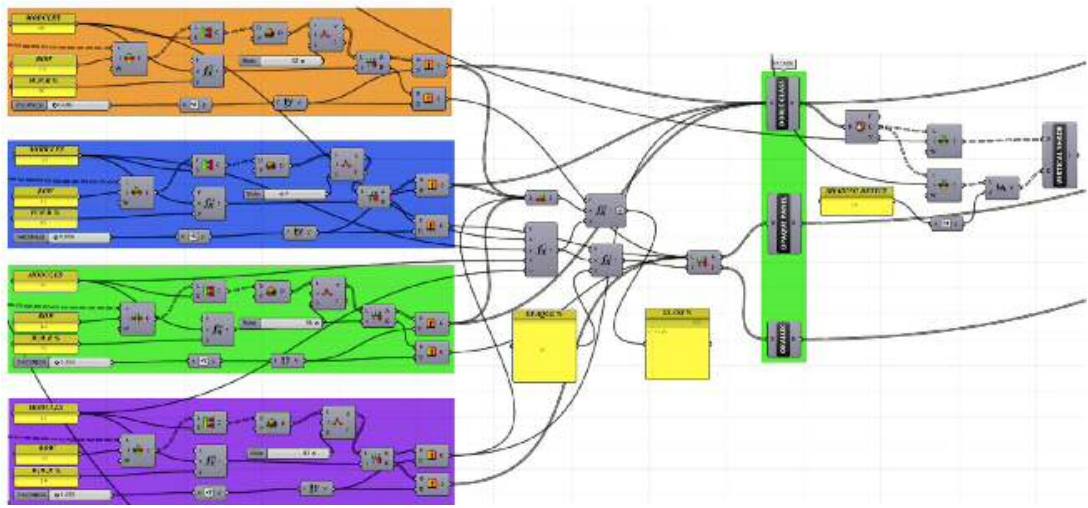

Figura 166- Imagem do Grasshopper usado na distribuição dos elementos da fachada. (Fonte: AMENÁBAR, 2013)

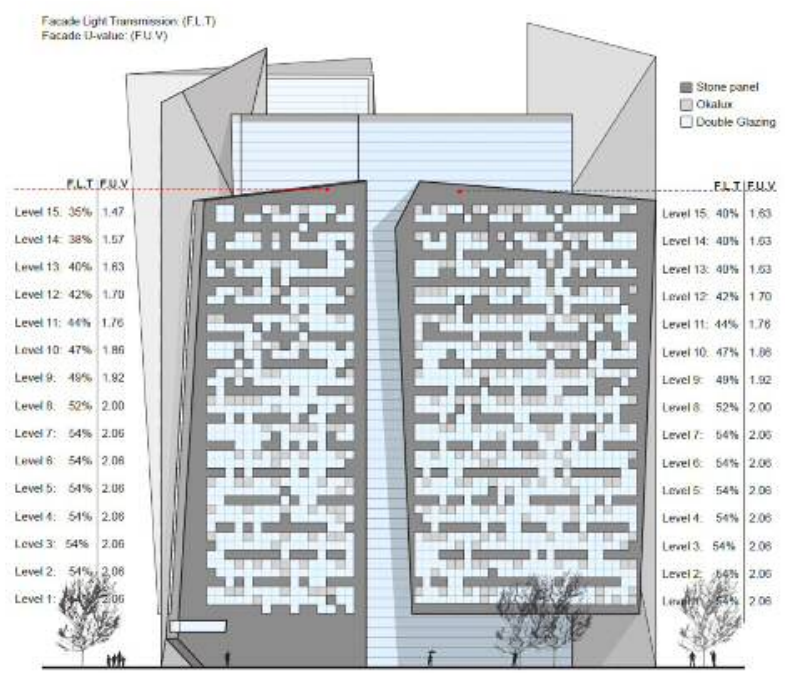

Figura 167- Fachada norte com os elementos distribuídos na fachada. (Fonte: AMENÁBAR, 2013) 


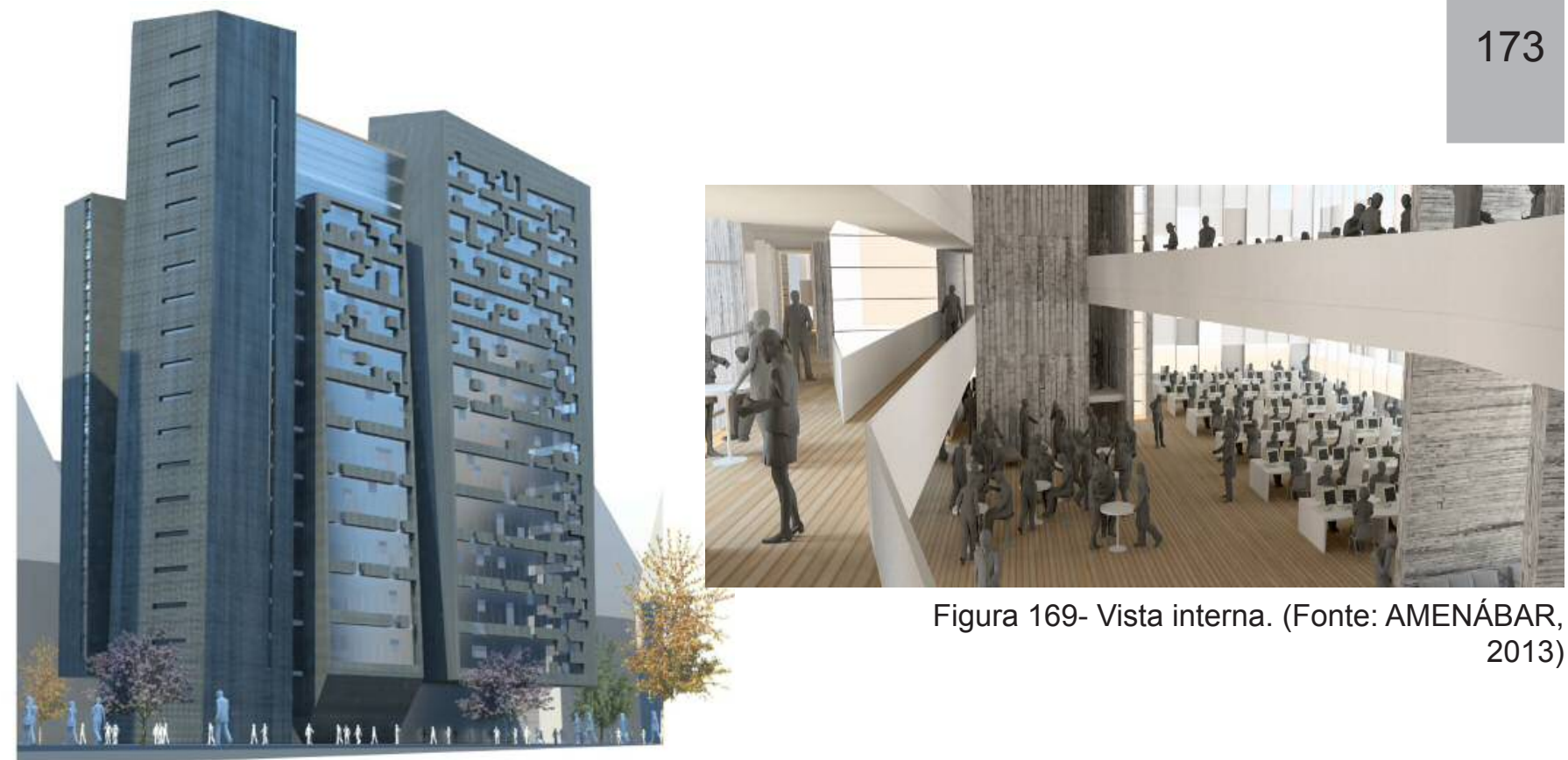

Figura168- Vista sudoeste do edifício. (Fonte:

AMENÁBAR, 2013)

luminoso e térmico, constituindo as opções de componentes a serem combinadas pelos programas de criação de formas paramétricas, como ilustrado nas figuras 166 e 167, sendo estes o programa de modelagem digital Rhinoceros e os plug-ins Grashopper e Geco.

\subsection{Projeto Viol}

\subsubsection{A proposta para o concurso de projeto}

O Projeto Viol foi um concurso fechado, realizado no ano de 2009, para a nova sede do Grupo Camargo Corrêa, em São Paulo. Nele, as equipes deveriam projetar duas torres com no máximo 140 metros de altura, de nível internacional, tendo sido possibilitada a divisão entre, no máximo, 2 locatários por pavimento. Segundo o grupo Camargo Corrêa, o projeto deveria ser criativo, inovador, um marco na cidade e de alta qualidade arquitetônica. Os custos de construção e operação deveriam ser os menores possíveis, além de ambientalmente responsável e energeticamente eficiente, com a utilização de materiais e métodos de construção compatíveis com a realidade brasileira.

A proposta aqui apresentada foi a elaborada pela equipe formada pelos escritórios Foster and Partners, de arquitetura, BDSP Partnership, de desempenho ambiental e 
sistemas prediais e ARUP and Partners, de engenharia de estruturas. Apesar de não ter vencido o concurso, o projeto em questão foi selecionado devido às lições metodológicas incorporadas no desenvolvimento da forma com base em estudos de desempenho ambiental.

O enfoque urbano da proposta foi transformar a área do terreno em uma praça, mantendo a vegetação local e privilegiando as vistas à partir do edifício. Assim, aproveitaram o terreno de $38.400 \mathrm{~m} 2$, com a construção de duas torres de 35 pavimentos com $64.150 \mathrm{~m} 2$ cada uma, uma área no térreo para serviços de $3.000 \mathrm{~m} 2$ e um centro de convenção de $1.000 \mathrm{~m} 2$.

\subsubsection{Elaboração da forma: estudos analíticos pró-projeto}

Esse exercício de projeto possui muitas similaridades com os estudos apresentados anteriormente, principalmente no que diz respeito ao uso de estudos analíticos simplificados de desempenho ambiental (mas com ferramentas avançadas de simulação computacional) na etapa conceitual de projeto. As principais etapas de preparação para a elaboração da forma foram:

- Levantamento das principais estratégias para o clima de São Paulo: sombreamento externo, iluminação natural, ventilação natural, massa térmica, átrio interno;

- Estudos de áreas para cada uso: área verde, área para escritórios, área para convenções e para serviços;

- Estudos de massa: primeiro, desenha-se a torre, elevando a mesma sobre pilotis; então, sobe-se com o parque no edifício e criam-se jardins em altura, permitindo-se a ventilação cruzada (fig. 172);

- Estudos de localização do core de elevadores: primeiramente no centro como um edifício típico em São Paulo, depois desloca-se para trás para aumentar a visão dos usuários, alarga-se a planta para melhorar ainda mais a visão, aumenta-se a fachada para melhorar a vista e a iluminação natural e curva-se a fachada; faz-se o mesmo para a parte de trás, visando diminuir a fachada leste e oeste, e criam-se jardins com pédireito triplo para melhorar a iluminação e a ventilação natural (fig. 173);

- Estudos analíticos, fase 1: estudos de desempenho térmico. Utiliza-se um caso base, 


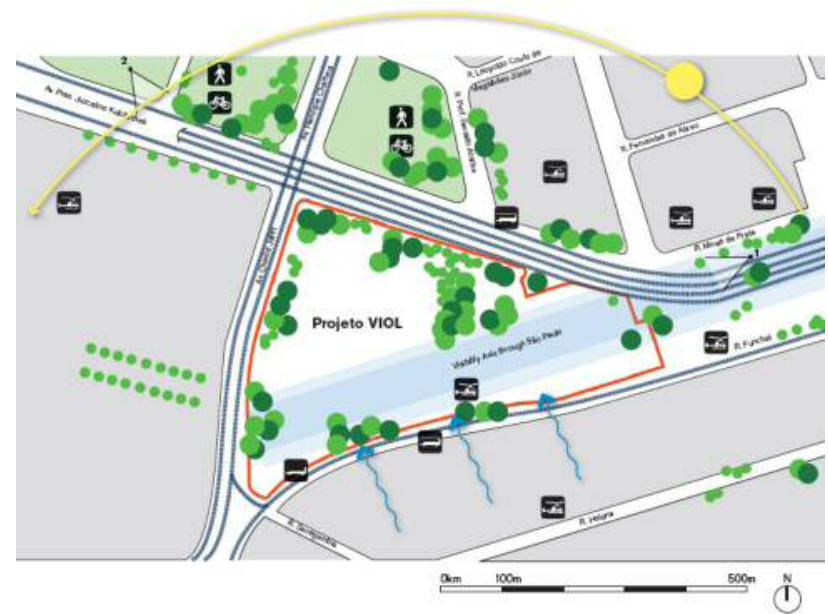

Figura 170 e 171- Localização da área do projeto.
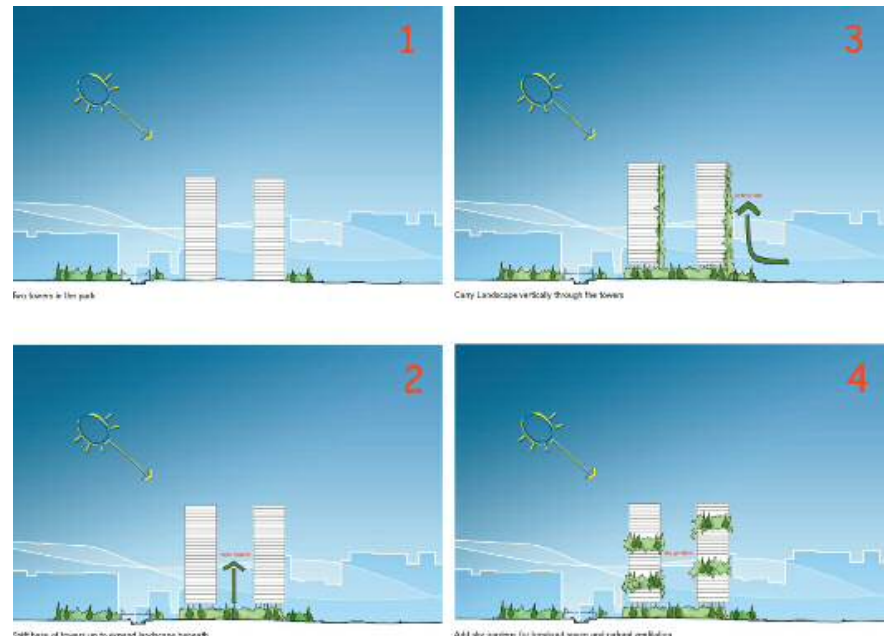

Figura 172- Estudos de massa. Fonte: BDSP, 2009.

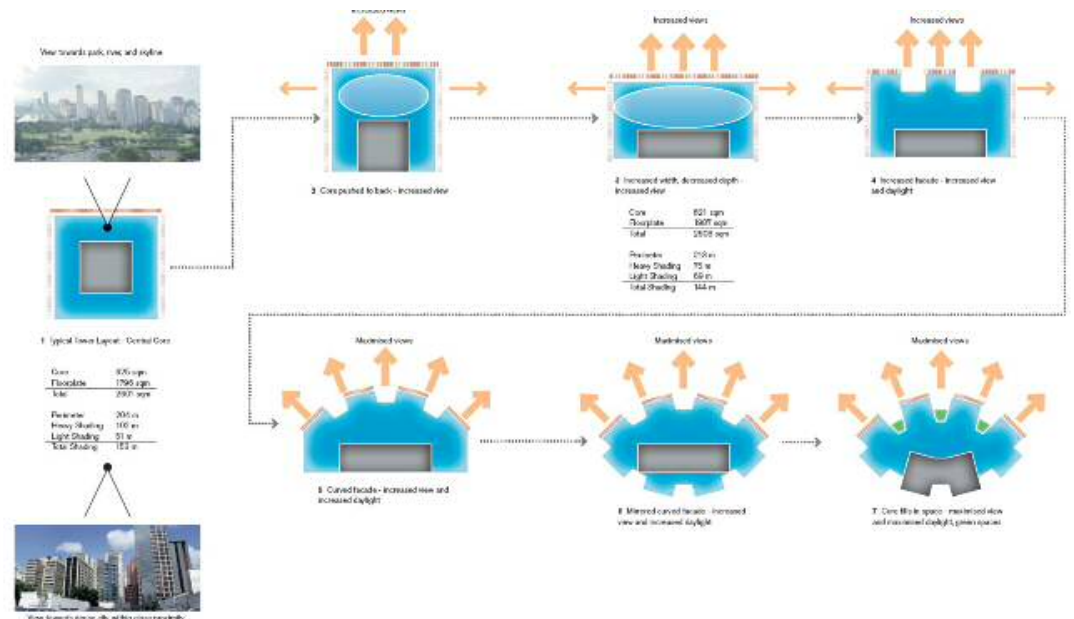

Figura 173 - Estudos para planta e localização do core de elevadores. Fonte: BDSP, 2009.

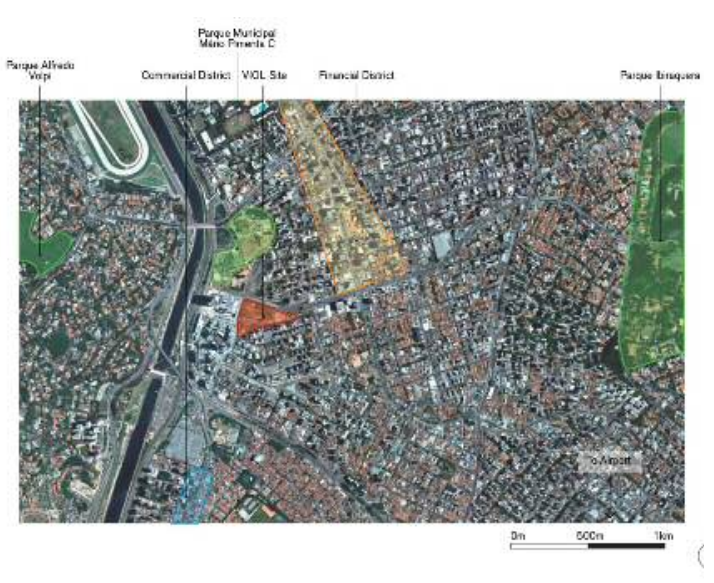



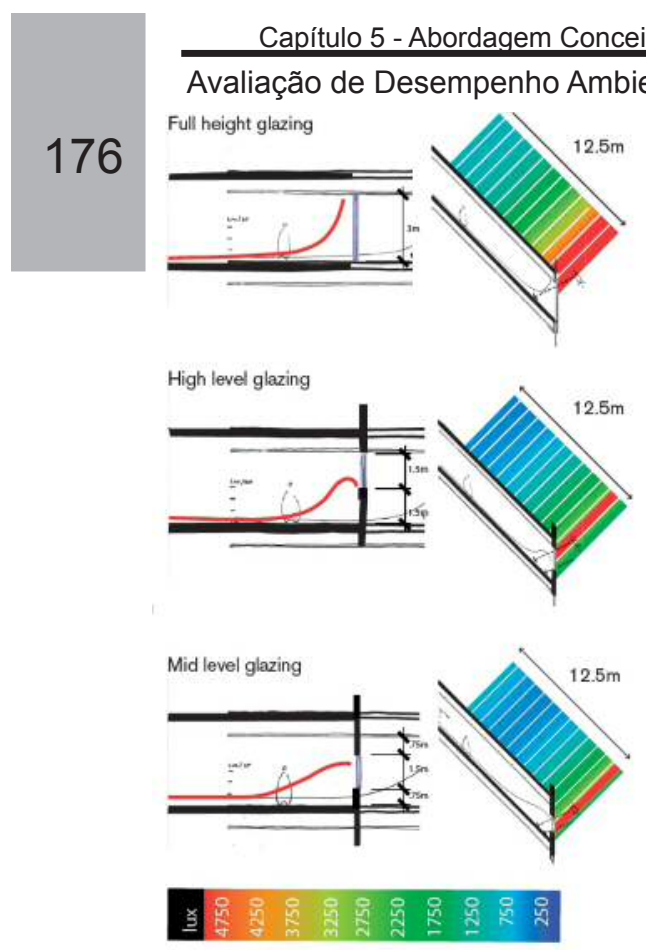

Figura 175- Estudos analíticos de iluminação, fase 2. Fonte: BDSP, 2009.

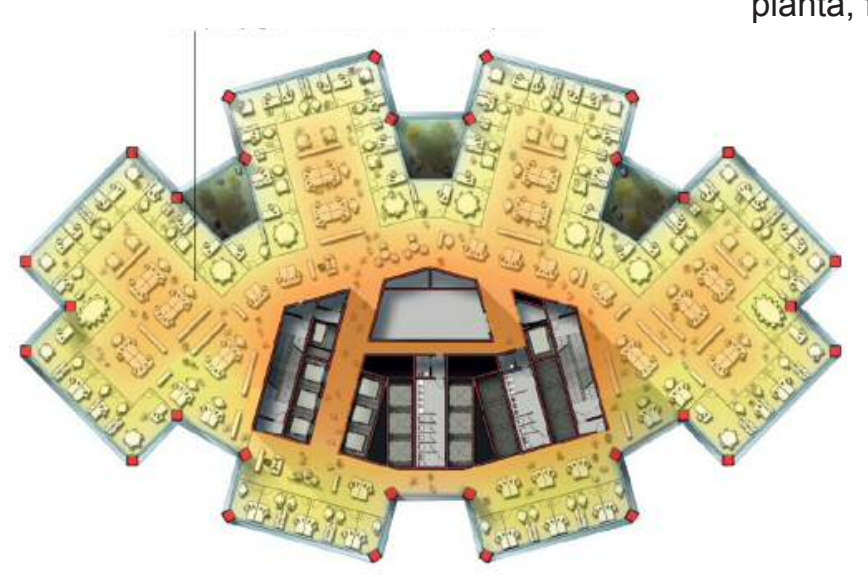

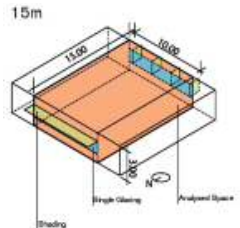
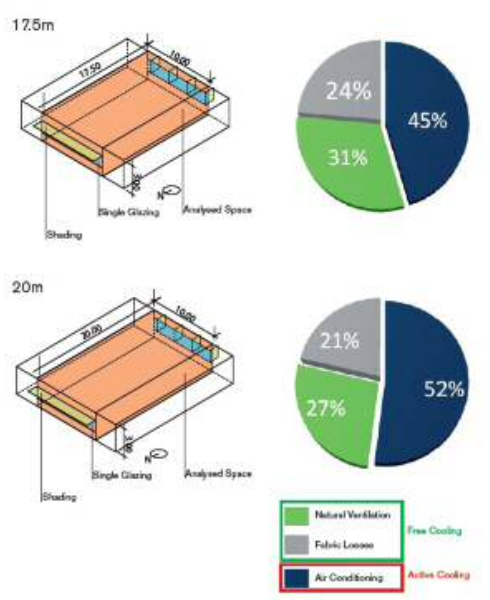

Figura 176 - Estudos analíticos de porcentagem do tempo em que se pode usar ventilação natural dependendo da profundidade da planta, fase 3. Fonte: BDSP, 2009.

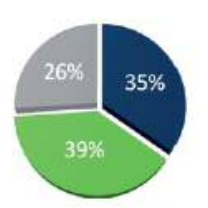

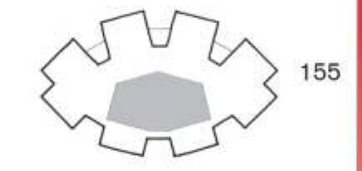
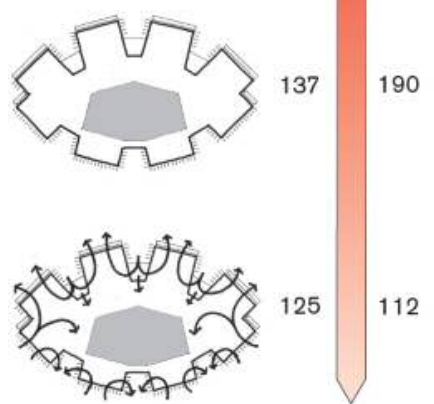

Figura 177 - Estudos analíticos de consumo de energia dependendo da estratégia utilizada, fase 3. Fonte: BDSP, 2009.

Figura 178 e 179- Estudos analíticos de iluminação e ventilação natural, fase 3. Fonte: BDSP, 2009

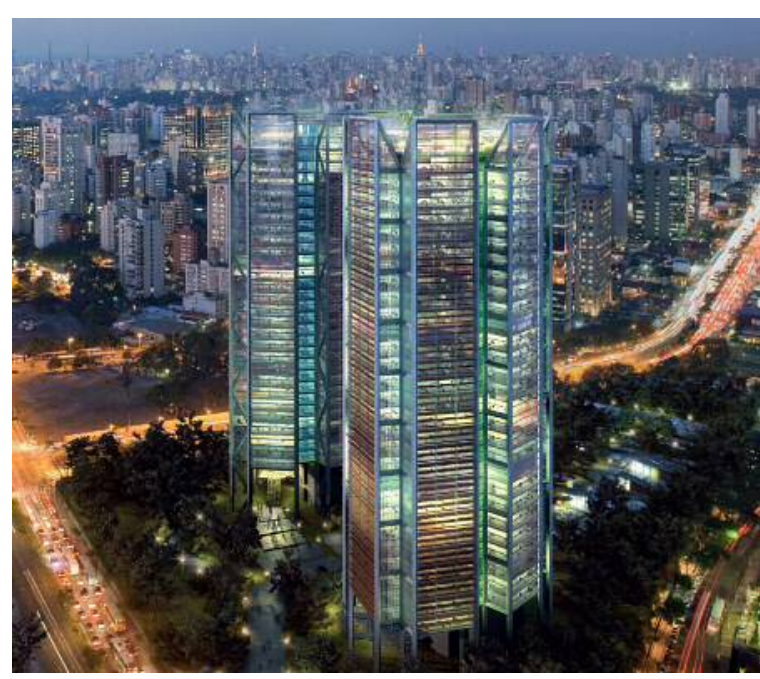

Figura 180- Modelo final. Fonte: BDSP, 2009.

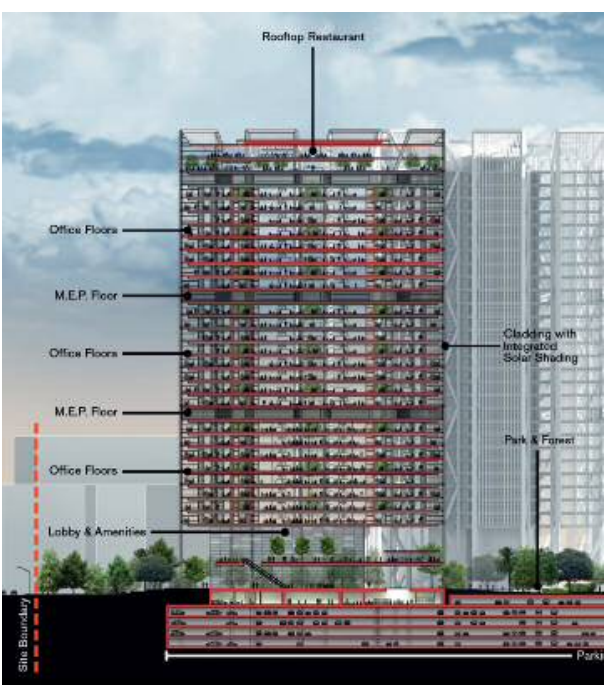

Figura 181- Corte. Fonte: BDSP, 2009. 
adiciona-se massa térmica exposta, ventilação noturna, elemento de sombreamento, trocam-se os vidros por vidros duplos e simples e, no final, avalia-se o melhor desempenho (fig. 174);

- Estudos analíticos, fase 2: de insolação, profundidade de planta e ventilação. Analisouse três profundidades de plantas (15m; 17,5m e $20 \mathrm{~m})$, com três alturas diferentes de janela (totalmente envidraçada, janela alta e janela média), com e sem sombreamento (fig. 175);

- Estudos analíticos, fase 3: de tipos de layout (celular e planta livre) com ventilação natural e com ar-condicionado (fig. 176, 177 e 178).

Nessa proposta de projeto para o concurso do Projeto Viol, a ideia chave para reduzir a quantidade de energia que um edifício precisa para o resfriamento, a iluminação, ventilação e equipamentos, consistiu em estratégias arquitetônicas que respondem ao ambiente externo com criatividade, apoiadas em avaliações quantitativas do seu desempenho ambiental. Como resultado dos estudos analíticos, foi possível atingir, em teoria, uma redução no consumo de energia de $54 \%$, através de uma forma inovadora, proteção solar adequada e uso da ventilação natural por grande parte do período de

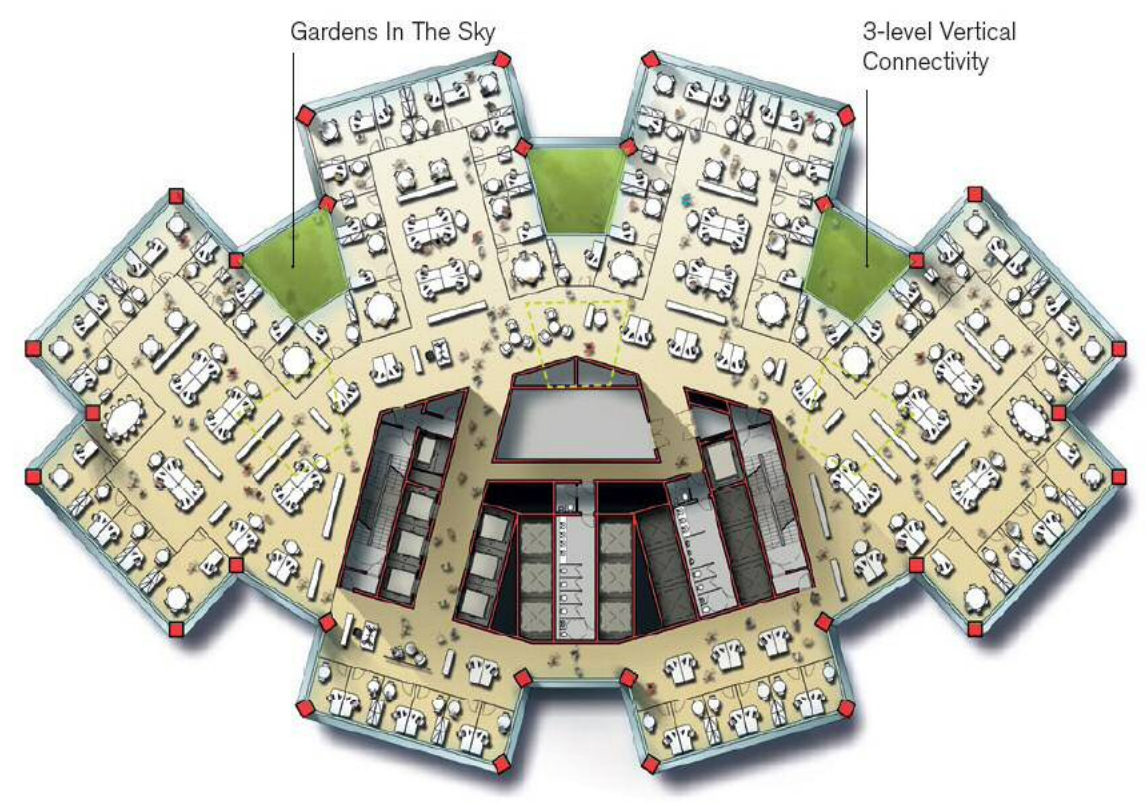

Provision of Social Meeting Spaces

Figura 182 - Áreas de convivência. Fonte: BDSP, 2009. 
ocupação.

\subsection{Projeto Paramétrico e Prototipagem Rápida: um Exercício de Projeto para a Fachada de um Edifício Alto, AA Visiting School, São Paulo, 2011}

A criação de formas arquitetônicas inovadoras é tema central dos processos de projeto que caracterizam a chamada arquitetura generativa. Nessa abordagem, inovações relacionadas aos processos e critérios de concepção da forma arquitetônica aplicam-se tanto ao edifício como aos seus componentes com o uso da simulação computacional, envolvendo questões de insolação, iluminação e ventilação.

\subsubsection{Abordagem metodológica: aspectos gerais}

Dando continuidade à discussão sobre a influência da tecnologia digital na arquitetura, o exercício de projeto, que será apresentado a seguir, explorou o tema do edifício alto de melhor desempenho ambiental, utilizando estratégias e ferramentas de geração de formas da chamada arquitetura generativa, também conhecida como arquitetura paramétrica (diferentemente dos procedimentos analíticos paramétricos do desempenho ambiental), combinadas a princípios, critérios e métodos de avaliação do desempenho ambiental. O projeto foi desenvolvido no workshop promovido pela escola de arquitetura Architectural Association School of Architecture, de Londres, e aconteceu em São Paulo, no ano de $2011^{1 .}$

A proposta partiu do desenvolvimento de um padrão geométrico para a formação de módulos de fachada que pudessem se movimentar, abrindo e fechando de acordo com a variação dos níveis de radiação incidente. Com isso, esses elementos de controle de radiação solar poderiam ser, então, estruturados de forma a serem aplicados ao longo da fachada de um edifício alto de escritórios, idealizado para a latitude de São Paulo.

Além do desenvolvimento dos componentes da fachada, fez parte do exercício, também, repensar a forma retangular padrão dos edifícios de escritórios da Avenida Paulista. Assim, a forma do edifício foi concebida com o objetivo de provocar um

1 O curso foi coordenado pelos professores da Architectural Association Anne Save de Beaurecueil e Franklin Lee, também sócios fundadores do escritório de arquitetura anglo-brasileiro SUBdV. 
auto-sombreamento parcial da área de fachada no período dos equinócios, sendo essa proteção complementada pelos componentes de padrão geométrico e operação previamente definidos.

Para a modelagem paramétrica, foram utilizados o programa Rhinoceros e seus aplicativos Grasshopper e Geco. A produção de modelos físicos e protótipos foi realizada com tecnologia de corte a laser e máquinas de usinagem CNC.

\subsubsection{Desenvolvimento do componente}

\section{Modelo físico}

O exercício de projeto teve início com a elaboração de modelos físicos que serviram de base para a modelagem paramétrica computacional, a qual, por sua vez, teve continuidade na fabricação digital de componentes para o projeto de fachada, com o entendimento das possibilidades formais e estruturais pelo modelo físico. Na sua etapa final, o processo de projeto volta para o aprimoramento dos modelos digitais no que se refere às questões propostas de desempenho ambiental, nesse caso, de controle da radiação e da iluminação natural.

Na busca por um padrão geométrico simplificado e de fácil repetição, o modelo físico do componente teve a sua forma definida por uma base triangular, cuja volumetria foi criada à partir da aplicação de esforços de tensão sobre uma superfície de tecido elástico, alcançados com o auxílio de linhas de costura, feitas sobre as laterais do triângulo com, aproximadamente, 15 centímetros de comprimento (fig. 183 e 184). O aspecto tridimensional e de estrutura rígida do padrão geométrico foi acentuado por um desenho de triângulos intercalados e de diferentes dimensões (os componentes), tensionados nos vértices de junção (fig. 185 e 186). No entanto, o resultado formal não alcançou, nessa primeira tentativa, a tridimensionalidade buscada para ser um módulo de fachada.

Visando alcançar a tridimensionalidade no modelo, montou-se uma estrutura externa em madeira, onde foram tensionados os vértices dos triângulos (fig. 187). No entanto, como o objetivo era chegar em um módulo para uma fachada, essa estrutura não se mostrou adequada.

Para a aplicação do padrão geométrico de triângulos tridimensionais em um plano de 


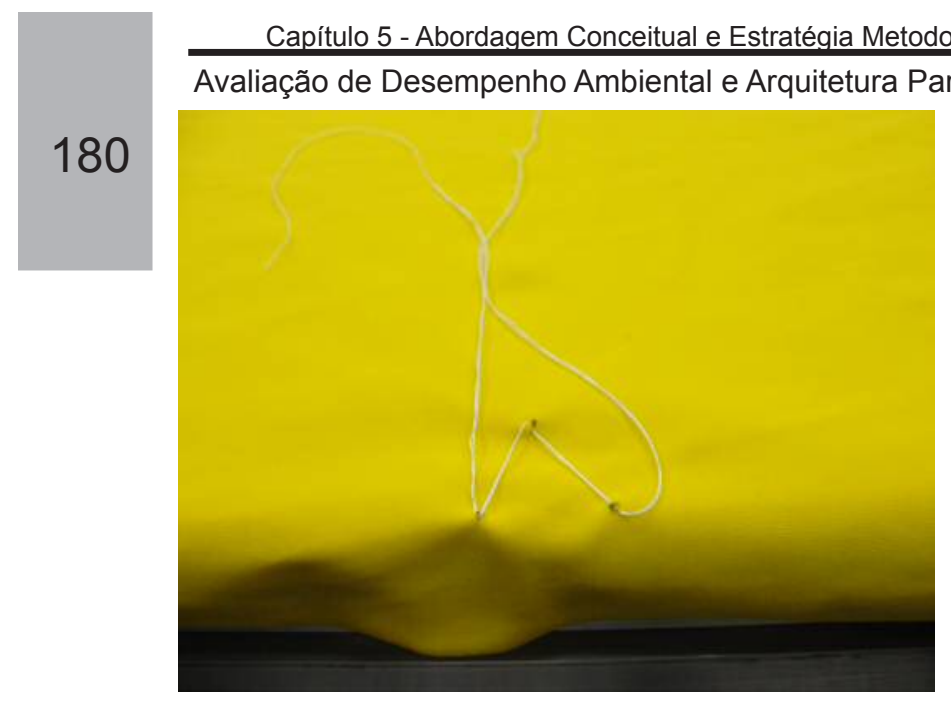

\section{lógica para o Projeto do Edifício Alto de Melhor Desempenho Ambiental} Avaliação de Desempenho Ambiental e Arquitetura Paramétrica Generativa para o Projeto do Edifício Alto

Figuras 183 e 184 - Desenho da forma triangular inicial sobre tecido elástico.
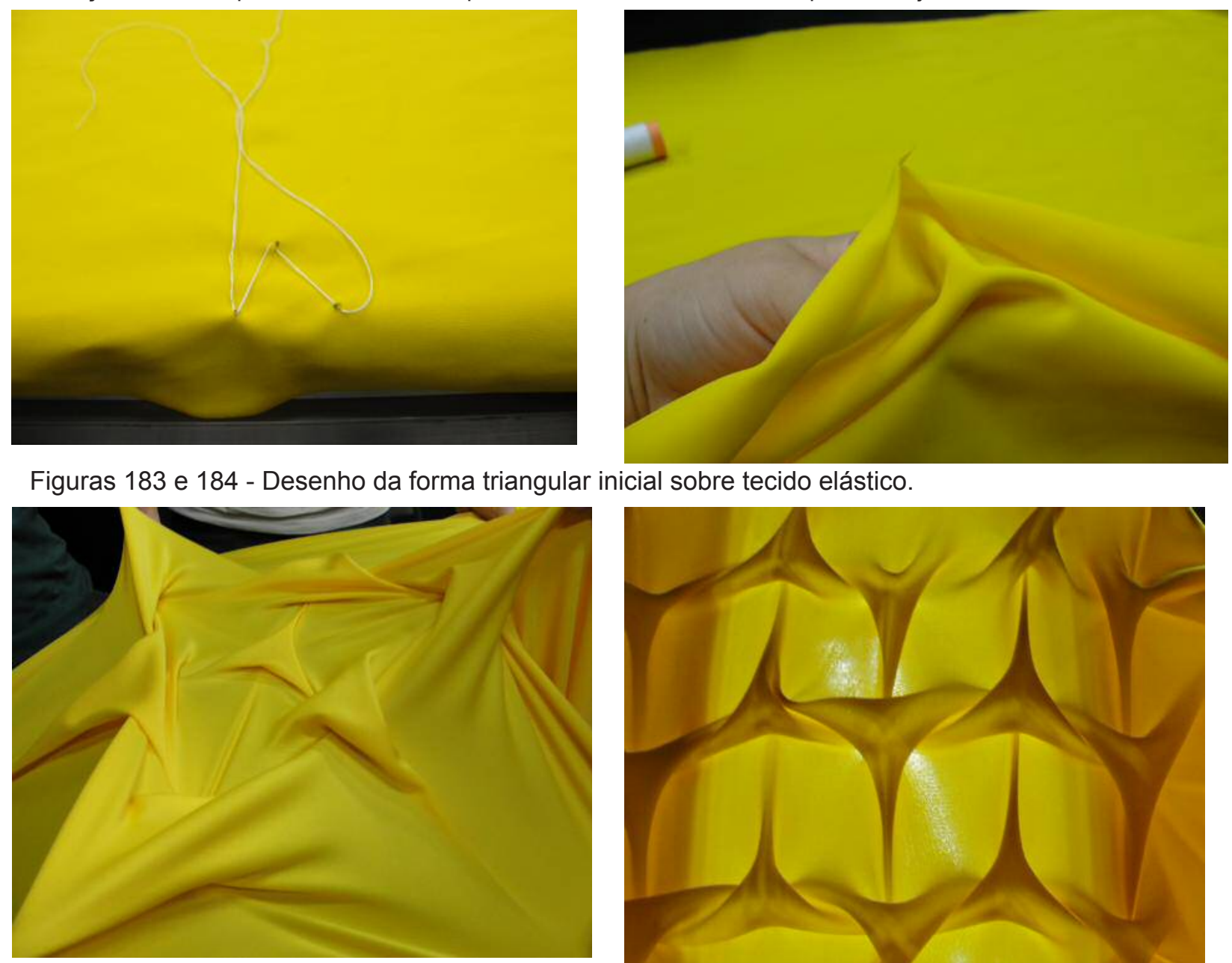

Figuras 185 e 186 - Padrão geométrico gerado a partir da forma triangular.
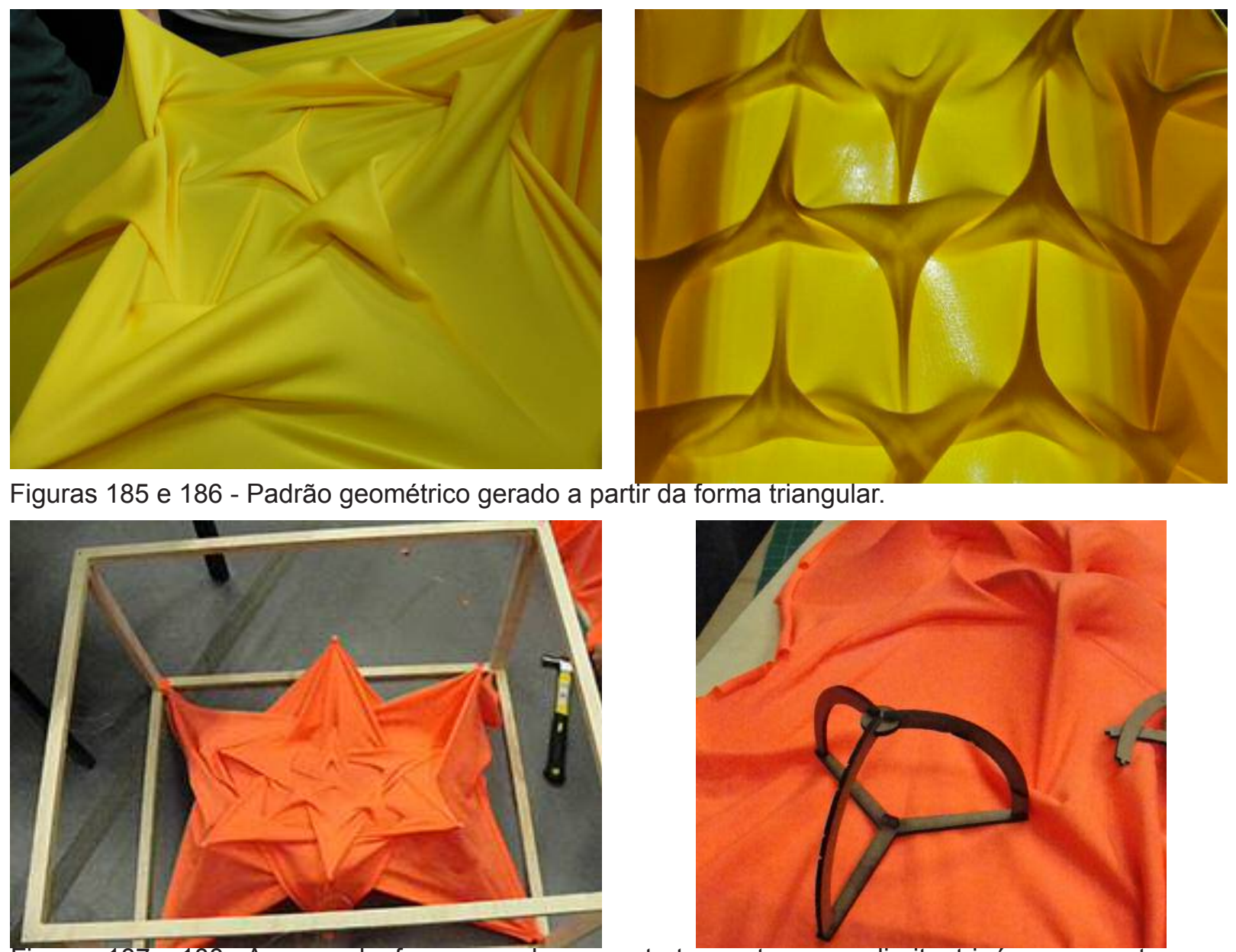

Figuras 187 e 188 - A esquerda, forma gerada com estrutura externa e a direita, tripé com suporte inferior.

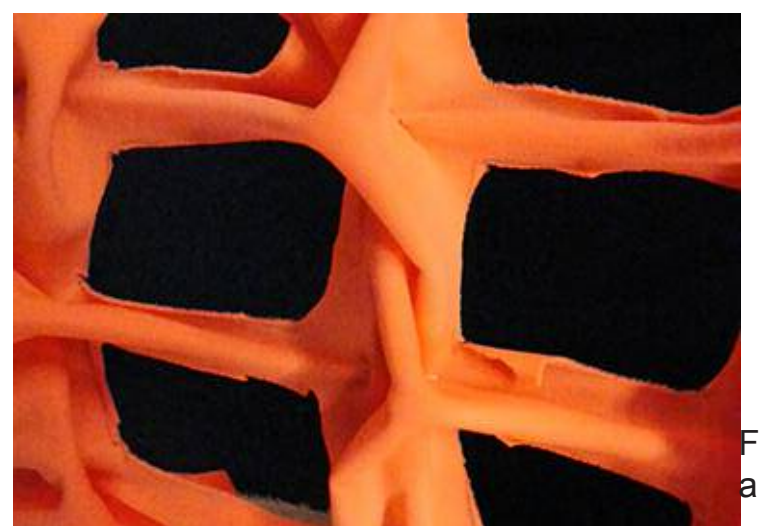

Figura 189 - Teste no modelo físico para as aberturas. 
fachada, fez-se necessária a inserção de uma estrutura interna de sustentação da forma, sem interferir nos esforços externos de tensão. Para isso, foi desenvolvido um tripé (cortado à laser) com encaixes na parte superior.

Visando manter a estrutura dos módulos criados pelo padrão geométrico independente da estrutura da fachada, houve a necessidade de inclusão de mais um elemento estrutural, agora horizontal, com encaixes nas pontas para o apoio das hastes verticais, que são as estruturas que fazem os triângulos ganharem forma tridimensional. Nesse sistema, a estrutura tensiona o tecido, que toma o formato de meia esfera, criando possibilidades de aberturas para a entrada da iluminação natural (fig. 188).

O passo seguinte (da evolução do padrão geométrico de triângulos tridimensionais para um elemento de proteção solar de fachada) foi a marcação de aberturas no modelo de tecido elástico tensionado, com a finalidade de permitir a passagem controlada e adequada da radiação solar pelo componente. No entanto, nesse caso, o modelo físico impôs uma limitação aos estudos de desempenho do componente como proteção solar. Pela sua condição tensionada e estática, a estrutura não permitiu a variação das aberturas e, consequentemente, do controle de radiação e luminosidade (fig. 189).

\section{Modelo digital}

A interação entre o modelo físico e a tecnologia digital foi efetivada com a passagem do padrão geométrico para a modelagem computacional, gerada pelo programa Rhinoceros. Com as possibilidades dos recursos computacionais, o modelo digitalizado serviu de base para estudos exploratórios sobre variações das aberturas do padrão geométrico, de acordo com oscilações da radiação solar incidente. Gerou-se uma versão modificada do padrão geométrico, originalmente produzido pela modelagem física, agora na forma digital.

No entanto, vale ressaltar aqui que a reprodução do modelo físico no modelo digital não se deu de forma direta, uma vez que o programa computacional Rhinoceros e o seu plug-in Grashopper trabalham com base em modelos matemáticos, e não com uma linguagem geométrica. Assim, o desafio da modelagem digital foi a criação de um modelo matemático que resultasse no mesmo desenho do objeto físico e com a possibilidade de ser operado parametricamente, respondendo a variações de dados 
climáticos.

A criação do modelo digital baseou-se em modelos matemáticos de representação de triângulos feita no programa Rhinoceros e no seu plug-in Grashopper. O resultado físico do padrão criado no modelo digital constituiu-se em uma estrutura essencialmente bidimensional, como consequência da simplificação geométrica da modelagem digital (fig. 190). No entanto, com o auxílio dos cortes à laser e a estrutura interna, que permaneceu a mesma, alcançou-se um modelo físico modificado, mas com os princípios volumétricos iniciais, com a profundidade inerente às estratégias de sombreamento. Em suma, o processo de concepção da forma trabalhou uma adaptação do modelo físico para o modelo eletrônico, que, por sua vez, gerou um novo modelo físico, mais elaborado.

\section{Prototipagem digital}

Retomando os trabalhos no modelo físico, o padrão geométrico modificado com aberturas controláveis foi, então, recortado à laser sobre o tecido elástico. Assim, nesse novo modelo, quanto mais tensionado estivesse o tecido, mais aberto estaria (fig. 191). Tendo em vista que o modelo antigo da estrutura era fixo e não permitia a variação das aberturas, foi desenvolvida uma estrutura retrátil para funcionar como a estrutura de um guarda-chuva, no qual as hastes, agora flexíveis, pudessem ser moldadas conforme o tecido fosse tensionado. A nova estrutura de sustentação foi montada sobre a base horizontal do modelo original, na qual hastes curvilíneas retráteis foram instaladas para a modelagem do tecido quando tensionado.

A evolução do sistema estrutural do modelo físico (fig.192) foi seguida, em paralelo, pela elaboração de um elemento geométrico parametrizado, na sua base digital, com as mesmas caraterísticas geométricas do modelo físico.

Como mencionado anteriormente, elegeu-se como parâmetro de controle das aberturas dos triângulos a incidência da radiação solar direta sobre o plano da malha de triângulos, ou seja, quanto maior a quantidade de radiação solar global sobre ela (a superfície dos triângulos), maior o fechamento da malha (fig.193). A adaptabilidade da solução permite que a mesma possa ser aplicada em qualquer orientação. Nesse exercício piloto de 
Capítulo 5 - Abordagem Conceitual e Estratégia Metodológica para o Projeto do Edifício Alto de Melhor Desempenho Ambiental Avaliação de Desempenho Ambiental e Arquitetura Paramétrica Generativa para o Projeto do Edifício Alto

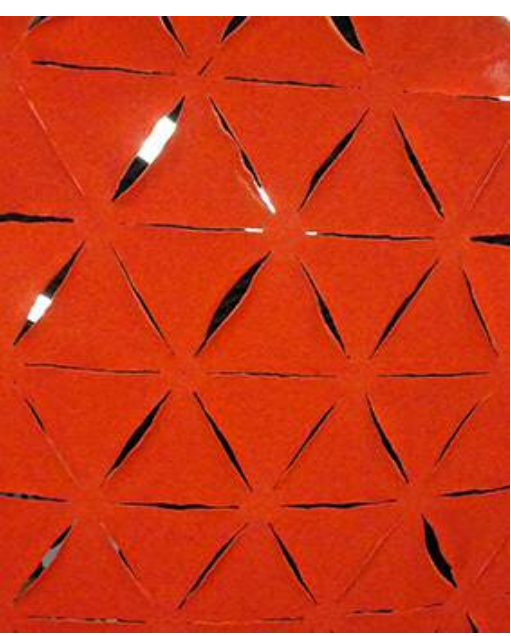

Figura 190 - Modelo digital cortado à laser sobre um tecido elástico.

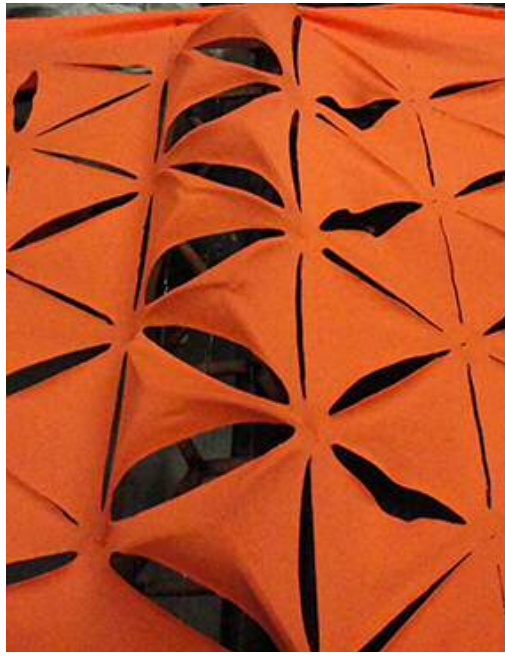

Figura 191 - Aberturas no tecido devido ao tensionamento do mesmo.

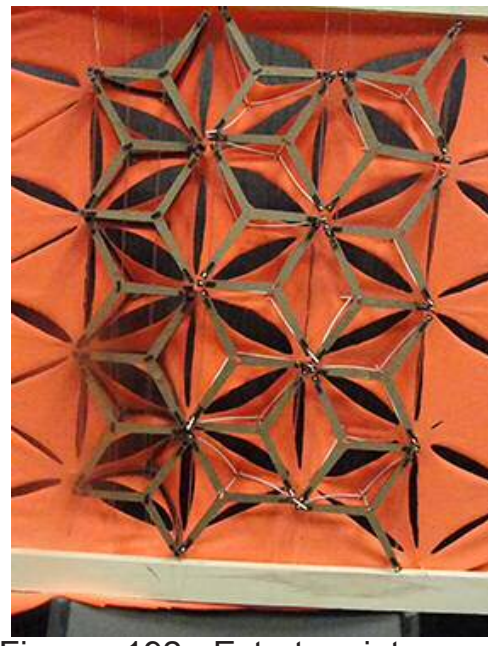

Figuras 192 - Estrutura interna do modelo retrátil.

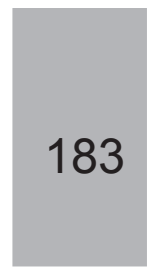

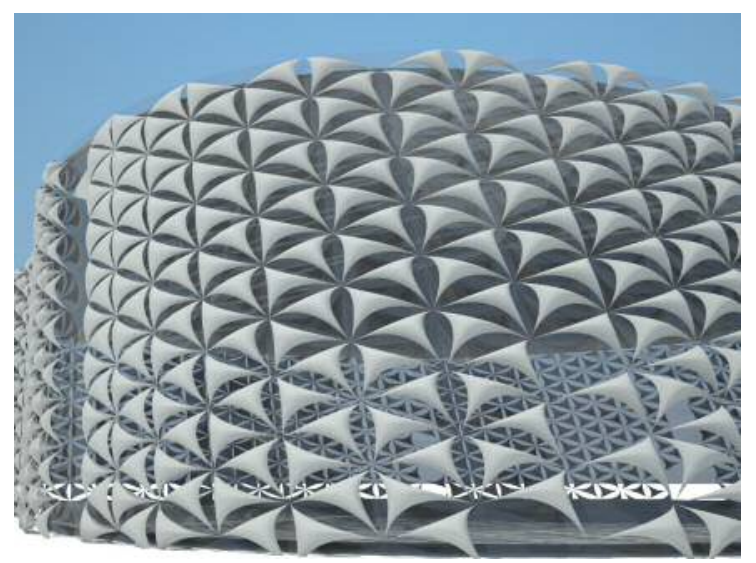

Figura 193 - Vista externa da composição dos componentes da fachada. Modelo eletrônico gerado pela combinação dos programas Rhino e Grasshopper.

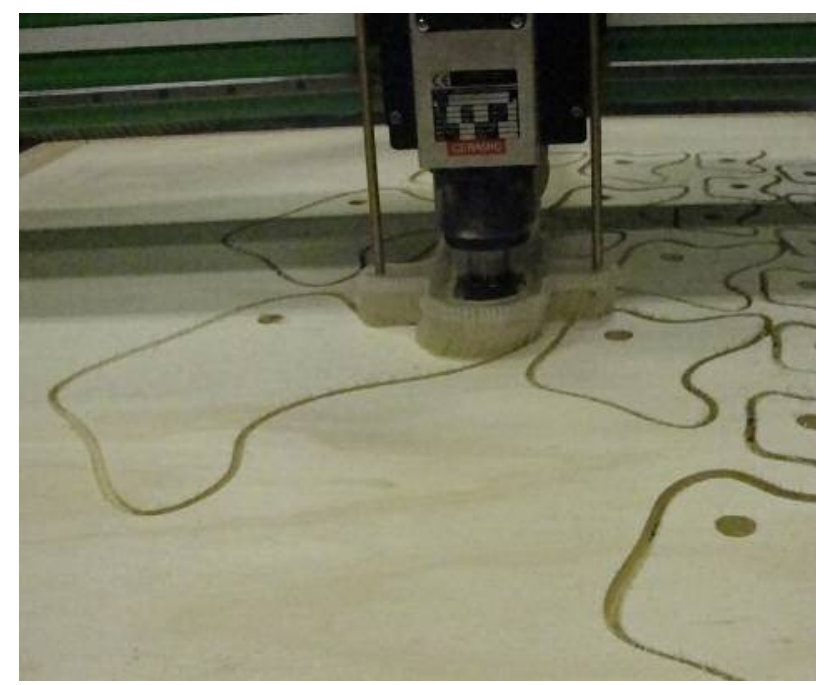

Figura 195 - Corte na CNC da maquete do edifício projetado.

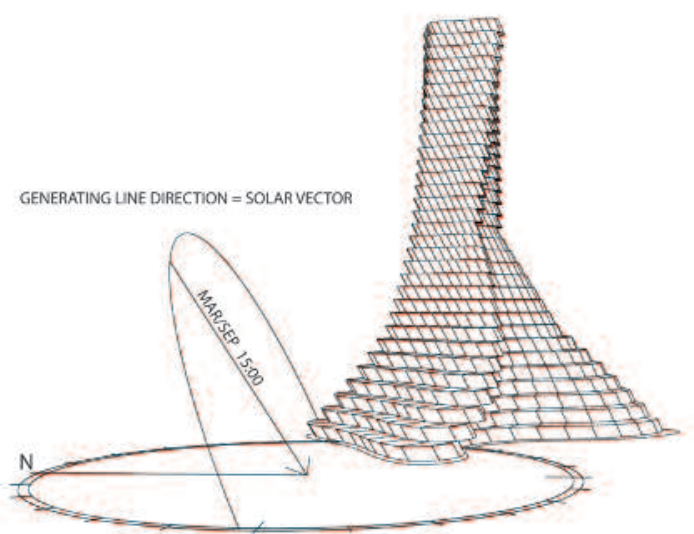

Figura 194 - Modelo eletrônico do edifício alto, com a indicação do angulo de inclinação dos planos verticais, objetivando o autos sombreamento parcial da forma.

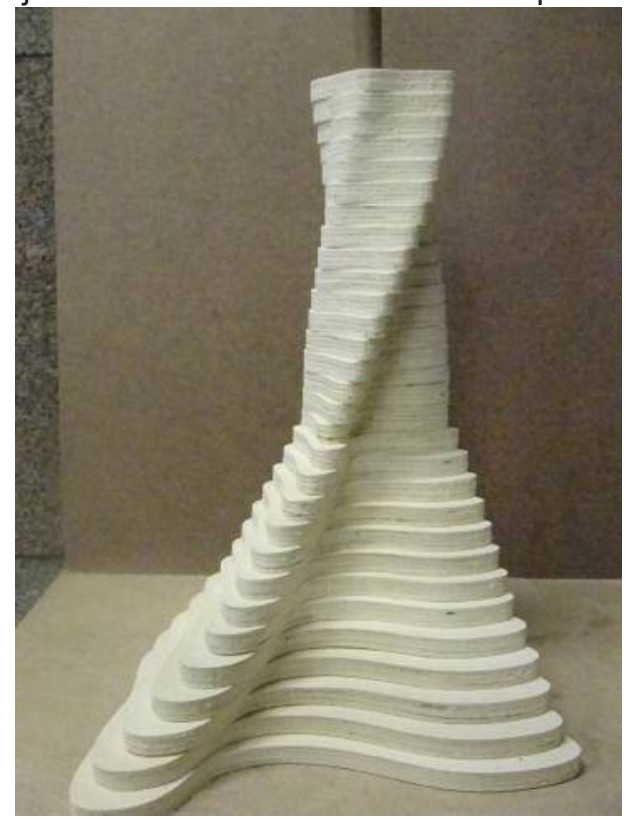

Figura 196 - Modelo físico do novo edifício alto, resultado do um processo paramétrico de geração de forma.

Umakoshi, Erica Mitie 
experimentação da solução formal, não foi estabelecido nenhum critério especifico em termos de quantidade de luz desejada no espaço interno.

Por fim, foi testada a relação gradual entre intensidade de radiação e tamanho da abertura, tomando como referência a orientação norte para a latitude de São Paulo (24o Sul). Os dados de radiação solar foram extraídos do banco de dados do programa Ecotect e conectadas ao modelo digital do Grasshopper pelo aplicativo Geco.

\subsubsection{O Edifício: modelagem e prototipagem digital}

Retomando o objetivo inicial desse exercício de projeto, o estudo do componente solar faz parte de uma proposta mais ampla de revisão não somente das fachadas, mas também da forma do edifício da "caixa de vidro", típico da arquitetura comercial, descontextualizada do clima. Assim, procedimentos paramétricos foram também aplicados na definição da forma de um edifício alto com o intuito de se criar um auto-sombreamento da forma, a ser complementado pela adição de componentes de proteção solar de fachada.

O auto sombreamento da forma foi estabelecido pela inclinação dos planos verticais das fachadas de cada pavimento e pelas reentrâncias da forma curvilínea da planta. A inclinação dos planos verticais seguiu o ângulo de altura solar dos equinócios (março e setembro) às 15:00 horas (fig. 194), resultando em uma proteção parcial das fachadas, que acaba por evitar a necessidade de projeções demasiadamente profundas, reforçando o papel dos elementos de sombreamento.

Os pavimentos de forma curvilínea do edifício alto foram projetados com diferentes raios e curvaturas, cujo efeito volumétrico foi estudado com base em um modelo físico que, assim como no caso dos componentes de sombreamento, foi produzido com o auxílio da fabricação digital, usando cortadoras do tipo CNC (fig. 195 e 196).

Complementando a estratégia de sombreamento, os componentes de proteção solar projetados pelo processo paramétrico foram adicionados sobre os planos inclinados da fachada, com a proposta de serem controlados automaticamente por meio de sensores posicionados estrategicamente na fachada e acionados pela incidência direta do sol.

O impacto dos componentes sobre a luz natural nos espaços internos foi testado com o recurso do aplicativo Geco, ligado ao banco de dados climáticos do Ecotect. As simulações de desempenho mostram que os níveis de iluminação natural no plano 


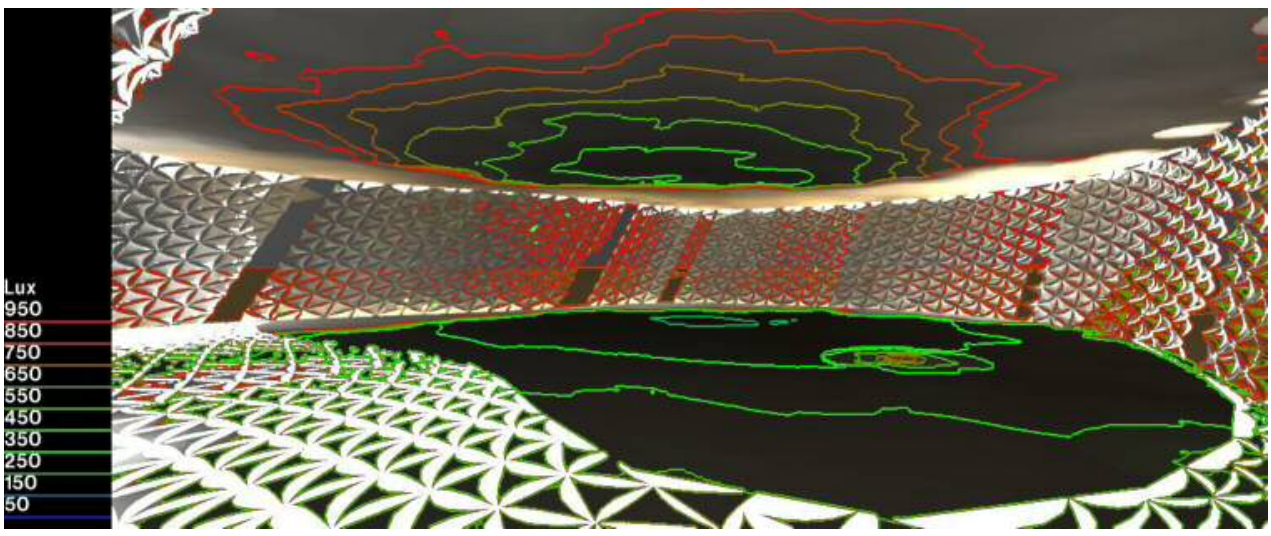

Figura 198 - Simulação do desempenho da iluminação natural no pavimento tipo às 9 horas no verão

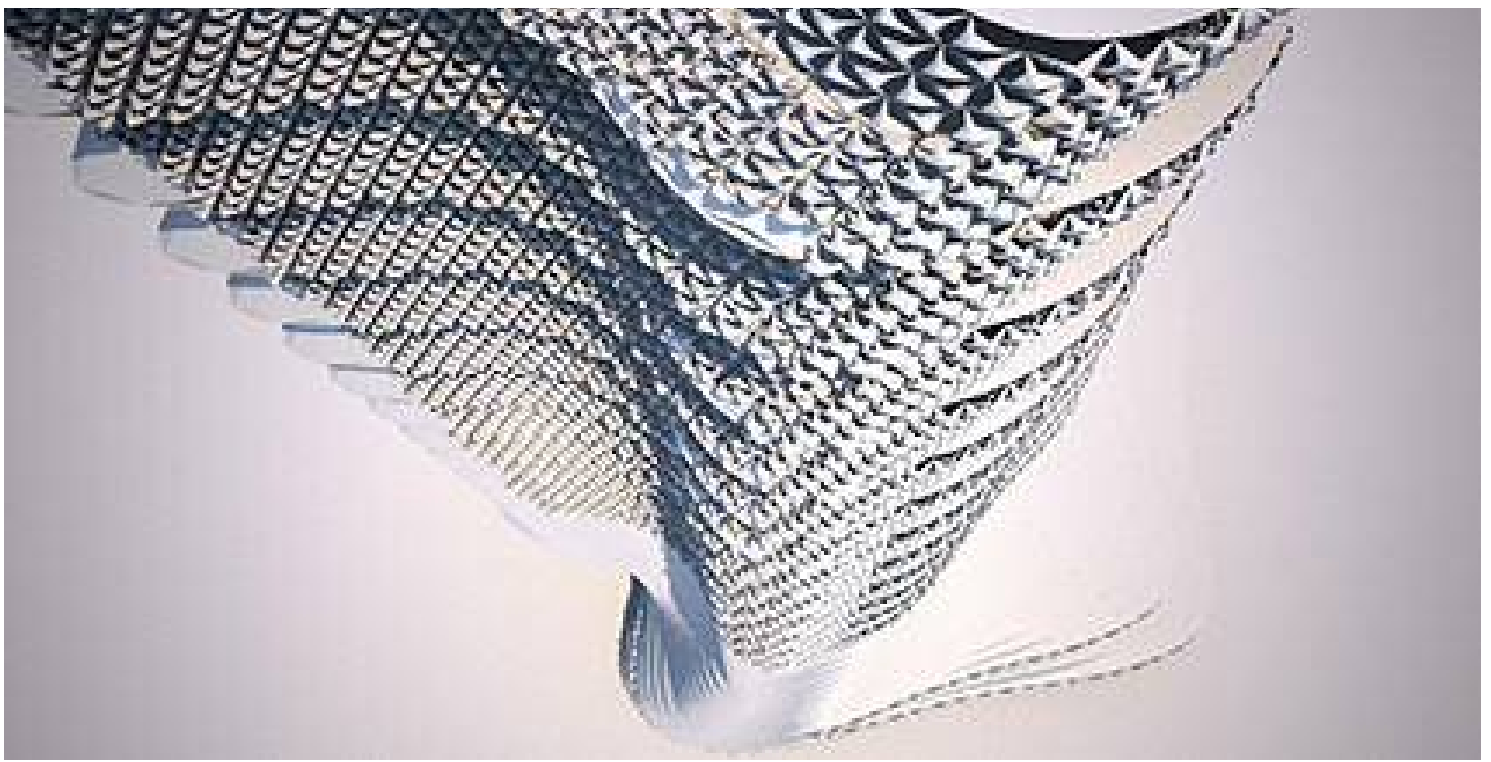

Figura 199 - Vista aérea do Projeto Final.

horizontal variam entre 500 e 250 lux, aproximadamente, às 9 horas num dia típico de verão na cidade de São Paulo, propiciando, assim, níveis favoráveis de iluminação natural para um ambiente de trabalho (fig. 197).

Entretanto, as simulações também mostram a passagem da radiação solar direta, que atinge uma área próxima à fachada. A fim de evitar o ofuscamento e o superaquecimento do ambiente interno por conta da radiação solar, a estratégia precisa de um refinamento, ou mesmo de uma estratégia complementar, uma vez que o simples fechamento da abertura do componente comprometeria os níveis médios de iluminação natural, que, apesar de satisfatórios, não são muito altos.

Aondulação do plano vertical da fachada, combinada à resposta dinâmica do componente de sombreamento, confere movimento e diversidade à solução arquitetônica final na medida em que o grau de abertura do componente se altera, de acordo com a sua 
posição e a sua consequente orientação solar (fig. 198).

O projeto do componente de proteção solar foi desenvolvido considerando as restrições e as necessidades estruturais do modelo físico, descobertas ao longo do processo de evolução da forma e da inserção de critérios específicos de desempenho ambiental. Como demonstrado ao longo desse processo, a interface entre a elaboração do modelo físico e o digital-paramétrico traz complexidade e originalidade ao processo de elaboração da forma. Com isso, questões de execução e funcionalidade da forma arquitetônica são levantadas e solucionadas ainda nas etapas de concepção do projeto. Dessa forma, esse processo de concepção projetual, com foco em estratégias de sombreamento, incluindo a forma do edifício e o componente da fachada, exercita a busca de originalidade da forma arquitetônica.

\subsection{Considerações Finais}

Os projetos aqui apresentados (projetos do SED da AA School of Architecture, Projeto Viol e o Projeto desenvolvido durante o workshop da AA Visiting School) propõem uma visão crítica (técnica e analítica) sobre o processo de projeto do edifício alto, resultando em inovação e originalidade da forma arquitetônica.

Todos têm em comum a utilização de critérios de desempenho ambiental como uma etapa determinante na elaboração da forma arquitetônica. Com exceção do último experimento, o da AA Visiting School, os critérios mencionados vão além da base conceitual e são resultados de estudos analíticos avançados de desempenho ambiental do edifício.

No entanto, ainda que as etapas de projeto sejam muito similares na elaboração e na escolha dos critérios de desempenho ambiental, de iluminação e ventilação natural, o processo de geração e o resultado final da forma, visto nos exercícios de projeto aqui apresentados, são particulares em cada caso, produzindo resultados arquitetônicos diferenciados.

No caso do primeiro projeto da AA (Tall Communities: Passive urban housing for the Tropics), existe a busca pela forma paramétrica sem a utilização das ferramentas de geração de forma, baseada, exclusivamente, nos programas computacionais Ecotect e 
no Autocad. O segundo (Environmental Performance of adaptive building design: urban housing in Seoul Korea) e o terceiro (Rethinking office building typology in continental mediterran climate) tiveram foco no desempenho energético quantitativo propriamente dito, também utilizando o Autocad como ferramenta de desenho e geração da forma, além dos softwares de desempenho ambiental. O terceiro, especificamente, é um exemplo do projeto paramétrico que utiliza técnicas e ferramentas do projeto convencional e introduz um software do projeto generativo, no caso da fachada.

O projeto Viol também guarda semelhanças com relação à escolha dos critérios e desenvolvimento de forma. Baseado em ferramentas convencionais de projeto como o Autocad, demonstra que exemplos da prática arquitetônica corrente de mercado, aclamada como realizadora de ícones e novos paradigmas de desempenho ambiental, também empregam o mesmo processo e utilizam os mesmos critérios. É o raciocínio e o processo que definem a arquitetura paramétrica generativa.

Por sua vez, o último exercício ainda carece de critérios objetivos para informar o processo de geração da forma (questões que vão ser retomadas no próximo capítulo), mas, por outro lado, introduz uma nova temática, qual seja, a relação da arquitetura paramétrica e a prototipagem rápida, que também é uma variante da arquitetura generativa, a qual, no entanto, não será trabalhada nesta pesquisa.

Observou-se, ainda, que apenas um dos exercícios de projeto da AA (o terceiro) e o exercício de projeto desenvolvido no workshop do AA Visiting School utilizaram ferramentas de projeto paramétrico. Entretanto, todos atingiram uma expressão arquitetônica de destaque. Trata-se, aqui, de um processo de projeto arquitetônico que prioriza estratégias ambientais e quantifica conceitos genéricos em cada contexto climático para, então, voltar para a arquitetura.

Da análise desses projetos apresentados, pode-se dizer que, por meio dos estudos analíticos preliminares, é possível que sejam elencadas as principais estratégias que norteiam o projeto, como, por exemplo, a orientação, a insolação, a ventilação natural e os espaços de convivência, dentre outros. Ou seja, tem-se a quantificação de conceitos e ideias genéricas que precisam se tornar especificas para informar a geração da forma e determinar o desempenho do edifício. 



\section{Capítulo 6:}


Capítulo 6 - Aplicação Metodológica de Intervenção Projetual e Avaliação de Desempenho de um Estudo de Caso na Cidade de São Paulo (Projeto)

190 Avaliação de Desempenho Ambiental e Arquitetura Paramétrica Generativa para o Projeto do Edifício Alto 


\section{Capítulo 6 - Aplicação Metodológica de Intervenção Projetual e Avaliação de Desempenho de um Estudo de Caso na Cidade de São Paulo (Projeto)}

\section{Introdução}

O método proposto consiste na aplicação de critérios de desempenho ambiental no processo de projeto da arquitetura paramétrica, ou seja, selecionar e utilizar os critérios de desempenho para informar e gerar parametricamente a forma utilizando a geometria complexa.

O foco do método se concentra nos primeiros estágios do projeto, onde a possibilidade de gerar uma arquitetura com geometria complexa e alcançar um desempenho otimizado é muito maior do que nas outras fases de projeto. Assim, pretendeu-se testar as habilidades de geração rápida da forma, característica da arquitetura paramétrica, e, com isso, explorar as opções de projeto.

O objetivo foi criar um cruzamento entre as simulações de conforto ambiental, o processo de projeto e a geometria complexa, visando melhorar a compreensão do impacto ambiental e, ao mesmo tempo, evitar uma geração gratuita da forma e dos seus componentes. Saliente-se que o desafio do projeto paramétrico não é apenas uma questão de geometria complexa e, sim, como incorporar os critérios de desempenho no processo de projeto.

Cabe ressaltar que a utilização dos critérios de desempenho ambiental e das questões ligadas às simulações de conforto no início do processo de projeto gera uma complexa rede de informações, com a qual a equipe de projeto precisa trabalhar.

Com relação às ferramentas de simulação, Augenbroe (2002) afirma que o foco precisa estar em: 1) rápida avaliação das alternativas de projeto; 2) ferramentas para dar suporte ao processo de decisão do projeto; 3) aprimorar as habilidades dos projetistas em resolver problemas não lineares e com múltiplos critérios.

Por fim, para testar a metodologia, foi realizado um exercício de projeto com base nas premissas do Projeto Viol, apresentado no capítulo 5. Porém, é importante frisar que não se trata esse estudo de uma contraposição ao processo do Viol, pois, na verdade, visa criar possibilidades para o processo de projeto da arquitetura paramétrica, o qual necessita de critérios mais objetivos. 


\subsection{Método de projeto}

O presente método foi desenvolvido para ser aplicado nas primeiras fases do processo de projeto (fig. 202). É nessa fase de geração da forma que se concentra o maior potencial para se atingir um melhor desempenho ambiental. Para isso, foram unidos critérios de desempenho e ferramentas paramétricas de geração da forma.

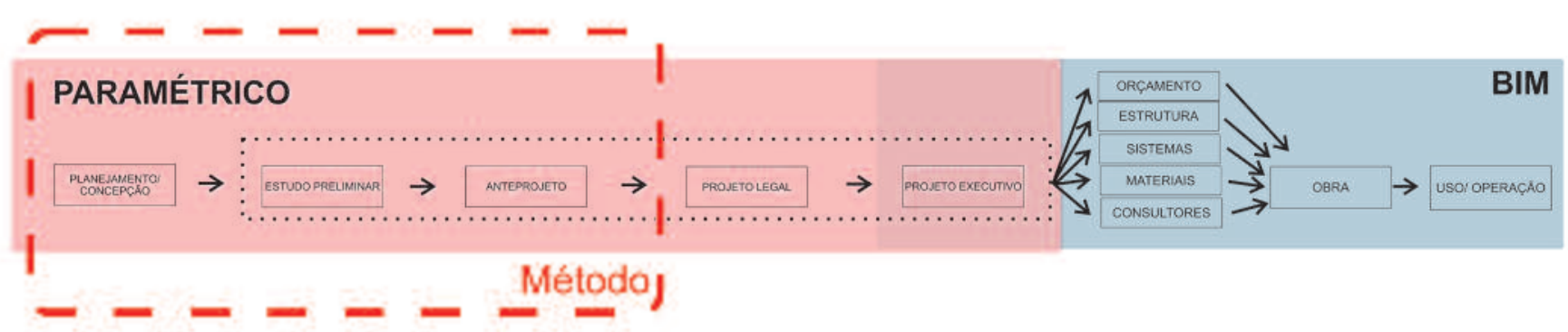

Figura 200- Processo de projeto.

\subsubsection{Procedimentos analíticos}

Método estabelecido em pesquisas e na prática.

- Análise do Clima

- Definição do programa arquitetônico

- Análise Sócio-Cultural

\section{Elaboração de modelos simplificados para a análise do desempenho ambiental}

-Entendimento das possibilidades e dos desafios do projeto tendo em vista essa primeira etapa.

- Verificação do impacto de parâmetros do clima, arquitetura e análise paramétrica.

- Contemplar variáveis de clima, ocupação, orientação, forma, materiais, proteção solar, área envidraçada e entorno.

- Clima: avaliar a variação de ciclos diurnos de temperatura, diferentes estações do ano e dias típicos.

- Ocupação: determinar a demanda, equipamentos, variação da densidade durante o dia e época do ano (horários). 
- Preparar um modelo simplificado (shoe box). O processo trabalha com muitas variáveis, mas ele pode ser bem focado à partir dos resultados de exemplos simplificados.

- Avaliar soluções de projeto utilizados em edifícios que demonstraram bom desempenho e que pode, ou não, estar no mesmo clima (Material, aberturas, átrios, etc.).

- Verificar a hierarquia dos parâmetros. lluminação antes da térmica. Onde a boa luz é importante. A iluminação pode permitir ou limitar a profundidade. Não faz sentido uma planta profunda, sendo desejável eliminar a iluminação artificial, melhorar as vistas para o exterior e reduzir as cargas térmicas (Lux, renovações-aberturas/janelas).

- Geração dos elementos formais para parametrizar a forma.

- Escolha do parâmetro ou do objetivo. No caso da iluminação e da insolação, bloquear a insolação direta e determinar uma quantidade de lux ideal. Já em relação à a térmica, é diferente, pois a temperatura não determina a forma, mas a iluminação sim. Isso reforça a importância da interação do processo analítico e a geração da forma.

- Pode ou não utilizar softwares paramétricos.

- Pode ser um processo corretivo (brise, área de vidro, intervenção na forma) ${ }^{1}$, paramétrico ${ }^{2}$ ou generativo ${ }^{3}$. Todas podem chegar numa forma original e particular.

6.1.2 geração de forma - com ênfase no projeto do edifício alto A partir dos dados gerados na avaliação analítica de desempenho, aplicá-los na geração da forma.

\section{Forma}

- Gerar Modelo no Grasshopper, pois substitui o modelo físico (3D), gerando geometrias que outros softwares não fazem, respondendo, assim, a critérios que poderiam ser feitos na mão. Facilita a geração de forma, diminuindo o tempo de simulação. Dado que define forma.

1 Como visto no capítulo 5 no projeto: "Environmental Performance of adaptive building design: urban housing in Seoul Korea ", Jeewon Paek

2 Como visto no capítulo 5 no projeto: "Tall Communities: Passive urban housing for the Tropics", Suraksha Bhatla

3 Como visto no capítulo 5 no Projeto Paramétrico e Prototipagem Rápida: um exercício de projeto para a fachada de um edifício alto, AA Visiting School. Umakoshi, Erica Mitie 
- Definir o que se precisa ser extraído do analítico (variáveis ambientais)

- Utilizar premissas do projeto arquitetônico e diretrizes para o desempenho ambiental (base conceitual) ${ }^{4}$.

\section{Variáveis ambientais}

\section{Geometria da insolação (proteção contra radiação solar direta) ${ }^{5}$}

- Definir a melhor forma para otimizar o desempenho da fachada em relação à insolação direta.

- Definir átrios e aberturas para o sombreamento e a ventilação.

- Primeiro estágio da fachada e definição dos componentes. Como os parâmetros informam o processo.

\section{lluminação natural}

- geometria solar.

- fixo - resistência da envoltória (Materiais).

- fixo - iluminação (Porcentagem de vidro na fachada).

- Questões móveis, controle da luz direta que é dinâmica (Proteções solares).

- dinâmica - luz.

- dinâmica - abertura para ventilação.

\section{Térmica}

4 Fala-se aqui de referências de projeto arquitetônico voltado ao desempenho ambiental retirados a partir de edifícios ícones do desempenho ambiental como visto no capítulo 1, além de exercícios de projeto como visto no capítulo 5 .

5 Como explicado no item 2.1 deu-se ênfase a iluminação e a insolação porque tem impacto imediato na geração da forma, sendo que a insolação pode ou não comprometer a iluminação. Como visto no capitulo 4, a facilidade de inserir a insolação como critério de geração da forma, possibilita a utilização arbitrária desse parâmetro. A questão da térmica não foi trabalhada como uma variável de geração de forma e de composição de fachada por questão de simplificação do exercício porém foram incorporadas nas premissas de projeto arquitetônico estabelecido no item anterior (forma). 
- Critérios de desempenho e componentes (Materiais).

- Trabalhar a forma global do edifício que é estática mas pode ser otimizada.

\section{Simulação Ecotect}

- Verificar se o modelo responde bem aos critérios de iluminação.

\section{Ajuste da forma}

- Corrigir e gerar novos elementos para o atendimento dos critérios. Nesse ponto, onde já existe um detalhamento da fachada, em que já foram testados alguns materiais, é o momento de utilizar uma das grandes potencialidades do Grasshopper, que éa capacidade de cálculo matemático para escolhas de cenários. Ou seja, é nesse momento que se pode definir com exatidão a porcentagem de material opaco, transparente e translúcido, e observar as opções de combinações que o Grasshopper pode fornecer (fig.201). Ou, então, definir valores para os quais elementos são subtraídos da fachada, como no caso do projeto da AA (fig. 202). Trata-se de uma velocidade e de uma quantidade de opções que a mente humana, por si só, não seria capaz de produzir. No entanto, há que se ter cuidado com a escolha e a definição dos critérios, como afirmado anteriormente.

\section{Simulação desempenho térmico (térmica dinâmica)}

- Verificação dos critérios de ventilação, térmica e conforto.

\section{Ajuste da forma}

- Corrigir e gerar novos elementos para o atendimento dos critérios

\section{Simulação Autodesk CFD}

- Verificação dos critérios de ventilação: tamanho das aberturas e porcentagem de abertura.

\section{Ajuste da forma}

- Corrigir e gerar novos elementos para o atendimento dos critérios.

Figura 203- Metodologia detalhada.

6.2 aplicação do método

Após o desenvolvimento do método, foi realizado um exercício de projeto que buscou 
Capítulo 6 - Aplicação Metodológica de Intervenção Projetual e Avaliação de Desempenho de um Estudo de Caso na Cidade de São Paulo (Projeto)

Avaliação de Desempenho Ambiental e Arquitetura Paramétrica Generativa para o Projeto do Edifício Alto

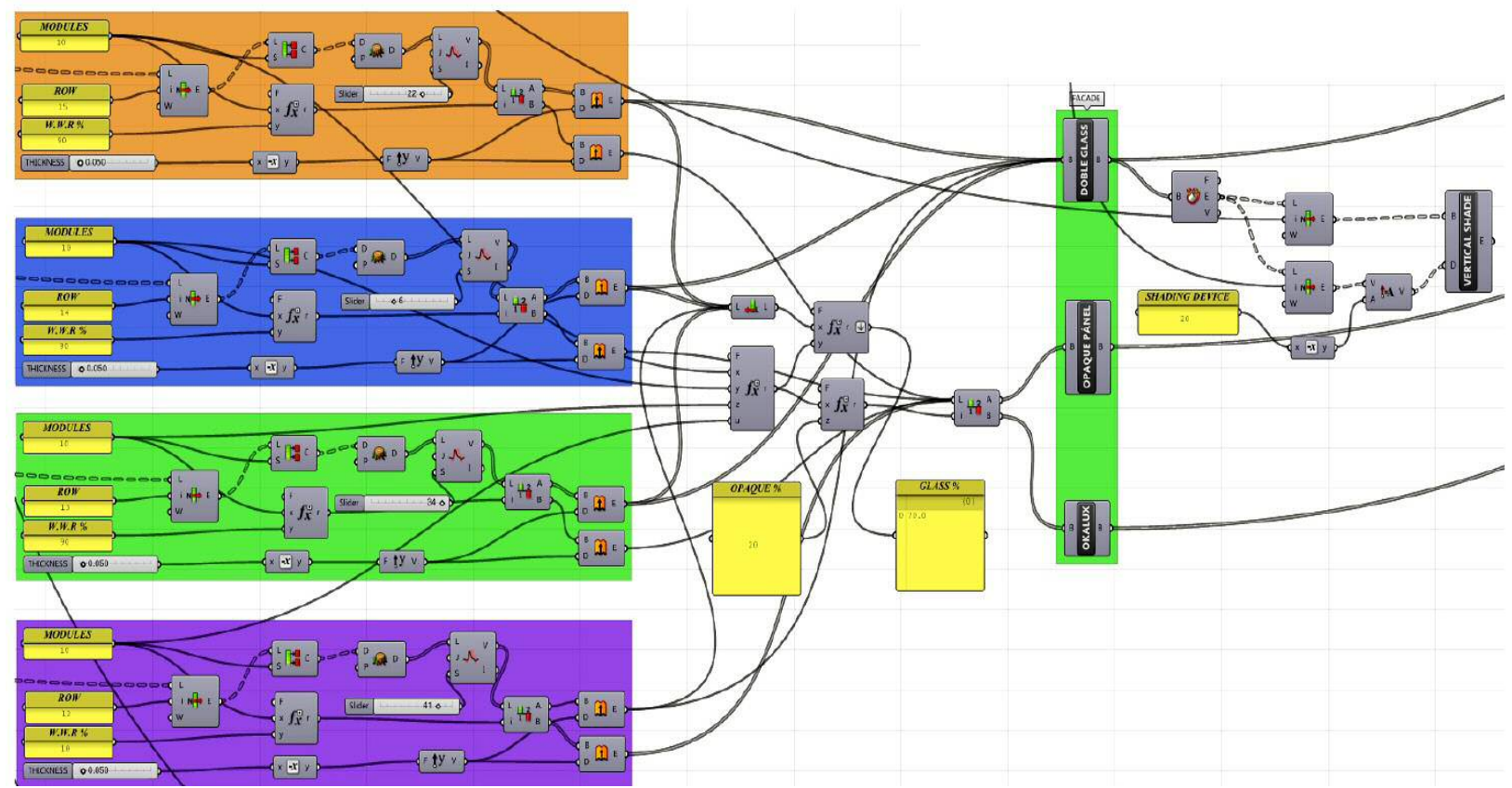

Figura 201 - Imagem que representa as funções e as opções de vedação para a fachada: opaca, translúcida e transparente. (AMENÁBAR, 2013)

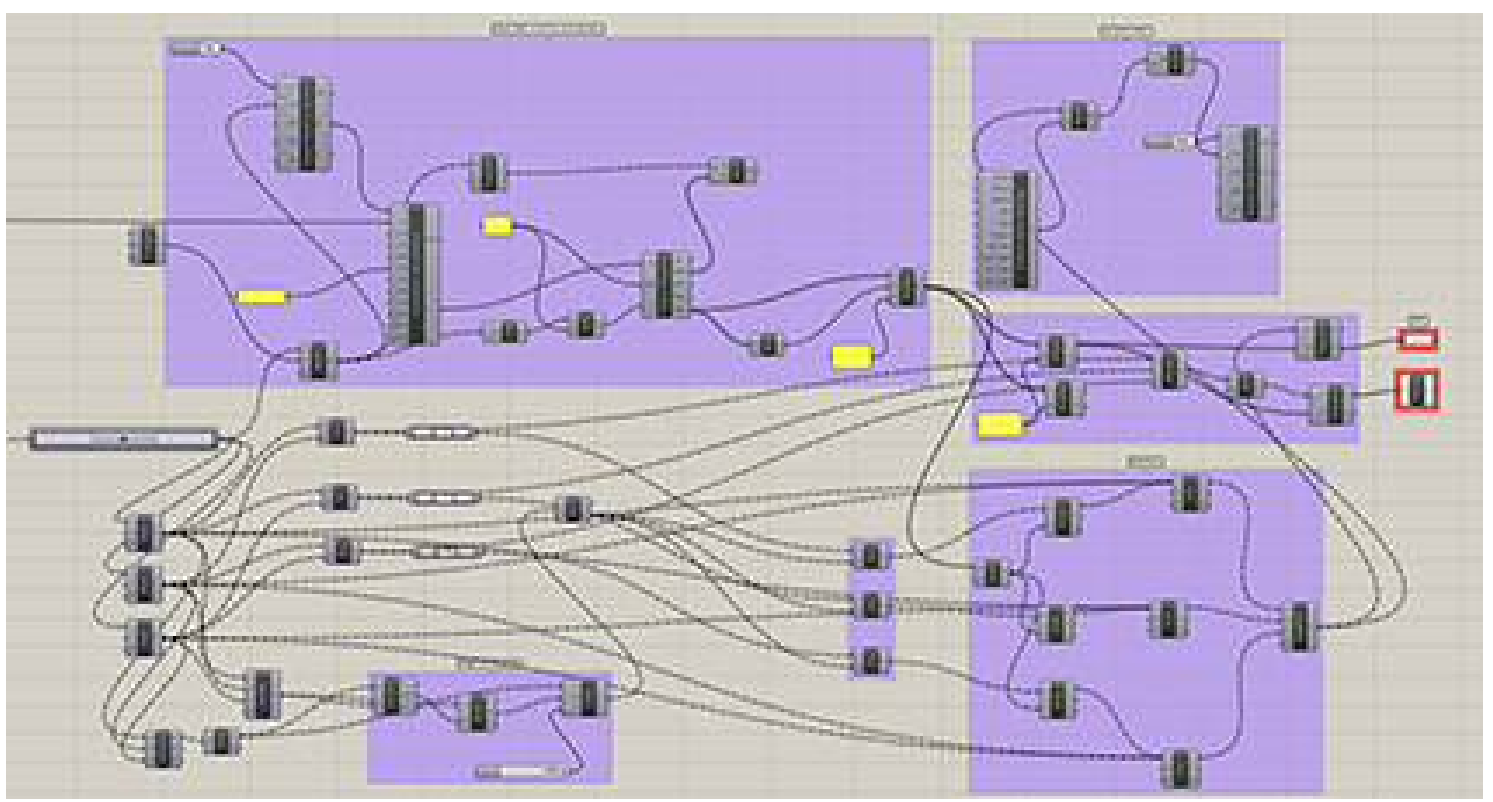

Figura 202 - Imagem que representa os passos para definir qual elemento excluir da fachada utilizando funções como "maior que" e "menor que" para os valores.

aplicar o método e analisar os resultados, servindo como base para a validação do mesmo. Para isso, foi selecionado o projeto Viol, apresentado no capítulo 5, aproveitando a mesma localização e o mesmo programa.

\subsubsection{Parâmetros do projeto}




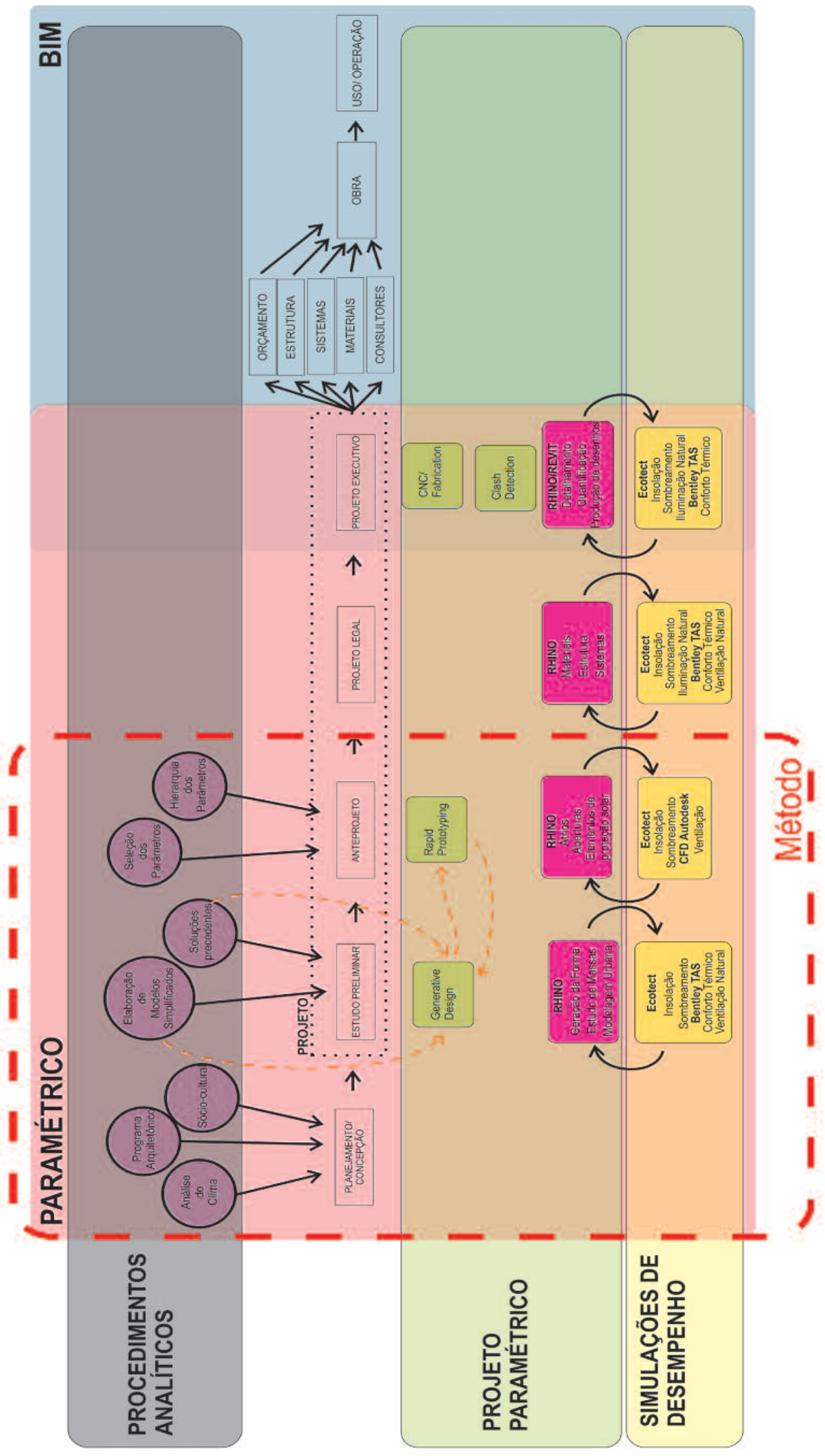



de Caso na Cidade de São Paulo (Projeto)

198 Avaliação de Desempenho Ambiental e Arquitetura Paramétrica Generativa para o Projeto do Edifício Alto

Alguns conceitos foram desenvolvidos e aparecem nitidamente na forma. Primeiro, a escolha da forma elíptica, aumentando as fachadas norte e sul e, consequentemente, reduzindo as fachadas leste e oeste. Foram feitos recortes na planta para aumentar as áreas de fachada e as vistas para o exterior. As áreas de convivência têm pé-direito triplo para aumentar a comunicação visual e a iluminação nos pavimentos. O core de elevadores, apesar de deslocado, ainda continua centralizado.

Como pode ser observado na figura 205, os elementos de sombreamento são horizontais e aplicados em algumas das fachadas.

Além das referências extraídas do Projeto Viol, foram utilizados no processo de projeto as principais informações de cada capítulo. Do capítulo 1, foram utilizados conceitos de projeto dos edifícios ícones do desempenho ambiental no cenário internacional, como, por exemplo, janelas que permitem a ventilação natural, átrios de pé direito variado, aumento da área de fachada em relação à área de pisos visando melhorar a iluminação,

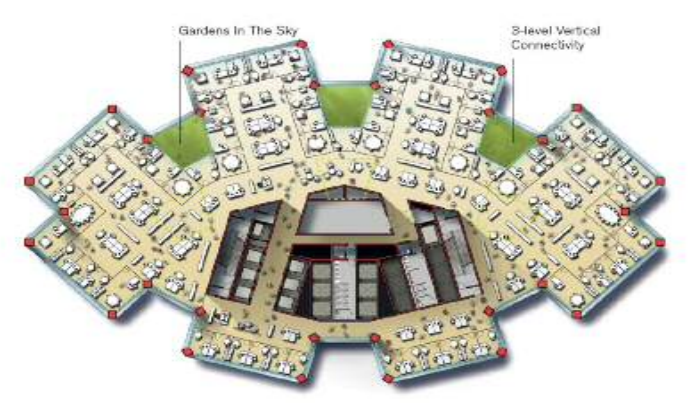

Figura 204 - Forma Elíptica, jardins, recorte na fachada e o core de elevadores.

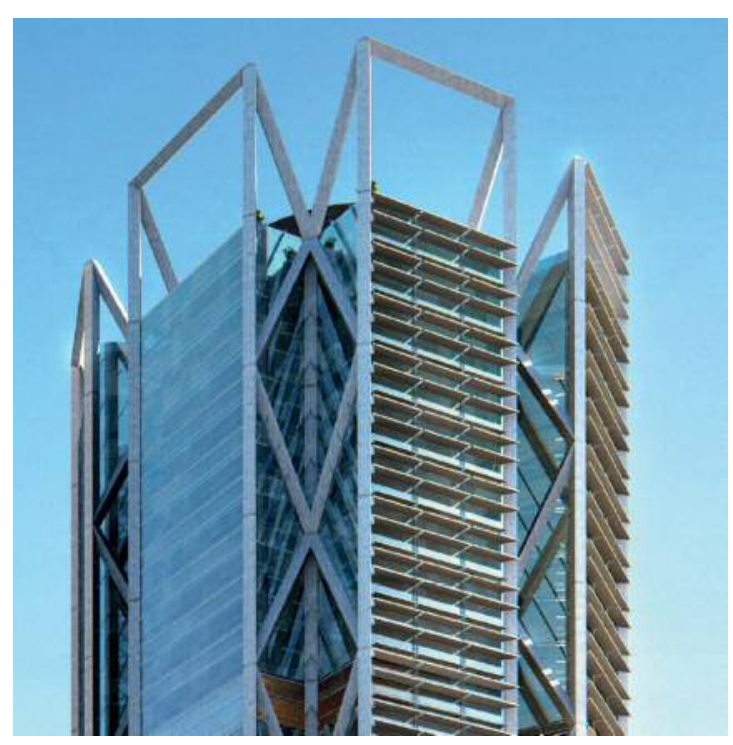

Figura 205- Elementos de sombreamento.

posicionamento do core e inserção urbana. Os conceitos da nova abordagem do conforto adaptativo e os critérios de desempenho foram extraídos do capítulo 2, sendo os princípios da adaptação ambiental do usuário, que busca alcançar o seu conforto, premissas de projeto para esse exercício, além de critérios qualitativos relacionados à iluminação e à ventilação natural, à comunicação visual, aos espaços de interação social e à expressão arquitetônica. Já em relação aos critérios quantitativos, foram consideradas as questões de eficiência do espaço, não permitindo que o empreendimento deixe de ser lucrativo, 
critérios de eficiência ambiental interna, como níveis de iluminação, horas de ventilação e porcentagem de área social, e critérios de desempenho energético e ambiental do edifício.

Do capítulo três, foram extraídos dados das medições e das simulações, dos quais se destacam as conclusões das simulações que indicam que, mesmo com uma fachada com alta porcentagem de área envidraçada (ou seja, WWR de 90\%), se bem sombreada, podem ser alcançados desempenhos similares às fachadas com um WWR de $70 \%$ com um sombreamento de $1 \mathrm{~m}$ ou, ainda, um desempenho melhor do que uma fachada com WWR de 50\% sem sombreamento. Além disso, será utilizada a massa térmica exposta das lajes, a ventilação noturna e temperaturas mais altas do set point para acionamento do sistema de ar-condicionado.

As ferramentas e o processo paramétrico foram referenciados no capítulo 4 e serviram como base conceitual do processo que será apresentado a seguir. Do capítulo 5 , extraíram-se os conceitos metodológicos dos exemplos apresentados, visando sintetizar uma metodologia nova que unisse os critérios ambientais, as ferramentas e os conceitos da arquitetura generativa.

\subsubsection{Desenvolvimento da forma}

A partir da forma escolhida, a elipse, foi modelado no Grasshopper, aplicativo do Rhinoceros, uma elipse de raios com $14 \mathrm{~m}$ e $28 \mathrm{~m}$, com altura de três pavimentos $(12 \mathrm{~m})$, configurando uma vila. Com o objetivo de se criar uma série de recortes na forma e proporcionar um incremento na comunicação visual, acesso à iluminação natural e a criação de espaços de convivência, foram criados 5 átrios, nomeados de Norte, Leste, Oeste, Sudeste e Sudoeste. Desses, apenas o Norte e o Sudoeste foram transformados em jardins verticais, o Norte com pé direito triplo e o Sudoeste com $6 \mathrm{~m}$ de pé direito. $\mathrm{O}$ Leste e o Oeste têm a função de aumentar o campo visual dos pavimentos e permitir uma melhor iluminação natural. Já o Sudeste tem, como função principal, a captação dos ventos predominantes e, assim, para evitar turbulências indesejadas, não será ocupado.

Para ajustar o dimensionamento desses átrios foram realizados estudos de insolação no Ecotect através do plug-in Geco. 
Capítulo 6 - Aplicação Metodológica de Intervenção Projetual e Avaliação de Desempenho de um Estudo de Caso na Cidade de São Paulo (Projeto)

Avaliação de Desempenho Ambiental e Arquitetura Paramétrica Generativa para o Projeto do Edifício Alto

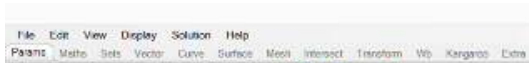

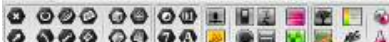

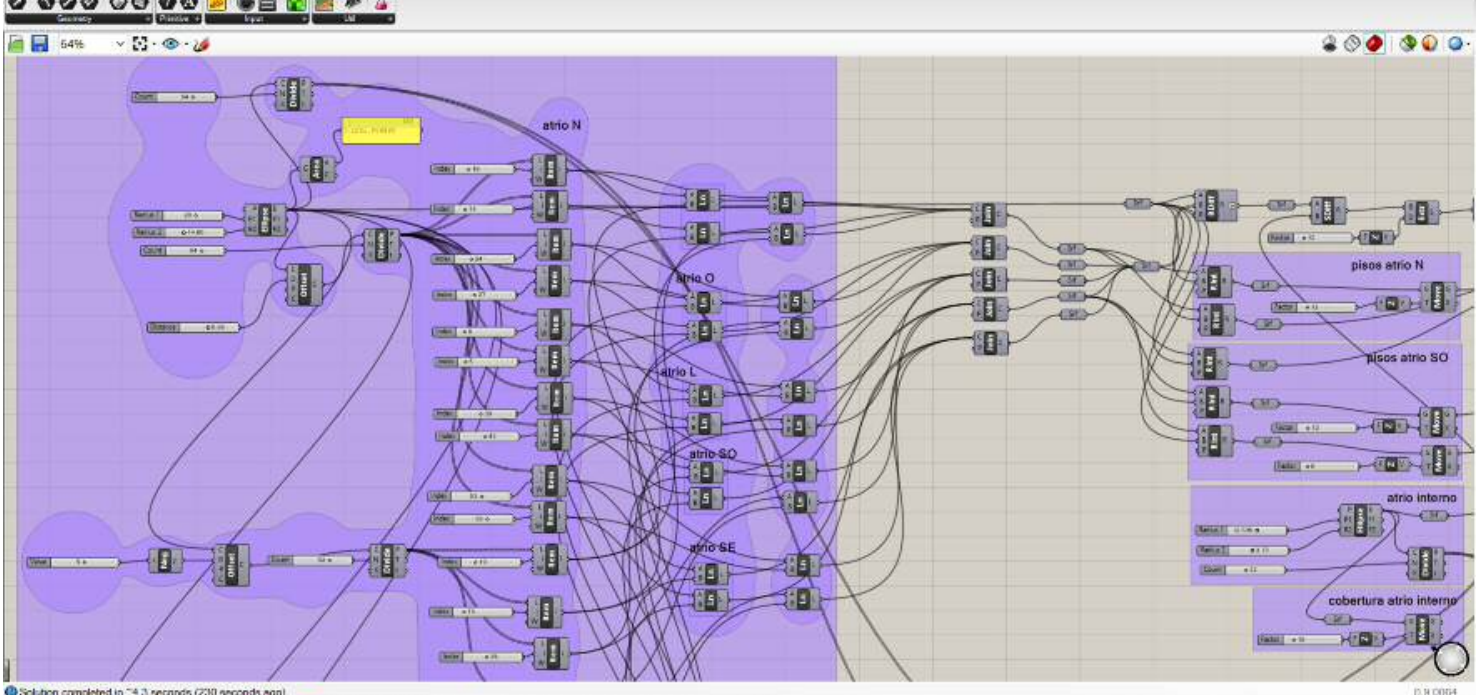

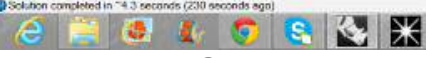

Figura 206- Grasshopper do pavimento tipo.

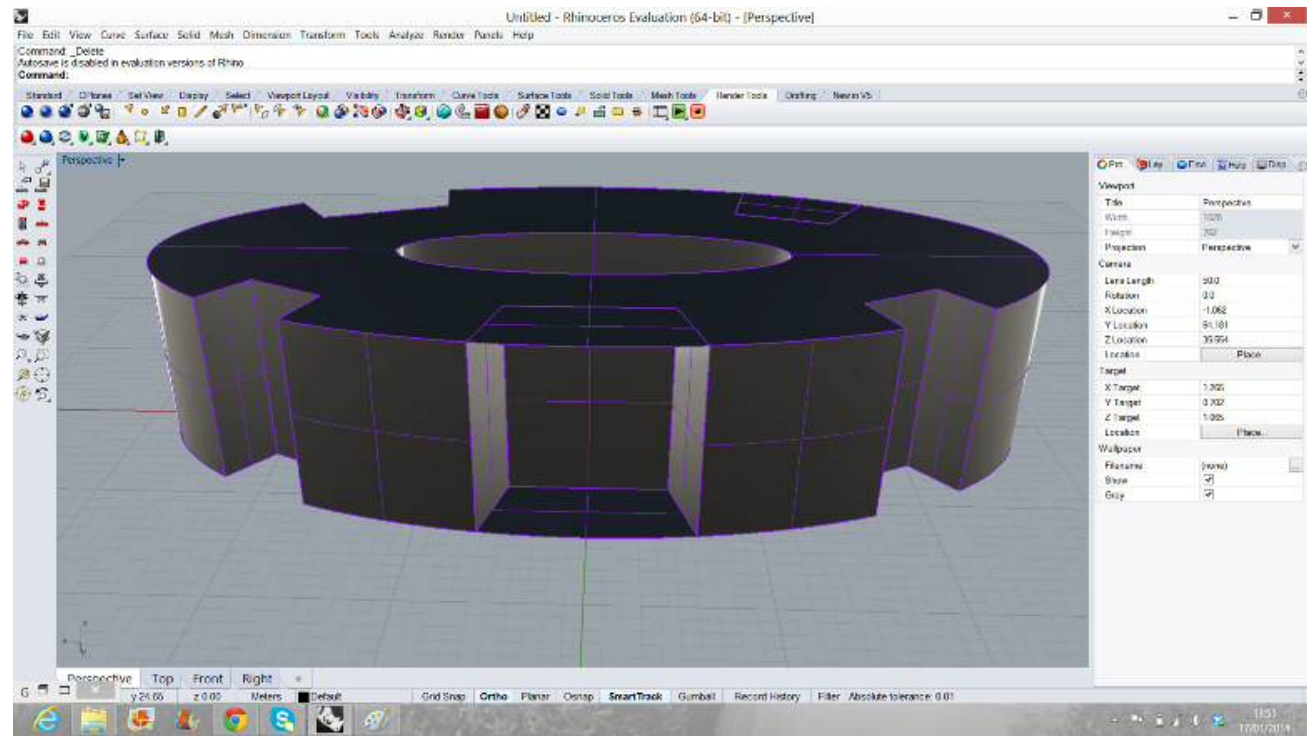

Figura 207- Elipse com os vazios criados. Fachada Norte.

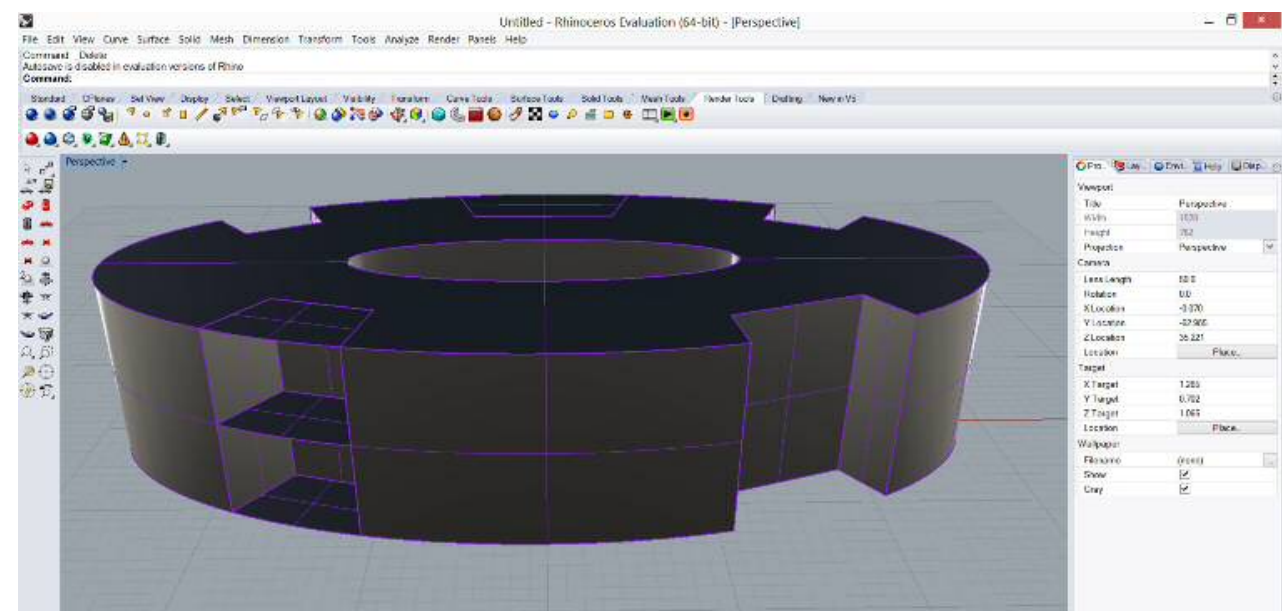

Figura 208- Elipse com os vazios criados. Fachada Sul. 
Capítulo 6 - Aplicação Metodológica de Intervenção Projetual e Avaliação de Desempenho de um Estudo de Caso na Cidade de São Paulo (Projeto)

Avaliação de Desemnenho Ambiental e Arquitetura Paramétrica Generativa nara o Proieto do Edifício Alto

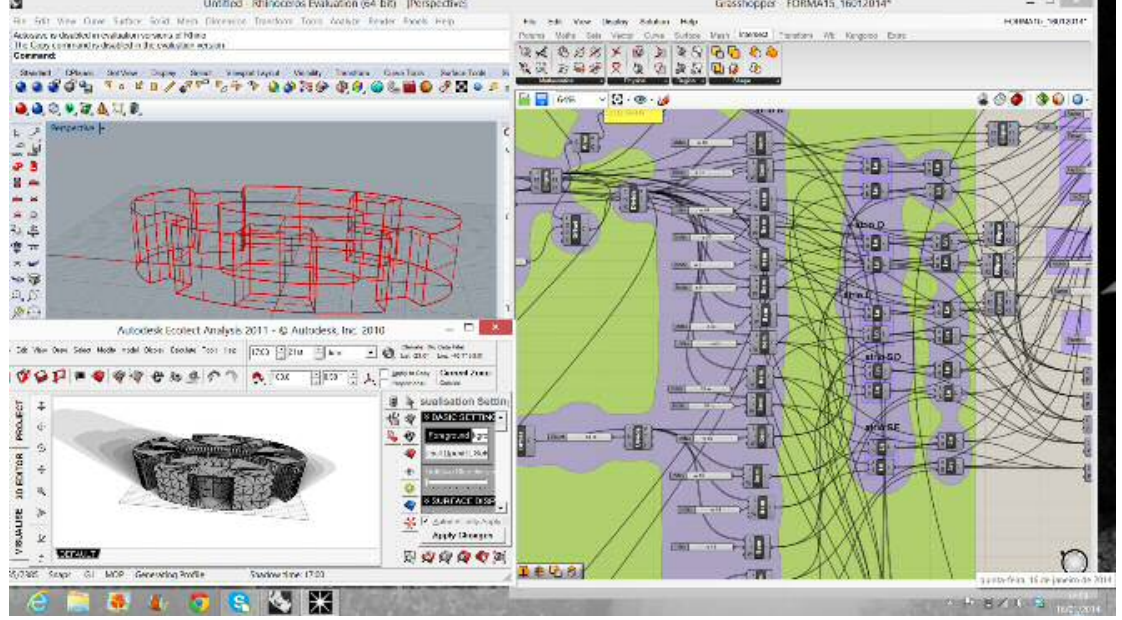

Figura 209 - Modelo sendo analisado no Ecotect através do link Geco do Grasshopper.

Para testar a volumetria do modelo foi criado um edifício com 180 metros.

Com relação à organização espacial e à distribuição dos ambientes de trabalho, foi pensada uma divisão de atividades, sendo que na fachada Norte, com três pavimentos, localizam-se os escritórios celulares. Já a fachada Sul, onde a incidência de radiação direta é menor, concentra os escritórios de planta livre e possui apenas dois pavimentos,

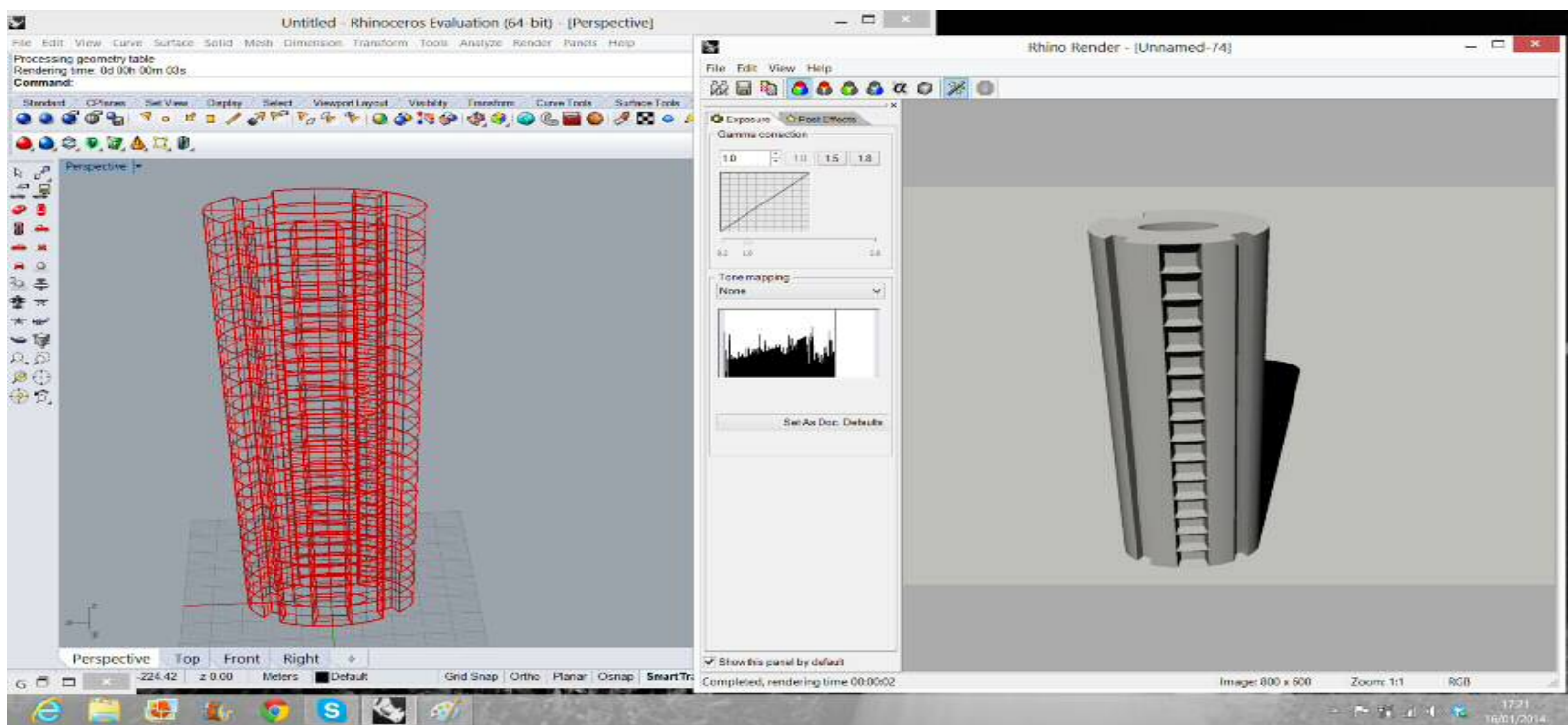

Figura 210- Modelo com 15 módulos. Fachada Norte.
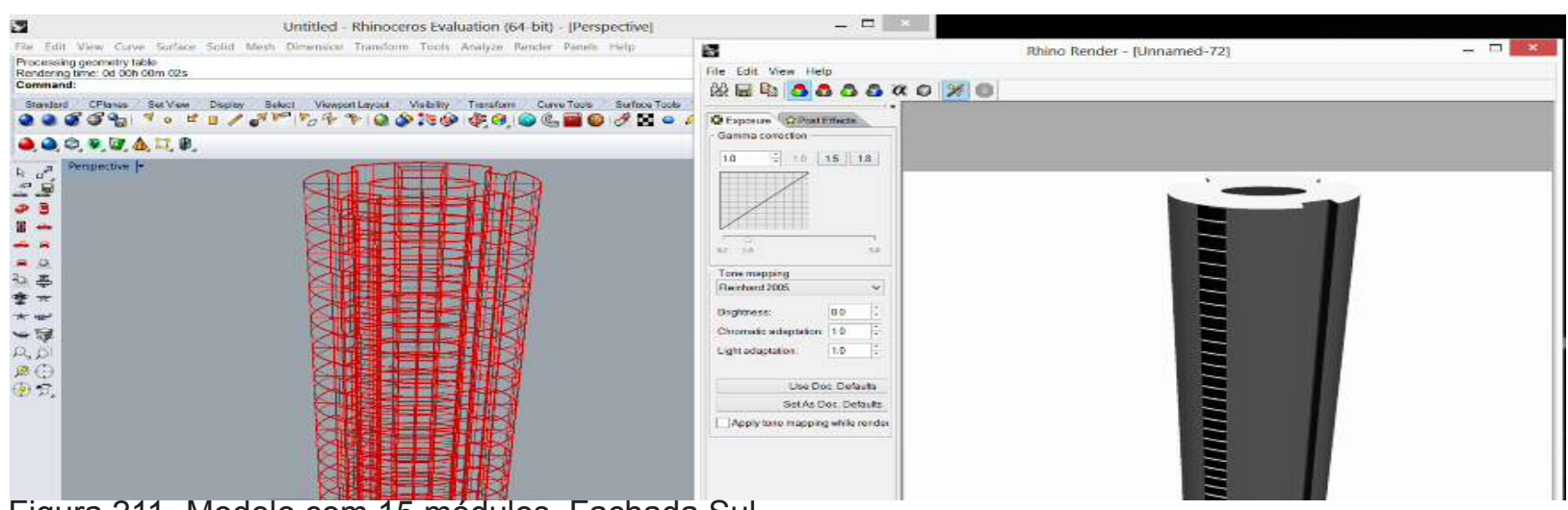

Figura 211- Modelo com 15 modulos. Fachada Sul.

Umakoshi, Erica Mitie 
resultando em um pé direito de $6 \mathrm{~m}$ de altura. No centro foi criado um átrio para permitir uma melhor distribuição da iluminação no primeiro pavimento da vila, permitindo que a mesma tenha uma maior ocupação com níveis aceitáveis de iluminação natural.

O core de elevadores, escadas e banheiros foi deslocado para as fachadas Leste e Oeste, minimizando o ganho de calor por elas.

\subsubsection{Desenvolvimento do componente}

Após o desenvolvimento da forma, foi preciso desenvolver o componente de sombreamento, que, segundo os estudos do capítulo 3, deveriam estar presentes em todas as orientações. Primeiramente, foi desenvolvido um modelo plano de malha triangular, como o desenvolvido no workshop da $\mathrm{AA}$, com dois tipos de abertura.

Visando testar o desempenho do componente, com relação ao sombreamento, foi realizada uma nova simulação de penetração do sol.

No entanto, essa treliça plana não respondeu bem ao controle de abertura desejado para o modelo. Então, foi desenvolvido um componente de base quadrada, como um tronco de pirâmide vazado, que, para cada orientação, tem um formato diferenciado.

Antes de se aplicar no modelo, foram feitos testes em uma forma simplificada para a verificação do desempenho no Ecotec.

Para a aplicação no modelo, foi utilizado um sistema chamado de Paneling, ou seja, é criado um painel na fachada do seu edifício, na qual o Grasshopper vai inserir de forma sistemática todos os seus componentes.

Como existe uma insolação diferenciada nas fachadas, optou-se por colocar na Sul os componentes com um tamanho superior do que os colocados na fachada Leste e Oeste. Para isso, foi preciso dividir de maneira diferente cada uma das fachadas.

A próxima etapa foi verificar a penetração de sol pelos componentes.

Porém, ao compor o edifício como um todo, o componente não obteve o mesmo desempenho visual da vila de três pavimentos, tornando-se muito parecido em todas as orientações.

Assim, foi preciso desenvolver novamente outro tipo de sombreamento. Testou-se uma 


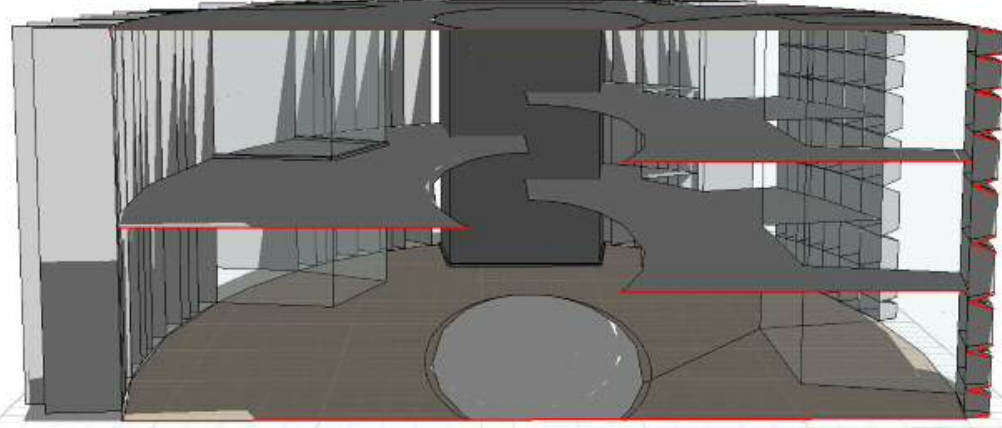

Figura 212- Corte do pavimento tipo.

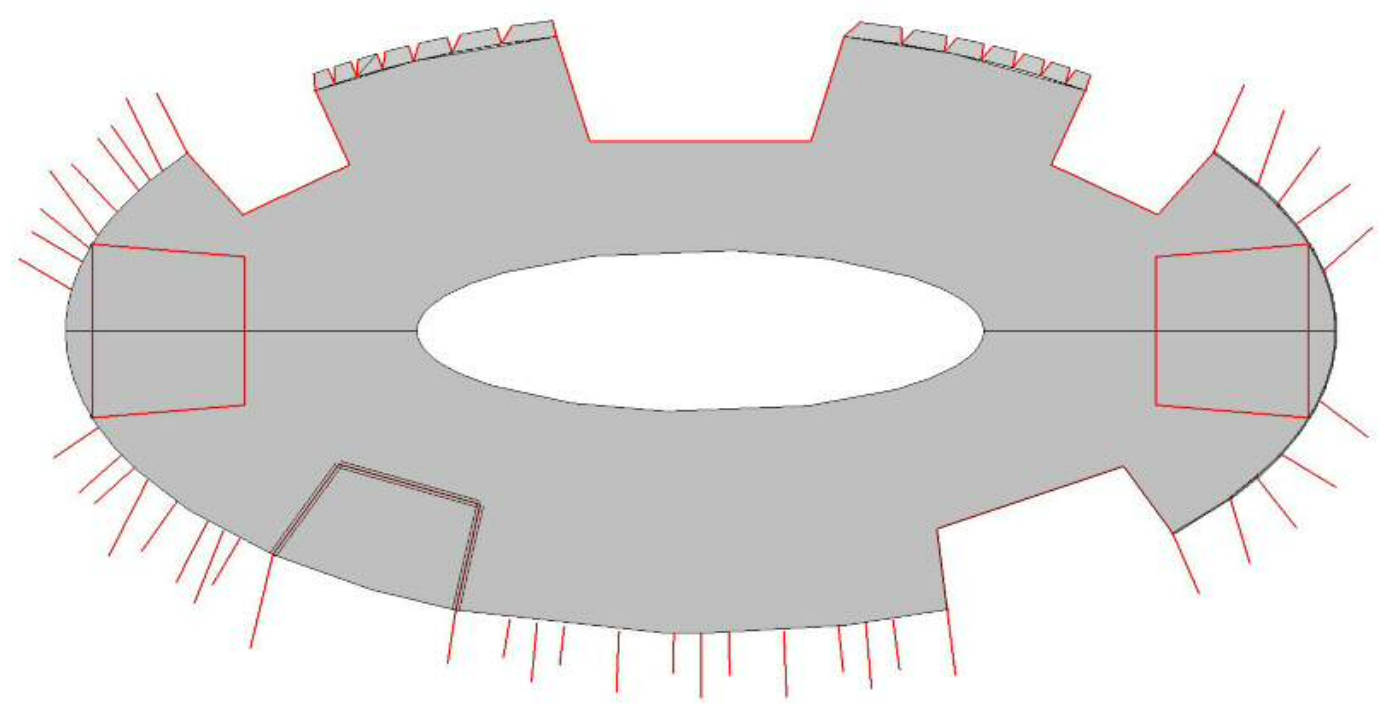

Figura 213 - Planta do pavimento tipo.
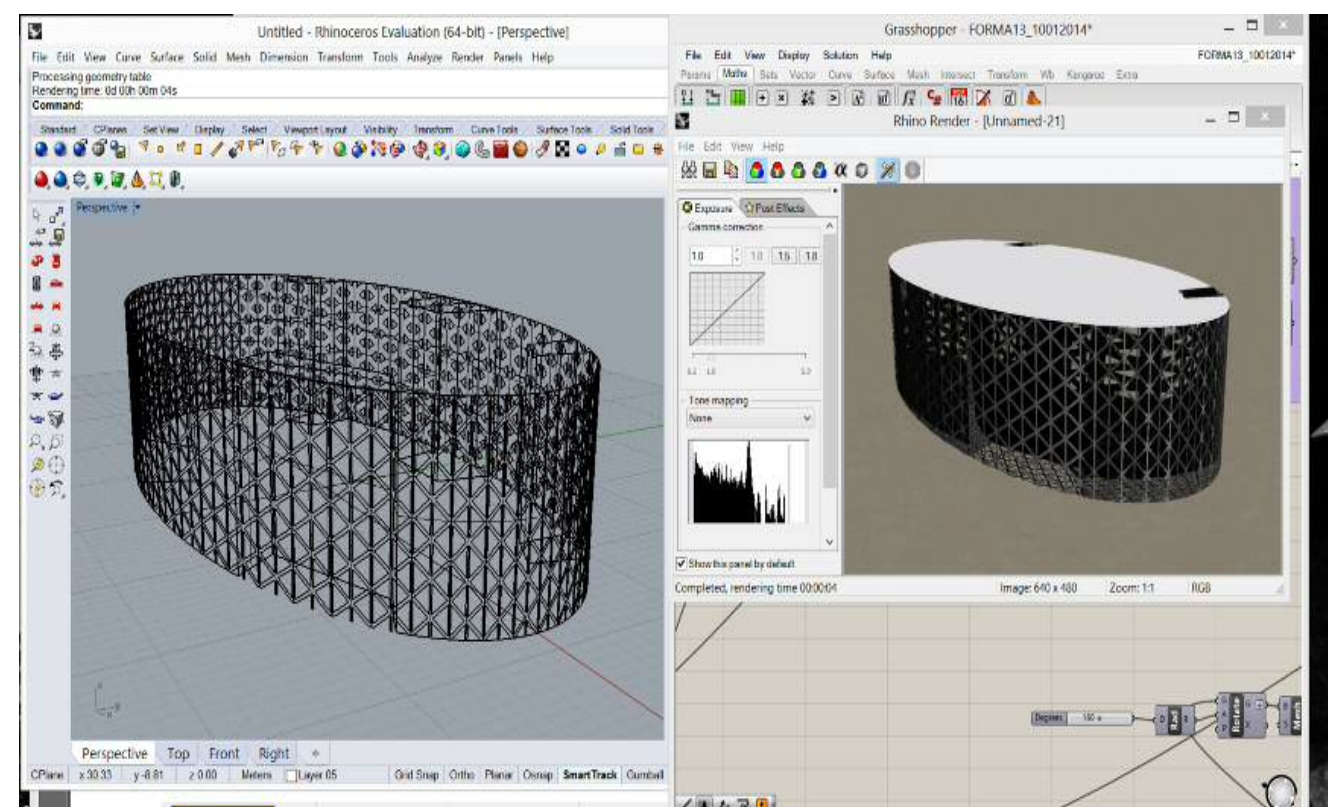

Figura 214 - Modelo da treliça triangular com dois tipos de abertura.

Umakoshi, Erica Mitie 
Capítulo 6 - Aplicação Metodológica de Intervenção Projetual e Avaliação de Desempenho de um Estudo de Caso na Cidade de São Paulo (Projeto)

204 Avaliação de Desempenho Ambiental e Arquitetura Paramétrica Generativa para o Projeto do Edifício Alto

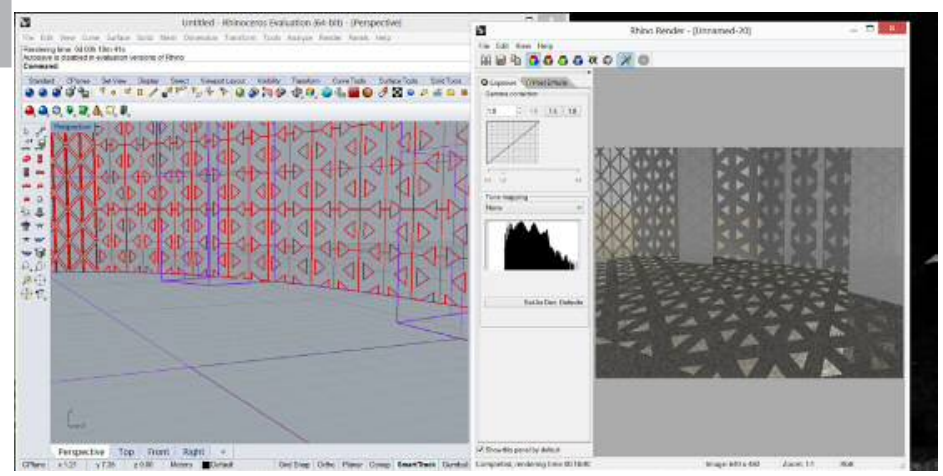

Figura 215- Penetração de sol através do painel de treliça triangular.
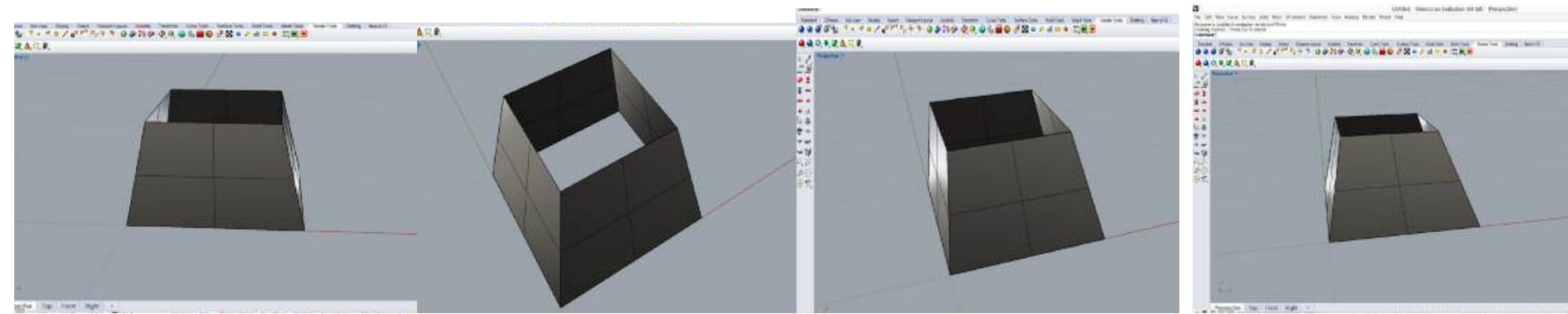

Figura 216 - Componentes desenvolvidos: Norte, Sul, Leste e Oeste.

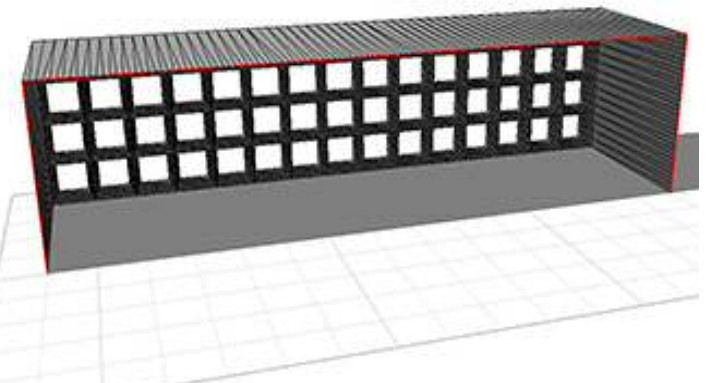

Figura 217- Modelo simplificado no Ecotect, fachada Sul 9h, verão.
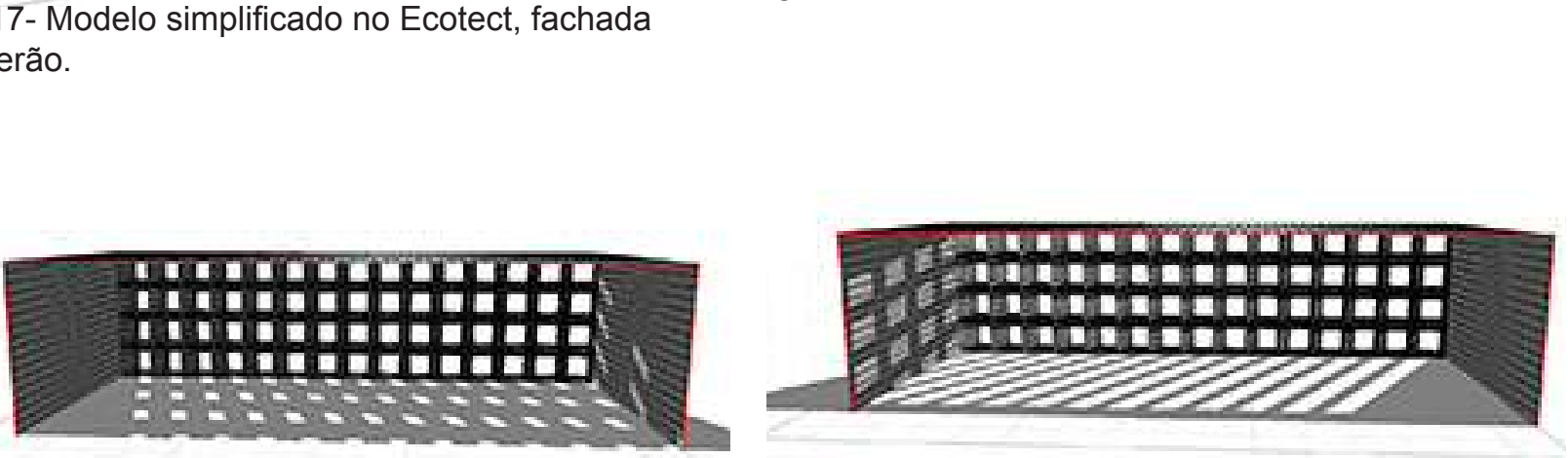

Figura 219- Fachada Oeste, 17h no inverno

Umakoshi, Erica Mitie

FAU-USP, fev. 2014
Figura 218- Fachada Norte, 9h no inverno

Figura 220- Fachada Oeste, 17h no verão 
Capítulo 6 - Aplicação Metodológica de Intervenção Projetual e Avaliação de Desempenho de um Estudo de Caso na Cidade de São Paulo (Projeto)
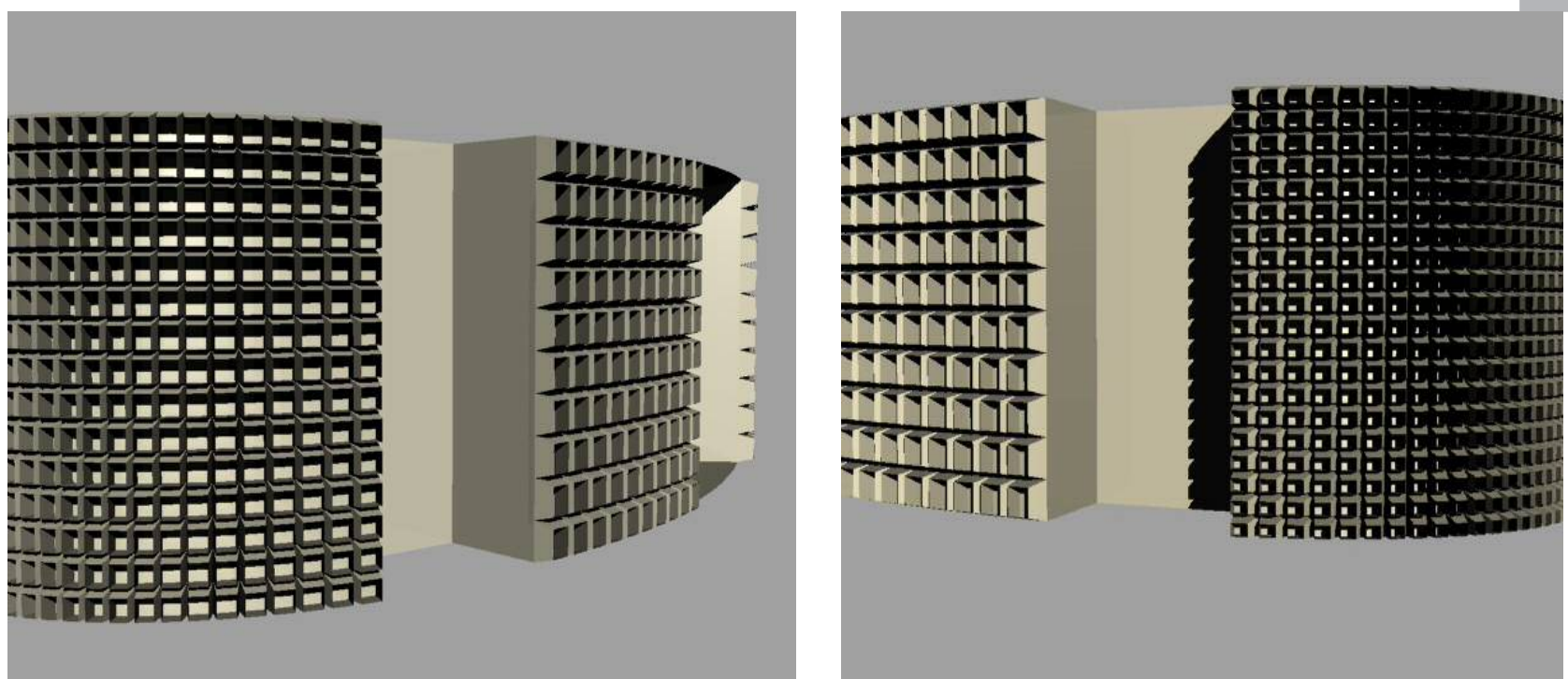

Figura 221 e 222- Componentes nas fachadas Leste e Norte, e nas fachadas Norte e Oeste.
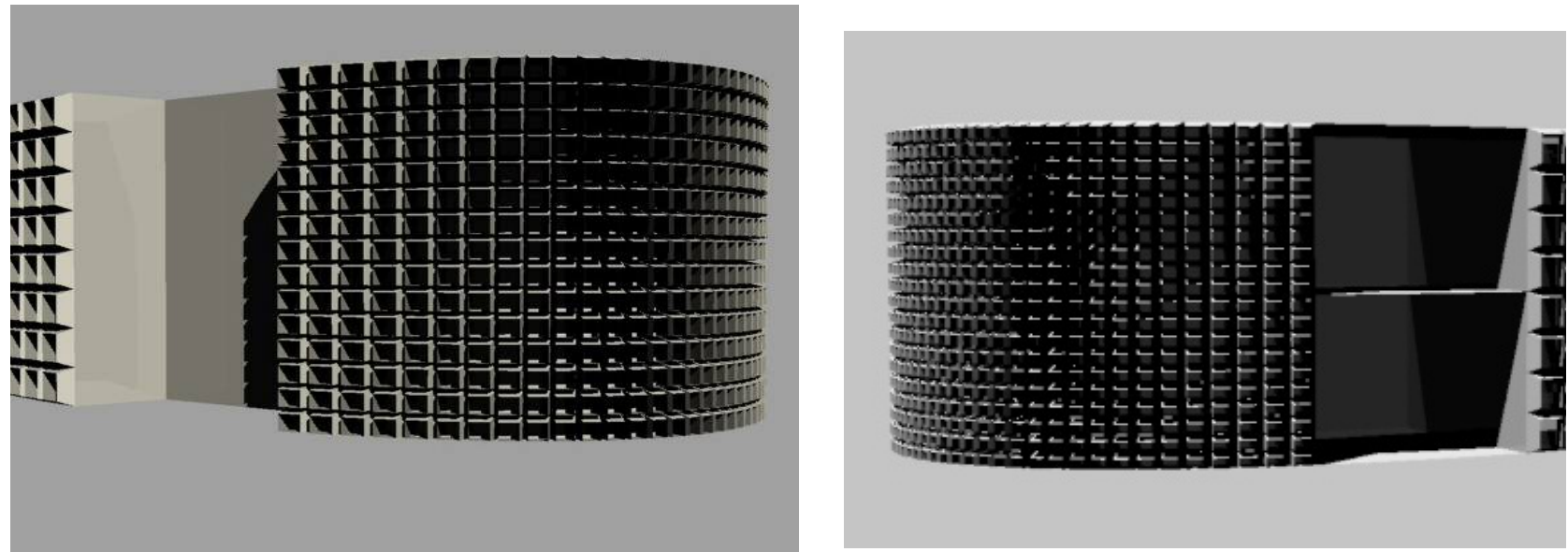

Figura 223 e 224- Componentes nas fachadas Sul e Leste, e nas fachadas Oeste e Sul.
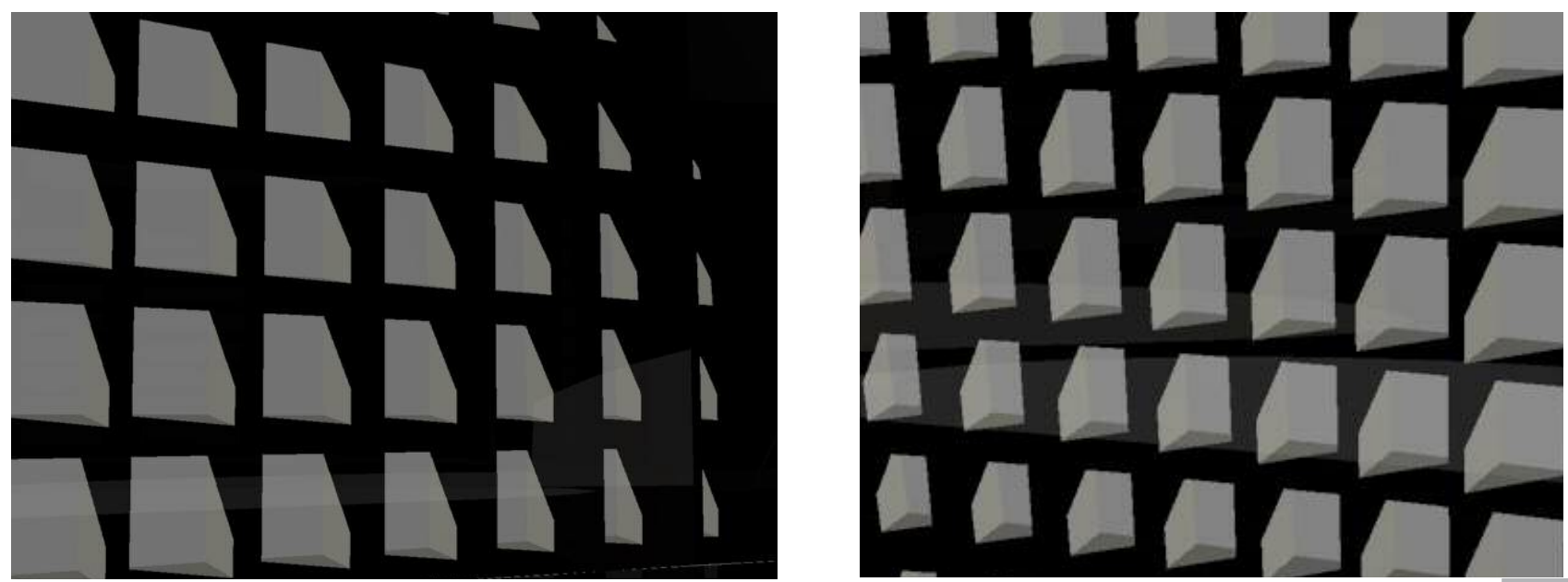

Figura 225 e 226 - Penetração de sol na fachada Sul as 9h e 17h respectivamente. 


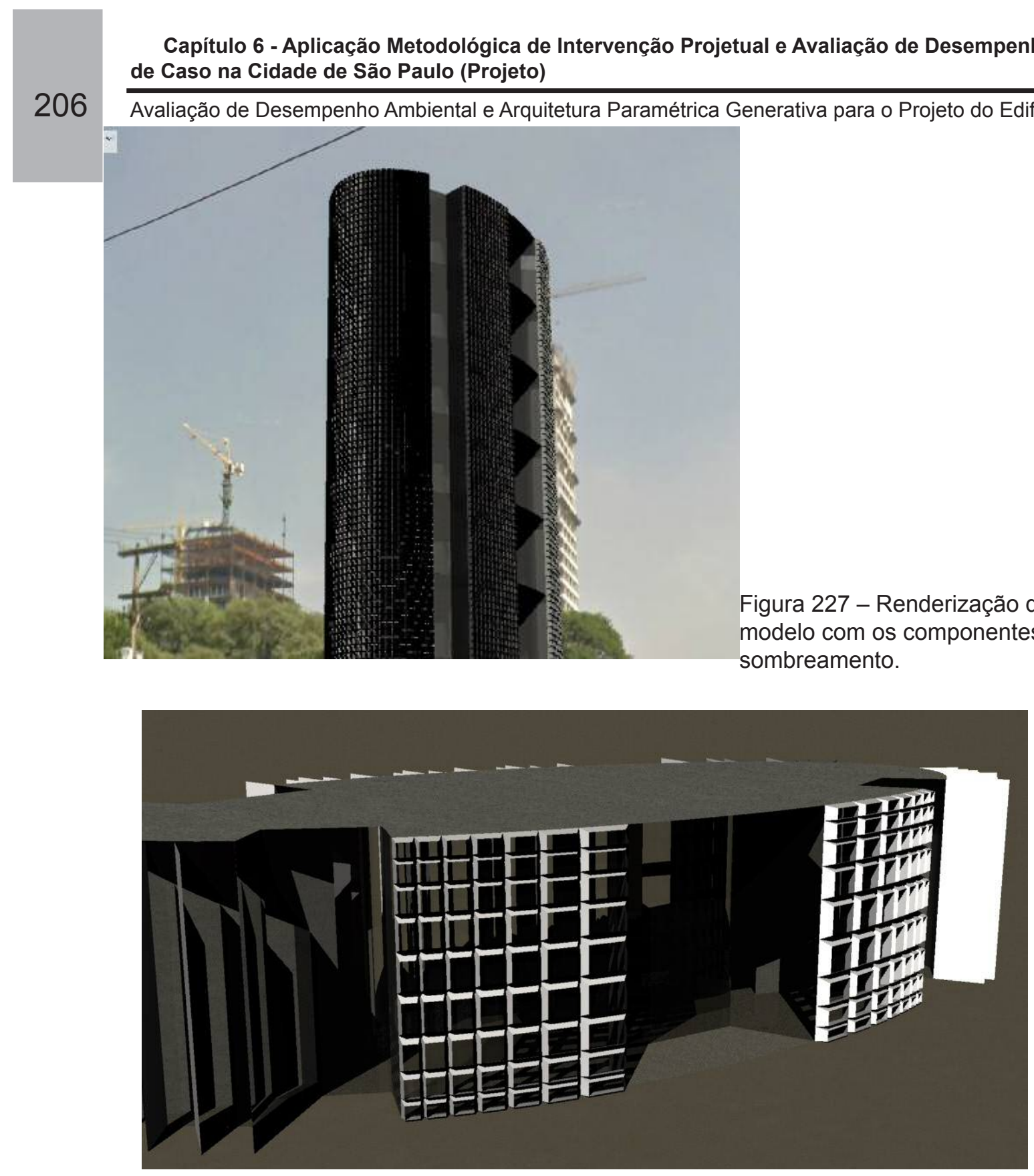

Figura 228 - Nova distribuição do componente quadrado na fachada Norte.

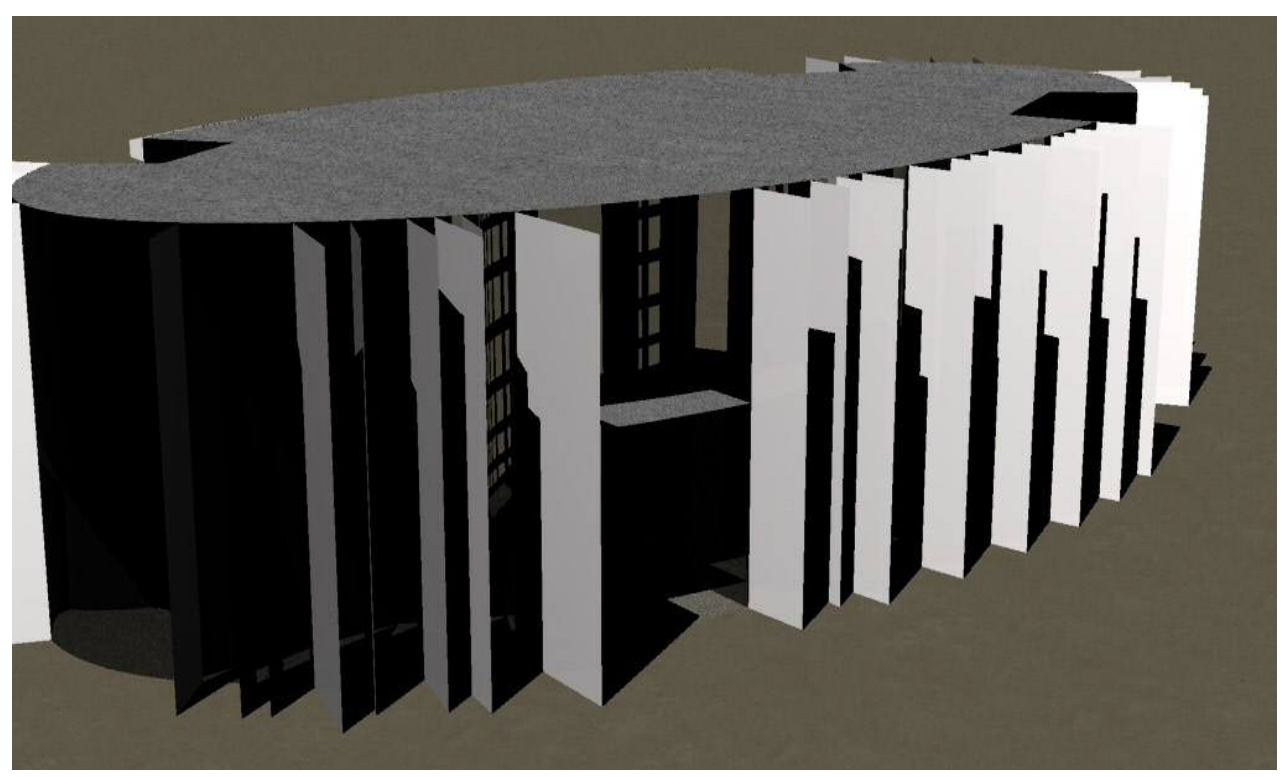

Figura 229- Elemento de sombreamento vertical na fachada Sul, FAU-USP, fev. 2014 


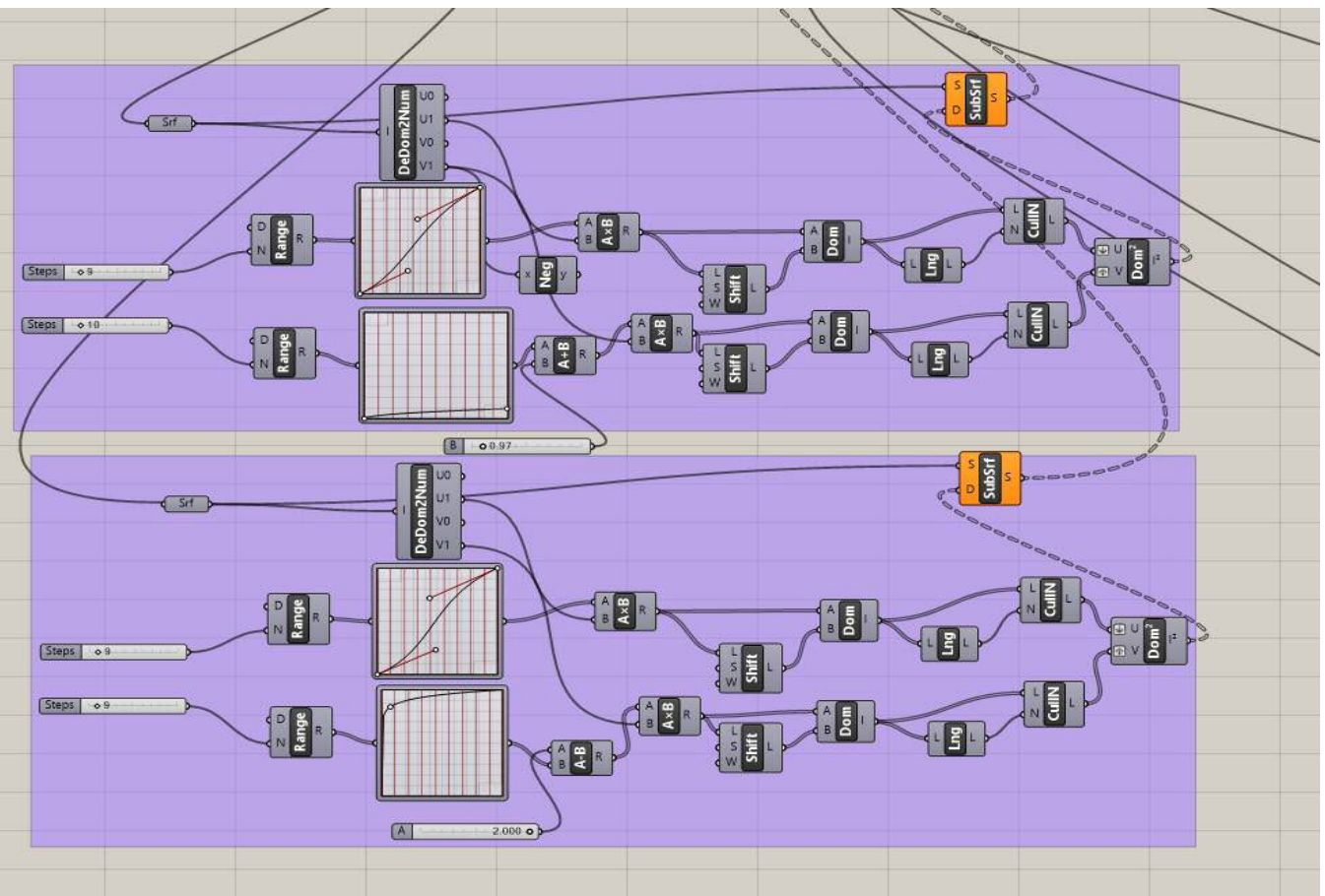

Figura 230 - Grasshopper do componente quadrado na fachada Norte.

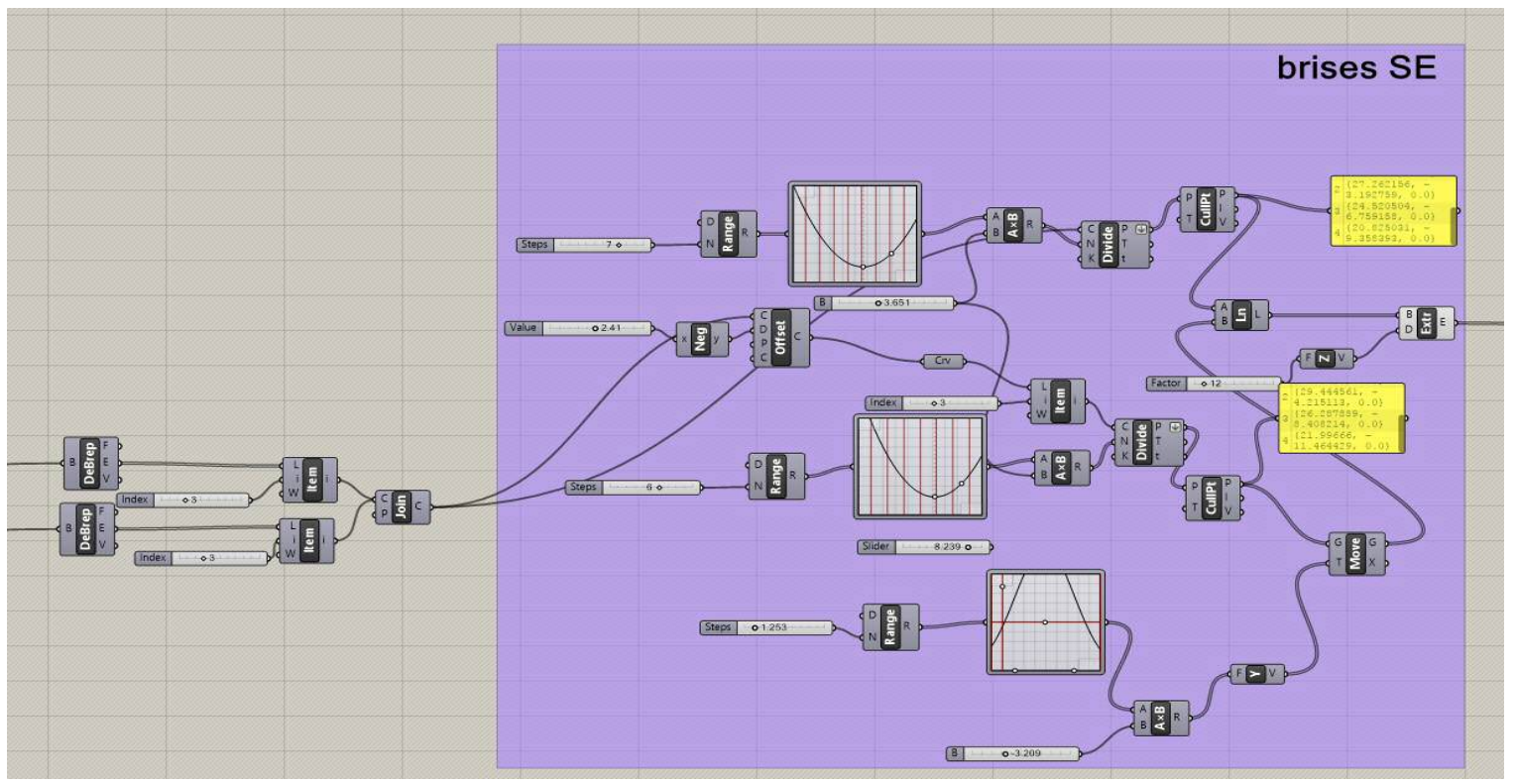

Figura 231- Grasshopper do Brise vertical da fachada SE.

nova forma de aplicação no componente quadrado para a fachada norte (fig. 228) e um novo elemento de sombreamento, agora vertical, foi aplicado nas outras fachadas (fig. 229). 


\subsubsection{Simulação de Iluminação}

Com a definição dos componentes nas fachadas, foram realizados testes no Radiance/ Ecotect com o intuito de verificar os níveis de iluminação natural nos pavimentos. Para isso, o modelo foi exportado do Rhinoceros para o Autocad $^{6}$, com a realização de ajustes e exportação para o Ecotect ${ }^{7}$.

Depois de importado o modelo no ecotect, ajustaram-se os materiais e montou-se uma malha 2D para a análise de iluminação. Foram realizadas simulações de iluminação natural para encontrar o desempenho luminoso em lux e em fator de luz natural (DF). Para isso, foi escolhido o dia 21 de junho, ao meio dia, com o céu nublado.

A partir da análise dos valores obtidos na simulação, pode-se observar que existe uma distribuição uniforme de iluminação natural pelo pavimento. Mostra-se, assim, que as proteções solares estão tendo um desempenho satisfatório.

Visando ampliar o estudo de iluminação natural, foram realizados estudos com o céu parcialmente nublado para os horários de $9 \mathrm{~h}, 12 \mathrm{~h}, 15 \mathrm{~h}$ e $17 \mathrm{~h}$, ou seja, horários no qual o edifício estará ocupado, no inverno e no verão.

Observa-se no gráfico acima (fig. 236) que a distribuição luminosa é bem uniforme no pavimento, apenas apresentando valores mais altos no caso de existência de insolação direta no pavimento, que é identificado na curva das 9h perto da fachada.

Da análise da figura 236, nota-se que perto da fachada norte os valores atingem níveis elevados, o que se deve à penetração de sol, indicando que nessas áreas, perto da janela, não devem ser alocados postos de trabalho, evitando-se, assim, o desconforto dos usuários.

Com isso, a primeira etapa do projeto da fachada está concluída, tendo em vista que o sombreamento e os átrios estão cumprindo o seu papel. No entanto, vale ressaltar que a contribuição luminosa dos átrios ainda está elevada, o que demanda novas análises e um estudo específico para a proteção solar dos mesmos, que não será desenvolvido neste trabalho. 
Capítulo 6 - Aplicação Metodológica de Intervenção Projetual e Avaliação de Desempenho de um Estudo de Caso na Cidade de São Paulo (Projeto)

Avaliação de Desempenho Ambiental e Arquitetura Paramétrica Generativa para o Projeto do Edifício Alto
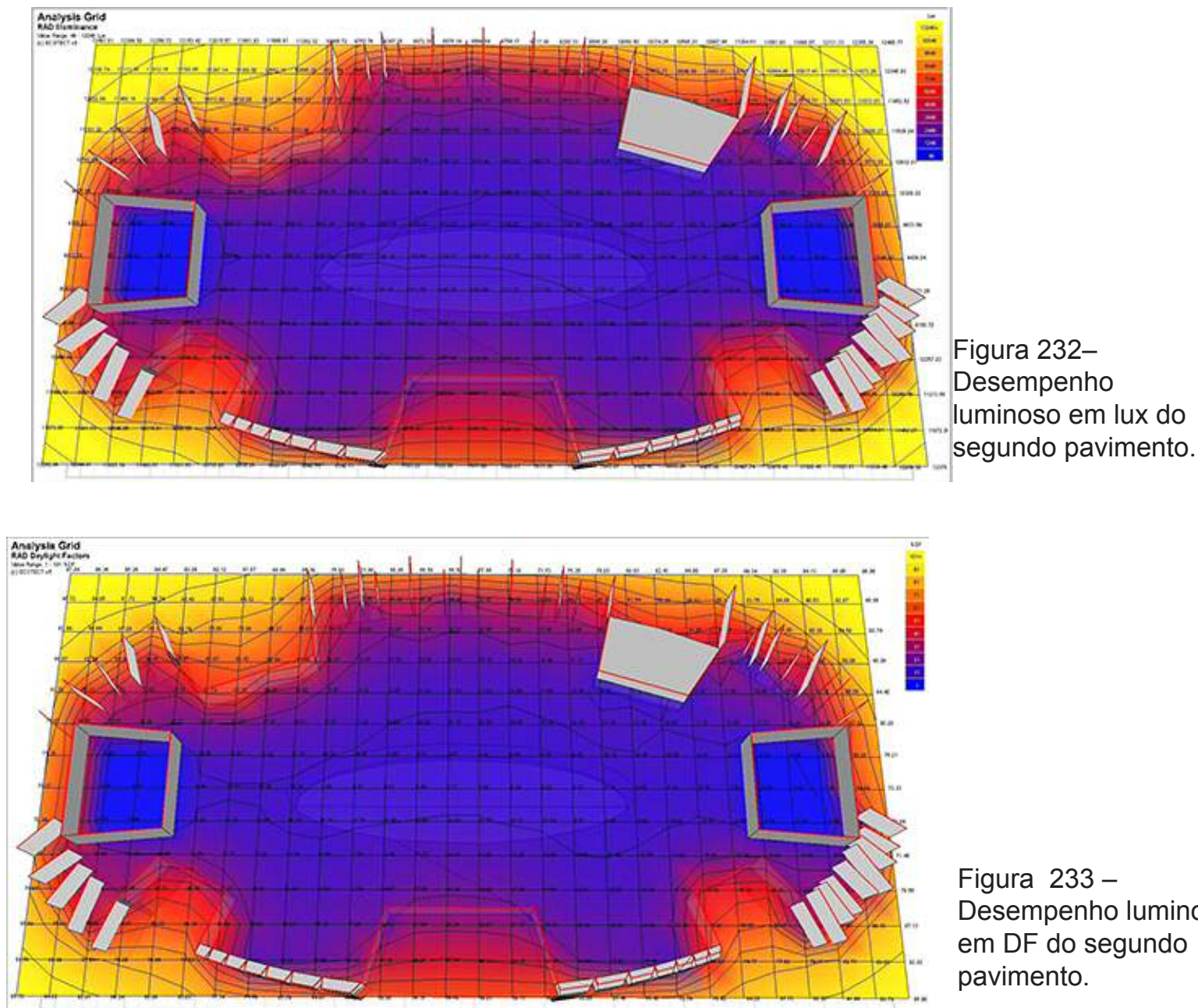

Figura $233-$

Desempenho luminoso em DF do segundo pavimento.

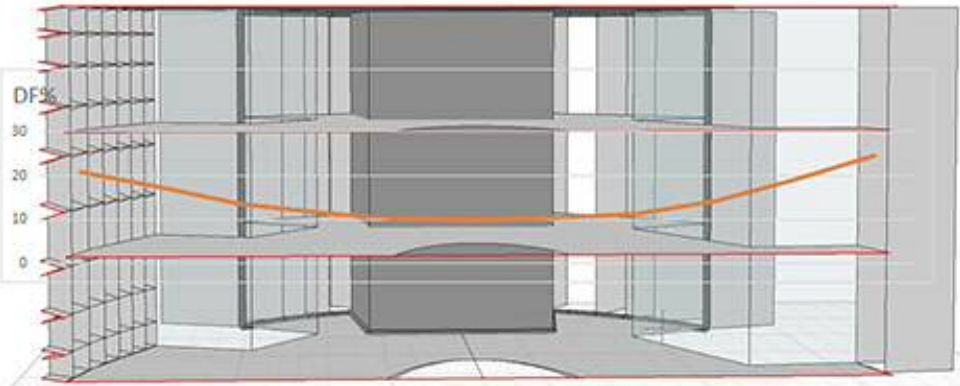

Figura 234-

Gráfico de distribuição luminosa no

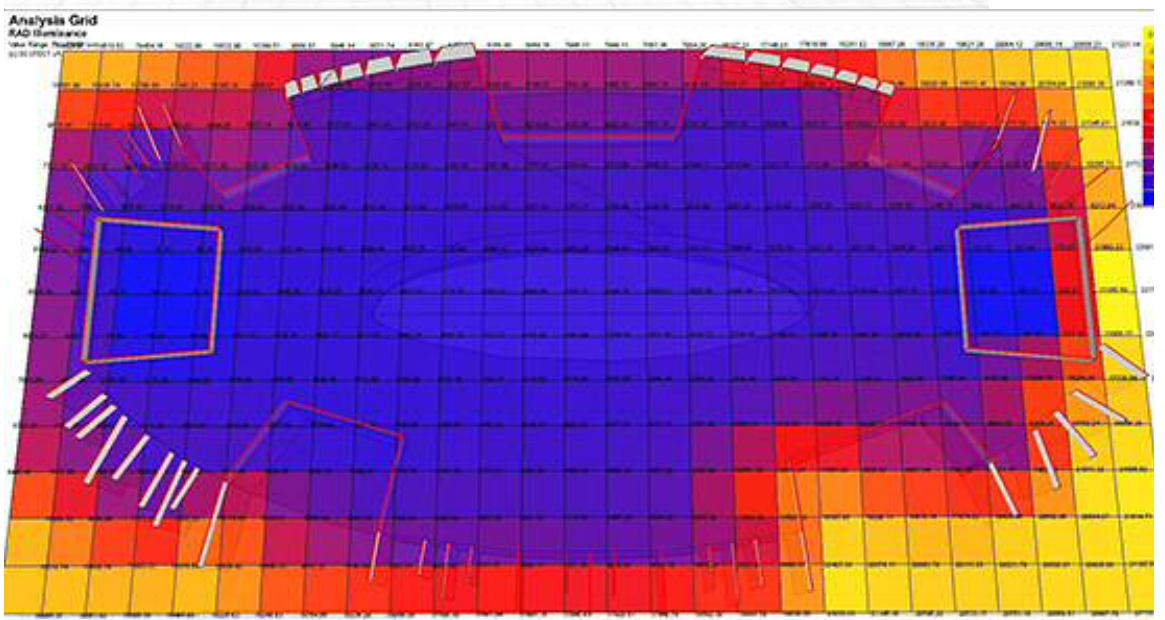
pavimento.

Figura 235 -

Desempenho luminoso em lux do segundo pavimento, às $9 \mathrm{~h}$ no verão com o céu parcialmente nublado.

Umakoshi, Erica Mitie 
Capítulo 6 - Aplicação Metodológica de Intervenção Projetual e Avaliação de Desempenho de um Estudo de Caso na Cidade de São Paulo (Projeto)

210 Avaliação de Desempenho Ambiental e Arquitetura Paramétrica Generativa para o Projeto do Edifício Alto

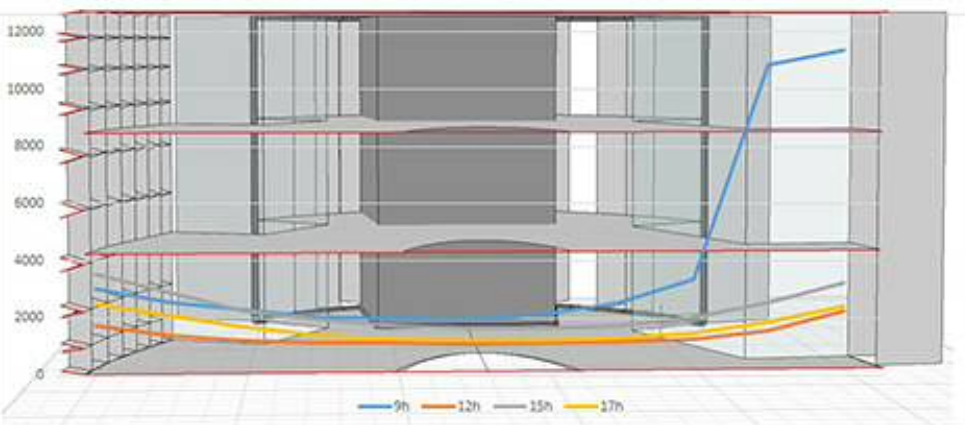

Figura $236-$

Desempenho luminoso

em lux do segundo

pavimento, no verão

com o céu parcialmente

nublado em quatro

horários distintos.

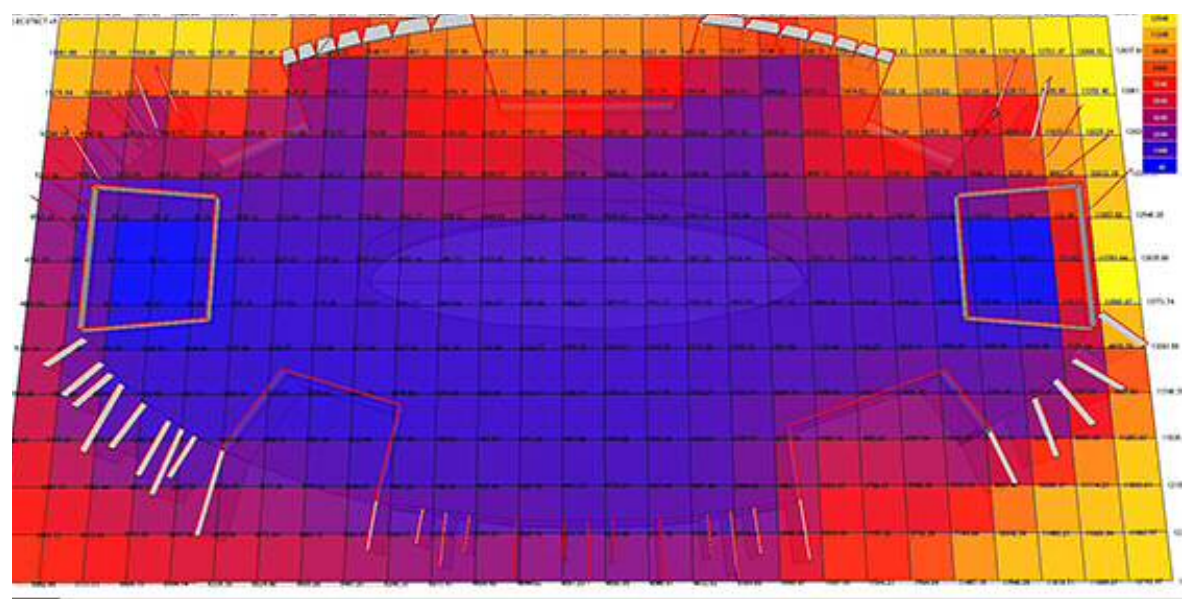

Figura 237-

Desempenho

luminoso em lux do

segundo pavimento,

às $9 \mathrm{~h}$ no inverno com

o céu parcialmente nublado.

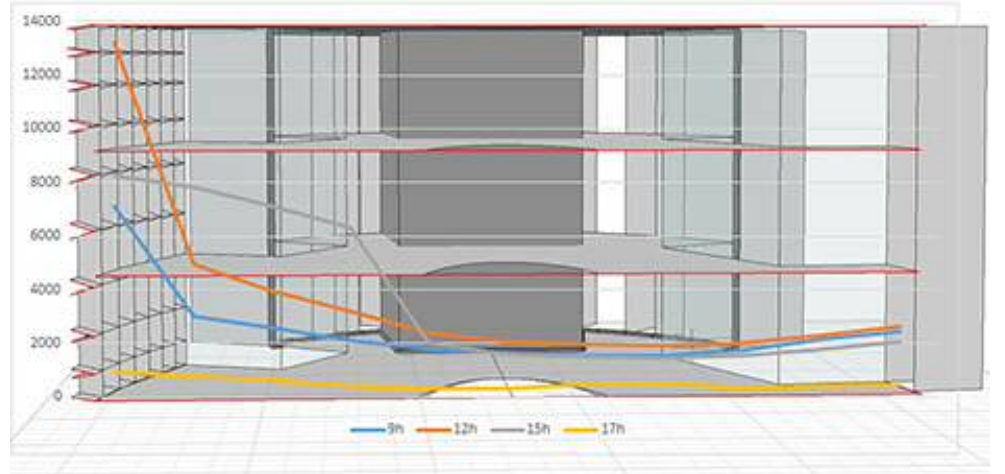

Figura 238- Desempenho luminoso em lux do segundo pavimento, no inverno com o céu parcialmente nublado em quatro horários distintos.
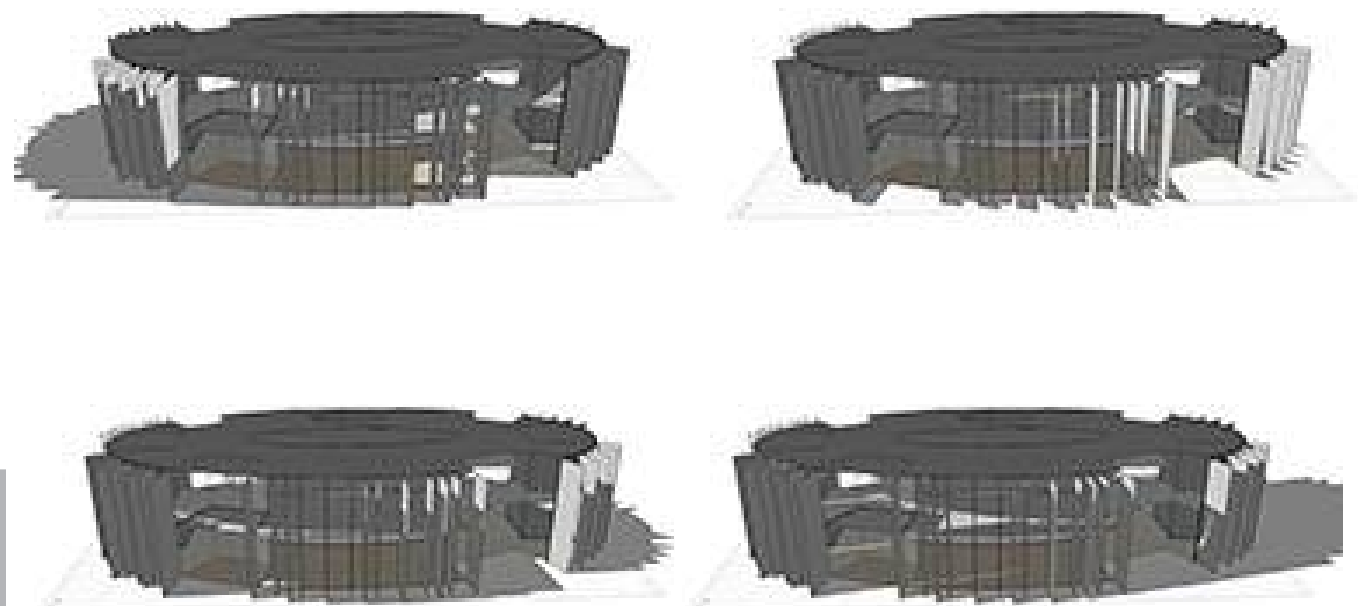

Figura 239-

Penetração de sol pelas fachadas no verão às $9 \mathrm{~h}, 13 \mathrm{~h}$, $15 \mathrm{~h}$ e $17 \mathrm{~h}$. 

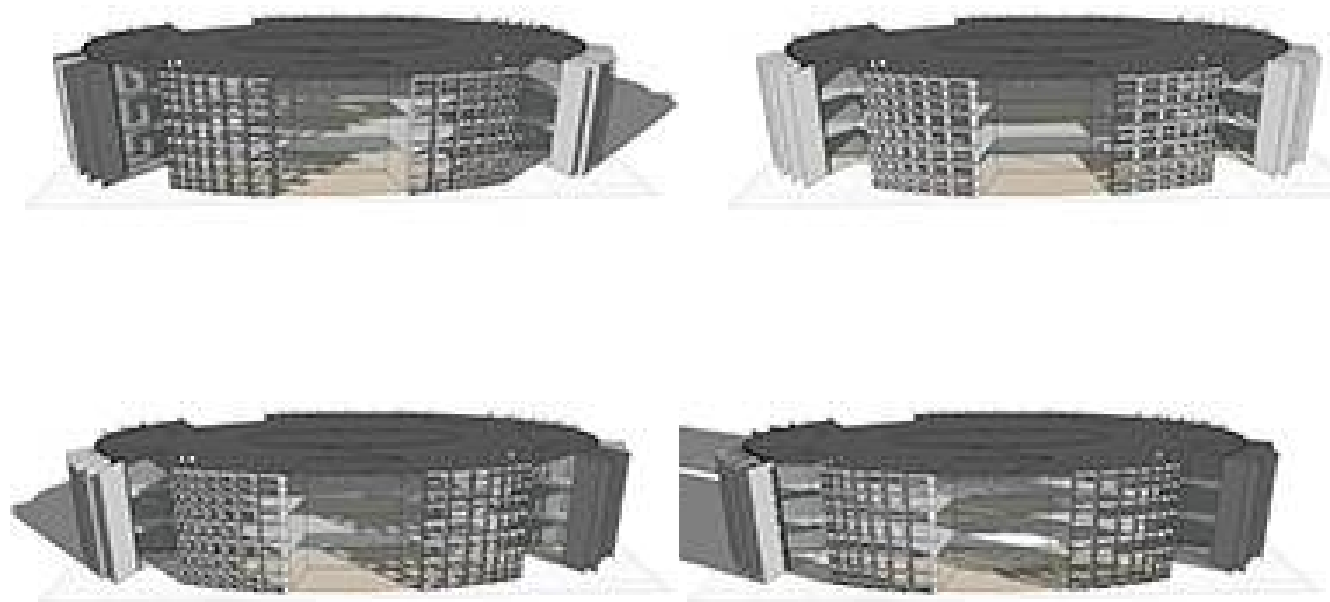

Figura 240-

Penetração de sol pelas fachadas no inverno às $9 \mathrm{~h}, 13 \mathrm{~h}$, $15 \mathrm{~h}$ e $17 \mathrm{~h}$.
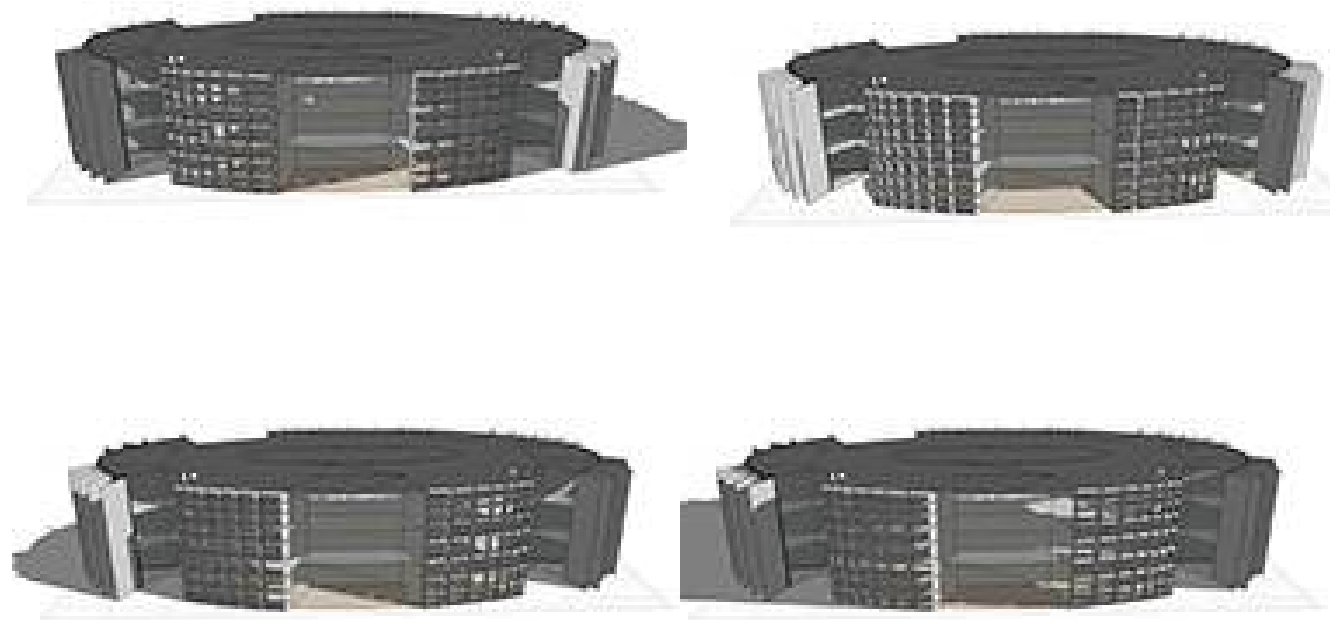

Figura 241-

Penetração de sol pelas fachadas nos equinócios às $9 \mathrm{~h}$, $13 \mathrm{~h}, 15 \mathrm{~h}$ e $17 \mathrm{~h}$.

6.2.5 Projeto final

Com isso, foi possível finalizar o projeto. 
Capítulo 6 - Aplicação Metodológica de Intervenção Projetual e Avaliação de Desempenho de um Estudo de Caso na Cidade de São Paulo (Projeto)

212 Avaliação de Desempenho Ambiental e Arquitetura Paramétrica Generativa para o Projeto do Edifício Alto

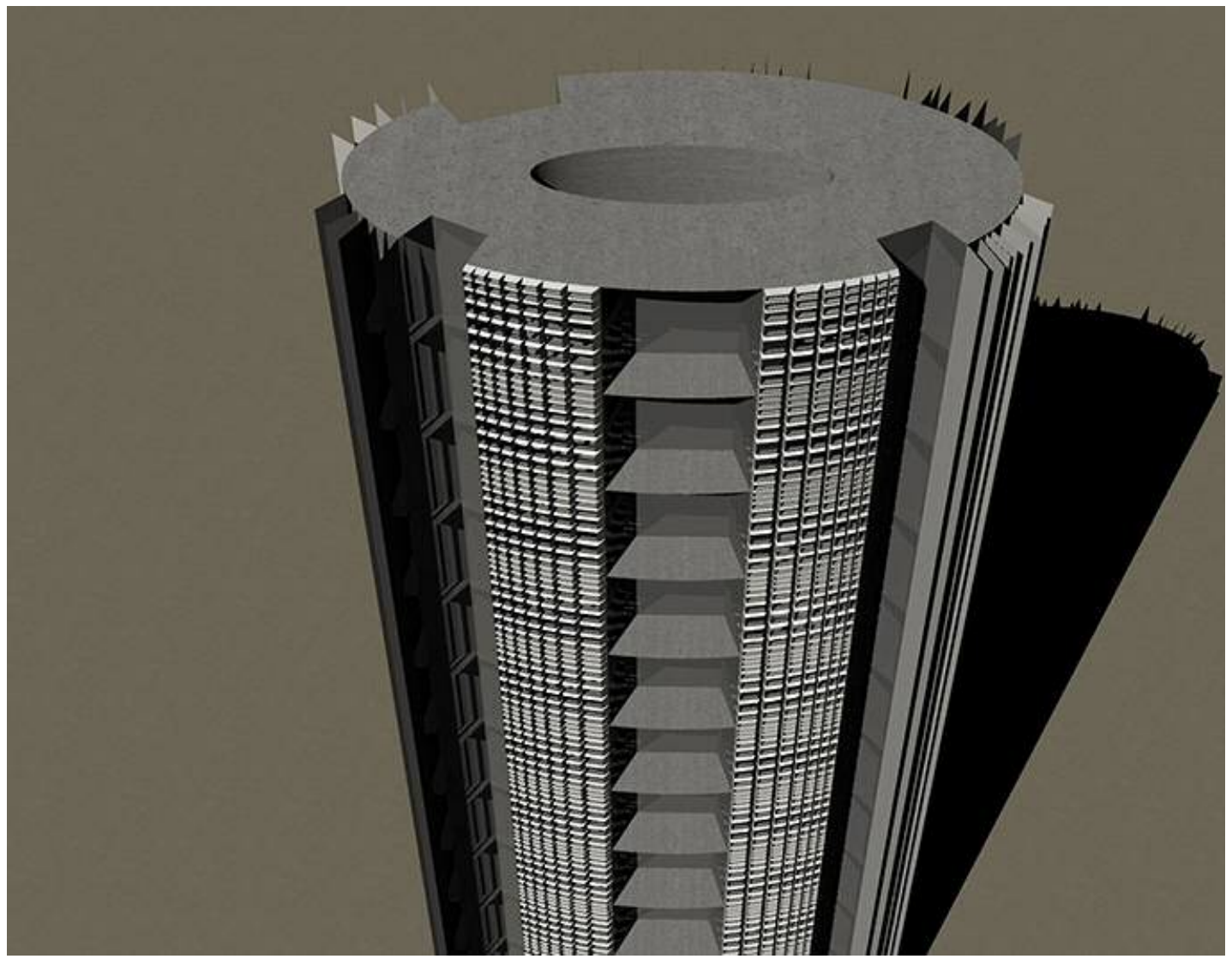

Figura 242- - Fachada Norte.

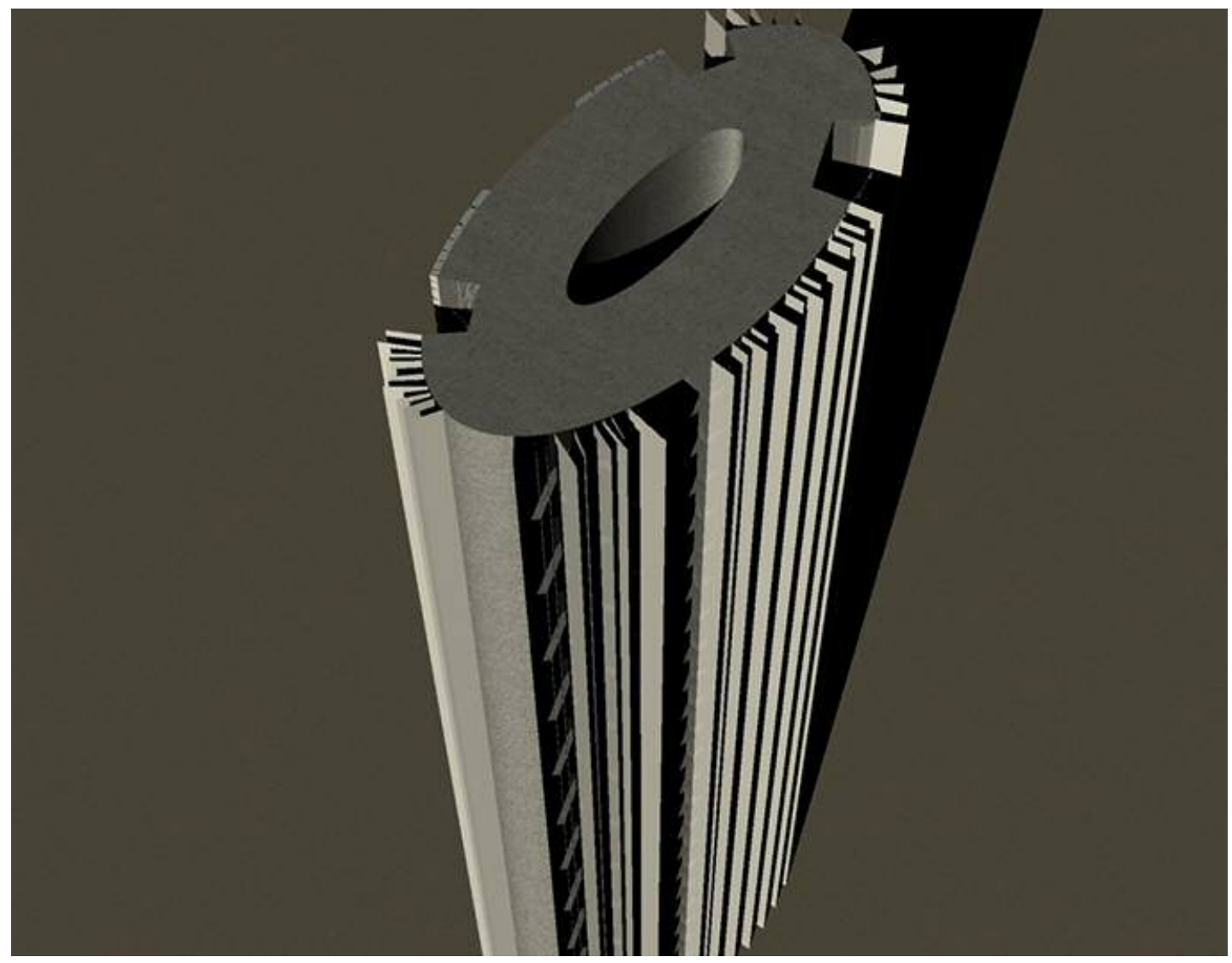

Figura 243 - Fachada Sul. 
Avaliação de Desempenho Ambiental e Arquitetura Paramétrica Generativa para o Projeto do Edifício Alto
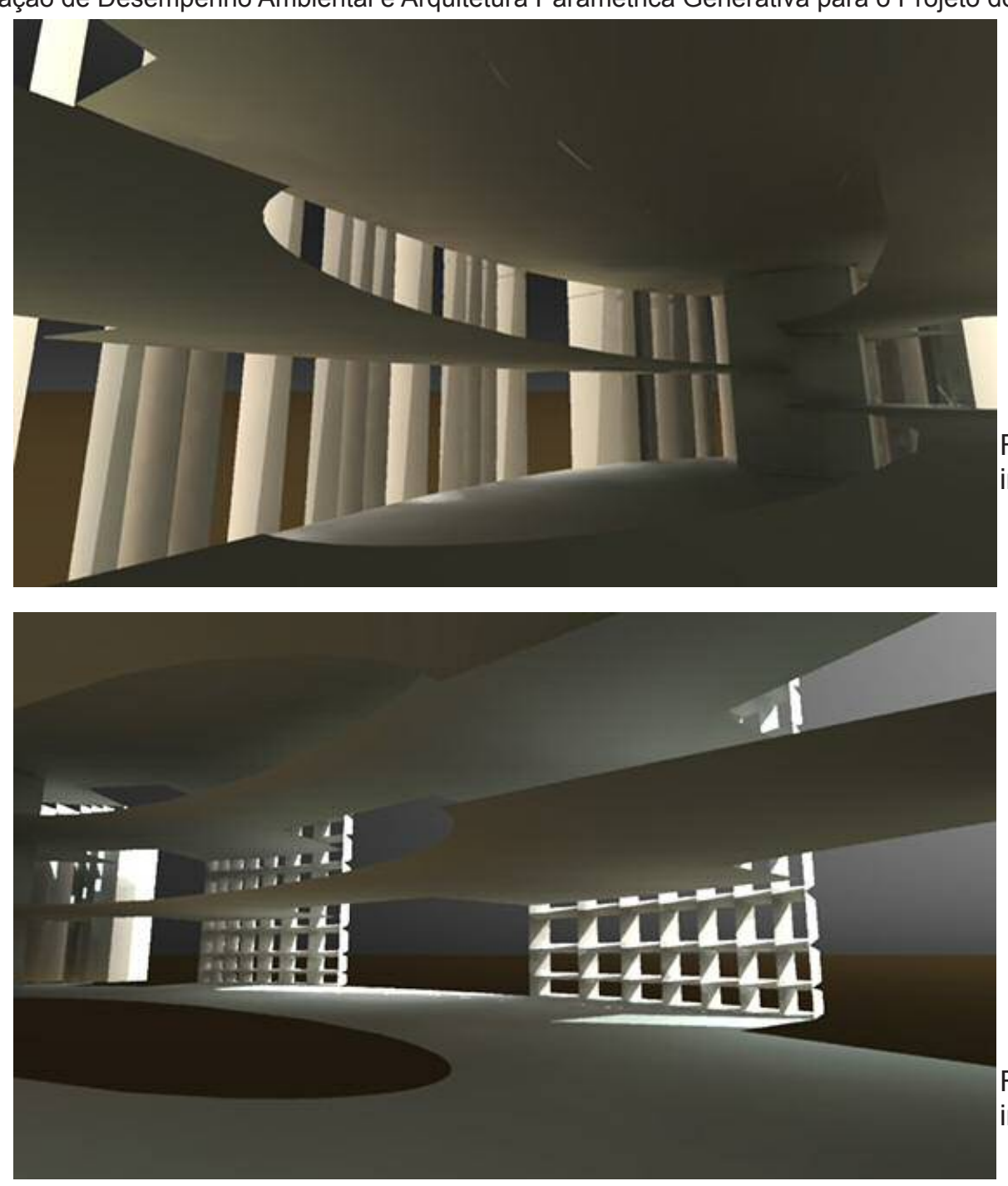

Figura 244 - Vista interna fachada Sul.

\subsection{Considerações finais}

Figura 245 - Vista interna fachada Norte.

O método de projeto aqui apresentado teve como objetivo instruir os arquitetos no uso de critérios ambientais para informar a geração da forma, demostrando como os estudos analíticos de desempenho, a partir dos critérios, podem integrar o processo de projeto. Vale ressaltar que o foco está nas primeiras fases do processo de projeto e que o conhecimento das questões de conforto são fundamentais para alimentar o método.

Trata-se de um processo de retroalimentação, em que são realizadas as avaliações e as simulações para, então, voltar-se à forma, corrigir, avaliar e decidir. Caso seja aplicada essa metodologia no princípio do projeto, os estudos de desempenho podem ser realizados inúmeras vezes sem que se comprometa muito o cronograma de projeto. São estudos rápidos, mas que acarretam grande diferença no resultado final, tanto na 
forma como no desempenho.

Vale ressaltar que o método pode ser aplicado em outras etapas do projeto, entendendose que a complexidade do modelo também se refletirá na complexidade das simulações, podendo consumir, consequentemente, uma maior quantidade de horas de trabalho.

O exercício de projeto, por sua vez, teve como objetivo demonstrar a aplicação do método, mas sem a pretensão de finalizar o projeto do edifício como um todo, tendo sido entendido que a complexidade dessa tipologia não caberia nesta pesquisa. Além disso, vale ressaltar que a discussão não se finda nesse exercício de projeto, sendo apenas uma opção dentre todas as outras possíveis respostas à geração de forma.

O papel das simulações em modelos base reduzidos (shoe box) também foram importantes para selecionar os critérios, sendo necessário que se tenha cuidado na aplicação, pois, levando-se em consideração a diferença na forma e a complexidade do modelo final, não se pode aplicar o componente ou o material e esperar o mesmo resultado. Há que se ter cautela e sempre realizar avaliações e simulações de desempenho para se tomar uma decisão.

Verificou-se, na aplicação do método, que no projeto do edifício alto é preciso que haja cuidado com o desenvolvimento de componentes de sombreamento, pois, quando analisados em grandes dimensões, podem perder o seu papel quanto à expressão arquitetônica. As simulações de iluminação demonstraram um grande potencial para informar o processo de dimensionamento dos componentes, sendo que, sem elas, não seria possível atingir uma precisão desejável.

Trata-se de trabalho para uma próxima etapa o desenvolvimento dos estudos de ventilação no pavimento tipo e o tratamento dos átrios. Demonstra-se, mais uma vez, que essa discussão não se encerra por aqui. 
Capítulo 7: 
Avaliação de Desempenho Ambiental e Arquitetura Paramétrica Generativa para o Projeto do Edifício Alto 


\section{Capítulo 7: Considerações Finais}

\subsection{Conclusões}

\subsubsection{Síntese dos capítulos}

No capítulo 1, discutiu-se o desempenho energético do edifício alto e destacou-se os ícones dessa nova geração aclamada como ambientalmente corretos. Com relação às questões ligadas ao consumo energético, viu-se que, dentro de um processo de projeto afinado, o consumo depende das decisões tomadas durante a fase de construção e de uma série de variáveis relacionadas com a ocupação. Em outras palavras, a operação real de um edifício é muito mais complexa do que um cenário de simulação. Por esta razão, apesar de todos os rigorosos processos de predição de consumo energético, baseados em simulações computacionais durante o processo de projeto, os resultados, geralmente, destoam significativamente do desempenho real do edifício. Entretanto, sistemas de avaliação e benchmarks são baseados em projeto e existe pouco incentivo para se avaliar o pós ocupação.

Visando desmistificar as questões de consumo energético do edifício alto, é preciso que os dados de consumo sejam disponibilizados e analisados separadamente antes de se formar uma opinião sobre altura versus maior consumo de energia. Sem esses dados, é difícil que se tenha certeza do real impacto da altura no consumo energético.

Apesar do caráter inovador e do valor icônico associado ao grupo de edifícios apresentados neste capítulo, os edifícios europeus representam a primeira iniciativa a desafiar o modelo comercial convencional, informando tecnicamente e inspirando arquitetonicamente novos projetos com qualidade ambiental e eficiência energética, ressaltando as soluções arquitetônicas e não apenas os sistemas prediais. Ainda que sejam considerados como referência, esses exemplos não podem ser tomados como soluções universais, dadas as diferenciações socioeconômicas, culturais e ambientais de cada contexto para os quais novos edifícios altos vêm sendo projetados e construídos.

No capítulo 2 foram discutidas questões referentes aos selos de desempenho ambiental, às novas questões de conforto e aos novos critérios qualitativos e quantitativos para avaliação de um edifício alto ambiental. Visando contribuir para a mudança do mercado, é necessária uma revisão crítica sobre a qualidade ambiental, bem como sobre o que 
Avaliação de Desempenho Ambiental e Arquitetura Paramétrica Generativa para o Projeto do Edifício Alto

agrega "valor" ao projeto de edifícios altos de escritórios. A definição clássica de área útil, que atribui o mesmo valor de locação para todas as áreas, é simplista demais e representa um importante obstáculo ao desenvolvimento e à propagação da qualidade ambiental em empreendimentos comerciais.

Apesar da importância de estudos preditivos do desempenho ambiental de edifícios na fase de projeto, como dito anteriormente, uma das principais barreiras para a melhoria do projeto em geral está na lacuna entre os dados teóricos e aqueles baseados no cenário real de ocupação. Isso ocorre porque o desempenho energético de um edifício em operação é bastante afetado por fatores que estão além do projeto, incluindo rotinas de gerenciamento, comportamento dos usuários e mudanças climáticas (COLE, BROWN, McKAY, 2010). Como pontuado por Gonçalves e Bode (2011a), aprender com a experiência real de edifícios ocupados é parte fundamental do processo de projeto de edifícios de melhor desempenho ambiental.

Nesse contexto, pode-se dizer que o processo de projeto pode ser favorecido pela busca por um selo de desempenho ambiental, pois, independentemente da certificação em questão, o processo em si requer a integração entre os diferentes agentes do projeto, bem como as avaliações de desempenho ambiental na fase de projeto. Porém, sem a comprovação do real desempenho ambiental e energético dos edifícios em uso e em operação, a certificação não passa de um simples instrumento de mercado, sem valor real.

As definições de conforto ambiental mudaram significativamente nos últimos cem anos, e isso influencia diretamente nas condições ambientais internas das edificações e na demanda por energia (Capells, Shove, 2004). Avaliar o nível de conforto térmico é fundamental para o estabelecimento de padrões de desempenho ambiental e energético de edifícios, mas não requer apenas uma compreensão do que o corpo humano pode suportar, e sim, até que ponto as pessoas estão dispostas a fazer mudanças comportamentais em busca do conforto em seu ambiente. Isso afeta a maneira como o usuário interage com o seu ambiente. Em suma, edifícios de menor impacto ambiental exigem um envolvimento mais proativo entre o ocupante, o edifício e o ambiente, o que reflete o grau de técnicas que utilizam soluções passivas e, se realmente necessárias, 
também ativas.

Ao proporcionar a possibilidade dos ocupantes dos edifícios de interferir no clima interno de acordo com sua própria preferência de conforto, maiores níveis de satisfação podem ser alcançados ao lado de economias significativas de energia. Tem-se, assim, o conceito de conforto adaptativo, que se aplica tanto a edifícios passivos como aos que utilizam sistemas ativos de arrefecimento ou aquecimento.

Ocupantes que vivem permanentemente em edifícios com ar-condicionado desenvolvem grandes expectativas em relação ao controle de temperatura e homogeneidade. Por outro lado, os ocupantes que vivem em edifícios ventilados naturalmente são, geralmente, mais capazes de controlar seu ambiente e se habituam à variabilidade climática e à diversidade térmica. Assim, suas preferências térmicas estendem-se a uma ampla gama de temperaturas e velocidades do ar. Além disso, pessoas que utilizam o transporte público para chegar ao trabalho têm uma adaptação ao meio ambiente muito maior do que as pessoas que vão trabalhar de carro com o ar-condicionado ligado, pessoas estas que também exigem uma maior homogeneidade térmica (YANNAS, 2008).

É válido dizer que o conforto térmico foi promovido por décadas como sendo um "produto" a ser comprado, no entanto, atualmente, o conforto térmico promovido pelos modelos adaptativos se transformou em um objetivo a ser alcançado pelo usuário, a um custo financeiro e ambiental mais baixo e resultados finais com maior satisfação dos usuários. De fato, estar fora da zona de conforto pode ser uma ótima oportunidade para uma mudança, para uma situação criativa, para algo que leve o usuário a interagir, de fato, com o ambiente em que está. Projetar de modo a fornecer variabilidade e meios necessários para que os usuários nos diferentes ambientes possam se adaptar, buscando conforto e satisfação enquanto indivíduos e coletividade.

Em busca de se definir quais critérios influenciam realmente no desempenho, foram apresentados critérios qualitativos e quantitativos. Os primeiros estão ligados a uma avaliação de observação do espaço urbano e interno, informações de conceitos e processo de projeto, além de respostas às questões climáticas. Já os quantitativos referem-se a dados de desempenho do edifício, que podem ser medidos e calculados. No entanto, vale ressaltar que nem todos estão ligados somente ao desempenho do 
Avaliação de Desempenho Ambiental e Arquitetura Paramétrica Generativa para o Projeto do Edifício Alto

edifício alto, podendo ser aplicados em outras tipologias de edificação.

Por sua vez, o capítulo 3 discutiu as possibilidades da ventilação natural na cidade de São Paulo. O clima da cidade é considerado ameno, sendo que, durante a maior parte do ano, as temperaturas permanecem entre $150 \mathrm{C}$ e $250 \mathrm{C}$. As temperaturas de verão, extraídas do banco de dados do ano típico, não são consideradas grandes desafios para o projeto caso seja possível bloquear os ganhos solares com elementos de sombreamento e criar estratégias para a ventilação natural. Outro fator importante ligado ao sombreamento é o fato da quantidades de radiação solar direta e difusa incidentes em um plano horizontal serem bastante semelhantes devido à alta frequência de céu encoberto. Com isso, uma das estratégias mais eficientes no bloqueio da radiação difusa é a redução das áreas envidraçadas, minimizando a visão do céu, ou através de elementos externos de proteção solar.

Com relação à umidade relativa, pode-se dizer que a média anual é de $80 \%$, sendo a ventilação natural, por isso, tão importante para se atingir o conforto, já que a movimentação do ar ajuda na retirada do exesso de umidade. Outro fator muito importante que deve ser levado em consideração é a sensação térmica dos usuários quando o sol bate diretamente sobre ele. Baker e Steemer (2002) afirmam que a sensação térmica desses usuários pode ser de $30 \mathrm{C}$ a $7 \mathrm{oC}$ superior à temperatura do ar. Com isso, a principal consequência da falta de controle da radiação direta é o fechamento de persianas e o acionamento da iluminação artificial durante todo o período de ocupação. Sendo assim, Cotta (2012) afirma que é necessário que se proteja as aberturas, principalmente na parte da manhã, quando os usuários chegam para trabalhar. Através disso, é possivel garantir que as persianas não impeçam a iluminação e nem a ventilação natural. No caso do uso de escritórios, é importante que haja uma iluminação de 300 lux no plano de trabalho para que o usuário não precise de uma complementação artificial. No entanto, de acordo com Baker (2009), o mínimo de iluminação aceitável utilizando o computador é de 150 lux. Além da iluminação natural, outros fatores ligados diretamente às aberturas são as vistas para o exterior e a ventilação.

Dos resultados das medições de conforto no edifício CBI-Esplanada, foi possível constatar a relação entre a ocupação e as condições térmicas, pois, quanto maior a ocupação, 
maiores foram as temperaturas internas registradas. Observações realizadas durante o período de medição mostraram que a abertura e o fechamento das janelas foram controlados diretamente pelo usuário mais próximo a elas, fato esse que limita a operação da janela somente a uma pessoa, podendo comprometer as condições de conforto de todo o ambiente, principalmente no período mais quente do verão. Infelizmente, as janelas voltadas ao átrio central, que poderiam contribuir para uma ventilação cruzada, são mantidas fechadas. A abertura dessas janelas que se localizam na face oposta às janelas da fachada poderiam melhorar as condições de conforto térmico, reduzindo a necessidade de utilização do sistema de condicionamento de ar. O problema de insolação direta nas estações de trabalho cria situações de superaquecimento e de ofuscamento, que poderiam ser resolvidas com o afastamento dessas estações de trabalho da janela e a colocação de elementos de sombreamento na parte externa da fachada. Outra questão problemática relacionada à eficiência energética no edifício é o fato da iluminação artificial na área de trabalho ser acionada por um único interruptor, denotando a necessidade de um novo sistema de iluminação artificial. Com essa atitude, poderia ser reduzido, significativamente, o consumo relacionado à iluminação artificial.

Das simulações de desempenho ambiental de um modelo base (shoe box), obtiveramse como resultados desempenhos semelhantes, em orientações distintas e com diferentes porcentagem de área envidraçada, o que demonstra que as fachadas não podem receber o mesmo tratamento.

A inserção de um brise horizontal na fachada revelou que, apesar de se tratar de um modelo simplificado, é possível a geração de grandes diferenças no desempenho. Ficou claro, com isso, que, apesar da grande exposição de uma fachada com WWR de $90 \%$, se bem sombreada, ela poderá alcançar um desempenho satisfatório num clima como o de São Paulo. Dessa forma, é importante ressaltar que a utilização de grandes panos de vidro só são possíveis quando bem sombreados.

As simulações utilizando massa térmica e a ventilação noturna mostraram que uma pequena mudança na configuração do pavimento e a abertura da janela num período não ocupado do edifício podem contribuir com a redução no consumo energético anual para o resfriamento, pois se retira o calor acumulado durante o dia através da ventilação. 
Avaliação de Desempenho Ambiental e Arquitetura Paramétrica Generativa para o Projeto do Edifício Alto

Quando falamos em conforto térmico e no ar-condicionado, estamos nos retratando, principalmente, à temperatura de setpoint do equipamento, pois é ela que vai determinar o tempo e a potência com os quais o mesmo irá trabalhar. Foram simulados três cenários, com temperaturas de setpoint de $24^{\circ} \mathrm{C}, 25^{\circ} \mathrm{C}, 26^{\circ} \mathrm{C}$ e $28^{\circ} \mathrm{C}$, que demonstraram reduções significativas nas cargas térmicas de resfriamento. Mas, vale ressaltar que a temperatura de $28^{\circ} \mathrm{C}$, mesmo sendo condizente com os limites apontados pelos modelos adaptativos de conforto térmico, necessita de uma aceitação cultural, tendo em vista que as pessoas já estão acostumadas a uma temperatura inferior a essa. Nota-se, ainda, que apesar de terem sido desenvolvidos para edificios ventilados naturalmente, o uso dos limites de conforto gerados pelos modelos adaptativos em edificios condicionados artificialmente está atrelado a economias relevantes de energia, além da constatação de que a dependência do condicionamento artificial pode ser questionada.

No capítulo 4, foram apresentadas as novas ferramentas digitais que vêm proporcionando uma renovação nas formas dos edifícios altos, introduzindo um novo repertório de curvas e deformações (Natividade, 2010). As formas produzidas são caracterizadas pelo alto nível de complexidade, presente tanto na expressão formal quanto nos processos de concepção exclusivamente digitais (Mitchel, 2005). O processo de projeto passa, então, a ter conceitos, lógicas, metodologias e conteúdos exclusivamente digitais, interações entre processos e produtos que geram formas.

No âmbito dessa nova forma de projetar, verifica-se o aparecimento de novas metodologias de projeto, que utilizam ferramentas computacionais altamente tecnológicas capazes de gerar modelos em 3D totalmente parametrizados, orientados a objetos e capazes de armazenar informações detalhadas dos mesmos. Enquanto a experimentação de formas na arquitetura se concentra em softwares que permitem essa manipulação livremente, projetando com parâmetros, algoritmos e até códigos genéticos, a indústria da construção se concentrou em trabalhar de maneira mais linear, com o armazenamento e o tratamento de dados e a otimização da construção, como no caso do BIM (OTTCHEN, 2009).

A metodologia BIM envolve todas as etapas relacionadas à vida do edifício, que vai desde o projeto até a construção, a fabricação, o uso e a manutenção. Ela se apoia em 
duas tecnologias principais, a modelagem paramétrica e a interoperabilidade. No que se refere ao método de trabalho, utiliza conceitos como a colaboração, a coordenação e a interoperabilidade. Apesar de suas várias definições, é consenso que o BIM supre a necessidade de redução da fragmentação entre os agentes da construção civil, melhora a sua eficiência e reduz os custos de perda de informação ao longo do processo de projeto, da construção e da manutenção do edifício (ANDRADE; RUSCHEL, 2011).

Pode-se dizer que o projeto de um edifício dentro do conceito BIM deixa de ser um sistema linear, que começa pelo arquiteto e termina na entrega do edifício construído, passando a ser um modelo no qual todos os profissionais envolvidos no processo de projeto interagem durante todas as fases de projeto, principalmente na primeira delas, evitando erros e aumentando a velocidade de projeto. Um dos principais conceitos no qual o BIM se apoia é a troca de informação entre a equipe envolvida. Andrade e Ruschel (2011) afirmam que é preciso saber identificar como e quando trocar as informações, além de quais devem ser trocadas, pois, assim, será possível compartilhar e coordenar as informações do modelo virtual por diferentes atores e em distintas atividades e estágios do processo de projeto. A troca de dados e informações entre o arquiteto e toda a equipe envolvida é feita por arquivos de mesmo padrão, permitindo, assim, que diferentes softwares possam ler essas informações. Com isso, para que se tenha uma boa interoperabilidade, é importante a implementação de um padrão de protocolo de troca de dados entre os softwares durante a fase de projeto.

Ainda dentro do conceito BIM, nota-se que os modelos são interativos e operados pela geometria associativa, são parametrizados, agregam informações sobre o projeto de determinada maneira que os modelos tradicionais não são capazes de representar (NATIVIDADE, 2010). Esses modelos BIM deixam de ser documentos estáticos de duas dimensões para se constituírem em entidades tridimensionais com possibilidade de inclusão da dimensão temporal (4D) e dos custos (5D), além da compatibilização automatizada por meio do clash detection (conflitos de projeto). Ou seja, o projeto utiliza informações paramétricas orientadas ao objeto, que, ao sofrerem modificações, desencadeiam mudanças em todos os desenhos, os quais deixam de ser linhas para serem representações interativas do modelo (KRYGIEL; NIES, 2008). 
Avaliação de Desempenho Ambiental e Arquitetura Paramétrica Generativa para o Projeto do Edifício Alto

Nota-se, assim, que a utilização da metodologia BIM tem, como benefícios, a documentação integrada, a visualização das etapas de projeto e construção, a montagem de uma base de dados de materiais, as avaliações relacionadas à sustentabilidade, o planejamento das fases da construção e o gerenciamento do pós-ocupação e do empreendimento em geral. No entanto, a implementação dessa metodologia requer uma mudança lenta e gradual no modo de projetar e na formação e capacitação técnica da equipe, que passa a ser multidisciplinar.

Outro conceito importante introduzido refere-se ao processo paramétrico, no qual um projeto paramétrico relaciona dimensões e parâmetros à geometria dentro de um intervalo pré-definido (LEACH, 2008). Com isso, ao se modificar um desses parâmetros, todo um sistema é alterado. No entanto, os softwares paramétricos não criam, necessariamente, um novo vocabulário de formas, mas garantem uma rapidez de mudança e controle das mesmas. Já o processo algorítmico, segundo Leach (2008), é aquele que utiliza processos matemáticos para resolução de problemas de projeto. É um processo de projeto em que o arquiteto não manipula a forma, e sim um código, ou um script, através de uma sequências de operações lógicas (CELANI, 2014-no prelo). Dessa forma, podese dizer que esse processo depende muito do domínio e da habilidade do projetista sobre as ferramentas geradoras de forma. Diante disso, Aish (2005) afirma que o processo constitui-se no controle das regras geradoras versus o resultado formal.

De modo geral, além da proficiência em computação, a utilização dessas estratégias ordena certas competências digitais, tais como noções de composição, gráficos vetoriais, manipulação de imagem, modelagem de superfície, modelagem de sólidos, edição de vídeo, renderização, animação, operações de banco de dados e interface com a web, além de conhecimento de geometria e afins. No entanto, a lista cada vez maior e mais exigente em habilidades múltiplas não significa o desenvolvimento da destreza computacional em detrimento de posicionamento crítico.

Utilizando o potencial criativo humano e a capacidade de processamento computacional de maneira sinérgica e complementar, é possível produzir novos conceitos, ideias e formas. Nesse sentido, o algoritmo pode ser visto como uma ferramenta de projeto que pode levar não somente à produção de formas originais, mas também de novos 
conceitos e ideias.

Kostas Terdizis (2006) aponta que a manipulação das formas complexas em software de modelagem não representa, por si só, a quebra de paradigmas, uma vez que a lógica de projeto permanece intocada. A verdadeira quebra de paradigma só poderá ocorrer com a utilização das ferramentas digitais de modo totalmente inovador, a ponto de modificar a maneira de pensar a arquitetura. Para tanto, seria necessário extrapolar certos nichos de pensamento cristalizados não só pelo paradigma moderno, como também pelas limitações da mente humana.

Transferir o ato de tomada de decisão do plano consciente da mente humana para um agente inconsciente como o computador pode gerar grandes mudanças na maneira de se pensar a arquitetura, a qual se deu, fundamentalmente, através do domínio total do arquiteto sobre o objeto projetado. Em outras palavras, os computadores podem ser capazes de complementar o raciocínio humano, haja vista que podem sugerir perspectivas distintas do mesmo (Terdizis, 2006).

Michael Meredith (2008) alerta que não só as arquiteturas algorítmicas, mas também as arquiteturas geradas digitalmente como um todo jamais devem vir desacompanhadas de atitude crítica, a fim de não se tornar um determinismo tecnológico moderno com nova roupagem. Ou seja, o poder de decisão através de técnicas computacionais não é aleatório, é conferido pelo arquiteto e pelos usuários da arquitetura, ou seja, são eles que decidem o que deve ou não ser realmente construído.

As novas ferramentas digitais estão agregando ao projeto paramétrico as simulações energéticas e os algoritmos, gerando um grande potencial para a criação de novas expressões arquitetônicas, que são justificadas pelo seu desempenho. A análise de desempenho é um princípio de projeto que considera alguns parâmetros prioritários ao qual o edifício tem que responder. Na arquitetura voltada ao desempenho, a prioridade não é a forma, mas o desempenho do edifício (Kolaveric; Malawaki, 2005). É importante ressaltar que, neste caso, o software não gera a forma propriamente, mas instrui o designer na mudança da geometria para o alcance do melhor desempenho dentro do aspecto analisado para, depois, submetê-la novamente à análise.

Estudos mais recentes têm tentado comprovar que a complexidade formal das 
Avaliação de Desempenho Ambiental e Arquitetura Paramétrica Generativa para o Projeto do Edifício Alto

arquiteturas geradas digitalmente pode surgir da manipulação de parâmetros utilitários, como é caso, por exemplo, dos dados de conforto ambiental do contexto de projeto. Essa nova abordagem vem adquirindo cada vez mais adeptos, haja vista que, nesse tipo de arquitetura, baseada em desempenho, o emprego do computador pode extrapolar a simples questão formal, trazendo uma complexidade de nova ordem.

O conjunto de dados climáticos estão disponíveis e organizados em um banco de dados que podemos conectar ao computador, o que garante o acesso a um grande mapa de dados. O que há de diferente, atualmente, é a possibilidade de se utilizar esses dados para controlar um processo de projeto mais dinâmico, distanciando-se de uma metodologia convencional de projeto.

Friesen (2009¹) afirma que, para controlar esse processo dinâmico, é preciso desenvolver um algoritmo que, alimentado pelos dados, possa extrair a informação que leva à geração da forma. Se esse tipo de algoritmo já existisse, com a mera necessidade de se realizar o seu download e de plugá-lo ao seu modelo, não seria possível criar uma solução inteligente de projeto, utilizando uma metodologia pré-existente. Os arquitetos têm, então, mais controle sobre o processo de projeto, em todos os níveis, pois podem manipular as informações através do processo, além de criar não apenas uma única solução, mas um conjunto de possíveis soluções.

As novas ferramentas digitais fornecem novos modelos de representação, novas metodologias de avaliação e novas técnicas de exploração de formas. O desenvolvimento dessas novas ferramentas permite a criação de projetos de melhor desempenho ambiental, permitindo aos arquitetos o desenvolvimento de novas opções de projeto, analisando-as simultaneamente durante o processo, de uma forma interativa e eficiente.

No entanto, as mudanças que podemos ver nas ferramentas não é acompanhada pela forma como as escolas de arquitetura ministram as aulas de geometria. Assim, a geração de formas dentro de um conceito computacional só será explorada a fundo quando novos conceitos de geometria como superfícies topológicas, curvas, vetores, malhas e fractais, dentre outros, forem introduzidos no ensino de arquitetura.

As ferramentas computacionais vêm redefinindo a prática da arquitetura e da construção. Os arquitetos, com isso, vêm ampliando a sua área de atuação desde o processo

1 . (Friesen em Beaurecueil; Lee, 2009) 
de projeto e de fabricação até à construção. Apesar de se tratar a tecnologia de um importante componente da arquitetura, há muitos outros parâmetros não quantificáveis, tais como as relações, as pressões culturais e os usuários, dentre outros aspectos, que não podem ser tratados simplesmente como determinismo tecnológico.

Os benefícios e possibilidades de design oferecidas pelas ferramentas digitais são muito grandes, mas os parâmetros que definem a arquitetura ainda são escolhidos pelos arquitetos. Da mesma forma, são eles que decidem quais arquiteturas valem a pena ser construídas. Dessa forma, Natividade (2010) afirma que acreditar que a tecnologia resolverá todos os nossos problemas é, vale frisar, ingenuidade. Acreditase que as estratégias algorítmicas e paramétricas para a geração de forma são ferramentas poderosas na solução de problemas cuja complexidade, nível de incerteza, ambiguidade ou número de soluções possíveis requerem a relação sinérgica entre mente humana e computador. No entanto, sem rigor e crítica, os projetos gerados digitalmente permanecerão apenas como exercícios de software.

No capítulo 5, foram apresentados projetos do SED da AA School of Architecture, o Projeto Viol e o Projeto desenvolvido durante o workshop da AA Visiting School, que propuseram uma visão crítica (técnica e analítica) sobre o processo de projeto do edifício alto, resultando em inovação e originalidade da forma arquitetônica. Todos os projetos apresentados têm em comum a utilização de critérios de desempenho ambiental como uma etapa determinante na elaboração da forma arquitetônica. Com exceção do último experimento, o da $A A$ Visiting School, os critérios mencionados vão além da base conceitual e são resultados de estudos analíticos avançados de desempenho ambiental do edifício. No entanto, ainda que as etapas de projeto sejam muito similares na elaboração e na escolha dos critérios de desempenho ambiental, de iluminação e ventilação natural, o processo de geração e o resultado final da forma, são particulares em cada caso, produzindo resultados arquitetônicos diferenciados.

No caso do primeiro projeto da AA (Tall Communities: Passive urban housing for the Tropics), existe a busca pela forma paramétrica sem a utilização das ferramentas de geração de forma, baseada, exclusivamente, nos programas computacionais Ecotect e no Autocad. O segundo (Environmental Performance of adaptive building design: urban 
Avaliação de Desempenho Ambiental e Arquitetura Paramétrica Generativa para o Projeto do Edifício Alto

housing in Seoul Korea) e o terceiro (Rethinking office building typology in continental mediterran climate) tiveram o foco no desempenho energético quantitativo propriamente dito, também utilizando o Autocad como ferramenta de desenho ou geração da forma, além dos softwares de desempenho ambiental. O terceiro, especificamente, é um exemplo do projeto paramétrico, introduzindo um software que utiliza técnicas e ferramentas do projeto convencional e do projeto generativo, no caso da fachada.

O projeto Viol também guarda semelhanças com relação à escolha dos critérios e desenvolvimento da forma, também baseada em ferramentas convencionais de projeto como o Autocad, demonstrando que exemplos da prática arquitetônica corrente de mercado, aclamada como realizadora de ícones e novos paradigmas de desempenho ambiental, também emprega o mesmo processo e utiliza os mesmos critérios. O último exercício, por sua vez, ainda carece de critérios objetivos para informar o processo de geração da forma, mas, por outro lado, introduz uma nova temática, qual seja, a relação da arquitetura paramétrica e a prototipagem rápida, que também é uma variante da arquitetura generativa, a qual, no entanto, não será trabalhada nesta pesquisa. É o raciocínio e o processo que definem a arquitetura generativa paramétrica.

Da análise desses projetos apresentados, pode-se dizer que, por meio dos estudos analíticos preliminares, é possível elencar as principais estratégias que norteiam o projeto, como, por exemplo, a orientação, a insolação, a ventilação natural e os espaços de convivência, dentre outros. Ou seja, tem-se a quantificação de conceitos e ideias genéricas que precisam se tornar especificas para informar a geração da forma e determinar o desempenho do edifício. E, apesar de apenas um dos exercícios de projeto da AA (o terceiro) e o exercício de projeto desenvolvido no workshop do AA Visiting School utilizarem ferramentas de projeto paramétrico, vale ressaltar que todos atingiram uma expressão arquitetônica de destaque. Trata-se, aqui, de um processo de projeto arquitetônico que prioriza estratégias ambientais e quantifica conceitos genéricos em cada contexto climático para, então, voltar para a arquitetura.

O método de projeto proposto no capítulo 6 consistiu na aplicação de critérios de desempenho ambiental no processo de projeto da arquitetura paramétrica generativa. Buscou-se selecionar e utilizar os critérios de desempenho para informar e gerar 
parametricamente a forma utilizando-se a geometria complexa. O foco residiu nos primeiros estágios do projeto, em que a possibilidade de gerar uma arquitetura com geometria complexa e alcançar um desempenho otimizado é muito maior do que nas outras fases de projeto. Assim, pretendeu-se testar as habilidades de geração rápida da forma, característica da arquitetura paramétrica, e, com isso, explorar as opções de projeto.

O objetivo consistiu em criar um cruzamento entre as simulações de conforto ambiental, o processo de projeto e a geometria complexa, visando melhorar a compreensão do impacto ambiental, e ao mesmo tempo, evitar uma geração gratuita da forma e dos seus componentes. Saliente-se que o desafio do projeto paramétrico não é apenas uma questão de geometria complexa e, sim, como incorporar os critérios de desempenho no processo de projeto. Cabe ressaltar que a utilização dos critérios de desempenho ambiental e de questões ligadas às simulações de conforto no início do processo de projeto gera uma complexa rede de informações com a qual a equipe de projeto precisa trabalhar.

É um processo de retroalimentação, em que são realizadas as avaliações e as simulações para, então, voltar-se à forma, corrigir, avaliar e decidir. Caso seja aplicada essa metodologia no princípio do projeto, os estudos de desempenho podem ser realizados inúmeras vezes sem que se comprometa o cronograma de projeto. São estudos rápidos, mas que fazem grande diferença no resultado final tanto na forma como no desempenho. No entanto, vale ressaltar que o método pode ser aplicado em outras etapas do projeto, entendendo-se que a complexidade do modelo também refletirá na complexidade das simulações, podendo consumir, consequentemente, uma maior quantidade de horas de trabalho.

O exercício de projeto, por sua vez, teve como objetivo demonstrar a aplicação do método, mas sem a pretensão de finalizar o projeto do edifício como um todo, tendo sido entendido que a complexidade dessa tipologia não caberia nessa pesquisa. Verificou-se, ainda, que no projeto do edifício alto é preciso que se tenha cuidado com o desenvolvimento de componentes de sombreamento, pois, quando analisados em grandes dimensões, podem perder o seu papel quanto à expressão arquitetônica. As 
Avaliação de Desempenho Ambiental e Arquitetura Paramétrica Generativa para o Projeto do Edifício Alto

simulações de iluminação demonstraram um grande potencial para informar o processo de dimensionamento dos componentes, sendo que, sem elas, não seria possível atingir uma precisão desejável.

\subsubsection{Validação da Hipótese}

A confirmação da hipótese de que critérios quantitativos e qualitativos de desempenho ambiental são definidores da expressão formal da arquitetura paramétrica do edifício alto foi alcançada com a aplicação do método desenvolvido no exercício de projeto apresentado no capítulo 6. Essa hipótese surgiu da utilização arbitrária, ou seja, sem critérios claros e precisos de desempenho ambiental na geração das formas dos edifícios altos, e vem ao encontro do conceito contemporâneo de conforto, da adaptação, das respostas específicas.

O objetivo geral do trabalho foi alcançado através da metodologia de projeto arquitetônico que relacionou a avaliação paramétrica de desempenho ambiental aos critérios qualitativos e quantitativos e à geração da forma, apresentado no capítulo 6 . Com isso, foi possível compreender como os critérios de desempenho ambiental informam e influenciam a geração da forma, utilizando, para isso, ferramentas paramétricas, como o Rhinoceros e o seu plug-in Grasshopper. O método resultou em um conjunto de diretrizes de projeto e critérios de desempenho, desenvolvidos para a formulação dessa proposta de metodologia de projeto e visualizado em um modelo teórico do edifício alto para a cidade de São Paulo

\subsubsection{Produtos da Pesquisa}

Os produtos da tese se confirmaram: (I) critérios qualitativos e quantitativos de desempenho ambiental do edifício alto, apresentados no capítulo 2, (II) diretrizes de projeto para a eficiência energética e o desempenho de ambientes de escritório no clima de São Paulo, formuladas com base nos estudos analíticos apresentados no capítulo 3, (III) metodologia de projeto paramétrico informada por critérios ambientais, apresentado no capítulo 6, (IV) solução projetual para edifícios de escritórios que utilizem ventilação e iluminação natural como estratégia principal para atingir o conforto dos usuários e reduzir o consumo de energia, apresentado, também, no capítulo 6.

Além disso, um dos produtos gerados, consequentemente, pelo método, é o 
estabelecimento de diretrizes aos projetistas, que já trabalham com os mecanismos do Grasshopper, e o modo de tratamento da inserção de critérios ambientais independentemente da forma. Ou seja, instrumentalizar o processo de geração da forma através da inserção de critérios de desempenho ambiental.

\subsection{Considerações finais}

O projeto de alto desempenho não deve se basear, exclusivamente, na tecnologia. Os verdadeiros projetos sustentáveis devem focar em soluções robustas que direcionem os investimentos para os elementos de construção de maior ciclo de vida, como por exemplo, a estrutura (60 anos ou mais) e a fachada (20-50 anos), ao invés de se preocupar com os sistemas (15-25 anos) (BDSP, 2010).

O projeto de um edifício que seja realmente eficiente é mais importante do que a adoção de sistemas técnicos complexos para que se atinja o conforto dos usuários. A prioridade de um projeto de alta qualidade ambiental recai no projeto de alto desempenho, ou seja, quanto melhor for a resposta da arquitetura aos desafios do clima local, melhor será a nota na avaliação de desempenho ambiental.

Com relação à questão das avaliações de desempenho hoje vislumbradas no mercado, pode-se dizer que, se o projeto busca atender apenas às metas atuais de desempenho, o edifício, quando finalizado, já não atenderá aos requisitos de desempenho, mostrandose obsoleto. É preciso, então, ter em mente as tendências futuras tanto de mercado como de mudanças climáticas para o direcionamento do projeto realmente sustentável (BDSP, 2010).

A metodologia de projeto que vise ao melhor desempenho deve realizar uma clara distinção entre a redução da demanda através de estratégias passivas e a otimização do desempenho do consumo de energia. A adoção de novas tecnologias, a criação de técnicas de projeto, a customização dos códigos de programação do projeto e os resultados das simulações de desempenho mostram, claramente, que as habilidades dos arquitetos foram ampliadas (PETERS, PETERS, 2013). No entanto, resta claro que o simples fato de se utilizar uma técnica computacional de geração de forma não garante uma boa arquitetura. 
Avaliação de Desempenho Ambiental e Arquitetura Paramétrica Generativa para o Projeto do Edifício Alto

Assim, para se atingir a qualidade no processo de projeto, é preciso:

- Ter conhecimento dos princípios e regras básicas do conforto;

- Saber operar os softwares de conforto;

- Ter conhecimento de geometria avançada;

- Ter conhecimento/domínio de softwares de geração da forma.

Isso tudo para se evitar resultados gratuitos e superficiais. Assim, mostra-se, mais uma vez, que a tecnologia (tanto de processos analíticos de desempenho como de geração de forma) deve estar inserida no processo de projeto, e não somente no final para que se resolva e se ateste qualquer resultado formal, revelando-se, assim, que a tecnologia não é fixa e corretiva, mas generativa.

\subsection{Desdobramentos Futuros}

Durante o desenvolvimento da pesquisa, diversas questões foram levantadas, porém, devido ao escopo, não puderam ser desenvolvidas. No entanto, foram selecionadas para o desenvolvimento futuro. São elas:

- Estudos aprofundados do tratamento dos átrios, que ainda se mostraram muito transparentes, influenciando o desempenho luminoso do projeto. Desenvolvimento e aplicação de componentes para controlar a radiação direta e difusa e, posteriormente, a avaliação do seu desempenho;

- Desenvolvimento de estudos quanto à forma e ao dimensionamento dos átrios, permitindo uma investigação da relação de proporção do tamanho do átrio e o tamanho das vilas, o seu posicionamento em planta e verticalmente ao longo do edifício. Investigação de uma foma mais dinâmica desse elemento arquitetônico que se mostrou tão importante ao desempenho ambiental do edificio alto;

- No método proposto, foram utilizados critérios de insolação e de iluminação como geradores da forma, pretende-se, numa próxima etapa, inserir questões como a ação dos ventos na geração da forma e a sua influência na ventilação natural dos ambientes. Para isso, será preciso realizar simulações em programas computacionais voltados à ventilação, os CFDs, ou Computer Fluid Dinamics; 
- Além do critério dos ventos, outro critério não abordado nesta pesquisa, mas que precisa ser desenvolvido em maior profundidade, refere-se à questão do desempenho acústico, principalmente quando se fala em abertura da janela numa cidade como São Paulo, onde a poluição sonora é uma questão a ser discutida;

- Estudos aprofundados em modelos detalhados de desempenho térmico dinâmico também será tema a ser desenvolvido num próximo trabalho, no qual poderá ser simulada a influência da forma e dos materiais, juntamente com os dados de ventilação, no desempenho do edifício alto, gerando-se, assim, dados como porcentagem de horas em conforto, temperatura interna máxima, número mínimo de renovações de ar e porcentagem de abertura das janelas, dentre outros;

- Aprofundamento e aplicação de estudos que envolvem a questão da prototipagem rápida e os materiais, verificando-se o desempenho estrutural do material em relação ao seu uso como elemento de proteção solar. 



\section{Capítulo 8:}


Avaliação de Desempenho Ambiental e Arquitetura Paramétrica Generativa para o Projeto do Edifício Alto 


\section{REFERÊNCIAS BIBLIOGRÁFICAS}

\section{Programas de simulação computacional}

AUTODESK (2013). ECOTECT. http://www.autodesk.com/

BENTLEY TAS Simulator V8i (2012). Tas Version 9.2.1.3. United Kingdom. Milton Keynes. http:// http://www.bentley.com/

METEOTEST (2009). Meteonorm 6.1. Switzerland. Bern. http://meteonorm.com/

\section{Revistas}

Architectural Design, Closing the Gap, March/April, 2009.

Architectural Design, Mathe+Matics of Space, July/August, 2011.

Architectural Design, Computation Works: The Building of Algorithmic Thought, March/ April, 2013.

Architectural Record, no8, 2010.

Architecture Today, no218, May 2011.

\section{Livros}

ADAM, Robert. Globalization and Architecture. Architectural Review. London, n. 1332, 2008.

AISH, R. From intuition to precision. Digital Desing: the Quest for New Paradigms. In: 23nd eCAADe Conference Proceedings. Lisboa, 2005.

AL MARASHI, Habiba; BHINDER, Jasleen. From the Tallest to the Greenest-Paradigm Shift in Dubai. In: Proceedings of CTBUH 8th World Congress 2008. Dubai: CTBUH, 2008.

ANDRADE, Cláudia. Avaliação da Ocupação física em edifícios de escritórios: o caso da Editora Abril em São Paulo. 2000. Dissertação (Mestrado em Arquitetura). Faculdade de Arquitetura e Urbanismo, Departamento de Tecnologia da Arquitetura, Universidade de São Paulo, São Paulo.

ANDRADE, M.; RUSCHEL, R. Building Information Modeling (BIM) In: Kowaltowiski, D; Moreira, D; Petreche, J; Fabrício, M. (orgs). O processo de projeto em arquitetura. São Paulo: Oficina de textos, 2011. 
ANDREASI, W. LAMBERTS, R. CÂNDIDO, C. Thermal acceptability assessment in buildings located in hot humid regions in Brazil. Building and Environment, V.45, 12251232, 2010.

AQUA. Referencial técnico de certificação Edifícios habitacionais - Processo AQUA @ FCAV - 2013 - Versão 2.

ARAÚJO, V. M. D. Parâmetros de conforto térmico para usuários de edificações escolares no litoral nordestino brasileiro. PhD thesis. University of São Paulo, São Paulo, 1996. $179 p p, 1996$.

ASHRAE (American Society of Heating, Refrigerating and Air Conditioning Engineers). Handbook of fundamentals. Atlanta: ASHRAE, 2009.

AUGENBROE, G. Trends in building simulation. Building and Environment, 2002, 37(89), 891-902.

BAKER, N., STEEMERS. K., Daylight Design of Buildings. London: James \& James Science Publishers, 2002.

Baker, N.V. A Handbook of Sustainable Refurbishment: Non-Domestic Buildings. London: Earthscan, 2009.

Balanço Energético Nacional (BEN) 2011: Ano base 2010 / Empresa de Pesquisa Energética. - Rio de Janeiro: EPE, 2011.

BATTLE, Timothy (ed.). The Commercial Offices Handbook. London: RIBA Enterprises, 2003.

BDSP Partnership Swiss Re House, London, Environmental Performance Report, Natural Ventilation BDSP Partnership, London 1998.

BDSP Partnership Projeto Viol, São Paulo, Environmental Performance Report, BDSP Partnership, London 2010.

BEEDLE, L.(ed.). Tall Buildings - 2000 and Beyond. Council on Tall Buildings and Urban Habitat. Bethlehem, USA: LeHigh University, 1990.

BENEVOLO, Leonardo. A Arquitetura no Novo Milênio. São Paulo: Estação Liberdade, 2007. 
BHATLA, S. Tall Communities: Passive Urban House for the Tropics. 2011. Dissertação (Mestrado em Arquitetura). M.Arch Sustainable Environmental Design 2009-11. Architectural Association School, Londres.

BINDER, Georges (ed.). Tall Buildings of Europe, the Middle East and Africa. Australia: Images Publishing, 2006.

BORGES, Carlos Alberto. O significado de desempenho nas edificações. revista. construcaomercado.com.br/negocios-incorporacao-construcao/103/norma-dedesempenho-o-significado-de-desempenho-nas-edificacoes-161144-1.asp

BRE (Building Research Establishment) BREAM 98 for offices. London: ECD Energy and Environment and University Press. Yves, 1998.

BRUAND, Yves. Arquitetura Contemporânea no Brasil. São Paulo: Perspectiva, 2005.

CABE (Comission for Architecture and Built Environment). Guidance on Tall Buildings. London: CABE, 2003.

CAMPI, Mario. Skyscrapers - An Architectural Type of Modern Urbanism. Boston: Birkhauser-Publishers for Architecture, 2000.

CAVALCANTE, Rodrigo de Castro Dantas. Simulação energética para análise da arquitetura de edifícios de escritório além da comprovação de conformidade com códigos de desempenho. Dissertação de Mestrado. Faculdade de Arquitetura e Urbanismo. Universidade de São Paulo, 2010.

CELANI, G. 101 Conceitos de Arquitetura e Urbanismo na Era Digital. No prelo

CENA, K.; and CLARK, J.A. Bioengineering, thermal physiology and Comfort. Elsevier, Amsterdam, 1981.

CHAPPELS, H. and E. SHOVE. Comfort: a review of philosophies and paradigms. Future Comforts Project, Uk ESRC programme. (2004).

CIBSE. Daylighting and Window Design. Lighting Guide LG10. Chartered Institution of Building Services Engineers, London, 1999.

CIBSE. CIBSE Guide F, Energy efficiency in buildings, 2nd Edition. London: CIBSE, 2004. 
COLE, Raymond J. et al. Re-contextualizing the notion of comfort. Building Research \& Information, 36:4, 323-336, 2008.

COLE, R. J.; BROWN, Z., McKAY, S. Building Buman Agency: A Timely Manifesto. In: Building Research and Information. No.38, pp. 339-350. Routledge, Taylor and Francis, 2010.

CORBUSIER, Le. The city of tomorrow and its planning. London : Architectural Press, 1947.

COTTA, J. The Impact of Window Design in the Environmental Performance of Work Environments in São Paulo. MSc Sustainable Environmental Design Dissertation project London: AA Graduate School, 2012.

Cushman \& Wakefield SEMCO. São Paulo Vertical. São Paulo:Gráfica IPSIS, 2004.

DAVIS, C; LAMBOT, I. Commerzbank, Frankfurt. Prototype for an Ecological High-rise. Switzerland: Basel, 1997.

Deutsche Energie-Agentur German. Regulation for energy saving in buildings and building systems. Energieeinsparverordnung, EnEV kompakt, Deutsche Energie-Agentur, 2007.

DUFFY, Francis. The New Office. Londres: Coran Octopus Limited, 1997.

EARTH DAY NEWYORK. Lessons Learned, High-Perfomance Buildings. An enviromental information and resource guide for the commercial real state industry. New York: The Durst Organization, 2000.

EASTMAN, C.;TEICHOLZ, P.;SACKS, R.; KASTON,K. BIM Hand Book: A Guide to Building Information Modeling. USA: Wiley, 2008.

FERREIRA, João Sette W. O Mito da Cidade-Global: o papel da ideologia na produção do espaço urbano. Rio de Janeiro: Editora Vozes Ltda., 2007.

FOSTER, W; HAWKES, D. Energy Efficient Buildings. Architecture, Engineering, and Environment. England : W.W. Norton \& Company, Inc., 2002.

FRAMPTON, Kenneth. Historia crítica da Arquitetura Moderna. São Paulo: Martins Fontes, 1997. 
FRECHETE, R; GILCHRIST, R. Towards Zero Energy: A Case Study of the Pearl River Tower, Guangzhou, China. In: Proceedings of CTBUH 8th World Congress 2008. Dubai: CTBUH, 2008.

FREJ, Anne B. Green Office Buildings: A Practical Guide Development. Washington D.C.: the Urban Land Institute, 2005.

FRICK, U.;GRABNER, T. @ [uto] A Collection of Past \& Ongoing Works. http://utos. blogspot.com/2011/11/geco for grasshopper 08 update v10260.html. Acessado em 25 de novembro de 2011.

FUJIOKA, P. O Edifício Itália e a arquitetura dos edifícios de escritórios em São Paulo. Dissertação de Mestrado. Faculdade de Arquitetura e Urbanismo. Universidade de São Paulo, 1996.

GAINES, J; JAGER, S. A Manifesto for Sustainable Cities. New York: Prestel Publishing, Ltd, 2009.

GAO, L.; CHEN, D.; NGUYEN, T. Using building information modeling for measuring the efficiency of building energy performance. In: International Conference on Computing in Civil and Building Engineering, 2010, Nottingham. Anais: Nottingham, Nottingham University Press, 2010.

GARRETA, Ariadna Alvarez. Rascacielos. México : Atrium Group, 2001.

GBC_BRASIL. Disponível em: < http://www.gbcbrasil.org.br/?p=certificacao>. Acesso em 20 de Maio de 2012, 2012.

GERBER, D. J.; SHIH-HSIN L. Geometric Complexity and Energy Simulation - Evolving Performance Driven Architectural Form, Open Systems: Proceedings of the 18th International Conference on Computer-Aided Architectural Design Research in Asia (CAADRIA 2013). Singapore, 2013. pp. 87-96 http://cumincad.scix.net/cgi-bin/works/ Show?caadria2013_006

GHIABAKLOU, Z. Natural Ventilation as a Design Strategy for Energy Saving. World Academy of Science, Engineering and Technology 71, 2010.

GIFFORD, Henry (2008). A Better Way To Rate Green Buildings. Available at: www. 
henrygifford.com

GINSEN, David (ed.). BIG \& GREEN - Toward sustainable architecture in the 21st century. New York: Princeton Architectural Press, 2002.

GLASSMAN, E. Performance Optimization VS Adaptation as Applied to Tall Buildings. Trabalho da disciplina GSD 6433: The Environmental Performance of Tall Building, Harvard University, Center for the Environment, dezembro, 2011.

GONCALVES, Joana Carla. A sustentabilidade do edifício alto. Tese de Doutorado. Faculdade de Arquitetura e Urbanismo. Universidade de São Paulo, 2003.

GONÇALVES, J. C. S.; BODE, K. The importance of real life data to sustain environmental claims for tall buildings. In: CTBUH Journal. International Journal on Tall Buildings and Urban Habitat. Chicago, CTBUH, Issue II, 2011 (a).

GONÇALVES, J. C. S.; BODE, K. The environmental value of buildings: a proposal for performance assessment with the reference to the case of the office tall building. In: Innovation. The European Journal of Social Sciences (versão eletrônica). Routledge, Taylor and Francis, 2011 (b).

GONÇALVES, Joana Carla Soares ; DUARTE, D. H. S. . Arquitetura Sustentável. Uma integração entre Ambiente, Projeto e Tecnologia em Experiências de Pesquisa, Prática e Ensino. Ambiente Construído (Online), v. 6, p. 51-81, 2006.

GONÇALVES, Joana Carla Soares ; DUARTE, D. H. S. . Environmental Urban Design for Central Urban Areas in São Paulo, Brazil. In: PLEA 2008 - Passive and Low Energy Architecture, 2008, Dublin. Towards Zero Energy Building. Dublin : University College Dublin, 2008.

GONÇALVES, Joana Carla Soares; UMAKOSHI, Erica Mitie. The Environmental Performance of Tall Buildings. London: Earthscan, 2010.

GONÇALVES, W., VALLE, R. M. GARCIA, E. S., O papel de mecanismos adaptativos no conforto térmico de estudantes universitários em Belo Horizonte - MG. ENCAC 2001, São Pedro - SP, Brazil. pp. 1 - 8.

HEERWAGEN, J. e R. C. Diamond (1992). Adaptations and Copin: Occupant Response 
to Discomfort in Energy Efficient Buildings. ACEEE Summer Study, Asimolar, California, ACEEE.

HEPNER, Alexandre. Desenho urbano, capital e ideologia em São Paulo : centralidade e forma urbana na marginal do Rio Pinheiros. Dissertação de Mestrado. Faculdade de Arquitetura e Urbanismo. Universidade de São Paulo, 2010.

HERNANDES, Thiago Zaldini. LEED-NC como sistema de avaliação da sustentabilidade: uma perspectiva nacional. Dissertação de Mestrado. Faculdade de Arquitetura e Urbanismo. Universidade de São Paulo, 2007. Orientador: Denise Helena Silva Duarte. HERNANDES, Thiago Zaldini ; DUARTE, D. H. S. ; GONÇALVES, Joana Carla Soares . Redefining the Tall Building for Sao Paulo: Urban Life and Environment.. In: PLEA 2003 - The 20th Conference on Passive and Low Energy Architecture, 2003, Santiago. Rethinking Development. Are we producing a people oriented habitat?. Santiago : PLEA, 2003.

Holger Koch-Nielsen. Stay Cool. A design guide for the built environment in hot climates. James \& James Ltd, 2002.

HUMPHREYS, M. (1995) Thermal comfort temperatures and the habits of hobbits. Standards for Thermal Comfort. F. Nicol, M. Humphreys, O. Sykes and S. Roaf. London, E \& F N Spon: 3-14.

HESCHONG, Lisa. Thermal Delight in Architecture. Cambridge, Mass.:MIT Press, 1990. IANNI, M.; SÁNCHEZ DE LEÓN, M. Applying Energy Performance-Based Design in Early Design Stages, Stouffs, Rudi and Sariyildiz, Sevil (eds.), Computation and Performance - Proceedings of the 31st eCAADe Conference - Volume 1, Faculty of Architecture, Delft University of Technology, Delft, The Netherlands, 2013. pp. 31-40 http://cumincad.scix.net/cgi-bin/works/Show?ecaade2013_051

JACOBSON, Robert (ed.). Information Design. Cambridge: The MIT Press, 2000.

JENKS, M; DEMPSEY, N. Future Forms and Design for Sustainable Cities. Oxford: Architectural Press, 2005.

JODIDIO, Philip. Architecture in China. Italy: Taschen, 2007. 
JODIDIO, Philip. Architecture in the Emirates. Italy: Taschen, 2007.

KALAY, Yehuda. Architecture`s New Media. Cambridge: The MIT Press, 2004.

KLINGER, Kevin; VERMILLION, Joshua. Visualizing Revisions: Representation Implications of Digital Fabrication. Peru: In Proceeding of 9th Iberoamerican Congress of Digital Graphics - SiGraDi, 2005.

KOLAVERIC, Branko; MALKAWI, Ali M. Performative Architecture. Nova York: Spon Press, 2005.

KOOLHAAS, Rem. Nova York Delirante. São Paulo: Cosac Naify, 2008.

KOHN PEDERSEN FOX, OVE ARUP AND PARTNERS INTERNATIONAL. 110 Bishopsgate, Environmental Statement, Part I: Planning Application to the Corporation of London, Kohn Pedersen Fox, Ove Arup and Partners International, London, 2001.

KRYGIEL, E; NIES, B. Green BIM. Indianapolis: Wiley Publishing, Inc., 2008.

LAISERIN, J. Comparing Pommes and Naranjas. Acessado em 26 de maio de 2009. <http://www.laiserin.com/feature/issue15/feature01php>

LAMBERTS et. al (2010). Towards a Brazilian standard for naturally ventilated buildings: guidelines for thermal and air movement acceptability. In Proceedings of Conference: Adapting to Change: New Thinking on Comfort Cumberland Lodge, Windsor, UK, 9-11 April. Network for Comfort and Energy Use in Buildings (http://nceub.org.uk). London, 2010.

LAWSON, B. How Designers Think. Architectural Press: Oxford, 2005.

LEAMAN, A. e B. Bordass (1995). Comfort and Complexity: Unmanageable Bedfellows? Workplace Comfort Forum, 18-19 May 1995, London.

LEAMAN, A. e B. Bordass (2000). Productivity in buildings: the "liller" variables. D. In Clements- Croome (Ed.) London, E\&F Spon.

LEE, Keunjoo. The Environmental Role of Transitional Spaces in Residential Tall Buildings in Seoul. Korea: With Reference to Natural Ventilation Strategies (MSc Dissertation). Environmental and Energy Programme, Architetural Association School of Architecture. London, 2011. 
LUNA, I; POWELL, K. KPF- Architecture and Urbanism 1993-2002. New York: Rizoli International Publications Inc., 2002.

MARCONDES, Monica Pereira. Soluções projetuais de fachadas para edifícios de escritórios com ventilação natural em São Paulo. Tese de Doutorado. Faculdade de Arquitetura e Urbanismo. Universidade de São Paulo, 2010.

MARSH, RAINES, C. Square One Comfort Calculator. ISO 7730. ISO, 1993. www. healthyheating.com/solutions.htm

MCNEEL, R. Grasshopper: Generative Modeling with Rhino. Seattle: McNeel North America, 2010.

MEREDITH, Michael. From control to design: parametric/ algorithm architecture. Barcelona, Actar-D, 2008.

MITCHELL, William. A Lógica da Arquitetura. Campinas: Editora Unicamp, 2008.

MITCHELL, William. Constructing an Authentic Architecture of Digital Era. In FLATCHBART, Georg; WEIBEL, Peter ed.), 2005, Disappearing Architecture, Birkhauser, Basel.

MILLER, Daniel. The Confort of Things. Cambridge: Polity Press, 2009.

MULFARTH, Roberta C. Kronka. Arquitetura de Baixo Impacto Humano e Ambiental. Tese de Doutorado. Faculdade de Arquitetura e Urbanismo. Universidade de São Paulo, 2002.

NATIVIDADE,V. Fraturas metodológicas nas arquitetura digitais. Dissertação de Mestrado. São Paulo: FAUUSP, 2010.

NOBRE, Eduardo Alberto Cusce. Reestruturação econômica e território: expansão recente do terciário na Marginal do rio Pinheiros. Tese de Doutorado. Faculdade de Arquitetura e Urbanismo. Universidade de São Paulo, 2000.

OLDFIELD, P; TRABUCCO, D.; WOOD, A. Five Energy Generations of Tall Buildings: A Historical Analysis of Energy Consumption in High Rise Buildings. In: Proceedings of CTBUH 8th World Congress 2008. Dubai: CTBUH, 2008.

OLESEN, B. The philosophy behind EN15251: Indoor environmental criteria for design 
and calculation of energy performance of buildings. Energy and Buildings, n 39, p. 740 $-749,2007$.

OLGYAY, V. Design with Climate. New Jersey: Princeton University, 1963.

Oliveira, M; Fabrício, M. Projeto paramétrico e prototipagem rápida: casos em instituições internacionais. In: Kowaltowiski, D; Moreira, D; Petreche, J; Fabrício, M. (orgs). O processo de projeto em arquitetura. São Paulo: Oficina de textos, 2011.

OSELAND, N., HUMPHREYS, M. Trends in Thermal Comfort Research. Watford, Building Research Establishment, 1993.

OSTERHAUS, W.K. Discomfort glare from daylight in computer offices:What do we really know? in: Proceedings of the 9th European Lighting Conference (Lux Europa), Reykjavik, Iceland, 2001.

OTTCHEN, C. The future of Information modelling and the end o theory. In AD Closing the Gap, vol 79 n 2.John Wiley \& Sons: London, 2009.

OXAMN, Rivka. Theory and design in the first digital age. In Design Studies no 27. Oxford: Elsevier, 2006.

OXMAN, R. Digital architecture as a challenge for design pedagogy: theory, knowledge, models and medium. Design Studies, v. 29, n. 2, p. 99-120, 2008. Disponível em: <www. elsevier.com/locate/destud.>. Acessado em 20 novembro 2013.

PAEK, J. Environmental Performance of Adaptable Building Envelope Design: Urban House Seoul, Korea. 2011. Dissertação (Mestrado em Arquitetura). M.Arch Sustainable Environmental Design 2009-11. Architectural Association School, Londres.

PARDINI, Andrea Fonseca. Contribuição ao entendimento da aplicação da certificação LEED e do conceito de custo no ciclo de em empreendimentos mais sustentáveis no Brasil. Dissertação de Mestrado.Faculdade de Engenharia Civil, Arquitetura e Urbanismo. Universidade Estadual de Campinas, 2009.

PETERS, T.; PETERS B. Inside Smartgeometry: Expanding the Architectural Possibilities of Computational Design. AD Smart 1. John Wiley \& Sons Ltd: West Sussex, 2013.

PUPO, R; CELANI, M. PROTOTIPAGEM RÁPIDA E FABRICAÇÃO DIGITAL NA 
ARQUITETURA: FUNDAMENTAÇÃO E FORMAÇÃO. IN: KOWALTOWISKI, D; MOREIRA, D; PETRECHE, J; FABRÍCIO, M. (ORGS). O PROCESSO DE PROJETO EM ARQUITETURA. SÃO PAULO: OFICINA DE TEXTOS, 2011.

POTTMAN, H; ASPERL, A.; HOFER, M.; KILIAN, A. ARCHITECTURAL GEOMETRY. EXTON: BENTLEY INSTITUTE PRESS, 2007.

POWELL, KENNETH. RICHARD ROGERS - ARCHITECTURE OF THE FUTURE. ITALY: BIRKHAUSER, 2006.

POWELL, ROBERT. RETHINKING THE SKYSCRAPER - THE COMPLETE ARCHITECTURE OF KEN YEANG. LONDON: THAMES \& HUDSON, 1999.

RASMUSSEN, STEEN EILER. ARQUITETURA VIVENCIADA. SÃO PAULO: MARTINS FONTES, 1998.

REES, PETER WYNNE. IT'S NOT WHAT YOU BUILD BUT THE PLACE WHERE YOU BUILD IT- LONDON: WORLD CITY IN A SUSTAINABLE LOCATION. IN: ANAIS DO CTBUH 8TH WORLD CONGRESS 2008. DUBAI: CTBUH, 2008.

RICHARDS, IVOR. T. R. HAMZAH \& YEANG: ECOLOGY OF THE SKY. AUSTRALIA: IMAGES PUBLISHING GROUP, 2001

RUTTEN, D. EVOLUTIONARY PRINCIPLES APPLIED TO PROBLEM SOLVING. SEPTEMBER 25, 2010. HTTP://WWW.GRASSHOPPER3D.COM/PROFILES/ BLOGS/EVOLUTIONARY-PRINCIPLES (ACCESSED NOVEMBER 20, 2011).

SARGENT, J. VIPER. OCTOBER 16, 2011. HTTP://WIKI.DIVA-FOR-RHINO.COM/ GRASSHOPPER_THERMAL. ACESSADO EM 28 DE NOVEMBRO DE 2011

SCHIMID, Aloísio Leoni. A Idéia de Conforto. Curitiba: Pacto Ambiental, 2005.

SERRA, Geraldo Gomes. Pesquisa em Arquitetura e Urbanismo: guia prático para o trabalho de pesquisadores em pós-graduação. São Paulo: EDUSP/Mandarin, 2006.

SILVA, Vanessa Gomes da. Avaliação da sustentabilidade de edifícios de escritórios brasileiros : diretrizes e base metodológica. Tese de Doutorado. Escola Politécnica. Universidade de São Paulo, 2003.

SMITH, P. Architecture in a Climate of Change: a guide to sustainable design. Oxford: 
Architectural Press, 2005.

SOZER, H; CLARK, R. Looking for Cultural Response and Sustainability in the Design of a High-rise Tower in the Middle East. In: Anais do CTBUH 8th World Congress 2008. Dubai: CTBUH, 2008.

SUCCAR, B. Building information modeling framework: a research and delivery foundation for industry stakeholders. In: Automation in Construction, n.18, 2009. www.elsevier.com/ locate/autcon. Acessado em 10 de abril de 2012.

TANTISEVI, K.; SORNSURIYA, K. Building information model for evaluating the building energy performance: a case study. In: International Conference on Computing in Civil and Building Engineering, 2010, Nottingham. Anais: Nottingham, Nottingham University Press, 2010.

TAVENOR, R. From Townscape to Skyscape. The Architectural Review. London: March, 2004.

TERDIZIS, Kostas. Algorithmic Architecture. Oxford: Architecturel Press, 2006.

THUESEN, N.; KIKEGAARD, P.; JENSEN, R. Evaluation of BIM and Ecotect for conceptual architectural design analisys. In: International Conference on Computing in Civil and Building Engineering, 2010, Nottingham. Anais: Nottingham, Nottingham University Press, 2010.

TORCELINE, P. S., et al., 2006. Zero Energy Buildings: A Critical Look at the Definition. [on line]. Available from: www.nrel.gov/docs/fy06osti/39833.pdf/ [Acessado em 30 de novembro de 2009].

TOY, V., Farm Fresh Outside the Lobby. New York, 9/19/2010. Disponível em: <http:// www.nytimes.com/2010/09/19/realestate/19posting.html/>. Acesso em: 20 de Maio de 2012.

UMAKOSHI, E. Uma Visão Crítica do Edifício Alto sob a Ótica da Sustentabilidade. Dissertação de Mestrado. Faculdade de Arquitetura e Urbanismo. Universidade de São Paulo, 2008.

XAVIER, A.; LEMOS, C.; CORONA, E. Arquitetura Moderna Paulistana. São Paulo: Pini, 1983 
WBCSD, 2007. Energy efficiency in buildings: Business realities and opportunities. Summary report. World Business Council for Sustainable Development, Geneva [on line]. Available from: http://www.wbcsd.org/Plugins/ [Acessado em 21 de novembro de 2009].

Wells, B.W.P. Subjective responses to the lighting installations in a modern office building and their design implications. Building and Environment, page 57-68, 1996.

WILLIS, C. Forms Folow Finance. New York: Princeton Architectural Press, 1995.

WOOD, A. Green or Grey? The Aesthetics of Tall Building Sustainability. In: Proceedings of CTBUH 8th World Congress 2008. Dubai: CTBUH, 2008.

Yannas, S. Challenging the supremacy of Airconditioning. 2A Architecture and Art, Issue 7, pp20-43, Dubai, 2008.

YEANG, K. Ecoskyscraper and Ecomimesis: New tall building typoloies. In: Anais do CTBUH $8^{\text {th World Congress 2008. Dubai: CTBUH, } 2008 .}$

YEANG, K; SPECTOR, A. (ed.) Green Design. London:Black Dog Publishing Ltd., 2011. YU, R.; NING G.; OSTWALD M. A Method for Comparing Designers' Behavior in Two Enviroments: Parametric and Geometric Modeling. Open Systems: Proceedings of the 18th International Conference on Computer-Aided Architectural Design Research in Asia (CAADRIA 2013). Singapore, 2013. pp. 479-488 http://cumincad.scix.net/cgi-bin/ works/Show?caadria2013_024 